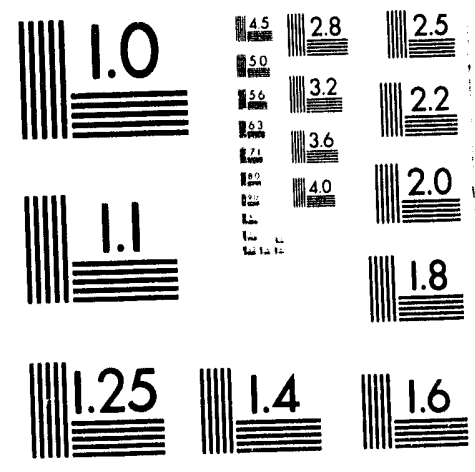


DOE/EIA-0554(94)

Distribution Category UC-950

\title{
Supplement to the Annual Energy Outlook 1994
}

\author{
March 1994
}

Energy Information Administration

Office of Integrated Analysis and Forecasting

U.S. Department of Energy

Washington, DC 20585

This report was prepared by the Energy Information Administration, the independent statistical and analytical agency within the Department of Energy. The information contained herein should not be construed as advocating or reflecting any policy position of the Department of Energy or of any other organization. 


\title{
Preface
}

The Supplement to the Annual Energy Outlook 1994 (Supplement) is a companion document to the Annual Energy Outlook 1994 (AEO94), (DOE/EIA-0383(94)), released in January 1994. The AEO94 presents national forecasts of energy production, demand, and prices through 2010 for five scenarios, including a reference case and four additional cases that assume higher and lower economic growth and higher and lower world oil prices. These forecasts are used by Federal, State, and local governments, trade associations, and other planners and decisionmakers in the public and private sectors.

Part I of the Supplement presents the key quantitative assumptions underlying the AEO94 projections, responding to requests by energy analysts for additional information on the forecasts. In Part II, the Supplement provides regional projections and other underlying details of the reference case projections in the AEO94.

The AEO94 and the Supplement were prepared by the Energy Information Administration (EIA), Office of Integrated Analysis and Forecasting, under the direction of Mary J. Hutzler (202/586-2222), Director of the Office of Integrated Analysis and Forecasting, Mark E. Rodekohr (202/586-1130), Director of the Energy Demand and Integration Division, and Scott Sitzer (202/586-2308), Director of the Energy Supply and Conversion Division. Detailed questions concerning the forecasts and the related model components may be addressed to the following analysts:

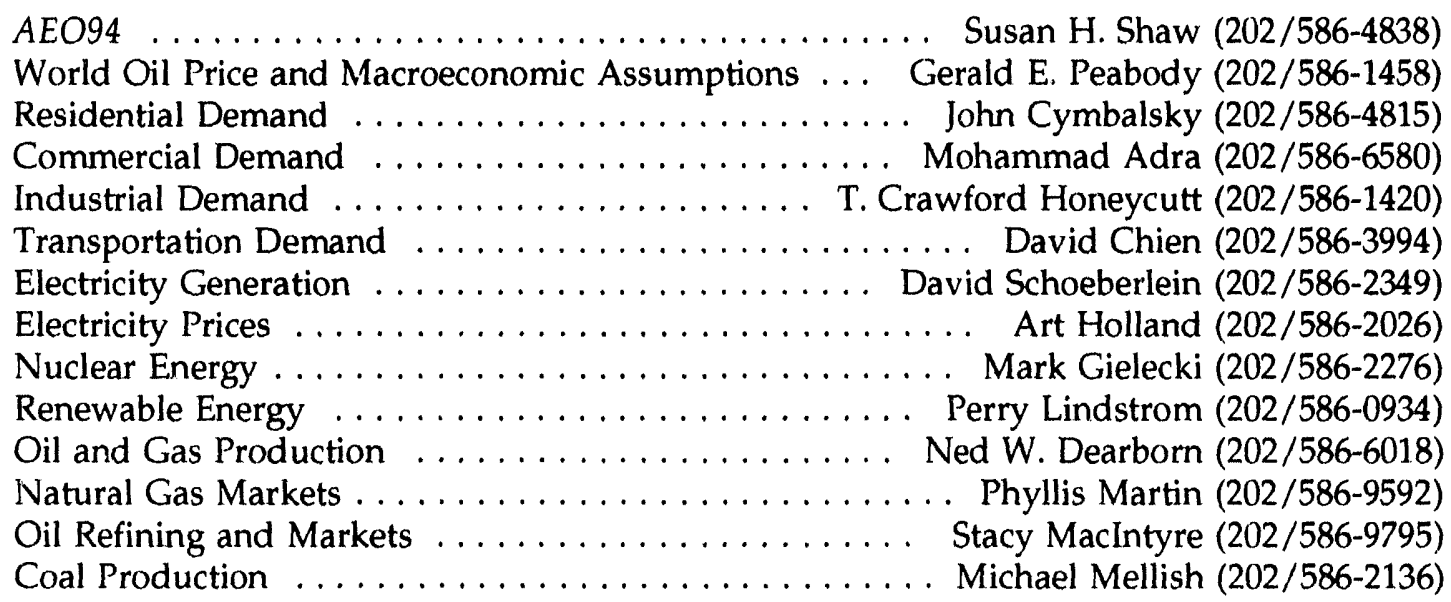

Forecast tables for the five scenarios presented in the AEO94 are available via modem on EIA's Electronic Publication System (202/586-2557). The tables presented in the AEO94 and this Supplement will be available on diskette from the Office of Integrated Analysis and Forecasting in March 1994. Copies of the AEO94, the Supplement, and model documentation reports for the National Energy Modeling System are available by contacting:

\author{
National Energy Information Center, EI-231 \\ Energy Information Administration \\ Forrestal Building, Room 1F-048 \\ Washington, DC 20585 \\ 202/586-8800 \\ TTY: For people who are deaf \\ or hard of hearing: (202)586-1181 \\ 9 a.m. to 5 p.m., eastern time, M-F
}




\section{Contents}

\section{Part I. Assumptions for the Annual Energy Outlook 1994}

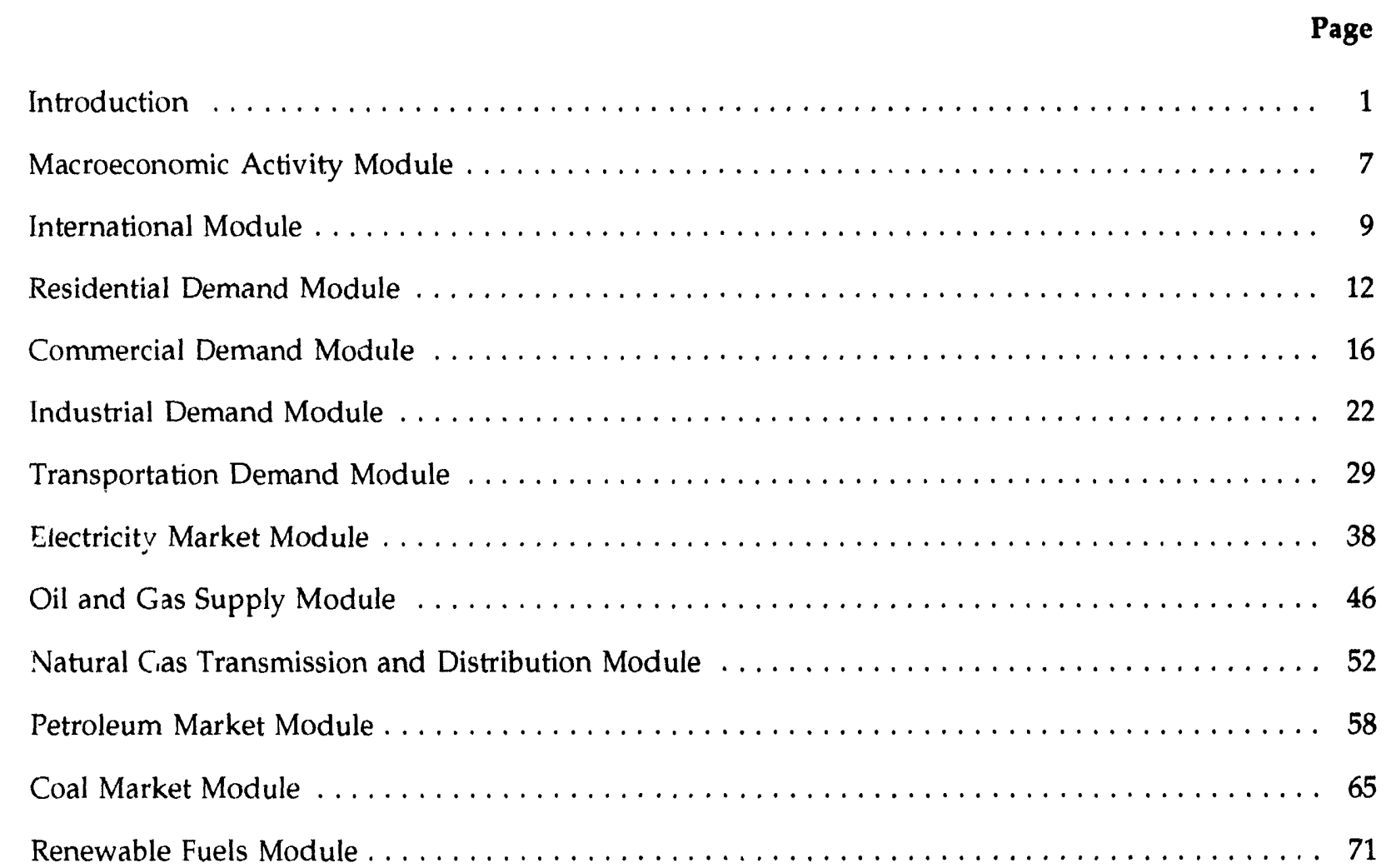

\section{Tables}

1. Growth in GDP, Labor Force, and Productivity $\ldots \ldots \ldots \ldots \ldots \ldots \ldots \ldots \ldots \ldots$

2. Average Annual Regional GDP Growth Rates, $1990-2010 \ldots \ldots \ldots \ldots \ldots \ldots \ldots \ldots \ldots \ldots$

3. Average Annual Regional Growth Rates for Oil Demand, $1990-2010 \ldots \ldots \ldots \ldots \ldots \ldots \ldots 11$

4. 1990 Households . . . . . . . . . . . . . . . . . . . . . . . . . . . . . . . . . 12

5. Capital Cost and Efficiency Ratings of Selected Equipment in $1998 \ldots \ldots \ldots \ldots \ldots \ldots \ldots$

6. Minimum and Maximum Life Expectancies of Equipment $\ldots \ldots \ldots \ldots \ldots \ldots \ldots \ldots \ldots$

7. 1989 Total Floorspace from Commercial Buildings Energy Consumption Survey . . . . . . 17

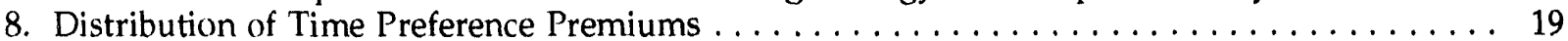

9. Technologies Characteristics for Space Heating in New England $\ldots \ldots \ldots \ldots \ldots \ldots \ldots \ldots$

10. Elasticity of Cogeneration Demand with Respect to Electricity Prices . . . . . . . . . . . . 21

11. EPACT Standards for Incandescent Reflector Lamps $\ldots \ldots \ldots \ldots \ldots \ldots \ldots \ldots \ldots \ldots . \ldots \ldots$

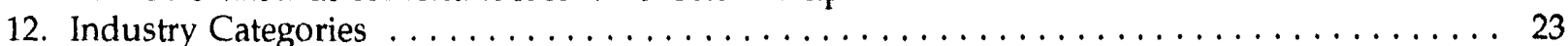

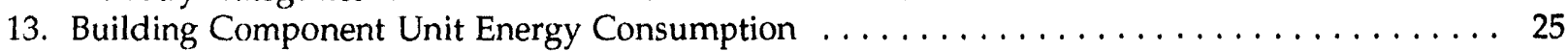

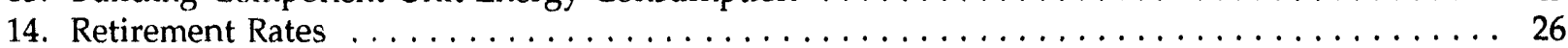

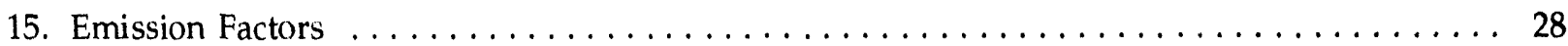

16. Macroeconomic Inputs to the Transportation Module $\ldots \ldots \ldots \ldots \ldots \ldots \ldots \ldots \ldots$ 


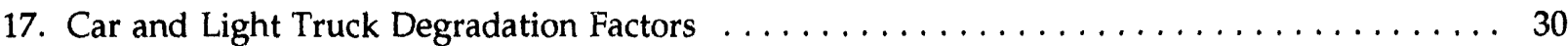

18. Commercial Fleet Size Class Shares by Fleet and Vehicle Type $\ldots \ldots \ldots \ldots \ldots \ldots \ldots \ldots 31$

19. Alternative-Fuel Vehicle Attribute Inputs For Three Stage Logit Model . . . . . . . . . . 32

20. Distribution of Rail Fuel Consumption by Fuel Type $\ldots \ldots \ldots \ldots \ldots \ldots \ldots \ldots \ldots \ldots$

21. Constant Available Seat-Miles Assumptions by Aircraft Type $\ldots \ldots \ldots \ldots \ldots \ldots \ldots \ldots . \ldots 35$

22. Future New Aircraft Technology Improvement List $\ldots \ldots \ldots \ldots \ldots \ldots \ldots \ldots \ldots \ldots \ldots$

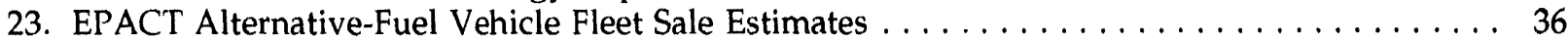

24. California Low Emission Vehicle Program Legislative Mandated Alternative-Fuel

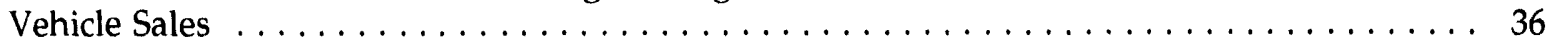

25. Capacity Types Represented in the Electricity Market Module $\ldots \ldots \ldots \ldots \ldots \ldots \ldots \ldots$

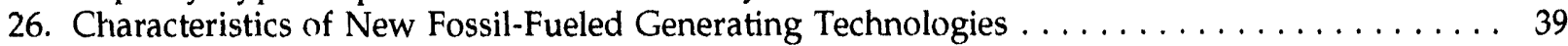

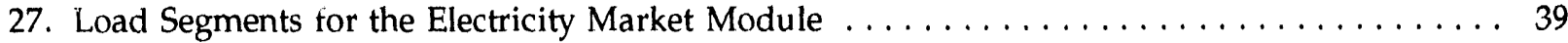

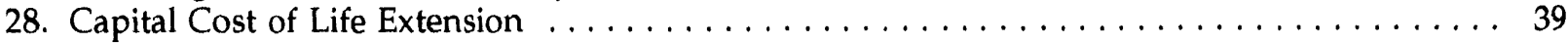

29. Average Utility Cost of Capital, $1990-1992 \ldots \ldots \ldots \ldots \ldots \ldots \ldots \ldots \ldots \ldots \ldots \ldots \ldots \ldots$

30. Crude Oil Recoverable Resources $\ldots \ldots \ldots \ldots \ldots \ldots \ldots \ldots \ldots \ldots \ldots \ldots \ldots \ldots$

31. Natural Gas Recoverable Resources $\ldots \ldots \ldots \ldots \ldots \ldots \ldots \ldots \ldots \ldots \ldots \ldots \ldots$

32. Drilling Activity Response $\ldots \ldots \ldots \ldots \ldots \ldots \ldots \ldots \ldots \ldots \ldots \ldots \ldots \ldots$

33. Projected EOR Production by Oil Price Case $\ldots \ldots \ldots \ldots \ldots \ldots \ldots \ldots \ldots \ldots \ldots \ldots \ldots$

34. Natural Gas Imports and Exports $\ldots \ldots \ldots \ldots \ldots \ldots \ldots \ldots \ldots \ldots \ldots \ldots \ldots \ldots \ldots$

35. Electric Utility Natural Gas Demand Classification $\ldots \ldots \ldots \ldots \ldots \ldots \ldots \ldots \ldots \ldots \ldots \ldots$

36. Markups For Local Firm Transportation Service $\ldots \ldots \ldots \ldots \ldots \ldots \ldots \ldots \ldots \ldots \ldots \ldots$

37. Incremental Storage Expansion Factors (Over Existing Levels) $\ldots \ldots \ldots \ldots \ldots \ldots \ldots \ldots \ldots$

38. FERC Order 636 Transition Costs by Pipeline Company $\ldots \ldots \ldots \ldots \ldots \ldots \ldots \ldots$

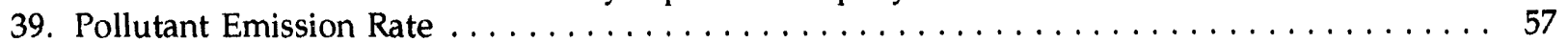

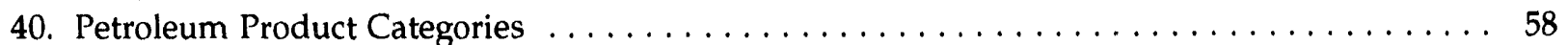

41. Percent Market Share for Gasoline Types by Census Division $\ldots \ldots \ldots \ldots \ldots \ldots \ldots \ldots \ldots$

42. Summary of Fixed Costs by Petroleum Administration for Defense Districts . . . . . . . . . 61

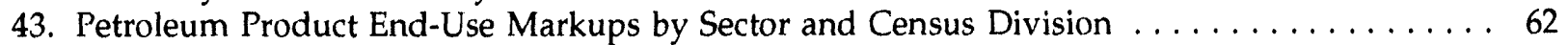

44. Taxes on Petroleum Transportation Fuels by Census Division $\ldots \ldots \ldots \ldots \ldots \ldots \ldots \ldots \ldots$

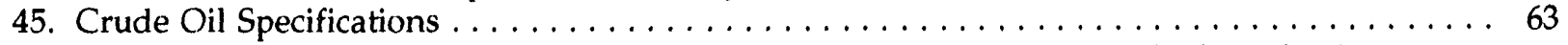

46. Retirement of Existing Underground Mine Production Capacity in the Coal Production

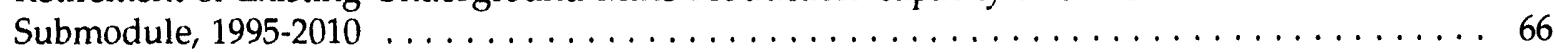

47. Retirement of Existing Surface Mine Production Capacity in the Coal Production

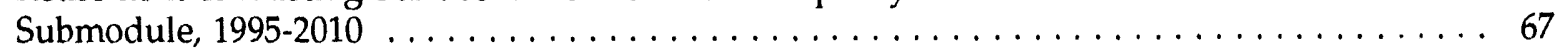

48. Transportation Rate Escalators, $1991-2010 \ldots \ldots \ldots \ldots \ldots \ldots \ldots \ldots \ldots \ldots \ldots$

49. World Steam Coal Import Demand by Import Region, $1995-2010 \ldots \ldots \ldots \ldots$. . . . . . . . 69

50. World Metallurgical Coal Import Demand by Import Region, 1995-2010 . . . . . . . . . . . 70

51. Renewable Fuels Cost and Performance Data $\ldots \ldots \ldots \ldots \ldots \ldots \ldots \ldots \ldots \ldots \ldots \ldots$

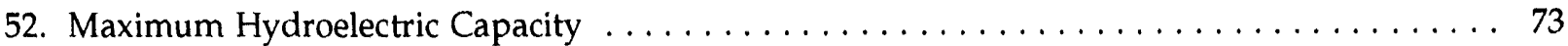

53. Geothermal Unplanned Capacity Build Limits $\ldots \ldots \ldots \ldots \ldots \ldots \ldots \ldots \ldots \ldots \ldots \ldots$

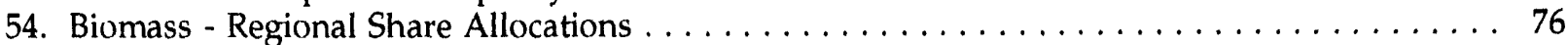

\section{Figures}

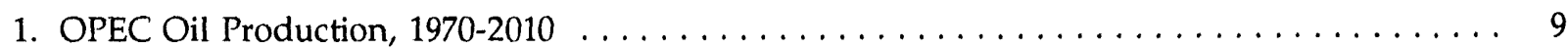

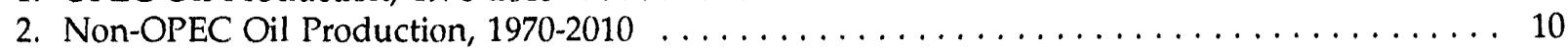




\section{Part II. Detailed Tables}

1. Energy Consumption by End-Use Sector and Source, New England Census Division . . . . 80

2. Energy Consumption by End-Use Sector and Source, Middle Atlantic Census Division . . . . 82

3. Energy Consumption by End-Use Sector and Source, East North Central Census Division . . 84

4. Energy Consumption by End-Use Sector and Source, West North Central Census Division . . 86

5. Energy Consumption by End-Use Sector and Source, South Atlantic Census Division ... . . 88

6. Energy Consumption by End-Use Sector and Source, East South Central Census Division . . 90

7. Energy Consumption by End-Use Sector and Source, West South Central Census Division . . 92

8. Energy Consumption by End-Use Sector and Source, Mountain Census Division . . . . . . 94

9. Energy Consumption by End-Use Sector and Source, Pacific Census Division . . . . . . . . 96

10. Energy Consumption by End-Use Sector and Source, United States . . . . . . . . . . . 98

11. Energy Prices by End-Use Sector and Source, New England Census Division . . . . . . . . 100

12. Energy Prices by End-Use Sector and Source, Middle Atlantic Census Division . . . . . . . 102

13. Energy Prices by End-Use Sector and Source, East North Central Census Division . . . . . . 104

14. Energy Prices by End-Use Sector and Source, West North Central Census Division . . . . . 106

15. Energy Prices by End-Use Sector and Source, South Atlantic Census Division . . . . . . . . 108

16. Energy Prices by End-Use Sector and Source, East South Central Census Division . . . . . 110

17. Energy Prices by End-Use Sector and Source, West South Central Census Division . . . . . . 112

18. Energy Prices by End-Use Sector and Source, Mountain Census Division . . . . . . . . . . 114

19. Energy Prices by End-Use Sector and Source, Pacific Census Division $\ldots \ldots \ldots \ldots \ldots \ldots 116$

20. Energy Pricns by End-Use Sector and Source, United States $\ldots \ldots \ldots \ldots \ldots \ldots \ldots \ldots \ldots$

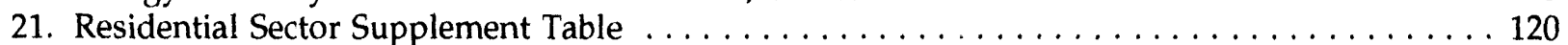

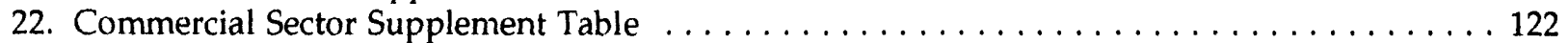

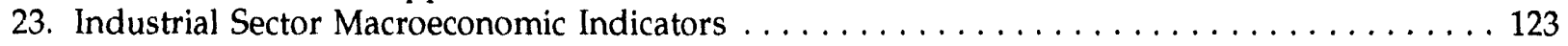

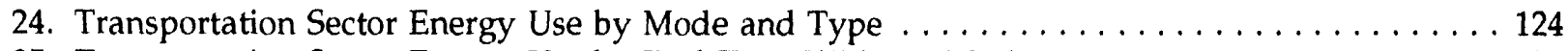

25. Transportation Sector Energy Use by Fuel Type Within a Mode $\ldots \ldots \ldots \ldots \ldots \ldots \ldots \ldots$

26. Light-Duty Vericle Energy Consumption by Technology Type and Fuel Type . . . . . . . 127

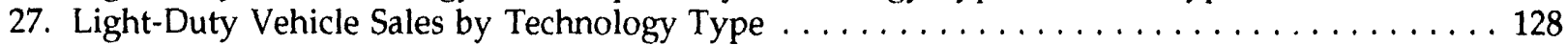

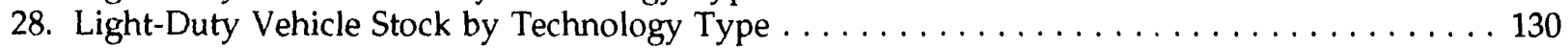

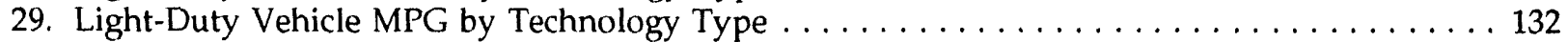

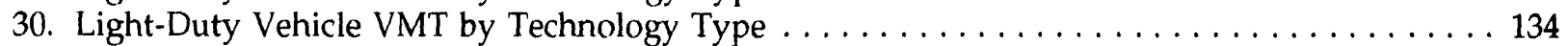

31. Transportation Fleet Car and Truck Fuel Consumption by Type and Technology $\ldots \ldots \ldots 135$

32. Transportation Fleet Car and Truck Sales by Type and Technology $\ldots \ldots \ldots \ldots \ldots \ldots \ldots$

33. Transportation Fleet Car and Truck Stock by Type and Technology $\ldots \ldots \ldots \ldots \ldots \ldots 137$

34. Transportation Fleet Car and Truck VMT by Type and Technology $\ldots \ldots \ldots \ldots \ldots \ldots \ldots 138$

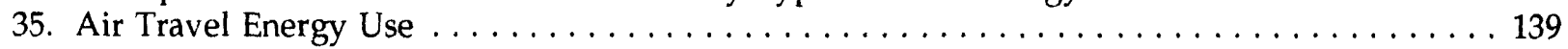

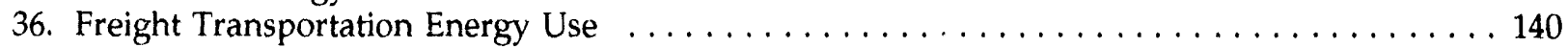

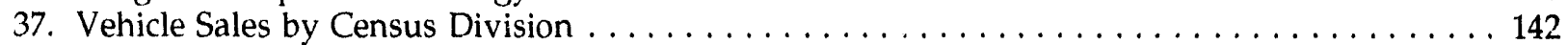

38. Electric Power Data and Projections for the EMM Region East Central Area Reliability

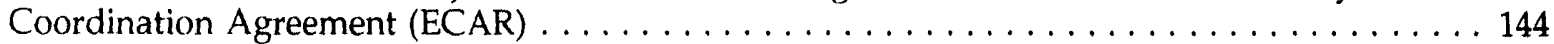

39. Electric Power Data and Projections for the EMM Region Electric Reliability Council of Texas (ERCOT) . . . . . . . . . . . . . . . . . . . . . . . . 147

40. Electric Power Data and Projections for the EMM Region Mid-A.tlantic Area

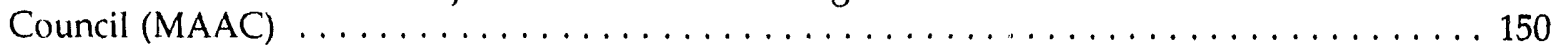

41. Electric Power Data and Projections for the EMM Region Mid-America Interconnected Network (MAIN) . ................................... 153

42. Electric Power Data and Projections for the EMM Region Mid-Continent Area Power

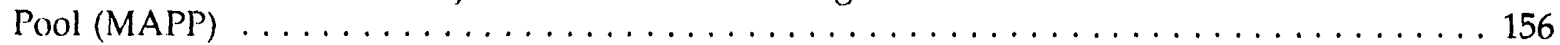

43. Electric Power Data and Projections for the EMM Region Northeast Power Coordinating Council/New York (NPCC/NY) . . . . . . . . . . . . . . . . . . . 159

44. Electric Power Data and Projections for the EMM Region Northeast Power

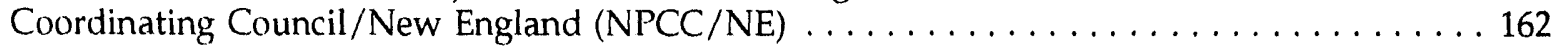


45. Electric Power Data and Projections for the EMM Region Southeastern Electric

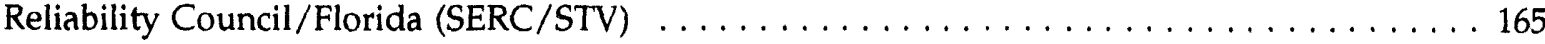

46. Electric Power Data and Projections for the EMM Region Southeastern Electric

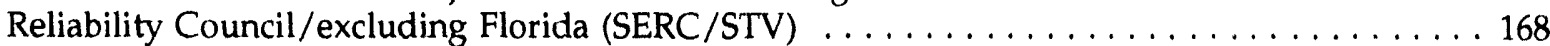

47. Electric Power Data and Projections for the EMM Region Southwest Power Pool (SPP) . . . . 171

48. Electric Power Data and Projections for the EMM Region Western Systems

Coordinating Council/Northwest Power Pool Area (WSCC/NWP) . . . . . . . . . . . . 174

49. Electric Power Data and Projections for the EMM Region Western Systems Coordinating

Council/ Rocky Mountain Power Area and Arizona (WSCC/RA) . . . . . . . . . . . . . 177

50. Electric Power Data and Projections for the EMM Region Western Systems Coordinating

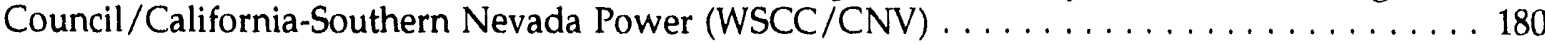

51. Electric Power Data and Projections for the United States $\ldots \ldots \ldots \ldots \ldots \ldots \ldots \ldots \ldots 183$

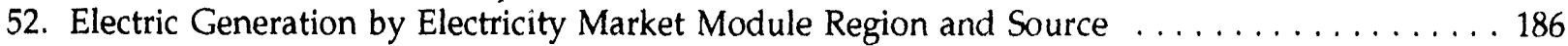

53. Electric Generating Capacity by Electricity Market Module Region and Source . . . . . . . . 189

54. Domestic Refinery Distillation Base Capacity, Expansion, and Utilization . . . . . . . . . . 192

55. Lower 48 Crude Oil Production and Wellhead Prices by Supply Region . . . . . . . . . . . 193

56. Lower 48 Natural Gas Prnfuction and Wellhead Prices by Supply Region . . . . . . . . . . . 194

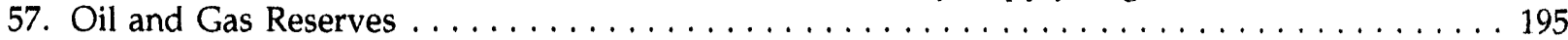

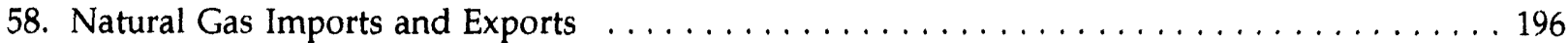

59. Domestic Coal Supply, Disposition, and Prices New England Census Division . . . . . . . 197

60. Domestic Coal Supply, Disposition, and Prices Middle Atlantic Census Division . . . . . . . 198

61. Domestic Coal Supply, Disposition, and Prices East North Central Census Division . . . . . 199

62. Domestic Coal Supply, Disposition, and Prices West North Central Census Division . . . . . . 200

63. Domestic Coal Supply, Disposition, and Prices South Atlantic Census Division . . . . . . . . 201

64. Domestic Coal Supply, Disposition, and Prices East South Central Census Division . . . . . 202

65. Domestic Coal Supply, Disposition, and Prices West South Central Census Division . . . . . . 203

66. Domestic Coal Supply, Disposition, and Prices Mountain Census Division . . . . . . . . . 204

67. Domestic Coal Supply, Disposition, and Prices Pacific Census Division . . . . . . . . . . 205

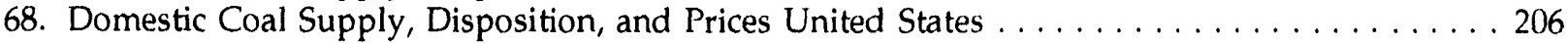

69. Coal Production and Minemouth Prices by Region $\ldots \ldots \ldots \ldots \ldots \ldots \ldots \ldots \ldots \ldots \ldots \ldots$

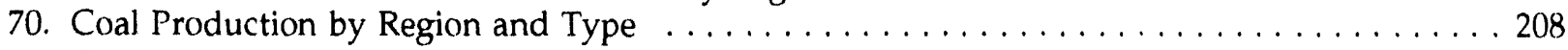

71. World Steam Coal Flows By Importing Regions and Exporting Countries . . . . . . . . . . . 209

72. World Metallurgical Coal Flows By Importing Regions and Exporting Countries . . . . . . 210

73. World Total Coal Flows By Importing Regions and Exporting Countries . . . . . . . . . 211

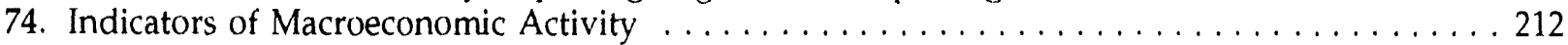

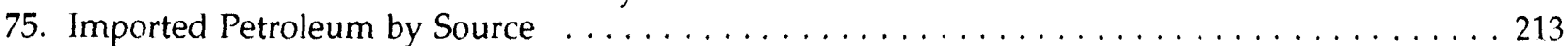

\section{Appendices}

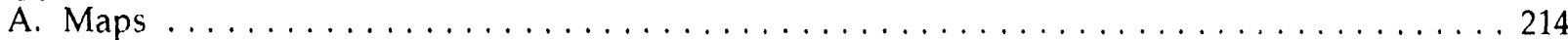

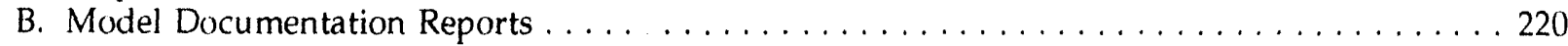


Part I

\section{Assumptions \\ for the \\ Annual Energy Outlook 1994}




\section{Introduction}

This section of the Supplement to the Annual Energy Outlook 1994 (Supplement) presents the major assumptions of the modeling system used to generate the projections in the Annual Energy Outlook 1994 (AEO94). In this context, assumptions include general features of the model structure, assumptions concerning energy markets, and the key input data and parameters that are most significant in formulating the model results. Detailed documentation of the modeling system is available in a series of documentation reports listed in Appendix B. ${ }^{1}$

\section{The National Energy Modeling System}

The projections in the AEO94 and the Supplement are the first produced with the new National Energy Modeling System (NEMS). NEMS is the result of a 2-year development effort by the Office of Integrated Analysis and Forecasting of the Energy Information Administration (EIA) to enhance and update its modeling and analysis capability.

NEMS is the latest in a series of computer-based energy modeling systems used by EIA and its predecessor organization, the Federal Energy Administration, to represent domestic energy-economy markets and projected trends in the midterm time period. These models have been used for the annual reports of energy projections since 1974 and for analytical studies requested by decisionmakers and analysts in the U.S. Congress and the Department of Energy's Office of Policy, Planning, and Program Evaluation. The most recent modeling system, the Intermediate Future Forecasting System, was used for the AEO from 1982 through 1993.

The purpose of NEMS is:

To illustrate the energy, economic, environmental, and energy security consequences on the United States of various energy policies and assumptions by providing forecasts of alternative energy futures in the mid and long-term periods, using a unified modeling system.

As its predecessor models, NEMS incorporates a market-based approach to energy analysis, balancing the supply of and demand for energy for each fuel and consuming sector and taking into account the economic competition between energy sources.

Development of NEMS has been accomplished with extensive communication between EIA and the community of energy modelers, analysts, and users of the EIA projections. This effort began in 1990 with a committee of the National Research Council of the National Academy of Sciences reviewing existing energy models and providing guidance on the development of NEMS. Background work for the design of NEMS was accomplished in 1991 by a NEMS Project Office and, later that year, EIA reorganized to form the Office of Integrated Analysis and Forecasting with the mission of developing and maintaining NEMS and conducting all forward-looking analyses in EIA. Design and development plans were communicated in a series of 40 component design reports prior to model implementation. These reports received wide distribution to the internal and external energy analysis and academic community, including an Energy Modeling Forum review group, and were in part the subject of formal review

\footnotetext{
'NEMS documentation and component design reports are available from the National Energy Information Center $(202 / 586-8800)$.
} 
through EIA's Independent Expert Review Program. ${ }^{2}$ Additional guidance is received through a NEMS User Group, including representatives of Government agencies, industry trade associations, Congressional organizations, and environmental groups. A public NEMS Conference in February 1993 presented model designs and methodologies and invited commentas y from energy and modeling experts.

The time horizon of NEMS is 25 years, the midterm period in which the structure of the economy, the nature of energy markets, and regional demographics are sufficiently understood that it is possible to represent considerable structural and regional detail. The majority of policies which are proposed today will have their greatest impacts during the midterm years.

NEMS was designed to support the analysis of the emerging energy issues of the 1990's. Energy market features that were formerly analyzed offline to the modeling system are now represented directly within NEMS; for example, the international oil market and the penetration of renewable energy sources. Also, the component modules incorporate greater structural detail to allow for the analysis of a variety of energy issues. Enhancements include a representation of natural gas pipeline transportation capacity and tariffs, an endogenous representation of the impacts of the Clean Air Act compliance options, an embedded refinery module that differentiates several crude oil types, enhanced representations of end-use services and standards in the buildings modules, an alternative-fuel vehicle module, a process representation of industrial sector energy use, and emissions reporting.

Because of the diverse nature of energy supply, demand, and conversion in the United States, NEMS supports regional modeling and analysis in order to portray transportation flows, to represent the regional differences in energy markets, and to provide policy impacts at the regional level. The level of regional detail for the end-use demand modules is the nine Census divisions. Other regional structures include production and consumption regions specific to oil, gas, and coal supply and distribution, the North American Electric Reliability Council regions and subregions for electricity, and the Petroleum Administration for Defense districts for refineries (Appendix A). Only national results are presented in the AEO94, with the regional and other detailed results in this Supplement.

For each fuel and consuming sector, NEMS balances the energy supply and demand, accounting for the economic competition between the various energy fuels and sources. NEMS is organized and implemented as a modular system. The modules represent each of the fuel supply markets, conversion sectors, and end-use consumption sectors of the energy system. NEMS also includes macroeconomic and international modules. The primary flows of information hetween each of these modules are the delivered prices of energy to the end user and the quantities consumed by product, region, and sector. The delivered prices of fuel encompass all the activities necessary to produce, import, and transport fuels to the end user. The information flows also include other data such as economic activity, domestic production activity, and international petroleum supply availability.

The integrating module of NEMS controls the execution of each of the component modules. To facilitate modularity, the components do not pass information to each other directly but communicate through a central data file. This modular design provides the capability to execute modules individually, thus allowing decentralized development of the system and independent analysis and testing of individual modules. This modularity allows the use of the methodology and level of detail most appropriate for each energy sector. NEMS solves by calling each supply, conversion, and end-use demand module in sequence until the delivered prices of energy and the quantities demanded have converged within tolerance, thus achieving an economic equilibrium of supply and demand in the consuming sectors. Solution is reached annually through the midterm horizon. Other variables are also evaluated for convergence such as petroleum product imports, crude oil imports, and several macroeconomic indicators.

\footnotetext{
'The Independent Expert Review Program provides for the review of EIA information products and is designed to produce unbiased reviews from experts in energy and energy-related fields who have no vested interest in the outcome of the review beyond technical excellence.
} 
Each NEMS component also represents the impact and cost of environmental regulations that affect that sector and reports key emissions. NEMS represents current environmental regulations, such as the Clean Air Act Amendments of 1990, and the costs of compliance with other regulations.

\section{Component Modules}

The component modules of NEMS represent the individual supply, demand, and conversion sectors of domestic energy markets and also include international and macroeconomic modules. In general, the modules interact through values representing the prices of energy delivered to the consuming sectors and the quantities of end-use energy consumption. This section provides brief summaries of each of the modules.

\section{Macroeconomic Activity Module}

The Macroeconomic Activity Module provides a set of essential macroeconomic drivers to the energy modules, a macroeconomic feedback mechanism within NEMS, and a mechanism to evaluate detailed macroeconomic and interindustry impacts associated with energy events. Key macroeconomic variables include gross domestic product (GDP), interest rates, disposable income, and employment. Industrial drivers are calculated for 32 industrial sectors. This module is a response surface representation of the Data Resources, Inc., Quarterly Model of the U.S. Economy.

\section{International Module}

The International Module represents the world oil markets, calculating the average world oil price and computing supply curves for five categories of imported crude oil for the Petroleum Market Module of NEMS, in response to changes in U.S. import requirements. International petroleum product supply curves, including curves for oxygenates, are also calculated.

\section{Residential and Commercial Demand Modules}

The Residential Demand Module forecasts consumption of residential sector energy by housing type and end use, subject to delivered energy prices, availability of renewable sources of energy, and macroeconomic variables representing disposable personal income, interest rates, and housing starts. The Commercial Demand Module forecasts consumption of commercial sector energy by building types and nonbuilding uses of energy and by category of end use, subject to delivered prices of energy, availability of renewable sources of energy, and macroeconomic variables representing GDP, employment, interest rates, and floorspace construction. Both modules estimate the equipment stock for the major end-use services, incorporating assessments of advanced technologies, including representations of renewable energy technologies, and analyses of both building shell and appliance standards.

\section{Industrial Demand Module}

The Industrial Demand Module forecasts the consumption of energy for heat and power and for feedstocks and raw materials in each of 32 industries, subject to the delivered prices of energy and macroeconomic variables representing GDP, interest rates, employment and labor cost, and the value of output for each industry. The industries are classified into three groups-energy intensive, nonenergy intensive, and nonmanufacturing. Of the eight energy-intensive industries, seven are modeled in the Industrial Demand Module with components for boiler/steam/cogeneration, buildings, and process/assembly use of energy. A representation of cogeneration and a recycling component are also included. The use of energy for petroleum refining is modeled in the Petroleum Market Module, and the projected consumption is included in the industrial totals. 


\section{Transportation Demand Module}

The Transportation Demand Module forecasts consumption of transportation sector fuels, including petroleum products, electricity, methanol, ethanol, and compressed natural gas by transportation inode, vehicle vintage, and size class, subject to delivered prices of energy fuels and macroeconomic variables representing disposable personal income, GDP, population, interest rates, and the value of output for industries in the freight sector. Fleet vehicles are represented separately to allow analysis of the Clean Air Act Amendments and other legislative proposals, and the module includes a component to explicitly assess the penetration of alternatively fueled vehicles.

\section{Electricity Market Module}

The Electricity Market Module represents generation, transmission, and pricing of electricity, subject to delivered prices for coal, petroleum products, and natural gas, costs of generation by centralized renewables, macroeconomic variables for costs of capital and domestic investment, and electricity load shapes and demand. There are four primary submodules-capacity planning, fuel dispatching, finance and pricing, and load and demand-side management. Nonutility generation and transmission and trade are represented in the planning and dispatching submodules. The levelized fuel cost of uranium fuel for nuclear generation is directly incorporated into the Electricity Market Module. All Clean Air Act compliance options are explicitly represented in the capacity expansion and dispatch decisions. Both new generating technologies and renewable technologies compete directly in these decisions. The competition between utility and nonutility generation and several options for wholesale pricing are included.

\section{Oil and Gas Supply Module}

The Oil and Gas Supply Module represents domestic crude oil, natural gas liquids, and natural gas production within an integrated framework that captures the interrelationships between the various sources of supply: onshore, offshore, and Alaska by both conventional and nonconventional techniques, including enhanced oil recovery and unconventional gas recovery from tight gas formations, devonian shale, and coalbeds. This framework analyzes cash flow and profitability to compute investment and drilling in each of the supply sources, subject to the prices for crude oil and natural gas, the domestic recoverable resource base, and technology. Oil and gas production functions are computed at a level of 12 supply regions, including 3 offshore and 3 Alaskan regions. This module also represents foreign sources of natural gas, including pipeline imports and exports with Canada and Mexico, and liquefied natural gas imports. The crude oil and natural gas liquids supply curves are input to the Petroleum Market Module in NEMS for conversion and blending into refined petroleum products. The supply curves for natural gas are input to the Natural Gas Transmission and Distribution Module.

\section{Natural Gas Transmission and Distribution Module}

The Natural Gas Transmission and Distribution Module represents the transmission, distribution, and pricing of natural gas, subject to end-use demand for natural gas, the production of domestic natural gas, and the availability and price of natural gas traded on the international market. The module tracks the flows of natural gas in an aggregate, domestic pipeline network, connecting the domestic and foreign supply regions with 12 demand regions. This capability allows the analysis of impacts of regional capacity constraints in the interstate natural gas pipeline network and the identification of pipeline capacity expansion requirements. There is an explicit representation of firm and interruptible markets for natural gas transmission and distribution, and the key components of pipeline and distributor tariffs are included in the pricing algorithms.

\section{Petroleum Market Module}

The Petroleum Market Module forecasts prices of petroleum products, crude oil and product import activity, and domestic refinery operations, including fuel consumption, subject to the demand for 
petroleum products, availability and price of imported petroleum, and domestic production of crude cill, natural gas liquids, and alcohol fuels. The module represents refining activities for the five Petroleum Administration for Defense districts, using the same crude oil types as the International Module. It explicitly models the requirements of the Clean Air Act Amendments of 1990 and the costs of new automotive fuels, such as oxygenated and reformulated gasoline, and includes oxygenated production and blending for reformulated gasoline. Costs include capacity expansion for refinery processing units. Enduse prices are based on the marginal costs of production, plus markups representing product distribution costs, State and Federal taxes, and environmental costs.

\section{Coal Market Module}

The Coal Market Module represents mining, transportation, and pricing of coal, subject to the end-use denand for coal differentiated by physical characteristics, such as the heat and sulfur content. The coal supply curves include a response to capacity utilization and fuel costs, as well as reserve depletion, labor productivity, and factor input costs. Thirty-iwo potential coal types are represented, differentiated by thermal grade, sulfur content, and mining process. Production and distribution are computed for 16 supply and 23 demand regions, by transportation mode. Transportation rates are constructed using imputed coal transportation costs and trends in factor input costs. The Coal Market Module also forecasts the requirements for U.S. coal exports and imports. The international coal market is represented offline to NEMS by a linear program which computes irade in 4 types of coal for 20 import and 16 export regions.

\section{Renewable Fuels Module}

The Renewable Fuels Module includes submodules representing wood, municipal solid waste, wind energy, solar energy, hydroelectric power, geothermal energy, and biofuels (ethanol) supply. (The Electricity Market Module represents market penetration of renewable technologies used for centralized electricity generation, and the end-use demand modules incorporate dispersed renewables.) This module provides costs and performance criteria to the Electricity Market Module and also interacts with the Petroleum Market Module to represent the production and pricing of alcohol fuels.

\section{Cases for the Annual Energy Outlook 1994}

The AEO94 presents five cases which differ from each other due to fundamental assumptions concerning the domestic economy and world oil market conditions. Three alternative assumptions are specified for each of these two factors, with the Reference Case using the mid-level assumption for each.

- Economic Growth. In the Reference Case, productivity grows at an average annual rate of 1.0 percent through 2010 and the labor force at 1.1 percent per year, yielding a growth in real GDP of 2.1 percent per year. In the High Economic Growth Case, productivity and the labor force grow at 1.1 and 1.3 percent per year, respectively, resulting in GDP growth of 2.4 percent annually. The average annual growth in productivity, the labor force, and GDP are 0.8, 1.0, and 1.8 percent, respectively, in the Low Economic Growth Case.

- World Oil Markets. In the Reference Case, the average world oil price remains below $\$ 20$ per barrel (in real 1992 dollars) through 1999 and then gradually increases to over $\$ 28$ per barrel in 2010. Reflecting uncertainty in world markets, the price in 2010 is slightly higher than $\$ 20$ per barrel in the Low Oil Price Case and approaches $\$ 35$ per barrel in ine High Oil Price Case. The key factor underlying the differences in the oil prices is the assumption concerning production in the Organization of Petroleum Exporting Countries (OPEC). Additional factors are oil production in non-OPEC countries, net oil exports by the formerly centrally planned economies, and the worldwide demand for oil. 
All projections are prepared assuming Federal, State, and local laws and regulations in effect on October 1, 1993. These include the additional fuels taxes in the Omnibus Budget Reconciliation Act of 1993, the Clean Air Act Amendments of 1990, and the Energy Policy Act of 1992. P'ending legislation, sections of existing legislation for which funds have not been appropriated, and provisions of the Climate Change Action Plan are not reflected in these forecasts. 


\section{Macroeconomic Activity Module}

The Macroeconomic Activity Module represents the interaction between the U.S. economy as a whole and energy markets. The rate of growth of the economy, measured by the growth in gross domestic product (GDP), is a key determinant of the growth in demand for energy. Associated economic factors, such as interest rates and income, strongly influence various elements of the supply and demand for energy. At the same time, reactions to energy markets by the aggregate economy, such as a slowdown in the rate of economic growth resulting from increasing energy prices, are also reflected in the module.

\section{Key Assumptions}

The output of the Nation's economy, measured by the gross domestic product (GDP), is assumed to increase over the period of the AEO94 forecast. However, an assumed slowdown in the expansion of the labor force after 2000 is assumed to lead to a slight decline in the GDP growth rate during the final decade of the forecast (Table 1). ${ }^{3}$

Table 1. Growth in GDP, Labor Force, and Produstivity (Percent per Year)

\begin{tabular}{|c|c|c|c|c|c|}
\hline Assumptions & $1990-1995$ & $1995-2000$ & $2000-2005$ & 2005-2010 & $1990-2010$ \\
\hline \multicolumn{6}{|l|}{ GDP } \\
\hline High Growth & 2.2 & 2.7 & 2.5 & 2.2 & 2.4 \\
\hline Reference & 1.9 & 2.4 & 2.2 & 1.9 & 2.1 \\
\hline Low Growth & 1.6 & 2.1 & 1.9 & 1.5 & 1.8 \\
\hline \multicolumn{6}{|l|}{ Labor Force } \\
\hline High Growth & 1.3 & 1.6 & 1.3 & 1.0 & 1.3 \\
\hline Reference & 1.2 & 1.4 & 1.1 & 0.8 & 1.2 \\
\hline Low Growth & 1.0 & 1.2 & 1.0 & 0.6 & 1.0 \\
\hline \multicolumn{6}{|l|}{ Productivity } \\
\hline High Growth . . . . . . . & 1.0 & 1.1 & 1.2 & 1.2 & 1.1 \\
\hline Reference ........ & 0.7 & 1.0 & 1.1 & 1.1 & 1.0 \\
\hline Low Growth ......... & 0.5 & 0.8 & 1.0 & 0.9 & 0.8 \\
\hline
\end{tabular}

GDP $=$ Gross domestic product.

Source: Energy Information Administration (EIA) runs of the Data Resources, Inc. (DRI) model incorporating ElA world oil price assumptions; based on DRl's Trend Growth and Optimistic and Pessimistic Projections reported in DRI/McGraw-Hill, Review of the U.S. Economy: Long-Range Focus, Winter 1992-93 (Lexington, MA), 1993.

The growth in the size of the labor force depends upon the growth in the population and the rate of participation in the labor force by the working age segments of the population. The Census Bureau's middle series population projection is used as the underlying population projection for the AEO94. Based on new projections released in December 1992, the Census Bureau assumes that the U.S. population will grow at a faster rate in the future than it predicted in its previous, 1988, forecast. The fertility rate is assumed in the AEO94 to remain at the current level of 2.1 live births per woman, an increase from the Census Bureau's previous forecast of 1.8 births per woman. Life expectancy at birth is assumed to be 82.1 years, an increase of 2.2 years. Net immigration is assumed to be 880,000 per year, an increase of 380,000 .

${ }^{3}$ DRI/McGraw-Hill, Review of the U.S. Economy: Long-Range Focus, Winter 1992-93, (Lexington, MA), 1993. 
The labor force participation rate is assumed to continue its rise to a peak in 2005 and then decline as "baby boom" cohorts begin to retire. Combining the population projections with labor force participation rates gives an increase in labor force growth early in the forecast and then a decline.

The productivity of labor is the second major determinant of economic growth. A key to achieving the Reference Case's long-run economic output growth of 2.1 percent is an anticipated recovery in the growth of productivity. Productivity growth slowed during the mid-1970's, compared to the growth experienced after World War II. There is no consensus about why productivity growth declined so much after 1973. Between 1980 and 1990, business investment's share of GDP declined at the same time that both the Federal budget deficit and the trade deficit increased. Since 1991, the economic recovery has been led by strong gains in business investment because of persistent low interest rates. Productivity has also shown strong gains as economic output has increased more rapidly than employment.

For economic output to grow at the assumed rate, the increases in investment and productivity must be higher than the decline in labor force growth expected after 2000. Demographics play a strong role in explaining future consumption and investment trends. Households composed of the elderly or of young adults have lower savings rates than households with middle-aged adults. In fact, elderly households may "dis-save" as previous investments for retirement are converted to income. Consequently, as the age composition of the labor force changes, the relative shares of GDP for consumption and investment shift. Consumption as a share of GDP is assumed to decline in the first 10 years, but then to increase gradually after 2005 as the "baby boomers" begin to retire. Correspondingly, investment gains are strong early in the forecast, but they later begin to slow as the consumption share of GDP increases and the investment share begins to decline. For the reference case, total savings as a share of GDP are assumed to increase over the forecast period. Personal and business savings shares are relatively constant, and the Federal government deficit is expected to decline. The Federal deficit reduction leads to an increased pool of funds available for investment, which is a key ingredient for boosting long-term economic growth.

The assumption of increasing productivity in the future, combined with a gradually declining Federal deficit, leads to the projected recovery in business investment's share of national output. Increased business fixed investment along with research and development spending help offset the decline in labor force growth, but eventually the weaker labor force growth dominates, limiting capital stock and potential output gains. Consequently, economic output is assumed to grow at a reduced rate in the final years of the forecast.

Tu reflect the uncertainty in forecasts of economic growth, the $A E O 94$ forecasts have been prepared with High and Low Economic Growth Cases in addition to the Reference Case. All three economic cases are based upon forecasts by Data Resources, Inc. (DRI). ${ }^{4}$ The DRI forecasts used in this AEO94 forecast are the Trend Growth scenario and the Optimistic and Pessimistic Projections. EIA has used DRI's forecasts directly, apart from an adjustment to incorporate EIA's world oil price assumptions. The three economic growth cases have been modified by EIA to incorporate the world oil price assumptions for the AEO94 Reference Case. Incorporating this change, the DRI projections are used as the starting point for the macroeconomic forecasts within the NEMS simulations for the AEO94.

The High Economic Growth Case incorporates higher labor force and productivity growth rate assumptions. Due to the higher productivity gains, inflation and interest rates are lower than in the Reference Case. Investment, disposable income, and industrial output are increased. The Low Economic Growth Case assumes lower labor force and productivity growth, with resulting higher prices, higher interest rates, and lower industrial output.

The regional disaggregations of the economic variables are solutions of the model; the final results for the regional distribution of income and nonagricultural employment are given in Table 74 in Part II.

${ }^{4}$ DRI/McGraw-Hill, Review of the U.S. Economy: Long-Range Focus, Winter 1992-93, (Lexington, MA), 1993. 


\section{International Module}

The International Module determines changes in the world oil price and the supply prices of petroleum products for import to the United States in response to changes in U.S. import requirements. A market clearing method is used to determine the price at which worldwide demand for oil is equal to the worldwide supply. The module determines new values for oil production and demand for regions outside the United States along with the new world oil price that balances supply and demand in the international oil market.

\section{Key Assumptions}

The level of oil production by countries in the Organization of Petroleum Exporting Countries (OPEC) is a key factor influencing the world oil price projections incorporated into this AEO94. Non-OPEC production, worldwide regional economic growth rates and the associated regional demand for oil, and the level of net oil exports from Eurasia (the former Soviet Union, China and Eastern Europe) are additional factors affecting the world oil price.

OPEC oil production is assumed to increase throughout the forecast, making OPEC the source for the worldwide increase in oil consumption expected over the forecast period (Figure 1). OPEC is assumed to be the source of additional production because its member nations hold a major portion of the world's total reserves - in the neighborhood of 750 billion barrels, over 75 percent of the world's total, at the end of 1992. ${ }^{5}$ For these $A E O 94$ forecasts, three different OPEC production paths are the principal assumptions leading to the three world oil price path cases examined: the Low Oil Price Case, Reference Case, and High Oil Price Case. The values assumed for OPEC production for the three world oil price cases are given in Figure 1.

Figure 1. OPEC Oil Production, 1970-2010 (Million Barrels per Day)

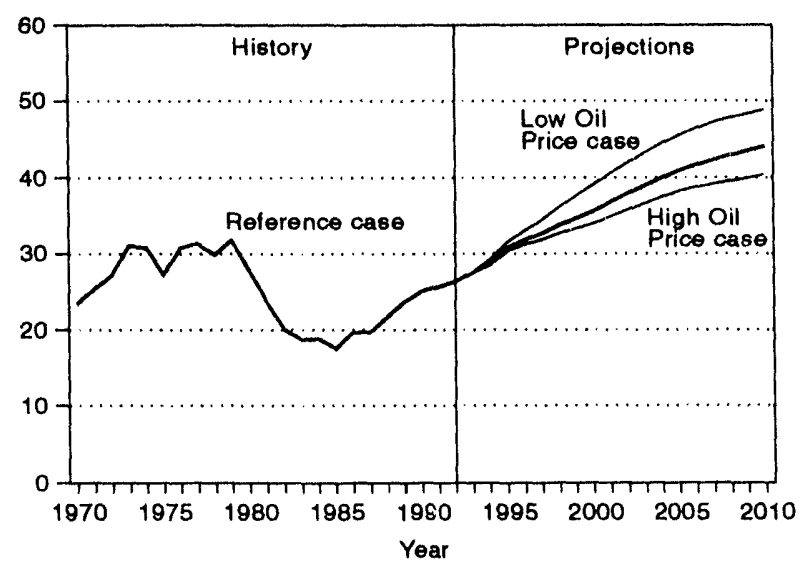

OPEC $=$ Organization of Petroleum Exporting Countries.

Source: Energy Information Administration, AEO 1994 National Energy Modeling System runs: LWOP94.D1221932; AEO94B.D1221934; and HWOP94.D1221932.

${ }^{5}$ Energy Information Administration, International Energy Outlook 1993, DOE/EIA-0484(93) (Washington DC, 1993). 
Non-OPEC oil production is expected to follow a fairly flat path-with a slight rise through the year 2000 and a modest decline thereafter-as production declines in some parts of the world are offset by increases in other regions (Figure 2). One fixed path for non-OPEC oil production is initially input for all three world oil price case projections. Non-OPEC production depends upon the values of world oil prices, so the final forecast solutions of the levels of non-OPEC production for the three oil prices cases diverge from the initial assumptions. Production is higher in the High Oil Price Case since more marginal wells are profitable at the higher prices. Likewise, lower world oil prices are associated with lower production levels. The final non-OPEC production paths for the three oil price cases are shown in Figure 2.

\section{Figure 2. Non-OPEC Oil Production, 1970-2010} (Million Barrels per Day)

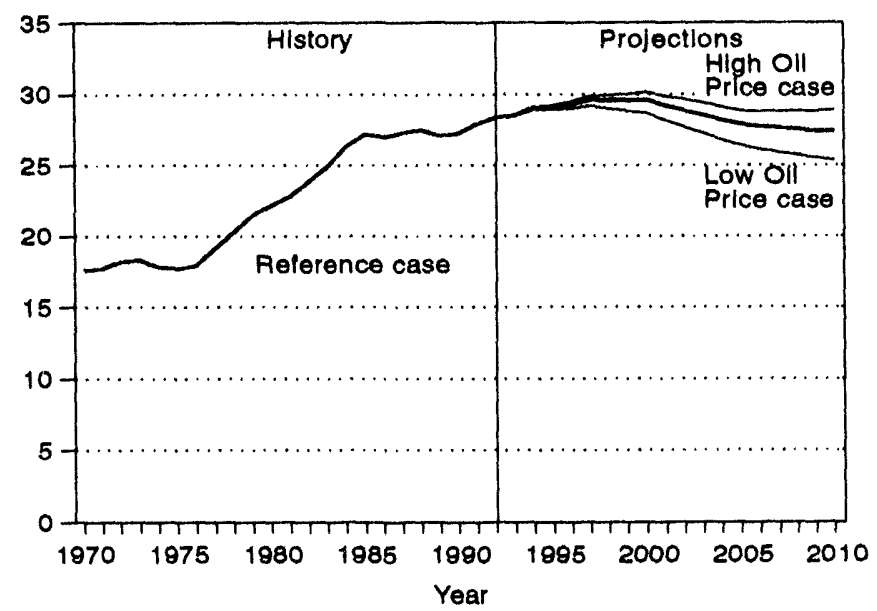

OPEC $=$ Organization of Petroleum Exporting Countries.

Source: Energy Information Administration, AEO 1994 National Energy Modeling System runs: LWOP94.D1221932; AEO94B.D1221934; and HWOP94.D1221932.

The assumed growth rates for gross domestic product (GDP) for various regions in the world are shown in Table 2. This set of growth rates for GDP was assumed for all three price cases. The GDP growth rate assumptions are from selected issues of The WEFA Group, World Economic Outlook. The WEFA GDP growth rates have been used for all regions of the world except for the developing countries, for which the GDP growth rates have been assumed to be about 1 percentage point per year lower than the WEFA values.

The WEFA GDP forecasts are made with limited consideration of prospective energy market conditions. Our analysis indicates that economic growth by the developing countries at the rates suggested by WEFA would put upward pressures on energy production and prices (particularly for oil) that could not be sustained by the market. These high economic growth rates would lead to oil prices high enough to retard economic growth. The one-percentage-point reduction in economic growth rates for developing countries provides for a better balance between sustainable economic growth rates and growth in energy production.

The values for growth in oil demand calculated in the International Module, which depend upon the oil price levels as well as the GDP growth rates, are shown in Table 3 for the three oil price cases by regions of the world. The different rates of growth for oil consumption in the three price cases reflect the different levels in consumption calculated for the different oil prices. 
Table 2. Average Annual Regional GDP Growth Rates, 1990-2010

(Percent per Year)

\begin{tabular}{|c|c|}
\hline Region & Gross Domestic Product \\
\hline Organization for Economic Cooperation and Development. & 2.4 \\
\hline Organization of Petroleum Exporting Countries $\ldots \ldots \ldots$ & 4.2 \\
\hline Other Developing Countries . . . . . . . . . . . & 4.3 \\
\hline Eurasia $\ldots \ldots \ldots \ldots$ & 2.4 \\
\hline Total World & 2.8 \\
\hline
\end{tabular}

Source: The WEFA Group, World Economic Service and World Economic Service Historical Data (June 1992) and World Economic Outlook (February and July 1993).

Table 3. Average Annual Regional Growth Rates for Oll Demand, 1890-2010

(Percent per Year)

\begin{tabular}{|c|c|c|c|}
\hline Region & Low Price & Reference & High Price \\
\hline Organization for Economic Cooperation and Development & 0.9 & 1.2 & 1.5 \\
\hline Organization of Petroleum Exporting Countries & 2.2 & 2.2 & 2.2 \\
\hline Other Developing Countries . . . . . . . . . . . & 2.2 & 2.5 & 2.7 \\
\hline Eurasia & 0.7 & 1.2 & 1.6 \\
\hline Total World & 1.2 & 1.5 & 1.8 \\
\hline
\end{tabular}

Source: Energy Information Administration, AEO 1994 National Energy Modeling System runs: LWOP94.D1221932; AEO94B.D1221934; and HWOP94.D1221932.

Economic growth and oil consumption in Eurasia (the former Soviet Union, China, and Eastern Europe) are projected to decline through 1995, with virtually all of the decline occurring in the former Soviet Union (FSU). Oil production in the FSU is assumed to decline through 1995 but to remain well above domestic FSU oil consumption. After 1995, oil production in the FSU recovers along with oil consumption, and the FSU remains a net exporter through 2010. In contrast, China is expected to become a net importer of oil before 1995 and remain so through 2010. Currently, Eastern Europe depends on imports for most of its oil and will continue to do so. However, as a group, Eurasia is assumed to remain a net exporter of oil to the rest of the world over the entire projection period. Eurasian net oil exports approach zero by 2010 in the High Oil Price Case, 1.6 million barrels per day in the Reference Case, and 3.2 million barrels per day in the Low Oil Price Case. 


\section{Residential Demand Module}

The Residential Demand Module is based on an equipment stock approach, using accounting methods to track the number of households and the energy consuming equipment contained in these houses. The primary inputs for the module are housing starts by type (single-family, multifamily and mobile homes) and Census division and prices by fuel type and Census division. The end-use services for which equipment is tracked include space conditioning (heating and cooling), water heating, refrigeration, freezers, cooking, and clothes dryers. In addition to these major end-use services, the average unit energy consumption (UEC ${ }^{6}$ ) is tracked for secondary heating, lighting, and other electric and nonelectric appliances. The geographic coverage is the nine Census divisions. The module's output includes number of households, equipment stock, average and marginal equipment efficiencies, and energy consumed by service, fuel, and geographic location. The fuels represented are distillate fuel oil, liquefied petroleum gas, natural gas, kerosene, electricity, wood, geothermal, coal, and solar (active) energy.

\section{Key Assumptions}

\section{Housing Stock Submodule}

The key driver in the residential sector is the number of occupied households. The number of households for the base year (1990) is derived from the Energy Information Administration's (EIA) Residential Energy Consumption Survey (RECS) (Table 4). The forecast for occupied households is based on the combination of the previous year's surviving stock and housing starts provided by the National Energy Modeling System's (NEMS) Macroeconomic Activity Module (MAM). The Housing Stock Submodule assumes a constant survival rate for each type of household unit; .995 for single-family units, .99 for multifamily units, and .981 for mobile home units.

Table 4. 1990 Households

(Thousands)

\begin{tabular}{|c|c|c|c|c|}
\hline Region & $\begin{array}{l}\text { Single-family } \\
\text { Units }\end{array}$ & $\begin{array}{l}\text { Multifamily } \\
\text { Units }\end{array}$ & $\begin{array}{l}\text { Mobile Home } \\
\text { Units }\end{array}$ & $\begin{array}{l}\text { Total } \\
\text { Units }\end{array}$ \\
\hline New England & 2,532 & 1,860 & 152 & 4,544 \\
\hline Mid Atlantic & 9,334 & 4,968 & 376 & 14,679 \\
\hline East North Central & 11,250 & 4,137 & 1,224 & 16,611 \\
\hline West North Central & 4,765 & 1,307 & 385 & 6,458 \\
\hline South Atlantic & 11,703 & 3,787 & 1,068 & 16,558 \\
\hline East South Central & 4,666 & 1,278 & 487 & 6,431 \\
\hline West South Central . . . . & 7,342 & 1,640 & 325 & 9,307 \\
\hline Mountain $\ldots \ldots \ldots$ & 3,469 & 887 & 489 & 4,844 \\
\hline Pacific & 9,302 & 4,551 & 706 & 14,559 \\
\hline United Statos $\ldots \ldots \ldots$ & 64,364 & 24,415 & 5,212 & 93,991 \\
\hline
\end{tabular}

Source: Energy Information Administration, Housing Characteristics 1990, DOE/ElA-0314(90) (Washington, DC, May 1992).

${ }^{6}$ Energy consumed by a technology or service measured in million Btu per household. 
Fuel consumption is dependent not only on the number of houses, but also on the type and geographic distribution of the houses. For example, distillate oil is the most common heating fuel in New England, while natural gas dominates in the Midwest. Liquefied petroleum gas is a prevalent heating fuel among mobile homes.

\section{Technology Choice Submodule}

The key inputs in the Technology Choice Submodule are fuel prices and equipment characteristics (capital cost, efficiency, etc.) by Census division. Fuel prices are exogenous variables passed to the submodule from the various supply modules through the NEMS integration system. Equipment characteristics are exogenous variables which can be modified to reflect Federal standards and anticipated changes in the market place. Table 5 lists capital cost and efficiency for selected residential appliances for the year 1998.

Table 5. Capital Cost and Efficiency Ratings of Selected Equipment in 1998

\begin{tabular}{|c|c|c|c|}
\hline Equipment & & $\begin{array}{l}\text { Capital Cost } \\
\text { (1989 dollars) }\end{array}$ & Efficiency Rating \\
\hline \multirow{2}{*}{ Electric Heat Pump } & base $\ldots \ldots$ & 2,297 & 10.00 \\
\hline & best $\ldots \ldots \ldots$ & 3,533 & 13.30 \\
\hline \multirow{2}{*}{ Natural Gas Furnace } & base $\ldots \ldots$ & 2,232 & .78 \\
\hline & best $\ldots \ldots \ldots$ & 2,686 & .95 \\
\hline \multirow{2}{*}{ Room Air Conditioner } & base $\ldots \ldots$ & 268 & 3.11 \\
\hline & best $\ldots \ldots \ldots$ & 371 & 3.60 \\
\hline \multirow{2}{*}{ Refrigerator ( 18 cubic feet) } & base $\ldots \ldots$ & 658 & 595 \\
\hline & best $\ldots \ldots \ldots$ & 780 & 300 \\
\hline \multirow{2}{*}{ Electric Water Heater } & base $\ldots \ldots$ & 272 & .93 \\
\hline & best $\ldots \ldots \ldots$ & 349 & .96 \\
\hline
\end{tabular}

Note: Base refers to the lowest efficiency equipment available to consumers in 1998. Best refers to the highest efficiency equipment available in 1998. Efficiency measurements vary by equipment type. Electric heat pumps are based on Seasonal Energy Efficiency Ratio (SEER); natural gas furnaces are based on Annual Fuel Utilization Efficiency; room air conditioners are based on Energy Efficiency Ratio (EER); refrigerators are based on kilowatthours per year; and water heaters are based on Energy Factor (delivered Btu divided by input Btu). See Table 21 in Part II of this report for a complete description of these efficiency ratings.

Sources: Lawrence Berkeley Laboratory, "U.S. Residential Appliance Energy Efficiency: Present Status and Future Directions," 1991. Lawrence Berkeley Laboratory, "Summary and Status Report: Residential Forecasting Database," December 1992. United States Environmental Protection Agency, Space Conditioning: The Next Frontier, April 1993.

A logit function estimates each service equipment's relative weight in a given market (service, housing type, and division). These relative weights are then normalized to determine the market share for each competing technology within a service. The logit function determines the market share for each competing technology on the basis of first cost and operating cost. The relative importance of each of these factors varies by service type. The installed efficiency for a given year is calculated by weighting all competing efficiencies by its respective market share.

\section{Appliance Stock Submodule}

The Appliance Stock Submodule computes the quantity and mix of equipment installed in new construction (based on the market shares mentioned above), tracks surviving equipment installed in previous years, and calculates the number of replacement units needed in the current year. 
A "saturation/penetration" approach is used to determine equipment purchases in a given year, therefore the number of appliance purchases is a function of the number of households. The number of newly constructed houses determines the number of appliances to be installed and the market shares (developed in the Technology Choice Submodule) determine the mix of the equipment. For existing structures (any house constructed prior to the current forecast year), the difference between the number of surviving houses and the number of surviving equipment determines the number of replacement equipment needed for a given year. Based on analysis of EIA's RECS data, the module assumes that equipment is replaced with like equipment; i.e., gas furnaces are replaced with gas furnaces with characteristics (improved efficiency) of those purchased in that year.

The Appliance Stock Submodule works in conjunction with the Housing Stock Submodule to track the number of each type of equipment. Several assumptions are made in tracking the equipment stock. First, it is assumed that an appliance survives a minimum number of years after installation. Second, appliances do not survive beyond the maximum life expectancy. Between the minimum and maximum life expectancy, all appliances retire based on a linear decay function. It is further assumed that, when a house is retired from the stock, all of the equipment contained in that house retires as well; i.e., there is no second-hand market for this equipment (Table 6).

Table 6. Minimum and Maximum Life Expectancies of Equipment

\begin{tabular}{|c|c|c|}
\hline Equipment & Minimum Life & Maximum Life \\
\hline Heat Pumps $\ldots \ldots \ldots \ldots \ldots \ldots \ldots \ldots$ & 3 & 19 \\
\hline All Other Heating Systems . . . . . . . . . . . . & 5 & 35 \\
\hline Room Air Conditioners $\ldots \ldots \ldots \ldots \ldots$ & 5 & 15 \\
\hline Central Air Conditioners $\ldots \ldots \ldots \ldots \ldots$ & 5 & 19 \\
\hline Electric Water Heaters . . . . . . . . . . . . & 8 & 14 \\
\hline All Other Water Heaters $\ldots \ldots \ldots \ldots$ & 10 & 18 \\
\hline Cooking Stoves $\ldots \ldots \ldots \ldots \ldots \ldots \ldots$ & 10 & 30 \\
\hline Clothes Dryers . . . . . . . . . . . . . . . . & 5 & 15 \\
\hline Refrigerators $\ldots \ldots \ldots \ldots \ldots \ldots \ldots \ldots$ & 10 & 20 \\
\hline Freezers $\ldots \ldots \ldots \ldots \ldots \ldots \ldots \ldots \ldots$ & 10 & 22 \\
\hline
\end{tabular}

Source: Appliance Magazine, Volume 47, Number 10, Oak Brook, IL, October 1990.

\section{Fuel Consumption Submodule}

Energy consumption is calculated by multiplying the vintaged equipment stock by their respective UEC's. The various levels of aggregated consumption (consumption by fuel, by service, etc.) are derived from these basic calculations. Included within these calculations are assumptions with regard to price elasticities, shell efficiency, and the Energy Policy Act of 1992.

\section{Short Term Price Effect}

It is assumed that prices have a direct effect on energy consumption; i.e., the annual change in the price of a fuel has an inverse effect on fuel consumption. The services affected by this assumption are space heating and cooling. The current value for this price elasticity is -0.15 .

\section{Shell Efficiency}

The shell integrity of the building envelope is an important determinant of the heating and cooling load for each type of household. In the NEMS Residential Demand Module, the shell integrity is represented 
by an index, which changes over time to reflect improvements in the building shell. The shell integrity index is dimensioned by vintage of house, fuel type, service (heating and cooling), and Census division.

The age, location, and type of heating fuel are important factors in determining the level of shell integrity. The age of homes are classified by new (post-1990) and old (pre-1991). The old homes are characterized by the RECS 1990 survey and are assigned a shell index value of 1.0 for the base year (1990). The improvement over time in the shell integrity of these homes is a function of fuel prices. As fuel prices increase relative to their 1990 levels, it is assumed that the shell integrity of these homes improves. New homes are more efficient than old homes in terms of their building envelope. Based on RECS data, newer homes are roughly 10 percent more efficient than the existing stock, depending upon the heating fuel and Census division. Over time, the shell integrity of new homes is assumed to improve as tighter building codes become more widespread. The shell integrity index affects the space heating and cooling loads directly, causing a decrease in fuel consumed for these services as the shell integrity improves.

\section{Legislation}

\section{Energy Policy Act of 1992}

The Energy Policy Act of 1992 (EPACT) contains several policies which are designed to improve residential sector energy efficiency. The EPACT policies analyzed in the NEMS Residential Demand Module include the sections relating to window labeling programs, low-flow showerheads, and building codes. The impact of building codes is captured in the shell efficiency index for new buildings listed above. Other EPACT provisions, such as home energy efficiency ratings and energy-efficient mortgages, which allow home buyers to qualify for higher loan amounts if the home is energy efficient, are voluntary, and their effects on residential energy consumption have not been estimated.

The window labeling program is designed to help consumers determine which windows are most energy efficient. These labels already exist for all major residential appliances. Based on analysis of RECS data, it is assumed that the window labeling program will decrease heating loads by 8 percent and cooling loads by 3 percent. Approximately 20 percent of the housing stock is affected by this policy by 2010 .

The low-flow showerhead program is designed to cut domestic hot water use for showers. It is assumed that these showerheads cut hot water use by 50 percent for shower use. Since showers account for approximately 30 percent of domestic hot water use, total hot water use decreases by 15 percent. It is further assumed that these showerheads are installed exclusively in new construction.

\section{National Appliance Energy Conservation Act of 1987}

The Technology Choice Submodule incorporates equipment standards established by the National Appliance Energy Conservation Act of 1987 (NAECA). Some of the NAECA standards implemented in the model include: a Seasonal Energy Efficiency Rating (SEER) of 10.0 for heat pumps; an Annual Fuel Utilization Efficiency (energy output over energy input) of .78 for oil and gas furnaces; an Efficiency Factor of .88 for electric water heaters; and refrigerator standards that set consumption limits to 976 kilowatthours per year in 1990 and 691 kilowatthours per year in 1993. 


\section{Commercial Demand Module}

The National Energy Modeling System (NEMS) Commercial Demand Module generates midterm forecasts of commercial sector energy demand. The Commercial Demand Module generates consumption forecasts by fuel (electricity, natural gas, distillate fuel oil, residual fuel oil, liquefied petroleum gas (LPG), coal, motor gasoline, and kerosene) at the Census division level using prices from the NEMS energy supply modules, macroeconomic variables from the NEMS system, and external data sources.?

The commercial sector encompasses business establishments that are not engaged in industrial or transportation activities. Commercial sector energy is consumed primarily within buildings. ${ }^{8}$ The Commercial Demand Module utilizes a microsimulation approach to project energy demands in commercial buildings. Energy consumed in commercial buildings is the sum of energy required to provide specific energy services using selected technologies.

The module structure carries out a sequence of four basic steps. The first step is to forecast commercial sector floorspace. The second step is to forecast the energy services (e.g., space heating, lighting, etc.) required by that building floorspace. The third step is to select specific technologies (e.g., gas furnaces, fluorescent lights, etc.) to meet the demand for energy services. The last step is to determine how much energy will be consumed by the equipment chosen to meet the demand for energy services.

\section{Key Assumptions}

The module is composed of five submodules: Floorspace, Service Demand, Technology Choice, End-Use Consumption, and Benchmarking. The five submodules are executed sequentially in the order presented, and the outputs of each submodule are inputs to subsequently executed submodules. As a result, key forecast drivers for the Floorspace Submodule are key drivers for the Service Demand Submodule, and so on.

\section{Floorspace Submodule}

Floorspace growth is determined by the combined effect of new floorspace construction and attrition of existing stock. Total floorspace is the sum of surviving floorspace and new additions.

\section{Existing Floorspace Attrition}

Existing floorspace is the existing standing stock as reported in the Commercial Buildings Energy Consumption Survey 1989 (CBECS) (Table 7). A logistic decay function is employed to backcast the existing stock of floorspace to provide vintages of existing floorspace. Surviving floorspace forecasts for each year in the forecast are disaggregated by Census division, vintage, and building type. The shape of this function is dependent upon the values of two parameters: average building lifetime and gamma. The gamma parameter acts as a shape parameter for the logistic function that determines the acceleration of

\footnotetext{
${ }^{7}$ Energy Information Administration, Model Documentation Report: Commercial Sector Demand Module of the National Energy Modeling System, forthcoming.

${ }^{8}$ There is a small amount of commercial energy consumption (from uses such as street lights), that is not attributed to buildings.
} 
the rate of retirement around the average building lifetime. The current values for the average building lifetime and gamma parameters are 59 years and 5.4, respectively. ${ }^{9}$

Table 7. 1989 Total Floorspace from Commercial Bulldings Energy Consumption Survey (Million Square Feet)

\begin{tabular}{|c|c|c|c|c|c|c|c|c|c|c|c|c|}
\hline Roglon & Ascembly & Education & $\begin{array}{l}\text { Food } \\
\text { selves }\end{array}$ & $\begin{array}{c}\text { Food } \\
\text { Eervice }\end{array}$ & $\begin{array}{l}\text { Hearth } \\
\text { care }\end{array}$ & Lodging & $\begin{array}{l}\text { Leros } \\
\text { Omce }\end{array}$ & $\begin{array}{l}8 \text { mell } \\
\text { Omce }\end{array}$ & $\begin{array}{c}\text { Mercentiled } \\
\text { service }\end{array}$ & $\begin{array}{l}\text { Wero- } \\
\text { houve }\end{array}$ & Other & Total \\
\hline Now England. & 431 & 294 & 80 & 80 & 118 & 188 & 481 & 231 & 608 & 310 & 363 & 3,174 \\
\hline Mid-Atiantic $\ldots . .$. & 1,077 & 1,584 & 171 & 195 & 258 & 361 & 1,367 & 643 & 2,039 & 1,500 & 1,190 & 10,395 \\
\hline East North Central .. & 837 & 1,604 & 79 & 236 & 478 & 482 & 1,054 & 561 & 1,853 & 2,045 & 1,453 & 10,680 \\
\hline West North Central .. & 571 & 617 & 48 & 101 & 438 & 499 & 273 & 393 & 1,207 & 594 & 531 & 5,273 \\
\hline South Aliantic ...... & 1,063 & 971 & 113 & 145 & 232 & 548 & 1,008 & 759 & 2,049 & 1,865 & 1,338 & 10,091 \\
\hline East South Central .. & 477 & 614 & 29 & 113 & 104 & 186 & 538 & 439 & 899 & 570 & 448 & 4,296 \\
\hline Woat South Central . . & 1,281 & 848 & 134 & 113 & 135 & 520 & 413 & 658 & 1,830 & 989 & 746 & 7,668 \\
\hline Mountain ........ & 504 & 962 & 35 & 68 & 101 & 236 & 305 & 401 & 798 & 534 & 444 & 4,388 \\
\hline Pacilic $\ldots \ldots \ldots \ldots$ & 670 & 674 & 101 & 105 & 100 & 479 & 1,421 & 873 & 1.085 & 846 & 775 & 7,219 \\
\hline United Stales ...... & 6,911 & 8,078 & 791 & 1,166 & 2,052 & 3,478 & 6,840 & 4,959 & 12,368 & 9,253 & 7,288 & 63,184 \\
\hline
\end{tabular}

Source: Energy Intormatlon Administration, Commerclal Bulldings Characteristlcs 1989, DOE/ElA-0246(89) (Washington, DC, June 1991).

\section{New Construction}

The primary driver of new construction is the implied growth rates embodied in an exogenous Data Resources, Inc. (DRI) forecast of total commercial floorspace that is based on F.W. Dodge data ${ }^{10}$ provided by the NEMS Macroeconomic Activity Module (MAM). New construction is calculated by applying DRI's assumed regional building retirement rates to the DRI building types, by Census division. The surviving floorspace from the previous year is subtracted from the DRI floorspace forecast for the current year from MAM to yield new floorspace additions. In the event that the new additions computations produce a negative value for a specific building type, it is assumed to be zero. New additions are then mapped to the NEMS Commercial Demand Module's building types based on the CBECS building types shares.

The DRI Regional Building Retirement Rates are:

- Northeast: $1.30 \%$

- Midwest: $1.33 \%$

- South: $1.29 \%$

- West: $1.30 \%$

Total forecasted floorspace varies across macroeconomic cases because floorspace growth is assumed to be affected by the economic and demographic factors implied in those cases. The projected floorspace, along with year-to-year changes in the composition of the stock by Census division and building type, determine the size and energy-consuming characteristics of the commercial buildings sector.

${ }^{9}$ For a detailed discussion on the parameters estimation of the logistic decay function see Energy Information Administration, Model Documentation Report: Commercial Sector Module of the National Energy Modeling System, Volume I, forthcoming.

${ }^{10}$ F.W. Dodge, Building Stock Database Methodology and 1991 Results. Construction Statistics and Forecasts, F.W. Dodge, McGraw-Hill, Inc., p. 6. 


\section{Service Demand Submodule}

Once the building inventory is projected, the module develops a forecast of demand for energy-consuming services within buildings. The module specifically tracks the following nine services: space heating, space cooling, ventilation, water heating, lighting, cooking, office equipment, refrigeration, and other miscellaneous uses. ${ }^{11}$ The energy use intensity (EUI), measured in thousand Btu per square foot, differs across service and building type. The EUI's are based on a conditional demand analysis of CBECS consumption data.

In each forecast year, a proportion of energy-consuming equipment (5 percent) wears out in existing floorspace, leaving a gap between the energy services demanded and the equipment available to meet this demand. The efficiency of the equipment that is chosen to replace this equipment, along with the efficiency of equipment chosen for new floorspace, is reflected in the calculated average efficiency of the equipment stock.

The module also accounts for any increase or decrease in consumers' level of usage of a service in response to a change in energy prices by adjusting service demand forecasts using short-term price elasticity of demand estimates for the major fuels of electricity, natural gas, and distillate fuel. A price elasticity of -0.15 is used in the current module.

Changes in floorspace and energy prices and improvements in shell and equipment efficiency affect service demand over the forecast period.

\section{Technology Choice Submodule}

The Technology Choice Submodule calculates the results of the capital stock decisions for the major fuels, electricity, natural gas, and distillate fuel, for the current year of the forecast. Capital stock decisions are driven by commercial consumers' behavioral rules assumptions, time preferences, fuel prices, relative individual technology capital costs, and operating and maintenance (O\&M) costs.

\section{Behavioral Rules}

The commercial mocule allows the use of several possible assumptions about consumer behavior. The consumer behavior assumptions are:

1. Least Cost Behavior. This rule assumes that commercial consumers consider all pieces of equipment that meet a given service, across all fuels, when faced with a capital stock decision. The consumer chooses the piece of equipment that meets the service at the lowest annualized lifetime cost.

2. Same Fuel Behavior. This rule restricts the capitol stock decision to the set of technologies that consume the same fuel that currently ments the decisionmaker's service demand. The consumer chooses from this subset of available technologies the specific equipment that meets the service at the lowest annualized lifetime cost.

3. Same Technology Behavior. Under this rule, commercial consumers consider only the available models of the same technology and fuel that currently meets service demand, when facing a capital stock decision. Equipment choices are, therefore, restricted to the subset of models of equipment available that use the same technology and fuel as existing equipment.

\footnotetext{
"I"Other" includes communications equipment, security equipment, some appliances, tools, cash registers, elevators, water fountains, and clocks.
} 


\section{Time Preferences}

Commercial consumers are assumed to have a variety of time preferences (the value of money now vs. later). The module employs a distribution of 11 real-time preferences (premiums to the risk-free interest rate), and a proportion of commercial consumers corresponding to each time preference (Table 8).

Table 8. Distribution of Time Preference Premiums

(Percentage)

\begin{tabular}{cc}
\hline Proportion of Consumers & Time Preference Premiums \\
\hline 12.4 & $1,000.0$ \\
14.4 & 152.9 \\
16.4 & 55.4 \\
19.2 & 30.9 \\
19.6 & 19.9 \\
10.4 & 13.7 \\
3.4 & 9.4 \\
1.2 & 6.4 \\
1.0 & 4.5 \\
1.0 & 2.9 \\
1.0 & 1.5 \\
\hline
\end{tabular}

Source: Energy Information Administration, Office of Integrated Analysis and Forecasting.

\section{Technology Characterization}

The module is designed to choose among a discretf set of technologies that are exogenously characterized by commercial availability, capital costs, O\&M costs, efficiencies, and lifetime (Table 9). The module employs a technology characterization database that encapsulates all pertinent commercial sector technology data by end use, fuel, and Census division in a highly flexible format. Representative equipment is identified in the database with a technology index as well as a vintage index, the index of the fuel it consumes, the index of the service it provides, its initial market share, the Census division index for which the entry under consideration applies, its efficiency (or coefficient of performance; efficacy in the case of lighting equipment), installed capital cost per unit of service demand satisfied, operating and maintenance cost per unit of service demand satisfied, average lifetime, year of initial availability, and last year available for purchase. Equipment may only be selected to satisfy service demand if the year in which the decision is made falls within the window of availability. However, equipment acquired prior to the lapse of its availability continues to be treated as part of the existing stock and is subject to replacement or retrofitting. This flexibility in phasing equipment in and out supports alternative standards specification. The menu of equipment can be easily modified to accommodate any technological innovation, market development, and policy intervention. 
Table 9. Technologles Characteristics for Space Heating in Now England

\begin{tabular}{|c|c|c|c|c|c|}
\hline Technology Clases & Vintage & Efficiency & $\begin{array}{l}\text { Llfotime } \\
\text { (yeare) }\end{array}$ & $\begin{array}{l}\text { Capital Cost } \\
\text { (1889s per } \\
\text { MBtu/hour) }\end{array}$ & $\begin{array}{c}\text { O\&M Cost } \\
\text { (1989\$ per } \\
\text { MBtuhour } \\
\text { per year) }\end{array}$ \\
\hline Electric Boilers . . . . . . . . & 1989 & 0.98 & 20 & 7.33 & 0.48 \\
\hline Electric Baseboard & 1989 & 0.99 & 15 & 19.82 & 3.50 \\
\hline $\begin{array}{l}\text { Electric Air Source Heat } \\
\text { Pump } \ldots \ldots \ldots \ldots \ldots\end{array}$ & $\begin{array}{l}1989 \text { - average } \\
1989 \text { - high efficiency } \\
1995 \\
2000\end{array}$ & $\begin{array}{l}1.56 \\
1.64 \\
2.53 \\
2.67\end{array}$ & $\begin{array}{l}16 \\
16 \\
16 \\
16\end{array}$ & $\begin{array}{l}57.32 \\
64.39 \\
72.04 \\
79.95\end{array}$ & $\begin{array}{l}4.02 \\
4.52 \\
5.40 \\
6.00\end{array}$ \\
\hline $\begin{array}{l}\text { Electric Water Source Heat } \\
\text { Pump } \ldots \ldots \ldots \ldots \ldots\end{array}$ & 1989 & 3.50 & 15 & 79.87 & 5.41 \\
\hline Gas Fumace & $\begin{array}{l}1989 \text { - average } \\
1989 \text { - high efficiency } \\
1992 \\
2000\end{array}$ & $\begin{array}{l}0.70 \\
0.78 \\
0.80 \\
0.83\end{array}$ & $\begin{array}{l}21 \\
21 \\
21 \\
21\end{array}$ & $\begin{array}{l}6.02 \\
6.49 \\
6.83 \\
6.92\end{array}$ & $\begin{array}{l}0.26 \\
0.26 \\
0.27 \\
0.28\end{array}$ \\
\hline Gas Boilers $\ldots \ldots \ldots \ldots$ & $\begin{array}{l}1989 \text { - average } \\
1989 \text { - high efficiency } \\
1992 \\
2000\end{array}$ & $\begin{array}{l}0.70 \\
0.77 \\
0.80 \\
0.84\end{array}$ & $\begin{array}{l}25 \\
25 \\
25 \\
25\end{array}$ & $\begin{array}{l}8.47 \\
9.13 \\
9.60 \\
9.71\end{array}$ & $\begin{array}{l}0.41 \\
0.41 \\
0.44 \\
0.44\end{array}$ \\
\hline Gas Air Source Heat Pump. & $\begin{array}{l}1994 \\
2000\end{array}$ & $\begin{array}{l}1.37 \\
1.40\end{array}$ & $\begin{array}{l}15 \\
15\end{array}$ & $\begin{array}{l}127.06 \\
130.05\end{array}$ & $\begin{array}{l}6.35 \\
6.50\end{array}$ \\
\hline Oil Fumace $\ldots \ldots \ldots \ldots$ & $\begin{array}{l}1989 \text { - average } \\
1989 \text { - high efficiency } \\
1998 \\
2000\end{array}$ & $\begin{array}{l}0.72 \\
0.81 \\
0.83 \\
0.86\end{array}$ & $\begin{array}{l}15 \\
15 \\
15 \\
15\end{array}$ & $\begin{array}{l}14.75 \\
15.90 \\
17.08 \\
17.30\end{array}$ & $\begin{array}{l}0.25 \\
0.25 \\
0.27 \\
0.28\end{array}$ \\
\hline Oil Boiler ............. & $\begin{array}{l}1989 \text { - average } \\
1989 \text { - high efficiency } \\
1992 \\
2000\end{array}$ & $\begin{array}{l}0.72 \\
0.80 \\
0.85 \\
0.86\end{array}$ & $\begin{array}{l}23 \\
23 \\
23 \\
23\end{array}$ & $\begin{array}{l}19.65 \\
21.18 \\
22.20 \\
22.48\end{array}$ & $\begin{array}{l}0.41 \\
0.41 \\
0.43 \\
0.43\end{array}$ \\
\hline
\end{tabular}

$O \& M=$ Operation and maintenance.

Note: Efficiency measurements vary by equipment type. Heat pumps (gas and electric) are based on the coefficient of performance (COP). Boilers and fumaces are based upon the ratio of Btu output to Btu input.

Source: Energy Information Administration, Model Documentation Report: Commercial Sector Module of the National Energy Modeling System, Appendix A, forthcoming.

\section{Cogeneration}

Nonutility power production applications within the commercial sector are concentrated in education, health care, office, and warehouse buildings. Historical data from Form EIA-867, "Annual Nonutility Power Producer Report," is used to derive electricity cogeneration for the years 1990 and 1991 by Census division, building type, and fuel. After 1991, a forecast of electricity cogeneration, as disaggregated above, is developed through a two-step process:

1. A baseline forecast is developed by multiplying the previous year's cogeneration by a growth factor of 0.2 percent a year.

2. This baseline forecast is then adjusted to reflect changes in the relative prices of electricity and generating fuels over the forecast period. Table 10 provides the elasticities that are applied to the ratio of the electricity and generating fuels prices. 
Table 10. Elasticity of Cogeneration Demand with Respect to Electricity Prices

\begin{tabular}{c|c|c|c}
\hline Natural Gas & Distlliate Fuel Oil & Residual Fuel Oil & Steam Coal \\
\hline-0.10 & -0.10 & -0.10 & -0.10 \\
\hline
\end{tabular}

Source: Energy Information Administration, Office of Integrated Analysis and Forecasting.

For each year of the forecast period, all cogenerated electricity is assumed to be sold to the grid and, subsequently, a portion is bought back to meet part of the consumption necessary to satisfy service demands.

\section{Legislation}

A key assumption incorporated in the technology selection process is that the equipment efficiency standards described in the Energy Policy Act of 1992 (EPACT) will become operative market choices in 1993. This is modeled by modifying the technology database to eliminate equipment that no longer meets energy efficiency standards.

The efficiency standards incorporated in the module are the minimum efficiencies set forth in EPACT. They pertain to small and large commercial package air conditioners and heating equipment systems; packaged terminal air conditioners and heat pumps; storage water heaters; instantaneous water heaters; non-fired water storage tanks; fluorescent lamps and incandescent reflector lamps. Table 11 illustrates EPACT standards in lumens per watt for incandescent reflector lamps.

Table 11. EPACT Standards for Incandescent Reflector Lamps

\begin{tabular}{|c|c|}
\hline Lamp Wattage & $\begin{array}{l}\text { Minimum Average Efficiency } \\
\text { (lumens per watt) }\end{array}$ \\
\hline $40-50 \ldots \ldots \ldots \ldots \ldots \ldots$ & 10.5 \\
\hline $51-66 \ldots \ldots \ldots \ldots \ldots \ldots$ & 11.0 \\
\hline$\ldots \ldots \ldots \ldots$ & 12.5 \\
\hline $86-115$. & 14.0 \\
\hline $116-155$ & 14.5 \\
\hline $156-205 \ldots \ldots$ & 15.0 \\
\hline
\end{tabular}

Source: Energy Policy Act of 1992, Title I, Subtitle C, Sections 122 and 124. 


\section{Industrial Demand Module}

The National Energy Modeling System (NEMS) Industrial Demand Module estimates energy consumption by energy source (fuels and feedstocks) for 26 manufacturing and 6 nonmanufacturing industries. The manufacturing industries are further subdivided into the energy-intensive manufacturing industries and nonenergy-intensive manufacturing industries. The distinction between the two sets of manufacturing industries pertains to the level of modeling. The energy-intensive industries are modeled through the use of a detailed process flow accounting procedure, whereas the nonenergy-intensive, as well as the nonmanufacturing, industries are modeled through econometrically based equations (Table 12). The Industrial Demand Module forecasts energy consumption at the four Census region levels; energy consumption at the Census division level is allocated by using the State Energy Data System (SEDS) ${ }^{12}$ data, and the shares remain constant over time.

The energy-intensive industries (food and kindred products, paper and allied products, bulk chemicals, glass and glass products, hydraulic cement, blast furnace and basic steel products, and primary aluminum) are modeled in more detail with aggregate process flows. Each industry is modeled as three separate but interrelated components consisting of the Process/Assembly Component (PA), the Buildings Component (BLD), and the Boiler/Steam/Cogeneration Component (BSC). The BSC Component satisfies the steam demand from the PA and BLD Components. In some industries, the PA Component produces byproducts that are consumed in the BSC Component. For the energy-intensive industries, the PA Component is broken down into the major production processes or end uses. Petroleum refining (Standard Industrial Classification 2911) is modeled in detail in a separate module of NEMS, and the projected energy consumption is included in the manufacturing total. The forecasts for oil and gas lease and plant and cogeneration consumption (Standard Industrial Classification 1311) are exogenous to the Industrial Demand Module, but endogenous to the NEMS modeling system.

\section{Key Assumptions}

The NEMS Industrial Demand Module combines the use of a bottom-up process modeling approach with a top-down econometric approach. An energy accounting framework was developed to trace energy flows from fuels to the industry's output. An important assumption in the development of this system is the use of 1988 baseline Unit Energy Consumption (UEC) estimates based on analysis of the Manufacturing Energy Consumption Survey 1988 (MECS) ${ }^{13}$ and Standard and Poor's Major Industrial Plant Database. ${ }^{14}$ The UEC represents the energy required to produce one unit of the industry's output. The output may be defined in terms of physical units (e.g., tons of steel) or in terms of the dollar value of output.

The module depicts the seven most energy-intensive manufacturing industries (apart from petroleum refining, which is modeled in the Petroleum Market Module of NEMS) with a detailed process flow approach. The dominant process technologies are characterized by a combination of unit energy consumption estimates and "technology possibility curves." The technology possibility curves indicate the energy intensity of new and existing stock relative to the 1988 stock over time. Rates of energy efficiency improvements assumed for new and existing plants vary by industry and process. These

\footnotetext{
${ }^{12}$ Energy Information Administration, State Energy Data Report 1991, DOE/EIA-0214(91) (Washington, DC, May 1993).

${ }^{13}$ Energy Information Administration, Manufacturing Energy Consumption Surcey: Consumption of Energy 1988, DOE/ElA0512(88) (Washington, DC, May 1991).

${ }^{14}$ Standard and Poor's, Inc., Major Industrial Plant Database, 1989.
} 
Table 12. Industry Categorles

\begin{tabular}{|c|c|}
\hline Energy-Intensive Manufacturing & Nonenergy-Intensive Manufacturing (continued) \\
\hline Food and Kindred Products(SIC 20) & Leather and Leather Products(SIC 31) \\
\hline Paper and Allied Products (SIC 26) & $\begin{array}{l}\text { Other Stone, Clay, and Glass (SIC } 325,326,327 \text {, } \\
328,329 \text { ) }\end{array}$ \\
\hline Bulk Chemicals (SIC 281, 282, 286, 287) & $\begin{array}{l}\text { Other Primary Metals (all but iron and steel and } \\
\text { primary aluminum) }\end{array}$ \\
\hline Glass and Glass Products (SIC $321,322,323$ ) & Fabricated Metal Products (SIC 34) \\
\hline Hydraulic Cement (SIC 324) & Industrial Machinery and Equipment(SIC 35) \\
\hline $\begin{array}{l}\text { Blast Furnace and Basic Steol Products (SIC 331, } \\
\text { 332) }\end{array}$ & Electronics, except Computers (SIC 36) \\
\hline Primary Aluminum (SIC 3334) & $\begin{array}{l}\text { Transportation Equipment (SIC 37) } \\
\text { Instruments and Other Electric Equipment (SIC 38) }\end{array}$ \\
\hline $\begin{array}{l}\text { Nonenergy-Intensive Manufacturing } \\
\text { Tobacco Products (SIC 21) }\end{array}$ & Miscellaneous Manufacturing Industries (SIC 39) \\
\hline Textile Mill Products (SIC 22) & Nonmanufacturing Industries \\
\hline Apparel and Other Textile Products (SIC 23) & Agricultural Production - Crops (SIC 01) \\
\hline Lumber and Wood Products (SIC 24) & $\begin{array}{l}\text { Other Agriculture including Livestock (SIC } 02,07,08 \text {, } \\
09 \text { ) }\end{array}$ \\
\hline Furniture and Fixtures (SIC 25) & Coal Mining (SIC 12) \\
\hline Printing and Publishing (SIC 27) & Oil and Gas Mining (SIC 13) \\
\hline Other Chemicals (SIC 283, 284, 285, 289) & Metal and Other Nonmetallic Mining (SIC 10, 14) \\
\hline Asphalt, Coal and Miscellaneous (SIC 295, 299) & Construction (SIC 15, 16, 17) \\
\hline $\begin{array}{l}\text { Rubber and Miscellaneous Plastics Products } \\
\text { (SIC 30) }\end{array}$ & \\
\hline
\end{tabular}

SIC = Standard Industrial Classification.

Source: Energy Information Administration, Model Documentation Report: Industrial Sector Demand Module of the National Energy Modeling System, forthcoming.

assumed rates were developed using professional engineering judgments regarding the energy characteristics, year of availability, and rate of market adoption of new process technologies.

\section{Process/Assembly Component}

The Process / Assembly Component models each major manufacturing production step for the energyintensive industries. The throughput production for each process step is computed as well as the energy required to produce it.

Within this component, the Unit Energy Consumption (UEC) is adjusted based on the technology possibility curves for each step. (For example, additions to waste fiber pulping capacity are assumed to 
require only 93 percent as much energy as does the average existing plant. $)^{15}$ The technology possibility curve is a means of embodying assumptions regarding new technology adoption in the manufacturing industry and the associated increased energy efficiency of capital without characterizing individual technologies. It is unlikely that new technology is employed in all new capacity additions. Many facilities will only partially incorporate the technology or need time to debug the operating aspects of the newly installed capacity. To some extent, all industries will increase the energy efficiency of their process and assembly steps. The reasons for the increased efficiency are not likely to be directly attributable to changing energy prices but due to other exogenous factors. Since the exact nature of the technology improvement is too uncertain to model in detail, the module employs a technology possibility function. In addition, byproducts produced in the Process/Assembly Component will serve as fuels for the Boiler/Steam/Cogeneration Component. In the industrial module, byproducts are assumed to be consumed before purchased fuel.

\section{Buildings Component}

The total buildings energy demand by industry for each region is the product of the building UEC and regional industrial employment. Building UEC's were derived by first estimating energy requirements for building lighting, air conditioning, and space heating, where space heating was further divided to estimate the amount provided by direct combustion of fossil fuels and that provided by steam (Table 13). Energy consumption in the Building Component for an industry is assumed to grow at the same rate as regional employment for that industry.

\section{Boiler/Steam/Cogeneration Component}

The steam demand and byproducts from the Process/Assembly and Building Components are passed to the Boiler/Steam/Cogeneration Component, which applies a heat rate and fuel share elasticities ${ }^{16}$ to the boiler share to compute the required energy consumption. The byproduct fuels are consumed before the quantity of purchased fuels is estimated. The heat rate is estimated from the Industrial Sector Technology Use Model, and the boiler fuel shares are assumed to be those estimated using the Major Industrial Plant Database. $^{17}$

\section{Nonenergy-Intensive Industries}

The UEC's for the Process/Assembly Component of the nonenergy-intensive industries are econometrically estimated with autonomous and price-induced technical change. The autonomous trend is represented by cumulative output from existing technology. The short-term response to fuel price changes occurs by applying the estimated own- and cross-price elasticities ${ }^{18}$ to the PA UEC's to reflect the response. The cumulative output variable captures any autonomous trend over time within the industry that may affect the energy intensiveness of the production process.

\section{Technology}

The amount of energy consumption reported by the industrial module is also a function of vintage of the capital stock that produces the output. It is assumed that new vintage stock will consist of state-of-the-art technologies that are more energy efficient than the average efficiency of the existing capital stock. Consequently, the amount of energy required to produce a unit of output using new capital stock is less

\footnotetext{
${ }^{15}$ Energy Information Administration, Model Documentation Report: Industrial Sector Demand Module of the National Energy Modeling System, forthcoming.

${ }^{15}$ The fuel share elasticities for the BSC component are from Separability, Functional Form and Regulatory Policy in Models of Interfuel Substitution, Timothy J. Considine, Energy Economics, April 1989. The estimates were used for both energy intensive and nonenergy intensive industries.

${ }^{17}$ Energy and Environmental Analysis, Inc., Overview: the Industrial Sector Technology Use Model: 1STUM-2, March 1986.

${ }^{18}$ The various elasticities are documented in Energy Information Administration, Model Documentation Report: Industrial Sector Demand Module of the National Energy Modeling System, forthcoming.
} 
Table 13. Bullding Component Unit Energy Consumption

(Trillion Btw Thousand People Employed)

\begin{tabular}{|c|c|c|c|c|c|}
\hline \multirow[b]{3}{*}{ SIC } & \multirow[b]{3}{*}{ Industry } & \multicolumn{4}{|c|}{ Bullding Uee and Energy Source } \\
\hline & & \multirow{2}{*}{$\begin{array}{c}\text { Llghting } \\
\text { Eleotrlc } \\
\text { UEC }\end{array}$} & \multicolumn{3}{|c|}{ HVAC } \\
\hline & & & $\begin{array}{l}\text { Elootrle } \\
\text { UEC }\end{array}$ & $\begin{array}{c}\text { Natural Gas } \\
\text { UEC }\end{array}$ & $\begin{array}{l}\text { Steam } \\
\text { UEC }\end{array}$ \\
\hline $20 \ldots \ldots \ldots \ldots \ldots$ & $\begin{array}{l}\text { Food \& Kindred } \\
\text { Products }\end{array}$ & 0.009 & 0.006 & 0.013 & 0.062 \\
\hline $21 \ldots \ldots \ldots \ldots$ & Tobacco Products & 0.007 & 0.005 & 0.000 & 0.071 \\
\hline $22 \ldots \ldots$ & $\begin{array}{l}\text { Textiles Mill } \\
\text { Products }\end{array}$ & 0.017 & 0.014 & 0.005 & 0.033 \\
\hline $23 \ldots \ldots \ldots \ldots \ldots$ & Apparel & 0.001 & 0.002 & 0.005 & 0.009 \\
\hline $24 \ldots \ldots \ldots \ldots \ldots$ & Lumber & 0.002 & 0.006 & 0.000 & 0.031 \\
\hline $25 \ldots \ldots \ldots \ldots$ & Fumiture & 0.001 & 0.002 & 0.002 & 0.030 \\
\hline $26 \ldots \ldots \ldots \ldots$ & $\begin{array}{l}\text { Paper \& Allied } \\
\text { Product }\end{array}$ & 0.054 & 0.008 & 0.002 & 0.096 \\
\hline $27 \ldots \ldots \ldots \ldots$ & $\begin{array}{l}\text { Printing \& } \\
\text { Publishing }\end{array}$ & 0.001 & 0.008 & 0.002 & 0.016 \\
\hline $281,282,288,287 \ldots \ldots$ & Bulk Chemicals & 0.037 & 0.018 & 0.002 & 0.118 \\
\hline $283,284,285,289 \ldots \ldots$ & Other Chemicals & 0.002 & 0.001 & 0.002 & 0.002 \\
\hline $2911 \ldots \ldots \ldots \ldots$ & $\begin{array}{l}\text { Petroloum } \\
\text { Refining }\end{array}$ & 0.156 & 0.074 & 0.036 & 0.123 \\
\hline $295,299 \ldots \ldots \ldots \ldots$ & Other Petroleum & 0.002 & 0.001 & 0.001 & 0.001 \\
\hline $30 \ldots \ldots \ldots \ldots \ldots$ & Rubber & 0.005 & 0.015 & 0.002 & 0.013 \\
\hline $31 \ldots \ldots \ldots \ldots \ldots$ & Leather & 0.003 & 0.003 & 0.000 & 0.035 \\
\hline $321,322,323 \ldots \ldots \ldots$ & $\begin{array}{l}\text { Glass and Glass } \\
\text { Products }\end{array}$ & 0.148 & 0.084 & 0.030 & 0.000 \\
\hline $324 \ldots \ldots \ldots \ldots \ldots$ & Hydraulic Cement & 0.010 & 0.006 & 0.000 & 0.000 \\
\hline $325,326,327,328,329$ & $\begin{array}{l}\text { Other Stone Clay } \\
\text { and Glass }\end{array}$ & 0.005 & 0.003 & 0.002 & 0.000 \\
\hline 331, 332, өtc. $\ldots \ldots \ldots$ & $\begin{array}{l}\text { Blast Fumaces \& } \\
\text { Basic Steel }\end{array}$ & 0.788 & 0.374 & 0.957 & 1.231 \\
\hline 3334,3341 , өtc. $\ldots \ldots \ldots$ & Primary Aluminum & 0.053 & 0.025 & 0.000 & 0.007 \\
\hline $333-336,339 \ldots \ldots \ldots$ & $\begin{array}{l}\text { Other Primary } \\
\text { Metals }\end{array}$ & 0.003 & 0.001 & 0.000 & 0.004 \\
\hline$\ldots \ldots \ldots \ldots \ldots$ & Fabricated Metals & 0.006 & 0.005 & 0.012 & 0.030 \\
\hline $35 \ldots \ldots \ldots \ldots \ldots$ & $\begin{array}{l}\text { Industrial } \\
\text { Machinery }\end{array}$ & 0.006 & 0.012 & 0.000 & 0.014 \\
\hline $36 \ldots \ldots \ldots \ldots$ & $\begin{array}{l}\text { Electronic } \\
\text { Equipment }\end{array}$ & 0.006 & 0.017 & 0.001 & 0.011 \\
\hline $37 \ldots \ldots \ldots \ldots$ & $\begin{array}{l}\text { Transportation } \\
\text { Equipment }\end{array}$ & 0.010 & 0.007 & 0.003 & 0.037 \\
\hline $38 \ldots \ldots \ldots \ldots \ldots$ & Instruments & 0.004 & 0.014 & 0.001 & 0.027 \\
\hline $39 \ldots \ldots \ldots \ldots$ & $\begin{array}{l}\text { Miscellaneous } \\
\text { Manufacturing }\end{array}$ & 0.003 & 0.003 & 0.007 & 0.011 \\
\hline
\end{tabular}

SIC = Standard Industrial Classification.

UEC = Unit Energy Consumption.

HVAC = Heating, Ventilation, Air Conditioning.

Source: Energy Information Administration, Model Documentation Report: Industrial Sector Demand Module of the National Energy Modeling System, forthcoming. 
than that required by the existing capital stock. Capital stock is grouped into three vintages: old, middle, and new. The old vintage consists of capital in production prior to 1991 and is assumed to retire at a fixed rate each year (Table 14). Middle vintage capital is that which is added after 1990 but not including the year of the forecast. New production capacity is built in the forecast years when the capacity of the existing stock of capital in the industrial model cannot produce the output forecasted by the NEMS Regional Macroeconomic Model. Capital additions during the forecast horizon are retired in subsequent years at the same rate as the pre-1991 capital stock.

Table 14. Retirement Rates

\begin{tabular}{|c|c|c|c|}
\hline Industry & $\begin{array}{l}\text { Retirement Rate } \\
\text { (percent) }\end{array}$ & Induatry & $\begin{array}{l}\text { Retirement Rate } \\
\text { (percent) }\end{array}$ \\
\hline $\begin{array}{l}\text { Food and Kindred } \\
\text { Products } \ldots \ldots \ldots \ldots\end{array}$ & 1.7 & $\begin{array}{l}\text { Blast Furnace and Basic } \\
\text { Steel Products (Blast } \\
\text { Furnace/Open Hearth) }\end{array}$ & 50.0 \\
\hline Tobacco Products ...... & 4.3 & $\begin{array}{l}\text { Blast Furnace and Basic } \\
\text { Steel Products (Blast } \\
\text { Furnace/Basic Oxygen } \\
\text { Furnace) }\end{array}$ & 0.0 \\
\hline Textile Mill Products .... & 4.6 & $\begin{array}{l}\text { Blast Furnace and Basic } \\
\text { Steel Products (Electric } \\
\text { Arc Furnace) }\end{array}$ & 1.5 \\
\hline $\begin{array}{l}\text { Apparel and Other Textile } \\
\text { Products ............ }\end{array}$ & 1.9 & Primary Aluminum & 2.1 \\
\hline $\begin{array}{l}\text { Lumber and Wood } \\
\text { Products ......... }\end{array}$ & 0.7 & Other Primary Metals & 1.2 \\
\hline Furniture and Fixtures ... & 1.0 & Fabricated Metals & 2.1 \\
\hline Paper and Allied Products & 2.3 & Industrial Machinery & 2.7 \\
\hline Printing and Publishing .. & 5.4 & Electronic Equipment & 4.5 \\
\hline Bulk Chemicals & 1.9 & Transportation Equipment & 1.6 \\
\hline Other Chemicals ....... & 3.6 & Instruments & 1.5 \\
\hline $\begin{array}{l}\text { Asphalt and Miscellaneous } \\
\text { Coal Products ........ }\end{array}$ & 2.2 & $\begin{array}{l}\text { Miscellaneous } \\
\text { Manufacturing }\end{array}$ & 2.3 \\
\hline
\end{tabular}

Source: Energy Information Administration, Model Documentation Report: Industrial Sector Demand Module of the National Energy Modeling System, forthcoming.

The energy intensity of the new capital stock relative to 1990 capital stock is reflected in the parameter of the Technology Possibility Curve estimated for each of the energy-intensive industries. These curves are based on engineering judgment of the likely future path of energy intensity changes. ${ }^{19}$ The energy intensity of the existing capital stock also is assumed to decrease over time, but not as rapidly as new capital stock. The net effect is that over time the amount of energy required to produce a unit of output declines. Although total energy consumption in the industrial sector is projected to increase, overall energy intensity is projected to decrease.

\footnotetext{
${ }^{19}$ Energy Information Administration, Model Documentation Report: Industrial Sector Demand Module of the National Energy Modeling System, forthcoming.
} 


\section{Cogeneration}

Cogeneration (the generation of electricity and steam) has been a standard practice in the industrial sector for many years. The cogeneration estimates in the module are based on the assumption that the historical relationship between industrial steam demand and cogeneration will continue in the future.

Parameter estimates for cogeneration are based on regressions from a panel of pooled time series and cross sectional data. The data source is Form EIA-867, "Annual Nonutility Power Producer Report," consisting of data from approximately 400 cogenerators for 1989, 1990, and 1991.

\section{Legislation}

The Energy Policy Act of 1992 (EPACT) and the Clean Air Act Amendments of 1990 (CAAA90) contain several implications for the industrial module. These implications fall into three categories: coke oven standards; efficiency standards for boilers, furnaces, and electric motors; and industrial process technologies. The industrial module assumes the leakage standards for coke oven doors do not reduce the efficiency of producing coke or increase unit energy consumption. The industrial module uses heat rates of 1.25 (80 percent efficiency) and 1.22 ( 82 percent efficiency) for gas and oil burners respectively. These efficiencies meet the EPACT standards. The standards for electric motors call for an increase of 10 percent efficiency. The industrial module incorporates a 10-percent savings for state-of-the-art motors increasing to 20-percent savings in 2015. Given the time lag in the legislation and the expected lifetime of electric motors, no further adjustments are necessary to meet the EPACT standards for electric motors The industrial module incorporates the necessary reductions in unit energy consumption for the energyintensive industries.

\section{Emissions}

Industrial emissions are modeled for total carbon. The emissions factors that are utilized to compute the levels are consistent with those used throughout the NEMS system (Table 15). The factors are assumed to be constant throughout the forecast horizon. 
Table 15. Emlasion Factore

\begin{tabular}{|c|c|c|}
\hline Fud Typo & $\begin{array}{l}\text { Million Motrlo Tons } \\
\text { Carbon per Quadrillion Btu }\end{array}$ & $\begin{array}{l}\text { Proportion of Nonfual Uee (If Any) } \\
\text { sequentered }\end{array}$ \\
\hline 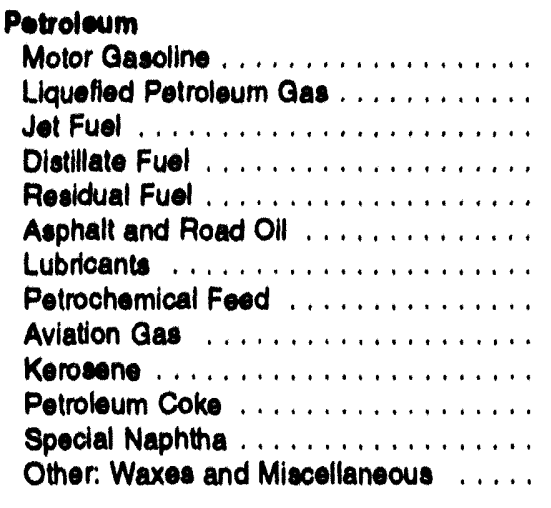 & $\begin{array}{l}19.23 \\
17.09 \\
19.27 \\
19.77 \\
21.44 \\
20.83 \\
21.00 \\
19.25 \\
19.23 \\
18.27 \\
27.04 \\
19.23 \\
20.80\end{array}$ & $\begin{array}{c}0.80 \\
: \\
\dot{0.00} \\
0.50 \\
0.80 \\
\dot{0} \\
1.00 \\
0.00 \\
1.00\end{array}$ \\
\hline $\begin{array}{l}\text { Cosl } \\
\text { Anthracite Coal } \ldots \ldots \ldots \ldots \ldots \ldots \ldots \\
\text { Bituminous Coal } \ldots \ldots \ldots \ldots \ldots \ldots \ldots \\
\text { Subbituminous Coal } \ldots \ldots \ldots \ldots \ldots \ldots \\
\text { Lignite } \ldots \ldots \ldots \ldots \ldots \ldots \ldots \ldots \ldots\end{array}$ & $\begin{array}{l}27.85 \\
25.12 \\
25.88 \\
26.35\end{array}$ & $\begin{array}{l}0.75 \\
0.75 \\
0.75 \\
0.75\end{array}$ \\
\hline $\begin{array}{l}\text { Natural Gas } \\
\text { Natural Gas } \ldots \ldots \ldots \ldots \ldots \ldots \ldots\end{array}$ & 14.39 & 0.33 \\
\hline
\end{tabular}

-The sequestered portion of nonfuel use does not emit carbon because it is permanently contained in the end product. Source: Energy intormation Administration, Emissions of Greenhouse Gases in the United States; 1985-1990, DOE/EIA-0573 (Washington, DC, Soptember 1993). 


\section{Transportation Demand Module}

The NEMS Transportation Demand Module estimates energy consumption across the 9 Census divisions and over 10 fuel types. Each fuel type is modeled according to fuel-specific technology attributes applicable by transportation mode. Total energy consumption is modeled by seven aggregate modes of transport: light-duty vehicles (cars, light trucks, and vans), freight trucks, freight and passenger airplanes, freight rail, freight shipping, mass transit, and miscellaneous transport. Light-duty vehicle fuel consumption is further subdivided into personal usage and commercial fleet consumption.

\section{Key Assumptions}

\section{Macroeconomic Sector Inputs}

Macroeconomic sector inputs used in the NEMS Transportation Demand Module (Table 16) consist of the following: gross domestic product, industrial output by Standard Industrial Classification code, personal disposable income, new car and light truck sales, total population, driving age population, total value of imports and exports, and the military budget.

Table 16. Macroeconomic Inputs to the Transportation Module

\begin{tabular}{l|r|r|r|r|r}
\hline Macroeconomic Input & 1990 & 1995 & 2000 & 2005 & 2010 \\
\hline New Car Sales (millions) . . . . . . . & 9.5 & 9.3 & 9.8 & 10.1 & 10.4 \\
New Light Truck Sales (millions) $\ldots \ldots$ & 4.4 & 5.3 & 5.7 & 6.3 & 6.5 \\
Driving Age Population (millions) . . . . & 192.7 & 202.1 & 212.8 & 223.8 & 235.4 \\
Total Population (millions) . . . . . . . . & 250.3 & 263.6 & 275.6 & 287.1 & 298.9 \\
\hline
\end{tabular}

Source: Energy Information Administration, AEO94 Forecasting System run AEO94B.D1221934.

\section{Light-Duty Vehicle Assumptions}

The vehicle sales share module holds vehicle sales shares by import and domestic manufacturers constant within a vehicle size class benchmarked to 1990 Oak Ridge National Laboratory data. ${ }^{20}$

The fuel economy module utilizes 52 new technologies for each size class based on the cost-effectiveness of each technology, and an initial availability year. The discounted stream of fuel savings is compared to the marginal cost of each technology. The fuel economy module assumes the following:

- Four-year payback period on all fuel saving technologies

- 10-percent real discount rate

- Corporate Average Fuel Efficiency (CAFE) standards remain constant at 1993 levels

${ }^{20}$ Oak Ridge National Laboratory, Transportation Energy Data Book: Edition 13, March 1993. 
- Expected future fuel prices are calculated based on an extrapolation of the growth rate between fuel prices 3 years and 5 years prior to the present year. This assumption is founded upon an assumed lead time of 3 to 5 years to significantly modify the vehicles offered by a manufacturer.

- Degradation factors (Table 17) used to convert Environmental Protection Agency (EPA) rated fuel economy to actual "on the road" fuel economy are based on application of a logistic curve to the projections of three factors: increases in city/highway driving, higher congestion levels, and rising highway speeds. ${ }^{21,22}$ Automobile and light truck degradation factors are assumed to be the same over time.

Table 17. Car and Light Truck Degradation Factors

\begin{tabular}{c|c|c|c}
\hline 1090 & 2000 & 2005 & 2010 \\
\hline .854 & .832 & .823 & .817 \\
\hline
\end{tabular}

Source: Decision Analysis Corporation of Virginia, "Fuel Dagradation Factor," Final Repont, Subtask 1, prepared for Energy Information Administration, August 3, 1992.

The vehicle miles traveled (VMT) module forecasts VMT as a function of the cost of driving per mile, income per capita, ratio of female to male VMT, and age distribution of the driving population. The ratio of female to male VMT is assumed to asymptotically approach 72 percent by 2010 . Total VMT is calibrated to Federal Highway Administration (FHWA) VMT data. ${ }^{23}$

\section{Commercial Fleet Assumptions}

With the current focus of transportation legislation on commercial fleets and their composition, the Transportation Demand Module has been designed to divide commercial fleets into three types of fleets: business, government, and utility. Based on this classification, commercial fleet vehicles vary in surviv al rates and duration in the fleet, before being folded back into the personal vehicle stock.

Sales shares of fleet vehicles by fleet type remain constant over the forecast period. Automobile fleets are divided into the following shares: business ( 85.59 percent), government $(7.09$ percent), and utilities (7.27 percent). Both car (23.17 percent) and light truck (13.95 percent) fleet sales are assumed to be a constant fraction of total vehicle sales. ${ }^{24}$

Alternative-fuel shares of fleet sales by fleet type are initially set according to historical shares, then compared to a minimum constraint level of sales based on legislative initiatives, such as the Energy Policy Act and the Low Emission Vehicle Program. ${ }^{25,26}$ Size class sales of alternative-fuel and conventional

\footnotetext{
"Maples, John D., "The Light-Duty Vehicle MPG Gap: It's Size Today and Potential limpacts in the Future," University of Tennessee Transportation Center, Knoxville, TN, May 28, 1993, Draft.

"Decision Analysis Corporation of Virginia, "Fuel Efficiency Degradation Factor," Final Report, Subtask 1, prepared for Energy Information Administration, August 3, 1992.

${ }^{23}$ U.S. Department of Transportation, Federul Highway Administration, Highway Statistics 1990, FHWA-PL-91-003, 1990.

${ }^{24}$ Oak Ridge National Laboratory, Fleet Vehicles in the United States: Composition, Operating Characteristics, and Fueling Practices, prepared for Department of Energy, Office of Transportation Technologies, and Office of Policy, Planning, and Analysis, March 1992.

${ }^{23}$ U.S. Department of Energy, Office of Domestic and International Energy Policy, Assessment of Costs and Benefits of Flexible and Alternative luel Use in the U.S. Transportation Sector, Technical Report Ten: Analysis of Alternative-Fuel Fleet Requirements, May 1992.

${ }^{26}$ California Air Resources Board, "Proposed Regulations for Low-Emission Vehicles and Clean Fuels, Staff Report," August 13, 1990
} 
vehicles are held constant at historical levels. ${ }^{27}$ (Table 18) Individual sa!es shares of alternative-fuel fleet vehicles by technology type are assumed to remain at historical levels for utility and government fleets, but vary for business fleets in accordance with the technology shares applied in the personal vehicle stocks.

Table 18. Commerclal Fleet Size Class Shares by Fleet and Vehicle Type (Percentage)

\begin{tabular}{|c|c|c|}
\hline Fleot Type by Size Class & Automoblles & Llght Trucks \\
\hline \multicolumn{3}{|l|}{ Business Fleet } \\
\hline Small & 4.55 & 37.34 \\
\hline Medium & 71.59 & 37.90 \\
\hline Large & 23.86 & 24.76 \\
\hline \multicolumn{3}{|l|}{ Government Fleet } \\
\hline Small & 4.35 & 21.34 \\
\hline$\ldots \ldots \ldots \ldots \ldots \ldots \ldots \ldots \ldots$ & 56.52 & 44.39 \\
\hline$\ldots \ldots \ldots \ldots \ldots \ldots \ldots \ldots$ & 39.13 & 34.27 \\
\hline \multicolumn{3}{|l|}{ Utility Fleet } \\
\hline$\ldots \ldots \ldots$ & 16.67 & 30.03 \\
\hline Medium & 70.00 & 38.51 \\
\hline $\operatorname{Larg}{ } \ldots \ldots \ldots \ldots \ldots \ldots \ldots \ldots$ & 13.33 & 31.46 \\
\hline
\end{tabular}

Source: Oak Ridge National Laboratory, Fleet Vehicles in the United States: Composition, Operating Characteristics, and Fueling Practices, prepared for the Department of Energy, Office of Transportation Technologies and Office of Policy, Planning, and Analysis, March 1992.

Annual VMT per vehicle by fleet type stays constant over the forecast period based on ORNL fleet data.

Fleet fuel economy for both conventional and alternative-fuel vehicles is assumed to be the same as the personal vehicle new vehicle fuel economy and is subdivided into thre? size classes.

\section{Vehicle Alternative-Fuel Technology Choice Assumptions}

The alternative-fuel technology choice module utilizes a discrete choice specification, which uses vehicle attributes as inputs and forecasts vehicle sales shares among the following 16 light-duty technologies: gasoline internal combustion engine (ICE), diesel ICE, ethanol flex, ethanol neat, methanol flex, methanol neat, electric dedicated (uses only electricity), electric hybrid with large ICE, electric hybrid with small ICE, electric hybrid with gas turbine, compressed natural gas (CNG), liquefied petroleum gas (LPG), gas turbine gasoline, gas turbine $\mathrm{CNG}$, fuel cell methanol, and fuel cell liquid hydrogen.

Listed below in Table 19 are a few examples of the input variables that correspond to the vehicle attributes used in the analysis. With the exception of vehicle fuel economy, all other attributes are exogenously set, based on offline analysis. ${ }^{28}$

\footnotetext{
${ }^{27}$ Oak Ridge National Laboratory, Fleet Vehicles in the United States: Composition, Operating Characteristics, and Fueling Practices, prepared for Department of Energy, Office of Transportation Technologies, and Office of Policy, Planning, and Analysis, March 1992.

${ }^{28}$ Science Applications International Corporation, "Alternative-Fuel Vehicle Module Database," Draft Report, Subtask 4 , prepared for Energy Information Administration, September 15, 1992.
} 
Table 19. Alternative-Fuel Vohicle Attribute Inputs For Three Stage Logit Model

\begin{tabular}{|c|c|c|c|c|c|c|c|}
\hline $\begin{array}{l}\text { Small Vehicle } \\
\text { Size Clase }\end{array}$ & Year & Gasoline & $\begin{array}{l}\text { Ethanol } \\
\text { Flex }\end{array}$ & $\begin{array}{l}\text { Methanol } \\
\text { Flox }\end{array}$ & CNG & $\begin{array}{l}\text { Electric } \\
\text { Vehicle } \\
\text { Hybrid }\end{array}$ & $\begin{array}{l}\text { Dedicated } \\
\text { Electric } \\
\text { Vehicle }\end{array}$ \\
\hline \multirow{2}{*}{$\begin{array}{l}\text { Vehicle Price (thousand } \\
1990 \text { dollars) } \ldots \ldots \ldots\end{array}$} & 1990 & 8.20 & 12.70 & 12.90 & 10.95 & $58.20^{a}$ & $53.20^{a}$ \\
\hline & 2010 & 12.18 & 12.85 & 13.05 & 13.23 & $22.81^{a}$ & $22.34^{\mathrm{a}}$ \\
\hline \multirow{2}{*}{$\begin{array}{l}\text { Vehicle MPG Relative to } \\
\text { Gasoline . . . . . . . . }\end{array}$} & 1990 & 1.00 & 1.06 & 1.10 & 0.96 & 1.42 & 1.54 \\
\hline & 2010 & 1.00 & 1.06 & 1.13 & 0.95 & 1.38 & 1.52 \\
\hline \multirow{2}{*}{$\begin{array}{l}\text { Vehicle Range } \\
(100 \text { miles }) \ldots \ldots \ldots\end{array}$} & 1990 & 3.50 & 2.60 & 2.20 & 2.25 & 2.25 & 1.08 \\
\hline & 2010 & 4.27 & 3.17 & 2.68 & 2.75 & 3.05 & 1.46 \\
\hline \multirow{2}{*}{$\begin{array}{l}\text { Fuel Availability Relative } \\
\text { to Gasoline ......... }\end{array}$} & 1990 & 1.00 & 0.01 & 0.01 & 0.01 & 0.05 & 0.05 \\
\hline & 2010 & 1.00 & 0.06 & 0.06 & 0.06 & 1.00 & 1.00 \\
\hline \multirow{2}{*}{$\begin{array}{l}\text { Emission Levels } \\
\text { Indexed to Gasoline }\end{array}$} & 1990 & 1.00 & 0.73 & 0.60 & 0.51 & 0.16 & 0.00 \\
\hline & 2010 & 1.00 & 1.19 & 1.27 & 0.87 & 1.71 & 0.01 \\
\hline \multirow{2}{*}{$\begin{array}{l}\text { Commercial Availability } \\
\text { Indexed to Gasoline . . }\end{array}$} & 1990 & 1.00 & 0.018 & 0.018 & 0.001 & 0.000 & 0.007 \\
\hline & 2010 & 1.00 & 0.998 & 0.998 & 0.924 & 0.818 & 0.993 \\
\hline
\end{tabular}

aElectric vehicle battery replacement cost included.

$\mathrm{CNG}=$ Compressed natural gas.

Source: Science Applications International Corporation, "Alternative-Fuel Vehicle Module Database," Draft Report, Subtask 4, prepared for Energy Information Administration, September 15, 1992.

Vehicle attributes vary by three size classes, and fuel availability varies by Census division. However, all vehicle attributes correspond to prototype vehicles. It is assumed that once the logit model estimates future sales shares, these shares are applicable to both cars and light trucks. Vehicle prices are assumed to represent mass production prices. All alternative-fuel vehicle fuel efficiencies are calculated relative to conventional gasoline miles per gallon. It is assumed that fuel efficiency improvements to conventional vehicles will be transferred to alternative-fuel vehicles. ${ }^{29}$ Specific individual alternative-fuel technological improvements are handled separately by varying the fuel efficiency index over time. Commercial availability estimates are assumed values according to a logistic curve based on the initial technology introduction date and were constructed in cooperation with the DOE Office of Energy Efficiency and Renewable Energy. Coefficients summarizing consumer valuation of vehicle attributes were derived from a stated preference survey conducted in California ${ }^{30}$ and are assumed to be representative of the United States.

\section{Freight Truck Assumptions}

The freight truck module converts industrial output in dollar terms to an equivalent measu:e of volume by using a freight adjustment coefficient. These freight truck adjustment coefficients vary by industrial SIC code, remaining constant over time, and are estimated from historical freight data. ${ }^{31,32}$ Freight truck

\footnotetext{
${ }^{29}$ Energy and Environmental Analysis, K.G. Duleep, initial coefficients for alternative-fuel vehicles relative to conventional vehicles were used from the Department of Energy, Office of Policy Analysis IDEAS Model.

${ }^{30}$ Bunch, David S., Mark Bradley, Thomas F. Golob, Ryuichi Kitamura, Gareth P. Occhiuzzo, "Demand for Clean-Fuel Personal Vehicles in California: A Discrete-Choice Stated Preference Survey," presented at the Conference on Transportation and Global Climate Change: Long Run Options, Asilomar Conference Center, Pacific Grove, CA, August 26, 1991.

${ }^{31}$ Decision Analysis Corporation of Va., Freight Transportation Requirements Analysis For The NEMS Transportation Sector Model, Subtask 5, P'repared for Energy Information Administration, August 3, 1992.
} 
load facturs (ton-miles per truck) by SIC code are constants formulated from historical load factors. ${ }^{33}$ Grow'th of VMT in the retail sector is assumed to be proportional to growth in total industrial output. Growth of VMT in the construction sector is assumed to be proportional to the growth in total disposable income. All freight trucks are subdivided into light, medium, and heavy-duty trucks. Freight truck fuel efficiency growth rates relative to fuel prices are tied to historical growth rates by size class. ${ }^{34}$ VMT freight estimates by size class and technology are based on historical growth rates. Fuel consumption by freight trucks is regionalized according to the State Energy Data Report 1991 distillate regional shares. ${ }^{35}$

\section{Freight and Transit Rail Assumptions}

The freight rail module receives industrial output by SIC code measured in real 1987 dollars and converts these dollars into an adjusted volume equivalent. Freight rail adjustment coefficients, which are used to convert dollars into volume equivalents, remain stant and are based on historical data. ${ }^{36,37}$ Initial freight rail efficiencies are based on the freight model from Argonne National Laboratory. ${ }^{38}$ The distribution of rail fuel consumption by fuel type remains constant and is based on historical data (Table 20). ${ }^{39}$ Regional freight rail consumption estimates are distributed according to the State Energy Data Report 1991. ${ }^{40}$

Table 20. Distribution of Rall Fuel Consumption by Fuel Type (Percent)

\begin{tabular}{|c|c|c|}
\hline Rail Transit Type & Diesel Fuel & Electricity \\
\hline Freight $\ldots \ldots \ldots \ldots \ldots \ldots \ldots \ldots \ldots$ & 100 & 0 \\
\hline \multicolumn{3}{|l|}{ Passenger } \\
\hline Transit & 0 & 100 \\
\hline Commuter ..... & 34 & 66 \\
\hline Intercity $\ldots \ldots \ldots \ldots \ldots \ldots \ldots \ldots \ldots$ & 73 & 27 \\
\hline
\end{tabular}

Source: Oak Ridge National Laboratory, Transportation Energy Databook: Edition 13, March 1993.

\section{Freight Domestic and International Shipping Assumptions}

The freight domestic shipping module also converts industrial output by SIC code measured in dollars, to a volumetric equivalent by SIC code. ${ }^{41}$ These freight adjustment coefficients are based on analysis of historical data ${ }^{42}$ and remain constant throughout the forecast period. Domestic shipping efficiencies are

\footnotetext{
${ }^{32}$ Reebie Associates, TRANSEARCH Freight Commodity Flow Database, Greenwich, Connecticut.

${ }^{33}$ Oak Ridge National Laboratory, Transportation Energy Data Book: Edition 13, March 1993.

${ }^{34}$ Oak Ridge National Laboratory, Transportation Energy Data Book: Edition 13, March 1993.

${ }^{35}$ Energy Information Administration, State Energy Data Report 1991, DOE/EIA-0214(91) (Washington, DC, May 1993).

${ }^{36}$ Decision Analysis Corporation of Va., Freight Transpoitation Requirements Analysis For The NEMS Transportation Sector Model, Su .ask 5, prepared for Energy Information Adrunistration, August 3, 1992.

${ }^{37}$ U.S. Department of Transportation, Federal Railroaci Administration, 1989 Carload Waybill Statistics; Territorial Distribution, Traffic and Revenue by Commodity Classes, September 19s! and prior issues.

${ }^{38}$ Argonne National Laboratory, Transportation Energy Demand Through 2010, 1992.

${ }^{39}$ Oak Ridge National Laboratory, Transportation Energy Data Book: Edition 13, March 1993.

${ }^{40}$ Energy Information Administration, State Energy Data Report 1991, DOE/ElA-0214(91) (Washington, DC, May 1993).

"Decision Analysis Corporation of Va., Freight Transportation Requirements Analysis For The NEMS Transportation Sector Model, Subtask 5, Prepared for Energy Information Administration, August 3, 1992.

${ }^{42}$ Army Corps of Engineers, Waterborne Commerce of the United States, Waterborne Statistics Center, New Orleans, La., 1991.
} 
based on the freight model by Argonne National Laboratory. ${ }^{43}$ The distribution of domestic and international shipping fuel consumption by fuel type remains constant throughout the analysis and is based on historical data. ${ }^{44}$ Regional domestic and international shipping consumption estimates are distributed according to the State Energy Data Report 1991 residual oil regional shares. ${ }^{45}$

\section{Air Travel Demand Assumptions}

The air travel demand module calculates the ticket price for travel as a function of fuel cost and other operating costs. Nonfuel operating costs are assumed to remain constant across the forecast horizon. ${ }^{46}$ A demographic index based on the propensity to fly was introduced into the air travel demand equation. ${ }^{47}$ The propensity to fly was made a function of the age and sex group distribution over the forecast period. ${ }^{48,49}$ The air travel demand module assumes that these relationships between the groups and their propensity to fly remain constant over time. International revenue passenger miles are a fixed percentage of domestic revenue passenger miles based on historical data. ${ }^{50}$ Load factors represented as the average number of passengers per airplane are assumed to remain constant over the forecast period.

\section{Aircraft Stock/Efficiency Assumptions}

The aircraft stock and efficiency module consists of a stock model of both wide and narrow body planes by vintage. The shifting of passenger load between narrow and wide body aircraft occurs at a constant historical annual 1-percent rate. ${ }^{51}$ The available seat-miles per plane, which measure the carrying capacity of the airplanes by aircraft type, remain constant and are based on holding the following constant within an aircraft type: airborne hours per aircraft per year, average flight speed, and the number of seats per aircraft (Table 21). The difference between the seat-miles demanded and the available seat-miles represents newly purchased aircraft. Aircraft purchases in a given year cannot change above historical annual growth rates, which sets an upper limit on the application of new aircraft to meet the gap between seat-miles demanded and available seat-miles. With a constraint on new aircraft purchases, it is assumed that when the gap exceeds historical aircraft sales levels, planes that have been temporarily stored or retired will be brought back into service. Technological availability, economic viability, and efficiency characteristics of new aircraft are based on the technologies listed in the Oaik Ridge National Laboratory Air Transport Energy Use Model..$^{52,53}$ Fuel efficiency of new aircraft acquisitions represents, at a minimum, a 5-percent improvement over the stock efficiency of surviving airplanes. ${ }^{54}$ Maximum growth rates of fuel efficiency for new aircraft are based on a future technology improvement list consisting of an estimate of the introduction year, jet fuel price, and an estimate of the proposed marginal fuel

\footnotetext{
${ }^{43}$ Argonne National Laboratory, Transportation Energy Demand Through 2010, 1992.

${ }^{44}$ Oak Ridge National Laboratory, Transportation Energy Data Book: Edition 13, March 1993.

${ }^{45}$ Energy Information Administration, State Energy Data Report 1991, DOE/ElA-0214(91) (Washington, DC, May 1993).

${ }^{46}$ U.S. Department of Transportation, Research and Special l'rograms Administration, Air Carrier Financial Statistics Quarterly and Monthly, December 1990/1989, and prior issues.

${ }^{47}$ Transportation Research Board, Forecasting Civil Aviation Activity: Methods and Approaches, Appendix A, Transportation Research Circular Number 372, June 1991

${ }^{48}$ Decision Analysis Corporation of Virginia, Proposed Methodology For Projecting Air Transportation Demand, Final Report, Subtask 2, July 8, 1992.

"Air Transport Association of America, Air Travel Survey, Washington D.C., 1990.

${ }^{50}$ U.S. Department of Transportation, U.S. International Air Travel Statistics, Transportation Systems Center, Cambridge, MA, annual $\mathrm{i}$ sues.

${ }^{51}$ U.S. Department of Transportation, Federal Aviation Administration, FAA Aviation Forecasts Fiscal Years 1993-2004, February 1993

${ }^{52}$ Oak Ridge National Laboratory, Energy Efficiency Improvement of Potential Commercial Aircraft to 2010, ORNL-6622, June 1990.

${ }^{53}$ Oak Ridge National Laboratory, Air Transport Energy Use Model, April 1991, Draft.

${ }^{5}$ U.S. Department of Transportation, Federal Aviation Administration, FAA Aviation Forecasts Fiscal Years 1993-2004, February 1993.
} 
efficiency improvement (Table 22). Regional shares of all types of aircraft fuel are assumed to be constant and are consistent with the State Energy Data Report 1991 estimate of regional jet fuel shares. ${ }^{55}$

Table 21. Constant Available Seat-Miles Assumptions by Aircraft Type

\begin{tabular}{|c|c|c|}
\hline Seat-Mile Varlable & Narrow Body Aircraft & Wide Body Aircraft \\
\hline Airborne Hours/Aircraft per Year & 2,383 & 3,336 \\
\hline Average Flight Speed (mph) . . . . & 400 & 485 \\
\hline Number of Seats/Aircraft $\ldots \ldots \ldots \ldots \ldots$ & 126 & 296 \\
\hline
\end{tabular}

Source: Federal Aviation Administration, FAA Aviation Forecasts Fiscal Years 1991-2002, FAA-APO 90-1, and previous editions.

Table 22. Future New Aircraft Technology Improvement List

\begin{tabular}{|c|c|c|c|c|}
\hline \multirow[b]{2}{*}{ Proposed Technology } & \multirow[b]{2}{*}{$\begin{array}{c}\text { Introduction } \\
\text { Year }\end{array}$} & \multirow{2}{*}{$\begin{array}{c}\text { Jet Fuel Price } \\
\text { Necessary For } \\
\text { Cost- } \\
\text { Effectlveness } \\
\text { (1987 dollars } \\
\text { per gallon) }\end{array}$} & \multicolumn{2}{|c|}{$\begin{array}{c}\text { Seat-Miles per Gallon Gain } \\
\text { Over } 1990 \\
\text { (percent) }\end{array}$} \\
\hline & & & Narrow Body & Wide Body \\
\hline \multicolumn{5}{|l|}{ Engines } \\
\hline Ultra-high Bypass & 1995 & 0.69 & 10 & 10 \\
\hline Propian $\ldots \ldots \ldots \ldots \ldots$ & 2000 & 1.36 & 23 & 0 \\
\hline \multicolumn{5}{|l|}{ Aerodynamics } \\
\hline Hybrid Laminar Flow . . . & 2020 & 1.53 & 15 & 15 \\
\hline Advanced Aerodynamics . . . . & 2000 & 1.70 & 18 & 18 \\
\hline \multicolumn{5}{|l|}{ Other } \\
\hline Weight Reducing Materials . . & 2000 & - & 15 & 15 \\
\hline Thermodynamics $\ldots \ldots \ldots$ & 2010 & 1.22 & 20 & 20 \\
\hline
\end{tabular}

Source: Greene, D.L., Energy Efficiency Improvement Potential of Commercial Aircraft to 2010, ORNL-6622, 6/1990. and from data tables in the Air Transportation Energy Use Model (ATEM), Oak Ridge National Laboratory.

\section{Legislation}

\section{Energy Policy Act of 1992}

Fleet alternative-fuel vehicle sales necessary to meet the Energy Policy Act of 1992 (EPACT) regulations come from the DOE Office of Domestic and International Energy Policy (Table 23). ${ }^{56}$ Total projected alternative-fuel vehicle sales are divided into fleets by government, utility, business, and fuel providers. The business fleets represent one-half of the DOE Office of Policy Analysis estimate, because it is assumed that only half of the business fleets are capable of being centrally fueled (refueled at the same location). Although inclusion of the business fleet is dependent upon a rulemaking by the Secretary of Energy, the assumption is that fuel displacement goals set in EPACT can only be reached by inclusion of the business fleet.

\footnotetext{
${ }^{55}$ Energy Information Administration, State Energy Data Report 1991, DOE/ElA-0214(91) (Washington, DC, May 1993).

${ }^{56}$ U.S. Department of Energy, Office of Domestic and International Energy Policy, Assessment of Costs and Benefits of Flexible and Alternative Fuel Use in the U.S. Transportation Sector, Technical Report Ten: Analysis of Alternative-Fuel Fleet Requirements, May 1992.
} 
Table 23. EPACT Alternative-Fuel Vehicle Fleet Sale Estimates

\begin{tabular}{l|l|c|c|c|c|c}
\hline Vehicle Type & Fleet Type & 1990 & 1995 & 2000 & 2005 & 2010 \\
\hline & $\begin{array}{l}\text { State and } \\
\text { Local } \\
\text { Government }\end{array}$ & 0 & 0 & 0 & 85,538 & 92,149 \\
Automobiles & $\begin{array}{l}\text { Federal } \\
\text { Government }\end{array}$ & 0 & 5,000 & 10,692 & 13,365 & 13,365 \\
& $\begin{array}{l}\text { Business } \\
\text { Fuel Provider }\end{array}$ & 0 & 64,637 & 69,633 & 405,826 & 437,189 \\
& 0 & 129,274 & 139,265 & 150,028 & 161,623 \\
\hline & State and & 0 & 0 & 0 & 19,612 & 21,128 \\
& Local \\
Government & Light Trucks & & & & & \\
& Federal \\
& Government & 0 & 5,000 & 10,692 & 13,365 & 13,365 \\
& Business & 0 & 32,319 & 34,816 & 94,612 & 101,924 \\
& Fuel Provider & 0 & 64,637 & 69,632 & 75,014 & 80,811 \\
\hline
\end{tabular}

Source: U.S. Department of Energy, Office of Domestic and International Energy Policy, Assessment of Costs and Bensfits of Flexible and Alternative Fuel Use in the U.S. Transportation Sector, Technical Report Ten: Analysis of Alternative-Fuel Fleet Requirements, May 1992.

\section{Low Emission Vehicle Program}

The Low Emission Vehicle Program (LEVP), which began in California, has now been instituted in New York and Massachusetts. The following Zero Emission Vehicle (ZEV) and Ultra-Low Emission Vehicle (ULEV) sales numbers (Table 24) come from the California Air Resources Board. ${ }^{57}$ In the Low Oil Price Case and the Reference Case, only the ZEV sales shares are used. With the High Oil Price Case, the ZEV and one-half of the ULEV sales shares are included. Only half of the ULEV sales were included, because there is uncertainty with respect to meeting the ULEV air standards with reformulated gasoline and a heated catalytic converter.

Table 24. California Low Emission Vehicle Program Legislative Mandated Alternative-Fuel Vehicle Sales

(Percentage)

\begin{tabular}{l|c|c|c|c|c|c|c}
\hline \multicolumn{1}{c|}{ Vehicle } & 1997 & 1998 & 1999 & 2000 & 2001 & 2002 & 2003 \\
\hline Ultra-Low Emission Vehicles (ULEV) & 2 & 2 & 2 & 2 & 5 & 10 & 15 \\
Zero Emission Vehicles (ZEV) &.- & 2 & 2 & 2 & 5 & 5 & 10 \\
\hline
\end{tabular}

Source: California Air Resources Board, "Proposed Regulations for Low Emission Vehicles and Clean Fuels, Staff Report," August 13, 1990.

\footnotetext{
${ }^{57}$ California Air Resources Board, "Proposed Regulations for Low Emission Vehicles and Clean Fuels, Staff Report," August 13, 1990.
} 
The alternative-fuel vehicle sales module compares these legislatively mandated sales to the results from the alternative-fuel vehicle logit market driven sales shares. The legislatively mandated sales serve as a minimum constraint to alternative-fuel vehicle sales.

\section{Emissions}

The NEMS Transportation Demand Module uses the same emissions coefficients by fuel type that are contained in the Industrial Deınand Module section. 


\section{Electricity Market Module}

The Electricity Market Module (EMM) of the National Energy Modeling System (NEMS) represents the planning, operations, and pricing of electricity in the United States. It is composed of four primary submodules-electricity capacity planning (ECP), electricity fuel dispatching (EFD), load and demand-side management (LDSM), and electricity finance and pricing (EFP). In addition, nonutility generation and supply and electricity transmission and trade are represented in the planning and dispatching submodules.

Based on fuel prices and electricity demands provided by the other modules of the NEMS, the EMM determines the most economical way to supply electricity, within environmental and operational constraints. There are assumptions about the operations of the electricity sector and the costs of various options in each of the EMM submodules. The major assumptions are summarized below.

\section{Key Assumptions}

\section{Capacity Types}

Twenty-four capacity types are presented in the EMM (Table 25).

Table 25. Capacity Types Represented in the Electricity Market Module

Capacity Type

Existing Unscrubbed Coal, sulfur dioxide standard $<=1.20$ pounds per million Btu

Existing Unscrubbed Coal, sulfur dioxide standard $<=2.50$ pounds per million Btu

Existing Unscrubbed Coal, sulfur dioxide standard $<=3.34$ pounds per million Btu

Existing Unscrubbed Coal, sulfur dioxide standard > 3.34 pounds per million Btu

Existing Scrubbed Coal to 2.5 pounds sulfur dioxide per million Btu

Existing Scrubbed Coal to 1.2 pounds sulfur dioxide per million Btu

Existing Scrubbed Coal to 0.6 pounds sulfur dioxide per million Btu

Existing Scrubbed Coal, 90 percent sulfur dioxide Removal

New High Sulfur Pulverized Coal with Wet Flue Gas Desulfurization

New Advanced Coal - Integrated Coal Gasification Combined Cycle

Oil/Gas Steam - Oil/Gas Steam Turbine

Combined Cycle - Conventional Gas/Oil Combined Cycle Combustion Turbine

New Advanced Combined Cycle - Advanced Gas/Oil Combined Cycle Combustion Turbine

Combustion Turbine - Conventional Combustion Turbine

Advanced Combustion Turbine - Steam Injected Gas Turbine

Nuclear - Evolutionary Advanced Boiling Water Reactor

Advanced Nuclear - Mid-Size Advanced Pressurized Water Reactor

Conventional Hydropower - Hydraulic Turbine

Pipeline Hydropower - Hydraulic Tumine

Pumped Storage - Hydraulic Turbine Reversible

Geothermal - Steam Turbine

Municipal Solid Waste

Biomass

Solar

Wind

Source: Energy Information Administration, Office of Integrated Analysis and Forecasting.

\section{New Fossil-Fueled Generating Plant Characteristics}

The operational characteristics of new generating technologies are the most important inputs to the ECP. The key characteristics for fossil-fueled technologies are summarized in Table 26. These characteristics are used, in combination with fuel price foresight from the NEMS Integrating Module, to compare 
resource options when new capacity is needed. The assumptions for nuclear technologies are described later in this section, while the costs and supplies of renewable generating technologies are described in the Renewable Fuels Module section.

Table 26. Characteristics of New Fossil-Fueled Generating Technologies

\begin{tabular}{|c|c|c|c|c|c|}
\hline Technology & Year Avallable & $\begin{array}{l}\text { Overnight Coote } \\
\text { (1987 dollare } \\
\text { per kllowatt) }\end{array}$ & $\begin{array}{l}\text { Heat Rate } \\
\text { (Btu per } \\
\text { kllowathour) }\end{array}$ & $\begin{array}{l}\text { Flxed O\&M } \\
\text { (1987 dollars } \\
\text { per kllowatt) }\end{array}$ & $\begin{array}{l}\text { Variable O\&M } \\
\text { (1987 dollare } \\
\text { per thousand } \\
\text { kllowatthours) }\end{array}$ \\
\hline $\begin{array}{l}\text { Pulverized Coal } \ldots \ldots \ldots \ldots \ldots \\
\text { Advanced Coal } \ldots \ldots \ldots \ldots \ldots \\
\text { Oil/Gas Steam } \ldots \ldots \ldots \ldots \ldots \\
\text { Combined-Cycle } \ldots \ldots \ldots \ldots \\
\text { Advanced Combined-Cycle } \ldots \ldots \\
\text { Combustion Turbine } \\
\text { Advanced Combustion Turbine } \ldots\end{array}$ & $\begin{array}{l}1990 \\
2000 \\
1990 \\
1990 \\
2005 \\
1990 \\
1990\end{array}$ & $\begin{array}{r}1,213 \\
1,345 \\
785 \\
486 \\
476 \\
352 \\
566\end{array}$ & $\begin{array}{r}9,856 \\
9,221 \\
9,680 \\
8,230 \\
7,869 \\
11,456 \\
9,631\end{array}$ & $\begin{array}{r}17.6 \\
33.3 \\
5.3 \\
3.7 \\
6.7 \\
0.6 \\
10.0\end{array}$ & $\begin{array}{l}4.3 \\
2.5 \\
5.2 \\
3.7 \\
2.6 \\
6.2 \\
5.0\end{array}$ \\
\hline
\end{tabular}

O\&M = Operation and maintenance.

Source: Argonne National Laboratory, "Cost and Performance Database lor Electric Power Generating Technologies."

\section{Representation of Electricity Demand}

The annual electricity demand projections from the NEMS demand modules are converted into load duration curves for each of the EMM regions (based on North American Electric Reliability Council regions and subregions) using historical hourly load data. However, unlike traditional load duration curves where the demands for an entire period would be ordered from highest to lowest, losing their chronological order, the load duration curves in the EMM are segmented into nine different time slices. The nine slices are given in Table 27. The time periods shown were mainly chosen to accommodate intermittent generating technologies (i.e., solar and wind facilities) and demand-side management programs.

Table 27. Load Segments for the Electricity Market Module

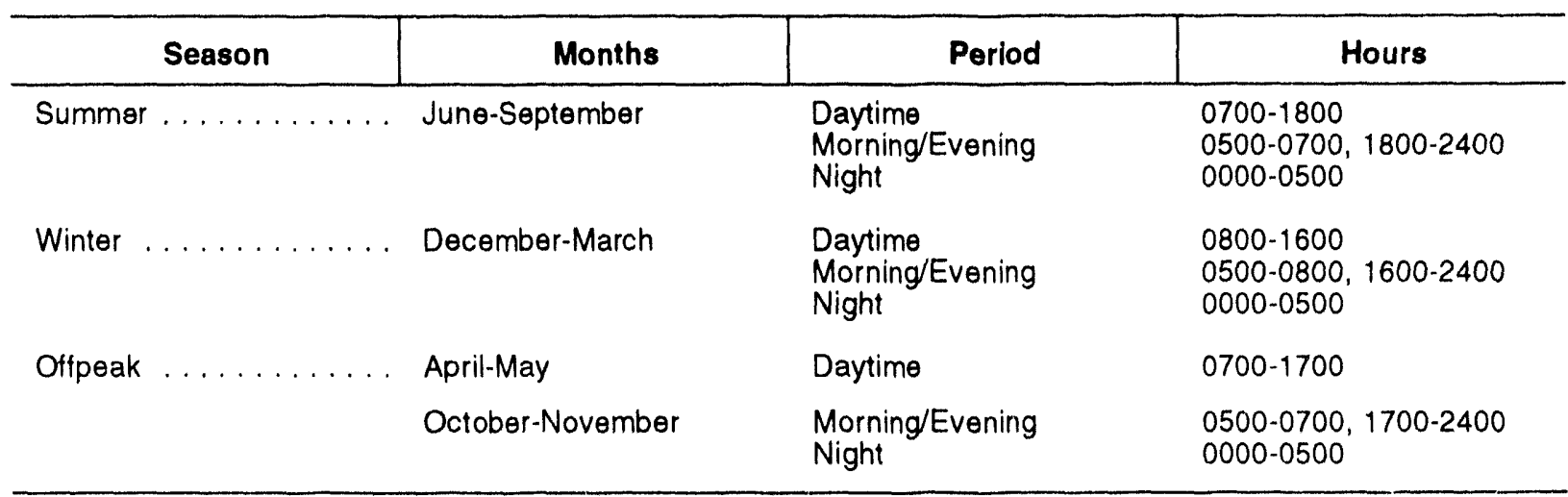

Note: The Summer and Winter Daytime and Evening periods are represented by 3 vertical slices (a peak slice and 2 off-peak slices), while all other periods are represented by 2 vertical slices (a total of 22 vertical slices).

Source: Energy Information Administration, Office of Integrated Analysis and Forecasting.

\section{Fossil Fuel-Fired Steam Plant Life Extension/Retirement}

A large number of the fossil fuel-fired steam plants operating today are approaching the end of their normal lives, typically after 40 to 45 years. However, utilities have not reported plans to retire these units and appear to be planning to utilize these plants for the foreseeable future. Fossil fuel-fired steam plants with nameplate ratings greater than or equal to 100 megawatts and with no reported retirement dates are considered eligible for life extension at capital costs (Table 28) typically lower than those of new construction. Gas and oil-fired steam plants are eligible for life extension only in the New England and 
West South Central Census divisions and the states of New York, New Jersey, Florida and California where these plants account for more than 10 percent of total generation. Regions that do not rely heavily on oil or gas generation are assumed to use other resource options more economically attractive. After 25 years of service, life extended plants are refurbished over 5 years during planned outages. In the EMM it is assumed that most of the fossil fuel-fired steam plants reaching 25 years of age (247 gigawatts of coalfired, and 96 gigawatts of oil- and gas-fired plants) will be maintained throughout the forecast period.

Table 28. Capltal Cost of Life Extension

(1987 Dollars per Kilowatt)

Fuel Type

Source: Energy Information Administration, Estimating the Capital Cost of Life Extension for Fossil-Fuel Steam Plants, DOE/EIA-0509 (Washington, DC, July 1988).

Units with nameplate capacities less than 100 megawatts are assumed to retire after 45 years of service. Approximately 60 gigawatts are retired over the forecast period. These include 14 gigawatts of retirements in 1992 to 2010 reported by utilities as well as 36 gigawatts of small fossil steam units (less than 100 megawatts capacity) retired at 45 years of age and 20 nuclear units totaling 14 gigawatts. Of the 14 gigawatts of nuclear capacity retired, 4.3 gigawatts have been reported to EIA by utilities.

\section{Nonutility Generation and Supply}

Nonutility generators (excluding cogenerators which are represented in the NEMS' refinery, oil and gas supply, and demand modules) compete with traditional electric utility supply options when new resources are needed. However, while the technology characteristics for nonutility units are assumed to be the same as those for utilities, the financial structure of nonutilities is represented differently. The break-even cost for each project is calculated based on single project financing. Based on previous analysis, the financial structure of nonutilities is assumed to be 80 percent debt and 20 percent equity. ${ }^{58}$ The cost of equity for nonutilities is assumed to be 1.5 percentage points higher than that for utilities, while the cost of debt to nonutilities is 0.75 percentage points higher.

The break-even costs of nonutility projects are compared with the levelized generation costs of utility projects in the capacity planning submodule and the most economical option is chosen. However, nonutility development is limited to reflect the debt obligation imposed on the purchasing utility. Debt rating agencies are including obligations to purchase power from nonutilities when calculating utilities' credit ratings. This inclusion of the off-balance sheet debt obligations has contributed to the downgrading of some utilities' debt. Currently, the adjusted national interest coverage ratio is approximately 2.96 , and it is allowed to fall to a low of 2.15 between 1990 and 2010 .

\section{Electricity Trade}

Both firm and economy electricity transactions among utilities in different regions are represented within the EMM. In general, firm power transactions involve the trading of capacity and energy to help another region satisfy its reserve margin requirement, while economy transactions involve energy transactions motivated by the marginal generation costs of different regions. The flow of power from region to region is constrained by the existing and planned capacity limits as reported on the April 1992 "Coordinated Bulk

\footnotetext{
${ }^{58}$ Memorandum from Lessly Goudarzi to Patricia Toner, dated January 21, 1993, Washington Consulting Group Task 92080 , "Nonutility Generation Supply Model Revisions."
} 
Power Supply Program Report" (DOE Form OE-411). Known firm power contracts are locked in for the term of the contract. In addition, in certain regions where data show an established commitment to build plants to serve another region, new plants are permitted to be built to serve the other region's needs. This option is available to compete with other resource options.

Economy transactions are determined in the dispatching submodule by comparing the marginal generating costs of adjacent regions in each time slice. If one region has less expensive generating resources available in a give time period (adjusting for transmission losses and transmission capacity limits) than another region, the regions are allowed to exchange power. The price for the economy transactions is assumed to be set by splitting the difference between the exporting and importing region's marginal generation costs.

\section{International Electricity Trade}

There are two components of international firm power trade which are represented in the EMM-existing and planned transactions, and unplanned transactions. Existing and planned transactions are obtained from the North American Electric Reliability Council regional publications of the "Coordinated Bulk Power Supply Program Report" (DOE Form OE-411). Unplanned firm power trade is represented by competing Canadian supply with U.S. domestic supply options. Canadian supply is represented via supply curves using cost data from the Department of Energy report Northern Lights: The Economic and Practical Potential of Imported Power from Canada (DOE/PE-0079).

International economy trade is determined exogenously based on historic trade relationships between the United States and Canada and Mexico and domestic demand growth expectations for each nation.

\section{Electricity Finance and Pricing}

The provisions of the Energy Policy Act of 1992 create a new class of electricity suppliers referred to as exempt wholesale generators. These exempt wholesale generators are included among nonutility producers and are assumed to have a capital structure which is highly leveraged, compared with that of investor-owned regulated utilities.

Prices for electricity are assumed to be regulated at the State level. Prices for the residential, commercial, industrial, and transportation sectors are developed by classifying costs into four categories: fuel, fixed operation and maintenance, variable operation and maintenance, and capital. These costs are allocated to each of the four customer classes using the proportion of sales to the class and each class's contribution to system peak load requirements. These allocated costs are divided by the sales to each sector to obtain electricity prices to the sector.

The costs of capital for 1990 through 1992, based on historic data, are shown in Table 29. The costs of capital for 1993 through 2010 are determined endogenously within the NEMS.

Table 29. Average Utility Cost of Capital, 1990-1992

$$
\text { (Percent) }
$$

\begin{tabular}{|c|c|c|c|}
\hline Capital Type & 1990 & 1991 & 1992 \\
\hline \multicolumn{4}{|l|}{ Equity } \\
\hline Common Stock & 12.8 & 12.5 & 12.2 \\
\hline Preferred Stock & 13.0 & 13.0 & 13.0 \\
\hline \multicolumn{4}{|l|}{ Debt } \\
\hline Privately Owned & 10.0 & 10.0 & 10.0 \\
\hline Publicly Owned & 7.0 & 7.0 & 7.0 \\
\hline
\end{tabular}

Source: Common Equity for Investor-Owned Utilities: Standard and Poor's Industry Survey, Utilities-Electric, Current Analysis, May 6, 1993. All Other: Annual Report of Major Electric Utilities, Licensees and Others, 1990-1992. 


\section{Now Nuclear Power Plant Orders}

It is assumed that four nuclear generating units currently under construction will be operational by 2010: Watts Bar 1 and 2 and Bellefonte 1 and 2. Watts Bar 1 and 2 (Tennessee Valley Authority (TVA) units) are in the active construction category, although work has yet to resume on Unit 2 . Scheduled fuel load dates for Units 1 and 2 are 1994 and 1997, respectively. It is assumed that the regulatory issues that led to the Watts Bar work stoppage will be resolved. Both units are included in the AEO94 projections, with Unit 1 assumed to begin operation in 1994 and Unit 2 in 1997.

Bellefonte 1 and 2 were removed from the indefinitely deferred status in March 1993. Engineering work has begun, with remaining construction work scheduled to resume in 1996. Unit 1 is about 80 percent complete, and Unit 2 is about 45 percent complete. Scheduled fuel load dates for Units 1 and 2 are $1998 / 99$ and 20122, respectively. The plant had been indefinitely deferred since 1988 when TVA mothballed the plant as a cost-cutting move at a time when load forecasts were flat. TVA's current demand forecasts, however, show a need for baseload capacity, including replacement capacity for an aging fossil fuel-fired generating stock. Finally, TVA is actively pursuing a carbon stabilization policy that can only be achieved by reducing their coal-fired generation. Unit 1 is assumed to begin operation in 1999 and Unit 2 in 2(X)2. It is also assumed that WNP1 and 3 and Perry 2 are canceled.

The licensing status as of year end 1992 defines unit operating life. This information includes the recoupment of construction time for those plants which have had their licenses redefined by the Nuclear Regulatory Commission. Operating plants to term assumes that there are no aging effects. This implies that the cost of operating nuclear power plants is cost-competitive with other technologies. On average, this forecast assumes no license renewal and no retirements prior to term. This assumption is based on an economic analysis of the operating lives of nuclear power plants in the United States. ${ }^{59}$

It is further assumed that no newly ordered nuclear power plants will be operational through 2010 for the following reasons:

- Concerns about the disposal of radioactive waste

- Public concerns about safety

- Concern about economic and financial risks

- Uncertainty about power plant performance

- Uncertainty in the licensing and regulatory processes.

With regard to the waste disposal issue, either a high-level waste repository, or, temporarily, a monitored retrievable storage facility is required; however, a permanent repository is not scheduled to be operational until at least 2010. A number of States have already expressed their intent, through either legislation (e.g., California), referendum (e.g., Oregon and Maine), or regulation (e.g., New York and Colorado) to not site new nuclear plants until the Federal Government has a license to operate a high-level waste repository. According to the Nuclear Waste Policy Act of 1982, DOE is to take title to nuclear waste beginning in 1998, but this provision will likely be adjudicated in the courts since a storage facility will not be available. Although DOE might finance the on-site storage of the waste pending a repository, this is only a temporary measure, and some plants are reaching the limits of their spent fuel storage facilities. Furthermore, with a number of nuclear units scheduled for retirement beginning around 2005, the lack of a high-level waste repository becomes critical for decommissioning purposes as well. According to the Nuclear Waste Policy Amendments Act of 1987, construction of a monitored retrievable storage (MRS) facility cannot begin until the Nuclear Regulatory Commission issues a construction permit for the highlevel waste repository. Under the current schedule, construction of an MRS could begin in 2004 at the earliest, and the facility would open in 2007, assuming a site is found and licensed to operate by the Nuclear Regulatory Commission. Given the history of schedule slippages in the waste repository program

\footnotetext{
${ }^{54}$ Hewlett, James G., "The Operating Costs and Longevity of Nuclear Power [Plants: Evidence from the USA, "Energy Policy, Volume 20, Number 7, July 1992.
} 
and the first-of-a-kind nature of the project, it is assumed that utilities, investors, and State regulatory commissions would not commit to a new order until an MRS was completed and available to receive waste. Assuming this occurs in 2007 and, given the 4- to 5-year construction leadtime for a new plant, an order placed in 20177 would result in an operational plant post-2010.

Public concerns about nuclear power plant operational safety and waste disposal must also be addressed. The safety concerns stem from the public's association of the technology with its weapons origin and the well-publicized accidents at operating plants, particularly at Three Mile Island and Chemobyl.

Utilities currently have an aversion to capital-intensive, long leadtime technologies. With the increased competition in electricity generation markets, especially from short leadtime, low capital cost options, this aversion is likely to increase in the future. In addition, there are substantial uncertainties associated with the costs and risks of nuclear power. Research has shown that there is a 3.5- to 4.0-percentage point risk premium associated with the common stock of utilities with nuclear power plants. ${ }^{60}$ More importantly, this risk premium is not related to construction and licensing-related issues, but rather to concerns about safety, operational factors, and decommissioning. There is growing investor concern about the escalation in decommissioning cost, early retirements, and the "stranded plant" problem. ${ }^{61}$

Additionally, even though vendors estimate competitive economics and 4- to 5-year construction leadtimes, these estimates are targets or best-case estimates. No nuclear plant to date has been built at initial estimated cost and schedule. ${ }^{62}$ Also, major parts of new midsize plants will be prefabricated and constructed modularly. This new construction approach, while likely to decrease leadtimes in follow-on units, is less flexible than the conventional approach if design changes are required and, therefore, adds uncertainty when building a first-of-a-kind unit. Also, a new plant will incorporate a large percentage of untested new technology, thereby greatly increasing the uncertainty associated with plant performance.

Given the history of ex post facto nuclear prudence reviews and cost disallowances, coupled with the high capital intensity of nuclear investments and historically long construction leadtimes, investments in nuclear technology would likely require some form of financial protection.

\section{Demand-Side Management}

Improvements in energy efficiency induced by growing energy prices, new appliance standards, and utility demand-side management programs are represented in the enduse demand models. Appliance choice decisions are a function of the relative costs and performance characteristics of a menu of technology options. Utilities have reported plans to increase their expenditures on demand-side management programs to more than $\$ 4$ billion per year by $1997 .^{63}$

\section{Fuel Price Expectations}

Capacity planning decisions for the electric power industry are based on a lifecycle cost analysis over a 30-year period. This requires foresight assumptions for fuel prices. Expected prices for coal, natural gas, and oil are derived using adaptive expectations, in which future prices are extrapolated from recent historical trends. ${ }^{\text {th }}$ Coal prices are estimated using a regression analysis based on the coal and world oil price from the previous year. For each oil product, future prices are estimated by applying a constant

\footnotetext{
${ }^{\text {sin }}$ Fuller, R., G. Hinman, and T. Lowinger, "The Impact of Nuclear Power on the Systematic Risk and Market Value of Electric Utility Common Stock," The linergy Journal, Volume 11, lssue 2

${ }^{n i}$ The stranded plant problem refers to capital-intensive plants that cannot recover all their capital costs because of the competitive pressure from lower cost plants.

${ }^{62}$ Energy Information Administration, An Analysis of Nuclear Pone'r Plant Construction Costs, DOE/EIA-0485 (Washington, DC, March 1986).

${ }^{43}$ Form ElA-861, "Annual Electric Utility Report," 1992.

${ }^{64}$ Energy Information Administration, NlMS Integrating Module Documentation Report, DOE/ElA-M057 (Washington, DC, December 1993)
} 
markup to an external forecast of world oil prices. The markups are calculated by taking the differences between the regional product prices and the world oil price for the previous forecast year. For natural gas, expected wellhead prices are based on a nonlinear function that relates the expected price to the cumulative domestic gas production. Delivered prices are developed by applying a constant markup, which represents the difference between the delivered and wellhead prices from the prior forecast year.

\section{Externality Costs}

Externality costs of $8.5,7.6$, and 0.8 mills per kilowatthour (1987 dollars) for pulverized coal, advanced coal, and gas turbines/combined cycle plants were assumed for the New York (NY) and California/Nevada (CNV) regions. Although other States have considered externality costs (e.g. Massachusetts and Wisconsin) in developing generating capacity options, they are located in regions in the EMM that include States with no externality costs. As a result, no externality costs were assumed for these multistate regions. The costs used for NY and CNV are based on the "low" cost estimates issued by the California Energy Commission. Conservative estimates were used because these costs have been changing frequently in some States that have them.

\section{Legislation}

\section{Clean Air Act Amendments of 1990}

It is assumed that electricity producers comply with the Clean Air Act Amendments of 1990, which mandate a limit of 8.95 million short tons of sulfur dioxide emissions by 2000 . Utilities are assumed to comply with the limits on sulfur emissions by retrofitting units with flue gas desulfurization (FGD) equipment, transferring or purchasing sulfur emission allowances, operating high-sulfur coal units at a lower capacity utilization rate, or switrhing to low-sulfur fuels. The costs for FGD equipment average approximately $\$ 144$ per kilowatt, in 1987 dollars, although the costs vary widely across the regions. It is also assumed that the market for trading emission allowances is allowed to operate without regulation and that the States do not further regulate the selection of coal to be used.

\section{Energy Policy Act of 1992}

The provisions of the Energy Policy Act of 1992 (EPACT) include revised licensing procedures for nuclear plants and the creation of exempt wholesale generators (EWG's).

EPACT allows the issuance of a combined construction and operating license for nuclear plants; however, it also allows for a post-construction hearing and judicial review. The uncertainty associated with waste, regulatory, and financial issues is sufficiently large to require their resolution or some manner of financial protection for investors before investments in nuclear power would take place. Unresolved, these conditions would lead to investments in alternative capacity additions or a delay in capital investment. Therefore, no newly ordered nuclear plants are assumed to become operational by 2010 .

EPACT reformed the Public Utility Holding Company Act of 1935 (PUHCA). Prior to the passage of EPACT, PUHCA required that utility holding companies register with the Securities and Exchange Commission (SEC) and restricted their business activities and corporate structures. ${ }^{65}$ Entities which wished to develop facilities in several States would be regulated under PUHCA. To avoid the stringent SEC regulation, nonutilities had to limit their development to a single State or limit their ownership share of projects to less than 10 percent. EPACT changed this by creating a class of generators which, under certain conditions, are exempt from PUHCA restrictions. These EWG's can be affiliated with an existing

\footnotetext{
${ }^{65} \mathrm{~A}$ registered utility holding company is defined as any company that owns or controls 10 percent of the voting securities of a public utility company. PUHCA defines a public utility company as any company that owns or operates generation, transmission, or distribution facilities for the sale of electricity to the public.
} 
utility (affiliated power producers) or independently owned (independent power producers). In general, subject to State commission approval, these facilities are free to sell their generation to any electric utility, but they cannot sell to a retail consumer. These EWG's are represented in NEMS.

\section{Emissions}

Emissions of sulfur dioxide, carbon, carbon dioxide, and carbon monoxide are estimated for each fuel used to generate electricity. Carbon, carbon dioxide, and carbon monoxide emissions are derived using coefficients from Energy Information Administration, Emissions of Greenhouse Gases in the United States 1985-1990), DOE/ElA-1573, September 1993. Uncontrolled sulfur dioxide emissions are calculated using the sulfur content for each fuel (passed from appropriate fuel modules). Since some sulfur from coal is retained in the boiler and not emitted into the atmosphere, the corresponding uncontrolled emission rates are reduced using retention rates from Energy Information Administration, Electric Power Annual 1991, DOE/EIA-(0348(91), February 1993.

Utilities are assumed to comply with the mandates set forth in the Clean Air Act Amendments of 1990 (CAAA9()) by reducing emissions of $\mathrm{NO}_{x}$ by 2 million tons from 1980 levels. Similarly, it is assumed that utilities will comply with CAAA90 and reduce their emissions of sulfur dioxide $\left(\mathrm{SO}_{2}\right)$ by 10 million tons over the forecast period. Consequently, the forecast assumes that the cost associated with purchasing an $\mathrm{SO}_{2}$ allowance (dollars per ton of $\mathrm{SO}_{2}$ ) is equivalent to the marginal cost of compliance (dollars per ton of $\mathrm{SO}_{2}$ removed). 


\section{Oil and Gas Supply Module}

The Oil and Gas Supply Module (OGSM) constitutes a comprehensive framework with which to analyze oil and gas supply. The OGSM provides crude oil and natural gas short-term supply parameters to both the Natural Gas Transmission and Distribution Module and the Petroleum Market Module. The OGSM simulates the activity of numerous firms that produce oil and natural gas from domestic fields throughout the United States, acquire natural gas from foreign producers for resale in the United States, or sell U.S. gas to foreign consumers.

OGSM encompasses domestic crude oil and natural gas supply by both conventional and nonconventional recovery techniques. Nonconventional recovery includes enhanced oil recovery and unconventional gas recovery from tight gas formations, devonian shale, and coalbeds. Foreign gas transactions may occur either via pipeline (Canada or Mexico) or transport ships as liquefied natural gas.

Primary inputs for the module are varied. One set of key assumptions concerns domestic economically recoverable oil and gas resources and the assumed expansion of the resource target due to the development and penetration of new technology. Another set of key assumptions concerns the response of drilling activities to changes in oil and gas prices. Other major factors affecting the projection include the start date and threshold price for the Alaskan Natural Gas Transportation System, projections for enhanced oil recovery production, supplemental gas supplies over time, and natural gas import and export capacities.

\section{Key Assumptions}

\section{Domestic Oil and Gas Economically Recoverable Resources and Technology}

Domestic oil and gas economically recoverable resources ${ }^{66}$ consist of proved reserves, ${ }^{67}$ inferred reserves, ${ }^{68}$ and undiscovered economically recoverable resources. ${ }^{69}$ OGSM employs regional estimates that are derived by EIA staff using analysis from the United States Geological Survey and the Minerals Management Service of the Department of the Interior, the National Petroleum Council, the Office of Fossil Energy of the Department of Energy, and the Potential Gas Committee. ${ }^{70}$ Published estimates were adjusted to remove intervening reserve additions resulting in estimates consistent with end-of-year 1990.

\footnotetext{
${ }^{66}$ Economically recoverable resources are those volumes considered to be of sufficient size and quality for their production to be commercially profitable by current conventional or nonconventional technologies, under specified economic conditions.

${ }^{67}$ Proned reseries are the estimated quantities that analysis of geological and engineering data demonstrate with reasonable certainty to be recoverable in future years from known reservoirs under existing economic and operating conditions.

${ }^{s 5}$ Inferred reserves are that part of expected ultimate recovery from known fields in excess of cumulative production plus current reserves

${ }^{64}$ Undiscovered resuturces are located outside oil and gas fields in which the presence of resources has been confirmed by exploratory drilling; they include resources from undiscovered pools within confirmed fields when they occur as unrelated accumulations controlled by distinctly separate structural features or stratigraphic conditions.

${ }^{70}$ Mast, Richard F, et al., United States Department of the Interior, Geological Survey and Minerals Management Service, I.stimates of Undiscovered Contentional Oil and Gas Resources in the United States-A Part of the Nation's Inergy Endoument, United States Covernment Printing Office, 1989; Cooke, Larry W., United States Department of the Interior, Minerals Management Service, Estimates of Undiscovered, Economically Reconerable Oil and Gas Resourc's for the Outer Continental Shelf, Revised as of January 1990, OCS Report MMS 91-0051, July 1991; National Petroleum Council, Committee on Natural Gas, The Potential for Natural Gas in the United States, Volume II, Source and Supply, Washington, D.C , December 1992; Fisher, William L., et al., Oil Resources Panel convened by the U.S. Department of Energy, An Assessment of the Oil Resource Base of the United States, October 1992; Potential Gas Committee, Potential Supply of Natural Gas in the United States (Decermber 31, 1992), Potential Gas Agency, Colorado School of Mines, May 1993.
} 
Expected recoverable resource estimates (Tables 30 and 31) reflect static technology and economic conditions. Within the projection period of the model, the state of technology development and penetration proceeds, thus expanding the volume of economically recoverable resources. The initial recoverable resource estimates reflect the 1990 level of technological development and penetration. The 2010 estimates are based on the assumed rate of technological progress.

Table 30. Crude Oil Recoverable Resources (Billion Barrels)

\begin{tabular}{|c|c|c|c|}
\hline \multirow[b]{2}{*}{ Crude Oil Resource Category } & \multicolumn{2}{|c|}{ Technology } & \multirow{2}{*}{$\begin{array}{c}\text { Technology } \\
\text { Improvement Rate } \\
\text { (percent) }\end{array}$} \\
\hline & 1990 Level & 2010 Level & \\
\hline Undiscovered & 43.21 & 64.22 & -. \\
\hline Onshore & 33.53 & 49.83 & 2.0 \\
\hline Offshore & 9.68 & 14.39 & 2.0 \\
\hline Inferred Reserves $\ldots \ldots \ldots \ldots$ & 26.34 & 39.45 & -. \\
\hline EOR $\ldots \ldots \ldots \ldots$ & 6.17 & 9.47 & 2.2 \\
\hline Other Onshore $\ldots \ldots \ldots$ & 17.70 & 26.30 & 2.0 \\
\hline Ofishore $\ldots \ldots \ldots \ldots \ldots \ldots \ldots$ & 2.47 & 3.68 & 2.0 \\
\hline Total Lower 48 States Unproved. & 69.55 & 103.67 &.- \\
\hline Alaska . . . . & 10.53 & 15.65 & 2.0 \\
\hline Total U.S. Unproved & 80.08 & 119.32 & -- \\
\hline Proved Reserves & 26.25 & 26.25 & -- \\
\hline Total Crude Oil & 106.33 & 145.57 & -- \\
\hline
\end{tabular}

$E O R=$ Enhanced oil recovery.

Source: Energy Information Administration, Office of Integrated Analysis and Forecasting.

\section{The Response of Drilling Activities to Price Changes}

Drilling activities in both the onshore and offshore areas of the lower 48 States respond to changes in oil and gas price levels. A change in the ratio of the wellhead oil or gas price to a constant user-specified scale factor leads to a corresponding change in the level of drilling activity relative to 1990 levels. The extent of the change is determined by user-specified response factors, formulated mathematically in the form of elasticities.

The response factors and scale factors used by the OGSM in computing the projections presented in the AEO94 are specified in Table 32.

\section{Alaskan Natural Gas}

The outlook for natural gas production from the North Slope of Alaska is affected strongly by the unique circumstances regarding its transport to market. Unlike virtually all other identified deposits of natural gas in the United States, North Slope gas lacks a means of economic transport to market. The lack of viable marketing potential at present has led to the use of Prudhoe Bay gas to maximize crude oil recovery in that field. This use is expected to delay extraction of gas for market until the post-2000 period. At that point, there is a strong expectation that rising prices will be adequate to cover costs of delivery to markets in the lower 48 States, resulting in the construction of the Alaskan Natural Gas Transportation System (ANGTS). 
Table 31. Natural Gas Recoverable Resources

(Trillion Cubic Feet)

\begin{tabular}{|c|c|c|c|}
\hline \multirow[b]{2}{*}{ Natural Gas Resource Category } & \multicolumn{2}{|c|}{ Technology } & \multirow{2}{*}{$\begin{array}{c}\text { Technology } \\
\text { Improvement Rate } \\
\text { (percent) }\end{array}$} \\
\hline & 1990 Level & 2010 Level & \\
\hline Undiscovered $\ldots \ldots \ldots \ldots \ldots \ldots \ldots$ & 356.63 & 529.93 & $\cdots$ \\
\hline$\ldots \ldots \ldots$ & 234.53 & 348.49 & 2.0 \\
\hline Ottshore $\ldots \ldots \ldots \ldots \ldots \ldots \ldots$ & 122.10 & 181.44 & 2.0 \\
\hline Inferred Reserves $\ldots \ldots \ldots \ldots \ldots \ldots$ & 145.30 & 215.91 & $\cdots$ \\
\hline Other Onshore $\ldots \ldots \ldots \ldots \ldots \ldots$ & 114.42 & 170.02 & 2.0 \\
\hline Offshore $\ldots \ldots \ldots \ldots \ldots \ldots$ & 30.89 & 45.90 & 2.0 \\
\hline Unconventional Gas Recovery & 316.63 & 470.50 & $\cdots$ \\
\hline Tight Gas $\ldots \ldots \ldots \ldots \ldots \ldots \ldots$ & 232.40 & 345.33 & 2.0 \\
\hline Devonian $\ldots \ldots \ldots \ldots \ldots \ldots$ & 21.23 & 31.55 & 2.0 \\
\hline Coalbed & 63.00 & 93.61 & 2.0 \\
\hline Total Lower 48 States Unproved . . . . . . & 818.56 & $1,216.34$ & -- \\
\hline Alaska $\ldots \ldots \ldots \ldots \ldots \ldots \ldots \ldots$ & 33.31 & 49.50 & 2.0 \\
\hline Total U.S. Unproved & 851.87 & $1,265.84$ & - \\
\hline Proved Reserves . . . . . . . . . . . . . & 169.35 & 169.35 & -- \\
\hline Total Natural Gas $\ldots \ldots \ldots \ldots$ & $1,021.22$ & $1,435.19$ & -- \\
\hline
\end{tabular}

Source: Energy Information Administration, Office of Integrated Analysis and Forecasting.

Table 32. Drilling Activity Response

\begin{tabular}{|c|c|c|c|c|c|c|c|c|}
\hline \multirow[b]{3}{*}{ Price Level } & \multicolumn{4}{|c|}{ Onshore Lower 48 States } & \multicolumn{4}{|c|}{ Offshore Lower 48 States } \\
\hline & \multicolumn{2}{|c|}{ Oll } & \multicolumn{2}{|c|}{ Natural Gas } & \multicolumn{2}{|c|}{ Oll } & \multicolumn{2}{|c|}{ Natural Gas } \\
\hline & $\begin{array}{l}\text { Resp. } \\
\text { Factor }\end{array}$ & $\begin{array}{l}\text { Scale } \\
\text { Factor }\end{array}$ & $\begin{array}{l}\text { Resp. } \\
\text { Factor }\end{array}$ & $\begin{array}{l}\text { Scale } \\
\text { Factor }\end{array}$ & $\begin{array}{l}\text { Resp. } \\
\text { Factor }\end{array}$ & $\begin{array}{l}\text { Scale } \\
\text { Factor }\end{array}$ & $\begin{array}{l}\text { Resp. } \\
\text { Factor }\end{array}$ & $\begin{array}{l}\text { Scale } \\
\text { Factor }\end{array}$ \\
\hline $\begin{array}{l}\text { Price less than } \\
\text { constant scale factor }\end{array}$ & 1 & 17.5 & 1 & 2.75 & 1 & $\begin{array}{l}\text { GOM: } 19.51 \\
\text { PAC: } 14.36\end{array}$ & 1 & $\begin{array}{l}\text { GOM: } 1.64 \\
\text { PAC: } 2.08\end{array}$ \\
\hline $\begin{array}{l}\text { Price equal to or } \\
\text { greater than } \\
\text { constant scale factor }\end{array}$ & 1 & 17.5 & 1 & 2.75 & 1 & $\begin{array}{l}\text { GOM: } 19.51 \\
\text { PAC: } 14.36\end{array}$ & 3 & $\begin{array}{l}\text { GOM: } 1.64 \\
\text { PAC: } 2.08\end{array}$ \\
\hline
\end{tabular}

GOM = Gulf of Mexico.

$P A C=$ Pacific region.

Notes: For onshore unconventional and deep gas, the price differentials observed in the base year are decreased by 5 percent annually as competitive forces operate to move the markets to a uniform clearing price. This adjustment mitigates the effect of the price response.

Source: Energy Information Administration, Office of Integrated Analysis and Forecasting. 
The estimates for gas from the North Slope that will be transported to lower 48 States markets through ANGTS are dependent on the capacity of this system. ANGTS is projected to flow gas to market in two phases, and it is assumed that production will be available to fully utilize the capacity in both phases, if constructed. Operational capacity for the first phase is 767 billion cubic feet per year delivered to the U.S./Canadian border. Annual capacity increases to 1,150 billion cubic feet upon the completion of the second phase. Operation for each phase is assumed to begin at mid-year, thus only half capacity is available for the first year of operation, with full capacity available in each year thereafter. It is assumed that ANGTS will not begin operations until 2005 at the earliest, to support oil recovery in the Prudhoe Bay field. Each phase of ANGTS is brought online in OGSM when the appropriate border-crossing price is reached for gas delivered to the lower 48 States. The price for phase one is $\$ 3.55$, in 1992 dollars per thousand cubic feet. When this price is reached, ANGTS is brought online in the following year, with a total flow of 383 billion cubic feet, reaching the full capacity of 767 billion cubic feet in subsequent years. If a higher threshold price of $\$ 4.76$, in 1992 dollars per thousand cubic feet is reached, then phase two will begin the following year. The flow will increase by 192 billion cubic feet, to 959 billion cubic feet, and in each subsequent year the flow will be 1,150 billion cubic feet. This methodology is applied in all the scenarios.

\section{Enhanced Oil Recovery}

Projections of crude oil production from enhanced oil recovery (EOR) are developed exogenously to complete the projections of total domestic oil production. Projections of EOR were derived by an interpolation (relative to the prices presented in the AEO94) of price-specific quantity projections from a National Petroleum Council study. ${ }^{11}$ The projections vary by world oil price assumption (Table 33).

Table 33. Projected EOR Production by Oil Price Case (Million Barrels per Year)

\begin{tabular}{ccccc}
\hline \multicolumn{2}{c|}{ Year } & Low Oil Price Case & Reference Case & High Oil Price Case \\
\hline $1990 \ldots \ldots \ldots \ldots \ldots \ldots$ & 239.8 & 239.8 & 239.8 \\
$1995 \quad \ldots \ldots \ldots \ldots \ldots \ldots$ & 252.6 & 252.6 & 252.6 \\
$2000 \ldots \ldots \ldots \ldots \ldots \ldots$ & 194.5 & 208.8 & 230.3 \\
$2005 \ldots \ldots \ldots \ldots \ldots$ & 150.0 & $\ldots \ldots \ldots$ & 258.8 & 287.6 \\
$2010 \ldots \ldots \ldots \ldots$ & 176.3 & 305.5 & 366.5 \\
\hline
\end{tabular}

$E O R=$ Enhanced oil recovery.

Source: Energy Information Administration, Office of Integrated Analysis and Forecasting.

\section{Supplemental Gas Supplies}

The projection for suppiemental gas supply is identified for three separate categories: synthetic natural gas (SNG) from liquids, SNG from coal, and other supplemental supplies.

Projected SNG production from liquids is based on an econometrically derived equation, with the independent variable being the regional average market price. SNG from the currently operating Great Plains Coal Gasification Plant is assumed to continue throughout the projection period, at 50 billion cubic feet per year. In all cases, it is assumed that in mid-year 2009 the Great Plains facility will close. Other supplemental supplies are held at a constant level of 53.48 billion cubic feet throughout the forecast.

\footnotetext{
${ }^{71}$ National Petroleum Council, Enhanced Oil Recovery (Washington, DC, June 1984).
} 


\section{Natural Gas Imports and Exports}

Pipeline import and export flow's from Mexico, Canadian import (from the United States) and export (to the United States) capacitie, and liquefied natural gas (LNG) imports and exports are projected exogenously to NEMS. Exogenously specified projections of pipeline import and export values from Canada and Mexico are shown below (Table 34).

Tabie 34. Natural Gas Imports and Exports

(Billion Cubic Feet per Year)

\begin{tabular}{|c|c|c|c|c|c|c|}
\hline \multirow[b]{2}{*}{ Year } & \multicolumn{2}{|c|}{ Canada } & \multicolumn{2}{|c|}{ Mexico } & \multicolumn{2}{|c|}{ Liquefied Natural Gas } \\
\hline & Imports $^{a}$ & Exports & Imports & Exports & Imports & Exports \\
\hline $1990 \ldots \ldots$ & 1,778 & 17 & 0 & 16 & 84 & 50 \\
\hline $1995 \ldots \ldots$ & 3,000 & 62 & 0 & 82 & 193 & 50 \\
\hline 2000 & 3,167 & 144 & 0 & 50 & 359 & 50 \\
\hline $2005 \ldots \ldots$ & 3,323 & 204 & 10 & 10 & 602 & 50 \\
\hline $2010 \ldots \ldots$ & 3,556 & 250 & 183 & 10 & 803 & 50 \\
\hline
\end{tabular}

${ }^{a}$ Canadian 'import' figures represent design capacity, not actual flow projections, because flows are not an assumption. Canadian import flows are determined endogenously within the model.

Source: Energy Information Administration, Office of Integrated Analysis and Forecasting.

Mexican import and export volumes for natural gas were drawn heavily from the analysis work supporting the recent National Petroleum Council study, The Potential for Natural Gas in the United States (Washington, DC, 1993).

Canadian production and exports to the United States are determined endogenously within the model. Assumed Canadian gas consumption levels (with an associated price) also affect the wellhead price by limiting the gas supply available for export to the United States. The consumption of gas in Canada was assumed to grow at 1.2 percent per year throughout the projection and in each scenario from its historical level of 2.47 trillion cubic feet in 1990 (taken from the International Energy Annual, DOE/EIA-0219(90)). Natural gas exports to Canada from the United States are expected to grow annually by 14 billion cubic feet from the 1990 level of approximately 17.4 billion cubic feet, reaching 238 billion cubic feet by 2010 . The Canadian resource base estimate used in the model for the beginning of year 1990 is 304 trillion cubic feet for gas, derived from figures published by the National Energy Board. This quantity was assumed to increase at a rate of 2 percent each projection year to reflect improvements in and penetration of technology.

LNG trade is determined exogenously to OGSM. Annual U.S. exports of LNG were assumed to be a constant 50 billion cubic feet through 2010. The outlook for LNG imports was based on a combination of influences, including available gasification capacity, announced plans by each company, tanker availability, expected utilization rates, projected gas prices and liquefaction capacity, and long-term contracts with a responsible purchaser. The outlook for LNG imports also includes an implicit assumption that no major operational or institutional difficulties arise that are not resolved expeditiously. In general, tankers were considered to be a constraining factor in the near term, but the necessary additional capacity is expected in time to support the projected flow volumes.

Currently, only two LNG import terminals are in operation: the Distrigas facility in Everett, Massachusetts, and the Trunkline facility in Lake Charles, Louisiana. The announced plans for the other two existing 
import terminals, at Cove Point, Maryland, and at Elba Island, Georgia, were the primary determinants of the time for reopening these facilities. Once in operation, continued maintenance is expected to be sufficient to keep all plants operable at the stated rates throughout the projection.

\section{Emissions}

Hydrocarbon combustion emissions are related to the estimates for industrial energy consumption. Fugitive emissions related to production are not included in the AEO94. 


\section{Natural Gas Transmission and Distribution Module}

The Natural Gas Transmission and Distribution Module (NGTDM) derives natural gas supply and end-use prices and flow patterns for movements of natural gas through the regional interstate network. The prices and flow patterns are derived by obtaining a market equilibrium across the three main components of the natural gas market: the supply component, the demand component, and the transmission and distribution network that links them. The major assumptions used within the NGTDM are divided into five general categories. They relate to (1) the classification of demand into firm and interruptible transportation service classes, (2) the pricing of transmission and distribution services, (3) the implementation of recent regulatory reform, (4) emissions associated with the transmission and distribution of natural gas, and (5) pipeline and storage capacity expansion and utilization. A complete discussion of NGTDM model assumptions is presented in Chapter 9 and Appendix F of Model Documentation Report: Natural Gas Transmission and Distribution Model of the National Energy Modeling System.

\section{Key Assumptions}

\section{Demand Classification}

Demands for natural gas are classified as either firm or interruptible service customers. Natural gas consumed by residential, commercial, and transportation end-use sectors is assumed to be transported under firm transportation rates. Natural gas consumed by industrial end users is transported under both firm and interruptible transportation service arrangements: transportation rates for natural gas consumed in industrial boilers and in refineries are assumed to be interruptible, while natural gas for all other industrial uses is assumed to be transported under firm transportation rates.

Electric utility natural gas demand is classified as either firm or interruptible. ${ }^{72}$ The interruptible service category is subdivided into services that are priced competitive with distillate fuel oil and services that are priced competitive with residual fuel oil. The classification is based on the type of utility boiler (Table 35).

Table 35. Electric Utility Natural Gas Demand Classification

\begin{tabular}{|c|c|}
\hline Service Category & Plant Type \\
\hline Firm & $\begin{array}{l}\text { Gas Steam Units } \\
\text { Gas Combined Cycle Units }\end{array}$ \\
\hline \multicolumn{2}{|l|}{ Interruptible } \\
\hline Competitive With Distillate Fuel Oil & $\begin{array}{l}\text { Gas Turbine Units } \\
\text { Dual-Fired Turbine Units }\end{array}$ \\
\hline Competitive With Residual Fuel Oil & Dual-Fired Steam Units \\
\hline
\end{tabular}

Source: Energy Information Administration, Office of Integrated Analysis and Forecasting.

\footnotetext{
${ }^{72}$ The electric utility end-use category includes gas consumption by regulated electric utilities as well as consumption of natural gas for electricity generation by nonutilities (independent power producers and wholesale electric generators). Natural gas consumption by cogenerators is included in industrial end-use consumption.
} 


\section{Pricing of Services}

Firm transportation rates for pipeline services are calculated assuming that the costs of new pipeline capacity will be rolled into the existing rate base. It is assumed that (1) prudency reviews restrict price increases for firm transportation services to less then 5 percent per year and (2) the tariff is capped at the rate reflecting a $7(0$-percent pipeline capacity utilization level.

End-use prices for residential, commercial, and firm industrial customers are derived by adding a markup to the regional hub price of natural gas associated with firm service. These markups which represent the costs of services provided by intrastate pipelines and distributors are assumed to be constant throughout the forecast (Table 36).

Table 36. Markups For Local Firm Transportation Service (1992 Dollars per Thousand Cubic Feet)

\begin{tabular}{|c|c|c|c|}
\hline Region & Residential & Commercial & Industrial \\
\hline New England & 4.42 & 3.02 & 1.06 \\
\hline Mid Atlantic . . & 3.80 & 2.51 & 0.96 \\
\hline East North Central & 2.20 & 1.64 & 0.81 \\
\hline West North Central .... & 2.02 & 1.19 & 0.30 \\
\hline South Atlantic . . . . . . & 3.32 & 2.16 & 0.39 \\
\hline East South Central .... & 2.51 & 1.87 & 0.10 \\
\hline West South Central .... & 2.72 & 1.44 & 0.12 \\
\hline Mountain ... & 1.83 & 1.18 & 0.21 \\
\hline Pacific $\ldots \ldots \ldots \ldots$ & 3.68 & 2.51 & 0.84 \\
\hline Florida & 5.89 & 2.41 & 0.64 \\
\hline Arizona/New Mexico . . . & 3.93 & 1.83 & 1.04 \\
\hline California ......... & 3.19 & 2.34 & 1.14 \\
\hline
\end{tabular}

Source: Energy Information Administration, Office of Integrated Analysis and Forecasting. Derived from Form ElA-76, "Annual Report of Natural and Supplemental Gas Supply and Disposition."

Similarly, prices for firm natural gas service to the electric utility sector are derived by adding a markup to the regional hub price of firm natural gas supplies. The markup for electric utilities is endogenously derived and is modified over the forecast period as a function of user-specified parameters. The base electric utility markup is the average of the 1990 and 1991 markup to gas steam and gas combined cycle units. This markup is derived as the difference between the NGTDM regional hub price for firm natural gas supplies and the historical regional electric utility price for gas steam units and gas combined cycle units as reported on the Federal Energy Regulatory Commission (FERC), Form FERC-423, "Monthly Report of Cost and Quality of Fuels for Electric Plants." During the forecast period, the base markup is linearly reduced so that, by 1999 , the markup is 50 percent of the average of the base value and a minimum markup. The minimum markup from the regional hub to the power plant is $\$ 0.12$ (1992 dollars per thousand cubic feet). Beyond 1999 the markup is held constant.

End-use prices for industrial interruptible service customers are a function of the price of natural gas to interruptible service customers at the regional hub and a competitive fuel price. The competitive price 
is based on a discounted weighted average price of a market basket of substitute fuels (residual and distillate fuel oil, liquefied petroleum gas, and steam coal). The regional weights applied to the prices of the substitute fuels that comprise the market basket are assumed to be constant throughout the forecast. The weights vary slightly from region to region. The average regional weights are 0.37 for distillate fuel oil, 0.33 for residual fuel oil, 0.04 for coal, and 0.26 for liquefied petroleum gas. The competitive price of natural gas is assumed to be 60 percent of the price of the market basket. This discount factor is assumed to be constant over the forecast period. In addition, the distributor markup for industrial interruptible service is bounded below by $\$ .12$ (1992 dollars per thousand cubic feet) and bounded above by the industrial firm service markup.

In the electric generation sector, the derivation of the competitive natural gas price employs a discount from the price of competing fuels (residual or distillate fuel oil). The discount factor is endogenously derived as a function of natural gas and fuel oil consumption levels in the electric generation sector. The end-use price is bounded by a minimum price equal to the sum of the interruptible regional hub price and a $\$ 0.12$ (1992 dollars per thousand cubic feet) markup for delivery of the supplies from the hub to the power plant.

Compressed natural gas (CNG) used as a vehicle fuel is assumed to compete with motor gasoline in the transportation market. Thus, the distributor markup is a function of the gasoline price, as well as the cost of natural gas at the city gate, and the cost of dispensing CNG at the refueling station. The end-use price for CNG after taxes is set below the motor gasoline price (in Btu equivalent units) after taxes, as long as necessary costs are covered. It is assumed that CNG is delivered to the refueling station under firm service transportation rates and the cost of dispensing the fuel is $\$ 0.40$ (1992 dollars per gallon equivalent). The Federal tax on CNG is equivalent to the \$0.043-per-gallon tax increase on gasoline as required in the Budget Reconciliation Act of 1993. For CNG, the markup from the firm service city gate price to the enduse price after taxes is set at 90 percent of the difference between the motor gasoline price (in Btu equivalent units) after taxes and the city gate price. This pricing methodology is phased in over a 5-year period to reflect the gradual phase-out of local incentive programs used to demonstrate CNG vehicles.

\section{Capacity Expansion and Utilization}

The model methodology assumes that pipeline and storage capacity is available 2 years from the decision to add new capacity. Average capital costs for pipeline expansion are assumed to be $\$ 1.51$ (1992 dollardays per thousand cubic feet-miles) for compression, $\$ 1.69$ for looping, and $\$ 2.17$ for new pipe. The average costs are regionalized by applying regional cost factors reflecting differences in terrain and labor costs.

It is assumed that pipelines and local distribution companies build and subscribe to a portfolio of pipeline and storage capacity to serve a 15-percent-colder-than-normal winter demand level. Annual maximum pipeline capacity utilization is assumed to be limited to 95 percent of the design capacity (with the exceptions of capacity into Florida and California which is limited to 100 percent of design capacity). The level and composition of demand as well as the availability and price of supplies may cause realized pipeline utilization levels to be lower than the maximum.

Additions to underground storage capacity are constrained to capture limitations of geology in each of the market regions. The constraints limit total storage additions to be less than an expansion factor times the 1990 storage capacity (Table 37).

The model methodology assumes that storage utilization plans are developed annually and that all natural gas is injected into storage in the off-peak period and is withdrawn during the peak period. Annual net storage withdrawals equal zero in all years of the forecast. 
Table 37. Incremental Storage Expansion Factors (Over Existing Lovels)

\begin{tabular}{|c|c|}
\hline Region & Expansion Factor \\
\hline 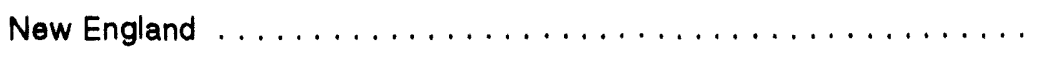 & 0 \\
\hline 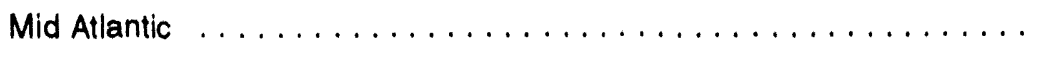 & 2.33 \\
\hline East North Central $\ldots \ldots \ldots \ldots \ldots \ldots \ldots \ldots \ldots \ldots$ & 3.00 \\
\hline West North Central . . . . . . . . . . . . . . . . . . . . . & 1.00 \\
\hline 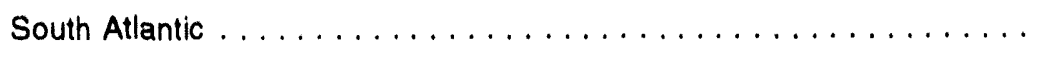 & 0.50 \\
\hline East South Central $\ldots \ldots \ldots \ldots \ldots \ldots \ldots \ldots \ldots \ldots$ & 7.00 \\
\hline West South Central . . . . . . . . . . . . . . . . . . . . . . & 3.00 \\
\hline 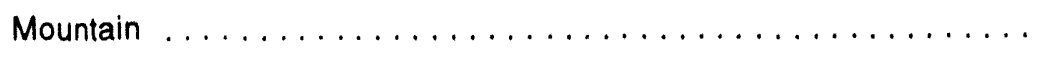 & 1.00 \\
\hline 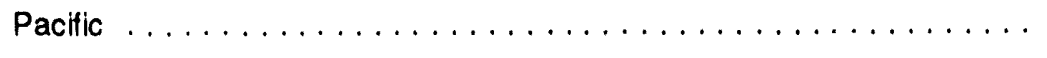 & 1.00 \\
\hline 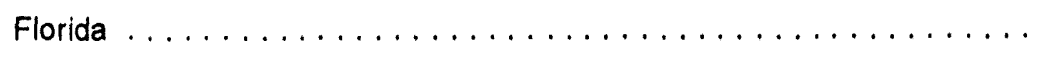 & 0 \\
\hline Arizona/New Mexico $\ldots \ldots \ldots \ldots \ldots \ldots \ldots \ldots \ldots \ldots$ & 0.33 \\
\hline 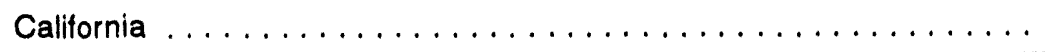 & 0.25 \\
\hline
\end{tabular}

Source: Energy Information Administration, Office of Integrated Analysis and Forecasting.

\section{Legislation and Regulation}

All interstate pipeline companies are assumed to have completed the switch from modified fixed variable (MFV) to straight fixed variable (SFV) rate design by January 1994 to comply with Federal Energy Regulatory Commission (FERC) Order 636 rate design changes. Approved transition costs are assumed to be consistent with FERC's revised cost estimate as published by the General Accounting Office in Natural Gas: Costs, Benefits, and Concerns Related to FERC Order 636, Final Report, November 1993 (Table 38). It is assumed that the Gas Supply Realignment (GSR) costs will be recovered over a 5-year period beginning in 1994. Furthermore, it is assumed that 90 percent of these costs will be assigned to firm transportation markets and 10 percent will be assigned to interruptible markets as stipulated in Order 636. Purchased Gas Adjustment Account Balance (Account 191) costs are assumed to be collected over a 2-year period, also beginning in 1994 . These costs will be paid only by firm transportation customers.

The AEO94 methodology employed in solving for the natural gas supply and demand equilibrium assumes that marginal costs are the basis for determining market-clearing prices throughout the forecast period. Although marginal cost pricing is currently inconsistent with past and most current practices which use average cost pricing, a number of recent events point to a trend toward marginal pricing in the gas industry. In addition to various aspects of Order 636, State Public Service Commissions are reviewing and advocating unbundling in the local distribution company (LDC) markets. To meet competition, crosssubsidization among customer classes is being eliminated, the market is being segmented for marketing purposes, LDC gas services are being unbundled, and gas service prices are being determined through competition. These factors lead to prices that reflect marginal pricing by customer class. How broadly and how rapidly marginal cost pricing is adopted throughout the natural gas industry is largely a function of implementation of recent FERC rulemaking, the level of activity in capacity release markets, and changes in State-level regulations. 
Table 38. FERC Order 636 Transition Costs by Pipeline Company (1992 Dollars)

\begin{tabular}{|c|c|c|c|}
\hline Interstate Pipeline Company & $\begin{array}{c}\text { Purchased Gas } \\
\text { Adjustment Account } \\
\text { Balance }\end{array}$ & $\begin{array}{l}\text { Cas Supply } \\
\text { Realignment }\end{array}$ & Total \\
\hline Algonquin Gas Transmission Co. ........ & 0 & 0 & 0 \\
\hline ANA Ppoline Company & 0 & $229,862,348$ & $229,862,348$ \\
\hline$\ldots \ldots \ldots \ldots \ldots$ & 97,814 & $29,344,130$ & $29,441,943$ \\
\hline Colorado Interstate Gas Co. $\ldots \ldots \ldots \ldots$ & 0 & $5,868,826$ & $5,868,826$ \\
\hline CNa Transmission Corp. ............ & $78,251,012$ & $33,256,680$ & $111,50 \%, 692$ \\
\hline Columbla Gas Tramsmission Corp. ....... & $171,174,089$ & 0 & $171,174,089$ \\
\hline Columbta Gull Transmission Corp. ....... & 0 & 0 & 0 \\
\hline East Tennessee Natural Gas Co. ........ & 0 & 0 & 0 \\
\hline El Paso Natural Gas Co. ............. & 0 & 0 & 0 \\
\hline Florlda Gas Transmission Co. $\ldots \ldots \ldots$ & 0 & $52,819,433$ & $52,819,433$ \\
\hline Great Lakes Gas Transmission Co. . . . . . & 0 & 0 & 0 \\
\hline Kern River Gas Transmlssion Co. ....... & 0 & 0 & 0 \\
\hline K.N Energy, Inc. . . . . . . . . . . & 0 & $244,534,413$ & $244,534,413$ \\
\hline Midwestern Gas Transmission Co. ....... & 0 & 0 & 0 \\
\hline Mississippl River Transmission Corp. . . . . . & 0 & $24,453,441$ & $24,453,441$ \\
\hline National Fuel Gas Supply Corp. ........ & 0 & 0 & 0 \\
\hline Natural Gas Pipelline Company of America & 0 & $537,975,709$ & $537,975,709$ \\
\hline Northem Border Plpeline Company ...... & 0 & 0 & 0 \\
\hline Northem Natural Gas Co. . . . . . . . & 0 & 0 & 0 \\
\hline Northwest Pipelline Corp. ............ & 48,907 & 19,500 & 68,407 \\
\hline Pactlic Gas Transmlssion Co. . . . . . . . & 0 & 0 & 0 \\
\hline Panhandle Eastern Pipe Line Co. . . . . . . & $19,562,753$ & $48,906,883$ & $68,469,636$ \\
\hline Questar Pipeline Co. . . . . . . . . . . & 0 & 0 & 0 \\
\hline Southem Natural Gas Co $\ldots \ldots \ldots \ldots$ & 0 & $465,593,522$ & $465,593,522$ \\
\hline Tennessee Gas Ppelline Co. . . . . . . . . & $120,897,814$ & $432,336,842$ & 553.234 .656 \\
\hline$\ldots \ldots \ldots \ldots \ldots$ & $83,028,212$ & $546,778,947$ & $629,807,159$ \\
\hline Texas Gas Transmission Corp. $\ldots \ldots \ldots$ & 0 & $171,174,089$ & $171,174,089$ \\
\hline Trallblazer Plpeline Co. ............. & 0 & 0 & 0 \\
\hline Transcontinental Gas P. L. Corp. .... . . . & 0 & 0 & 0 \\
\hline Transwestern Pipelline co. ........... & $14,085,182$ & $16,139,271$ & $30,224,453$ \\
\hline Trunkllno Gas Company $\ldots \ldots \ldots \ldots$ & $14,672,065$ & $9,781,377$ & $24,453,441$ \\
\hline Unted Gas Ppo Line Co. $\ldots \ldots \ldots \ldots$ & $6,749,150$ & $20,540,891$ & $27,290,040$ \\
\hline Williams Natural Gas Company...$\ldots \ldots$ & $17,606,478$ & $29,344,130$ & $46,950,607$ \\
\hline Williston Basin Interstate Gas Co. . . . . . . & 0 & $19,562,753$ & $29,562,753$ \\
\hline Wyoming Interstate Natural Gas Co. . . . . & 0 & 0 & 0 \\
\hline Other Pipeline Companies . . . & $5,022,597$ & $225,402,041$ & $230,424,637$ \\
\hline Total Industry Costs $\ldots \ldots \ldots \ldots \ldots$ & $531,196,072$ & $3,143,695,225$ & $3,674,891,297$ \\
\hline
\end{tabular}

Source: Memorandum from Ellzabeth Moler (FERC) to Chairman John Dingell, Response to Chalrman Dingell's Questions Regarding Varlous Aspects of Order 636. March 16, 1993. 


\section{Emissions}

Ambient emissions attributable to fuel combustion by natural gas transmission network compressors are a function of pipeline fuel use and emissions coefficients. An average emission coefficient vector was derived for each emission type represented in NEMS, using coefficients for different types of compressors and the 1990 national composition of compressor capacity (e.g. 23-percent reciprocating engine and 77-percent gas turbines). It is assumed that emission control technologies currently used on the compressors and the nationa' composition of the compressor capacity do not change over the forecast. Thus, the emission factors are kept constant throughout the forecast period (Table 39).

Table 39. Pollutant Emission Rate

(Thousand Pounds per Billion Cubic Feet Pipeline Fuel Use)

\begin{tabular}{|c|c|}
\hline Pollutant & Emieston Ros \\
\hline$\ldots \ldots \ldots \ldots \ldots \ldots$ & $32,681.8$ \\
\hline$\ldots \ldots \ldots \ldots \ldots \ldots \ldots$ & 191.0 \\
\hline Carbon Dioxide (CO2) & $118,728.2$ \\
\hline Sulfur Oxides (SOX) & 0.6 \\
\hline Nitrogen Oxides (NOX) & 1013.0 \\
\hline Volatile Organic Compounds (VOC) & 34.0 \\
\hline Methane $(\mathrm{CH} 4)$ & 250.0 \\
\hline Particulates & 0.0 \\
\hline
\end{tabular}

Source: Environmental Protection Agency, Compilation of Air Pollutant Emission Factors, Fourth Edition, AP.42, September, 1985, p. 3.2-2; and Energy Information Administration, Emissions of Greenhouse Gases in the United States, 1985-1990, DOE/EIA-0573 (Washington, DC, September 1993). 


\section{Petroleum Market Module}

The Petroleum Market Module (PMM) forecasts petroleum product prices and sources of supply for meeting petroleum product demand. The sources of supply include crude oil (both domestic and imported), petroleum product imports, other refinery inputs including alcohols and ethers, natural gas plant liquids production, and refinery processing gain. In addition, the PMM estimates capacity expansion and fuel consumption of domestic refineries.

The PMM contains a linear programming (LP) representation of refining activities in five U.S. regions. The LP provides the marginal costs of production for a number of traditional and new petroleum products. The LP results are used to determine end-use product prices for each Census division using the assumptions and methods described below.

\section{Key Assumptions}

\section{Product Types and Specifications}

The PMM models refinery production of the products shown in Table 40.

Table 40. Potroloum Product Categories

\begin{tabular}{|c|c|}
\hline Product Category & Specific Products \\
\hline Motor Gasoline. & $\begin{array}{l}\text { Traditional Unleaded, Oxygenated, Reformulated, } \\
\text { Reformulated/ High Oxygen }\end{array}$ \\
\hline Jet Fuel $\ldots \ldots \ldots \ldots \ldots \ldots \ldots \ldots \ldots \ldots$ & Kerosene-type \\
\hline Distillates & Kerosene, Heating Oil, Highway Diesel \\
\hline Residual Fuels $\ldots \ldots \ldots \ldots \ldots \ldots \ldots \ldots$ & Low Sulfur, High Sulfur \\
\hline Liquefied Petroloum Gases . . . . . . . . . . . . . . . . & Propane, LPG Mixed \\
\hline Petrochemical Feedstocks & $\begin{array}{l}\text { Petrochemical Naphtha, Petrochemical Gas Oil, } \\
\text { Propylene, Aromatics }\end{array}$ \\
\hline Others $\ldots \ldots \ldots \ldots \ldots \ldots \ldots \ldots$ & $\begin{array}{l}\text { Lubes and Waxes, Asphalt/Road Oil, Still Gas, } \\
\text { Petroleum Coke, Special Naphthas }\end{array}$ \\
\hline
\end{tabular}

Source: Energy Information Administration, Oftice of Integrated Analysis and Forecasting.

The costs of producing new formulations of gasoline and diesel fuel that will be phased in as a result of the Clean Air Act Amendments of 1990 (CAAA90) are determined within the LP by incorporating specifications and demands for these fuels. The PMM assumes that the specifications for these new fuels will remain the same as specified in current legislation. 


\section{Motor Gasoline Specifications and Market Shares}

In order to differentiate between formulations of gasoline, the following specifications are included in PMM: octane, oxygen content, Reid vapor pressure (RVP), benzene content, aromatic content, lead/manganese content, sulfur content, and olefin content. Beginning in 1995, reformulated "asoline must meet the specifications of a simple model developed by the Environmental Protection Agency (EPA) which allows no lead content, limits benzene content to 1.0 percent and aromatics content to 25 percent by volume, requires an oxygen content of 2.0 percent by weight, and caps nitrogen oxide emissions at a baseline level. The PMM does not incorporate the complex model which the EPA is still developing. The complex model could establish different specifications for post-1997 reformulated gasoline.

New requirements for RVP are seasonal and are not consistent across different areas of each refining region, or Petroleum Administration for Defense (PAD) district. The PMM assumes that these variations in RVP are captured in the following annual averages:

$\begin{array}{ll}\text { PAD District I } & -9.6 \mathrm{psi} \\ \text { PAD District II } & -9.6 \mathrm{psi} \\ \text { PAD District III } & -9.6 \mathrm{psi} \\ \text { PAD District IV } & -9.6 \mathrm{psi} \\ \text { PAD District V } & -9.2 \mathrm{psi}\end{array}$

These annual average specifications are based on population data and seasonal consumption.

The seasonal element of the oxygen requirements is handled by market shares. Within the PMM, total gasoline demand is disaggregated into demand for traditional, oxygenated, reformulated, and reformulated/high-oxygen gasolines by applying assumptions about the annual market share for each type. The shares change over time based on assumptions about market penetration of new fuels. Annual assumptions for each region account for the seasonal and city-by-city nature of the regulations. (See Table 41 for AEO94 market share assumptions.) The market shares reflect the mandated use of reformulated blends in nonattainment areas as well as assumptions about opt-in and splilover demand from outside of these areas. AEO94 assumes a 5-percent spillover of oxygenated and reformulated gasoline into attainment areas. The oxygenated gasoline shares assume wintertime participation of 39 carbon monoxide nonattainment areas and year-round participation of Minnesota beginning in 1995. AEO94 also assumes that, starting in 1995, reformulated gasoline will be consumed in the nine required areas plus additional areas that have already announced intentions to opt-in. ${ }^{73}$ By 1996, all ozone nonattainment areas designated as moderate are assumed to opt-in to the reformulated gasoline program and all serious nonattainment areas are assumed to opt-in by 1997. The moderate areas are assumed to opt-in first because plans for solving ozone pollution problems in these areas (State Implementation Plans) must be submitted to the EPA before those of serious nonattainment areas.

The CAAA90 provided for special treatment of California that would allow different specifications for oxygenated and reformulated gasoline in that State. In 1992, California requested a waiver from the wintertime oxygen requirements of 2.7 percent, reducing the requirement to a range of 1.8 to 2.2 percent. The PMM assumes that PAD District V refiners must meet the California specifications. Therefore, for 1993-1994, the specifications for oxygenated gasoline in PAD District V meet a 2.0-percent standard. Starting in 1996, the specifications for reformulated gasoline in PAD District V are the same as California standards.

\footnotetext{
${ }^{73}$ Required areas: Baltimore, Chicago, Hartford, Houston, Los Angeles, Milwaukee, New York City, IPhiladelphia, and San Diego. 1995 Opt-ins: Texas, District of Columbia, New Jersey, Maryland, Delaware, New York, Connecticut, Virginia, New Hampshire, Massachusetts, Pennsylvania, Maine, and Rhode Island.
} 
Table 41. Percent Market Share for Gasoline Types by Census Division

\begin{tabular}{|c|c|c|c|c|c|c|c|c|c|}
\hline \multirow[b]{2}{*}{ Gasoline Typaryear } & \multicolumn{9}{|c|}{ Consus Divlelon } \\
\hline & 1 & 2 & 3 & 4 & 5 & 6 & 7 & 8 & 9 \\
\hline \multicolumn{10}{|l|}{ Traditional Gseoline } \\
\hline $1990-1991 \ldots \ldots$ & 100.00 & 100.00 & 100.00 & 100.00 & 100.00 & 100.00 & 100.00 & 100.00 & 100.00 \\
\hline 1992 & 96.47 & 89.10 & 100.00 & 100.00 & 100.00 & 100.00 & 100.00 & 95.63 & 87.20 \\
\hline 1993 & 89.31 & 66.97 & 100.00 & 100.00 & 100.00 & 100.00 & 100.00 & 86.77 & 61.20 \\
\hline 1994 & 89.31 & 66.97 & 100.00 & 100.00 & 100.00 & 100.00 & 100.00 & 86.77 & 61.20 \\
\hline $1995 \ldots \ldots$ & 9.05 & 7.69 & 75.82 & 83.93 & 79.00 & 100.00 & 70.15 & 86.77 & 36.53 \\
\hline 1996 & 9.05 & 7.69 & 35.00 & 72.90 & 57.02 & 67.43 & 66.39 & 66.62 & 17.81 \\
\hline 1997 forward & 9.05 & 7.69 & 35.00 & 62.97 & 50.18 & 67.43 & 63.65 & 66.62 & 17.81 \\
\hline \multicolumn{10}{|c|}{ Oxygenated Gasollne (2.7\% oxygen) } \\
\hline $1990-1991 \ldots \ldots$ & 0.00 & 0.00 & 0.00 & 0.00 & 0.00 & 0.00 & 0.00 & 0.00 & 0.00 \\
\hline 1992 & 3.53 & 10.80 & 0.00 & 0.00 & 0.00 & 0.00 & 0.00 & 4.37 & 12.80 \\
\hline 1993 & 10.69 & 33.03 & 0.00 & 0.00 & 0.00 & 0.00 & 0.00 & 13.23 & 38.80 \\
\hline 1994 & 10.69 & 33.03 & 0.00 & 0.00 & 0.00 & 0.00 & 0.00 & 13.23 & 38.80 \\
\hline 1995 & 0.00 & 0.00 & 0.00 & 16.07 & 0.00 & 0.00 & 0.00 & 13.23 & 17.77 \\
\hline $1996 \ldots \ldots \ldots$ & 0.00 & 0.00 & 0.00 & 16.07 & 0.00 & 0.00 & 0.00 & 8.82 & 6.13 \\
\hline 1997 forward . . . . & 0.00 & 0.00 & 0.00 & 26.00 & 0.00 & 0.00 & 0.00 & 8.82 & 6.13 \\
\hline \multicolumn{10}{|c|}{ Reformulated - Oxygenated Gasoline (2.7\% oxygen) } \\
\hline $1990-1991$ & 0.00 & 0.00 & 0.00 & 0.00 & 0.00 & 0.00 & 0.00 & 0.00 & 0.00 \\
\hline 1992 & 0.00 & 0.00 & 0.00 & 0.00 & 0.00 & 0.00 & 0.00 & 0.00 & 0.00 \\
\hline 1993 & 0.00 & 0.00 & 0.00 & 0.00 & 0.00 & 0.00 & 0.00 & 0.00 & 0.00 \\
\hline $1994 \ldots \ldots \ldots$ & 0.00 & 0.00 & 0.00 & 0.00 & 0.00 & 0.00 & 0.00 & 0.00 & 0.00 \\
\hline $1995 \ldots \ldots$ & 10.69 & 32.15 & 0.00 & 0.00 & 0.00 & 0.00 & 0.00 & 0.00 & 0.00 \\
\hline $1996 \ldots \ldots$ & 10.69 & 32.15 & 0.00 & 0.00 & 0.00 & 0.00 & 0.00 & 0.00 & 0.00 \\
\hline 1997 forward & $10.1 j 9$ & 32.15 & 0.00 & 0.00 & 0.00 & 0.00 & 0.00 & 0.00 & 0.00 \\
\hline \multicolumn{10}{|c|}{ Roformulated Gasoline (2.0\% oxygen) } \\
\hline $1990-1991$ & 0.00 & 0.00 & 0.00 & 0.00 & 0.00 & 0.00 & 0.00 & 0.00 & 0.00 \\
\hline 1992 & 0.00 & 0.00 & 0.00 & 0.00 & 0.00 & 0.00 & 0.00 & 0.00 & 0.00 \\
\hline 1993 & 0.00 & 0.00 & 0.00 & 0.00 & 0.00 & 0.00 & 0.00 & 0.00 & 0.00 \\
\hline $1994 \ldots$ & 0.00 & 0.00 & 0.00 & 0.00 & 0.00 & 0.00 & 0.00 & 0.00 & 0.00 \\
\hline 1995 & 80.26 & 60.16 & 24.18 & 0.00 & 21.00 & 0.00 & 29.87 & 0.00 & 45.70 \\
\hline 1996 & 80.26 & 60.16 & 65.00 & 11.03 & 42.98 & 32.57 & 33.61 & 24.55 & 76.06 \\
\hline 1997 forward & 80.26 & 60.16 & 65.00 & 11.03 & 49.82 & 32.57 & 36.35 & 24.55 & 76.06 \\
\hline
\end{tabular}

Source: Energy Information Administration, Office of Integrated Analysis and Forecasting.

\section{Diesel Fuel Specifications and Market Shares}

In order to account for diesel desulfurization regulations, low-sulfur diesel is differentiated from other distillates. Specifications for sulfur, aromatics content, and for cetane index are included in the PMM. Diesel fuel supplied to Census Division 9 is assumed to meet California Air Resources Board requirements which are more severe than Federal specifications. 
The PMM contains a sharing methodology to allocate distillate demands between low- and high-sulfur. Market shares for low-sulfur diesel and distillate fuel are estimated based on data from EIA's annual Fuel Oil and Kerosene Sales Report. Since about 20 percent of current demand in the transportation sector is off-highway, 80 percent of transportation demand for distillate fuel is assumed to be low-sulfur. Consumption of low-sulfur distillate outside of the transportation sector is assumed to be zero.

\section{End-Use Product Prices}

End-use petroleum product prices are based on marginal costs of production plus production-related fixed costs plus distribution costs and taxes. The marginal costs of production are determined by the model and represent variable costs of production including additional costs for meeting reformulated fuels provisions of the CAAA90. Fixed refinery costs include fixed operating costs, ${ }^{74}$ a 4-percent return on assets, and environmental costs associated with controlling pollution at refineries ${ }^{75}$ (Table 42). Assuming that refinery-related fixed costs are recovered in the prices of light products, fixed costs are allocated among the prices of liquefied petroleum gases, gasoline, distillate, and jet f'rel. These costs are based on average annual estimates and are assumed constant over the forecast period.

Table 42. Summary of Fixed Costs by Petroleum Administration for Defense Districts (1992 Dollars per Barrel)

\begin{tabular}{|c|c|c|c|c|c|}
\hline Cost Category & $\begin{array}{c}\text { PAD } \\
\text { District I }\end{array}$ & $\begin{array}{c}\text { PAD } \\
\text { District II }\end{array}$ & $\begin{array}{c}\text { PAD } \\
\text { District III }\end{array}$ & $\begin{array}{c}\text { PAD } \\
\text { District IV }\end{array}$ & $\begin{array}{c}\text { PAD } \\
\text { District V }\end{array}$ \\
\hline Fixed Operating Costs & 3.19 & 2.05 & 2.43 & 2.01 & 3.06 \\
\hline Return on Assets at 4 Percent & 0.29 & 0.17 & 0.25 & 0.22 & 0.28 \\
\hline Environmental Costs & 0.28 & 0.34 & 0.33 & 0.43 & 0.37 \\
\hline Total . . . . . . . . & 3.76 & 2.56 & 3.01 & 2.66 & 3.71 \\
\hline
\end{tabular}

Source: Energy Information Administration, Office of Integrated Analysis and Forecasting.

The costs of distributing and marketing petroleum products are represented by adding fixed distribution costs to the marginal and refinery fixed costs of products. The distribution costs are applied at the Census division level (Table 43) and are assumed constant throughout the forecast and across scenarios. Distribution costs for each product, sector, and Census division represent average historical differences between end-use and wholesale prices. State and Federal taxes are also added to certain products to determine final end-use prices (Table 44).

\section{Crude Oil Quality}

In the PMM, the quality of crude oil is characterized by average gravity and sulfur levels. Both domestic and imported crude oil are divided into five categories as defined by the ranges of gravity and sulfur shown in Table 45.

A "composite" crude oil with the appropriate yields and qualities is developed for each category by averaging the characteristics of specific crude oil streams that fall into each category. W'hile the domestic and foreign categories are the same, the composite crudes for each categcry may differ because different crude streams make up the composites. For domestic crude oil, an estimate of total production is made first, then shared out to each of the five categories based on historical data. For imported crude oil, a separate supply curve is provided for each of the five categories.

\footnotetext{
${ }^{74}$ Fixed operating costs include payroll, maintenance, labor and materials, depreciation, and other expenses.

${ }^{75}$ Environmental cost estimates are based on National Petroleum Council, U.S. Petroleum Refining - Meeting Requirements for Cleaner Fuels and Refineries, Volume I (Washington, DC, August 1993).
} 
Table 43. Petroleum Product End-Use Markups by Sector and Census Division (1992 Dollars per Million Btu)

\begin{tabular}{|c|c|c|c|c|c|c|c|c|c|}
\hline \multirow[b]{2}{*}{ Sector/Product } & \multicolumn{9}{|c|}{ Census Divielon } \\
\hline & 1 & 2 & 3 & 4 & 5 & 6 & 7 & 8 & 9 \\
\hline \multicolumn{10}{|l|}{ Realdential Sector } \\
\hline Distillate Fuel Oil $\ldots \ldots \ldots \ldots$ & 2.59 & 2.94 & 2.09 & 1.94 & 2.92 & 2.05 & 1.27 & 1.88 & 2.56 \\
\hline Gasoline . . & 0.00 & 0.00 & 0.00 & 0.00 & 0.00 & 0.00 & 0.00 & 0.00 & 0.00 \\
\hline Kerosene & 3.13 & 3.42 & 2.67 & 2.39 & 2.79 & 1.85 & 1.85 & 5.10 & 6.69 \\
\hline Liquefied Petroleum Gases . . . . . & 8.66 & 8.43 & 6.02 & 3.70 & 7.97 & 6.63 & 5.73 & 5.52 & 8.44 \\
\hline \multicolumn{10}{|l|}{ Commercial Sector } \\
\hline Distillate Fuel Oil $\ldots . . \ldots \ldots$ & 0.87 & 0.74 & 0.21 & 0.11 & 0.29 & 0.21 & 0.25 & 0.17 & 0.31 \\
\hline Gasoline & 1.09 & 1.04 & 0.94 & 1.23 & 1.03 & 1.21 & 1.27 & 1.10 & 0.89 \\
\hline Kerosene ................ & 1.08 & 0.58 & 0.22 & 0.79 & 0.64 & 1.37 & 0.83 & 0.79 & 0.79 \\
\hline Liquefied Petroleum Gases . . . . . & 7.90 & 7.31 & 4.86 & 4.11 & 6.85 & 4.22 & 1.81 & 4.26 & 6.44 \\
\hline Low-Sulfur Residual Fuel Oil . . . . & 0.11 & 0.33 & 0.29 & 0.36 & 0.33 & 0.10 & -0.04 & -0.46 & 0.65 \\
\hline \multicolumn{10}{|l|}{ Utillty Sector } \\
\hline Distillate Fuel Oil . . . . . . . . . & -0.07 & 0.19 & 0.18 & 0.16 & -0.06 & 0.52 & 0.41 & 0.25 & 0.52 \\
\hline High-Sulfur Residual Fuel Oil . . . & -0.22 & 0.17 & 0.82 & 0.41 & 0.01 & -0.04 & 0.41 & 0.79 & 0.30 \\
\hline Low-Sulfur Residual Fuel Oil . ... . & -0.02 & 0.14 & 1.37 & 0.83 & 0.13 & 2.33 & 0.80 & 0.80 & 1.28 \\
\hline \multicolumn{10}{|l|}{ Transportation Sector } \\
\hline Distillate Fuel Oil $\ldots \ldots \ldots \ldots$ & 1.64 & 1.35 & 0.91 & 1.00 & 1.05 & 0.86 & 0.99 & 1.05 & 1.37 \\
\hline Ethanol $\ldots \ldots \ldots \ldots \ldots \ldots$ & 0.00 & 0.00 & 0.00 & 0.00 & 0.00 & 0.00 & 0.00 & 0.00 & 0.00 \\
\hline Gasoline $\ldots \ldots \ldots \ldots \ldots \ldots$ & 1.06 & 0.97 & 0.92 & 1.16 & 0.98 & 1.22 & 1.26 & 1.03 & 0.81 \\
\hline High-Sulfur Residual Fuel Oil ... & -0.29 & 0.08 & 0.75 & -0.01 & -0.11 & -0.30 & 0.65 & 0.87 & 0.59 \\
\hline Jet Fuel & 0.05 & 0.04 & -0.18 & -0.16 & -0.43 & 0.07 & 0.05 & -0.29 & 0.13 \\
\hline Liquefied Petroleum Gases . . . . . & 9.25 & 7.86 & 5.64 & 3.94 & 6.95 & 4.75 & 1.47 & 4.39 & 6.40 \\
\hline Methanol $\ldots \ldots \ldots \ldots \ldots$ & 0.00 & 0.00 & 0.00 & 0.00 & 0.00 & 0.00 & 0.00 & 0.00 & 0.00 \\
\hline \multicolumn{10}{|l|}{ Industrial Sector } \\
\hline Asphalt and Road Oil $\ldots \ldots \ldots$ & 1.18 & 1.04 & 1.47 & 1.99 & 1.10 & 1.24 & 1.40 & 1.88 & 62.02 \\
\hline Distillate Fuel Oil $\ldots \ldots \ldots \ldots$ & 0.74 & 0.60 & 0.58 & 0.53 & 0.66 & 0.48 & 0.53 & 0.46 & 0.54 \\
\hline Gasoline $\ldots \ldots \ldots \ldots \ldots$ & 1.08 & 0.95 & 0.92 & 1.26 & 0.98 & 1.23 & 1.26 & 1.15 & 0.92 \\
\hline Kerosene $\ldots \ldots \ldots \ldots \ldots \ldots$ & 1.41 & 0.60 & 0.62 & 0.06 & 0.57 & 0.82 & 0.22 & 0.06 & 0.65 \\
\hline Liquefied Petroleum Gases . . . . . & 8.25 & 7.22 & 5.54 & 3.38 & 6.68 & 3.79 & 0.68 & 4.01 & 6.38 \\
\hline Low-Sulfur Residual Fuel Oil . . . . & 0.07 & 0.24 & 0.29 & 0.27 & 0.35 & 0.47 & -0.01 & -0.14 & 0.43 \\
\hline
\end{tabular}

Sources: Markups based on data from Energy Information Administration (ElA), ElA-782A, "Refiners'/Gas Plant Operators' Monthly Petroleum Product Sales Report"; EIA, ElA-782B, "Resellers'/Retailers' Monthly Petroleum Feport Product Sales Report"; ElA, FERC-423, "Monthly Report of Cost and Quality of Fuels for Electric Plants"; EIA, ElA-759 "Monthly Power Plant Report"; EIA, State Energy Data Report 1991. DOE/ElA-0214(91) (Washington, DC, May 1993); State Energy Price and Expenditures Report 1990, DOE/EIA-0376(90) (Washington, DC, September 1992); and EIA, Petroleum Marketing Annual 1992, DOE/EIA-0487(92) (Washington, DC, July 1993). 
Table 44. Taxes on Petroleum Transportation Fuels by Census Division (1992 Dollars per Million Btu)

\begin{tabular}{|c|c|c|c|c|c|c|c|c|c|}
\hline \multirow[b]{2}{*}{ Year/Product } & \multicolumn{9}{|c|}{ Census Division } \\
\hline & 1 & 2 & 3 & 4 & 5 & 6 & 7 & 8 & 9 \\
\hline \multicolumn{10}{|l|}{1993} \\
\hline Gasoline" & 3.00 & 2.77 & 2.77 & 2.51 & 2.36 & 2.57 & 2.66 & 2.68 & 2.92 \\
\hline Diesel ... & 2.92 & 2.97 & 2.89 & 2.68 & 2.38 & 2.60 & 2.77 & 2.66 & 3.00 \\
\hline Liquefied Petroleum Gases & 1.50 & 1.50 & 1.50 & 1.50 & 1.50 & 1.50 & 1.50 & 1.50 & 1.50 \\
\hline Methanol $\ldots \ldots \ldots \ldots \ldots \ldots \ldots$ & 4.48 & 4.11 & 3.91 & 3.74 & 3.43 & 3.89 & 4.02 & 4.03 & 3.77 \\
\hline Ethanol .... & 3.68 & 3.38 & 3.23 & 3.09 & 2.84 & 3.20 & 3.31 & 3.32 & 3.10 \\
\hline \multicolumn{10}{|l|}{ Additional 1994} \\
\hline Gasoline ${ }^{a}$ & 0.34 & 0.34 & 0.34 & 0.34 & 0.34 & 0.34 & 0.34 & 0.34 & 0.41 \\
\hline Diesel . . . . . . . . . . . . . . & 0.30 & 0.30 & 0.30 & 0.30 & 0.30 & 0.30 & 0.30 & 0.30 & 0.37 \\
\hline Liquefied Petroleum Gases & 0.46 & 0.46 & 0.46 & 0.46 & 0.46 & 0.46 & 0.46 & 0.46 & 0.46 \\
\hline Methanol & 0.63 & 0.63 & 0.63 & 0.63 & 0.63 & 0.63 & 0.63 & 0.63 & 0.63 \\
\hline Ethanol $\ldots . .$. & 0.51 & 0.51 & 0.51 & 0.51 & 0.51 & 0.51 & 0.51 & 0.51 & 0.51 \\
\hline \multicolumn{10}{|l|}{ Addltional 1996} \\
\hline Jet Fuel & 0.31 & 0.31 & 0.31 & 0.31 & 0.31 & 0.31 & 0.31 & 0.31 & 0.31 \\
\hline
\end{tabular}

Tax also applies to gasoline consumed in the commercial and industrial sectors.

Sources: Aggregated from Energy Information Administration, Petroleum Marketing Monthly, DOE/EIA-0380(93/10) (Washington, DC, October 1993), Table EN1; Califomia Proposition Nos. 108 and 111.

Table 45. Crude Oll Specifications

\begin{tabular}{|c|c|c|}
\hline Crude Oll Categories & $\begin{array}{c}\text { Sulfur } \\
\text { (percent) }\end{array}$ & $\begin{array}{c}\text { Gravity } \\
\text { (degrees API) }\end{array}$ \\
\hline Low Sulfur Light & $0 \cdot 0.5$ & $>24$ \\
\hline Medium Sulfur Heavy . . . . . . . . . . . . . . . & $0.35-1.1$ & $>24$ \\
\hline High Sulfur Light . . . . . . . . . . . . . . . . . & $>1.1$ & $>32$ \\
\hline High Sulfur Heavy . . . . . . . . . . . . . . . & $>1.1$ & $24 \cdot 33$ \\
\hline High Sulfur Very Heavy . . . . . . . . . . . . & $>0$ & $0-23$ \\
\hline
\end{tabular}

Source: Energy Information Administration, Office of Integrated Analysis and Forecasting.

\section{Regional Assumptions}

PMM refining regions are the five Petroleum Administration for Defense (PAD) districts. Individual refineries are aggregated into one linear programming representation for each PAD district region. In order to interact with other NEMS modules with different regional representations, certain PMM inputs and outputs are converted from a PAD district to a non-PAD district regional structure and vice-versa.

\section{Capacity Expansion Assumptions}

PMM models capacity expansion for distillation capacity, vacuum distillation, hydrotreating, coking, fluid catalytic cracking, hydrocracking, alkylation, and methyl tertiary butyl ether (MTBE) manufacture. Capacity expansion occurs by processing unit, starting from base year capacities established by PAD district using historical data. Expansion is determined when the value received from the additional product sales exceeds the investment and operating costs of the new unit. The investment costs assume a 15-percent rate of return over a 15-year plant life. Expansion through 1993 is determined by adding to 
the existing capacities of units planned and under construction that are expected to begin operating during this time. Capacity expansion is done in 3-year increments. For example, after the model has reached a solution for forecast year 1993, the PMM looks ahead and determines the optimal capacities given the demands and prices existing in the 1996 forecast year. The PMM then allows 50 percent of that capacity to be built in forecast year 1994, 25 percent in 1995, and 25 percent in 1996. At the end of 1996, the cycle begins anew.

Additions to crude oil distillation capacity or downstream processing units are assumed to be limited due to environmental restrictions and difficulty in obtaining permits. A limit on capacity expansion of 300,000 barrels per day was assumed for each refining region. Only one region, PAD District III, reached this constraint.

\section{Legislation}

The PMM reflects recent national and regional legislative and regulatory changes that will affect future petroleum supply and product prices. It incorporates taxes imposed by the 1993 Budget Reconciliation Act as well as costs resulting from environmental legislation.

The Budget Reconciliation Act imposes a tax increase of 4.3 cents per gallon on transportation fuels including gasoline, diesel, liquefied petroleum gases, and jet fuel. Except for jet fuel, the tax began on October 1, 1993, and takes effect in the PMM in forecast year 1994. Jet fuel has been granted a 2-year delay.

With a goal of reducing tailpipe emissions in areas failing to meet Federal air quality standards (nonattainment areas), Title II of the CAAA90 established regulations for gasoline formulation. Starting in November 1992, gasoline sold during the winter in 39 carbon monoxide nonattainment areas was required to be oxygenated ${ }^{76}$ Starting in 1995, gasoline sold in nine major U.S. cities which are the most severe ozone nonattainment areas must be reformulated to reduce volatile organic compounds (which contribute to ozone formation) and toxic air pollutants, as well as meet a number of other new specifications. Additional areas with less severe ozone problems may choose to "opt-in" to the reformulated gasoline requirement. In a few metropolitan areas with both ozone and carbon monoxide problems, the requirements for oxygenated and reformulated gasoline will overlap. In other words, during the winter months a reformulated/high oxygen gasoline will be required. ${ }^{77}$

Title II of the CAAA90 also established regulations on the sulfur and aromatics content of diesel fuel. Starting October 1, 1993, all diesel fuel sold for on-highway use must contain less sulfur and meet new aromatics or cetane level standards.

A number of pieces of legislation are aimed at controlling air, water, and waste emissions from refineries themselves. The PMM incorporates related environmental investments as refinery fixed costs. The estimated expenditures are based on results of the 1993 National Petroleum Council Study. ${ }^{78}$ These investments reflect compliance with Titles I, III, and V of CAAA90, the Clean Water Act, the Resource Conservation and Recovery Act, and anticipated regulations including the phase-out of hydrofluoric acid and a broad-based requirement for corrective action. No costs for remediation beyond the refinery site are included.

\section{Emissions}

Emissions attributable to the combustion of fuel at refineries are estimated by the industrial module.

\footnotetext{
${ }^{76}$ Oxygenated gasoline must contain an oxygen content of 2.7 percent by weight.

${ }^{77}$ Gasoline that meets the requirements of reformulated gasoline and has an oxygen content of 2.7 percent by weight.

${ }^{78}$ National Petroleum Council, U.S. Petroleum Refining - Meeting Requirements for Cleaner Fuels and Refineries, Volume I (Washington, DC, August 1993).
} 


\section{Coal Market Module}

The Coal Market Module (CMM) provides forecasts of U.S. coal production, consumption, exports, distribution, and prices. The CMM comprises three submodules: the Coal Production Submodule, the Coal Distribution Submodule, and the Coal Export Submodule.

\section{Key Assumptions}

\section{Coal Production Submodule}

The Coal Production Submodule (CPS) generates a different set of supply curves for the CMM for each year of the forecast. Separate supply curves are developed for each of 16 supply regions, 16 coal types, and 2 mine types (surface or underground). The supply curves generated reflect the relationship between capacity utilization and minemouth prices in the short-run. In addition, annual adjustments to the CPS supply curves are made to reflect the effects of reserve depletion and changes in labor productivity and factor input costs (labor and diesel fuel).

To estimate annual production capacity for each supply curve, the CPS makes use of projections of planned coal-fired capacity additions (net of retirements) from the Electricity Market Module and coal distribution projections from the CDS. Projections for labor costs are provided by the Macroeconomic Activity Module, and diesel fuel costs are obtained from the Petroleum Market Module.

The key assumptions underlying the CPS are:

- Estimates of recoverable coal reserves are based on the EIA Demonstrated Reserve Base (DRB) of in-ground coal resources of the United States. Resource estimates from the DRB are correlated with data on coal quality and geological characteristics from other sources to create a Coal Reserves Data Base. Estimates are developed on a regionally disaggregated basis. Recoverable coal reserves in the United States are estimated at 261 billion short tons. Low-sulfur recoverable coal reserves are estimated to total nearly 100 billion short tons, with 87 percent concentrated in the West.

- Coal producers face lead-time constraints for bringing new production capacity on line to meet increased demand. In the CPS, it is assumed that coal producers add new mine capacity in response to long-term changes in coal demand and that lowest- cost reserves will be mined first. The CPS uses projections of coal-fired generating capacity from the Electricity Market Module as an indicator of long-term growth in coal demand.

- In the short term, mining costs are assumed to vary with changes in capacity utilization of mines, labor productivity, arid factor input costs. In the CPS, factor input costs are represented by projections of diesel fuel prices from the Petroleum Market Module and labor costs from the Macroeconomic Activity Module.

- Between 1978 and 1990, U.S. coal mining productivity increased at an average rate of 6.6 percent per year. The major factors underlying these gains were falling coal prices, structural change in 
the industry, and technological improvements in coal mining. ${ }^{79}$ Based on the expectation that further penetration of certain more productive mining technologies, such as longwalls and large capacity surface mining equipment, will gradually level off, productivity improvements are assumed to continue, but to decline in magnitude. Different rates of improvement are assumed by region and by mine type, surface and deep. The following general pattern applies for the rate of improvement: from 1990 to 2000, declining from 6 to 2 percent per year; and from 2000 to 2010, declining from 2 to 1 percent.

- The CPS accounts for the retirement of existing mines over the forecast by annually decrementing the segment of coal supply curves represented by existing mines. The decrements used for this year's forecast, by coal supply region, mining method, and year, are shown in Tables 46 and 47.

Table 46. Retirement of Existing Underground Mine Production Capacity in the Coal Production Submodule, 1995-2010

(Fractions)

\begin{tabular}{|c|c|c|c|c|}
\hline Coal Production Regions & 1995 & 2000 & 2005 & 2010 \\
\hline Pennsylvania, Ohio, Maryland . . . . . . . . . . . . . & 0.09 & 0.20 & 0.33 & 0.63 \\
\hline West Virginia, North . . . . . . . . . . . . . . . . . . . & 0.18 & 0.34 & 0.46 & 0.71 \\
\hline West Virginia, South . . . . . . . . . . . . . . . . & 0.42 & 0.68 & 0.76 & 0.89 \\
\hline Kentucky, East .......................... & 0.57 & 0.83 & 0.92 & 0.93 \\
\hline Virginia, Tennesse $\ldots \ldots \ldots \ldots \ldots \ldots$ & 0.43 & 0.61 & 0.80 & 0.92 \\
\hline 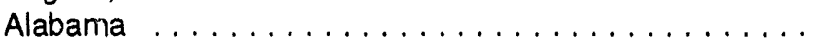 & 0.02 & 0.09 & 0.30 & 0.34 \\
\hline 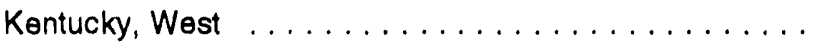 & 0.28 & 0.39 & 0.62 & 0.72 \\
\hline 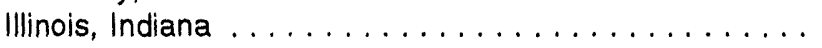 & 0.04 & 0.29 & 0.56 & 0.67 \\
\hline Arkansas, lowa, Kansas, Missouri, Oklahoma . . . . . . . . . & $\cdots$ & $\cdots$ & $\cdots$ & $\cdots$ \\
\hline Texas, Louisiana . . . . . . . . . . . . . . . . . . . . . . . . . & -- & $\cdots$ & -- & $\cdots$ \\
\hline North Dakota, South Dakota, Montana . . . . . . . . . . . . & -- & $\cdots$ & $\cdots$ & $\cdots$ \\
\hline Wyoming, East . . . . . . . . . . . . . . . . . . . & -- & -- & $\cdots$ & - \\
\hline Wyoming, West $\ldots \ldots \ldots \ldots \ldots \ldots \ldots$ & 0.07 & 0.07 & 0.07 & 1.00 \\
\hline Arizona, New Mexico, Colorado, Utah . . . . . . . . . . . & 0.17 & 0.25 & 0.32 & 0.41 \\
\hline Washington, Oregon, California .......... .... & $\cdots$ & -- & -- & 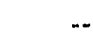 \\
\hline 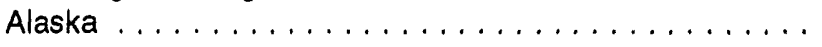 & $\cdots$ & -- & $\cdots$ & -. \\
\hline
\end{tabular}

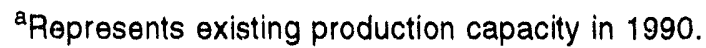

.. = no existing underground production capacity in these regions.

Source: Energy Information Administration, Office of Integrated Analysis and Forecasting.

\section{Coal Distribution Submodule}

The Coal Distribution Submodule (CDS) determines the least-cost (minemouth price plus transportation cost) supplies of coal by supply region for a given set of coal demands in each demand sector in each demand region using a heuristic algorithm which compares alternative sources. Production and distribution are computed for 16 supply and 23 demand regions for 23 demand subsectors.

The projected levels of industrial, coking, and residential/commercial coal demand are provided by the Industrial, Commercial, and Residential Demand Modules; electricity coal demands are provided by the Electricity Market Module and coal export demands are provided by the Coal Export Submodule. Coal supply curves are provided by the CPS.

\footnotetext{
${ }^{79}$ Energy Information Administration, The U.S. Coal Industry, 1970-1990: Two Decades of Change, DOE/EIA-0559 (Washington, DC, November 1992).
} 
Table 47. Retirement of Existing Surface Mine Production Capacity in the Coal Production Submodule, 1995-2010

(Fractions)

\begin{tabular}{|c|c|c|c|c|}
\hline Supply Regions & 1995 & 2000 & 2005 & 2010 \\
\hline Pennsylvania, Ohio, Maryland & 0.50 & 0.64 & 0.81 & 0.83 \\
\hline West Virginia, North . ....... & 0.66 & 0.66 & 1.00 & 1.00 \\
\hline West Virginia, South ...................... & 0.48 & 0.80 & 0.98 & 0.98 \\
\hline Kentucky, East & 0.60 & 0.84 & 0.93 & 0.97 \\
\hline Virginia, Tennessee ... & 0.74 & 0.89 & 0.94 & 0.94 \\
\hline Alabama & 0.41 & 0.43 & 0.61 & 0.84 \\
\hline Kentucky, West & 0.63 & 0.76 & 0.98 & 0.98 \\
\hline Illinois, Indiana & 0.48 & 0.68 & 0.80 & 0.91 \\
\hline Arkansas, lowa, Kansas, Missouri, Oklahoma . & 0.33 & 0.36 & 0.41 & 0.41 \\
\hline Texas, Louisiana & 0.00 & 0.00 & 0.01 & 0.01 \\
\hline North Dakota, South Dakota, Montana . . . . . . . . . . . & 0.06 & 0.07 & 0.17 & 0.22 \\
\hline Wyoming, East $\ldots \ldots \ldots \ldots \ldots \ldots \ldots \ldots \ldots$ & 0.00 & 0.05 & 0.17 & 0.45 \\
\hline Wyoming, West & 0.00 & 0.07 & 0.16 & 0.37 \\
\hline Arizona, New Mexico, Colorado, Utah & 0.14 & 0.14 & 0.21 & 0.36 \\
\hline Washington, Oregon, California ... & 0.00 & 0.00 & 0.00 & 0.58 \\
\hline Alaska $\ldots \ldots \ldots \ldots \ldots \ldots \ldots$ & 0.00 & 0.00 & 0.00 & 0.00 \\
\hline
\end{tabular}

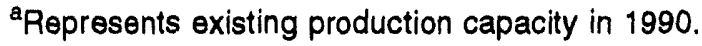

Source: Energy Information Administration, Office of Integrated Analysis and Forecasting.

The key assumptions underlying the CDS are:

- In the CDS, base-year transportation costs are estimates of average transportation costs for each origin-destination pair. These costs are computed as the difference between the average delivered price for a demand region (by sector and for export) and the average minemouth price for a supply region. Delivered price data are from Form EIA-3, "Quarterly Coal Consumption ReportManufacturing Plants," Form EIA-5, "Coke Plant Report-Quarterly," Federal Energy Regulatory Commission (FERC) Form 423, "Monthly Report of Cost and Quality of Fuels for Electric Plants," and the U.S. Bureau of the Census' Monthly Report EM-522. Minemouth price data are from Form EIA-7A, "Coal Production Report."

Coal transportation costs are assumed to change uniformly over time across all regions and demand sectors. Transportation rates are escalated over time in response to projected variations in Reference Case fuel costs (No. 2 diesel fuel), labor costs (railroad related wage plus wage supplements), and other rail-industry related operating costs (material and supplies, equipment rent, purchased services, depreciation, interest, and taxes). The transportation rate escalators used for all five AEO94 scenarios are shown in Table 48.

- Available data on utility coal contracts (volume, duration, coal type, and origin and destination of shipments) are incorporated into the CDS to represent coal shipments under contract. The contract data are based on FERC Form 423, "Monthly Report of Cost and Quality of Fuels for Electric Plants," supplemented with information on contract duration from the Coal Transportation Rate Data Base (CTRDB) maintained by the EIA. These existing contracts are honored through their reported expiration date. Most of these contracts expire by the year 2000 . 
Table 48. Transportation Rate Escalators, 1991-2010

$(1987=1.0000)$

\begin{tabular}{|c|c|}
\hline Year & $\begin{array}{c}\text { Transportation } \\
\text { Escalators }\end{array}$ \\
\hline $1991 \ldots \ldots \ldots$ & $\ldots 1.0221$ \\
\hline $1992 \ldots \ldots \ldots$ & $\ldots 1.0231$ \\
\hline $1993 \ldots \ldots \ldots$ & $\ldots 1.0060$ \\
\hline $1994 \ldots \ldots \ldots$ & $\ldots 1.0141$ \\
\hline $1995 \ldots \ldots$ & $\ldots 1.0147$ \\
\hline $1996 \ldots \ldots$ & $\ldots .1 .0164$ \\
\hline $1997 \ldots \ldots \ldots$ & $\ldots 1.0181$ \\
\hline $1998 \ldots \ldots \ldots$ & $\ldots 1.0207$ \\
\hline $1999 \ldots \ldots \ldots$ & $\ldots \ldots 1.0246$ \\
\hline $2000 \ldots \ldots \ldots$ & . . 1.0279 \\
\hline $2001 \ldots \ldots$ & $\ldots .1 .0328$ \\
\hline $2002 \ldots \ldots \ldots$ & $\ldots 1.0362$ \\
\hline $2003 \ldots \ldots \ldots$ & $\ldots 1.0405$ \\
\hline $2004 \ldots \ldots \ldots$ & $\ldots 1.0432$ \\
\hline $2005 \ldots \ldots \ldots$ & $\ldots .1 .0452$ \\
\hline $2006 \ldots \ldots \ldots$ & $\ldots 1.0475$ \\
\hline $2007 \ldots \ldots \ldots$ & . . 1.0499 \\
\hline $2008 \ldots \ldots$ & . . 1.0527 \\
\hline $2009 \ldots \ldots$ & $\ldots 1.0583$ \\
\hline $2010 \ldots \ldots$ & . . 1.0629 \\
\hline
\end{tabular}

Source: Energy Information Administration, Office of Integrated Analysis and Forecasting.

\section{Coal Export Submodule}

The Coal Export Submodule (CES) is a linear program (LP) which provides annual forecasts of U.S. steam and metallurgical coal exports, in the context of world coal trade, for input to the CMM. The LP determines the pattern of world coal trade flows that minimize the production and transportation costs of meeting a pre-specified set of regional coal import demands. It does this subject to constraints on export capacity, trade flows, and sulfur emissions.

The CES projects steam and metallurgical coal trade flows from 16 coal-exporting regions of the world to 20 import regions for 4 coal types (coking, low-sulfur steam, high-sulfur steam, and subbituminous). The CES includes five U.S. export regions and four U.S. import regions.

The key assumptions underlying the CES are:

- The coal market is competitive. In other words, no large suppliers or group of producers are able to influence the price through adjusting their output. This means suppliers gain no producer surplus. Producers' decisions on how much and who they supply to are driven by their costs, rather than prices being set by perceptions of what the market can bear. In this situation the buyer gains the full consumer surplus.

- Coal buyers (importing regions) will tend to spread their purchases among several suppliers in order to reduce the impact of supply disruption, even though this will add to their purchase costs. Similarly, producers will choose not to rely on any one buyer and will diversify their sales. 
- While subbituminous coal is included, use of this coal is constrained by the capacity of subbituminous coal-fired plants in an import region and the extent that it can be substituted/blended.

- Coking coal is treated as homogeneous. The model does not address quality parameters that define coking coals. The values of these quality parameters are defined within small ranges and affect world coking flows very little.

Data inputs to the CES:

- In the CES, U.S. coal exports are determined, in part, by the projected level of world coal import demand. World steam and metallurgical coal import demands for the AEO94 forecast scenarios are shown in Tables 49 and 50.

Table 49. World Steam Coal Import Demand by Import Region, 1995-2010 (Million Metric Tons of Coal Equivalent)

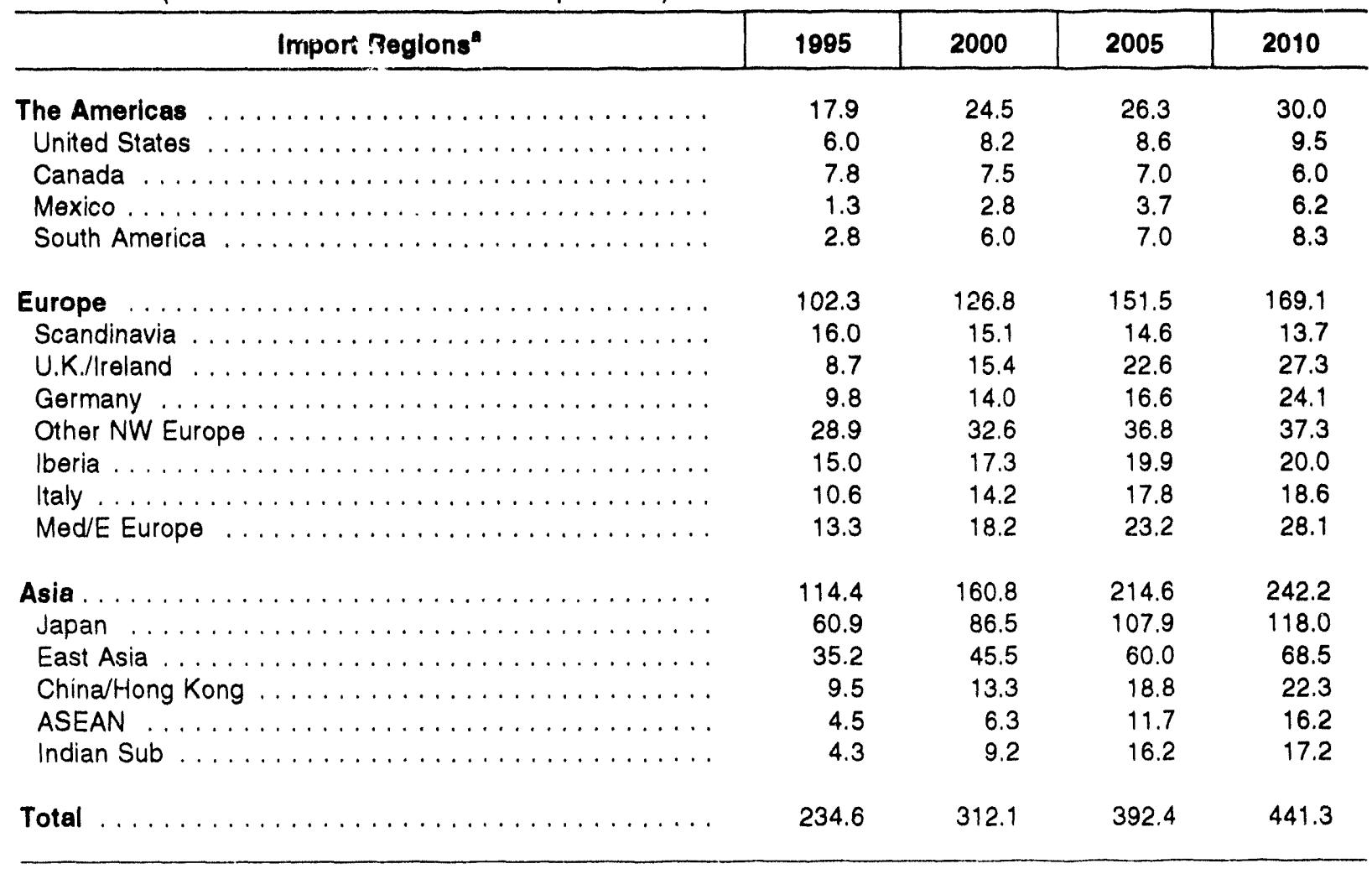

Import Regions: United States: United States; Canada: Canada; Scandinavia: Denmark, Finland, Norway, Sweden; U.K.Areland: Ireland, United Kingdom; Germany: Austria, Germany; Other NW Europe: Belgium, France, Luxembourg, Netherlands; Iberia: Portugal, Spain; Italy: Italy; Med/E Europe: Algeria, Bulgaria, Croatia, Egypt, Greece, Israel, Malta, Morocco, Romania, Tunisia, Turkey; Mexico: Mexico; South America: Argentina, Brazil, Chile; Japan: Japan; East Asia: North Korea, South Korea, Taiwan; China/Hong Kong: China, Hong Kong; ASEAN: Malaysia, Philippines, Thailand; Indian Sub: Bangladesh, India, Iran, Pakistan, Sri Lanka.

Notes: One "metric ton of coal equivalent" contains 27.78 million Btu. Totals may not equal sum of components due to independent rounding.

Source: Energy Information Administration, Office of Integrated Analysis and Forecasting. 
Table 50. World Motallurgical Coal Import Demand by Import Reglon, 1995-2010 (Million Metric Tons of Coal Equivalent)

\begin{tabular}{|c|c|c|c|c|}
\hline Import Reglons" & 1995 & 2000 & 2005 & 2010 \\
\hline The Americas $\ldots \ldots \ldots \ldots \ldots \ldots \ldots$ & 18.4 & 18.0 & 17.6 & 16.7 \\
\hline United States $\ldots \ldots \ldots \ldots \ldots \ldots \ldots \ldots \ldots \ldots \ldots$ & 0.0 & 0.0 & 0.0 & 0.0 \\
\hline Canada $\ldots \ldots \ldots \ldots \ldots \ldots \ldots \ldots \ldots \ldots$ & 4.0 & 4.0 & 3.5 & 3.0 \\
\hline Mexico ........................... & 1.6 & 1.5 & 1.7 & 1.4 \\
\hline South America $\ldots \ldots \ldots \ldots \ldots \ldots \ldots \ldots \ldots$ & 12.8 & 12.5 & 12.4 & 12.3 \\
\hline$\ldots \ldots \ldots \ldots \ldots \ldots \ldots \ldots$ & 50.2 & 47.2 & 47.9 & 46.8 \\
\hline Scandinavia $\ldots \ldots \ldots \ldots \ldots \ldots \ldots \ldots \ldots$ & 2.4 & 2.0 & 1.8 & 1.7 \\
\hline 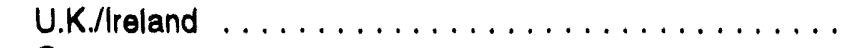 & 8.1 & 7.4 & 7.1 & 6.7 \\
\hline Germany $\ldots \ldots \ldots \ldots \ldots \ldots \ldots \ldots \ldots$ & 3.8 & 3.9 & 6.0 & 7.5 \\
\hline Other NW Europe $\ldots \ldots \ldots \ldots \ldots \ldots \ldots \ldots \ldots$ & 12.5 & 10.7 & 10.1 & 9.3 \\
\hline 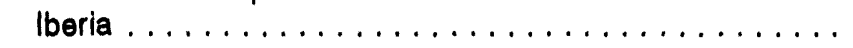 & 1.5 & 1.7 & 1.6 & 1.5 \\
\hline 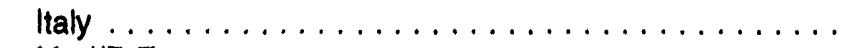 & 4.4 & 3.9 & 3.7 & 3.5 \\
\hline Med/E Europe $\ldots \ldots \ldots \ldots \ldots \ldots \ldots \ldots \ldots$ & 17.5 & 17.6 & 17.6 & 16.6 \\
\hline Asia. & 87.9 & 84.0 & 81.5 & 76.9 \\
\hline$\ldots \ldots \ldots \ldots \ldots \ldots \ldots \ldots \ldots$ & 59.1 & 52.7 & 49.1 & 45.5 \\
\hline East Asia $\ldots \ldots \ldots \ldots \ldots \ldots \ldots \ldots \ldots$ & 17.1 & 19.2 & 19.1 & 18.2 \\
\hline China/Hong Kong $\ldots \ldots \ldots \ldots \ldots \ldots \ldots$ & 2.2 & 2.2 & 2.7 & 3.2 \\
\hline 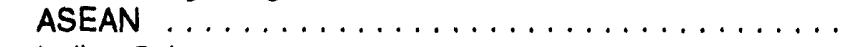 & 0.0 & 0.0 & 0.0 & 0.0 \\
\hline Indian Sub $\ldots \ldots \ldots \ldots \ldots \ldots \ldots \ldots \ldots$ & 9.5 & 9.9 & 10.6 & 10.0 \\
\hline Total & 156.5 & 149.2 & 147.0 & 140.4 \\
\hline
\end{tabular}

almport Regions: United States: United States; Canada: Canada; Scandinavia: Denmark, Finland, Norway, Sweden; U.K.Areland: Ireland, United Kingdom; Germany: Austria, Germany; Other NW Europe: Belgium, France, Luxembourg, Netherlands; Iberia: Portugal, Spain; Italy: Italy; Med/E Europe: Algeria, Bulgaria, Croatia, Egypt, Greece, Israel, Malta, Morocco, Romania, Tunisia, Turkey; Mexico: Mexico; South America: Argentina, Brazil, Chile; Japan: Japan; East Asia: North Korea, South Korea, Taiwan; China/Hong Kong: China, Hong Kong; ASEAN: Malaysia, Philippines, Thailand; Indian Sub: Bangladesh, India, Iran, Pakistan, Sri Lanka.

Notes: One "metric ton of coal equivalent" contains 27.78 million Btu. Totals may not equal sum of components due to independent rounding.

Source: Energy Information Administration, Office of Integrated Analysis and Forecasting.

\section{Legislation}

It is assumed that provisions of the Energy Policy Act of 1992 that relate to the future funding of the Health and Benefits Fund of the United Mine Workers of America will have no significant effect on estimated production costs, although liabilities of company's contributions will be redistributed. The electric utility demand for coal, which represented over 86 percent of domestic coal demand in 1990, incorporates the provisions of the Clean Air Act Amendments of 1990. It is assumed that utilities will be granted the full flexibility to meet the specified reductions in sulfur dioxide emissions.

\section{Emissions}

Carbon emissions from coal combustion are estimated for the electricity, industrial (industrial steam and coking), residential, and commercial sectors. Methane emissions, which occur during the extraction, preparation, transport, and storage of coal, are not modeled or reported. 


\section{Renewable Fuels Module}

The Renewable Fuels Module (RFM) consists of seven highly distinct submodules that represent the major renewable energy technologies. Some, such as ethanol and other biomass products, are fuels in the conventional sense of the word, while others, such as wind and solar radiation, are energy sources that do not require the production of a fuel. A common feature that extends across all renewable energy forms is that consumption of the energy form today does not lessen the supply of that form in the future. The technologies cover the gamut of commercial market penetration, from hydroelectric power, which was the original source of electricity generation and is a mature and possibly declining source, to new power systems using wind, solar, biomass and geothermal energy, which in some cases require technological innovation to become cost effective or have inherent characteristics, such as intermittency, which make their penetration into the electricity grid dependent upon new methods for utility system planning or upon low-cost energy storage.

Because of the high degree of diversity of the energy forms within the RFM, the submodules of the RFM have interaction only with modules and submodules outside of the RFM rather than links with other RFM submodules. These interactions occur through common elements of the model with the Electricity Market Module (EMM) and the Petroleum Market Module (PMM) for ethanol. Because of the high level of integration with these other National Energy Modeling System (NEMS) modules, the final outputs (levels of consumption and market penetration over time) for renewable energy forms are largely dependent upon assumptions in those other modules. The RFM includes the investment tax and energy production credits called for in the Energy Policy Act of 1992 for the appropriate energy types.

Three renewable fuels are used in either cogeneration or industrial electricity generation. They are biomass, hydroelectric power, and municipal solid waste (MSW) which provide 16 percent, 2 percent, and less than 1 percent of the power, respectively.

\section{Key Assumptions}

\section{Dispersed Renewables}

Dispersed renewables, technologies in which the energy is consumed at the site of its production, are modeled within the demand modules. The dispersed renewables included in the demand modules of NEMS are biomass, solar thermal, and geothermal heat pumps. Dispersed wind (electric and nonelectric) and dispersed photovoltaics (including distributed grid-connected-i.e., at the substation level-generation) are not included in NEMS. Additionally, passive solar applications are not included in NEMS.

\section{Electric Power Generation}

The RFM specifically and NEMS in general considers only grid-connected, central-power generation. This means that distributed sources such as some types of photovoltaic, Stirling engine solar, and wind generation that is not from a central power station are not included in the energy balances for the AEO94. The renewable submodules that interact with the EMM are the hydroelectric power, solar, wind, geothermal, wood, and MSW submodules. Each provides specific data that characterize that resource in a representative manner. In addition, a set of cost and performance data is provided directly to the EMM. These data are central to the build and dispatch decisions of the EMM. The data are presented in Table 51. 
Table 51. Renowable Fuels Cost and Performance Data (1987 Dollars)

\begin{tabular}{|c|c|c|c|c|c|c|c|}
\hline Parametore & $\begin{array}{l}\text { Hydro- } \\
\text { oleotrle }\end{array}$ & $\begin{array}{c}\text { solar } \\
\text { Thormal" }\end{array}$ & $\begin{array}{l}\text { Photo- } \\
\text { voltalce }\end{array}$ & Wind & $\begin{array}{l}\text { Oeo- } \\
\text { thormal }\end{array}$ & Maw & Wood \\
\hline \multicolumn{8}{|l|}{ Capacity Factor } \\
\hline Maximum & 0.43 & 0.47 & 0.25 & 0.37 & 0.80 & 0.85 & 0.70 \\
\hline Minimum & 0.43 & 0.29 & 0.25 & $0.29^{b}$ & 0.80 & 0.85 & 0.70 \\
\hline Overnight Capltal Cost (dollars per kllowatt) & 1,812 & 2,208 & 1,215 & 903 & 1,541 & 4,389 & 1,402 \\
\hline Fixed Operating Costs (dollars per Klowatt) & 10.00 & 27.86 & 0.00 & 20.86 & 40.73 & 15.06 & 84.69 \\
\hline Variable Operating Costs (mills per kllowatthour) & 3.14 & 0.00 & 2.00 & 0.00 & 0.00 & $-36.45^{\mathrm{c}}$ & $23.31^{\mathrm{d}}$ \\
\hline Date of Co,nmercial Avallability & 1990 & 2005 & 1990 & 1990 & 1997 & 1990 & 2000 \\
\hline Construction Lead Time (years) & N/A & 3.00 & 1.00 & 2.00 & 3.00 & 3.00 & 3.00 \\
\hline
\end{tabular}

MSW = Municipal solid waste.

-Solar thermal will only operate in Electricity Market Module reglons 2, 5, \& 10-13 because of its requirement for slgnificant direct, normal insolation.

Varies according to time slice and reglon. Value selected as representative for 2010

"Negative value represents tlpping fees for MSW disposal.

¿Value represents the sum of varlable operating and maintenance and fuel costs.

Notes: All technologies and coste only consider grid-connected electricity generation.

Sources: Hydroelectrlc: Forms ElA-B60 and ElA-867. Solar Thermal: Pacific Gas \& Electric Co., "Solar Central Recelver Technology Advancement for Electric Utility Applicajon" (San Francisco, CA, Seplember 1988). Photovoltalce: Technology Characterizations from DOE/EE. Wind: Electric Power Research Institute (EPRI), Technical Assessment Guide (TAG) 1993. Coothermal: EPRI-TAG, 1993. MSW: EPRI-TAG, 1993. Blomase: Department of Energy, Offlce of Solar Energy Conversion, "Electriclty from Blomass: A Development Strategy. 1992."

\section{Conventional Hydroelectric Power Submodule}

\section{Background}

The Hydroelectric Power Submodule represents planned new conventional hydroelectric power capacity connected to the transmission grid and reported on EIA Form-860, "Annual Electric Generator Report" and Form-867, "Annual Nonutility Power Producer Report." The submodule does not estimate additional unplanned capacity. Moreover, the submodule does not estimate any hydroelectric capacity not connected to the grid or hydropower uses other than for electric power (such as for direct drives). Finally, the submodule also excludes pumped storage hydroelectric power, which is considered a storage medium for coal and nuclear power and is not a renewable energy use. Hydroelectric power is not competed against any other electricity generation technologies for capacity expansion, and all the hydropower generated (from power marketing administrations, etc.) is consumed. The submodule provides for conventional hydropower, the available capacity, capacity factors, costs (capital and fixed and variable operating and maintenance) to the EMM by region. The fossil-fuel heat rate equivalents for hydropower, like all other submodules, are provided to the report writer for consumption calculation purposes only. An important factor determining the future growth in hydropower capacity and generation potential is the licensing/relicensing decisions of the Federal Energy Regulatory Commission (FERC).

\section{Assumptions}

- Because of hydroelectric power's position in the merit order of generation it is assumed that all available installed hydroelectric capacity will be used within the constraints of available water supply and general operating requirements. 
- Capacity expansion is determined exogenously based on industry data as reported on Forms EIA-860 and EIA-867. Unplanned capacity changes (expansion or decrements) could be a variable for future sensitivity analysis, yet are assumed to be zero for the Reference Case and alternative cases as little unplanned growth is currently anticipated.

Data for hydroelectric capacity (Table 52) are derived from capacity changes report on Forms EIA-860 and EIA-867 and are outputs from the Hydroelectric Power Submodule.

Table 52. Maximum Hydroelectric Capacity (Megawatts)

\begin{tabular}{|c|c|c|c|}
\hline Year & Maximum Capacity & Year & Maximum Capacity \\
\hline 1990. & $\ldots \ldots 74,640$ & 2001 & 77,540 \\
\hline 1991. & $\ldots \ldots 74,640$ & 2002 & 77,550 \\
\hline 1992. & 74,930 & 2003 & 77,560 \\
\hline 1993. & 75,030 & 2004 & 77,580 \\
\hline 1994. & 75,340 & 2005 & 77,5919 \\
\hline 1995 & 75,470 & 2006 & 77,600 \\
\hline 1996. & 75,670 & 2007 & . 77,620 \\
\hline 1997. & 75,800 & 2008 & . . 77,620 \\
\hline 1998 & 76,690 & 2009 & 77,620 \\
\hline 1999 & 77,500 & 2010 & . 77,620 \\
\hline 2000 & 77,530 & & \\
\hline
\end{tabular}

Source: Energy Information Administration, Office of Integrated Analysis and Forecasting.

\section{Solar Electric Submodule}

\section{Background}

The Solar Electric Submodule (SOLES) currently models two solar technologies, crystalline silicon photovoltaic collectors (PV) and central receiver solar thermal electric systems (ST). PV is assumed to be available in all $15 \mathrm{EMM}$ regions while ST is available in only 6 regions, primarily in the southwestern United States, where the necessary kind of solar conditions prevail. The technological performance, costs, and other data used in NEMS are derived for PV from the Technological Characterization efforts of the Department of Energy, Office of Energy Efficiency and Renewable Energy, and for ST from the Pacific Gas and Electric Co. report entitled "Solar Central Receiver Technology Advancement for Electric Utility Application" dated September 1988. SOLES provides to the EMM: capital investment cost, fixed O \& M costs, variable operating costs, construction lead times, and the profile of construction costs as the percent of the total cost spent each year. For reporting purposes, solar output is aggregated into one number which is primarily ST with a small portion of it PV.

\section{Assumptions}

- Because solar technologies are more expensive than other utility grid-connected technologies, the early penetration will be driven by broader economic decisions such as the desire to become familiar with a new technology and environmental considerations.

- Solar resources are well in excess of conceivable demand, so that supply curves are considered to be flat within regions. Accordingly, there is no reason to track installed solar capacity in NEMS. In the nine regions where ST technology is not modeled, the level of direct, normal 
insolation (the kind needed for that technology) is insufficient to make that tecl:nology commercially viable.

- NEMS models the 10-percent investment tax credit for solar electric power generation by taxpaying entities. However, it does not include the 1.5-cent-per-kilowatthour subsiciy to solar energy production for State and nonprofit electric cooperatives, since it does not ketp track of these distinctions within the model.

\section{Wind-Electric Power Submodule}

\section{Background}

The specific wind technology modeled in NEMS is the horizontal-axis wind turbine. Unlike the sclar resource, wind is considered a finite resource so the submodule calculates a maximum available capacity by North American Electric Reliability Council (NERC) region. The minimum economically viable wind speed is about $13 \mathrm{mph}$, and wind speeds are categorized into three wind classes according to annual mean wind power density. For the AEO94, the RFM passes only one category per NERC region to the EMM. The wind category used represents an aggregation of the two best wind classes with the most significant amount of wind resources. Wind resource data on the amount and quality of wind per NERC region come from Pacific Northwest Laboratories (PNL) studies and publications. ${ }^{80}$ The technological performance, cost, and other data used in NEMS are derived from the Electric Power Research Institute's (EPRI) Technology Assessment Guide (TAG).

Maximum wind capacity, capacity factors, capital costs, fixed and variable operating and maintenance costs and incentives are provided to the EMM for capacity planning and dispatch decisions. The fossilfuel heat rate equivalents for wind, like all other submodules, are provided to the report writer for energy consumption calculation purposes only. These form the basis on which the EMM will decide how much power generation capacity is available from wind eitergy.

\section{Assumptions}

- Only grid-connected (utility and nonutility) generation is included. The forecasts do not include dispersed electric generation.

- Availability of wind power is based on the PNL Environmental and Moderate Land-Use Exclusions Scenario, in which some of the windy land area is not available for siting of wind turbines. The percent of total windy land unavailable under this scenario consists of all environmentally protected lands (such as parks and wilderness areas), all urban lands, all wetlands, 50 percent of forest lands, 30 percent of agricultural lands, and 10 percent of range and barren lands.

- Depending on the NERC region, the cost of competing fuels and other factors, wind plants can be built to meet system capacity requirements or as a "fuel saver" to displace generation from existing capacity. For wind to penetrate as a fuel saver, the total fixed (capital and fixed operations and maintenance) costs plus operating (variable operations and maintenance minus applicable subsidies from EPACT) for new wind units must be less than the operating costs for existing capacity.

\footnotetext{
${ }^{80}$ Elliott, D.L., L.L. Wendell and G.L. Gower, "An Assessment of the Available Windy Land Area and Wind Energy Potential in the Contiguous United States," Pacific Northwest Laboratory Operated for the U.S. Department of Energy by Battelle Memorial Institute (Contract DE-AC06-76RLO 1830), August 1991.
} 
- Because of downwind turbulence and other aerodynamic effects, the model assumes an average spacing between turbine rows of 5 rotor diameters and a lateral spacing between turbines of 10 rotor diameters. This spacing requirement determines the amount of power that can be generated from windy land area and is factored into requests for generating capacity by the EMM.

- It is expected that wind turbine technology will improve in performance and that blade lengths will increase, as the cubic relationship between the area swept by the rotor and power generation provides a large incentive for increasing blade length. Capacity factors are assumed to increase to a national average of about 33 percent.

\section{Geothermal-Electric Power Submodule}

\section{Background}

In developing geothermal capacity growth projections, hydrothermal resources are considered but hot dry rock is not included in the analysis. This is because the technology will not be available until late in the projection period, and reliable cost and resource data are not yet available. While the Geothermal-Electric Power Submodule (GES) was not interactively linked to NEMS, upper build limits for unplanned capacity additions produced in preliminary model runs were utilized. The GES utilizes a process of resource accounting based on Sandia National Laboratory's 1991 geothermal resource assessment. ${ }^{81}$ Site-specific costs, including those for drilling, steam collection, and electricity transmission to the grid, as well as site characteristics, are used in identifying available resources and capacities by EMM region. The value obtained from the GES for region 13 (California) was modified by adding 1.3 gigawatts by 2010 to reflect nonmarket considerations. Interim values which maintained the above-described endpoints for capacity were defined by incorporating the trends indicated in a recent geothermal industry survey, which results in the values shown in Table 53. ${ }^{82}$ These. "were passed to the EMM, along with the cost and performance data shown in Table 51, for $\mathrm{C}$ selection.

Table 53. Geothermal Unplanned Capacity Build Limits (Megawatts Electric)

\begin{tabular}{|c|c|c|c|}
\hline \multirow[b]{2}{*}{ Year } & \multicolumn{3}{|c|}{ Electricity Market Module Region } \\
\hline & 11 & 12 & 13 \\
\hline 2000 & 374 & 28 & 2,026 \\
\hline 2005 & 458 & 34 & 2,931 \\
\hline 2010 & 1,040 & 50 & 4,310 \\
\hline
\end{tabular}

Note: Capacity limits are assumed to increase linearly beiween 2000 and 2005 and between 2005 and 2010 .

Source: Energy Information Administration, Office of Integrated Analysis and Forecasting.

\footnotetext{
${ }^{81}$ Sandia National Laboratory, "Supply of Geothermal Power from Hydrothermal Sources: A Study of the Cost of Power in 20 and 40 Years," June 1991.

${ }^{82}$ Kruger, Paul, and Evan Hughes, Electric Power Research Instituie, "1993 Survey of the Geothermal Electric Industry," Geothermal Resources Council Transactions, 1993, p. 525-529.
} 


\section{Assumptions}

- Existing and planned capacity data are accessed directly by the EMM. The build limits in Table 53 are independent of this capacity. The data are obtained from the Forms EIA-860 and EIA-867.

- Limits on new capacity (Table 53) are determined by site data in each region and are based on conservative estimates of the total resource.

- Supply and demand are assumed to be homogeneous within a region (i.e. supply is not linked to specific electricity transmission grids).

- Plant retirements are not considered within the GES. Insufficient information is available on retirement plans for capacity that was installed prior to the simulation period. New plants installed during the midterm forecast are assumed not to retire during the period.

- Capital and operating costs shown in Table 51 are used by EMM for geothermal build and dispatch decisions.

\section{Biomass (Wood)-Electric Power Submodule}

\section{Background}

In the electricity sector, capital and operating costs, fuel costs, and capacity factors, as shown in Table 51 , are provided to the EMM to allow wood-fired units to compete with other fuels. Fuel costs are combined with variable operating costs. Expert judgment was used to establish a lower limit on total capacity additions. A trend of gradually increasing annual capacity additions from 300 megawatts in 2000 to 700 megawatts in 2010 was assumed. Regional-specific criteria for allocating capacity to regions were developed from data on the distribution of the major fuel supply, which is whole tree chips. The shares imposed are displayed in Table 54.

Table 54. Biomass - Regional Share Allocations

\begin{tabular}{|c|c|c|}
\hline & Region & Shares \\
\hline 1 & (ECAR) & 0.20 \\
\hline 3 & (MAAC). & 0.05 \\
\hline 4 & (MAIN) $\ldots \ldots \ldots$ & 0.04 \\
\hline 6 & $(N Y) \ldots \ldots \ldots$ & 0.03 \\
\hline 7 & (NE) & 0.08 \\
\hline 9 & (STV) & 0.37 \\
\hline 10 & (SPP) & 0.14 \\
\hline 11 & (NWP) & 0.09 \\
\hline
\end{tabular}

Source: Energy Information Administration, Office of Integrated Analysis and Forecasting.

\section{Assumptions}

- Existing and planned capacity data are accessed directly by the EMM. The data are obtained from the Forms EIA-860 and EIA-867. The above build limits are independent of this capacity. 
- The conversion technology represented upon which the costs in Table 51 are based is an advanced gasifier - combined cycle plant. Co-firing with coal is a distinct possibility, but it would not add capacity.

- The submodule deals with noncaptive wood consumption only. Consumption by the wood products and paper industries is modeled in the industrial demand model.

\section{Biomass (Municipal Solid Waste)-Electric Power Submodule}

\section{Background}

Municipal Solid Waste (MSW) combustion is treated within NEMS as a separate technology whose electricity production is exogenous to the EMM. The cost of producing electricity is passed to the EMM only as an input to the calculation that derives the average cost of producing electricity. Energy from MSW is a byproduct of waste disposal activity and, therefore, not competed against other technologies in model decisions regarding new capacity additions.

\section{Assumptions}

- MSW is assumed to displace other energy forms lower in the merit order.

- Build decisions are based on a stepwise process involving waste disposal parameters.

- Gross domestic product (GDP) is used as the principal driver in establishing the supply of MSW.

- The heat content of the MSW is assumed to increase from 5,114 Btu per pound in 1990 to $5,569 \mathrm{Btu}$ per pound in 2000 and remain at that level for the remainder of the projection.

- The percentage of waste combusted is estimated to trend upward from 15 percent in 1990 to 30 percent by 2010. This latter value is developed from an analysis of current regional percentages and assumed limits and growth rates for each region.

- The total energy from MSW projected for the United States is disaggregated into regions, sectors, and energy types (electricity and steam). This breakdown is performed by maintaining the projected 1996 distribution of these factors as represented in the Government Advisory Associates database of MSW plants.

- Capacities are computed from total energy by applying an assumed heat rate of 16,284 Btu per kilowatthour and capacity factor of 0.85 for all regions and years.

\section{Biofuels (Ethanol) Supply Submodule}

\section{Background}

The Biofuels (Ethanol) Supply Submodule (BSS) employs supply functions on an annual basis through 2010 for ethanol produced from corn to produce transportation fuel.

\section{Assumptions}

- Corn feedstock production is provided exogenously to NEMS. Only ethanol production from corn is currently modeled. 
- Most production is projected to come from PAD District II, where most of the corn is grown. This is not an assumption of the model but rather a result of the exogenous projections of feedstock costs and quantities. However, it is assumed that the mathematical decision will approximate reality to the point that it captures most of the production.

- The tax subsidy to ethanol of $\$ .54$ per gallon of ethanol (5.4 cents per gallon subsidy to gasohol at a 10-percent volumetric blending portion) is applied within the PMM.

- Interregional transportation costs are not calculated within the BSS model.

\section{Legislation}

The RFM includes the investment tax and energy production credits called for in the Energy Policy Act of 1992 (EPACT) for the appropriate energy types. EPACT provides a renewable electricity production credit of 1.5 cents per kilowatthour for electricity produced by wind, applied to plants that become operational between January 1, 1994, and June 30,1999. The credit extends for 10 years after the date of initial operation. EPACT also includes provisions that allow an investment tax credit of 10 percent for solar and geothermal technologies that generate electric power. This credit is represented as a 10-percent reduction in the capital costs in the RFM.

\section{Emissions}

Emissions attributable to the combustion of renewable fuels used to generate electricity are estimated by the EMM. 


$$
\text { I: }
$$


Table 1. Energy Consumption by End-Use Sector and Source Now England Census Division (Quadrillion Btu per Year)

\begin{tabular}{|c|c|c|c|c|c|}
\hline \multirow{2}{*}{ Sector and Source } & \multicolumn{4}{|c|}{ Roterence Case } & \multirow{2}{*}{$\begin{array}{l}\text { Annual } \\
\text { Growth } \\
1990-2010 \\
\text { (preent) }\end{array}$} \\
\hline & 1980 & 2000 & 2005 & 2010 & \\
\hline \multicolumn{6}{|l|}{ Residential } \\
\hline Distillate Fuel $\ldots \ldots \ldots \ldots \ldots \ldots \ldots \ldots$ & 0.242 & 0.274 & 0.281 & 0.287 & $0.8 \%$ \\
\hline Kerosene $\ldots \ldots \ldots \ldots \ldots \ldots \ldots \ldots$ & 0.008 & 0.007 & 0.006 & 0.005 & $-1.9 \%$ \\
\hline Liquetied Petroleum Gas . . . . . . . . . . . . . . & 0.021 & 0.020 & 0.019 & 0.018 & $-0.8 \%$ \\
\hline Natural Gas $\ldots \ldots \ldots \ldots \ldots \ldots \ldots \ldots$ & 0.176 & 0.200 & 0.203 & 0.208 & $0.8 \%$ \\
\hline 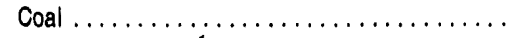 & 0.002 & 0.001 & 0.001 & 0.001 & $.1 .3 \%$ \\
\hline Renewable Energy' $\ldots \ldots \ldots \ldots \ldots \ldots \ldots$ & 0.039 & 0.040 & 0.041 & 0.041 & $0.3 \%$ \\
\hline Electricity $\ldots \ldots \ldots \ldots \ldots \ldots \ldots \ldots \ldots$ & 0.128 & 0.135 & 0.140 & 0.147 & $0.7 \%$ \\
\hline Total $\ldots \ldots \ldots \ldots \ldots \ldots \ldots \ldots$ & 0.616 & 0.676 & 0.691 & 0.708 & $0.7 \%$ \\
\hline \multicolumn{6}{|l|}{ Commerclal } \\
\hline Distillate Fuel .. & 0.077 & 0.073 & 0.067 & 0.062 & $-1.1 \%$ \\
\hline Kerosene $\ldots \ldots \ldots \ldots \ldots \ldots \ldots \ldots$ & 0.002 & 0.002 & 0.002 & 0.002 & $.0 .2 \%$ \\
\hline Molor Gasolin $\theta^{2} \ldots \ldots \ldots \ldots \ldots \ldots$ & 0.003 & 0.003 & 0.003 & 0.003 & $.0 .3 \%$ \\
\hline Residual Fuel $\ldots \ldots \ldots \ldots \ldots \ldots \ldots \ldots$ & 0.057 & 0.070 & 0.077 & 0.085 & $2.0 \%$ \\
\hline Natural Gas $\ldots \ldots \ldots \ldots \ldots \ldots \ldots$ & 0.100 & 0.115 & 0.121 & 0.127 & $1.2 \%$ \\
\hline Other' $\ldots \ldots \ldots \ldots \ldots \ldots \ldots \ldots \ldots$ & 0.006 & 0.006 & 0.006 & 0.006 & $0.0 \%$ \\
\hline Renewable Energy $\ldots \ldots \ldots \ldots \ldots \ldots \ldots$ & 0.000 & 0.000 & 0.000 & 0.000 & $5.1 \%$ \\
\hline Electricity $\ldots \ldots \ldots \ldots \ldots \ldots \ldots \ldots \ldots$ & 0.134 & 0.140 & 0.139 & 0.134 & $0.0 \%$ \\
\hline Total $\ldots \ldots \ldots \ldots \ldots \ldots \ldots \ldots \ldots$ & 0.379 & 0.407 & 0.415 & 0.418 & $0.6 \%$ \\
\hline \multicolumn{6}{|l|}{ Industriaf } \\
\hline Distillate Fuel $\ldots \ldots \ldots \ldots \ldots \ldots \ldots$ & 0.029 & 0.034 & 0.037 & 0.039 & $1.5 \%$ \\
\hline Liquefied Petrolaum Gas . . . . . . . . . . . . . . & 0.009 & 0.008 & 0.008 & 0.009 & $.0 .3 \%$ \\
\hline Motor Gasoling ${ }^{2} \ldots \ldots \ldots \ldots \ldots \ldots \ldots$ & 0.005 & 0.007 & 0.008 & 0.008 & $2.6 \%$ \\
\hline Petrochemical Feedstocks $\ldots \ldots \ldots \ldots \ldots \ldots$ & 0.013 & 0.013 & 0.013 & 0.013 & $0.0 \%$ \\
\hline Residual Fuel $\ldots \ldots \ldots \ldots \ldots \ldots \ldots$ & 0.063 & 0.054 & 0.052 & 0.051 & $.1 .0 \%$ \\
\hline Other Petroleum ${ }^{6} \ldots \ldots \ldots \ldots \ldots \ldots$ & 0.057 & 0.067 & 0.072 & 0.075 & $1.4 \%$ \\
\hline Natural Gas $^{7} \ldots \ldots \ldots \ldots \ldots \ldots$ & 0.084 & 0.116 & 0.124 & 0.129 & $2.2 \%$ \\
\hline Metallurgical Coal $\ldots \ldots \ldots \ldots \ldots \ldots \ldots \ldots$ & 0.000 & 0.000 & 0.000 & 0.000 & N/A \\
\hline Steam Coal $\ldots \ldots \ldots \ldots \ldots \ldots \ldots \ldots$ & 0.008 & 0.011 & 0.012 & 0.015 & $3.2 \%$ \\
\hline Net Coal Coke Imports $\ldots \ldots \ldots \ldots \ldots \ldots$ & 0.000 & 0.000 & 0.000 & 0.000 & N/A \\
\hline Renewable Energy $\ldots \ldots \ldots \ldots \ldots \ldots \ldots$ & 0.136 & 0.158 & 0.176 & 0.190 & $1.7 \%$ \\
\hline Electricity $\ldots \ldots \ldots \ldots \ldots \ldots \ldots$ & 0.093 & 0.103 & 0.111 & 0.117 & $1.2 \%$ \\
\hline Total $\ldots \ldots \ldots \ldots \ldots \ldots \ldots \ldots$ & 0.488 & 0.570 & 0.613 & 0.647 & $1.3 \%$ \\
\hline \multicolumn{6}{|l|}{ Transportation } \\
\hline Distillate Fuel & 0.119 & 0.140 & 0.153 & 0.162 & $1.5 \%$ \\
\hline Jet Fuel ${ }^{\natural} \ldots \ldots \ldots \ldots \ldots \ldots \ldots \ldots$ & 0.092 & 0.070 & 0.077 & 0.082 & $.0 .6 \%$ \\
\hline Motor Gasoline $e^{2} \ldots \ldots \ldots \ldots \ldots \ldots$ & 0.664 & 0.689 & 0.714 & 0.714 & $0.4 \%$ \\
\hline Residual Fuel $\ldots \ldots \ldots \ldots \ldots \ldots \ldots \ldots$ & 0.011 & 0.013 & 0.014 & 0.015 & $1.6 \%$ \\
\hline Liquefied Petroleum Gas . . . . . . . . . . . . . . & 0.003 & 0.004 & 0.007 & 0.011 & $7.2 \%$ \\
\hline Other Petroleum $\ldots \ldots \ldots \ldots \ldots \ldots \ldots$ & 0.009 & 0.009 & 0.009 & 0.010 & $0.6 \%$ \\
\hline Fipeline Fuel Natural Gas $\ldots \ldots \ldots \ldots \ldots$ & 0.002 & 0.002 & 0.002 & 0.003 & $1.4 \%$ \\
\hline Compressed Natural Gas . . . . . . . . . . . . . & 0.000 & 0.008 & 0.014 & 0.020 & $23.0 \%$ \\
\hline Renewables $(e t h a n o l)^{10} \ldots \ldots \ldots \ldots \ldots$ & 0.000 & 0.001 & 0.002 & 0.003 & $33.0 \%$ \\
\hline Liquid Hydrogen $\ldots \ldots \ldots \ldots \ldots \ldots \ldots$ & 0.000 & 0.000 & 0.000 & 0.000 & $94.2 \%$ \\
\hline Methanol $^{11} \ldots \ldots \ldots \ldots \ldots \ldots \ldots \ldots$ & 0.000 & 0.000 & 0.002 & 0.004 & $38.2 \%$ \\
\hline Electricity $\ldots \ldots \ldots \ldots \ldots \ldots \ldots \ldots \ldots$ & 0.003 & 0.004 & 0.007 & 0.010 & $6.1 \%$ \\
\hline Total $\ldots \ldots \ldots \ldots \ldots \ldots \ldots \ldots \ldots$ & 0.902 & 0.940 & 1.000 & 1.034 & $0.7 \%$ \\
\hline \multicolumn{6}{|l|}{ Electric Utilitlos ${ }^{12}$} \\
\hline Distillate Fuel $\ldots \ldots \ldots \ldots \ldots \ldots \ldots \ldots$ & 0.002 & 0.001 & 0.001 & 0.003 & $1.8 \%$ \\
\hline Residual Fuel $\ldots \ldots \ldots \ldots \ldots \ldots \ldots \ldots \ldots$ & 0.280 & 0.191 & 0.212 & 0.151 & $.3 .0 \%$ \\
\hline Natural Gas $\ldots \ldots \ldots \ldots \ldots \ldots \ldots \ldots \ldots$ & 0.091 & 0.149 & 0.152 & 0.160 & $2.8 \%$ \\
\hline Steam Coal . . . . . . . . . . . . . . . . . & 0.162 & 0.167 & 0.159 & 0.163 & $0.0 \%$ \\
\hline Nuclear Power $\ldots \ldots \ldots \ldots \ldots \ldots \ldots \ldots$ & 0.400 & 0.449 & 0.447 & 0.347 & $.0 .7 \%$ \\
\hline Renewable Energy/Other ${ }^{13} \ldots \ldots \ldots \ldots \ldots \ldots$ & 0.208 & 0.198 & 0.238 & 0.327 & $2.3 \%$ \\
\hline Total $\ldots \ldots \ldots \ldots \ldots \ldots \ldots \ldots \ldots$ & 1.144 & 1.155 & 1.210 & 1.161 & $0.0 \%$ \\
\hline
\end{tabular}


Table 1. Energy Consumption by End-Use Sector and Source

Now England Census Division (Continued)

(Quadrillion Btu per Year)

\begin{tabular}{|c|c|c|c|c|c|}
\hline \multirow{2}{*}{ Soctor and Source } & \multicolumn{4}{|c|}{ Relerence Ceses } & \multirow{2}{*}{$\begin{array}{c}\text { Annual } \\
\text { Growth } \\
1000-2010 \\
\text { (percant) }\end{array}$} \\
\hline & 1900 & 2000 & 2006 & 2010 & \\
\hline \multicolumn{6}{|l|}{ Primery Energy Coneumption } \\
\hline Distillate Fuel $\ldots \ldots \ldots \ldots \ldots \ldots \ldots \ldots$ & 0.471 & 0.521 & 0.539 & 0.553 & $0.8 \%$ \\
\hline Kerosene $\ldots \ldots \ldots \ldots \ldots \ldots \ldots \ldots \ldots \ldots$ & 0.009 & 0.008 & 0.008 & 0.007 & $.1 .6 \%$ \\
\hline Jet Fuep. & 0.092 & 0.070 & 0.077 & 0.082 & $-0.6 \%$ \\
\hline Llquefied Petroleum Gas & 0.037 & 0.035 & 0.038 & 0.042 & $0.6 \%$ \\
\hline Motor Gasolin $\theta^{2} \ldots \ldots$ & 0.671 & 0.699 & 0.724 & 0.725 & $0.4 \%$ \\
\hline Petrochemical Foodstocks & 0.013 & 0.013 & 0.013 & 0.013 & $0.0 \%$ \\
\hline Residual Fuel ......... & 0.411 & 0.328 & 0.355 & 0.303 & $.1 .5 \%$ \\
\hline Other Petroleum" & 0.066 & 0.076 & 0.081 & 0.085 & $1.3 \%$ \\
\hline Natural Gas .... & 0.430 & 0.590 & 0.616 & 0.647 & $2.1 \%$ \\
\hline Metallurgical Coal & 0.000 & 0.000 & 0.000 & 0.000 & $N / A$ \\
\hline Steam Coal ........................ & 0.174 & 0.181 & 0.175 & 0.181 & $0.2 \%$ \\
\hline 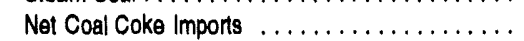 & 0.000 & 0.000 & 0.000 & 0.000 & N/A \\
\hline Nuclear Power $\ldots \ldots \ldots \ldots \ldots \ldots$ & 0.400 & 0.449 & 0.447 & 0.347 & $.0 .7 \%$ \\
\hline Renewable Energy/Other" & 0.383 & 0.397 & 0.459 & 0.565 & $2.0 \%$ \\
\hline Total...$\ldots \ldots \ldots \ldots \ldots \ldots \ldots \ldots \ldots \ldots$ & 3.181 & 3.366 & 3.531 & 3.560 & $0.6 \%$ \\
\hline Eloctricity Consumption (all eactors) & 0.368 & 0.392 & 0.390 & 0.406 & $0.7 \%$ \\
\hline
\end{tabular}

'includes electricity generated by the sector tor self-use from hydroelectric, geothermal, wood and wood waste, municipal solid waste, other biomass, wind, photovoltaic and solar thermal sources, and non-electric energy from renewable sources, such as solar thermal water heaters, ground-water heat pumps, and wood.

'Includes ethanol (blends of 10 percent or less) and ethers blended into gasoline.

Includes liquefied petrolt. Im gas and coal.

Includes commercial sector electricity cogenerated using wood and wood waste, municipal solid waste, and other biomass; nonelectric energy from renewable sources, such as active solar and passive solar systems, geothermal heat pumps, and solar water heating systems.

"Fuel consumption includes consumption for cogeneration.

includes petroleum coke, asphalt, road oil, lubricants, still gas, and miscellaneous petroleum products.

${ }^{7}$ Includes lease and plant fuel.

Includes naphtha and kerosene type.

"includes aviation gasoline and lubricants.

${ }^{10}$ Only E85 (85 percent ethanul).

"Only M85 (85 percent methanol).

${ }^{12}$ Includes consumption of energy by electric utilities, independent power producers, and small power producers that sell power to the grid.

${ }^{19}$ includes electricity sold to utllities by nonutilities, including cogenerators, from hydroelectric, geothermal, wood and wood waste, municipal solid waste, other biomass, wind, photovoltaic and solar thermal sources, plus waste heat and net electricity imports. Does not include own use.

${ }^{14}$ Includes untinished oils, natural gasoline, motor gasoline blending compounds, aviation gasoline, lubricants, still gas, asphalt, road oil, and miscellaneous petroleum products.

${ }^{18}$ Includes electricity generated for sale to electric utilities and for self use from renewable sources, non-fiectrlc energy from renewable sources, electricity generated from waste heal, net electricity imports, liquid hyc ogen, and methanol.

Btu $=$ British thermal unit.

N/A $=$ Not applicable.

Note: Totals may not equal sum of components due to independent rounding.

Sources: 1990 coal consumption: Energy information Administration (ElA), Quarterly Coal Report, DOE/EIA-0121 (90/4Q) (Washington, D.C. May 1991) and State Energy Data Report 1991, DOE/EIA-0214(91) (Washington, D.C., May 1993). 1990 natural gas consumption: ElA, Natural Gas Annual 1982 Volume 1, DOE/EIA-0131(92)/1 (Washington, D.C. November 1993). 1900 consumption other than coal and natural gas: ElA, Monthly Energy Review, DOE/EIA-0035(93/07) (Washington, D.C., July 1993) and Otfice of Coal, Nuclear, Electric and Alternate Fuels estimates. Figures for 108 . may differ from published data due to internal conversion factors within the AEO 1094 National Energy Modeling System. The 1090 values are not final and may be updated in EIA publicatlons. Projectlons: EIA, AEO 1994 National Energy Modeling System run AEO94B.D1221934. 
Table 2. Energy Consumption by End-Use Sector and Source Middle Atlantic Census Division

(Quadrillion Btu per Year)

\begin{tabular}{|c|c|c|c|c|c|}
\hline \multirow{2}{*}{ Sector and Sourcs } & \multicolumn{4}{|c|}{ Reterence Caes } & \multirow{2}{*}{$\begin{array}{l}\text { Annual } \\
\text { Growth } \\
1900-2010 \\
\text { (percent) }\end{array}$} \\
\hline & 1090 & 2000 & 2008 & 2010 & \\
\hline \multicolumn{6}{|l|}{ Residential } \\
\hline Distillate Fuel $\ldots \ldots \ldots \ldots \ldots \ldots \ldots \ldots$ & 0.321 & 0.325 & 0.316 & 0.304 & $.0 .3 \%$ \\
\hline Kerosene $\ldots \ldots \ldots \ldots \ldots \ldots \ldots \ldots$ & 0.019 & 0.017 & 0.016 & 0.015 & $.1 .5 \%$ \\
\hline Liquelied Petroleum Gas . . . . . . . . . . . . . . & 0.027 & 0.026 & 0.024 & 0.023 & $.0 .9 \%$ \\
\hline Nalural Gas $\ldots \ldots \ldots \ldots \ldots \ldots \ldots$ & 0.772 & 0.830 & 0.807 & 0.798 & $0.2 \%$ \\
\hline 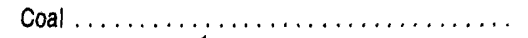 & 0.021 & 0.018 & 0.017 & 0.016 & $.1 .3 \%$ \\
\hline Renewable Energy ${ }^{\prime} \ldots \ldots \ldots \ldots \ldots \ldots \ldots$ & 0.086 & 0.090 & 0.089 & 0.088 & $0.1 \%$ \\
\hline Electricity $\ldots \ldots \ldots \ldots \ldots \ldots \ldots \ldots \ldots$ & 0.332 & 0.337 & 0.339 & 0.346 & $0.2 \%$ \\
\hline Total $\ldots \ldots \ldots \ldots \ldots \ldots \ldots \ldots \ldots$ & 1.579 & 1.642 & 1.600 & 1.590 & $0.0 \%$ \\
\hline \multicolumn{6}{|l|}{ Commercial } \\
\hline$\ldots \ldots \ldots \ldots \ldots \ldots$ & 0.148 & 0.142 & 0.132 & 0.124 & $.0 .9 \%$ \\
\hline$\ldots \ldots \ldots \ldots \ldots \ldots \ldots$ & 0.003 & 0.003 & 0.003 & 0.003 & $.0 .4 \%$ \\
\hline$\ldots \ldots \ldots \ldots \ldots \ldots$ & 0.014 & 0.013 & 0.013 & 0.013 & $.0 .4 \%$ \\
\hline Residual Fuel $\ldots \ldots \ldots \ldots \ldots \ldots \ldots \ldots$ & 0.125 & 0.098 & 0.087 & 0.077 & $-2.4 \%$ \\
\hline Natural Gas $\ldots \ldots \ldots \ldots \ldots \ldots \ldots \ldots$ & 0.449 & 0.452 & 0.446 & 0.444 & $-0.1 \%$ \\
\hline Other $\ldots \ldots \ldots \ldots \ldots \ldots \ldots \ldots \ldots \ldots$ & 0.024 & 0.023 & 0.022 & 0.022 & $.0 .4 \%$ \\
\hline Renewabie Energy $\ldots \ldots \ldots \ldots \ldots \ldots \ldots$ & 0.000 & 0.001 & 0.001 & 0.001 & $4.9 \%$ \\
\hline Electricity $\ldots \ldots \ldots \ldots \ldots \ldots \ldots \ldots$ & 0.388 & 0.399 & 0.387 & 0.365 & $.0 .3 \%$ \\
\hline Total $\ldots \ldots \ldots \ldots \ldots \ldots \ldots \ldots \ldots$ & 1.153 & 1.130 & 1.093 & 1.049 & $-0.5 \%$ \\
\hline \multicolumn{6}{|l|}{ Industriaf } \\
\hline$\ldots \ldots \ldots \ldots \ldots \ldots \ldots \ldots$ & 0.074 & 0.085 & 0.094 & 0.100 & $1.5 \%$ \\
\hline Liquetied Petroleum Gas . . . . . . . . . . . . . & 0.026 & 0.031 & 0.033 & 0.035 & $1.5 \%$ \\
\hline Motor Gasoline ${ }^{2} \ldots \ldots \ldots \ldots \ldots \ldots \ldots$ & 0.014 & 0.021 & 0.024 & 0.026 & $2.9 \%$ \\
\hline Petrochemical Feedstocks $\ldots \ldots \ldots \ldots \ldots$ & 0.127 & 0.121 & 0.124 & 0.127 & $0.0 \%$ \\
\hline Residual Fuel $\ldots \ldots \ldots \ldots \ldots \ldots \ldots \ldots$ & 0.089 & 0.097 & 0.097 & 0.095 & $0.3 \%$ \\
\hline Other Petroleum ${ }^{\circ} \ldots \ldots \ldots \ldots \ldots \ldots \ldots$ & 0.357 & 0.449 & 0.467 & 0.478 & $1.5 \%$ \\
\hline Natural Gas $^{\prime} \ldots \ldots \ldots \ldots \ldots \ldots \ldots \ldots$ & 0.447 & 0.487 & 0.518 & 0.540 & $1.0 \%$ \\
\hline Metallurgical Coal $\ldots \ldots \ldots \ldots \ldots \ldots \ldots$ & 0.316 & 0.232 & 0.203 & 0.176 & $.2 .9 \%$ \\
\hline Steam Coal $\ldots \ldots \ldots \ldots \ldots \ldots \ldots \ldots \ldots$ & 0.155 & 0.161 & 0.189 & 0.206 & $1.4 \%$ \\
\hline Net Coal Coke imports $\ldots \ldots \ldots \ldots \ldots \ldots$ & 0.000 & 0.000 & 0.000 & 0.000 & $N / A$ \\
\hline Renewable Energy $\ldots \ldots \ldots \ldots \ldots \ldots \ldots$ & 0.191 & 0.218 & 0.237 & 0.256 & $1.5 \%$ \\
\hline Electricity $\ldots \ldots \ldots \ldots \ldots \ldots \ldots \ldots$ & 0.317 & 0.353 & 0.379 & 0.400 & $1.2 \%$ \\
\hline Total $\ldots \ldots \ldots \ldots \ldots \ldots \ldots \ldots \ldots \ldots$ & 2.115 & 2.254 & 2.364 & 2.438 & $0.7 \%$ \\
\hline \multicolumn{6}{|l|}{ Transportation } \\
\hline Distillate Fuel & 0.344 & 0.404 & 0.434 & 0.469 & $1.6 \%$ \\
\hline$\ldots \ldots \ldots \ldots \ldots \ldots \ldots \ldots$ & 0.361 & 0.386 & 0.422 & 0.456 & $1.2 \%$ \\
\hline Motor Gasoline ${ }^{2} \ldots \ldots \ldots \ldots \ldots \ldots \ldots$ & 1.669 & 1.737 & 1.777 & 1.798 & $0.4 \%$ \\
\hline Residual Fuel $\ldots \ldots \ldots \ldots \ldots \ldots \ldots \ldots$ & 0.091 & 0.107 & 0.118 & 0.128 & $1.8 \%$ \\
\hline Liquefied Petroleum Gas . . . . . . . . . . . . . . & 0.008 & 0.011 & 0.020 & 0.030 & $7.1 \%$ \\
\hline Other Petroleum ${ }^{0} \ldots \ldots \ldots \ldots \ldots \ldots \ldots$ & 0.024 & 0.024 & 0.025 & 0.026 & $0.6 \%$ \\
\hline Pipeline Fuel Natural Gas $\ldots \ldots \ldots \ldots \ldots \ldots$ & 0.043 & 0.039 & 0.041 & 0.041 & $.0 .3 \%$ \\
\hline Compressed Natural Gas . . . . . . . . . . . . . . & 0.000 & 0.021 & 0.038 & 0.057 & N/A \\
\hline Renewables (ethanol) ${ }^{10} \ldots \ldots \ldots \ldots \ldots \ldots$ & 0.000 & 0.002 & 0.005 & 0.009 & $33.0 \%$ \\
\hline Liquid Hydrogen $\ldots \ldots \ldots \ldots \ldots \ldots \ldots$ & 0.000 & 0.000 & 0.000 & 0.000 & $94.2 \%$ \\
\hline Methanol $^{11} \ldots \ldots \ldots \ldots \ldots \ldots \ldots$ & 0.000 & 0.001 & 0.005 & 0.010 & $38.2 \%$ \\
\hline Electricity $\ldots \ldots \ldots \ldots \ldots \ldots \ldots \ldots$ & 0.009 & 0.012 & 0.020 & 0.029 & $6.0 \%$ \\
\hline Total $\ldots \ldots \ldots \ldots \ldots \ldots \ldots \ldots \ldots$ & 2.549 & 2.745 & 2.804 & 3.052 & $0.9 \%$ \\
\hline \multicolumn{6}{|l|}{ Electric Utilitles ${ }^{12}$} \\
\hline Distillate Fuel . . & 0.000 & 0.001 & 0.001 & 0.000 & $.2 .1 \%$ \\
\hline Residual Fuel $\ldots \ldots \ldots \ldots \ldots \ldots \ldots \ldots \ldots$ & 0.428 & 0.307 & 0.315 & 0.282 & $-2.1 \%$ \\
\hline Natural Gas $\ldots \ldots \ldots \ldots \ldots \ldots \ldots$ & 0.282 & 0.333 & 0.391 & 0.347 & $1.0 \%$ \\
\hline Steam Coal . . . . . . . . . . . . . . . . & 1.234 & 1.258 & 1.242 & 1.474 & $0.9 \%$ \\
\hline Nuclear Power $\ldots \ldots \ldots \ldots \ldots \ldots \ldots \ldots$ & 0.943 & 1.116 & 1.112 & 0.845 & $-0.6 \%$ \\
\hline Renewable Energy/Other ${ }^{13} \ldots \ldots \ldots \ldots \ldots$ & 0.397 & 0.488 & 0.530 & 0.694 & $2.8 \%$ \\
\hline Total $\ldots \ldots \ldots \ldots \ldots \ldots \ldots \ldots$ & 3.283 & 3.500 & 3.590 & 3.643 & $0.5 \%$ \\
\hline
\end{tabular}


Table 2. Energy Consumption by End-Use Sector and Source
Middle Atlantlc Census Division (Continued)
(Quadrillion Btu per Year)

\begin{tabular}{|c|c|c|c|c|c|}
\hline \multirow{2}{*}{ Sector and Source } & \multicolumn{4}{|c|}{ Reterence Case } & \multirow{2}{*}{$\begin{array}{c}\text { Annual } \\
\text { Growth } \\
1900-2010 \\
\text { (percent) }\end{array}$} \\
\hline & 1990 & 2000 & 2006 & 2010 & \\
\hline \multicolumn{6}{|l|}{ Primary Energy Consumption } \\
\hline 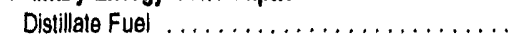 & 0.888 & 0.957 & 0.977 & 0.997 & $0.6 \%$ \\
\hline$\ldots \ldots \ldots \ldots \ldots$ & 0.023 & 0.021 & 0.019 & 0.018 & $.1 .3 \%$ \\
\hline Jet Fuel $\ldots$ & 0.361 & 0.386 & 0.422 & 0.456 & $1.2 \%$ \\
\hline Liquelied Petroleum Gas & 0.066 & 0.073 & 0.082 & 0.093 & $1.7 \%$ \\
\hline Motor Gasoline ${ }^{2} \ldots \ldots$ & 1.697 & 1.771 & 1.814 & 1.836 & $0.4 \%$ \\
\hline Petrochemical Feedstocks & 0.127 & 0.121 & 0.124 & 0.127 & $0.0 \%$ \\
\hline Residual Fuel $\ldots . . . .$. & 0.733 & 0.609 & 0.616 & 0.583 & $.1 .1 \%$ \\
\hline Other Petroleum ${ }^{14}$ & 0.380 & 0.473 & 0.492 & 0.504 & $1.4 \%$ \\
\hline Nalural Gas .... & 1.994 & 2.161 & 2.240 & 2.227 & $0.6 \%$ \\
\hline Metallurgical Coal & 0.316 & 0.232 & 0.203 & 0.176 & $.2 .9 \%$ \\
\hline Steam Coal $\ldots \ldots \ldots \ldots \ldots \ldots \ldots \ldots$ & 1.429 & 1.454 & 1.466 & 1.714 & $0.9 \%$ \\
\hline 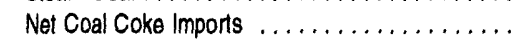 & 0.000 & 0.000 & 0.000 & 0.000 & $N / A$ \\
\hline Nuclear Power $\ldots \ldots \ldots \ldots \ldots \ldots \ldots$ & 0.943 & 1.116 & 1.112 & 0.845 & $.0 .6 \%$ \\
\hline Renewable Energy/Other ${ }^{13}$. & 0.675 & 0.799 & 0.867 & 1.057 & $2.3 \%$ \\
\hline Total $\ldots \ldots \ldots \ldots \ldots \ldots \ldots \ldots \ldots \ldots \ldots \ldots$ & 9.632 & 10.174 & 10.433 & 10.633 & $0.5 \%$ \\
\hline Electrictty Consumption (all sectors) $\ldots . \ldots \ldots$ & 1.046 & 1.100 & 1.126 & 1.140 & $0.4 \%$ \\
\hline
\end{tabular}

'Includes electricity generated by the sector tor self-use from hydroelectric, geothermal, wood and wood waste, municipal solid waste, other biomass, wind, photovoltaic and solar thermal sousces, and non-electric energy from renewable sources, such as solar thermal water heaters, ground-water heat pumps, and wood.

${ }^{2}$ Includes ethanol (blends of 10 percent or less) and ethers blended into gasoline.

${ }^{3}$ Includes liquelied petroleum gas and coal.

"Includes commercial sector electricity cogenerated using wood and wood waste, municipal solid waste, and other biomass; nonelectric energy from renewable sources, such as active solar and passive solar systems, geothermal heat pumps, and solar water heating systems.

${ }^{3}$ Fuel consumption includes consumption for cogeneration.

'Includes petroleum coke, asphalt, road oil, lubricants, still gas, and miscellaneous petroleum products.

${ }^{7}$ Includes lease and plant fuel.

includes naphtha and kerosene type.

includes aviation gasoline and lubricants.

${ }^{10}$ Only -95 ( 85 percent ethanol).

"Only M85 (85 percent methanol)

${ }^{12}$ Includes consumption of energy by electric utilities, independent power producers, and small power producers that sell power to the grid.

${ }^{13}$ Includes electricity sold to utilities by nonutilities, including cogenerators, from hydroelectric, geothermal, wood and wood waste, municipal solid waste, other biomass, wind, photovoltaic and solar thermal sources, plus waste heat and net electricity imports. Does not include own use.

${ }^{14}$ Includes untinished oils, natural gasoline, motor gasoline blending compounds, aviation gasoline, lubricants, still gas, asphalt, road oil, and miscellaneous petroleum products.

${ }^{15}$ Includes electricity generated for sale to electric utilities and for self use from renewable sources, non-electric energy from renewable sources, electricity generated from waste heat, net electricity imports, liquid hydrogen, and methanol.

Btu $=$ British thermal unit.

$N / A=$ Not applicable

Note: Totals may not equal sum of components due to independent rounding.

Sources: 1990 coal consumption: Energy Intormation Administration (EIA), Quarterly Coal Report, DOE/EIA-0121(90/4Q) (Washington, D.C. May 1991) and State Energy Data Report 1991, DOE/ElA-0214(91) (Washington, D.C., May 1993). 1990 natural gas consumption: ElA, Natural Gas Annual 1992 Volume 1, DOE/ElA-0131(92)/1 (Washington, D.C., November 1993). 1990 consumption other than coal and natural gas: ElA, Monthly Energy Review, DOE/ElA-0035(93/07) (Washington, D.C. July 1993) and Otlice of Coal, Nuclear, Electric and Alternate Fuels estimates. Figures for 1990 may differ trom published data due to internal conversion factors within the AEO 1994 National Energy Modeling System. The 1990 values are not firal and may be updated in EIA publications. Projectlons: EIA, AEO 1994 National Energy Modeling System run AEO94B.D1221934. 
Table 3. Energy Consumption by End-Use Sector and Source East North Contral Consus Division

(Quadrillion Btu per Year)

\begin{tabular}{|c|c|c|c|c|c|}
\hline \multirow{2}{*}{ Sector and Source } & \multicolumn{4}{|c|}{ Reference Cass } & \multirow{2}{*}{$\begin{array}{l}\text { Amual } \\
\text { Crowth } \\
\text { 1ceo-2010 } \\
\text { (percent) }\end{array}$} \\
\hline & 1990 & 2000 & 2006 & 2010 & \\
\hline \multicolumn{6}{|l|}{ Residentlal } \\
\hline Distillate Fuel $\ldots \ldots \ldots \ldots \ldots \ldots \ldots \ldots$ & 0.092 & 0.102 & 0.101 & 0.099 & $0.4 \%$ \\
\hline Kerosene $\ldots \ldots \ldots \ldots \ldots \ldots \ldots \ldots$ & 0.007 & 0.007 & 0.007 & 0.007 & $.0 .4 \%$ \\
\hline Llquefled Petroleum Gas . . . . . . . . . . . . . . . . . & 0.078 & 0.079 & 0.075 & 0.072 & $.0 .4 \%$ \\
\hline Natural Gas $\ldots \ldots \ldots \ldots \ldots \ldots \ldots \ldots$ & 1.372 & 1.498 & 1.483 & 1.462 & $0.3 \%$ \\
\hline Coal $\ldots \ldots \ldots \ldots \ldots \ldots \ldots \ldots$ & 0.014 & 0.012 & 0.012 & 0.011 & $.1 .2 \%$ \\
\hline Renewable Energy' $\ldots \ldots \ldots \ldots \ldots \ldots \ldots$ & 0.115 & 0.120 & 0.118 & 0.117 & $0.1 \%$ \\
\hline Electricity $\ldots \ldots \ldots \ldots \ldots \ldots \ldots \ldots$ & 0.459 & 0.476 & 0.479 & 0.486 & $0.3 \%$ \\
\hline Total $\ldots \ldots \ldots \ldots \ldots \ldots \ldots \ldots \ldots$ & 2.139 & 2.294 & 2.276 & 2.254 & $0.3 \%$ \\
\hline \multicolumn{6}{|l|}{ Commorclal } \\
\hline Distillate Fuel $\ldots \ldots \ldots \ldots \ldots \ldots \ldots \ldots$ & 0.046 & 0.064 & 0.067 & 0.067 & $1.9 \%$ \\
\hline Kerosene $\ldots \ldots \ldots \ldots \ldots \ldots \ldots \ldots$ & 0.002 & 0.002 & 0.002 & 0.002 & $-0.2 \%$ \\
\hline Motor Gasoline $e^{2} \ldots \ldots \ldots \ldots \ldots \ldots$ & 0.017 & 0.018 & 0.018 & 0.018 & $0.3 \%$ \\
\hline Residual Fuel $\ldots \ldots \ldots \ldots \ldots \ldots \ldots$ & 0.004 & 0.004 & 0.004 & 0.003 & $.0 .3 \%$ \\
\hline Natural Gas $\ldots \ldots \ldots \ldots \ldots \ldots \ldots$ & 0.656 & 0.678 & 0.680 & 0.679 & $0.2 \%$ \\
\hline$\ldots \ldots \ldots \ldots \ldots \ldots$ & 0.040 & 0.040 & 0.039 & 0.039 & $-0.2 \%$ \\
\hline Renewable Energy $\ldots \ldots \ldots \ldots \ldots \ldots \ldots$ & 0.005 & 0.010 & 0.010 & 0.011 & $4.6 \%$ \\
\hline Electricity $\ldots \ldots \ldots \ldots \ldots \ldots \ldots \ldots$ & 0.428 & 0.497 & 0.514 & 0.515 & $0.9 \%$ \\
\hline Total $\ldots \ldots \ldots \ldots \ldots \ldots \ldots \ldots \ldots$ & 1.197 & 1.311 & 1.334 & 1.334 & $0.6 \%$ \\
\hline \multicolumn{6}{|l|}{ Industriaf } \\
\hline Distillate Fuel $\ldots \ldots \ldots \ldots \ldots \ldots \ldots$ & 0.142 & 0.175 & 0.184 & 0.194 & $1.6 \%$ \\
\hline Liquetied Petroleum Gas . . . . . . . . . . . . . . & 0.104 & 0.135 & 0.150 & 0.165 & $2.3 \%$ \\
\hline Motor Gasoline $\theta^{2} \ldots \ldots \ldots \ldots \ldots \ldots$ & 0.024 & 0.030 & 0.031 & 0.033 & $1.6 \%$ \\
\hline Petrochemical Feedstocks $\ldots \ldots \ldots \ldots \ldots \ldots$ & 0.117 & 0.151 & 0.170 & 0.188 & $2.4 \%$ \\
\hline Residual Fuel $\ldots \ldots \ldots \ldots \ldots \ldots \ldots \ldots$ & 0.058 & 0.041 & 0.043 & 0.046 & $.1 .2 \%$ \\
\hline Other Petroleum $\ldots \ldots \ldots \ldots \ldots \ldots \ldots$ & 0.609 & 0.683 & 0.666 & 0.685 & $0.6 \%$ \\
\hline Natural Gas $^{{ }^{7}} \ldots \ldots \ldots \ldots \ldots \ldots \ldots$ & 1.235 & 1.435 & 1.499 & 1.576 & $1.2 \%$ \\
\hline Metallurgical Coal ................... & 0.462 & 0.317 & 0.278 & 0.245 & $-3.1 \%$ \\
\hline Steam Coal $\ldots \ldots \ldots \ldots \ldots \ldots \ldots \ldots$ & 0.445 & 0.506 & 0.561 & 0.585 & $1.4 \%$ \\
\hline Net Coal Coke imports $\ldots \ldots \ldots \ldots \ldots \ldots$ & 0.002 & 0.004 & 0.004 & 0.004 & $3.9 \%$ \\
\hline Renewable Energy $\ldots \ldots \ldots \ldots \ldots \ldots \ldots$ & 0.357 & 0.480 & 0.534 & 0.587 & $2.5 \%$ \\
\hline Electricity $\ldots \ldots \ldots \ldots \ldots \ldots \ldots$ & 0.680 & 0.830 & 0.909 & 0.980 & $1.8 \%$ \\
\hline Total $\ldots \ldots \ldots \ldots \ldots \ldots \ldots \ldots \ldots \ldots$ & 4.234 & 4.787 & 5.029 & 5.288 & $1.1 \%$ \\
\hline \multicolumn{6}{|l|}{ Transportation } \\
\hline$\ldots \ldots \ldots \ldots \ldots \ldots$ & 0.632 & 0.783 & 0.848 & 0.916 & $1.9 \%$ \\
\hline Jet Fuel ${ }^{8} \ldots \ldots \ldots \ldots \ldots \ldots \ldots \ldots$ & 0.248 & 0.256 & 0.279 & 0.300 & $1.0 \%$ \\
\hline Motor Gasoline ${ }^{2} \ldots \ldots \ldots \ldots \ldots \ldots \ldots$ & 2.268 & 2.431 & 2.478 & 2.492 & $0.5 \%$ \\
\hline Residual Fuel $\ldots \ldots \ldots \ldots \ldots \ldots \ldots \ldots$ & 0.002 & 0.003 & 0.003 & 0.003 & $2.0 \%$ \\
\hline Liquefied Petroleum Gas . . . . . . . . . . . . . & 0.009 & 0.013 & 0.021 & 0.032 & $6.8 \%$ \\
\hline Other Petroleum $\ldots \ldots \ldots \ldots \ldots \ldots \ldots$ & 0.028 & 0.031 & 0.032 & 0.033 & $0.8 \%$ \\
\hline Pipeline Fuel Natural Gas . . . . . . . . . . . . . & 0.054 & 0.050 & 0.059 & 0.063 & $0.7 \%$ \\
\hline Compressed Natural Gas . . . . . . . . . . . . . . & 0.000 & 0.022 & 0.039 & 0.058 & $N / A$ \\
\hline Renewables (ethanol) ${ }^{10} \ldots \ldots \ldots \ldots \ldots$ & 0.000 & 0.002 & 0.005 & 0.009 & $33.1 \%$ \\
\hline Liquid Hydrogen $\ldots \ldots \ldots \ldots \ldots \ldots \ldots$ & 0.000 & 0.000 & 0.000 & 0.000 & $94.4 \%$ \\
\hline Methanol $^{\prime \prime} \ldots \ldots \ldots \ldots \ldots \ldots \ldots \ldots$ & 0.000 & 0.001 & 0.005 & 0.010 & $38.3 \%$ \\
\hline Electricity $\ldots \ldots \ldots \ldots \ldots \ldots \ldots \ldots$ & 0.010 & 0.014 & 0.021 & 0.031 & $5.7 \%$ \\
\hline Total $\ldots \ldots \ldots \ldots \ldots \ldots \ldots \ldots$ & 3.253 & 3.605 & 3.791 & 3.946 & $1.0 \%$ \\
\hline \multicolumn{6}{|l|}{ Electric Utilitles ${ }^{12}$} \\
\hline Distillate Fuel $\ldots \ldots \ldots \ldots \ldots \ldots \ldots \ldots$ & 0.000 & 0.001 & 0.001 & 0.000 & $0.0 \%$ \\
\hline Residual Fuel $\ldots \ldots \ldots \ldots \ldots \ldots \ldots$ & 0.000 & 0.001 & 0.000 & 0.000 & $13.1 \%$ \\
\hline Vatural Gas $\ldots \ldots \ldots \ldots \ldots \ldots \ldots \ldots$ & 0.044 & 0.031 & 0.186 & 0.377 & $11.3 \%$ \\
\hline Steam Coal . . . . . . . . . . . . . . . . & 3.919 & 4.282 & 4.293 & 4.476 & $0.7 \%$ \\
\hline Nuclear Power $\ldots \ldots \ldots \ldots \ldots \ldots \ldots \ldots$ & 1.414 & 1.577 & 1.576 & 1.462 & $0.2 \%$ \\
\hline Renewable Energy/Other ${ }^{13} \ldots \ldots \ldots \ldots \ldots$ & 0.025 & 0.173 & 0.217 & 0.261 & $12.4 \%$ \\
\hline Total $\ldots \ldots \ldots \ldots \ldots \ldots \ldots \ldots \ldots$ & 5.372 & 6.065 & 6.273 & 6.576 & $1.0 \%$ \\
\hline
\end{tabular}


Table 3. Energy Consumption by End-Use Sector and Source East North Central Census Division (Continued) (Quadrillion Btu per Year)

\begin{tabular}{|c|c|c|c|c|c|}
\hline \multirow{2}{*}{ Sector and Sourco } & \multicolumn{4}{|c|}{ Rolerence Cases } & \multirow{2}{*}{$\begin{array}{l}\text { Amnual } \\
\text { Growth } \\
1000-2010 \\
\text { (percent) }\end{array}$} \\
\hline & 1980 & 2000 & 2006 & 2010 & \\
\hline \multicolumn{6}{|l|}{ Primary Energy Consumption } \\
\hline Distillate Fuel ....... & 0.912 & 1.126 & 1.200 & 1.276 & $1.7 \%$ \\
\hline Kerosene ... & 0.009 & 0.008 & 0.008 & 0.008 & $-0.4 \%$ \\
\hline Jet Fuel $\ldots \ldots \ldots \ldots$ & 0.248 & 0.256 & 0.279 & 0.300 & $1.0 \%$ \\
\hline Liquefied Petroloum Gas. & 0.205 & 0.241 & 0.262 & 0.284 & $1.6 \%$ \\
\hline Motor Gasoline ${ }^{2} \ldots \ldots$ & 2.310 & 2.478 & 2.528 & 2.543 & $0.5 \%$ \\
\hline Petrochemical Feadstocks & 0.117 & 0.151 & 0.170 & 0.188 & $2.4 \%$ \\
\hline Residual Fuel ......... & 0.064 & 0.048 & 0.050 & 0.053 & $.1 .0 \%$ \\
\hline Other Pelroleum ${ }^{14}$ & 0.638 & 0.714 & 0.698 & 0.719 & $0.6 \%$ \\
\hline Natural Gas .... & 3.365 & 3.713 & 3.946 & 4.215 & $1.1 \%$ \\
\hline Metallurgical Coal & 0.462 & 0.317 & 0.278 & 0.245 & $.3 .1 \%$ \\
\hline Steam Coal ........... & 4.405 & 4.825 & 4.890 & 5.097 & $0.7 \%$ \\
\hline Net Coal Coke Imports & 0.002 & 0.004 & 0.004 & 0.004 & $3.9 \%$ \\
\hline Nuclear Power.... . & 1.414 & 1.577 & 1.576 & 1.462 & $0.2 \%$ \\
\hline Renewable Energy/Other" & 0.502 & 0.785 & 0.889 & 0.995 & $3.5 \%$ \\
\hline 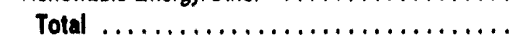 & 14.618 & 16.246 & 16.779 & 17.387 & $0.8 \%$ \\
\hline Electriclty Consumption (all sectors) ......... & 1.577 & 1.817 & 1.925 & 2.012 & $1.2 \%$ \\
\hline
\end{tabular}

'Includes electricity generated by the sector for sell-use from hydroelectric, geothermal, wood and wood waste, municipal solid waste, other biomass, wind, photovoltaic and solar thermal sources, and non-electric energy from renewable sources, such as solar thermal water heaters, ground-water heat pumps, and wood.

'Includes ethanol (blends of 10 percent or less) and ethers blended into gasoline.

Includes liquetied petroleum gas and coal.

"Includes commercial sector electricify cogenerated using wood and wood waste, municipal solid waste, and other biomass; nonelectric energy from renewable sources, such as active solar and passive solar systems, geothermal heat pumps, and solar water heating systems.

${ }^{5}$ Fuel consumption includes consumption for cogeneration.

"Includes petroleum coke, asphalt, road oil, lubricants, still gas, and miscellaneous petroleum products.

'Includes lease and plant fuel.

Includes naphtha and kerosene type.

Includes aviation gasoline and lubricants.

${ }^{10}$ Only E85 (85 percent ethanol).

"Only M85 (85 percent methanol).

${ }^{12}$ Includes consumption of energy by electric utilities, independent power producers, and small power producers that sell power to the grid.

${ }^{13}$ Includes electricity sold to utilities by nonutilities, including cogenerators, from hydroelectric, geothermal, wood and wood waste, municipal solid waste, other biomass, wind, photovoltaic and solar thermal sources, plus waste heat and net electricity imports. Does not include own use.

${ }^{14}$ includes untinished oils, natural gasoline, motor gasoline blending compounds, aviation gasoline, lubricants, still gas, asphalt, road oil, and miscellaneous petroleum products.

${ }^{13}$ includes electricity generated for sale to electric utilities and for self use from renewable sources, non-electric energy from renewable sources, electricity generated from waste heat, net electricity imports, liquid hydrogen, and methanol.

Btu $=$ British thermal unit.

N/A $=$ Not applicable.

Note: Totals may not equal sum of components due to independent rounding.

Sources: 1990 coal consumption: Energy Information Administration (EIA), Quarterly Coal Report, DOE/EIA-0121(80/4Q) (Washington, D.C. May 1991) and State Energy Data Report 1991, DOE/ElA-0214(91) (Washington, D.C., May 1993). 1990 natural gas consumption: ElA, Natural Gas Annual 1992 Volume 1, DOE/EIA-0131(92)/1 (Washington, D.C., November 1993). 1990 consumption other than coal and natural gas: ElA, Monthly Energy Review, DOE/EIA-0035(93/07) (Washington, D.C., July 1993) and Ottice of Coal, Nuclear, Electric and Alternate Fuels estimates. Figures for 1990 may differ trom publist,ed dala due to internal conversion lactors within the AEO 1994 National Energy Modeling System. The 1990 values are not final and may be updated in ElA publications. Projectlons: EIA, AEO 1994 National Energy Modeling System run AEO94B.D1221934. 
Table 4. Energy Consumption by End-Use Sector and Source West North Central Census Division (Quadrilion Btu per Year)

\begin{tabular}{|c|c|c|c|c|c|}
\hline \multirow{2}{*}{ sector and scurce } & \multicolumn{4}{|c|}{ Peterences Cases } & \multirow{2}{*}{$\begin{array}{l}\text { Amual } \\
\text { Crowth } \\
1 \text { co-2010 } \\
\text { (pramt) }\end{array}$} \\
\hline & 1000 & 2000 & 2005 & 2010 & \\
\hline \multicolumn{6}{|l|}{ Pavidential } \\
\hline$\ldots \ldots \ldots \ldots \ldots$ & 0.036 & 0.039 & 0.038 & 0.036 & $0.0 \%$ \\
\hline Kerosene $\ldots \ldots \ldots \ldots \ldots \ldots \ldots \ldots$ & 0.001 & 0.001 & 0.001 & 0.001 & $0.7 \%$ \\
\hline Llquelied Petroleum Gas . . ............... & 0.052 & 0.052 & 0.050 & 0.047 & $.0 .5 \%$ \\
\hline Natural Gas $\ldots \ldots \ldots \ldots \ldots \ldots \ldots \ldots$ & 0.439 & 0.473 & 0.465 & 0.462 & $0.3 \%$ \\
\hline 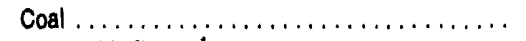 & 0.006 & 0.005 & 0.005 & 0.005 & $-1.2 \%$ \\
\hline Renewable Energy' $\ldots \ldots \ldots \ldots \ldots \ldots \ldots$ & 0.046 & 0.050 & 0.050 & 0.050 & $0.4 \%$ \\
\hline Electricity $\ldots \ldots \ldots \ldots \ldots \ldots \ldots \ldots$ & 0.236 & 0.248 & 0.251 & 0.256 & $0.4 \%$ \\
\hline Total $\ldots \ldots \ldots \ldots \ldots \ldots \ldots \ldots \ldots$ & 0.800 & 0.898 & 0.859 & 0.888 & $0.3 \%$ \\
\hline \multicolumn{6}{|l|}{ Commerclal } \\
\hline Distillate Fuel $\ldots \ldots \ldots \ldots \ldots \ldots \ldots$ & 0.019 & 0.019 & 0.017 & 0.016 & $.0 .8 \%$ \\
\hline Kerosene $\ldots \ldots \ldots \ldots \ldots \ldots \ldots \ldots$ & 0.000 & 0.001 & 0.001 & 0.001 & N/A \\
\hline Motor Gasoling $\theta^{2} \ldots \ldots \ldots \ldots \ldots \ldots \ldots$ & 0.013 & 0.014 & 0.015 & 0.015 & $1.0 \%$ \\
\hline Residual Fuel $\ldots \ldots \ldots \ldots \ldots \ldots \ldots \ldots$ & 0.003 & 0.003 & 0.003 & $0.0) 3$ & $N / A$ \\
\hline Natural Gas $\ldots \ldots \ldots \ldots \ldots \ldots \ldots$ & 0.301 & 0.299 & 0.298 & 0.296 & $.0 .1 \%$ \\
\hline Other $\ldots \ldots \ldots \ldots \ldots \ldots \ldots \ldots \ldots$ & 0.020 & 0.021 & 0.021 & 0.021 & $0.1 \%$ \\
\hline Renewable Energy $\ldots \ldots \ldots \ldots \ldots \ldots \ldots$ & 0.001 & 0.003 & 0.003 & 0.004 & $5.6 \%$ \\
\hline Electricity $\ldots \ldots \ldots \ldots \ldots \ldots \ldots \ldots$ & 0.190 & 0.206 & 0.208 & 0.201 & $0.3 \%$ \\
\hline Total $\ldots \ldots \ldots \ldots \ldots \ldots \ldots \ldots \ldots$ & 0.540 & 0.584 & 0.563 & 0.656 & $0.1 \%$ \\
\hline \multicolumn{6}{|l|}{ industriaf } \\
\hline Distillate Fuel $\ldots \ldots \ldots \ldots \ldots \ldots \ldots \ldots$ & 0.143 & 0.179 & 0.188 & 0.199 & $1.7 \%$ \\
\hline Liquetled Petroleum Gas . ............... & 0.094 & 0.121 & 0.135 & 0.148 & $2.3 \%$ \\
\hline Motor Gasolin $\theta^{2} \ldots \ldots \ldots \ldots \ldots \ldots \ldots$ & 0.031 & 0.037 & 0.039 & 0.041 & $1.5 \%$ \\
\hline Petrochemical Feedstocks $\ldots \ldots \ldots \ldots \ldots$ & 0.035 & 0.045 & 0.051 & 0.056 & $2.4 \%$ \\
\hline Residual Fuel $\ldots \ldots \ldots \ldots \ldots \ldots \ldots \ldots$ & 0.013 & 0.010 & 0.010 & 0.011 & $.0 .8 \%$ \\
\hline Other Petroleum $\ldots \ldots \ldots \ldots \ldots \ldots \ldots$ & 0.247 & 0.270 & 0.265 & 0.272 & $0.5 \%$ \\
\hline Natural Gas ${ }^{7} \ldots \ldots \ldots \ldots \ldots \ldots \ldots$ & 0.447 & 0.515 & 0.532 & 0.553 & $1.1 \%$ \\
\hline Metallurgical Coal $\ldots \ldots \ldots \ldots \ldots \ldots \ldots$ & 0.000 & 0.000 & 0.000 & 0.000 & $N / A$ \\
\hline 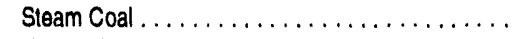 & 0.206 & 0.234 & 0.259 & 0.271 & $1.4 \%$ \\
\hline Net Coal Coke Imports $\ldots \ldots \ldots \ldots \ldots \ldots$ & 0.000 & 0.000 & 0.000 & 0.000 & N/A \\
\hline Renewable Energy $\ldots \ldots \ldots \ldots \ldots \ldots \ldots$ & 0.118 & 0.168 & 0.181 & 0.194 & $2.5 \%$ \\
\hline Electricity $\ldots \ldots \ldots \ldots \ldots \ldots \ldots \ldots$ & 0.218 & 0.270 & 0.296 & 0.319 & $1.9 \%$ \\
\hline Total $\ldots \ldots \ldots \ldots \ldots \ldots \ldots \ldots \ldots \ldots \ldots$ & $1.5 \% 2$ & 1.849 & 1.956 & 2.064 & $1.5 \%$ \\
\hline \multicolumn{6}{|l|}{ Transportation } \\
\hline Distillate Fuel $\ldots \ldots \ldots \ldots \ldots \ldots \ldots \ldots$ & 0.356 & 0.459 & 0.499 & 0.541 & $2.1 \%$ \\
\hline Jet Fuel ${ }^{0} \ldots \ldots \ldots \ldots \ldots \ldots \ldots \ldots \ldots$ & 0.113 & 0.102 & 0.110 & 0.118 & $0.2 \%$ \\
\hline Motor Gasoline $e^{2} \ldots \ldots \ldots \ldots \ldots \ldots \ldots$ & 1.041 & 1.143 & 1.163 & 1.169 & $0.6 \%$ \\
\hline Residual Fuel $\ldots \ldots \ldots \ldots \ldots \ldots \ldots$ & 0.000 & 0.000 & 0.000 & 0.000 & $0.5 \%$ \\
\hline Liquefied Petroleum Gas . . . . ........... & 0.004 & 0.006 & 0.009 & 0.014 & $6.6 \%$ \\
\hline Other Petroleum ${ }^{9} \ldots \ldots \ldots \ldots \ldots \ldots \ldots$ & 0.013 & 0.015 & 0.015 & 0.016 & $1.0 \%$ \\
\hline Pipeline Fuel Natural Gas $\ldots \ldots \ldots \ldots \ldots$ & 0.075 & 0.051 & 0.052 & 0.048 & $\cdot 2.2 \%$ \\
\hline Compressed Natural Gas ................ & 0.000 & 0.009 & 0.016 & 0.024 & $23.2 \%$ \\
\hline Renewables (ethanol) $)^{10} \ldots \ldots \ldots \ldots \ldots$ & 0.000 & 0.001 & 0.002 & 0.004 & $33.2 \%$ \\
\hline Liquid Hydrogen $\ldots \ldots \ldots \ldots \ldots \ldots \ldots$ & 0.000 & 0.000 & 0.000 & 0.000 & $94.6 \%$ \\
\hline Methano|" $\ldots \ldots \ldots \ldots \ldots \ldots \ldots \ldots$ & 0.000 & 0.001 & 0.002 & 0.004 & $38.5 \%$ \\
\hline Electricity $\ldots \ldots \ldots \ldots \ldots \ldots \ldots \ldots$ & 0.004 & 0.006 & 0.009 & 0.013 & $5.7 \%$ \\
\hline Total $\ldots \ldots \ldots \ldots \ldots \ldots \ldots \ldots \ldots$ & 1.606 & 1.791 & 1.878 & 1.851 & $1.0 \%$ \\
\hline \multicolumn{6}{|l|}{ Electrlc Utiltios ${ }^{12}$} \\
\hline Distillate Fuel ... & 0.002 & 0.003 & 0.007 & 0.005 & $5.2 \%$ \\
\hline Residual Fuel $\ldots \ldots \ldots \ldots \ldots \ldots \ldots$ & 0.001 & 0.000 & 0.000 & 0.000 & $.8 .6 \%$ \\
\hline Natural Gas $\ldots \ldots \ldots \ldots \ldots \ldots \ldots \ldots$ & 0.045 & 0.075 & 0.093 & 0.123 & $5.1 \%$ \\
\hline 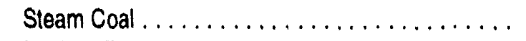 & 1.914 & 2.049 & 2.209 & 2.461 & $1.3 \%$ \\
\hline Nuclear Power $\ldots \ldots \ldots \ldots \ldots \ldots \ldots \ldots$ & 0.239 & 0.267 & 0.266 & 0.225 & $-0.3 \%$ \\
\hline Renewable Energy/Other's . & 0.118 & 0.104 & 0.108 & 0.111 & $.0 .3 \%$ \\
\hline Total $\ldots \ldots \ldots \ldots \ldots \ldots \ldots \ldots \ldots$ & 2.366 & 2.499 & 2.683 & 2.825 & $1.1 \%$ \\
\hline
\end{tabular}


Table 4. Energy Consumption by End-Use Sector and Source West North Contral Consus Division (Continued) (Quadrillion Btu per Year)

\begin{tabular}{|c|c|c|c|c|c|}
\hline \multirow{2}{*}{ Soctor and source } & \multicolumn{4}{|c|}{ Relerencos Cass } & \multirow{2}{*}{$\begin{array}{l}\text { Amnual } \\
\text { Growth } \\
1900-2010 \\
\text { (percant) }\end{array}$} \\
\hline & 1000 & 2000 & 2000 & 2010 & \\
\hline \multicolumn{6}{|l|}{ Primery Energy Consumption } \\
\hline 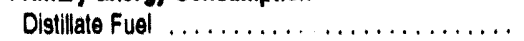 & 0.556 & 0.699 & 0.749 & 0.797 & $1.8 \%$ \\
\hline Kerosene ................ & 0.001 & 0.001 & 0.001 & 0.001 & $0.4 \%$ \\
\hline Jet Fuep. & 0.113 & 0.102 & 0.110 & 0.118 & $0.2 \%$ \\
\hline Liquelied Petroleum Gas & 0.159 & 0.189 & 0.204 & 0.219 & $1.6 \%$ \\
\hline Molor Gasolin $\theta^{2} \ldots \ldots$ & 1.084 & 1.194 & 1.217 & 1.226 & $0.6 \%$ \\
\hline Petrochemical Feedstocks & 0.035 & 0.045 & 0.051 & 0.056 & $2.4 \%$ \\
\hline Residual Fuel .......... & 0.017 & 0.013 & 0.014 & 0.014 & $.0 .8 \%$ \\
\hline Other Petroleum ${ }^{14}$ & 0.260 & 0.285 & 0.280 & 0.287 & $0.5 \%$ \\
\hline Natural Gas .... & 1.308 & 1.422 & 1.456 & 1.505 & $0.7 \%$ \\
\hline Metallurgical Coal & 0.000 & 0.000 & 0.000 & 0.000 & N/A \\
\hline Steam Coal ......... & 2.137 & 2.300 & 2.484 & 2.748 & $1.3 \%$ \\
\hline Net Coal Coke Imponts .. & 0.000 & 0.000 & 0.000 & 0.000 & N/A \\
\hline Nuclear Power ....... & 0.239 & 0.267 & 0.266 & 0.225 & $.0 .3 \%$ \\
\hline Renowable Energy/Other" & 0.284 & 0.326 & 0.347 & 0.367 & $1.3 \%$ \\
\hline Total $\ldots \ldots \ldots \ldots \ldots \ldots \ldots \ldots \ldots \ldots \ldots \ldots \ldots$ & 6.212 & 6.843 & 7.170 & 7.584 & $1.0 \%$ \\
\hline Electriclty Consumpition (all sectors) ......... & 0.640 & 0.729 & 0.763 & 0.789 & $1.0 \%$ \\
\hline
\end{tabular}

'Includes electrinity yenerated by the sector tor self-use from hydroelectric, geothermal, wood and wood waste, municipal solid waste, other biomass, wiri, photovoltaic and solar thermal sources, and non-electric energy from renewable sources, such as solar thermal water heaters, ground-water heat pumps, and wood.

'Includes ethanol (blends of 10 percent or less) and ethers blended into gasoline.

includes liquetied petroleum gas and coal.

"Includes commercial sector electricity cogenerated using wood and wood waste, municipal solid waste, and other biomass; nonelectr. ane igy from renewable sources, such as axtive solar and passive solar systems, geothermal heat pumps, and solar water heating systems.

'Fuel consumption includes consumption toi cogeneration.

includes petroleum coke, asphalt, road oil, lubricants, still gas, and miscellaneous petroleum products.

'Includes lease and plant tuel.

Includes naphtha and kerosene type.

"Includes aviation gasoline and lubricants.

${ }^{10}$ Only E85 (85 percent ethanol).

"Only M85 (85 percent methanol).

${ }^{12}$ Includes consumption of energy by electric utilities, independent power producers, and small power producers that sell power to the grid.

'Includes electricity sold to utilities by nonutilities, including cogenerators, from hydroelectric, geothermal, wood and wood waste, municipal solid waste, other biomass, wind, photovoltaic and solar thermal sources, plus waste heat and net electricity imports. Does not include own use.

"1"includes untinished oils, natural gasoline, motor gasoline blending compounds, aviation gasoline, lubricants, still gas, asphall, :oard oil, and miscellaneous pelroleum products.

${ }^{15}$ In cludes electricity generated for sale to electric utilities and for sell use from renewable sources, non-electric energy from renewable sources, electricity generated from waste heat, net electricity imports, liquid hydrogen, and methanol.

Btu $=$ British thermal unit.

N/A $=$ Not applicable.

Note: Totals may not equal sum of components due to independent rounding.

Sources: 1990 coal consumption: Energy Inlormation Administration (ElA), Quarterly Coal Report, DOE/EIA-0121(90/4Q) (Washington, D.C. May 1991) and State Energy Data Report 1991, DOE/EIA-0214(91) (Washington, D.C., May 1993). 1990 natural gas consumption: ElA, Natural Gas Annual 1992 Volume 1, DOEJEIA-0131(92)/1 (Washington, D.C., November 1993). 1990 consumption other than coal and natural gas: ElA, Monthly Energy Review, DOE/EIA-0035(93/07) (Washington, D.C., July 198 , and OHlice of Coal, Nuclear, Electric and Alternate Fuels estimates. Figures for 1990 may differ from published data due to internal conversion factors within the AEO 1994 National Energy Modeling System. The 1990 values are not tinal and may be updated in ElA publications. Prolectlone: EIA, AEO 199, National Energy Modeling System run AEO94B.D1221934. 
Table 5. Energy Consumption by End-Use Sector and Source South Atlantic Consus Division (Quadrillion Btu per Year)

\begin{tabular}{|c|c|c|c|c|c|}
\hline \multirow{2}{*}{ Sector and Source } & \multicolumn{4}{|c|}{ Relerenco Cases } & \multirow{2}{*}{$\begin{array}{l}\text { Annual } \\
\text { Crowth } \\
1 \text { ceo-2010 } \\
\text { (percent) }\end{array}$} \\
\hline & 1000 & 2000 & 2005 & 2010 & \\
\hline \multicolumn{6}{|l|}{ Realdential } \\
\hline Distillate Fuel & 0.094 & 0.100 & 0.097 & 0.092 & $.0 .1 \%$ \\
\hline Kerosene $\ldots \ldots \ldots \ldots \ldots \ldots \ldots \ldots$ & 0.023 & 0.025 & 0.025 & 0.025 & $0.3 \%$ \\
\hline Liquelied Petroleum Gas ............... & 0.087 & 0.063 & 0.059 & 0.055 & $.1 .0 \%$ \\
\hline Natural Gas $\ldots \ldots \ldots \ldots \ldots \ldots \ldots \ldots$ & 0.339 & 0.423 & 0.440 & 0.463 & $1.6 \%$ \\
\hline Coal $\ldots \ldots \ldots \ldots \ldots \ldots \ldots \ldots \ldots$ & 0.007 & 0.006 & 0.005 & 0.005 & $-1.3 \%$ \\
\hline 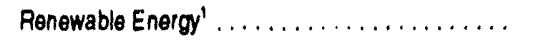 & 0.081 & 0.091 & 0.094 & 0.096 & $0.9 \%$ \\
\hline Electricity $\ldots \ldots \ldots \ldots \ldots \ldots \ldots \ldots \ldots$ & 0.721 & 0.829 & 0.875 & 0.932 &. $.3 \%$ \\
\hline Total $\ldots \ldots \ldots \ldots \ldots \ldots \ldots \ldots \ldots$ & 1.336 & 1.638 & 1.805 & 1.668 & $1.1 \%$ \\
\hline \multicolumn{6}{|l|}{ Commerclal } \\
\hline$\ldots \ldots \ldots \ldots \ldots$ & 0.075 & 0.084 & 0.086 & 0.089 & $0.9 \%$ \\
\hline Kerosene $\ldots \ldots \ldots \ldots \ldots \ldots \ldots \ldots$ & 0.003 & 0.003 & 0.003 & 0.002 & $.1 .0 \%$ \\
\hline Motor Gasoline ${ }^{2} \ldots \ldots \ldots \ldots \ldots \ldots \ldots$ & 0.021 & 0.021 & 0.021 & 0.021 & N/A \\
\hline Residual Fuel $\ldots \ldots \ldots \ldots \ldots \ldots \ldots$ & 0.025 & 0.023 & 0.023 & 0.022 & $.0 .6 \%$ \\
\hline Natural Gas $\ldots \ldots \ldots \ldots \ldots \ldots \ldots \ldots$ & 0.244 & 0.298 & 0.322 & 0.349 & $1.8 \%$ \\
\hline Other $^{3} \ldots \ldots \ldots \ldots \ldots \ldots \ldots \ldots$ & 0.024 & 0.023 & 0.022 & 0.022 & $.0 .4 \%$ \\
\hline$\ldots \ldots \ldots \ldots \ldots \ldots$ & 0.001 & 0.001 & 0.001 & 0.001 & $4.3 \%$ \\
\hline Electricity $\ldots \ldots \ldots \ldots \ldots \ldots \ldots \ldots$ & 0.578 & 0.706 & 0.765 & 0.817 & $1.7 \%$ \\
\hline Total $\ldots \ldots \ldots \ldots \ldots \ldots \ldots \ldots \ldots \ldots$ & 0.973 & 1.160 & 1.243 & 1.324 & $1.6 \%$ \\
\hline \multicolumn{6}{|l|}{ Industriaf } \\
\hline Distillate Fuel $\ldots \ldots \ldots \ldots \ldots \ldots \ldots$ & 0.118 & 0.134 & 0.144 & 0.154 & $1.3 \%$ \\
\hline Liquefied Petroleum Gas ............... & 0.043 & 0.055 & 0.061 & 0.067 & $2.2 \%$ \\
\hline Motor Gasoline $e^{2} \ldots \ldots \ldots \ldots \ldots \ldots \ldots$ & 0.027 & 0.032 & 0.034 & 0.037 & $1.5 \%$ \\
\hline Petrochemical Foedstocks .............. & 0.152 & 0.186 & 0.207 & 0.227 & $2.0 \%$ \\
\hline Residual Fuel $\ldots \ldots \ldots \ldots \ldots \ldots \ldots \ldots$ & 0.116 & 0.120 & 0.125 & 0.131 & $0.6 \%$ \\
\hline Other Petroleum ${ }^{6} \ldots \ldots \ldots \ldots \ldots \ldots \ldots$ & 0.361 & 0.410 & 0.430 & 0.451 & $1.1 \%$ \\
\hline Natural Gas' $\ldots \ldots \ldots \ldots \ldots \ldots \ldots$ & 0.652 & 0.727 & 0.774 & 0.820 & $1.2 \%$ \\
\hline 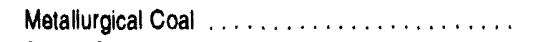 & 0.109 & 0.082 & 0.072 & 0.063 & $.2 .7 \%$ \\
\hline Steam Coal $\ldots \ldots \ldots \ldots \ldots \ldots \ldots \ldots$ & 0.415 & 0.469 & 0.516 & 0.559 & $1.5 \%$ \\
\hline Net Coal Coke Imponts $\ldots \ldots \ldots \ldots \ldots \ldots$ & 0.002 & 0.010 & 0.014 & 0.014 & $11.0 \%$ \\
\hline Renewable Energy $\ldots \ldots \ldots \ldots \ldots \ldots \ldots$ & 0.365 & 0.447 & 0.492 & 0.544 & $2.0 \%$ \\
\hline Electricity $\ldots \ldots \ldots \ldots \ldots \ldots \ldots \ldots$ & 0.518 & 0.630 & 0.691 & 0.749 & $1.9 \%$ \\
\hline Total $\ldots \ldots \ldots \ldots \ldots \ldots \ldots \ldots \ldots$ & 2.886 & 3.301 & 3.562 & 3.817 & $1.4 \%$ \\
\hline \multicolumn{6}{|l|}{ Transportation } \\
\hline$\ldots \ldots \ldots \ldots \ldots \ldots \ldots$ & 0.632 & 0.829 & 0.929 & 1.044 & $2.5 \%$ \\
\hline Jet Fuel $\ldots$ & 0.448 & 0.566 & 0.628 & 0.694 & $2.2 \%$ \\
\hline$\ldots \ldots \ldots \ldots$ & 2.540 & 2.875 & 3.014 & 3.128 & $1.0 \%$ \\
\hline Residual Fuel $\ldots \ldots \ldots \ldots \ldots \ldots \ldots \ldots$ & 0.117 & 0.150 & 0.172 & 0.194 & $2.6 \%$ \\
\hline Liquetiod Petroleum Gas . . . . . . . . . . . . . . & 0.009 & 0.014 & 0.025 & 0.038 & $7.5 \%$ \\
\hline Other Petroleum $\ldots \ldots \ldots \ldots \ldots \ldots \ldots$ & 0.034 & 0.039 & 0.041 & 0.046 & $1.4 \%$ \\
\hline Pipeline Fuel Natural Gas $\ldots \ldots \ldots \ldots \ldots$ & 0.039 & 0.046 & 0.043 & 0.041 & $0.3 \%$ \\
\hline Compressed Natural Gas . . . . . . . . . . . . . & 0,000 & 0.024 & 0.045 & 0.069 & N/A \\
\hline Renewables (ethanol) ${ }^{10} \ldots \ldots \ldots \ldots \ldots \ldots$ & 0.000 & 0.002 & 0.006 & 0.010 & $33.8 \%$ \\
\hline Liquid Hydrogen $\ldots \ldots \ldots \ldots \ldots \ldots \ldots \ldots$ & 0.000 & 0.000 & 0.000 & 0.000 & $95.5 \%$ \\
\hline Methanol" ${ }^{11}$. & 0.000 & 0.001 & 0.005 & 0.012 & $39.1 \%$ \\
\hline Electricity $\ldots \ldots \ldots \ldots \ldots \ldots \ldots \ldots$ & 0.010 & 0.015 & 0.024 & 0.036 & $6.4 \%$ \\
\hline Total $\ldots \ldots \ldots \ldots \ldots \ldots \ldots \ldots \ldots \ldots$ & 3.631 & 4.562 & 4.833 & 5.312 & $1.6 \%$ \\
\hline \multicolumn{6}{|l|}{ Electric Utilities ${ }^{12}$} \\
\hline Distillate Fuel & 0.011 & 0.062 & 0.105 & 0.082 & $10.6 \%$ \\
\hline Residual Fuel $\ldots \ldots \ldots \ldots \ldots \ldots \ldots$ & 0.377 & 0.294 & 0.307 & 0.248 & $.2 .1 \%$ \\
\hline Natural Gas $\ldots \ldots \ldots \ldots \ldots \ldots \ldots \ldots$ & 0.242 & 0.747 & 1.100 & 1.072 & $7.7 \%$ \\
\hline Steam Coal $\ldots \ldots \ldots \ldots \ldots \ldots \ldots \ldots$ & 3.037 & 3.529 & 3.682 & 4.411 & $1.9 \%$ \\
\hline Nuclear Power $\ldots \ldots \ldots \ldots, \ldots \ldots \ldots$ & 1.716 & 2.173 & 2.267 & 2.145 & $1.1 \%$ \\
\hline Renewable Energy/Other' ${ }^{19}$. & 0.304 & 0.405 & 0.462 & 0.526 & $2.8 \%$ \\
\hline Total $\ldots \ldots \ldots \ldots \ldots$ & 5.670 & 7.210 & 7.923 & 8.484 & $2.0 \%$ \\
\hline
\end{tabular}




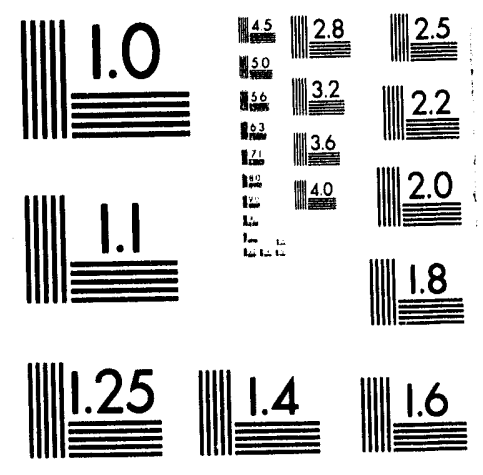



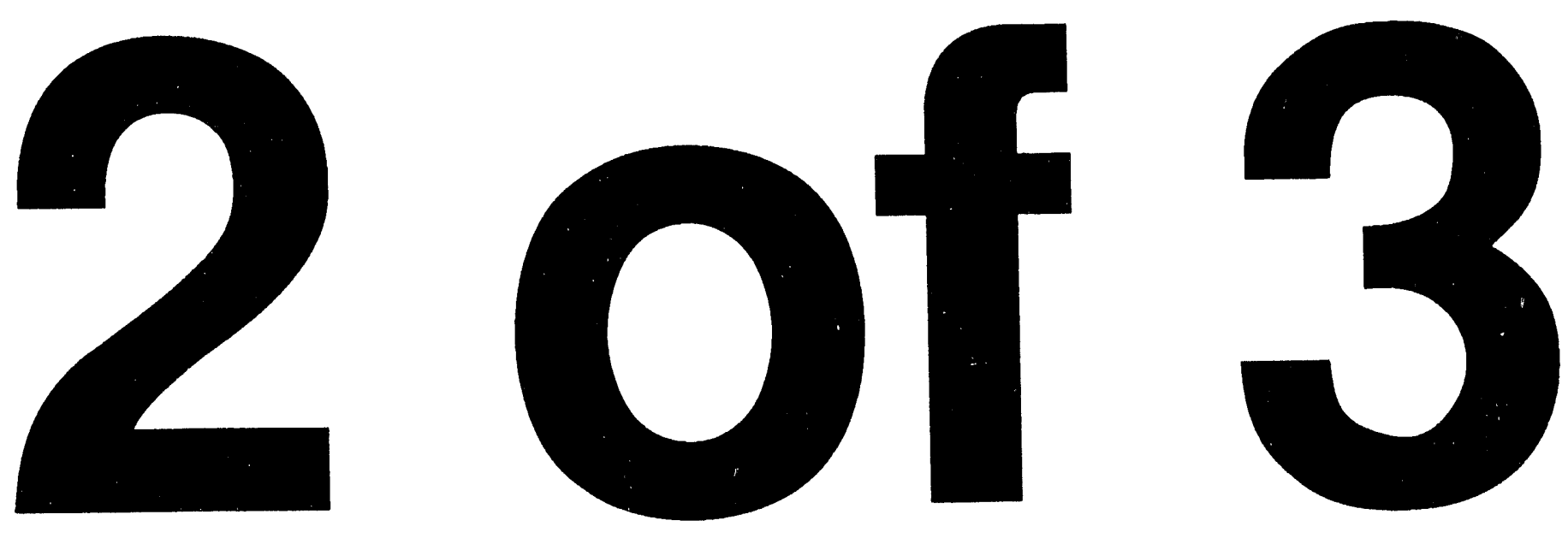


\section{Table 5. Energy Consumption by End-Use Sector and Source South Atlantic Census Division (Continued) (Quadrillion Btu per Year)}

\begin{tabular}{|c|c|c|c|c|c|}
\hline \multirow{2}{*}{ Sector and Source } & \multicolumn{4}{|c|}{ Reterences Case } & \multirow{2}{*}{$\begin{array}{l}\text { Annual } \\
\text { Growth } \\
1690-2010 \\
\text { (percent) }\end{array}$} \\
\hline & 1980 & 2000 & 2005 & 2010 & \\
\hline \multicolumn{6}{|l|}{ Primary Energy Consumption } \\
\hline Distillate Fuel & 0.930 & 1.209 & 1.361 & 1.461 & $2.3 \%$ \\
\hline$\ldots \ldots \ldots \ldots \ldots \ldots$ & 0.026 & 0.028 & 0.027 & 0.027 & $0.2 \%$ \\
\hline Jet Fuel $\ldots \ldots \ldots \ldots \ldots \ldots \ldots \ldots \ldots \ldots$ & 0.448 & 0.566 & 0.628 & 0.694 & $2.2 \%$ \\
\hline Liquefled Petroleum Gas $\ldots \ldots \ldots \ldots \ldots \ldots$ & 0.131 & 0.144 & 0.156 & 0.172 & $1.4 \%$ \\
\hline Motor Gasoline $e^{2} \ldots \ldots \ldots \ldots \ldots \ldots$ & 2.589 & 2.928 & 3.070 & 3.187 & $1.0 \%$ \\
\hline Petrochemical Feodstocks ............... & 0.152 & 0.186 & 0.207 & 0.227 & $2.0 \%$ \\
\hline Residual Fuel .......... & 0.635 & 0.587 & 0.627 & 0.594 & $-0.3 \%$ \\
\hline Other Petroleum ${ }^{14}$ & 0.395 & 0.449 & 0.472 & 0.497 & $1.2 \%$ \\
\hline Natural Gas & 1.517 & 2.265 & 2.724 & 2.813 & $3.1 \%$ \\
\hline Metallurgical Coal .... & 0.109 & 0.082 & 0.072 & 0.063 & $-2.7 \%$ \\
\hline Stoam Coal .............. & 3.470 & 4.015 & 4.215 & 4.986 & $1.8 \%$ \\
\hline Net Coal Coke Imports $\ldots \ldots \ldots \ldots \ldots \ldots$ & 0.002 & 0.010 & 0.014 & 0.014 & $11.0 \%$ \\
\hline Nuclear Power...... . & 1.716 & 2.173 & 2.267 & 2.145 & $1.1 \%$ \\
\hline Renewable Energy/Other ${ }^{16}$. & 0.701 & 0.947 & 1.060 & 1.190 & $2.3 \%$ \\
\hline 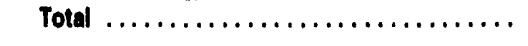 & 12.860 & 16.680 & 16.900 & 18.070 & $1.7 \%$ \\
\hline Elactrictity Consumption (all eactors) ......... & 1.828 & 2.181 & 2.365 & 2.635 & $1.6 \%$ \\
\hline
\end{tabular}

'Includes electricity generated by the sector for self-use from hydroelectric, geothermal, wood and wood waste, municipal solid waste, other blomass, wind, photovoltaic and soler thermal sources, and non-electric energy from renewable sources, such as solar thermal water heaters, ground-water heat pumps, and wood.

Includes ethanol (blends of 10 percent or less) and ethers blended into gasoline.

'Includes liquefied petroleum gas and coal.

"Includes commercial sector electricity cogenerated using wood and wood waste, municipal solid waste, and other biomass; nonelectric energy from renewable sources, such as active solar and passive solar systems, geothermal heat pumps, and solar water heating systems.

"Fuel consumption includes consumption for cogeneration.

"Includes petroleum coke, asphalt, road oil, lubricants, still gas, and miscellaneous petroleum products.

'Includes lease and plant fuel.

"Includes naphtha and kerosene type.

Includes aviation gasoline and lubricants.

${ }^{10}$ Only E85 (85 percent ethanol).

"Only M85 (85 percent methanol).

${ }^{12}$ Includes consumption of energy by electric utilities, independent power producers, and small power producers that sell power to the grid.

${ }^{13}$ Includes electricity sold to utilities by nonutilities, including cogenerators, from hydroelectric, geothermal, wood and wood waste, municipal solid waste, other biomass, wind, photovoltaic and solar thermal sources, plus waste heat and net electricity imports. Does not include own use.

${ }^{14}$ Includes unfinished oils, natural gasoline, motor gasoline blending compounds, aviation gasoline, lubricants, still gas, asphalt, road oil, and miscellaneous petroleum products.

${ }^{18}$ Includes electricity generated for sale to electric utilities and for self use from renewable sources, non-electric energy from renewable sources, electricity generated from waste heat, nel electricity imports, liquid hydrogen, and methanol.

Btu $=$ British thermal unit.

$\mathrm{N} / \mathrm{A}=$ Not applicable.

Note: Totals may not equal sum of components due to independent rounding.

Sources: 1990 coal consumption: Energy information Administration (EIA), Quarterly Coal Report, DOEJEIA-0121(90/4Q) Washington, D.C. May 1991) and State Energy Data Report 1991, DOE/EIA-0214(91) (Washington, D.C., May 1993). 1990 natural gas consumption: ElA, Natural Gas Annual 1992 Volume 1, DOE/EIA-0131(92)/1 (Washington, D.C., November 1993). 1990 consumption other than coal and natural gas: EIA, Monthly Energy Review, DOE/EIA-0035(93/07) (Washington, D.C. July 1093) and Office of Coal, Nuclear, Electric and Alternate Fuels estimates. Figures for 1990 may differ from published data due to internal conversion factors within the AEO 1994 National Energy Modeling System. The 1990 values are not final and may be updated in ElA publications. Projectlons: EIA, AEO 1994 National Energy Modeling System run AEO94B.D1221934. 
Table 6. Energy Consumption by End-Use Sector and Source

East South Central Consus Division

(Quadrillion Btu per Year)

\begin{tabular}{|c|c|c|c|c|c|}
\hline \multirow{2}{*}{ Sector and Source } & \multicolumn{4}{|c|}{ Reterence Case } & \multirow{2}{*}{$\begin{array}{l}\text { Annual } \\
\text { Growth } \\
\text { 19e0-2010 } \\
\text { (percent) }\end{array}$} \\
\hline & 1000 & 2000 & 2005 & 2010 & \\
\hline \multicolumn{6}{|l|}{ Resldential } \\
\hline Distillate Fuel .. & 0.005 & 0.006 & 0.006 & 0.005 & $0.1 \%$ \\
\hline Kerosene $\ldots \ldots \ldots \ldots \ldots \ldots \ldots \ldots$ & 0.004 & 0.004 & 0.004 & 0.004 & $.0 .5 \%$ \\
\hline Llquefied Petroleum Gas . . . . . . . . . . . . . . . & 0.030 & 0.031 & 0.030 & 0.028 & $-0.4 \%$ \\
\hline Natural Gas $\ldots \ldots \ldots \ldots \ldots \ldots \ldots \ldots$ & 0.178 & 0.206 & 0.208 & 0.213 & $0.9 \%$ \\
\hline Coal $\ldots \ldots \ldots \ldots \ldots \ldots \ldots \ldots \ldots$ & 0.004 & 0.003 & 0.003 & 0.003 & $-1.3 \%$ \\
\hline Renewable Energy' $\ldots \ldots \ldots \ldots \ldots \ldots \ldots$ & 0.066 & 0.072 & 0.071 & 0.070 & $0.3 \%$ \\
\hline Electricity $\ldots \ldots \ldots \ldots \ldots \ldots \ldots \ldots$ & 0.268 & 0.287 & 0.293 & 0.302 & $0.6 \%$ \\
\hline Total $\ldots \ldots \ldots \ldots \ldots \ldots \ldots \ldots$ & 0.557 & 0.608 & 0.615 & 0.625 & $0.6 \%$ \\
\hline \multicolumn{6}{|l|}{ Commercial } \\
\hline Distillate Fuel $\ldots \ldots \ldots \ldots \ldots \ldots \ldots \ldots$ & 0.017 & 0.020 & 0.020 & 0.020 & $0.8 \%$ \\
\hline Kerosene $\ldots \ldots \ldots \ldots \ldots \ldots \ldots \ldots$ & 0.001 & 0.001 & 0.001 & 0.001 & $-0.3 \%$ \\
\hline Motor Gasoline $\theta^{2} \ldots \ldots \ldots \ldots \ldots \ldots \ldots$ & 0.007 & 0.007 & 0.007 & 0.007 & $0.3 \%$ \\
\hline Residual Fuel $\ldots \ldots \ldots \ldots \ldots \ldots \ldots \ldots$ & 0.004 & 0.004 & 0.004 & 0.004 & N/A \\
\hline Natural Gas $\ldots \ldots \ldots \ldots \ldots \ldots \ldots$ & 0.121 & 0.125 & 0.126 & 0.128 & $0.3 \%$ \\
\hline$\ldots \ldots \ldots \ldots \ldots \ldots$ & 0.013 & 0.013 & 0.013 & 0.013 & $.0 .1 \%$ \\
\hline Renewable Energy $\ldots \ldots \ldots \ldots \ldots \ldots$ & 0.000 & 0.000 & 0.000 & 0.000 & $5.4 \%$ \\
\hline Electricity $\ldots \ldots \ldots \ldots \ldots \ldots \ldots \ldots$ & 0.149 & 0.171 & 0.174 & 0.175 & $0.8 \%$ \\
\hline Total $\ldots \ldots \ldots \ldots \ldots \ldots \ldots \ldots \ldots$ & 0.313 & 0.341 & 0.346 & 0.349 & $0.5 \%$ \\
\hline \multicolumn{6}{|l|}{ Industriaf } \\
\hline Distillate Fuel $\ldots \ldots \ldots \ldots \ldots \ldots \ldots \ldots$ & 0.120 & 0.131 & 0.141 & 0.151 & $1.2 \%$ \\
\hline Liquefled Petroleum Gas . . . . . . . . . . . . . . . & 0.037 & 0.042 & 0.047 & 0.051 & $1.6 \%$ \\
\hline$\ldots \ldots \ldots \ldots \ldots \ldots$ & 0.013 & 0.015 & 0.017 & 0.018 & $1.7 \%$ \\
\hline Petrochemical Feedstocks . . . . . . . . . . . . . . & 0.058 & 0.071 & 0.079 & 0.087 & $2.0 \%$ \\
\hline Residual Fuel $\ldots \ldots \ldots \ldots \ldots \ldots \ldots \ldots$ & 0.014 & 0.010 & 0.010 & 0.010 & $-1.4 \%$ \\
\hline Other Petroleum ${ }^{6} \ldots \ldots \ldots \ldots \ldots \ldots$ & 0.252 & 0.305 & 0.309 & 0.320 & $1.2 \%$ \\
\hline Natural Gas $^{\top} \ldots \ldots \ldots \ldots \ldots \ldots \ldots$ & 0.458 & 0.575 & 0.606 & 0.638 & $1.7 \%$ \\
\hline Metallurgical Coal . ................. & 0.121 & 0.089 & 0.078 & 0.068 & $\cdot 2.8 \%$ \\
\hline Steam Coal $\ldots \ldots \ldots \ldots \ldots \ldots \ldots \ldots \ldots$ & 0.212 & 0.244 & 0.267 & 0.289 & $1.6 \%$ \\
\hline Net Coal Coke Imports $\ldots \ldots \ldots \ldots \ldots \ldots$ & 0.000 & 0.001 & 0.002 & 0.001 & $8.3 \%$ \\
\hline Renewable Energy $\ldots \ldots \ldots \ldots \ldots \ldots \ldots$ & 0.193 & 0.226 & 0.243 & 0.259 & $1.5 \%$ \\
\hline Electricity $\ldots \ldots \ldots \ldots \ldots \ldots \ldots \ldots$ & 0.368 & 0.451 & 0.494 & 0.536 & $1.9 \%$ \\
\hline Total $\ldots \ldots \ldots \ldots \ldots \ldots \ldots \ldots \ldots \ldots$ & 1.848 & 2.160 & 2.292 & 2.431 & $1.4 \%$ \\
\hline \multicolumn{6}{|l|}{ Transportation } \\
\hline Distillate Fuel $\ldots \ldots \ldots \ldots \ldots \ldots \ldots \ldots$ & 0.372 & 0.487 & 0.528 & 0.570 & $2.2 \%$ \\
\hline Jet Fuel ${ }^{\theta}$. & 0.105 & 0.090 & 0.098 & 0.105 & $0.0 \%$ \\
\hline Motor Gasoline ${ }^{2} \ldots \ldots \ldots \ldots \ldots \ldots \ldots$ & 0.917 & 1.031 & 1.052 & 1.057 & $0.7 \%$ \\
\hline Residual Fuel $\ldots \ldots \ldots \ldots \ldots \ldots \ldots$ & 0.028 & 0.036 & 0.039 & 0.043 & $2.1 \%$ \\
\hline Liquefied Petroleum Gas . . . . . . . . . . . . . . . & 0.003 & 0.005 & 0.008 & 0.012 & $6.5 \%$ \\
\hline Other Petroleum ${ }^{9} \ldots \ldots \ldots \ldots \ldots \ldots \ldots$ & 0.012 & 0.013 & 0.013 & 0.014 & $1.0 \%$ \\
\hline Pipeline Fuel Natural Gas $\ldots \ldots \ldots \ldots \ldots$ & 0.100 & 0.113 & 0.122 & 0.129 & $1.3 \%$ \\
\hline Compressed Natural Gas . . . . . . . . . . . . . . . & 0.000 & 0.007 & 0.013 & 0.020 & $23.4 \%$ \\
\hline Renewables (ethanol) ${ }^{10} \ldots \ldots \ldots \ldots \ldots$ & 0.000 & 0.001 & 0.002 & 0.003 & $33.4 \%$ \\
\hline Liquid Hydrogen $\ldots \ldots \ldots \ldots \ldots \ldots \ldots$ & 0.000 & 0.000 & 0.000 & 0.000 & $94.9 \%$ \\
\hline Methanol $^{11} \ldots \ldots \ldots \ldots \ldots \ldots \ldots \ldots$ & 0.000 & 0.000 & 0.002 & 0.003 & $38.7 \%$ \\
\hline Electricity $\ldots \ldots \ldots \ldots \ldots \ldots \ldots \ldots$ & 0.004 & 0.005 & 0.008 & 0.011 & $5.6 \%$ \\
\hline Total $\ldots \ldots \ldots \ldots \ldots \ldots \ldots \ldots$ & 1.541 & 1.788 & 1.886 & 1.896 & $1.2 \%$ \\
\hline \multicolumn{6}{|l|}{ Electric Utillibes ${ }^{12}$} \\
\hline Distillate Fuel $\ldots \ldots \ldots \ldots \ldots \ldots \ldots$ & 0.000 & 0.001 & 0.006 & 0.011 & $20.6 \%$ \\
\hline Residual Fuel $\ldots \ldots \ldots \ldots \ldots \ldots \ldots \ldots$ & 0.001 & 0.001 & 0.002 & 0.001 & $.0 .7 \%$ \\
\hline Natural Gas $\ldots \ldots \ldots \ldots \ldots \ldots \ldots \ldots$ & 0.072 & 0.082 & 0.094 & 0.065 & $.0 .5 \%$ \\
\hline Steam Coal $\ldots \ldots \ldots \ldots \ldots \ldots \ldots \ldots \ldots$ & 1.911 & 1.987 & 1.998 & 1.998 & $0.2 \%$ \\
\hline Nuclear Power $\ldots \ldots \ldots \ldots \ldots \ldots \ldots \ldots$ & 0.303 & 0.338 & 0.340 & 0.337 & $0.5 \%$ \\
\hline Renewable Energy/Other ${ }^{\text {is }}$. & 0.231 & 0.233 & 0.233 & 0.233 & $0.0 \%$ \\
\hline Total $\ldots \ldots \ldots \ldots \ldots \ldots \ldots \ldots$ & 2.526 & 2.642 & 2.673 & 2.646 & $0.2 \%$ \\
\hline
\end{tabular}


Table 6. Energy Consumption by End-Use Sector and Source East South Central Census Division (Continued) (Quadrillion Btu per Year)

\begin{tabular}{|c|c|c|c|c|c|}
\hline \multirow{2}{*}{ ctor and Sourco } & \multicolumn{4}{|c|}{ Relerences Canes } & \multirow{2}{*}{$\begin{array}{l}\text { Annual } \\
\text { Growth } \\
\text { Ipe0-2010 } \\
\text { (percent) }\end{array}$} \\
\hline & 1990 & 2000 & 2005 & 2010 & \\
\hline \multicolumn{6}{|l|}{ Primary Energy Conoumpiton } \\
\hline Distillate Fuel $\ldots \ldots \ldots \ldots \ldots \ldots \ldots$ & 0.514 & 0.645 & 0.702 & 0.759 & $2.0 \%$ \\
\hline$\ldots \ldots \ldots \ldots \ldots \ldots \ldots \ldots$ & 0.005 & 0.005 & 0.005 & 0.004 & $-0.4 \%$ \\
\hline Jet Fuel . & 0.105 & 0.090 & 0.098 & 0.105 & $0.0 \%$ \\
\hline Liquefied Petroleum Gas. & 0.076 & 0.084 & 0.090 & 0.097 & $1.2 \%$ \\
\hline Motor Gasoline ${ }^{2} \ldots \ldots$ & 0.937 & 1.054 & 1.076 & 1.082 & $0.7 \%$ \\
\hline Petrochemical Feedstocks. & 0.058 & 0.071 & 0.079 & 2.087 & $2.0 \%$ \\
\hline Residual Fuel & 0.048 & 0.050 & 0.055 & 0.058 & $1.0 \%$ \\
\hline Other Petroleum 14 & 0.263 & 0.318 & 0.322 & 0.334 & $1.2 \%$ \\
\hline Natural Gas & 0.930 & 1.109 & 1.170 & 1.193 & $1.3 \%$ \\
\hline Metallurgical Coal ...... & 0.121 & 0.089 & 0.078 & 0.068 & $-2.8 \%$ \\
\hline Steam Coal ........... & 2.134 & 2.242 & 2.276 & 2.297 & $0.4 \%$ \\
\hline Net Coal Coke Imponts ... & 0.000 & 0.001 & 0.002 & 0.001 & $8.3 \%$ \\
\hline Nuclear Power & 0.303 & 0.338 & 0.340 & 0.337 & $0.5 \%$ \\
\hline Renewable Energy/Other ${ }^{18}$ & 0.490 & 0.531 & 0.551 & 0.569 & $0.8 \%$ \\
\hline Total $\ldots \ldots \ldots \ldots \ldots \ldots \ldots \ldots \ldots \ldots \ldots \ldots$ & 5.904 & 6.626 & 6.843 & 6.890 & $0.8 \%$ \\
\hline Eloctrictiy Consumption (all sactors) ... & 0.769 & 0.913 & 0.869 & 1.023 & $1.3 \%$ \\
\hline
\end{tabular}

1 Includes electricity generated by the sector for self-use from hydroelectric, geothermal, wood and wood waste, municipal solid waste, other biomass, wind, photovoltaic and solar thermal sources, and non-electric energy from renewable sources, such as solar thermal water heaters, ground-water heat pumps, and wood.

${ }^{2}$ Includes ethanol (blends of 10 percent or less) and ethers blended into gasoline.

Includes liquefied petroleum gas and coal.

"Includes commercial sector electricity cogenerated using wood and wood waste, municipal solid waste, and other biomass; nonelectric energy from renewable sources, such as active solar and passive solar systems, geothermal heat pumps, and solar water heating systems.

${ }^{6} \mathrm{Fuel}$ consumption includes consumption for cogeneration.

'Includes petroleum coke, asphalt, road oil, lubricants, still gas, and miscellaneous petroleum products.

${ }^{7}$ Includes lease and plant fuel.

Includes naphtha and kerosene type.

Includes aviation gasoline and lubricants.

${ }^{10}$ Only E85 (85 percent ethanol).

"Only M85 (85 percent methanol).

${ }^{12}$ Includes consumption of energy by electric utilities, independent power producers, and small power producers that sell power to the grid.

${ }^{13}$ Includes electricity sold to utilities by nonutilities, including cogenerators, from hydroelectric, geothermal, wood and wood waste, municipal solid waste, other biomass, wind, photovoltaic and solar thermal sources, plus waste heat and net electricity imports. Does not include own use.

"Includes unfinished oils, natural gasoline, motor gasoline blending compounds, aviation gasoline, lubricants, still gas, asphalt, road oil, and miscellaneous petroleum products.

${ }^{15}$ Includes electricity generated for sale to electric utilities and for self use from renewable sources, non-electric energy from renewable sources, electricity generated from waste heat, net electricity imports, liquid hydrogen, and methanol.

Btu $=$ British thermal unit

N/A $=$ Not applicable.

Note: Totals may not equal sum of components due to independent rounding.

Sources: 1990 coal consumption: Energy Information Administration (ElA), Quarterly Coal Report, DOE/EIA-0121(90/4Q) (Washington, D.C. May 1991) and State Energy Data Report 1991, DOE/EIA-02 14(91) (Washington, D.C., May 1993). 1990 nat ital gas Consumption: ElA, Natural Gas Annual 1992 Volume 1, DOE/EIA-0131(92)/1 (Washington, D.C., November 1993). 1990 consumptio; other than coal and natural gas: EIA, Monthly Energy Review, DOE/ElA-0035(93/07) (Washington, D.C., July 1993) and Office of Coal, Nuclear, Electric and Alternate Fuels estimates. Figures for 1990 may differ from published data due to internal conversion factors within the AEO 1994 National Energy Modeling System. The 1990 values are not final and may be updated in EIA publications. Projectlone: EIA, AEO 1984 National Energy Modeling System run AEO94B.D1221934. 
Table 7. Energy Consumption by End-Use Sector and Source West South Central Census Division

(Quadrillion Btu per Year)

\begin{tabular}{|c|c|c|c|c|c|}
\hline \multirow{2}{*}{ Sector and Source } & \multicolumn{4}{|c|}{ Reterence Caes } & \multirow{2}{*}{$\begin{array}{l}\text { Annual } \\
\text { Growth } \\
1900-2010 \\
\text { (preent) }\end{array}$} \\
\hline & 1900 & 2000 & 2005 & 2010 & \\
\hline \multicolumn{6}{|l|}{ Resldential } \\
\hline Distillate Fuel $\ldots \ldots \ldots$ & 0.000 & 0.000 & 0.000 & 0.000 & $0.8 \%$ \\
\hline Kerosene $\ldots \ldots \ldots \ldots \ldots \ldots \ldots \ldots$ & 0.000 & 0.000 & 0.000 & 0.000 & $0.9 \%$ \\
\hline Liquefled Petroleum Gas . . . . . . . . . . . . . & 0.036 & 0.036 & 0.034 & 0.033 & $.0 .5 \%$ \\
\hline Natural Gas $\ldots \ldots \ldots \ldots \ldots \ldots \ldots \ldots$ & 0.380 & 0.415 & 0.414 & 0.417 & $0.5 \%$ \\
\hline Coal $\ldots \ldots \ldots \ldots \ldots \ldots \ldots \ldots \ldots$ & 0.000 & 0.000 & 0.000 & 0.000 & $.1 .3 \%$ \\
\hline Renewable Energy ${ }^{1} \ldots \ldots \ldots \ldots \ldots \ldots$ & 0.037 & 0.044 & 0.048 & 0.051 & $1.7 \%$ \\
\hline Electricity $\ldots \ldots \ldots \ldots \ldots \ldots \ldots \ldots$ & 0.449 & 0.470 & 0.483 & 0.502 & $0.6 \%$ \\
\hline Total $\ldots \ldots \ldots \ldots \ldots \ldots \ldots \ldots \ldots \ldots$ & 0.006 & 0.995 & 0.979 & 1.004 & $0.5 \%$ \\
\hline \multicolumn{6}{|l|}{ Commorcial } \\
\hline Distillate Fuel $\ldots \ldots \ldots \ldots \ldots \ldots \ldots \ldots$ & 0.031 & 0.032 & 0.032 & 0.032 & $0.1 \%$ \\
\hline Kerosene $\ldots \ldots \ldots \ldots \ldots \ldots \ldots \ldots$ & 0.000 & 0.000 & 0.000 & 0.000 & $-0.3 \%$ \\
\hline Motor Gasoline $\theta^{2} \ldots \ldots \ldots \ldots \ldots \ldots$ & 0.016 & 0.017 & 0.017 & 0.018 & $0.4 \%$ \\
\hline Residual Fuel $\ldots \ldots \ldots \ldots \ldots \ldots \ldots \ldots \ldots$ & 0.001 & 0.001 & 0.001 & 0.001 & $.0 .6 \%$ \\
\hline Natural Gas $\ldots \ldots \ldots \ldots \ldots \ldots \ldots \ldots$ & 0.267 & 0.301 & 0.317 & 0.337 & $1.2 \%$ \\
\hline Other $^{3} \ldots \ldots \ldots \ldots \ldots \ldots \ldots \ldots \ldots$ & 0.007 & 0.006 & 0.006 & 0.006 & $.0 .2 \%$ \\
\hline Renewable Energy $\ldots \ldots \ldots \ldots \ldots \ldots \ldots$ & 0.000 & 0.001 & 0.001 & 0.001 & $5.6 \%$ \\
\hline Electricity $\ldots \ldots \ldots \ldots \ldots \ldots \ldots \ldots$ & 0.367 & 0.414 & 0.430 & 0.437 & $0.9 \%$ \\
\hline Total $\ldots \ldots \ldots \ldots \ldots \ldots \ldots \ldots$ & 0.602 & 0.773 & 0.804 & 0.832 & $0.9 \%$ \\
\hline \multicolumn{6}{|l|}{ Industriaf } \\
\hline Distillate Fuel $\ldots \ldots \ldots \ldots \ldots \ldots \ldots \ldots$ & 0.268 & 0.298 & 0.320 & 0.343 & $1.2 \%$ \\
\hline Liquefied Petroleum Gas . . . . . . . . . . . . . . & 1.199 & 1.497 & $1.65 ?$ & 1.814 & $2.1 \%$ \\
\hline Motor Gasoline ${ }^{2} \ldots \ldots \ldots \ldots \ldots \ldots$ & 0.031 & 0.038 & 0.041 & 0.044 & $1.8 \%$ \\
\hline Petrochemical Feedstocks $\ldots \ldots \ldots \ldots \ldots \ldots$ & 0.573 & 0.704 & 0.783 & 0.859 & $2.0 \%$ \\
\hline Residual Fuel $\ldots \ldots \ldots \ldots \ldots \ldots \ldots \ldots$ & 0.020 & 0.013 & 0.014 & 0.015 & $.1 .5 \%$ \\
\hline Other Petroleum ${ }^{\circ} \ldots \ldots \ldots \ldots \ldots \ldots \ldots$ & 1.142 & 1.372 & 1.372 & 1.407 & $1.0 \%$ \\
\hline Natural Gas' $\ldots \ldots \ldots \ldots \ldots \ldots \ldots \ldots$ & 3.819 & 4.148 & 4.409 & 4.631 & $1.0 \%$ \\
\hline Metallurgical Coal $\ldots \ldots \ldots \ldots \ldots \ldots \ldots \ldots$ & 0.000 & 0.000 & 0.000 & 0.000 & $N / A$ \\
\hline Steam Coal $\ldots \ldots \ldots \ldots \ldots \ldots \ldots \ldots$ & 0.096 & 0.111 & 0.121 & 0.131 & $1.5 \%$ \\
\hline Net Coal Coke Imports $\ldots \ldots \ldots \ldots \ldots \ldots$ & 0.000 & 0.000 & 0.000 & 0.000 & $N / A$ \\
\hline Renewable Energy $\ldots \ldots \ldots \ldots \ldots \ldots \ldots$ & 0.180 & 0.217 & 0.233 & 0.252 & $1.7 \%$ \\
\hline Electricity $\ldots \ldots \ldots \ldots \ldots \ldots \ldots \ldots$ & 0.450 & 0.538 & 0.586 & 0.631 & $1.7 \%$ \\
\hline Total $\ldots \ldots \ldots \ldots \ldots \ldots \ldots \ldots \ldots$ & 7.804 & 8.935 & 9.535 & 10.127 & $1.3 \%$ \\
\hline \multicolumn{6}{|l|}{ Transportation } \\
\hline Distillate Fuel $\ldots \ldots \ldots \ldots \ldots \ldots \ldots \ldots$ & 0.575 & 0.742 & 0.813 & 0.890 & $2.2 \%$ \\
\hline Jet Fuel ${ }^{0} \ldots \ldots \ldots \ldots \ldots \ldots \ldots \ldots$ & 0.741 & 0.956 & 1.054 & 1.148 & $2.2 \%$ \\
\hline Motor Gasoline ${ }^{2} \ldots \ldots \ldots \ldots \ldots \ldots$ & 1.612 & 1.851 & 1.908 & 1.941 & $0.9 \%$ \\
\hline Residual Fuel $\ldots \ldots \ldots \ldots \ldots \ldots \ldots \ldots$ & 0.303 & 0.401 & 0.450 & 0.495 & $2.5 \%$ \\
\hline Liquefied Petroleum Gas . . . . . . . . . . . . & 0.006 & 0.009 & 0.015 & 0.022 & $6.9 \%$ \\
\hline Other Petroleum ${ }^{0} \ldots \ldots \ldots \ldots \ldots \ldots \ldots$ & 0.028 & 0.031 & 0.032 & 0.034 & $0.9 \%$ \\
\hline Pipeline Fuel Natural Gas . . . . . . . . . . . . . & 0.203 & 0.200 & 0.215 & 0.226 & $0.6 \%$ \\
\hline Compressed Natural Gas . . . . . . . . . . . . . . . . & 0.000 & 0.014 & 0.025 & 0.037 & $N / A$ \\
\hline Renewables (ethanol) ${ }^{10} \ldots \ldots \ldots \ldots \ldots$ & 0.000 & 0.001 & 0.003 & 0.006 & $33.7 \%$ \\
\hline Liquid Hydrogen $\ldots \ldots \ldots \ldots \ldots \ldots$ & 0.000 & 0.000 & 0.000 & 0.000 & $95.3 \%$ \\
\hline Methanol $^{11} \ldots \ldots \ldots \ldots \ldots \ldots \ldots$ & 0.000 & 0.001 & 0.003 & 0.006 & $38.9 \%$ \\
\hline Electricity $\ldots \ldots \ldots \ldots \ldots \ldots \ldots \ldots \ldots$ & 0.006 & 0.009 & 0.014 & 0.020 & $5.9 \%$ \\
\hline Total $\ldots \ldots \ldots \ldots \ldots \ldots \ldots \ldots \ldots$ & 3.476 & 4.214 & 4.531 & 4.826 & $1.7 \%$ \\
\hline \multicolumn{6}{|l|}{ Electric Utillties ${ }^{12}$} \\
\hline Distillate Fuel $\ldots \ldots \ldots \ldots \ldots \ldots \ldots$ & 0.000 & 0.001 & 0.001 & 0.001 & $17.6 \%$ \\
\hline Residual Fuel $\ldots \ldots \ldots \ldots \ldots \ldots \ldots \ldots$ & 0.006 & 0.008 & 0.008 & 0.007 & $1.2 \%$ \\
\hline Natural Gas $\ldots \ldots \ldots \ldots \ldots \ldots \ldots$ & 1.527 & 1.682 & 1.785 & 1.751 & $0.7 \%$ \\
\hline 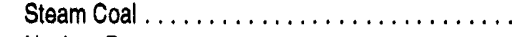 & 1.850 & 2.085 & 2.210 & 2.232 & $0.9 \%$ \\
\hline Nuclear Power $\ldots \ldots \ldots \ldots \ldots \ldots \ldots \ldots$ & 0.471 & 0.622 & 0.625 & 0.618 & $1.4 \%$ \\
\hline Renewable Energy/Other ${ }^{13}$. & 0.023 & 0.032 & 0.053 & 0.083 & $6.7 \%$ \\
\hline Total $\ldots \ldots \ldots \ldots \ldots \ldots \ldots \ldots \ldots \ldots \ldots$ & 3.685 & 4.429 & 4.681 & 4.683 & $1.2 \%$ \\
\hline
\end{tabular}


Table 7. Energy Consumption by End-Use Sector and Source

West South Central Census Division (Continued)

(Quadrillion Btu per Year)

\begin{tabular}{|c|c|c|c|c|c|}
\hline \multirow{2}{*}{ Sector and Sourco } & \multicolumn{4}{|c|}{ Relerenco Case } & \multirow{2}{*}{$\begin{array}{c}\text { Annual } \\
\text { Growth } \\
1900-2010 \\
\text { (percent) }\end{array}$} \\
\hline & 1900 & 2000 & 2006 & 2010 & \\
\hline \multicolumn{6}{|l|}{ Primary Energy Consumption } \\
\hline Distillate Fuel .............. & 0.875 & 1.072 & 1.167 & 1.266 & $1.9 \%$ \\
\hline Kerosene $, \ldots \ldots, \ldots, \ldots, \ldots, \ldots, \ldots$ & 0.001 & 0.001 & 0.001 & 0.001 & $0.4 \%$ \\
\hline 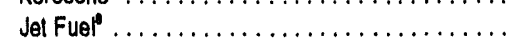 & 0.741 & 0.956 & 1.054 & 1.148 & $2.2 \%$ \\
\hline Liquelied Petroleum Gas & 1.248 & 1.547 & 1.712 & 1.875 & $2.1 \%$ \\
\hline Motor Gasoline $\theta^{2} \ldots \ldots$ & 1.659 & 1.906 & 1.967 & 2.003 & $0.9 \%$ \\
\hline Petrochemical Feodstocks & 0.573 & 0.704 & 0.783 & 0.859 & $2.0 \%$ \\
\hline Residual Fuel ......... & 0.330 & 0.423 & 0.473 & 0.518 & $2.3 \%$ \\
\hline Other Petroleum 14 .... & 1.170 & 1.403 & 1.404 & 1.441 & $1.0 \%$ \\
\hline Natural Gas .... & 6.196 & 6.759 & 7.165 & 7.400 & $0.9 \%$ \\
\hline 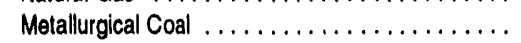 & 0.000 & 0.000 & 0.000 & 0.000 & N/A \\
\hline Steam Coal $\ldots \ldots \ldots \ldots \ldots \ldots \ldots \ldots$ & 1.946 & 2.196 & 2.391 & 2.363 & $1.0 \%$ \\
\hline Net Coal Coke Imports .................... & 0.000 & 0.000 & 0.000 & 0.000 & N/A \\
\hline 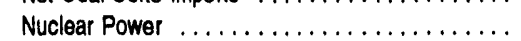 & 0.471 & 0.622 & 0.625 & 0.618 & $1.4 \%$ \\
\hline Renewable Energy/Other ${ }^{16}$. & 0.240 & 0.295 & 0.340 & 0.400 & $2.6 \%$ \\
\hline Total $\ldots \ldots \ldots \ldots \ldots \ldots \ldots \ldots \ldots \ldots$ & 15.200 & 17.806 & 18.019 & 19.692 & $1.3 \%$ \\
\hline Electriclty Consumption (all sectors) ......... & 1.273 & 1.432 & 1.512 & 1.580 & $1.1 \%$ \\
\hline
\end{tabular}

'Includes electricity generated by the sector for self-use from hydroelectric, geothermal, wood and wood waste, municipal solid waste, other biomass, wind, photovoltaic and solar thermal sources, and non-electric energy from renewable sources, such as solar thermal water heaters, ground-water heat pumps, and wood.

${ }^{2}$ Includes ethanol (blends of 10 percent or less) and ethers blended into gasoline.

'Includes liquefied petroleum gas and coal.

"Includes commercial sector electricity cogenerated using wood and wood waste, municipal solid waste, and other biomass; nonelectric energy

from renewable sources, such as active solar and passive solar systems, geothermal heat pumps, and solar water heating systems.

${ }^{6} \mathrm{Fuel}$ consumption includes consumption for cogeneration.

"Includes petroleum coke, asphalt, road oil, lubricants, still gas, and miscellaneous petroleum products.

${ }^{7}$ Includes lease and plant fuel.

includes naphtha and kerosene type.

'includes aviation gasoline and lubricants.

${ }^{10}$ Only E85 (85 percent oíianol).

${ }^{11}$ Only M85 (85 percent methanol).

${ }^{12}$ Includes consumption of energy by electric utilities, independent power producers, and small power producers that sell power to the grid.

19 includes electricity sold to utilities by nonutilities, including cogenerators, from hydroelectric, geothermal, wood and wood waste, municipal solid waste, other biomass, wind, photovoltalc and solar thermal sources, plus waste heat and net electricity imports. Does not include own use.

"Includes unfinished oils, natural gasoline, motor gasoline blending compounds, aviation gasoline, lubricants, still gas, asphall, road oll, and miscellaneous petroleum products.

"Includes electriciry generated for sale to electric utilities and for self use from renewable sources, non-electric energy from renewable sources, electricity generated from waste heat, net electricity imports, liquid hydrogen, and methanol.

Btu $=$ British thermal unit.

N/A $=$ Not applicable.

Note: Totals may not equal sum of components due to independent rounding.

Sources: $1990 \mathrm{coal}$ consumption: Energy Information Administration (EIA), Quarterly Coal Report, DOE/EIA-0121 (80/4Q) (Washington, D.C. May 1991) and State Energy Data Report 1991, DOE/EIA-0214(91) Washington, D.C. May 1993), 1990 natural gas consumption: EIA, Natural Gas Annual 1092 Volume 1, DOE/EIA-0131(92)/1 (Washington, D.C., November 1993). 1990 consumption other than coal and natural gas: ElA, Monthly Energy R.эview, DOEJEIA-0035(83/07) (Washington, D.C., July 1993) and OHlice of Coal, Nuclear, Electric and Alternate Fuels estimates. Figures for 1990 may difter from published data due to internal conversion factors within the AEO 1994 National Energy Modeling System. The 1990 values are not final and may be updated in ElA publications. Projections: ElA, AEO 1094 National Energy Modeling System run AEOQ4B.D1221934. 
Table 8. Energy Consumption by End-Use Sector and Source Mountain Census Division (Quadrillion Btu per Year)

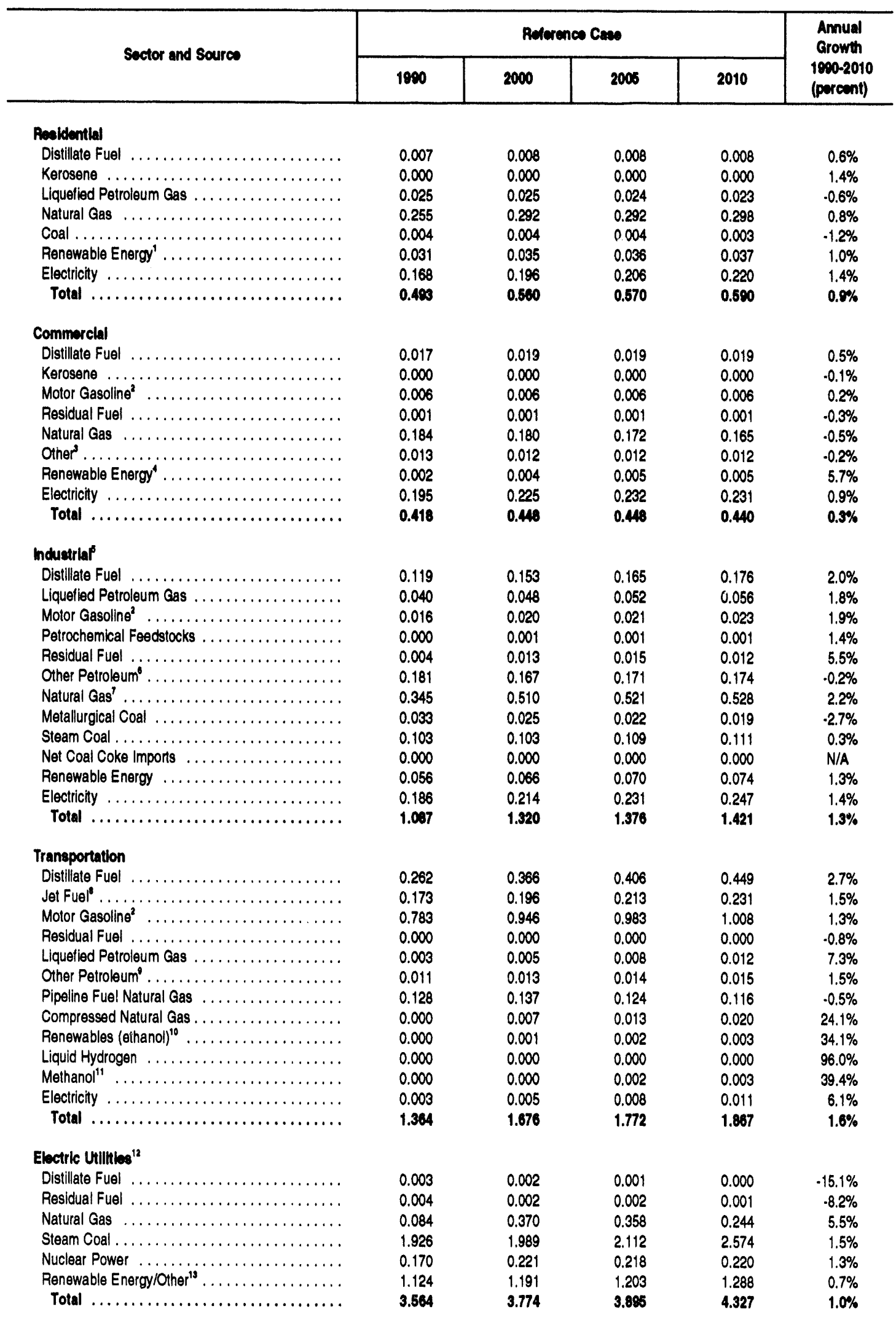


Table 8. Energy Consumption by End-Use Sector and Source Mountain Consus Division (Continued) (Quadrillion Btu per Year)

\begin{tabular}{|c|c|c|c|c|c|}
\hline \multirow{2}{*}{ Sector and Source } & \multicolumn{4}{|c|}{ Referenco Case } & \multirow{2}{*}{$\begin{array}{l}\text { Annual } \\
\text { Growth } \\
1990-2010 \\
\text { (percent) }\end{array}$} \\
\hline & 1900 & 2000 & 2005 & 2010 & \\
\hline \multicolumn{6}{|l|}{ Prinary Energy Concumption } \\
\hline Kerosene $\ldots \ldots \ldots \ldots \ldots \ldots \ldots \ldots$ & 0.000 & 0.001 & 0.001 & 0.001 & $0.8 \%$ \\
\hline Jet Fuel $\ldots \ldots \ldots \ldots \ldots \ldots \ldots \ldots \ldots$ & 0.173 & 0.186 & 0.213 & 0.231 & $1.5 \%$ \\
\hline Liquefied Petroleum Gas . ................ & 0.072 & 0.082 & 0.087 & 0.095 & $1.4 \%$ \\
\hline Motor Gasolin $\theta^{2} \ldots \ldots \ldots \ldots \ldots \ldots \ldots$ & 0.805 & 0.971 & 1.010 & 1.037 & $1.3 \%$ \\
\hline Petrochemical Feodstocks . . . . . . . . . . . . . & 0.000 & 0.001 & 0.001 & 0.001 & $1.4 \%$ \\
\hline Residual Fuel $\ldots \ldots \ldots \ldots \ldots \ldots \ldots$ & 0.009 & 0.016 & 0.018 & 0.014 & $2.1 \%$ \\
\hline Steam Coal $\ldots \ldots \ldots \ldots \ldots \ldots \ldots \ldots$ & 2.042 & 2.104 & 2.232 & 2.696 & $1.4 \%$ \\
\hline Net Coal Coke Imports $\ldots \ldots \ldots \ldots \ldots \ldots$ & 0.000 & 0.000 & 0.000 & 0.000 & N/A \\
\hline Nuclear Power & 0.170 & 0.221 & 0.218 & 0.220 & $1.3 \%$ \\
\hline Renewable Energy/Other ${ }^{18}$ & 1.213 & 1.297 & 1.317 & 1.410 & $0.8 \%$ \\
\hline Total $\ldots \ldots \ldots \ldots \ldots \ldots \ldots \ldots \ldots \ldots$ & 6.376 & 7.130 & 7.386 & 7.837 & $1.1 \%$ \\
\hline Electriclty Consumption (all sectors) $\ldots \ldots \ldots$. & 0.552 & 0.630 & 0.676 & 0.700 & $1.3 \%$ \\
\hline
\end{tabular}

'Includes electricity generated by the sector for self-use from hydroelectric, geothermal, wood and wood waste, municipal solid waste, other biomass, wind, photovoltaic and solar thermal sources, and non-electric energy from renewable sources, such as solar thermal water heaters, ground-water heat pumps, and wood.

${ }^{2}$ Includes ethanol (blends of 10 percent or less) and ethers blended into gasoline.

Includes liquefied petroleum gas and coal.

"includes commercial sector electricity cogenerated using wood and wood waste, municipal solid waste, and other biomass; nonelectric energy from renewable sources, such as active solar and passive solar systems, geothermal heat pumps, and solar water heating systems.

${ }^{8} \mathrm{Fuel}$ consumption includes consumption for cogeneration.

Includes petroleum coke, asphalt, road oll, lubricants, still gas, and miscellaneous petroleum products.

'Includes lease and plant fuel.

"includes naphtha and kerosene type.

Includes aviation gasoline and lubricants.

${ }^{10}$ Only E85 (85 percent ethanol).

"Only M85 (85 percent methanol).

${ }^{12}$ includes consumption of energy by electric utlities, independent power producers, and small power producers that sell power to the grid.

${ }^{13}$ Includes eiectricity sold to utilities by nonutilities, including cogenerators, from hydroelectric, geothermal, wood and wood waste, municipal solid waste, other blomass, wind, photovoltaic and solar thermal sources, plus waste heat and net electricity imports. Does not inciude own use.

${ }^{14}$ Includes untinished oils, natural gasoline, motor gasoline blending compounds, aviation gasoline, lubricants, still gas, asphalt, road oil, and miscellaneous petroleum products.

${ }^{18}$ Includes electricity generated for sale to electric utilities and for self use from renewable sources, non-electric energy from renewable sources, electricity generated from waste heat, net electricity imports, liquid hydrogen, and methanol.

Btu $=$ British thermal unit.

$\mathrm{N} / \mathrm{A}=$ Not applicable.

Note: Totals may not equal sum of components due to independent rounding.

Sources: $1890 \mathrm{coal}$ consumption: Energy Information Administration (ElA), Quarterly Coal Report, DOE/EIA-0121(90/4Q) (Washington, D.C. May 1991) and State Energy Data Report 1991, DOE/EIA-0214(91) (Washington, D.C., May 1993), 1990 natural gas consumption: EIA, Natural Gas Annual 1902 Volume 1, DOE/EIA-0131(92)/1 (Washington, D.C., November 1993). 1990 consumption other than coal and natural gas: ElA, Monthly Energy Review, DOE/EIA-0035(93/07) (Washington, D.C., July 1983) and Office of Coal, Nuclear, Electric and Alternate Fuels estimates. Figures for 1990 may differ from published data due to internal conversion factors within the AEO 1904 National Energy Modeling System. The 1890 values are not final and may be updated in ElA publications. Projectlone: EIA, AEO 1894 National Energy Modeling System run AEO94B.D1221934. 
Table 9. Energy Consumption by End-Use Sector and Source

Pacific Consus Division

(Quadrillion Btu per Year)

\begin{tabular}{|c|c|c|c|c|c|}
\hline \multirow{2}{*}{ Sector and Source } & \multicolumn{4}{|c|}{ Reference Case } & \multirow{2}{*}{$\begin{array}{l}\text { Annual } \\
\text { Growth } \\
1990-2010 \\
\text { (percent) }\end{array}$} \\
\hline & 1990 & 2000 & 2005 & 2010 & \\
\hline \multicolumn{6}{|l|}{ Residential } \\
\hline Distillate Fuel $\ldots \ldots \ldots \ldots \ldots \ldots \ldots \ldots$ & 0.039 & 0.042 & 0.041 & 0.040 & $0.1 \%$ \\
\hline Kerosene $\ldots \ldots \ldots \ldots \ldots \ldots \ldots \ldots \ldots$ & 0.001 & 0.001 & 0.001 & 0.001 & $0.1 \%$ \\
\hline Liquetied Petroleum Gas . . . . . . . . . . . . . . & 0.026 & 0.027 & 0.028 & 0.029 & $0.5 \%$ \\
\hline Natural Gas $\ldots \ldots \ldots \ldots \ldots \ldots \ldots \ldots$ & 0.610 & 0.659 & 0.661 & 0.674 & $0.5 \%$ \\
\hline Coal $\ldots \ldots \ldots \ldots \ldots \ldots \ldots \ldots \ldots \ldots \ldots$ & 0.003 & 0.003 & 0.003 & 0.003 & $\cdot 1.2 \%$ \\
\hline Renewable Energy' $\ldots \ldots \ldots \ldots \ldots \ldots \ldots \ldots$ & 0.108 & 0.111 & 0.111 & 0.111 & $0.2 \%$ \\
\hline Electricity $\ldots \ldots \ldots \ldots \ldots \ldots \ldots \ldots \ldots$ & 0.391 & 0.416 & 0.427 & 0.442 & $0.6 \%$ \\
\hline Total $\ldots \ldots \ldots \ldots \ldots \ldots \ldots \ldots \ldots \ldots$ & 1.179 & 1.259 & 1.272 & 1.299 & $0.5 \%$ \\
\hline \multicolumn{6}{|l|}{ Commercial } \\
\hline Distillate Fuel $\ldots \ldots \ldots \ldots \ldots \ldots \ldots \ldots$ & 0.056 & 0.063 & 0.066 & 0.067 & $0.9 \%$ \\
\hline Kerosene $\ldots \ldots \ldots \ldots \ldots \ldots \ldots \ldots$ & 0.000 & 0.000 & 0.000 & 0.000 & $-0.4 \%$ \\
\hline Motor Gasoline $e^{2} \ldots \ldots \ldots \ldots \ldots \ldots$ & 0.013 & 0.013 & 0.013 & 0.012 & $-0.4 \%$ \\
\hline Residual Fuel $\ldots \ldots \ldots \ldots \ldots \ldots \ldots \ldots$ & 0.013 & 0.016 & 0.017 & 0.019 & $1.8 \%$ \\
\hline Natural Gas $\ldots \ldots \ldots \ldots \ldots \ldots \ldots \ldots$ & 0.379 & 0.433 & 0.458 & 0.488 & $1.3 \%$ \\
\hline Other $\ldots \ldots \ldots \ldots \ldots \ldots \ldots \ldots \ldots$ & 0.011 & 0.011 & 0.011 & 0.010 & $.0 .3 \%$ \\
\hline Renewable Energy ${ }^{4} \ldots \ldots \ldots \ldots \ldots \ldots$ & 0.003 & 0.007 & 0.008 & 0.009 & $5.7 \%$ \\
\hline Electricity $\ldots \ldots \ldots \ldots \ldots \ldots \ldots \ldots \ldots$ & 0.431 & 0.542 & 0.594 & 0.638 & $2.0 \%$ \\
\hline Total $\ldots \ldots \ldots \ldots \ldots \ldots \ldots \ldots$ & 0.806 & 1.094 & 1.166 & 1.244 & $1.6 \%$ \\
\hline \multicolumn{6}{|l|}{ Industriaf } \\
\hline Distillate Fuel $\ldots \ldots \ldots \ldots \ldots \ldots \ldots \ldots$ & 0.168 & 0.180 & 0.194 & 0.208 & $1.1 \%$ \\
\hline Liquefied Petroleum Gas . . . . . . . . . . . . . . . & 0.056 & 0.051 & 0.055 & 0.060 & $0.3 \%$ \\
\hline Motor Gasoline $e^{2}, \ldots \ldots \ldots \ldots \ldots \ldots$ & 0.023 & 0.029 & 0.032 & 0.034 & $1.9 \%$ \\
\hline Petrochemical Feedstocks . . . . . . . . . . . . . . & 0.026 & 0.030 & 0.032 & 0.035 & $1.5 \%$ \\
\hline Residual Fuel $\ldots \ldots \ldots \ldots \ldots \ldots \ldots \ldots$ & 0.039 & 0.105 & 0.075 & 0.076 & $3.4 \%$ \\
\hline Other Petroleum ${ }^{6} \ldots \ldots \ldots \ldots \ldots \ldots$ & 0.615 & 0.654 & 0.679 & 0.687 & $0.6 \%$ \\
\hline Natural Gas ${ }^{\prime} \ldots \ldots \ldots \ldots \ldots \ldots \ldots$ & 1.016 & 1.099 & 1.214 & 1.272 & $1.1 \%$ \\
\hline Metallurgical Coal $\ldots \ldots \ldots \ldots \ldots \ldots \ldots$ & 0.000 & 0.000 & 0.000 & 0.000 & N/A \\
\hline Steam Coal $\ldots \ldots \ldots \ldots \ldots \ldots \ldots \ldots \ldots$ & 0.072 & 0.071 & 0.075 & 0.076 & $0.2 \%$ \\
\hline Net Coal Coke imports $\ldots \ldots \ldots \ldots \ldots \ldots$ & 0.000 & 0.000 & 0.000 & 0.000 & $N / A$ \\
\hline Renewable Energy $\ldots \ldots \ldots \ldots \ldots \ldots \ldots \ldots$ & 0.366 & 0.421 & 0.452 & 0.484 & $1.4 \%$ \\
\hline Electricity $\ldots \ldots \ldots \ldots \ldots \ldots \ldots \ldots$ & 0.397 & 0.452 & 0.486 & 0.519 & $1.4 \%$ \\
\hline Total $\ldots \ldots \ldots \ldots \ldots \ldots \ldots \ldots \ldots$ & 2.772 & 3.003 & 3.294 & 3.451 & $1.1 \%$ \\
\hline \multicolumn{6}{|l|}{ Transportation } \\
\hline$\ldots \ldots \ldots \ldots \ldots$ & 0.537 & 0.655 & 0.714 & 0.779 & $1.9 \%$ \\
\hline Jet Fuel ${ }^{\ominus} \ldots \ldots \ldots \ldots \ldots \ldots \ldots \ldots$ & 0.848 & 1.095 & 1.202 & 1.306 & $2.2 \%$ \\
\hline Molor Gasoling ${ }^{2} \ldots \ldots \ldots \ldots \ldots \ldots$ & 2.082 & 2.328 & 2.408 & 2.453 & $0.8 \%$ \\
\hline Residual Fuel $\ldots \ldots \ldots \ldots \ldots \ldots \ldots \ldots$ & 0.478 & 0.615 & 0.690 & 0.760 & $2.3 \%$ \\
\hline Llquefied Petroleum Gas . . . . . . . . . . . . . . & 0.008 & 0.012 & 0.022 & 0.033 & $7.3 \%$ \\
\hline Other Petroleum ${ }^{\prime} \ldots \ldots \ldots \ldots \ldots \ldots \ldots$ & 0.035 & 0.038 & 0.039 & 0.042 & $0.8 \%$ \\
\hline Pipeline Fuel Natural Gas $\ldots \ldots \ldots \ldots \ldots$ & 0.037 & 0.053 & 0.062 & 0.061 & $2.5 \%$ \\
\hline Compressed Natural Gas . . . . . . . . . . . . . . . & 0.000 & 0.022 & 0.040 & 0.060 & $N / A$ \\
\hline Renewables (ethanol) ${ }^{10} \ldots \ldots \ldots \ldots \ldots \ldots$ & 0.000 & 0.002 & 0.005 & 0.009 & $33.6 \%$ \\
\hline Liquid Hydrogen $\ldots \ldots \ldots \ldots \ldots \ldots \ldots \ldots$ & 0.000 & 0.000 & 0.000 & 0.000 & $95.1 \%$ \\
\hline Methanol" ${ }^{\prime \prime} \ldots \ldots \ldots \ldots \ldots \ldots \ldots$ & 0.000 & 0.001 & 0.005 & 0.010 & $38.8 \%$ \\
\hline Electricity $\ldots \ldots \ldots \ldots \ldots \ldots \ldots \ldots$ & 0.009 & 0.014 & 0.022 & 0.031 & $6.2 \%$ \\
\hline Total $\ldots \ldots \ldots \ldots \ldots \ldots \ldots \ldots \ldots$ & 4.036 & 4.835 & 5.200 & 5.544 & $1.6 \%$ \\
\hline \multicolumn{6}{|l|}{ Electric Uilitiles ${ }^{12}$} \\
\hline Distillate Fuel $\ldots \ldots \ldots \ldots \ldots \ldots \ldots \ldots$ & 0.006 & 0.005 & 0.005 & 0.005 & $-0.5 \%$ \\
\hline Residual Fuel $\ldots \ldots \ldots \ldots \ldots \ldots \ldots \ldots$ & 0.134 & 0.127 & 0.127 & 0.121 & $.0 .5 \%$ \\
\hline Natural Gas $\ldots \ldots \ldots \ldots \ldots \ldots \ldots \ldots$ & 0.515 & 0.894 & 1.079 & 0.962 & $3.2 \%$ \\
\hline Steam Coal . . . . . . . . . . . . . . . . . . . & 0.146 & 0.146 & 0.143 & 0.143 & $.0 .1 \%$ \\
\hline$\ldots \ldots \ldots \ldots \ldots$ & 0.539 & 0.445 & 0.450 & 0.374 & $\cdot 1.8 \%$ \\
\hline Renewable Energy/Other ${ }^{13} \ldots \ldots \ldots \ldots \ldots$ & 1.209 & 1.405 & 1.509 & 1.691 & $1.7 \%$ \\
\hline Total $\ldots \ldots \ldots \ldots \ldots \ldots \ldots \ldots$ & 2.450 & 3.021 & 3.313 & 3.297 & $1.5 \%$ \\
\hline
\end{tabular}


Table 9. Energy Consumntion by End-Use Sector and Source

Pacific Census Division (Continued)

(Quadrillion Btu per Year)

\begin{tabular}{|c|c|c|c|c|c|}
\hline \multirow{2}{*}{ Secior and Source } & \multicolumn{4}{|c|}{ Relerencos Case } & \multirow{2}{*}{$\begin{array}{c}\text { Anmual } \\
\text { Growth } \\
1900-2010 \\
\text { (percent) }\end{array}$} \\
\hline & 1900 & 2000 & 2006 & 2010 & \\
\hline \multicolumn{6}{|l|}{ Primary Energy Conoumption } \\
\hline Distillate Fuel ............ & 0.806 & 0.945 & 1.020 & 1.099 & $1.6 \%$ \\
\hline Kerosene $\ldots \ldots \ldots \ldots \ldots \ldots \ldots \ldots$ & 0.001 & 0.001 & 0.001 & 0.001 & $0.0 \%$ \\
\hline$\ldots \ldots \ldots \ldots$ & 0.848 & 1.095 & 1.202 & 1.306 & $2.2 \%$ \\
\hline Liquefled Petroleum Gas & 0.095 & 0.096 & 0.109 & 0.127 & $1.5 \%$ \\
\hline Motor Gasolin $\theta^{2}$ & 2.119 & 2.370 & 2.452 & 2.500 & $0.8 \%$ \\
\hline Petrochemical Feedstocks & 0.026 & 0.030 & 0.032 & 0.035 & $1.5 \%$ \\
\hline Residual Fuel & 0.664 & 0.862 & 0.910 & 0.976 & $1.9 \%$ \\
\hline Other Petroleum" & 0.650 & 0.692 & 0.718 & 0.729 & $0.6 \%$ \\
\hline Natural Gas .... & 2.558 & 3.160 & 3.514 & 3.516 & $1.6 \%$ \\
\hline Metallurgical Coal ..... & 0.000 & 0.000 & 0.000 & 0.000 & N/A \\
\hline Steam Coal .... & 0.228 & 0.225 & 0.226 & 0.228 & $0.0 \%$ \\
\hline Net Coal Coke Imports & 0.000 & 0.000 & 0.000 & 0.000 & N/A \\
\hline Nuclear Power ...... & 0.539 & 0.445 & 0.450 & 0.374 & $.1 .8 \%$ \\
\hline Renewable Energy/Other ${ }^{16}$. & 1.685 & 1.947 & 2.090 & 2.315 & $1.6 \%$ \\
\hline 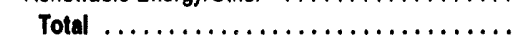 & 10.124 & 11.800 & 12.724 & 13.204 & $1.3 \%$ \\
\hline Electriclty Consumption (all sactors) ......... & 1.220 & 1.425 & 1.528 & 1.691 & $1.4 \%$ \\
\hline
\end{tabular}

'Includes electricity generated by the sector for self-use from hydroelectrlc, geothermal, wood and wood waste, municipal solid waste, other biomass, wind, photovoltaic and solar thermal sources, and non-electric energy from renewable sources, such as solar thermal water heaters, ground-water heat pumps, and wood.

Includes ethanol (blends of 10 percent or less) and ethers blended into gasoline.

${ }^{3}$ Includes liquefied petroleum gas and coal.

"Includes commercial sector electricity cogenerated using wood and wood waste, municipal solid waste, and other biomass; nonelectric energy from renewable sources, such as active solar and passive solar systems, geothermal heat pumps, and solar water heating systems.

'Fuel consumption includes consumption for cogeneration.

"Includes petroleum coke, asphalt, road oll, lubricants, still gas, and miscellaneous petroleum products.

${ }^{7}$ includes lease and plant fuel.

"Includes naphtha and kerosene type.

includes aviation gasoline and lubricants.

${ }^{10}$ Only E85 (85 percent ethanol).

${ }^{11}$ Only M85 (85 percent methanol).

${ }^{12}$ Includes consumption of energy by electric utilities, independent power producers, and small power producers that sell power to the grid.

${ }^{19}$ Includes electricity sold to utilities by nonutilities, including cogererators, from hydroelectric, geothermal, wood and wood waste, municipal solid waste, other biomass, wind, photovoltaic and solar thermal sources, plus waste heat and net electricity imports. Does not include own use.

${ }^{14}$ includes unfinished oils, natural gasoline, motor gasoline blending compounds, aviation gasoline, lubricants, still gas, asphalt, road oil, and miscellaneous petroleum products.

${ }^{18}$ Includes electricity generated for sale to electric utilities and for self use from renewable sources, non-electric energy from renewable sources, electricity generated from waste heat, net electricity imports, liquid hydrogen, and methanol.

Btu $=$ British thermal unit.

$\mathrm{N} / \mathrm{A}=$ Not applicable.

Note: Totals may not equal sum of components due to independent rounding.

Sources: 1980 coal consumption: Energy Information Administration (ElA), Quarterly Coal Report, DOE/ElA-0121(80/4Q) (Washinglon, D.C. May 1991) and State Energy Data Report 1991, DOEJElA-0214(01) (Washington, D.C., May 1993). 1990 natural gas consumption: ElA, Natural Gas Annual 1992 Volume 1, DOE/EIA-0131(92)/1 (Washington, D.C., November 1993). 1990 consumption other than coal and natural gas: ElA, Monthly Energy Review, DOEJEIA-0035(93/07) (Washington, D.C., July 1993) and OHlice of Coal, Nuclear, Electric and Alternale Fuels estimates. Figures for 1990 may differ trom published data due to internal conversion factors within the AEO 1994 National Energy Modeling System. The 1990 values are not final and may be updated in EIA publications. Projectlons: EIA, AEO 1994 National Energy Modeling System run AEO94B.D1221934. 
Table 10. Energy Consumption by End-Use Sector and Source

United States

(Quadrillion Btu per Year)

\begin{tabular}{|c|c|c|c|c|c|}
\hline \multirow{2}{*}{ Sector and Source } & \multicolumn{4}{|c|}{ Pelerence Cen } & \multirow{2}{*}{$\begin{array}{l}\text { Annual } \\
\text { Crowth } \\
1900-2010 \\
\text { (percent) }\end{array}$} \\
\hline & 1900 & 2000 & 2005 & 2010 & \\
\hline \multicolumn{6}{|l|}{ Ponldential } \\
\hline Distillate Fuel $\ldots \ldots \ldots \ldots \ldots \ldots \ldots \ldots$ & 0.84 & 0.90 & 0.89 & 0.87 & $0.2 \%$ \\
\hline Kerosene $\ldots \ldots \ldots \ldots \ldots \ldots \ldots \ldots$ & 0.06 & 0.06 & 0.06 & 0.06 & $-0.5 \%$ \\
\hline Liquefied Petroleum Gas . . . . . . . . . . . . . . & 0.36 & 0.36 & 0.34 & 0.33 & $.0 .5 \%$ \\
\hline Natural Gas $\ldots \ldots \ldots \ldots \ldots \ldots \ldots$ & 4.52 & 5.00 & 4.97 & 4.99 & $0.5 \%$ \\
\hline Coal $\ldots \ldots \ldots \ldots \ldots \ldots \ldots \ldots \ldots \ldots$ & 0.06 & 0.05 & 0.05 & 0.05 & $-1.3 \%$ \\
\hline Renewable Energy' $\ldots \ldots \ldots \ldots \ldots \ldots \ldots$ & 0.61 & 0.65 & 0.66 & 0.66 & $0.4 \%$ \\
\hline Electricity $\ldots \ldots \ldots \ldots \ldots \ldots \ldots \ldots$ & 3.15 & 3.39 & 3.49 & 3.63 & $0.7 \%$ \\
\hline Total $\ldots \ldots \ldots \ldots \ldots \ldots \ldots \ldots$ & 9.61 & 10.41 & 10.46 & 10.60 & $0.5 \%$ \\
\hline \multicolumn{6}{|l|}{ Commercial } \\
\hline Distillate Fuel $\ldots \ldots \ldots \ldots \ldots \ldots \ldots \ldots$ & 0.49 & 0.52 & 0.51 & 0.49 & $0.1 \%$ \\
\hline Kerosene $\ldots \ldots \ldots \ldots \ldots \ldots \ldots \ldots$ & 0.01 & 0.01 & 0.01 & 0.01 & $-0.5 \%$ \\
\hline Motor Gasoline ${ }^{2} \ldots \ldots \ldots \ldots \ldots \ldots \ldots$ & 0.11 & 0.11 & 0.11 & 0.11 & $0.2 \%$ \\
\hline Residual Fuel $\ldots \ldots \ldots \ldots \ldots \ldots \ldots \ldots$ & 0.23 & 0.22 & 0.22 & 0.22 & $-0.4 \%$ \\
\hline Natural Gas $\ldots \ldots \ldots \ldots \ldots \ldots \ldots \ldots \ldots$ & 2.70 & 2.88 & 2.94 & 3.01 & $0.6 \%$ \\
\hline Other $\ldots \ldots \ldots \ldots \ldots \ldots \ldots \ldots \ldots$ & 0.16 & 0.15 & 0.15 & 0.15 & $-0.2 \%$ \\
\hline Renewable Energy ${ }^{4} \ldots \ldots \ldots \ldots \ldots \ldots \ldots$ & 0.01 & 0.03 & 0.03 & 0.03 & $5.2 \%$ \\
\hline Electricity $\ldots \ldots \ldots \ldots \ldots \ldots \ldots \ldots \ldots$ & 2.86 & 3.30 & 3.44 & 3.51 & $1.0 \%$ \\
\hline Total $\ldots \ldots \ldots \ldots \ldots \ldots \ldots \ldots$ & 6.57 & 7.22 & 7.41 & 7.58 & $0.7 \%$ \\
\hline \multicolumn{6}{|l|}{ Induatrial ${ }^{5}$} \\
\hline Distillate Fuel $\ldots \ldots \ldots \ldots \ldots \ldots \ldots \ldots$ & 1.18 & 1.37 & 1.47 & 1.56 & $1.4 \%$ \\
\hline Liquelled Petroleum Gas . . . . . . . . . . . . . & 1.61 & 1.99 & 2.20 & 2.40 & $2.0 \%$ \\
\hline Motor Gasoline ${ }^{2} \ldots \ldots \ldots \ldots \ldots \ldots$ & 0.18 & 0.23 & 0.25 & 0.26 & $1.8 \%$ \\
\hline Petrochemical Feedstocks . . . . . . . . . . . . . . & 1.10 & 1.32 & 1.46 & 1.59 & $1.9 \%$ \\
\hline Residual Fuel $\ldots \ldots \ldots \ldots \ldots \ldots \ldots \ldots$ & 0.42 & 0.46 & 0.44 & 0.45 & $0.4 \%$ \\
\hline Other Petroleum $\ldots \ldots \ldots \ldots \ldots \ldots \ldots$ & 3.82 & 4.38 & 4.43 & 4.55 & $0.9 \%$ \\
\hline Natural Gas $^{7} \ldots \ldots \ldots \ldots \ldots \ldots \ldots$ & 8.50 & 9.61 & 10.20 & 10.69 & $1.2 \%$ \\
\hline Metallurgical Coal $\ldots \ldots \ldots \ldots \ldots \ldots \ldots \ldots$ & 1.04 & 0.74 & 0.65 & 0.57 & $\cdot 2.9 \%$ \\
\hline Steam Coal $\ldots \ldots \ldots \ldots \ldots \ldots \ldots \ldots \ldots$ & 1.71 & 1.91 & 2.11 & 2.24 & $1.4 \%$ \\
\hline Net Coal Coke imports $\ldots \ldots \ldots \ldots \ldots \ldots$ & 0.00 & 0.01 & 0.02 & 0.02 & $N / A$ \\
\hline Renewable Energy $\ldots \ldots \ldots \ldots \ldots \ldots \ldots$ & 1.96 & 2.40 & 2.62 & 2.84 & $1.9 \%$ \\
\hline Electricity $\ldots \ldots \ldots \ldots \ldots \ldots \ldots \ldots \ldots$ & 3.23 & 3.84 & 4.18 & 4.50 & $1.7 \%$ \\
\hline Total $\ldots \ldots \ldots \ldots \ldots \ldots \ldots \ldots \ldots$ & 24.78 & 28.27 & 30.02 & 31.68 & $1.2 \%$ \\
\hline \multicolumn{6}{|l|}{ Trameportation } \\
\hline Distillate Fuel $\ldots \ldots \ldots \ldots \ldots \ldots \ldots$ & 3.83 & 4.87 & 5.32 & 5.82 & $2.1 \%$ \\
\hline Jet Fuel $\ldots \ldots \ldots \ldots \ldots \ldots \ldots \ldots \ldots$ & 3.13 & 3.72 & 4.08 & 4.44 & $1.8 \%$ \\
\hline Motor Gasoline ${ }^{2} \ldots \ldots \ldots \ldots \ldots \ldots \ldots$ & 13.58 & 15.03 & 15.50 & 15.76 & $0.7 \%$ \\
\hline Residual Fuel $\ldots \ldots \ldots \ldots \ldots \ldots \ldots \ldots$ & 1.03 & 1.32 & 1.49 & 1.64 & $2.3 \%$ \\
\hline Liquefied Petroleum Gas . . . . . . . . . . . . . & 0.02 & 0.08 & 0.13 & 0.20 & $12.3 \%$ \\
\hline Other Petroleum ${ }^{\prime} \ldots \ldots \ldots \ldots \ldots \ldots \ldots$ & 0.22 & 0.21 & 0.22 & 0.24 & $0.3 \%$ \\
\hline Pipeline Fuel Natural Gas $\ldots \ldots \ldots \ldots \ldots \ldots$ & 0.68 & 0.69 & 0.72 & 0.73 & $0.3 \%$ \\
\hline Compressed Natural Gas . . . . . . . . . . . . . . . & 0.00 & 0.13 & 0.24 & 0.37 & N/A \\
\hline Renewables $(\theta \text { thanol })^{10} \ldots \ldots \ldots \ldots \ldots$ & 0.00 & 0.01 & 0.03 & 0.06 & $33.4 \%$ \\
\hline Liquid Hydrogen $\ldots \ldots \ldots \ldots \ldots \ldots \ldots$ & 0.00 & 0.00 & 0.00 & 0.00 & $94.9 \%$ \\
\hline Methanol $^{1 t} \ldots \ldots \ldots \ldots \ldots \ldots \ldots$ & 0.00 & 0.01 & 0.03 & 0.06 & $38.7 \%$ \\
\hline Electricity $\ldots \ldots \ldots \ldots \ldots \ldots \ldots \ldots$ & 0.01 & 0.08 & 0.13 & 0.18 & $15.9 \%$ \\
\hline Total $\ldots \ldots \ldots \ldots \ldots \ldots \ldots \ldots \ldots \ldots$ & 22.50 & 26.16 & 27.01 & 29.50 & $1.4 \%$ \\
\hline \multicolumn{6}{|l|}{ Electric Utilitims ${ }^{12}$} \\
\hline Distillate Fuel ... & 0.02 & 0.08 & 0.13 & 0.11 & $7.7 \%$ \\
\hline Residua ${ }^{\prime}$ Fuel $\ldots \ldots \ldots \ldots \ldots \ldots$ & 1.23 & 0.93 & 0.97 & 0.81 & $-2.1 \%$ \\
\hline Natural Gas $\ldots \ldots \ldots \ldots \ldots \ldots \ldots \ldots$ & 2.88 & 4.36 & 5.24 & 5.10 & $2.9 \%$ \\
\hline Steam Coal . . . . . . . . . . . . . . . . . . & 16.10 & 17.49 & 18.05 & 19.93 & $1.1 \%$ \\
\hline Nuclear Power $\ldots \ldots \ldots \ldots \ldots \ldots \ldots$ & 6.20 & 7.21 & 7.30 & 6.57 & $0.3 \%$ \\
\hline Renewable Energy/Other ${ }^{1 s} \ldots \ldots \ldots \ldots \ldots$ & 3.64 & 4.23 & 4.55 & 5.21 & $1.8 \%$ \\
\hline Total $\ldots \ldots \ldots \ldots \ldots \ldots \ldots \ldots \ldots$ & 30.07 & 34.30 & 36.24 & 37.74 & $1.1 \%$ \\
\hline
\end{tabular}


Table 10. Energy Consumption by End-Use Sector and Source United States (Continued) (Quadrillion Btu per Year)

\begin{tabular}{|c|c|c|c|c|c|}
\hline \multirow{2}{*}{ Sector and Source } & \multicolumn{4}{|c|}{ Reterencos Cass } & \multirow{2}{*}{$\begin{array}{l}\text { Amual } \\
\text { Orowth } \\
\text { 19e0-2010 } \\
\text { (percent) }\end{array}$} \\
\hline & 1090 & 2000 & 2005 & 2010 & \\
\hline
\end{tabular}

\section{Primary Energy Consumption}

Distillate Fuel $\ldots \ldots \ldots \ldots \ldots \ldots \ldots \ldots$

Kerosene $\ldots \ldots \ldots \ldots \ldots \ldots \ldots \ldots \ldots \ldots$

Jet Fuel $\ldots \ldots \ldots \ldots \ldots \ldots \ldots \ldots \ldots \ldots$

Liquelied Petroleum Gas ...............

Motor Gasoline $\theta^{2} \ldots \ldots \ldots \ldots \ldots \ldots \ldots \ldots$

Petrochemical Feedstocks $\ldots \ldots \ldots \ldots \ldots \ldots \ldots$

Residual Fuel ......................

Other Petroleum ${ }^{11} \ldots \ldots \ldots \ldots \ldots \ldots \ldots \ldots \ldots \ldots$

Natural Gas $\ldots \ldots \ldots \ldots \ldots \ldots \ldots \ldots \ldots \ldots$

Metallurgical Coal $\ldots \ldots \ldots \ldots \ldots \ldots \ldots \ldots$

Stoam Coal . . . . . . . . . . . . . . . . . . . .

Net Coal Coke imports . . . . . . . . . . . .

Nuclear Power ......................

Renewable Energy/Other ${ }^{16} \ldots \ldots \ldots \ldots \ldots \ldots$

Total

Electricty Consumption (all sectors)

$\begin{array}{rr}6.36 & 7.72 \\ 0.08 & 0.07 \\ 3.13 & 3.72 \\ 2.06 & 2.49 \\ 13.87 & 15.37 \\ 1.10 & 1.32 \\ 2.91 & 2.94 \\ 4.04 & 4.59 \\ 19.30 & 22.67 \\ 1.04 & 0.74 \\ 17.96 & 19.54 \\ 0.00 & 0.01 \\ 6.20 & 7.21 \\ 6.22 & 7.32 \\ 84.20 & \mathbb{8 . 7 3}\end{array}$

8.31
0.07
4.08
2.74
15.86
1.46
3.12
4.65
24.31
0.65
20.29
0.02
7.30
7.92
100.79
8.86
0.07
4.44
3.00
16.14
1.59
3.11
4.79
24.89
0.57
22.31
0.02
6.57
8.87
105.23

$1.7 \%$

9.25

10.62

11.25

11.84

$-0.5 \%$

$1.8 \%$

$1.9 \%$

$0.8 \%$

$1.9 \%$

$0.3 \%$

$0.8 \%$

$1.3 \%$

$.2 .9 \%$

$1.1 \%$

N/A

$0.3 \%$

$1.8 \%$

$1.1 \%$

'Includes electricity generated by the sector for self-use from hydroelectric, geothermal, wood and wood waste, municipal solid waste, other biomass, wind, photovoltaic and solar thermal sources, and non-electric energy from renewable sources, such as solar thermal water heaters, ground-water heat pumps, and wood.

Includes ethanol (blends of 10 percent or less) and ethers blended into gasoline.

${ }^{3}$ Includes liquefied petroleum gas and coal.

"Includes commercial sector electricity cogenerated using wood and wood waste, municipal solid waste, and other biomass; nonelectric energy from renewable sources, such as active solar and passive solar systems, geothermal heat pumps, and solar water heating systems.

'Fuel consumption includes consumption for cogeneration.

Includes petroleum coke, asphaht, road oil, lubricants, still gas, and miscellaneous petroleum products.

'Includes lease and plant fuel.

includes naphtha and kerosene type.

includes aviation gasoline and lubricants.

${ }^{10}$ Only E85 (85 percent ethanol).

"Only MB5 (85 percent methanol).

${ }^{12}$ Includes consumption of energy by electric utilities, independent power producers, and small power producers that sell power to the grid.

${ }^{13}$ Includes electricity sold to utilities by nonutilities, including cogenerators, from hydroalectric, geothermal, wood and wood waste, municipal solid waste, other biomass, wind, photovoltalc and solar thermal sources, plus waste heal and net electricity imports. Does not include own use.

"includes unfinished oils, natural gasoline, motor gasoline blending compounds, aviation gasoline, lubricants, still gas, asphalt, road oil, and miscellaneous petroleum products.

${ }^{13}$ Includes electricity generated for sale to electric utilities and for self use from renewable sources, non-electric energy from renewable sources, electricity generated from waste heat, net electricity imports, liquid hydrogen, and methanol.

Btu = British thermal unit.

N/A $=$ Not applicable.

Note: Totals may not equal sum of components due to independent rounding.

Sources: 1990 coal consumption: Energy Intormation Administration (ElA), Quarterly Coal Report, DOE/EIA-0121(80/4Q) (Washington, D.C. May 1991) and State Energy Data Report 1991, DOE/EIA-0214(91) (Washington, D.C., May 1993). 1990 natural gas consumption: EIA, Natural Gas Annual 1992 Volume 1, DOE/EIA-0131(92)/1 (Washington, D.C., November 1993). 1990 consumption other than coal and natural gas: EIA, Monthly Energy Review, DOE/EIA-0035(93/07) (Washington, D.C., July 1993) and Ottice of Coal, Nuclear, Electric and Alternate Fuels estimates. Figures for 1900 may differ from published data due to internal conversion factors within the AEO 1994 National Energy Modeling System. The 1990 values are not final and may be updated in EIA publications. Projectiona: EIA, AEO 1994 National Energy Modeling System run AEO94B.D1221834. 
Table 11. Energy Prices by End-Use Sector and Source Now England Census Division

(1992 Dollars per Million Btu)

\begin{tabular}{|c|c|c|c|c|c|}
\hline \multirow{2}{*}{ Sector and Sourco } & \multicolumn{4}{|c|}{ Relerences Ceses } & \multirow{2}{*}{$\begin{array}{l}\text { Amual } \\
\text { Growth } \\
1600-2010 \\
\text { (percant) }\end{array}$} \\
\hline & 1900 & 2000 & 2000 & 2010 & \\
\hline Residential $\ldots \ldots \ldots \ldots \ldots \ldots \ldots \ldots \ldots \ldots$ & 12.92 & 13.62 & 14.88 & 16.01 & $1.1 \%$ \\
\hline Primary Energy $\ldots \ldots \ldots \ldots \ldots \ldots \ldots \ldots$ & 8.51 & 8.57 & 9.38 & 10.07 & $0.8 \%$ \\
\hline Petroleum Products $\ldots \ldots \ldots \ldots \ldots \ldots \ldots$ & 8.76 & 8.01 & 8.84 & 9.43 & $0.4 \%$ \\
\hline Distillate Fuel $\ldots \ldots \ldots \ldots \ldots \ldots \ldots$ & 8.25 & 7.59 & 8.43 & 9.01 & $0.4 \%$ \\
\hline Liquelied Petroleum Gas ............... & 14.22 & 13.76 & 15.00 & 15.97 & $0.6 \%$ \\
\hline Natural Gas $\ldots \ldots \ldots \ldots \ldots \ldots \ldots$ & 8.16 & 9.44 & 10.22 & 11.08 & $1.5 \%$ \\
\hline Electricity $\ldots \ldots \ldots \ldots \ldots \ldots \ldots \ldots \ldots$ & 28.44 & 32.43 & 34.96 & 37.05 & $1.3 \%$ \\
\hline Commerclal $\ldots \ldots \ldots \ldots \ldots \ldots \ldots \ldots$ & 12.82 & 12.34 & 12.41 & 12.76 & $0.0 \%$ \\
\hline Primary Energy $\ldots \ldots \ldots \ldots \ldots \ldots \ldots$ & 5.91 & 6.18 & 6.91 & 7.55 & $1.2 \%$ \\
\hline Petroleum Products $\ldots \ldots \ldots \ldots \ldots \ldots \ldots$ & 5.48 & 5.02 & 5.67 & 6.09 & $0.5 \%$ \\
\hline Distillate Fuel $\ldots \ldots \ldots \ldots \ldots \ldots \ldots$ & 6.58 & 5.87 & 6.71 & 7.29 & $0.5 \%$ \\
\hline Residual Fuel $\ldots \ldots \ldots \ldots \ldots \ldots \ldots \ldots$ & 3.27 & 3.43 & 4.08 & 4.58 & $1.7 \%$ \\
\hline Natural Gas $\ldots \ldots \ldots \ldots \ldots \ldots \ldots \ldots$ & 6.55 & 7.74 & 8.52 & 9.38 & $1.8 \%$ \\
\hline Electricity $\ldots \ldots \ldots \ldots \ldots \ldots \ldots \ldots \ldots$ & 25.40 & 24.10 & 23.28 & 23.75 & $.0 .3 \%$ \\
\hline ............ & 9.22 & 8.00 & 9.63 & 10.28 & $0.5 \%$ \\
\hline Primary Energy $\ldots \ldots \ldots \ldots \ldots \ldots \ldots$ & 5.02 & 5.14 & 5.96 & 6.61 & $1.4 \%$ \\
\hline Petroleum Products..$\ldots \ldots \ldots \ldots \ldots \ldots$ & 4.97 & 4.74 & 5.66 & 6.32 & $1.2 \%$ \\
\hline Distillate Fuel $\ldots \ldots \ldots \ldots \ldots \ldots \ldots$ & 6.66 & 5.74 & 6.58 & 7.16 & $0.4 \%$ \\
\hline Liquefied Petroleum Gas ............... & 11.56 & 13.35 & 14.59 & 15.56 & $1.5 \%$ \\
\hline Residual Fuel $\ldots \ldots \ldots \ldots \ldots \ldots \ldots \ldots$ & 3.24 & 3.40 & 4.04 & 4.54 & $1.7 \%$ \\
\hline Natural Gas ${ }^{1} \ldots \ldots \ldots \ldots \ldots \ldots \ldots$ & 5.36 & 5.97 & 6.71 & 7.47 & $1.7 \%$ \\
\hline Metallurgical Coal ...... & 0.00 & 0.00 & 0.00 & 0.00 & N/A \\
\hline Steam Coal $\ldots \ldots \ldots \ldots \ldots \ldots \ldots \ldots$ & 2.68 & 2.85 & 3.02 & 2.99 & $0.6 \%$ \\
\hline Electricity $\ldots \ldots \ldots \ldots \ldots \ldots \ldots \ldots \ldots$ & 21.40 & 20.95 & 20.38 & 20.92 & $.0 .1 \%$ \\
\hline Transportation $\ldots \ldots \ldots \ldots \ldots \ldots \ldots \ldots$ & 9.83 & 10.56 & 11.41 & 12.08 & $1.0 \%$ \\
\hline Primany Energy $\ldots \ldots \ldots \ldots \ldots \ldots \ldots \ldots$ & 9.89 & 10.50 & 11.34 & 11.97 & $1.0 \%$ \\
\hline Petroleum Products $\ldots \ldots \ldots \ldots \ldots \ldots \ldots$ & 9.89 & 10.50 & 11,34 & 11.97 & $1.0 \%$ \\
\hline Distillate Fuel ${ }^{2} \ldots \ldots \ldots \ldots \ldots \ldots \ldots$ & 9.91 & 10.22 & 11.14 & 11.64 & $0.8 \%$ \\
\hline Jet Fuel ..... & 6.33 & 5.73 & 6.51 & 7.17 & $0.6 \%$ \\
\hline$\ldots \ldots \ldots \ldots \ldots$ & 10.56 & 11.25 & 12.09 & 12.76 & $0.9 \%$ \\
\hline$\ldots \ldots \ldots \ldots \ldots \ldots, \ldots$ & 2.65 & 2.48 & 3.19 & 3.80 & $1.8 \%$ \\
\hline Natural $\mathrm{Gas}^{5}$. . & 4.00 & 10.46 & 11.30 & 11.98 & $5.6 \%$ \\
\hline Electricity $\ldots \ldots \ldots \ldots \ldots \ldots \ldots \ldots \ldots$ & 20.46 & 21.55 & 21.26 & 21.41 & $0.2 \%$ \\
\hline Total End-Uee Energy $\ldots \ldots \ldots \ldots \ldots \ldots \ldots$ & 11.10 & 11.64 & 12.58 & 13.41 & $0.0 \%$ \\
\hline Primary Energy $\ldots \ldots \ldots \ldots \ldots \ldots \ldots \ldots$ & 10.93 & 11.33 & 12.11 & 12.82 & $0.8 \%$ \\
\hline Electricity $\ldots \ldots \ldots \ldots \ldots \ldots \ldots \ldots \ldots$ & 25.41 & 26.16 & 26.55 & 27.66 & $0.4 \%$ \\
\hline \multicolumn{6}{|l|}{ Electric Utilities } \\
\hline Fossil Fuel Average . & 2.65 & 2.95 & 3.49 & 3.83 & $1.9 \%$ \\
\hline Petroleum Products . . . . . . . . . . . . . . . & 3.07 & 3.17 & 3.82 & 4.36 & $1.8 \%$ \\
\hline Distillale Fuel $\ldots \ldots \ldots \ldots \ldots \ldots \ldots$ & 5.92 & 4.93 & 5.77 & 6.35 & $0.4 \%$ \\
\hline Residual Fuel & 3.05 & 3.16 & 3.81 & 4.32 & $1.8 \%$ \\
\hline Natural Gas $\ldots \ldots \ldots \ldots \ldots \ldots \ldots$ & 2.61 & 3.73 & 4.41 & 5.13 & $3.4 \%$ \\
\hline Steam Coal $\ldots \ldots \ldots \ldots \ldots \ldots \ldots$ & 1.93 & 2.00 & 2.16 & 2.05 & $0.3 \%$ \\
\hline
\end{tabular}


Table 11. Energy Prices by End-Use Sector and Source Now England Census Division (Continued) (1992 Dollars per Million Btu)

\begin{tabular}{|c|c|c|c|c|c|}
\hline \multirow{2}{*}{ Soctor and Sources } & \multicolumn{4}{|c|}{ Relerenco Case } & \multirow{2}{*}{$\begin{array}{l}\text { Amual } \\
\text { Growth } \\
1600-2010 \\
\text { (percant) }\end{array}$} \\
\hline & 1000 & 2000 & 2005 & 2010 & \\
\hline \multicolumn{6}{|l|}{ Averege Price to All Ueare' } \\
\hline Petroleum Products . & 7.78 & 8.20 & 8.99 & 9.77 & $1.1 \%$ \\
\hline Distillate Fuel $\ldots$ & 8.29 & 7.93 & 8.85 & 9.44 & $0.7 \%$ \\
\hline Jet Fuel .... & 6.33 & 5.73 & 6.51 & 7.17 & $0.6 \%$ \\
\hline Liquetled Petroleum Gas .... & 13.10 & 13.87 & 15.31 & 16.48 & $1.2 \%$ \\
\hline Motor Gasoline $\ldots$......... & 10.56 & 11.25 & 12.09 & 12.76 & $0.9 \%$ \\
\hline Residual Fuel ........................ & 3.10 & 3.23 & 3.88 & 4.40 & $1.8 \%$ \\
\hline (................... & 6.16 & 6.99 & 7.76 & 8.58 & $1.7 \%$ \\
\hline (n.................. & 2.00 & 2.08 & 2.25 & 2.16 & $0.4 \%$ \\
\hline 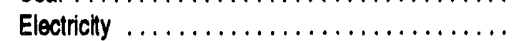 & 25.41 & 26.16 & 26.55 & 27.66 & $0.4 \%$ \\
\hline
\end{tabular}

'Excludes uses for lease and plant fuel.

${ }^{2}$ Includes Federal and State taxes on diesel fuel and excludes county and local taxes.

'Kerosene-type jet fuel.

Average price for all grades. Includes Federal and State taxes and excludes county and local taxes.

'Compressed natural gas used as a vohicle fuel.

Weighted averages of end-use fuel prices are derived from the prices shown in each sector and the corresponding sectoral consumption. For each sector, electricity and natural gas prices are derived by dividing total revenues by sales.

Btu $=$ British thermal unit.

N/A = Not applicable.

Sources: 1990 petroleum prices: Energy Intormation Administration (EIA), State Energy Price and Expenditure Report 1991, DOE/EIA0376(91) (Washington,D.C., September 1993). 1090 coal prices: ElA, Quarterly Coal Report, DOE/ElA-0121(90/4Q) (Washington, D.C., May 1991); ElA, Annual Energy Review 1002, DOE/EIA-0384(92) (Washington, D.C., June 1993), Table A6; and ElA, State Energy Price and Expenditures Revort 1991, DOE/EIA-0376(91) (Washington, D.C., September 1993). 1990 industrial and transportation natural gas delivered prices: EIA, AEO National Energy Modeling System run AEO94B.D1221934. Other 1990 natural gas prices: EIA, Natural Gas Annual, DOE/EIA0131 (92)/1 (Washington, DC, November 1993). 1090 electricity prices: EIA, AEO 1994 National Energy Modeling System run AEO94B.D1221834. Projectione: EIA, AEO 1994 National Energy Modeling System run AEO94B.D1221934. 
Table 12. Energy Prices by End-Use Sector and Source Middle Atlantic Consus Division (1992 Dollars per Million Btu)

\begin{tabular}{|c|c|c|c|c|c|}
\hline \multirow{2}{*}{ Sector and Source } & \multicolumn{4}{|c|}{ Relerences Case } & \multirow{2}{*}{$\begin{array}{l}\text { Annud } \\
\text { Growth } \\
\text { 19:0-2010 } \\
\text { (perent) }\end{array}$} \\
\hline & 1090 & 2000 & 2005 & 2010 & \\
\hline Paskdential $\ldots \ldots \ldots \ldots \ldots \ldots \ldots \ldots \ldots$ & 12.74 & 13.14 & 14.14 & 15.55 & $1.0 \%$ \\
\hline Primary Energy $\ldots \ldots \ldots \ldots \ldots \ldots \ldots$ & 7.67 & 8.25 & 9.00 & 9.73 & $1.2 \%$ \\
\hline Petroleum Products $\ldots \ldots \ldots \ldots \ldots \ldots \ldots$ & 8.92 & 8.24 & 9.10 & 9.70 & $0.4 \%$ \\
\hline Distillate Fuel $\ldots \ldots \ldots \ldots \ldots \ldots \ldots \ldots$ & 8.40 & 7.83 & 8.68 & 9.26 & $0.5 \%$ \\
\hline Liqueiled Petroleum Gas . . . . . . . . . . . . . & 14.40 & 13.42 & 14.66 & 15.63 & $0.4 \%$ \\
\hline Natural Gas $\ldots \ldots \ldots \ldots \ldots \ldots \ldots$ & 7.21 & 8.38 & 9.10 & 9.89 & $1.6 \%$ \\
\hline Electricity $\ldots \ldots \ldots \ldots \ldots \ldots \ldots \ldots$ & 30.47 & 30.78 & 32.01 & 34.96 & $0.7 \%$ \\
\hline 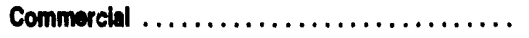 & 13.02 & 13.52 & 14.37 & 14.87 & $0.7 \%$ \\
\hline Primary Energy $\ldots \ldots \ldots \ldots \ldots \ldots \ldots \ldots$ & 5.61 & 6.22 & 6.98 & 7.72 & $1.6 \%$ \\
\hline Petroleum Products $\ldots \ldots \ldots \ldots \ldots \ldots \ldots$ & 5.54 & 5.25 & 6.09 & 6.71 & $1.0 \%$ \\
\hline Distillate Fuel $\ldots \ldots \ldots \ldots \ldots \ldots \ldots$ & 6.23 & 5.63 & 6.48 & 7.06 & $0.6 \%$ \\
\hline Residual Fuel . . . . . . . . . . . . . . & 3.98 & 3.59 & 4.23 & 4.73 & $0.9 \%$ \\
\hline Natural Gas $\ldots \ldots \ldots \ldots \ldots \ldots \ldots$ & 5.78 & 6.92 & 7.63 & 8.43 & $1.9 \%$ \\
\hline Electricity $\ldots \ldots \ldots \ldots \ldots \ldots \ldots \ldots$ & 27.62 & 26.91 & 27.79 & 28.23 & $0.1 \%$ \\
\hline 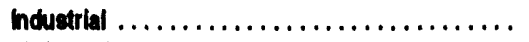 & 6.43 & 6.70 & 7.41 & 8.02 & $1.1 \%$ \\
\hline Primary Energy $\ldots \ldots \ldots \ldots \ldots \ldots \ldots \ldots$ & 4.08 & 4.22 & 4.88 & 5.44 & $1.5 \%$ \\
\hline Petroleum Products $\ldots \ldots \ldots \ldots \ldots \ldots \ldots$ & 5.32 & 4.72 & 5.60 & 6.25 & $0.8 \%$ \\
\hline Distillate Fuel $\ldots \ldots \ldots \ldots \ldots \ldots \ldots$ & 6.20 & 5.50 & 6.34 & 6.92 & $0.6 \%$ \\
\hline Liquefied Petroleum Gas . .............. & 10.93 & 12.21 & 13.45 & 14.42 & $1.4 \%$ \\
\hline Residual Fuel $\ldots \ldots \ldots \ldots \ldots \ldots \ldots$ & 3.81 & 3.50 & 4.15 & 4.64 & $1.0 \%$ \\
\hline Natural Gas $^{1} \ldots \ldots \ldots \ldots \ldots \ldots \ldots$ & 4.59 & 5.32 & 6.00 & 6.71 & $1.9 \%$ \\
\hline Metallurgical Coal $\ldots \ldots \ldots \ldots \ldots \ldots \ldots$ & 1.86 & 2.05 & 2.17 & 2.12 & $0.6 \%$ \\
\hline Steam Coal $\ldots \ldots \ldots \ldots \ldots \ldots \ldots$ & 1.65 & 1.61 & 1.64 & 1.67 & $0.1 \%$ \\
\hline Electricity $\ldots \ldots \ldots \ldots \ldots \ldots \ldots \ldots \ldots$ & 18.26 & 18.41 & 18.96 & 19.44 & $0.3 \%$ \\
\hline Transportation $\ldots \ldots \ldots \ldots \ldots \ldots \ldots \ldots \ldots$ & 9.00 & 9.60 & 10.42 & 11.04 & $1.0 \%$ \\
\hline Primary Energy . . . . . . . . . . . . . . . & 9.05 & 9.55 & 10.35 & 10.95 & $1.0 \%$ \\
\hline Petroleum Products . . . . . . . . . . . . . & 9.06 & 9.55 & 10.34 & 10.94 & $0.9 \%$ \\
\hline Distillate Fuel ${ }^{2} \ldots \ldots \ldots \ldots \ldots \ldots$ & 9.53 & 9.88 & 10.79 & 11.29 & $0.9 \%$ \\
\hline Jet Fuel $\ldots \ldots \ldots \ldots \ldots \ldots \ldots \ldots$ & 6.01 & 5.62 & 6.39 & 7.05 & $0.8 \%$ \\
\hline Motor Gasoline ${ }^{4} \ldots \ldots \ldots \ldots \ldots \ldots$ & 9.99 & 10.81 & 11.64 & 12.30 & $1.0 \%$ \\
\hline Residual Fuøl $\ldots \ldots \ldots \ldots \ldots \ldots \ldots$ & 3.14 & 2.79 & 3.50 & 4.11 & $1.4 \%$ \\
\hline Natural $\mathrm{Gas}^{8} \ldots \ldots \ldots \ldots \ldots \ldots \ldots$ & 4.97 & 10.09 & 10.91 & 11.58 & $4.3 \%$ \\
\hline Electricity $\ldots \ldots \ldots \ldots \ldots \ldots \ldots \ldots$ & 19.69 & 20.17 & 20.20 & 20.64 & $0.2 \%$ \\
\hline Total End-Use Energy $\ldots \ldots \ldots \ldots \ldots \ldots \ldots$ & 9.73 & 10.00 & 10.86 & 11.68 & $0.8 \%$ \\
\hline Primary Energy $\ldots \ldots \ldots \ldots \ldots \ldots \ldots \ldots$ & 9.59 & 9.97 & 10.72 & 11.42 & $0.9 \%$ \\
\hline Electricity $\ldots \ldots \ldots \ldots \ldots \ldots \ldots \ldots$ & 25.62 & 25.30 & 25.95 & 27.01 & $0.3 \%$ \\
\hline \multicolumn{6}{|l|}{ Electric Utillibes } \\
\hline Fossil Fuel Average $\ldots \ldots \ldots \ldots \ldots \ldots \ldots \ldots$ & 2.28 & 2.24 & 2.57 & 2.59 & $0.6 \%$ \\
\hline Petroleum Products $\ldots \ldots \ldots \ldots \ldots \ldots \ldots$ & 3.80 & 3.39 & 4.05 & 4.55 & $0.9 \%$ \\
\hline Distillate Fuel $\ldots \ldots \ldots \ldots \ldots \ldots \ldots$ & 5.92 & 5.09 & 5.93 & 6.51 & $0.5 \%$ \\
\hline Residual Fuel $\ldots \ldots \ldots \ldots \ldots \ldots \ldots$ & 3.80 & 3.38 & 4.05 & 4.54 & $0.9 \%$ \\
\hline Natural Gas $\ldots \ldots \ldots \ldots \ldots \ldots \ldots$ & 2.51 & 3.18 & 3.78 & 4.47 & $2.9 \%$ \\
\hline Steam Coal $\ldots \ldots \ldots \ldots \ldots \ldots \ldots$ & 1.69 & 1.72 & 1.81 & 1.77 & $0.2 \%$ \\
\hline
\end{tabular}


Table 12. Energy Prices by End-Use Sector and Source

Middle Atlantic Census Division (Continued)

(1992 Dollars per Million Btu)

\begin{tabular}{|c|c|c|c|c|c|}
\hline \multirow{2}{*}{ Sector and Sourco } & \multicolumn{4}{|c|}{ Relorenco Case } & \multirow{2}{*}{$\begin{array}{l}\text { Annual } \\
\text { Crowth } \\
1900-2010 \\
\text { (percent) }\end{array}$} \\
\hline & 1090 & 2000 & 2005 & 2010 & \\
\hline \multicolumn{6}{|l|}{ Average Prlos to All Ueers' } \\
\hline$\ldots \ldots \ldots \ldots \ldots \ldots$ & 8.29 & 8.16 & 9.09 & 9.71 & $0.8 \%$ \\
\hline Jet Fuel $\ldots \ldots \ldots \ldots \ldots \ldots \ldots \ldots \ldots$ & 6.01 & 5.62 & 6.39 & 7.05 & $0.8 \%$ \\
\hline Liquefied Petroleum Gas . . . . . . . . . . . . . . . & 12.39 & 13.03 & 14.44 & 15.57 & $1.2 \%$ \\
\hline Motor Gasoline ${ }^{4} \ldots \ldots$. . & 9.99 & 10.81 & 11.64 & 12.30 & $1.0 \%$ \\
\hline Residual Fuel $\ldots \ldots \ldots \ldots \ldots \ldots \ldots \ldots$ & 3.75 & 3.33 & 3.98 & 4.49 & $0.9 \%$ \\
\hline Nc:ural Gas ... & 5.61 & 6.58 & 7.16 & 8.00 & $1.8 \%$ \\
\hline
\end{tabular}

${ }^{1}$ Excludes uses for lease and plant fuel.

${ }^{2}$ Includes Federal and State taxes on diesel fuel and excludes county and local taxes.

'Kerosene-type jet fuel.

Average price for all grades. Includes Federal and State taxes and excludes county and local taxes.

'Compressed natural gas used as a vehicle fuel.

Weighted averages of end-use fuel prices are derived from the prices shown in each sector and the corresponding sectoral consumption.

For each sector, electricity and natural gas prices are derived by dividing total revenues by sales.

Btu = British thermal unit.

Sources: 1990 petroleum prices: Energy Information Administration (ElA), State Energy Price and Expenditure Report 1981, DOE/EIA0376(91) (Washington,D.C., September 1993). 1990 coal prices: ElA, Quarterly Coal Report, DOE/ElA-0121(90/4Q) (Washington, D.C., May 1991); ElA, Annual Energy Review 1992, DOE/ElA-0384(92) (Washington, D.C., June 1993), Table A6; and ElA, State Energy Price and Expenditures Report 1091, DOE/EIA-0376(91) (Washington, D.C., September 1993). 1990 industrial and transportation natural gas delivered prices: EIA, AEO National Energy Modeling System run AEO94B.D1221934. Other 1990 natural gas prices: ElA, Natural Gas Annual, DOEJEIA0131 (92)/1 (Washington, DC, November 1093). 1090 electricity prices: EIA, AEO 1994 National Energy Modeling System run AEO94B.D1221934. Projectlone: EIA, AEO 1994 National Energy Modeling System run AEO94B.D1221934. 
Table 13. Energy Prices by End-Use Sector and Source East North Central Census Division (1992 Dollars per Million Btu)

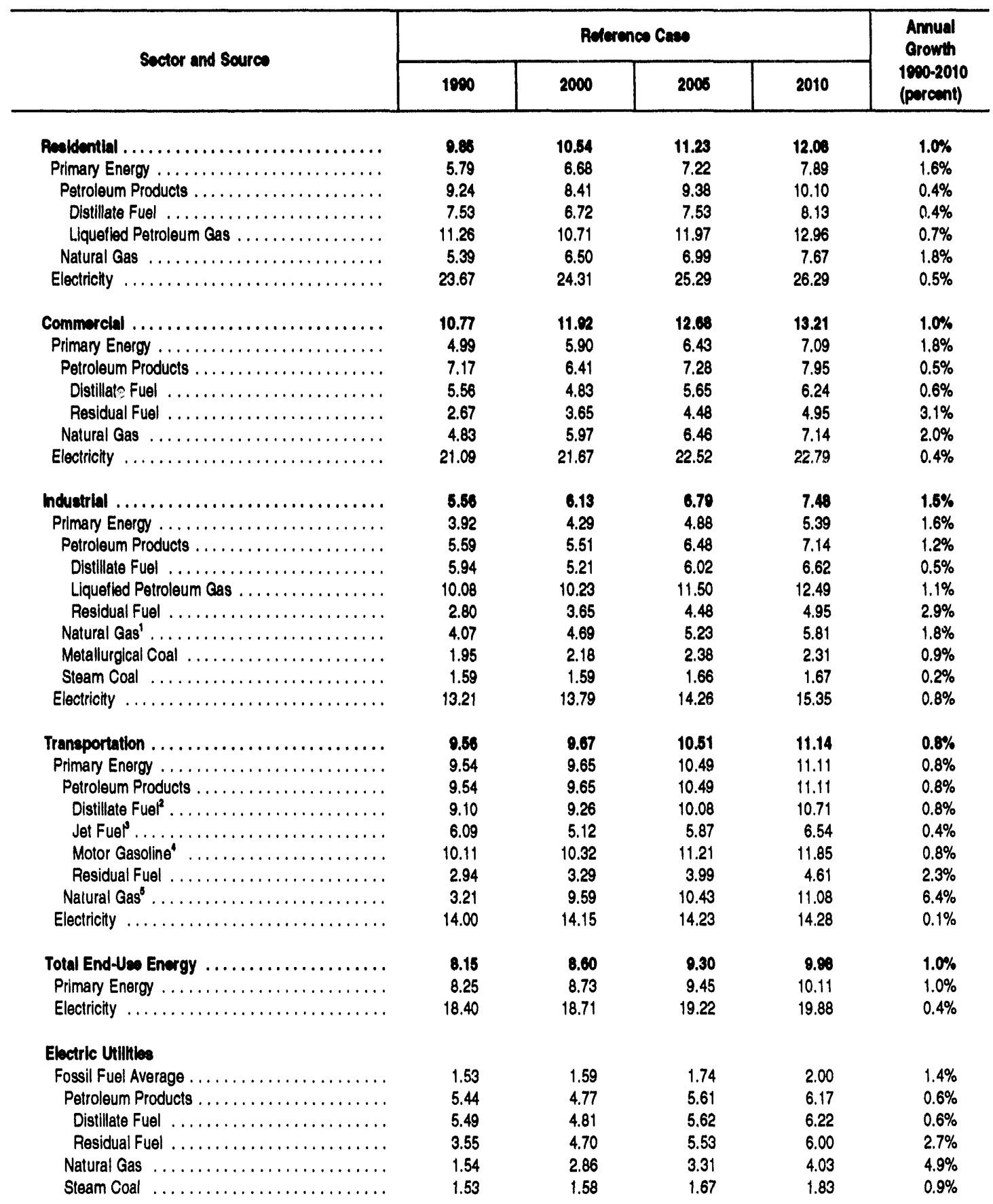


Table 13. Energy Prices by End-Use Sector and Source East North Central Census Division (Continued) (1992 Dollars per Million Btu)

\begin{tabular}{|c|c|c|c|c|c|}
\hline \multirow{2}{*}{ Sector and Source } & \multicolumn{4}{|c|}{ Ruterence Caso } & \multirow{2}{*}{$\begin{array}{l}\text { Annual } \\
\text { Crowth } \\
1900-2010 \\
\text { (perent) }\end{array}$} \\
\hline & 1900 & 2000 & 2005 & 2010 & \\
\hline \multicolumn{6}{|l|}{ Average Price to All Uears" } \\
\hline Jet Fuel $\ldots \ldots \ldots \ldots \ldots \ldots \ldots \ldots$ & 6.09 & 5.12 & 5.87 & 6.54 & $0.4 \%$ \\
\hline Liquetied Petroleum Gas . . . . . . . . . . . . & 10.53 & 10.46 & 11.77 & 12.81 & $1.0 \%$ \\
\hline Motor Gasoline ${ }^{4} \ldots \ldots \ldots$ & 10.11 & 10.32 & 11.21 & 11.85 & $0.8 \%$ \\
\hline Residual Fuel $\ldots \ldots \ldots \ldots \ldots \ldots \ldots \ldots$ & 2.80 & 3.65 & 4.45 & 4.93 & $2.9 \%$ \\
\hline Natural Gas $\ldots \ldots \ldots \ldots \ldots \ldots \ldots$ & 4.77 & 5.68 & 6.08 & 6.60 & $1.6 \%$ \\
\hline
\end{tabular}

'Excludes uses for lease and plant fuel.

${ }^{2}$ Includes Federal and State taxes on diesel fuel and excludes county and local taxes.

${ }^{3}$ Kerosene-type jet tuel.

Average price for all grades. Includes Federal and State taxes and excludes county and local taxes.

'Compressed natural gas used as a vehicle fuel.

Weighted averages of end-use fuel prices are derived from the prices shown in each sector and the corresponding sectoral consumption. For each sector, electricity and natural gas prices are derived by dividing total revenues by sales.

Btu $=$ British thermal unit.

Sources: 1990 petroleum prices: Energy Information Administration (ElA). State Energy Price and Expenditure Report 1991, DOE/EIA0376(81) (Washington,D.C., September 1993). 1990 coal prices: EIA, Quarterly Coal Report, DOEJEIA-0121(90/4Q) (Washington, D.C., May 1991); ElA, Annual Energy Review 1992, DOE/EIA-0384(92) (Washington, D.C., June 1993), Table A6; and ElA, State Energy Price and Expenditures Report 1991, DOE/ElA-0376(91) (Washington, D.C., September 1993). 1990 industrial and transportation natural gas delivered prices: EIA, AEO National Energy Modeling System run AEO94B.D1221934. Other 1990 natural gas prices: EIA, Natura/ Gas Annual, DOE/EIA0131 (82)/1 (Washington, DC, November 1993). 1990 electricity prices: ElA, AEO 1994 National Energy Modeling System run AEO94B.D1221934. Projectlone: EIA, AEO 1994 National Energy Modeling System run AEO94B.D1221934. 
Table 14. Energy Prices by End-Use Sector and Source West North Central Census Division

(1992 Dollars per Million Btu)

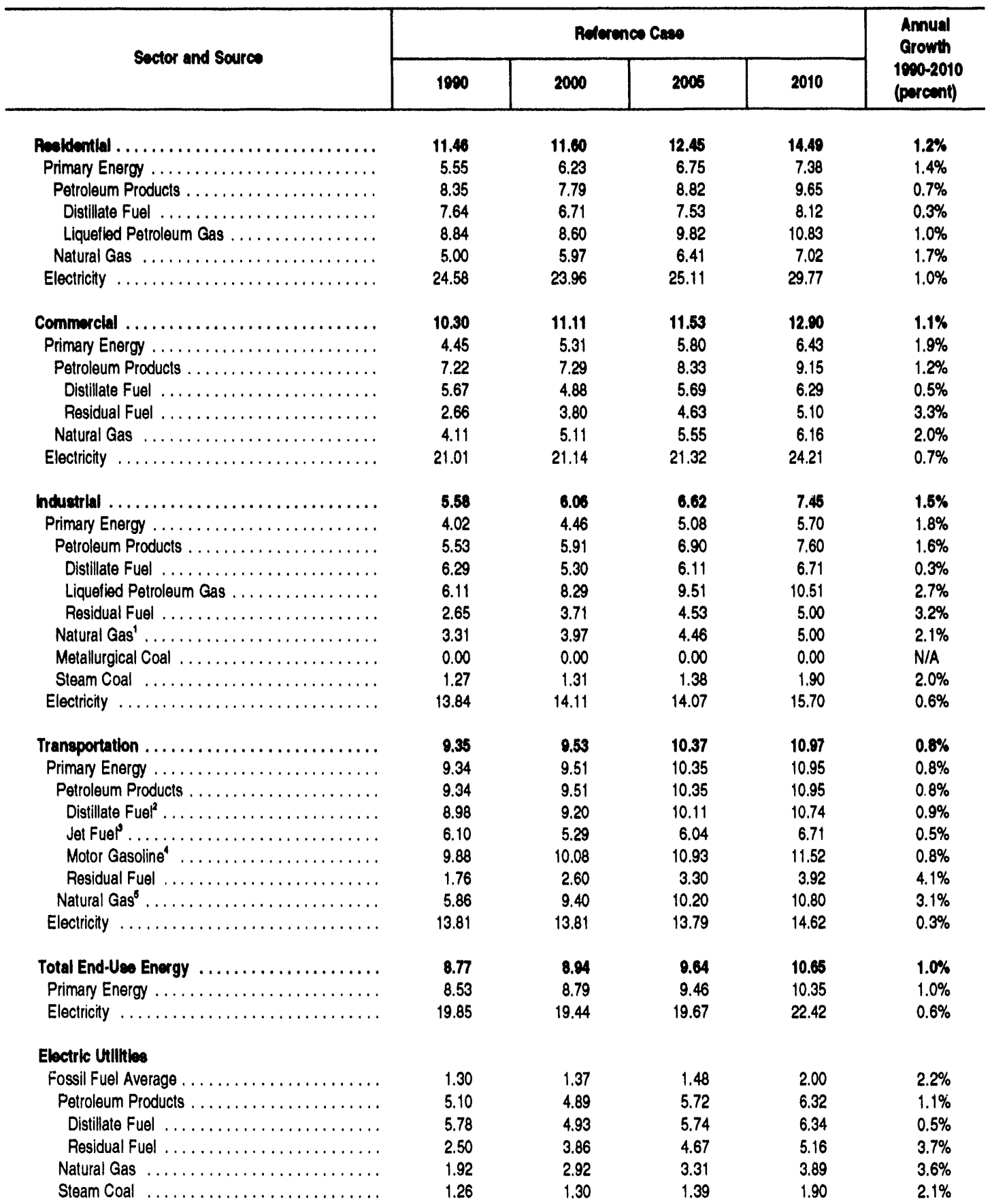


Table 14. Energy Prices by End-Use Sector and Source West North Central Census Division (Continued) (1992 Dollars per Million Btu)

\begin{tabular}{|c|c|c|c|c|c|}
\hline \multirow{2}{*}{ Sector and Source } & \multicolumn{4}{|c|}{ Relerencos Cases } & \multirow{2}{*}{$\begin{array}{l}\text { Amual } \\
\text { Crowth } \\
19 \text { co-2010 } \\
\text { (premt) }\end{array}$} \\
\hline & 1000 & 2000 & 2005 & 2010 & \\
\hline \multicolumn{6}{|l|}{ Average Price to All Users' } \\
\hline Petroleum Products & 8.33 & 8.51 & 9.39 & 10.02 & $0.9 \%$ \\
\hline Distillate Fuel $\ldots . . .$. & 8.08 & 7.92 & 8.84 & 9.50 & $0.8 \%$ \\
\hline Jet Fuel $\ldots \ldots \ldots \ldots \ldots \ldots \ldots \ldots$ & 6.10 & 5.29 & 6.04 & 6.71 & $0.5 \%$ \\
\hline Liquelied Petroleum Gas . . . . . . . . . . . . . & 7.15 & 8.49 & 9.74 & 10.77 & $2.1 \%$ \\
\hline Motor Gasoline $\quad \ldots \ldots \ldots$ & 9.89 & 10.09 & 10.93 & 11.53 & $0.8 \%$ \\
\hline Residual Fuel $\ldots \ldots \ldots \ldots \ldots \ldots \ldots \ldots$ & 2.63 & 3.71 & 4.53 & 5.00 & $3.3 \%$ \\
\hline Natural Gas $\ldots \ldots \ldots \ldots \ldots \ldots \ldots \ldots$ & 4.01 & 4.93 & 5.36 & 5.91 & $2.0 \%$ \\
\hline Coal $\ldots \ldots \ldots \ldots \ldots \ldots \ldots \ldots \ldots$ & 1.27 & 1.31 & 1.39 & 1.91 & $2.0 \%$ \\
\hline Electricity $\ldots \ldots \ldots \ldots \ldots \ldots \ldots \ldots$ & 19.85 & 19.44 & 19.67 & 22.42 & $0.6 \%$ \\
\hline
\end{tabular}

'Excludes uses for lease and plant fuel.

'Includes Federal and State taxes on diesel fuel and excludes county and local taxes.

'Kerosene-type jet fuel.

"Average price for all grades. Includes Federal and State taxes and excludes county and local taxes.

${ }^{3}$ Compressed natural gas used as a vehicle fuel.

Weighted averages of end-use fuel prices are derived from the prices shown in each sector and the corresponding sectoral consumption. For each sector, electricity and natural gas prices are derived by dividing total revenues by sales.

Btu $=$ British thermal unit.

N/A = Not applicable.

Sources: 1990 petroleum prices: Energy Information Administration (ElA), State Energy Price and Expenditure Report 1991, DOE/EIA0376(91) (Washington,D.C., September 1993). 1990 coal prices: ElA, Quarterly Coal Report, DOEJElA-0121(90/4Q) (Washingron, D.C., May 1991): ElA, Annual Energy Review 1992, DOEJElA-0384(92) (Washington, D.C., June 1993), Table A6; and ElA, State Energy Price and Expenditures Report 1991, DOE/ElA-0376(81) (Washington, D.C., September 1993). 1990 industrial and transportation natural gas delivered prices: EIA, AEO National Energy Modeling System run AEO94B.D1221934. Other 1990 natural gas prices: ElA, Natural Gas Annual, DOE/EIA0131 (92)/1 (Washington, DC, November 1993). 1990 electricity prices: ElA, AEO 1994 National Energy Modeling System run AEO94B.D1221934. Projectlons: EIA, AEO 1994 National Energy Modeling System run AEO94B.D1221934. 
Table 15. Energy Prices by End-Use Sector and Source South Atlantic Consus Division (1992 Dollars per Million Btu)

\begin{tabular}{|c|c|c|c|c|c|}
\hline \multirow{2}{*}{ Sector and Source } & \multicolumn{4}{|c|}{ Relerences Ceses } & \multirow{2}{*}{$\begin{array}{l}\text { Annual } \\
\text { Crowth } \\
1900-2010 \\
\text { (percent) }\end{array}$} \\
\hline & 1000 & 2000 & 2005 & 2010 & \\
\hline Resldentlal $\ldots \ldots \ldots \ldots \ldots \ldots \ldots \ldots \ldots$ & 17.57 & 17.58 & 18.62 & 19.92 & $0.6 \%$ \\
\hline Primary Energy $\ldots \ldots \ldots \ldots \ldots \ldots \ldots$ & 7.95 & 8.38 & 9.08 & 9.76 & $1.0 \%$ \\
\hline Distillate Fuel . . . . . . . . . . . . . . & 8.35 & 7.82 & 8.63 & 9.24 & $0.5 \%$ \\
\hline Liquefled Petroleum Gas .............. & 12.53 & 12.89 & 14.16 & 15.15 & $1.0 \%$ \\
\hline Natural Gas $\ldots \ldots \ldots \ldots \ldots \ldots \ldots \ldots$ & 6.95 & 7.96 & 8.61 & 9.34 & $1.5 \%$ \\
\hline Electricity $\ldots \ldots \ldots \ldots \ldots \ldots \ldots \ldots$ & 24.67 & 24.40 & 25.46 & 26.89 & $0.4 \%$ \\
\hline Commerclal $\ldots \ldots \ldots \ldots \ldots \ldots \ldots \ldots$ & 15.38 & 15.41 & 15.90 & 16.15 & $0.2 \%$ \\
\hline Residual Fuel . . . . . . . . . . . . . . & 3.37 & 3.81 & 4.64 & 5.11 & $2.1 \%$ \\
\hline Natural Gas $\ldots \ldots \ldots \ldots \ldots \ldots$ & 5.48 & 6.47 & 7.10 & 7.82 & $1.8 \%$ \\
\hline Electricity $\ldots \ldots \ldots \ldots \ldots \ldots \ldots \ldots$ & 22.00 & 21.26 & 21.46 & 21.39 & $.0 .1 \%$ \\
\hline mdustrial $\ldots \ldots \ldots \ldots \ldots \ldots \ldots \ldots \ldots$ & 6.52 & 6.72 & 7.29 & 7.76 & $0.9 \%$ \\
\hline Primary Energy $\ldots \ldots \ldots \ldots \ldots \ldots \ldots$ & 3.85 & 4.09 & 4.71 & 5.19 & $1.5 \%$ \\
\hline Petroleum Products $\ldots \ldots \ldots \ldots \ldots \ldots \ldots \ldots$ & 5.16 & 5.00 & 5.90 & 6.53 & $1.2 \%$ \\
\hline Distillate Fuel $\ldots \ldots \ldots \ldots \ldots \ldots \ldots$ & 6.01 & 5.56 & 6.37 & 6.98 & $0.8 \%$ \\
\hline Liquefled Petroleum Gas . . . . . . . . . . . . . . & 10.50 & 11.60 & 12.86 & 13.85 & $1.4 \%$ \\
\hline Residual Fuel . . . . . . . . . . . . . . & 3.35 & 3.84 & 4.66 & 5.13 & $2.2 \%$ \\
\hline Natural Gas' ${ }^{1} \ldots \ldots \ldots \ldots \ldots \ldots \ldots$ & 3.84 & 4.50 & 5.11 & 5.73 & $2.0 \%$ \\
\hline Distillate Fuel $\left.\right|^{2} \ldots \ldots \ldots \ldots \ldots \ldots \ldots$ & 8.87 & 8.98 & 9.90 & 10.53 & $0.9 \%$ \\
\hline Jet Fuel $\ldots \ldots \ldots \ldots$ & 5.96 & 5.20 & 6.03 & 6.71 & $0.6 \%$ \\
\hline Motor Gasoline' $\ldots \ldots \ldots \ldots \ldots \ldots \ldots$ & 9.85 & 10.14 & 11.00 & 11.63 & $0.8 \%$ \\
\hline Residuat Fuel $\ldots \ldots \ldots \ldots \ldots \ldots \ldots \ldots$ & 2.79 & 2.55 & 3.25 & 3.87 & $1.7 \%$ \\
\hline Natural $\mathrm{Gas}^{5} \ldots \ldots \ldots \ldots \ldots \ldots \ldots$ & 4.63 & 9.44 & 10.26 & 10.90 & $4.4 \%$ \\
\hline Electricity $\ldots \ldots \ldots \ldots \ldots \ldots \ldots \ldots$ & 13.72 & 13.63 & 13.47 & 13.54 & $-0.1 \%$ \\
\hline Total End-Use Energy .................. & 10.50 & 10.60 & 11.38 & 12.00 & $0.7 \%$ \\
\hline Primany Energy $\ldots \ldots \ldots \ldots \ldots \ldots \ldots \ldots$ & 9.30 & 9.42 & 10.13 & 10.71 & $0.7 \%$ \\
\hline Electricity $\ldots \ldots \ldots \ldots \ldots \ldots \ldots \ldots$ & 21.52 & 20.84 & 21.26 & 21.79 & $0.1 \%$ \\
\hline \multicolumn{6}{|l|}{ Electric Utilities } \\
\hline Fossil Fuel Average . ................. & 2.01 & 2.29 & 2.64 & 2.70 & $1.5 \%$ \\
\hline Petroleum Products . ................. & 3.15 & 3.69 & 4.72 & 5.22 & $2.5 \%$ \\
\hline Distillate Fuel $\ldots \ldots \ldots \ldots \ldots \ldots \ldots \ldots$ & 5.28 & 4.84 & 5.65 & 6.26 & $0.9 \%$ \\
\hline Residual Fuel $\ldots \ldots \ldots \ldots \ldots \ldots \ldots$ & 3.09 & 3.45 & 4.40 & 4.87 & $2.3 \%$ \\
\hline Natural Gas $\ldots \ldots \ldots \ldots \ldots \ldots \ldots \ldots$ & 2.64 & 3.24 & 3.89 & 4.47 & $2.7 \%$ \\
\hline$\ldots \ldots \ldots \ldots \ldots$ & 1.81 & 1.94 & 2.04 & 2.08 & $0.7 \%$ \\
\hline
\end{tabular}


Table 15. Energy Prices by End-Use Sector and Source South Atlantic Consus Division (Continued) (1992 Dollars per Million Btu)

\begin{tabular}{|c|c|c|c|c|c|}
\hline \multirow{2}{*}{ Sector and Source } & \multicolumn{4}{|c|}{ Relerences Cases } & \multirow{2}{*}{$\begin{array}{l}\text { Armual } \\
\text { Crowth } \\
1900-2010 \\
\text { (perent) }\end{array}$} \\
\hline & 1900 & 2000 & 2000 & 2010 & \\
\hline \multicolumn{6}{|l|}{ Average Price to All Users' } \\
\hline Petroleum Products ... & 7.93 & 8.04 & 8.87 & 8.54 & $0.9 \%$ \\
\hline 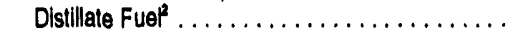 & 8.16 & 8.03 & 8.86 & 9.60 & $0.8 \%$ \\
\hline Jet Fuel $\ldots \ldots \ldots \ldots \ldots \ldots \ldots \ldots \ldots$ & 5.96 & 5.20 & 6.03 & 6.71 & $0.6 \%$ \\
\hline Liqueried Petroleum Gas . . . . . . . . . . . . . . & 11.55 & 12.39 & 13.72 & 14.78 & $1.2 \%$ \\
\hline Motor Gasoline ${ }^{4} \ldots \ldots \ldots \ldots \ldots \ldots \ldots$ & 9.85 & 10.14 & 11.00 & 11.63 & $0.8 \%$ \\
\hline Residual Fuel $\ldots \ldots \ldots \ldots \ldots \ldots \ldots \ldots$ & 3.09 & 3.31 & 4.15 & 4.61 & $2.0 \%$ \\
\hline Natural Gas ...... & 4.66 & 5.06 & 5.51 & 6.24 & $1.5 \%$ \\
\hline Coal $\ldots \ldots \ldots \ldots \ldots \ldots \ldots \ldots \ldots$ & 1.81 & 1.95 & 2.05 & 2.09 & $0.7 \%$ \\
\hline Electricity $\ldots \ldots \ldots \ldots \ldots \ldots \ldots \ldots$ & 21.52 & 20.84 & 21.26 & 21.79 & $0.1 \%$ \\
\hline
\end{tabular}

${ }^{1}$ Excludes uses for lease and plant fuel.

${ }^{2}$ Includes Federal and State taxes on diesel fuel and excludes county and local taxes.

"Kerosene-iype jet fuel.

"Average price tor all grades. Includes Federal and State taxes and excludes county and local taxes.

Compressed natural gas used as a vehicle fuel.

Weighted averages of end-use fuel prices are derived from the prices shown in each sector and the corresponding sectoral consumption. For each sector, electricity and natural gas prices are derived by dividing total revenues by sales.

Btu $=$ British thermal unit.

Sources: 1990 petroleum prices: Energy information Administration (EIA), State Energy Price and Expenditure Report 1981, DOE/EIA0376(81) (Washington,D.C., September 1993). $1990 \mathrm{coal}$ prices: EIA, Quarterly Coal Report, DOE/EIA-0121(90/4Q) (Washington, D.C., May 1991); ElA, Annual Energy Review 1092, DOEJEIA-0384(92) (Washington, D.C., June 1993), Table A6; and ElA, State Energy Price and Expenditures Report 1991, DOE/EIA-0376(91, (Washingiuil, D.C., September 1093). 1090 industrial and transportation natural gas delivered prices: EIA, AEO National Energy Modeling System run AEO94B.D1221934. Other 1990 natural gas prices: ElA, Natural Gas Annual, DOE/EIA0131 (92)/1 (Washington, DC, November 1993). 1090 electricity prices: ElA, AEO 1994 National Energy Modeling System run AEO94B.D1221934. Propetione: EIA AEO 11/94 National Energy Modeling System run AEO94B.D1221934. 
Table 16. Energy Prices by End-Use Sector and Source East South Contral Consus Division (1992 Dollars per Million Btu)

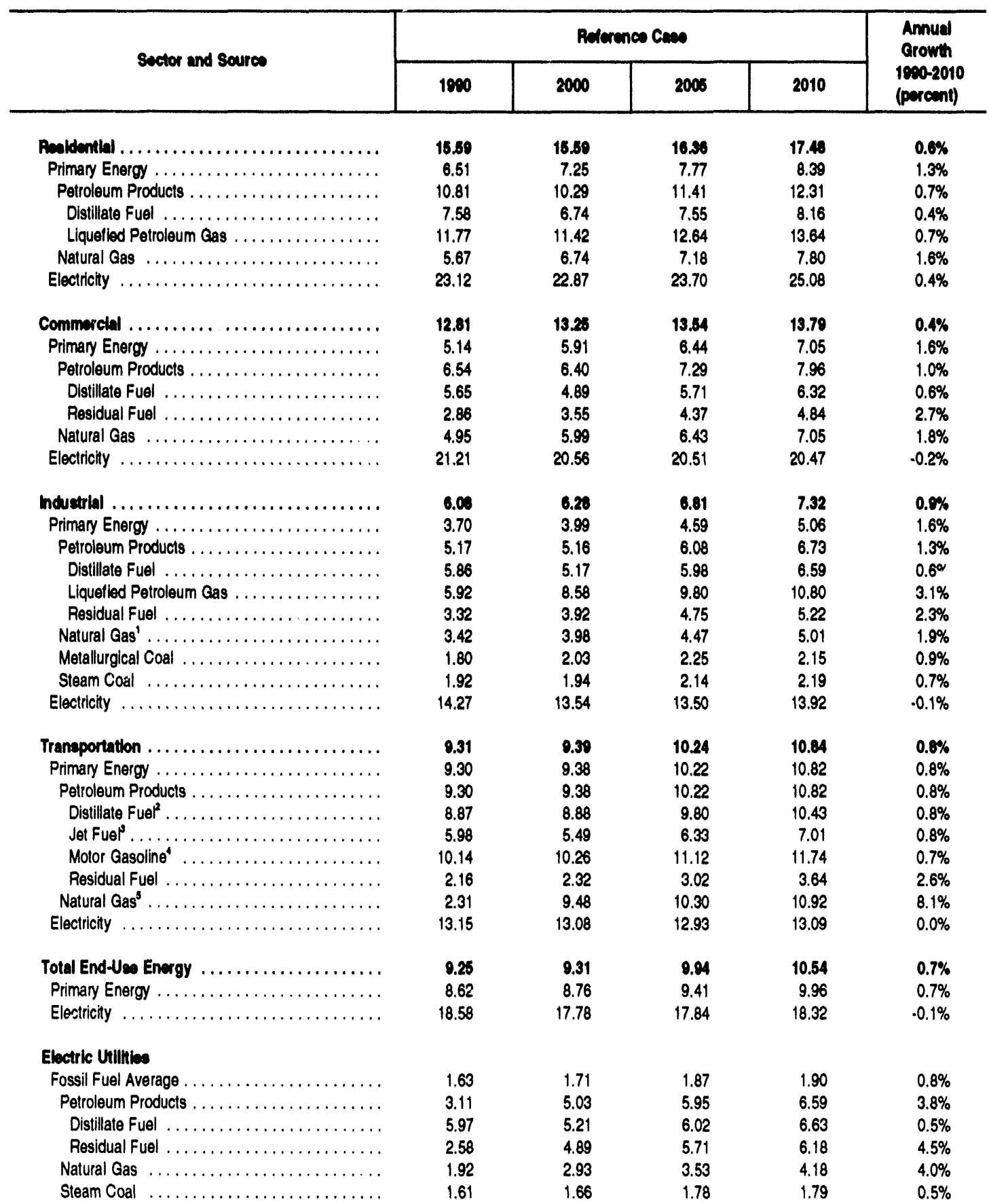


Table 16. Energy Prices by End-Use Sector and Source East South Central Census Division (Continued) (1992 Dollars per Million Btu)

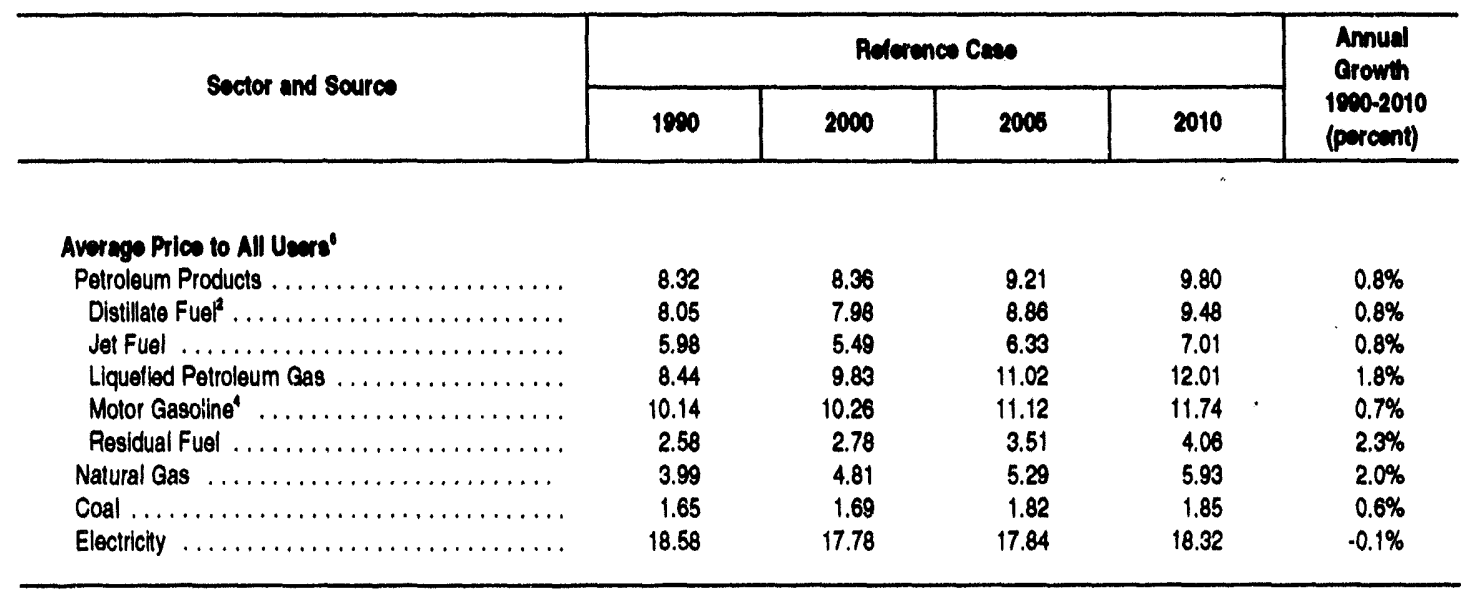

'Excludes uses for lease and plant fuel.

${ }^{2}$ Includes Federal and State taxes on diesel fuel and excludes county and local taxes.

'Kerosene-type jet fuel.

"Average price for all grades. Includes Federal and State taxes and excludes county and local taxes.

'Compressed natural gas used as a vehicle fuel.

Weighted averages of end-use fuel prices are derlved from the prices shown in each sector and the corresponding sectoral consumption. For each sector, electricity and natural gas prices are derived by dividing total revenues by sales.

Btu $=$ British thermal unit.

Sources: 1990 petroleum prices: Energy Information Administration (EIA), State Energy Price and Expendifure Report 1991, DOE/EIA0376(91) (Washington,D.C., September 1993). 1990 coal prices: ElA, Quarterly Coal Report, DOEJElA-0121 (90/4Q) (Washington, D.C., May 1991); ElA, Annual Energy Review 1992, DOE/ElA-0384(82) (Washington, D.C., June 1993), Table A6; and ElA, State Energy Price and Expenditures Report 1891, DOE/EIA-0376(91) (Washington, D.C., September 1993). 1990 industrial and transportation natural gas delivered prices: EIA, AEO National Energy Modeling System run AEO94B.D1221934. Other 1900 natural gas prices: EIA, Natura/ Gas Annual, DOE/EIA0131 (92)/1 (Washington, DC, November 1993). 1990 electricity prices: ElA, AEO 1994 National Energy Modeling System run AEO94B.D1221934. Propectlone: EIA, AEO 1994 National Energy Modeling System run AEO94B.D1221934. 
Table 17. Energy Prices by End-Use Sector and Source West South Central Census Division (1992 Dollars per Million Btu)

\begin{tabular}{|c|c|c|c|c|c|}
\hline \multirow{2}{*}{ Sector and Source } & \multicolumn{4}{|c|}{ Reterencos Cases } & \multirow{2}{*}{$\begin{array}{l}\text { Annual } \\
\text { Crowth } \\
1900-2010 \\
\text { (preent) }\end{array}$} \\
\hline & 1000 & 2000 & 2005 & 2010 & \\
\hline Resldential ....................... & 16.41 & 16.85 & 16.84 & 18.70 & $0.7 \%$ \\
\hline 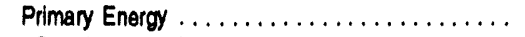 & 6.24 & 6.84 & 7.29 & 7.86 & $1.2 \%$ \\
\hline Petroleum Products $\ldots \ldots \ldots \ldots \ldots \ldots \ldots$ & 10.95 & 10.36 & 11.57 & 12.56 & $0.7 \%$ \\
\hline Distillate Fuel . . . ................. & 6.10 & 5.87 & 6.69 & 7.30 & $0.9 \%$ \\
\hline Liquefled Petroleum Gas . ............. & 11.00 & 10.42 & 11.64 & 12.64 & $0.7 \%$ \\
\hline Natural Gas $\ldots \ldots \ldots \ldots \ldots \ldots \ldots$ & 5.78 & 6.54 & 6.94 & 7.49 & $1.3 \%$ \\
\hline Electricity $\ldots \ldots \ldots \ldots \ldots \ldots \ldots \ldots$ & 25.90 & 24.69 & 25.91 & 28.41 & $0.5 \%$ \\
\hline Commorclal $\ldots \ldots \ldots \ldots \ldots \ldots \ldots \ldots$ & 14.06 & 14.63 & 15.31 & 16.56 & $0.0 \%$ \\
\hline Primary Energy $\ldots \ldots \ldots \ldots \ldots \ldots \ldots \ldots$ & 4.82 & 5.41 & 5.88 & 6.44 & $1.5 \%$ \\
\hline Petroleum Products $\ldots \ldots \ldots \ldots \ldots \ldots \ldots$ & 6.80 & 6.65 & 7.55 & 8.24 & $1.0 \%$ \\
\hline Distillate Fuel $\ldots \ldots \ldots \ldots \ldots \ldots \ldots$ & 5.58 & 4.86 & 5.67 & 6.28 & $0.6 \%$ \\
\hline Residual Fuel $\ldots \ldots \ldots \ldots \ldots \ldots \ldots$ & 2.69 & 3.40 & 4.22 & 4.69 & $2.8 \%$ \\
\hline Natural Gas $\ldots \ldots \ldots \ldots \ldots \ldots \ldots$ & 4.41 & 5.18 & 5.58 & 6.13 & $1.7 \%$ \\
\hline Eloctricity $\ldots \ldots \ldots \ldots \ldots \ldots \ldots \ldots$ & 22.21 & 22.60 & 23.53 & 25.69 & $0.7 \%$ \\
\hline Industrial $\ldots \ldots \ldots \ldots \ldots \ldots \ldots \ldots \ldots$ & 4.73 & 4.74 & 5.50 & 6.23 & $1.4 \%$ \\
\hline Primary Energy $\ldots \ldots \ldots \ldots \ldots \ldots \ldots \ldots$ & 4.02 & 4.03 & 4.79 & 5.48 & $1.6 \%$ \\
\hline Petroleum Products $\ldots \ldots \ldots \ldots \ldots \ldots \ldots$ & 5.27 & 4.88 & 5.91 & 6.77 & $1.3 \%$ \\
\hline Distillate Fuel $\ldots \ldots \ldots \ldots \ldots \ldots \ldots \ldots$ & 5.92 & 5.14 & 5.95 & 6.56 & $0.5 \%$ \\
\hline Liquefied Potroleum Gas . . . . . . . . . . . . . . & 4.87 & 5.37 & 6.59 & 7.59 & $2.2 \%$ \\
\hline Residual F:al $\ldots \ldots \ldots \ldots \ldots \ldots \ldots$ & 2.75 & 3.42 & 4.25 & 4.71 & $2.7 \%$ \\
\hline Natural Gas' $\ldots \ldots \ldots \ldots \ldots \ldots \ldots$ & 2.78 & 3.16 & 3.63 & 4.12 & $2.0 \%$ \\
\hline Metallurgical Coal $\ldots \ldots \ldots \ldots \ldots \ldots \ldots$ & 0.00 & 0.00 & 0.00 & 0.00 & N/A \\
\hline Sleam Coal $\ldots \ldots \ldots \ldots \ldots \ldots \ldots$ & 1.38 & 1.34 & 1.38 & 1.44 & $0.2 \%$ \\
\hline Electricity $\ldots \ldots \ldots \ldots \ldots \ldots \ldots \ldots$ & 14.71 & 14.64 & 15.16 & 16.36 & $0.5 \%$ \\
\hline 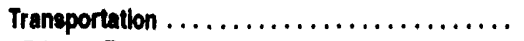 & 8.01 & 8.16 & 8.84 & 9.51 & $0.9 \%$ \\
\hline Primary Energy . . . . . . . . . . . . . . . & 8.00 & 8.15 & 8.92 & 9.50 & $0.9 \%$ \\
\hline Petroleum Products . ................. & 8.00 & 8.14 & 8.91 & 9.48 & $0.9 \%$ \\
\hline Distillate Fuet ${ }^{2} \ldots \ldots \ldots \ldots \ldots \ldots \ldots$ & 8.63 & 9.11 & 10.02 & 10.65 & $1.1 \%$ \\
\hline$\ldots \ldots \ldots \ldots \ldots \ldots \ldots$ & 5.91 & 5.39 & 6.22 & 6.90 & $0.8 \%$ \\
\hline Motor Gasoline ${ }^{4} \ldots \ldots \ldots \ldots \ldots \ldots$ & 9.80 & 10.31 & 11.17 & 11.79 & $0.9 \%$ \\
\hline Residual Fuel $\ldots \ldots \ldots \ldots \ldots \ldots \ldots$ & 2.72 & 3.26 & 3.96 & 4.58 & $2.6 \%$ \\
\hline Natural $\mathrm{Gas}^{\mathrm{s}} \ldots \ldots \ldots \ldots \ldots \ldots \ldots$ & 3.32 & 9.53 & 10.34 & 10.96 & $62 \%$ \\
\hline Electricity $\ldots \ldots \ldots \ldots \ldots \ldots \ldots \ldots$ & 13.18 & 12.78 & 12.97 & 13.19 & $0.0 \%$ \\
\hline Total End-Use Energy ................... & 7.21 & 7.12 & 7.87 & 6.64 & $0.9 \%$ \\
\hline Primary Energy $\ldots \ldots \ldots \ldots \ldots \ldots \ldots \ldots$ & 6.52 & 6.55 & 7.30 & 8.00 & $1.0 \%$ \\
\hline Electricity $\ldots \ldots \ldots \ldots \ldots \ldots \ldots \ldots \ldots$ & 20.81 & 20.23 & 20.95 & 22.69 & $0.4 \%$ \\
\hline \multicolumn{6}{|l|}{ Electric Villitiss } \\
\hline Fossill Fuel Average $\ldots \ldots \ldots \ldots \ldots \ldots \ldots \ldots$ & 1.88 & 2.11 & 2.31 & 2.87 & $2.1 \%$ \\
\hline Petroleum Products . ................. & 3.94 & 4.05 & 5.14 & 5.63 & $1.8 \%$ \\
\hline Distillate Fuel $\ldots \ldots \ldots \ldots \ldots \ldots \ldots$ & 5.73 & 5.02 & 5.83 & 6.44 & $0.6 \%$ \\
\hline Residual Fuel $\ldots \ldots \ldots \ldots \ldots \ldots \ldots$ & 3.93 & 3.98 & 5.05 & 5.52 & $1.7 \%$ \\
\hline Natural Gas $\ldots \ldots \ldots \ldots \ldots \ldots \ldots$ & 2.26 & 2.63 & 3.08 & 3.62 & $2.4 \%$ \\
\hline Steam Coal $\ldots \ldots \ldots \ldots \ldots \ldots \ldots$ & 1.60 & 1.68 & 1.67 & 2.26 & $1.7 \%$ \\
\hline
\end{tabular}


Table 17. Energy Prices by End-Use Sector and Source

West South Central Census Division (Continued)

(1992 Dollars per Million Btu)

\begin{tabular}{|c|c|c|c|c|c|}
\hline \multirow{2}{*}{ Sector and Sourco } & \multicolumn{4}{|c|}{ Reterences Cases } & \multirow{2}{*}{$\begin{array}{c}\text { Annual } \\
\text { Growth } \\
19 \text { co-2010 } \\
\text { (percent) }\end{array}$} \\
\hline & 1000 & 2000 & 2006 & 2010 & \\
\hline
\end{tabular}

\begin{tabular}{|c|c|c|c|c|c|}
\hline \multicolumn{6}{|l|}{ Averago Prlce to All Users' } \\
\hline Pelroleum Products & 6.82 & 6.70 & 7.59 & 8.29 & $1.0 \%$ \\
\hline$\ldots \ldots \ldots \ldots \ldots \ldots$ & 7.69 & 7.88 & 8.78 & 9.43 & $1.0 \%$ \\
\hline Jet Fuel $\ldots \ldots \ldots \ldots \ldots \ldots \ldots \ldots \ldots$ & 5.91 & 5.39 & 6.22 & 6.90 & $0.8 \%$ \\
\hline Liquefled Petroleum Gas ................ & 5.06 & 5.51 & 6.72 & 7.72 & $2.1 \%$ \\
\hline Motor Gasoline $\ldots \ldots \ldots \ldots \ldots \ldots \ldots$ & 9.80 & 10.31 & 11.17 & 11.79 & $0.9 \%$ \\
\hline Residual Fuel ... & 2.74 & 3.28 & 3.99 & 4.59 & $2.6 \%$ \\
\hline Natural Gas $\ldots \ldots \ldots \ldots \ldots \ldots \ldots$ & 2.96 & 3.37 & 3.82 & 4.35 & $1.9 \%$ \\
\hline$\ldots \ldots \ldots \ldots \ldots \ldots$ & 1.59 & 1.66 & 1.66 & 2.22 & $1.7 \%$ \\
\hline Electricity $\ldots \ldots \ldots \ldots \ldots \ldots \ldots \ldots$ & 20.81 & 20.23 & 20.95 & 22.69 & $0.4 \%$ \\
\hline
\end{tabular}

'Excludes uses for lease and plant fuel.

'Includes Federal and State taxes on diesel fuel and excludes county and local taxes.

'Kerosene-type jet fuel.

"Average price for all grades. Includes Federal and State taxes and excludes county and local taxes.

${ }^{5}$ Compressed natural gas used as a vehicle fuel.

Weighted averages of end-use fuel prices are derived from the prices shown in each sector and the corresponding sectoral consumption. For each sector, electricity and natural gas prices are derived by dividing total revenues by sales.

Btu $=$ British thermal unit.

N/A $=$ Not applicable.

Sources: 1990 pelroleum prices: Energy Intormation Administration (ElA), Stale Energy Price and Expenditure Report 1091, DOE/EIA0376(81) (Washington,D.C., September 1993). $1990 \mathrm{coal}$ prices: ElA, Quarterly Coal Report, DOE/EIA-0121(00/4Q) (Washington, D.C., May 1991); ElA, Annual Energy Review 1092, DOEJEIA-0384(92) (Washington, D.C., June 1993), Table A6; and ElA, State Energy Price and Expenditures Report 1091, DOE/EIA-0376(91) (Washington, D.C., September 1993). 1990 industrial and transportation natural gas delivered prices: EIA, AEO National Energy Modeling System run AEO94B.D1221934. Other 1090 natural gas prices: ElA, Natural Gas Annual, DOE/EIA0131 (92)/1 (Washington, DC, November 1893). 1090 electricity prices: ElA, AEO 1004 National Energy Modeling System run AEC,94B.D1221934. Propetione: EIA, AEO 1904 National Energy Modeling System run AEO94B.D1221934. 
Table 18. Energy Prices by End-Use Sector and Source Mountain Census Division (1992 Dollars per Million Btu)

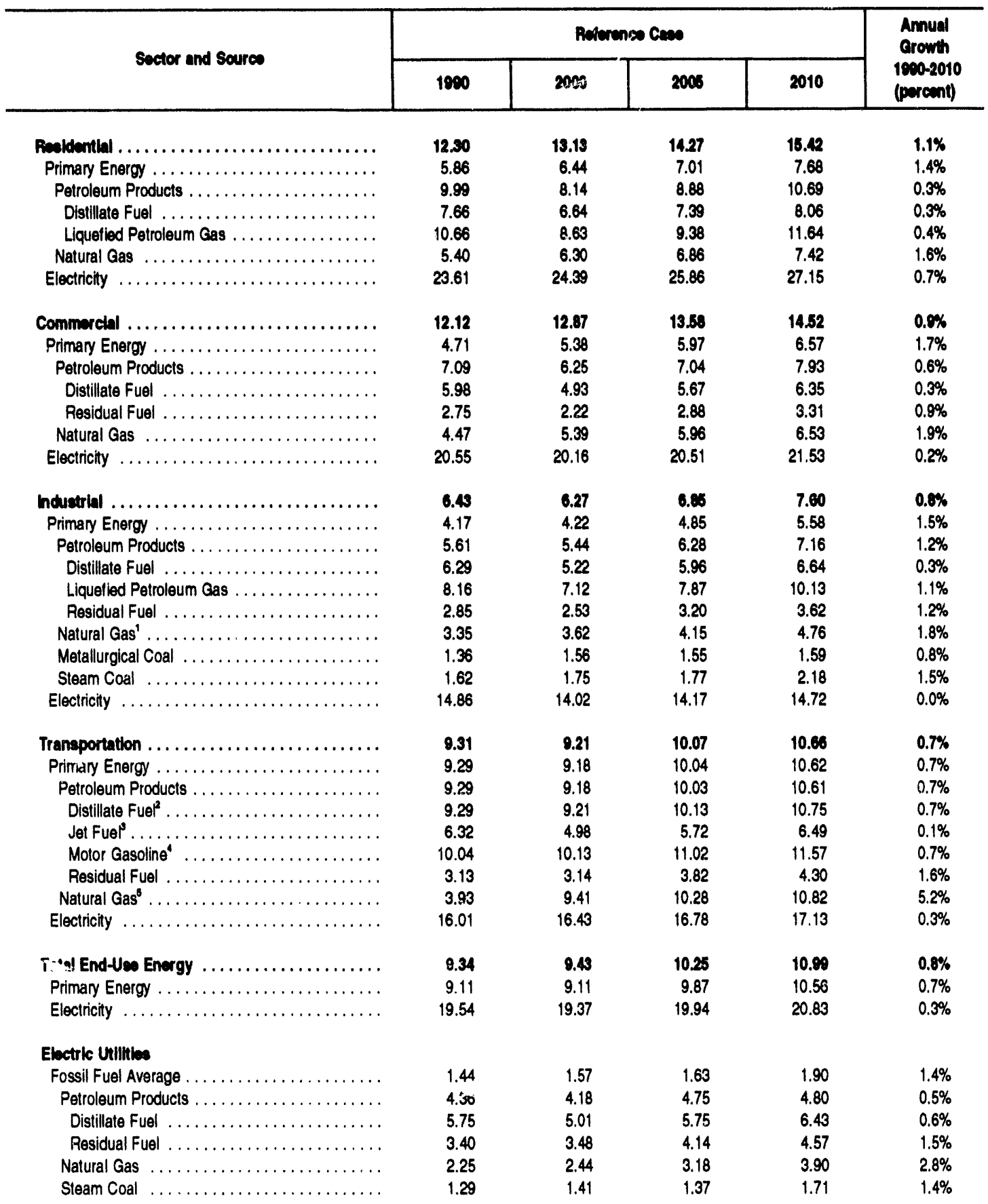


Table 18. Energy Prices by End-Use Sector and Source Mountain Census Division (Continued) (1992 Dollars per Million Btu)

\begin{tabular}{|c|c|c|c|c|c|}
\hline \multirow{2}{*}{ Sector and Source } & \multicolumn{4}{|c|}{ Reterencs Cases } & \multirow{2}{*}{$\begin{array}{l}\text { Annud } \\
\text { erowth } \\
\text { 1eco-2010 } \\
\text { (perent) }\end{array}$} \\
\hline & 1900 & 2000 & 2006 & 2010 & \\
\hline \multicolumn{6}{|l|}{ Averegs Price to All Ueere" } \\
\hline Dlstillate Fuel ${ }^{2} \ldots \ldots \ldots \ldots \ldots \ldots \ldots \ldots$ & 8.22 & 7.89 & 8.79 & 9.48 & $0.7 \%$ \\
\hline Jet Fuel $\ldots \ldots \ldots \ldots \ldots \ldots \ldots \ldots$ & 6.32 & 4.98 & 5.72 & 6.49 & $0.1 \%$ \\
\hline Liquefied Petroleum Gas . . . . . . . . . . . . . . . & 9.04 & 7.72 & 8.50 & 10.79 & $0.9 \%$ \\
\hline Motor Gasoline ${ }^{4} \ldots \ldots \ldots \ldots \ldots \ldots$ & 10.04 & 10.13 & 11.02 & 11.57 & $0.7 \%$ \\
\hline Residual Fuel $\ldots \ldots \ldots \ldots \ldots \ldots \ldots \ldots$ & 3.09 & 2.65 & 3.30 & 3.67 & $0.9 \%$ \\
\hline Natural Gas $\ldots \ldots \ldots \ldots \ldots \ldots \ldots \ldots$ & 3.72 & 4.24 & 4.90 & 5.73 & $2.2 \%$ \\
\hline Coal $\ldots \ldots \ldots \ldots \ldots \ldots \ldots \ldots \ldots$ & 1.31 & 1.43 & 1.39 & 1.73 & $1.4 \%$ \\
\hline Electricity $\ldots \ldots \ldots \ldots \ldots \ldots \ldots \ldots \ldots$ & 19.54 & 19.37 & 19.94 & 20.83 & $0.3 \%$ \\
\hline
\end{tabular}

'Excludes uses for lease and plant fuel.

${ }^{2}$ Includes Federal and State texes on diesel fuel and excludes county and local texes.

'Kerosene-type jet tuel.

'Average price for all grades. Includes Federal and State lexes and excludes county and local taxes.

'Compressed natural gas used as a vehicle fuel.

Weighted averages of end-use fuel prices are derived from the prices shown in each sector and the corresponding sectoral consumption. For each sector, electricity and natural gas prices are derived by dividing total revenues by sales.

Btu = British thermal unit.

Sources: 1990 petroleum prices: Energy Information Administration (ElA), State Energy Price and Expenditure Report 1091, DOE/EIA0376(91) (Washington,D.C., September 1993). 1990 coal prices: ElA, Quarterly Coal Report, DOE/ElA-0121(90/4Q) (Washington, D.C., May 1991); ElA, Annual Energy Review 1992, DOE/ElA-0384(82) (Washington, D.C., June 1993), Table A6; and ElA, State Energy Price and Expenditures Report 1091, DOE/ElA-0376(91) (Washington, D.C., September 1993). 1990 industrial and transportation natural gas delivered prices: EIA, AEO National Energy Modeling System run AEO94B.D1221934. Other 1800 natural gas prices: ElA, Natura/ Gas Annual, DOE/EIA0131 (92)/1 (Washington, DC, November 1993). 1990 electricity prices: ElA, AEO 1994 National Energy Modeling System run AEO94B.D1221934. Projectlons: EIA, AEO 1994 National Energy Modeling System run AEO94B.D1221934. 
Table 19. Energy Prices by End-Use Sector and Source

Pacific Census Division

(1992 Dollars per Million Btu)

\begin{tabular}{|c|c|c|c|c|c|}
\hline \multirow{2}{*}{ Sector and Source } & \multicolumn{4}{|c|}{ Ruterenco Caso } & \multirow{2}{*}{$\begin{array}{l}\text { Annual } \\
\text { Crowth } \\
1900-2010 \\
\text { (preent) }\end{array}$} \\
\hline & 1900 & 2000 & 2005 & 2010 & \\
\hline Residentlal $\ldots \ldots \ldots \ldots \ldots \ldots \ldots \ldots \ldots$ & 12.18 & 13.84 & 16.13 & 16.26 & $1.6 \%$ \\
\hline Primary Energy $\ldots \ldots \ldots \ldots \ldots \ldots \ldots \ldots$ & 6.32 & 7.05 & 7.73 & 8.44 & $1.5 \%$ \\
\hline Petroleum Products . . . . . . . . . . . . . . . . & 10.22 & 8.83 & 9.64 & 11.15 & $0.4 \%$ \\
\hline$\ldots \ldots \ldots \ldots \ldots \ldots \ldots$ & 7.90 & 6.74 & 7.50 & 8.35 & $0.3 \%$ \\
\hline Liquefied Petroleum Gas ................. & 13.68 & 11.93 & 12.68 & 14.94 & $0.4 \%$ \\
\hline Natural Gas $\ldots \ldots \ldots \ldots \ldots \ldots \ldots \ldots$ & 5.91 & 6.88 & 7.55 & 8.17 & $1.6 \%$ \\
\hline Electricity $\ldots \ldots \ldots \ldots \ldots \ldots \ldots \ldots \ldots$ & 22.36 & 25.78 & 27.85 & 29.46 & $1.4 \%$ \\
\hline Commercial $\ldots \ldots \ldots \ldots \ldots \ldots \ldots \ldots$ & 12.92 & 14.23 & 16.24 & 16.38 & $1.2 \%$ \\
\hline Primary Energy . . . . . . . . . . . . . . . . & 5.29 & 5.85 & 6.49 & 7.12 & $1.5 \%$ \\
\hline Petroleum Products $\ldots \ldots \ldots \ldots \ldots \ldots \ldots \ldots$ & 6.30 & 5.36 & 6.06 & 6.84 & $0.4 \%$ \\
\hline Distillate Fuel $\ldots \ldots \ldots \ldots \ldots \ldots \ldots$ & 5.69 & 4.50 & 5.25 & 6.10 & $0.3 \%$ \\
\hline Residual Fuel $\ldots \ldots \ldots \ldots \ldots \ldots \ldots$ & 3.81 & 3.57 & 4.22 & 4.84 & $1.2 \%$ \\
\hline Natural Gas $\ldots \ldots \ldots \ldots \ldots \ldots \ldots \ldots$ & 5.07 & 5.99 & 6.61 & 7.22 & $1.8 \%$ \\
\hline Electricity $\ldots \ldots \ldots \ldots \ldots \ldots \ldots \ldots$ & 21.27 & 22.50 & 23.54 & 25.03 & $0.8 \%$ \\
\hline mdustrial $\ldots \ldots \ldots \ldots \ldots \ldots \ldots \ldots \ldots \ldots$ & 6.62 & 6.26 & 6.92 & 7.71 & $0.8 \%$ \\
\hline Primary Energy $\ldots \ldots \ldots \ldots \ldots \ldots \ldots \ldots$ & 4.72 & 4.19 & 4.86 & 5.59 & $0.8 \%$ \\
\hline Petroleum Products $\ldots \ldots \ldots \ldots \ldots \ldots \ldots \ldots$ & 5.48 & 4.87 & 5.78 & 6.62 & $1.0 \%$ \\
\hline Distillate Fuel $\ldots \ldots \ldots \ldots \ldots \ldots \ldots$ & 5.73 & 4.73 & 5.48 & 6.33 & $0.5 \%$ \\
\hline Liquefied Petroleum Gas . . . . . . . . . . . . . . & 9.67 & 9.86 & 10.62 & 12.88 & $1.4 \%$ \\
\hline Residual Fuel $\ldots \ldots \ldots \ldots \ldots \ldots \ldots \ldots$ & 3.41 & 3.35 & 4.00 & 4.63 & $1.5 \%$ \\
\hline Natural Gas' $\ldots \ldots \ldots \ldots \ldots \ldots \ldots \ldots$ & 4.15 & 3.54 & 4.07 & 4.75 & $0.7 \%$ \\
\hline Metallurgical Coal $\ldots \ldots \ldots \ldots \ldots \ldots \ldots$ & 0.00 & 0.00 & 0.00 & 0.00 & N/A \\
\hline Steam Coal $\ldots \ldots \ldots \ldots \ldots \ldots \ldots \ldots$ & 1.26 & 1.49 & 1.47 & 1.51 & $0.9 \%$ \\
\hline Electricity $\ldots \ldots \ldots \ldots \ldots \ldots \ldots \ldots$ & 15.14 & 15.10 & 15.67 & 16.53 & $0.4 \%$ \\
\hline Transportation $\ldots \ldots \ldots \ldots \ldots \ldots \ldots \ldots \ldots$ & 8.34 & 8.04 & 8.89 & 9.57 & $0.7 \%$ \\
\hline Primary Energy $\ldots \ldots \ldots \ldots \ldots \ldots \ldots \ldots$ & 8.33 & 8.02 & 8.86 & 9.53 & $0.7 \%$ \\
\hline Petroleum Products $\ldots \ldots \ldots \ldots \ldots \ldots \ldots$ & 8.33 & 8.01 & 8.85 & 9.51 & $0.7 \%$ \\
\hline Distillate Fuel ${ }^{2} \ldots \ldots \ldots \ldots \ldots \ldots \ldots$ & 9.42 & 9.70 & 10.68 & 11.82 & $1.1 \%$ \\
\hline Jet Fuel $\ldots \ldots \ldots \ldots \ldots \ldots \ldots \ldots$ & 6.25 & 5.50 & 6.35 & 7.13 & $0.7 \%$ \\
\hline Motor Gasoline $\ldots \ldots \ldots \ldots \ldots \ldots \ldots$ & 10.04 & 9.97 & 10.95 & 11.53 & $0.7 \%$ \\
\hline Residual Fuel $\ldots \ldots \ldots \ldots \ldots \ldots \ldots \ldots$ & 3.66 & 3.51 & 4.16 & 4.78 & $1.3 \%$ \\
\hline Natural $\mathrm{Gas}^{\mathrm{s}} \ldots \ldots \ldots \ldots \ldots \ldots \ldots$ & 4.23 & 9.30 & 10.24 & 10.82 & $4.8 \%$ \\
\hline Electricity $\ldots \ldots \ldots \ldots \ldots \ldots \ldots \ldots$ & 13.50 & 14.84 & 15.63 & 16.12 & $0.9 \%$ \\
\hline Total End-Use Energy ................. & 8.81 & 8.97 & 9.83 & 10.63 & $0.9 \%$ \\
\hline Primary Energy $\ldots \ldots \ldots \ldots \ldots \ldots \ldots \ldots$ & 8.59 & 8.56 & 9.37 & 10.13 & $0.8 \%$ \\
\hline Electricity $\ldots \ldots \ldots \ldots \ldots \ldots \ldots \ldots$ & 19.58 & 21.03 & 22.13 & 23.35 & $0.9 \%$ \\
\hline \multicolumn{6}{|l|}{ Electric Utilities } \\
\hline Fossil Fuel Average $\ldots \ldots \ldots \ldots \ldots \ldots \ldots$ & 3.10 & 3.06 & 3.62 & 4.15 & $1.5 \%$ \\
\hline Petroleum Products $\ldots \ldots \ldots \ldots \ldots \ldots \ldots \ldots$ & 4.62 & 4.21 & 4.87 & 5.51 & $0.9 \%$ \\
\hline Distillate Fuel $\ldots \ldots \ldots \ldots \ldots \ldots \ldots$ & 4.92 & 4.70 & 5.46 & 6.31 & $1.3 \%$ \\
\hline Residual Fuel $\ldots \ldots \ldots \ldots \ldots \ldots \ldots \ldots$ & 4.61 & 4.19 & 4.84 & 5.47 & $0.9 \%$ \\
\hline Natural Gas $\ldots \ldots \ldots \ldots \ldots \ldots \ldots \ldots$ & 3.11 & 3.17 & 3.77 & 4.28 & $1.6 \%$ \\
\hline Steam Coal $\ldots \ldots \ldots \ldots \ldots \ldots \ldots \ldots$ & 1.63 & 1.34 & 1.28 & 2.06 & $1.2 \%$ \\
\hline
\end{tabular}


Table 18. Energy Prices by End-Use Sector and Source

Pacific Census Division (Continued)

(1992 Dollars per Million Btu)

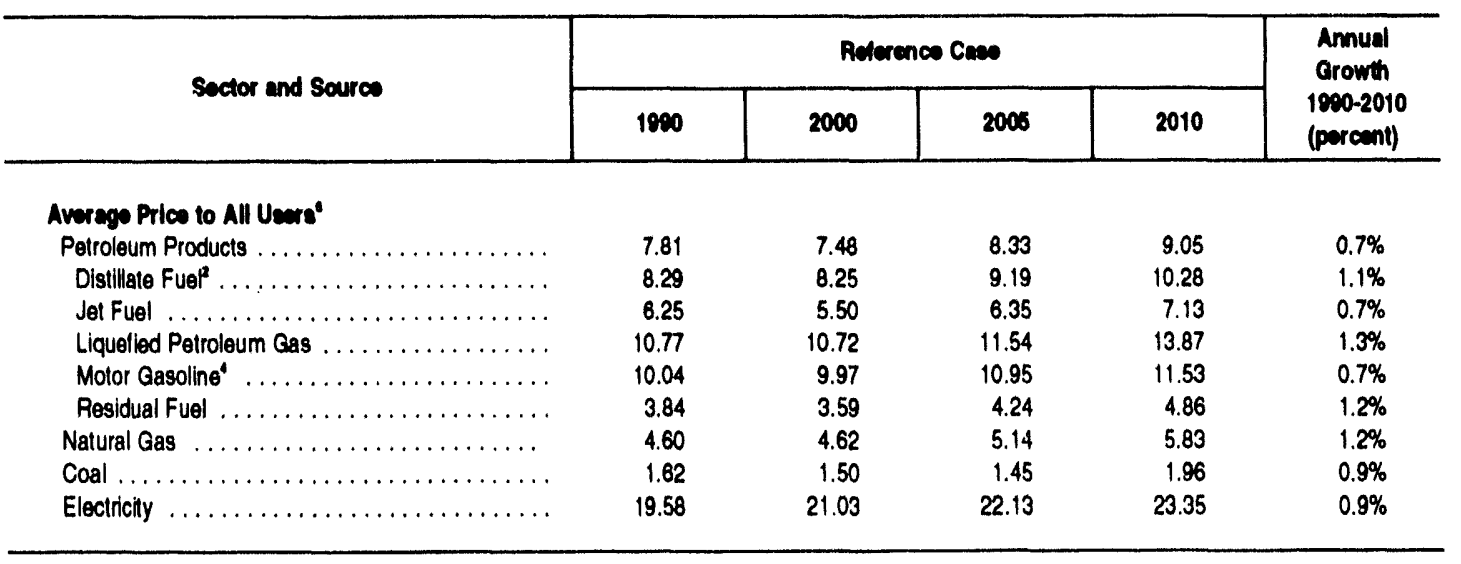

'Excludes uses for lease and plant fuel.

Includes Federal and State taxes on diesel fuel and excludes county and local taxes.

'Kerosene-lype jet fuel.

'Average price for all grades. Includes Federal and State taxes and excludes counly and local taxes.

"Compressed natural gas used as a vehicle fuel.

Weighted averages of end-use fuel prices are derived from the prices shown in each sector and the corresponding sectoral consumplion. For each sector, electricity and natural gas prices are derived by dividing total revenues by sales.

Btu $=$ British thermal unit.

N/A = Not applicable.

Sourcee: 1900 petroleum prices: Energy Information Administration (ElA), State Energy Price and Expenditure Report 1081, DOE/EIA0376(81) (Washington,D.C., September 1993). 1090 coal prices: ElA, Quarterly Coal Report, DOE/ElA-0121(90/4Q) (Washington, D.C., May 1991); ElA, Annual Energy Review 1092, DOEJElA-0384(82) (Washington, D.C., June 1993), Table A6; and ElA, Slate Energy Price and Expenditures Report 1091, DOEJEIA-0376(91) (Washington, D.C., September 1993). 1990 industrial and transportation natural gas delivered prices: EIA, AEO National Energy Modeling System run AEO94B.D1221934. Other 1090 natural gas prices: ElA, Natural Gas Annual, DOE/EIA0131 (82)/1 (Washington, DC, November 1993). 1990 electricity prices: EIA, AEO 1994 National Energy Modeling System run AEO94B.D1221934. Propetlone: EIA, AEO 1994 National Energy Modeling System run AEO94B.D1221934. 
Table 20. Energy Prices by End-Use Sector and Source

United States

(1992 Dollars per Million Btu)

\begin{tabular}{|c|c|c|c|c|c|}
\hline \multirow{2}{*}{ Sector and Source } & \multicolumn{4}{|c|}{ Relerencos Cass } & \multirow{2}{*}{$\begin{array}{l}\text { Arnual } \\
\text { Crowth } \\
1000-2010 \\
\text { (percent) }\end{array}$} \\
\hline & 1990 & 2000 & 2005 & 2010 & \\
\hline Renidemilal $\ldots \ldots \ldots \ldots \ldots \ldots \ldots \ldots \ldots$ & 13.12 & 13.60 & 14.61 & 16.02 & $1.0 \%$ \\
\hline Primary Energy $\ldots \ldots \ldots \ldots \ldots \ldots \ldots \ldots$ & 6.72 & 7.32 & 7.94 & 8.63 & $1.3 \%$ \\
\hline Petroleum Products $\ldots \ldots \ldots \ldots \ldots \ldots \ldots$ & 9.49 & 8.51 & 9.40 & 10.14 & $0.3 \%$ \\
\hline$\ldots \ldots \ldots \ldots \ldots \ldots \ldots \ldots$ & 8.55 & 7.51 & 8.34 & 8.94 & $0.2 \%$ \\
\hline Liquelled Petroleum Gas . . . . . . . . . . . . . & 11.67 & 11.13 & 12.30 & 13.49 & $0.7 \%$ \\
\hline Natural Gas $\ldots \ldots \ldots \ldots \ldots \ldots \ldots$ & 6.00 & 7.05 & 7.62 & 8.30 & $1.6 \%$ \\
\hline Electricity $\ldots \ldots \ldots \ldots \ldots \ldots \ldots \ldots$ & 24.98 & 25.39 & 26.66 & 28.58 & $0.7 \%$ \\
\hline Commerclal $\ldots \ldots \ldots \ldots \ldots \ldots \ldots \ldots \ldots$ & 12.76 & 13.45 & 14.15 & 14.00 & $0.8 \%$ \\
\hline Primany Energy $\ldots \ldots \ldots \ldots \ldots \ldots \ldots \ldots$ & 5.27 & 5.89 & 6.50 & 7.16 & $1.5 \%$ \\
\hline Petroleum Products $\ldots \ldots \ldots \ldots \ldots \ldots \ldots$ & 6.35 & 5.77 & 6.59 & 7.24 & $0.7 \%$ \\
\hline Distillate Fuel $\ldots \ldots \ldots \ldots \ldots \ldots \ldots$ & 6.51 & 5.22 & 6.02 & 6.63 & $0.1 \%$ \\
\hline Residual Fuel $\ldots \ldots \ldots \ldots \ldots \ldots \ldots \ldots$ & 3.66 & 3.56 & 4.23 & 4.72 & $1.3 \%$ \\
\hline Natural Gas $\ldots \ldots \ldots \ldots \ldots \ldots \ldots \ldots$ & 5.00 & 6.04 & 6.60 & 7.27 & $1.9 \%$ \\
\hline Electricity $\ldots \ldots \ldots \ldots \ldots \ldots \ldots \ldots$ & 22.49 & 22.38 & 22.90 & 23.72 & $0.3 \%$ \\
\hline Industrlal $\ldots \ldots \ldots \ldots \ldots \ldots \ldots \ldots \ldots$ & 5.75 & 5.80 & 6.83 & 7.20 & $1.1 \%$ \\
\hline Primary Energy $\ldots \ldots \ldots \ldots \ldots \ldots \ldots \ldots$ & 4.09 & 4.16 & 4.84 & 5.45 & $1.4 \%$ \\
\hline Petroleum Products $\ldots \ldots \ldots \ldots \ldots \ldots \ldots$ & 5.71 & 5.06 & 6.03 & 6.80 & $0.9 \%$ \\
\hline Distillate Fuel $\ldots \ldots \ldots \ldots \ldots \ldots \ldots$ & 6.06 & 5.20 & 6.00 & 6.65 & $0.5 \%$ \\
\hline Llquetied Petroleum Gas . . . . . . . . . . . . & 5.76 & 6.41 & 7.61 & 8.67 & $2.1 \%$ \\
\hline Residual Fuel $\ldots \ldots \ldots \ldots \ldots \ldots \ldots \ldots$ & 3.31 & 3.54 & 4.28 & 4.80 & $1.9 \%$ \\
\hline Natural Gas' $\ldots \ldots \ldots \ldots \ldots \ldots \ldots$ & 3.46 & 3.85 & 4.37 & 4.93 & $1.8 \%$ \\
\hline Metallurgical Coal $\ldots \ldots \ldots \ldots \ldots \ldots \ldots$ & 1.87 & 2.08 & 2.25 & 2.20 & $0.8 \%$ \\
\hline Steam Coal $\ldots \ldots \ldots \ldots \ldots \ldots \ldots$ & 1.64 & 1.70 & 1.80 & 1.91 & $0.8 \%$ \\
\hline Electricity $\ldots \ldots \ldots \ldots \ldots \ldots \ldots \ldots \ldots$ & 15.22 & 15.03 & 15.32 & 16.11 & $0.3 \%$ \\
\hline 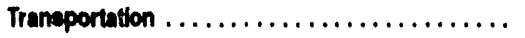 & 6.72 & 8.98 & 0.80 & 10.42 & $0.0 \%$ \\
\hline 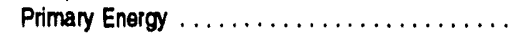 & 8.72 & 8.96 & 9.77 & 10.38 & $0.9 \%$ \\
\hline Petroleum Products $\ldots \ldots \ldots \ldots \ldots \ldots \ldots$ & 8.81 & 8.95 & 9.77 & 10.37 & $0.8 \%$ \\
\hline Distillate Fuel ${ }^{2} \ldots \ldots \ldots \ldots \ldots \ldots \ldots$ & 9.03 & 9.28 & 10.19 & 10.87 & $0.9 \%$ \\
\hline Jet Fuer $\ldots \ldots \ldots \ldots \ldots \ldots \ldots \ldots$ & 6.06 & 5.38 & 6.20 & 6.91 & $0.7 \%$ \\
\hline Motor Gasolinet $\ldots \ldots \ldots \ldots \ldots \ldots \ldots$ & 9.73 & 10.30 & 11.17 & 11.79 & $1.0 \%$ \\
\hline Residual Fuel $\ldots \ldots \ldots \ldots \ldots \ldots \ldots$ & 3.18 & 3.23 & 3.90 & 4.52 & $1.8 \%$ \\
\hline Natural $\mathrm{Gas}^{8} \ldots \ldots \ldots \ldots \ldots \ldots \ldots$ & 3.51 & 9.61 & 10.45 & 11.08 & $5.9 \%$ \\
\hline Electricity $\ldots \ldots \ldots \ldots \ldots \ldots \ldots \ldots$ & 18.15 & 15.33 & 15.49 & 15.78 & $.0 .7 \%$ \\
\hline Total End-Une Energy $\ldots \ldots \ldots \ldots \ldots \ldots$ & 8.80 & 9.01 & 9.77 & 10.52 & $0.9 \%$ \\
\hline Primary Energy $\ldots \ldots \ldots \ldots \ldots \ldots \ldots \ldots$ & 8.45 & 8.67 & 9.40 & 10.07 & $0.9 \%$ \\
\hline Electricity $\ldots \ldots \ldots \ldots \ldots \ldots \ldots \ldots$ & 20.79 & 20.63 & 21.16 & 22.19 & $0.3 \%$ \\
\hline \multicolumn{6}{|l|}{ Electric Uillition } \\
\hline Fossil Fuel Average . . . . . . . & 1.81 & 1.96 & 2.21 & 2.45 & $1.5 \%$ \\
\hline Petroleum Products $\ldots \ldots \ldots \ldots \ldots \ldots \ldots$ & 3.55 & 3.58 & 4.39 & 4.94 & $1.7 \%$ \\
\hline Distillate Fuel $\ldots \ldots \ldots \ldots \ldots \ldots \ldots$ & 6.00 & 4.84 & 5.67 & 6.31 & $0.3 \%$ \\
\hline Residual Fuel & 3.52 & 3.48 & 4.22 & 4.75 & $1.5 \%$ \\
\hline Natural Gas $\ldots \ldots \ldots \ldots \ldots \ldots \ldots \ldots$ & 2.46 & 2.92 & 3.51 & 4.08 & $2.6 \%$ \\
\hline Steam Coal $\ldots \ldots \ldots \ldots \ldots \ldots \ldots$ & 1.56 & 1.63 & 1.70 & 1.92 & $1.1 \%$ \\
\hline
\end{tabular}


Table 20. Energy Prices by End-Use Sector and Source United States (Continued)

(1992 Dollars per Million Btu)

\begin{tabular}{|c|c|c|c|c|c|}
\hline \multirow{2}{*}{ Sector and Source } & \multicolumn{4}{|c|}{ Roterences Coses } & \multirow{2}{*}{$\begin{array}{l}\text { Amual } \\
\text { Crowth } \\
1 \text { ceo-2010 } \\
\text { (percent) }\end{array}$} \\
\hline & 1000 & 2000 & 2005 & 2010 & \\
\hline \multicolumn{6}{|l|}{ Averago Price to All Uemrs' } \\
\hline Distillate Fuel ${ }^{2} \ldots$ & 8.18 & 8.04 & 8.93 & 9.64 & $0.8 \%$ \\
\hline Jet Fuel $\ldots \ldots \ldots \ldots \ldots \ldots \ldots \ldots \ldots$ & 6.06 & 5.38 & 6.20 & 6.91 & $0.7 \%$ \\
\hline Liquelied Petroleum Gas . . . . . . . . . . . . . & 6.45 & 7.37 & 8.56 & 9.69 & $2.1 \%$ \\
\hline Motor Gasoline' $\ldots .$. & 9.73 & 10.30 & 11.17 & 11.79 & $1.0 \%$ \\
\hline Residual Fuel ........ & 3.38 & 3.38 & 4.08 & 4.64 & $1.6 \%$ \\
\hline Natural Gas $\ldots \ldots \ldots \ldots \ldots \ldots \ldots \ldots$ & 4.20 & 4.77 & 5.26 & 5.89 & $1.7 \%$ \\
\hline
\end{tabular}

'Excludes uses for lease and plant fuel.

'Includes Federal and State taxes on diesel fuel and excludes county and local taxes.

"Kerosene-type jet fuel.

"Average price for all grades. Includes Federal and State taxes and excludes county and local taxes.

"Compressed natural gas used as a vehicle fuel.

Weighted averages of end-use fuel prices are derived from the prices shown in each sector and the corresponding sectoral consumption. For each sector, electricity and natural gas prices are derived by dividing total revenues by sales.

Btu = British thermal unit.

Sources: 1990 petroleum prices: Energy Information Administration (EIA), State Energy Price and Expenditure Report 1891, DOE/EIA0376(91) (Washington,D.C., September 1993). 1900 coal prices: ElA, Quarterly Coal Report, DOE/ElA-0121(90/4Q) (Washington, D.C., May 1991); ElA, Annual Energy Review 1092, DOE/ElA-0384(92) (Washington, D.C., June 1993), Table A6; and ElA, State Energy Price and Expenditures Report 1991, DOEJElA-0376(91) (Washington, D.C., September 1993). 1900 industrial and transportation natural gas delivered prices: EIA, AEO National Energy Modeling System run AEO94B.D1221934. Other 1990 natural gas prices: ElA, Natural Gas Annual, DOE/EIA0131 (92)/1 (Washington, DC, November 1993). 1990 electricity prices: EIA, AEO 1994 National Energy Modeling System run AEO94B.D1221934. Projectlons: EIA, AEO 1994 National Energy Modeling Systern run AEO94B.01221934. 
Table 21. Residentlal Sector Supplement Table

\begin{tabular}{|c|c|c|c|c|c|}
\hline \multirow{2}{*}{ Equipment Stock Data } & \multicolumn{4}{|c|}{ Relerence Case } & \multirow{2}{*}{$\begin{array}{c}\text { Annual } \\
\text { Crowth } \\
1900-2010 \\
\text { (percent) }\end{array}$} \\
\hline & 1000 & 2000 & 2005 & 2010 & \\
\hline \multicolumn{6}{|l|}{ Equipment Stock (million unlts) } \\
\hline \multicolumn{6}{|l|}{ Main Space Heaters } \\
\hline Electric Heat Pumps ... & 6.44 & 8.67 & 9.84 & 11.12 & $2.8 \%$ \\
\hline Electric Other $\ldots \ldots \ldots \ldots \ldots \ldots \ldots \ldots$ & 15.09 & 15.83 & 16.31 & 16.82 & $0.5 \%$ \\
\hline Natural Gas Heat Pumps $\ldots \ldots \ldots \ldots \ldots \ldots$ & 0.00 & 0.11 & 0.18 & 0.25 & N/A \\
\hline Natural Gas Other $\ldots \ldots \ldots \ldots \ldots \ldots \ldots$ & 51.73 & 57.32 & 59.99 & 62.80 & $1.0 \%$ \\
\hline 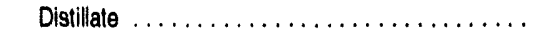 & 10.41 & 10.05 & 10.10 & 10.14 & $-0.1 \%$ \\
\hline Liquid Petroleum Gas . . . . . . . . . . . . . . & 4.39 & 3.91 & 3.75 & 3.61 & $-1.0 \%$ \\
\hline Kerosene $\ldots \ldots \ldots \ldots \ldots \ldots \ldots \ldots$ & 1.09 & 0.91 & 0.84 & 0.78 & $-1.6 \%$ \\
\hline Wood Stoves $\ldots \ldots \ldots \ldots \ldots \ldots \ldots \ldots$ & 3.89 & 3.79 & 3.75 & 3.71 & $.0 .2 \%$ \\
\hline Geothermal Heat Pumps . .............. & 0.15 & 0.36 & 0.48 & 0.61 & $7.3 \%$ \\
\hline Total $\ldots \ldots \ldots \ldots \ldots \ldots \ldots \ldots \ldots$ & 83.18 & 100.86 & 105.23 & 109.84 & $0.6 \%$ \\
\hline \multicolumn{6}{|l|}{ Space Cooling (million unlts) } \\
\hline Electric Heat Pumps $\ldots \ldots \ldots \ldots \ldots \ldots$ & 6.44 & 8.67 & 9.84 & 11.12 & $2.8 \%$ \\
\hline Natural Gas Heat Pumps . . . . . . . . . . . . . & 0.00 & 0.11 & 0.18 & 0.25 & N/A \\
\hline Geothermal Heat Pumps $\ldots \ldots \ldots \ldots \ldots \ldots$ & 0.15 & 0.36 & 0.48 & 0.61 & $7.3 \%$ \\
\hline Central Air Conditioners . . . . . . . . . . . . & 30.68 & 37.47 & 40.93 & 44.49 & $1.9 \%$ \\
\hline Room Air Conditioners $\ldots \ldots \ldots \ldots \ldots \ldots \ldots$ & 40.20 & 40.23 & 40.33 & 40.49 & $0.0 \%$ \\
\hline Total $\ldots \ldots \ldots \ldots \ldots \ldots \ldots \ldots \ldots$ & 77.47 & 88.84 & 91.76 & 89.85 & $1.1 \%$ \\
\hline \multicolumn{6}{|l|}{ Water Heaters (million unlts) } \\
\hline Electric $\ldots \ldots \ldots \ldots \ldots \ldots \ldots \ldots$ & 35.28 & 37.71 & 39.15 & 40.77 & $0.7 \%$ \\
\hline Natural Gas $\ldots \ldots \ldots \ldots \ldots \ldots \ldots \ldots$ & 50.37 & 55.81 & 58.61 & 61.55 & $1.0 \%$ \\
\hline Distillate $\ldots \ldots \ldots \ldots \ldots \ldots \ldots \ldots \ldots$ & 5.14 & 5.15 & 5.20 & 5.26 & $0.1 \%$ \\
\hline Liquid Petroleum Gas . . . . . . . . . . . . . . & 3.20 & 3.00 & 2.93 & 2.88 & $.0 .5 \%$ \\
\hline Solar Thermal . . . . . . . . . . . . . . & 0.55 & 0.62 & 0.66 & 0.69 & $1.1 \%$ \\
\hline Total $\ldots \ldots \ldots \ldots \ldots \ldots \ldots \ldots \ldots$ & 94.55 & 102.29 & 106.55 & 111.16 & $0.6 \%$ \\
\hline \multicolumn{6}{|l|}{ Cooking Equipment (million unito) } \\
\hline Electric $\ldots \ldots \ldots \ldots \ldots \ldots \ldots \ldots$ & 54.85 & 60.11 & 62.96 & 66.00 & $0.9 \%$ \\
\hline Natural Gas $\ldots \ldots \ldots \ldots \ldots \ldots \ldots$ & 33.78 & 36.76 & 38.35 & 40.05 & $0.9 \%$ \\
\hline Liquid Petroleum Gas $\ldots \ldots \ldots \ldots \ldots \ldots$ & 5.36 & 4.80 & 4.59 & 4.42 & $.1 .0 \%$ \\
\hline Total $\ldots \ldots \ldots \ldots \ldots \ldots \ldots \ldots$ & 93.90 & 101.66 & 105.89 & 110.46 & $0.8 \%$ \\
\hline \multicolumn{6}{|l|}{ Clothes Dryers (million units) } \\
\hline Electric $\ldots \ldots \ldots \ldots \ldots \ldots \ldots \ldots$ & 49.46 & 54.55 & 57.02 & 59.56 & $0.9 \%$ \\
\hline Natural Gas $\ldots \ldots \ldots \ldots \ldots \ldots \ldots$ & 15.22 & 14.38 & 13.95 & 13.54 & $.0 .6 \%$ \\
\hline Total $\ldots \ldots \ldots \ldots \ldots \ldots \ldots \ldots \ldots$ & 64.68 & 68.93 & 70.97 & 73.10 & $0.6 \%$ \\
\hline \multicolumn{6}{|l|}{ Other Appliances (million units) } \\
\hline Refrigerators. $\ldots \ldots \ldots \ldots \ldots \ldots \ldots \ldots$ & 101.83 & 110.14 & 114.67 & 119.55 & $0.8 \%$ \\
\hline Freezers. $\ldots \ldots \ldots \ldots \ldots \ldots \ldots \ldots \ldots$ & 32.41 & 31.40 & 31.05 & 30.89 & $-0.2 \%$ \\
\hline \multicolumn{6}{|l|}{$\begin{array}{l}\text { Stock Average Equlpment Efficiency } \\
\text { Main Space Heaters }\end{array}$} \\
\hline Electric Heat Pumps (HSPF) . . . . . . . . . . . & 6.76 & 7.32 & 7.49 & 7.60 & $0.6 \%$ \\
\hline Natural Gas Heat Pumps (COP) . . . . . . . . . . . & 1.04 & 1.25 & 1.25 & 1.25 & $0.9 \%$ \\
\hline Geothermal Heat Pumps (HSPF) . . . . . . . . . & 9.35 & 11.60 & 11.96 & 12.17 & $1.3 \%$ \\
\hline Natural Gas Furnace (AFUE) $\ldots \ldots \ldots \ldots \ldots$ & 0.67 & 0.73 & 0.76 & 0.78 & $0.7 \%$ \\
\hline Distillate Furnace (AFUE) $\ldots \ldots \ldots \ldots \ldots$ & 0.76 & 0.79 & 0.80 & 0.81 & $0.3 \%$ \\
\hline \multicolumn{6}{|l|}{ Space Cooling Systems } \\
\hline Electric Heat Pumps (SEER) & 8.56 & 9.76 & 10.12 & 10.35 & $0.9 \%$ \\
\hline Natural Gas Heat Pumps (COP) . . . . . . . . . . . & 0.93 & 1.07 & 1.07 & 1.07 & $0.7 \%$ \\
\hline Geothermal Heat Pumps (SEER) . . . . . . . . . & 9.62 & 11.96 & 12.34 & 12.56 & $1.3 \%$ \\
\hline Central Air Conditioners (SEER) . . . . . . . . . . . & 8.60 & 9.52 & 9.87 & 10.11 & $0.8 \%$ \\
\hline Room Air Conditioners (EER) . . . . . . . . . . & 7.47 & 8.80 & 10.03 & 10.26 & $1.6 \%$ \\
\hline \multicolumn{6}{|l|}{ Water Heaters } \\
\hline Electric (EF). . & 0.83 & 0.87 & 0.89 & 0.91 & $0.4 \%$ \\
\hline Natural Gas (EF) $\ldots \ldots \ldots \ldots \ldots \ldots \ldots$ & 0.51 & 0.54 & 0.56 & 0.56 & $0.5 \%$ \\
\hline Distillate (EF) $\ldots \ldots \ldots \ldots \ldots \ldots \ldots$ & 0.48 & 0.54 & 0.57 & 0.57 & $0.8 \%$ \\
\hline Liquid Petroleum Gas (EF) . . . . . . . . . . . & 0.51 & 0.54 & 0.56 & 0.56 & $0.5 \%$ \\
\hline
\end{tabular}


Table 21. Residential Sector Supplement Table (Continued)

\begin{tabular}{|c|c|c|c|c|c|}
\hline \multirow{2}{*}{ Equipment Stock Deta } & \multicolumn{4}{|c|}{ Reterence Cases } & \multirow{2}{*}{$\begin{array}{l}\text { Annual } \\
\text { Growth } \\
\text { 19e0-2010 } \\
\text { (percent) }\end{array}$} \\
\hline & 1990 & 2000 & 2006 & 2010 & \\
\hline Froezers. . & 984.00 & 737.50 & 614.87 & 496.04 & $.3 .4 \%$ \\
\hline
\end{tabular}

'Does not include microwave ovens or outdoor grills.

HSPF = Heating Seasonal Perlormance Factor: The total heating output of a heat pump during its normal annual usage period for heating divided by total electric input in watt-hours during the same perlod.

$\mathrm{COP}=$ Coefficient of Performance: Energy elliciency rating measure determined, unde: specitic lesting conditions, by dividing the energy output by the energy input.

AFUE = Annuai Fuel Utilization Elficiency: Efticiency rating based on average usage, including on and off cycling, as set out in the standardized Department of Energy lest procedures.

SEER = Seasonal Energy Efficiency Ratio: The total cooling of a central unitary air conditioner or a unitary heat pump in Btu during its normal annual usage period lor cooling divided by the total electric energy input in wall-hours during the same period.

EER = Energy Etticiency Ration: A ratio calculated by dividing the cooling capacity in Blu per hour by the power input in watts at any given sel of rating conditions, expressed in Blu per hour per watt.

$E F=$ Elficiency Factor: Elficiency (measured in Btu out / Btu in) ol water heaters under certain lest conditions specified by the Department of Energy.

Btu = British thermal unit

N/. Not applicable.

Note: Tolals may not equal sum of components due to independent rounding

Sources: 1990: Energy Information Administration (ElA). Household Energy Consumption and Expenditures 1990, DOE/EIA-0321(90) (Washington, D.C., February 1093) and ElA, State Energy Data Report, DOE/EIA.0214(91) (Washington, D.C., May 1993). Projectlone: EIA, AEO 1994 National Energy Modeling System run AEO94B,D1221934. 
Table 22. Commerclal Sector Supplement Table

\begin{tabular}{|c|c|c|c|c|c|}
\hline \multirow{2}{*}{ Indlcators } & \multicolumn{4}{|c|}{ Reterencos Caes } & \multirow{2}{*}{$\begin{array}{l}\text { Amual } \\
\text { Growth } \\
\text { 19e0-2010 } \\
\text { (percent) }\end{array}$} \\
\hline & 1000 & 2000 & 2006 & 2010 & \\
\hline \multicolumn{6}{|l|}{$\begin{array}{l}\text { Bullding Energy Consumption' } \\
\text { (quedrillion Btu) }\end{array}$} \\
\hline Assembly & 0.45 & 0.42 & 0.39 & 0.37 & $.0 .9 \%$ \\
\hline Education $\ldots \ldots \ldots \ldots \ldots \ldots \ldots \ldots \ldots$ & 0.68 & 0.62 & 0.58 & 0.53 & $-1.2 \%$ \\
\hline Food Sales $\ldots \ldots \ldots \ldots \ldots \ldots \ldots \ldots \ldots$ & 0.19 & 0.20 & 0.20 & 0.21 & $0.6 \%$ \\
\hline Food Sorvice ......................... & 0.31 & 0.31 & 0.32 & 0.32 & $0.3 \%$ \\
\hline Heath Care $\ldots \ldots \ldots \ldots \ldots \ldots \ldots \ldots$ & 0.43 & 0.49 & 0.49 & 0.50 & $0.7 \%$ \\
\hline Lodging $\ldots \ldots \ldots \ldots \ldots \ldots \ldots \ldots \ldots \ldots \ldots$ & 0.42 & 0.42 & 0.41 & 0.40 & $.0 .2 \%$ \\
\hline Oftlico $\cdot$ Largo $\ldots \ldots \ldots \ldots \ldots \ldots \ldots \ldots$ & 0.71 & 0.84 & 0.88 & 0.90 & $1.2 \%$ \\
\hline Ottico - Small $\ldots \ldots \ldots \ldots \ldots \ldots \ldots \ldots \ldots$ & 0.56 & 0.65 & 0.69 & 0.70 & $1.1 \%$ \\
\hline Mercantile/Service ..................... & 1.09 & 1.29 & 1.39 & 1.48 & $1.5 \%$ \\
\hline Warehouse $\ldots \ldots \ldots \ldots \ldots \ldots \ldots \ldots$ & 0.56 & 0.63 & 0.65 & 0.65 & $0.8 \%$ \\
\hline Other $\ldots \ldots \ldots \ldots$ & 0.49 & 0.44 & 0.41 & 0.38 & $.1 .3 \%$ \\
\hline Total $\ldots \ldots \ldots \ldots \ldots \ldots \ldots \ldots \ldots \ldots \ldots \ldots$ & 6.80 & 6.39 & 6.42 & 6.46 & $0.5 \%$ \\
\hline \multicolumn{6}{|l|}{ Enticiency indicators } \\
\hline \multicolumn{6}{|l|}{$\begin{array}{l}\text { Space Heathy } \\
\text { (cooflicient of performances) }\end{array}$} \\
\hline$\ldots \ldots \ldots$ & 1.19 & 1.33 & 1.38 & 1.42 & $0.9 \%$ \\
\hline Natural Gas $\ldots \ldots \ldots \ldots \ldots \ldots \ldots \ldots$ & 0.71 & 0.76 & 0.78 & 0.80 & $0.6 \%$ \\
\hline Distillate $\ldots \ldots \ldots \ldots \ldots \ldots \ldots \ldots \ldots \ldots$ & 0.72 & 0.78 & 0.80 & 0.81 & $0.6 \%$ \\
\hline \multicolumn{6}{|l|}{$\begin{array}{l}\text { Space Cooling } \\
\text { (coofficlent of pertormanco) })^{2}\end{array}$} \\
\hline Electricity & 2.83 & 3.32 & 3.54 & 3.75 & $1.4 \%$ \\
\hline$\ldots \ldots \ldots \ldots \ldots$ & 1.04 & 1.20 & 1.23 & 1.26 & $1.0 \%$ \\
\hline \multicolumn{6}{|l|}{$\begin{array}{l}\text { Water Heating } \\
\text { (coefficient of performance) })^{2}\end{array}$} \\
\hline Electricity & 0.76 & 0.83 & 0.84 & 0.85 & $0.5 \%$ \\
\hline Natural Gas & 0.67 & 0.71 & 0.73 & 0.74 & $0.5 \%$ \\
\hline Distillate $\ldots \ldots \ldots \ldots \ldots \ldots \ldots \ldots \ldots \ldots \ldots$ & 0.67 & 0.71 & 0.73 & 0.74 & $0.5 \%$ \\
\hline \multicolumn{6}{|l|}{$\begin{array}{l}\text { Lighting Effleacy" } \\
\text { (lumens per watt) }\end{array}$} \\
\hline Electricity & 41.55 & 47.04 & 49.60 & 51.93 & $1.1 \%$ \\
\hline
\end{tabular}

'Excludes commercial sector energy consumption (from uses such as street lights) that is not attributable to buildings.

${ }^{2} E$ nergy efficiency raling measure determined, under specific testing conditions, by dividing the energy output by the energy input.

${ }^{3} \mathrm{~A}$ measurement of the ratio of light produced by a light source to the electrical power used to produce that quality of light, expressed in lumens per watt.

Btu $=$ British thermal unit

Note: Totals may not equal sum of components due to independent rounding.

Source 1000 and Projectlone: Energy Information Administration, AEO 1994 National Energy Modeling System run AEO948.D1221934. 
Table 23. Industrial Sector Macroeconomic Indlcators

\begin{tabular}{|c|c|c|c|c|c|}
\hline \multirow{2}{*}{ Indicators } & \multicolumn{4}{|c|}{ Peterencos Cases } & \multirow{2}{*}{$\begin{array}{l}\text { Amual } \\
\text { Growth } \\
1000-2010 \\
\text { (porcant) }\end{array}$} \\
\hline & 1000 & 2000 & 2000 & 2010 & \\
\hline GDP (ollition 19e7 dollars) ................. & $4,077.4$ & $0,040.7$ & $6,730.3$ & $7,396.7$ & $2.1 \%$ \\
\hline Non-Agricultural Employment (millions) ........ & 109.8 & 124.6 & 132.8 & 139.6 & $1.2 \%$ \\
\hline \multicolumn{6}{|l|}{$\begin{array}{l}\text { Value of Croses Output } \\
\text { (billion } 1987 \text { dollare) }\end{array}$} \\
\hline \multicolumn{6}{|l|}{ Nonmanufacturing Sector } \\
\hline Agricultural .... & 178.8 & 211.8 & 224.5 & 238.3 & $1.4 \%$ \\
\hline Mining $\ldots \ldots \ldots \ldots \ldots$ & 130.8 & 131.8 & 136.2 & 141.3 & $0.4 \%$ \\
\hline Construction $\ldots \ldots \ldots \ldots$ & 573.6 & 717.2 & 797.5 & 868.0 & $2.1 \%$ \\
\hline \multicolumn{6}{|l|}{ Menufacturing Sactor } \\
\hline Food and Kindred Products & 348.1 & 412.6 & 439.2 & 473.8 & $1.6 \%$ \\
\hline Tobacco Products ....... & 30.1 & 26.5 & 25.5 & 25.7 & $.0 .8 \%$ \\
\hline Textile Mill Products & 54.2 & 64.8 & 70.6 & 77.7 & $1.8 \%$ \\
\hline \multicolumn{6}{|l|}{ Apparel and Other Textlle } \\
\hline Products ............ & 78.6 & 85.4 & 89.1 & 95.5 & $1.0 \%$ \\
\hline Lumber and Wood Products . & 66.4 & 78.3 & 86.1 & 92.4 & $1.7 \%$ \\
\hline Furniture and Fbxdures ....... & 39.1 & 44.4 & 49.9 & 53.9 & $1.6 \%$ \\
\hline Paper and Allied Products $\ldots \ldots \ldots \ldots \ldots \ldots$ & 110.6 & 138.1 & 151.3 & 165.6 & $2.0 \%$ \\
\hline Printing and Publishing $\ldots \ldots \ldots$ & 88.4 & 104.2 & 113.2 & 123.8 & $1.7 \%$ \\
\hline Chemical and Allied Products. . & 251.2 & 312.6 & 348.6 & 386.7 & $2.2 \%$ \\
\hline Bulk Chemicals ....................... & 146.5 & 182.2 & 207.3 & 231.8 & $2.3 \%$ \\
\hline \multicolumn{6}{|l|}{ Other Chemicals and } \\
\hline Allied Products .......... & 104.6 & 130.4 & 141.3 & 154.9 & $2.0 \%$ \\
\hline Pelroleum and Coal Products. . & 132.1 & 138.2 & 142.0 & 145.9 & $0.5 \%$ \\
\hline \multicolumn{5}{|l|}{ Other Petroloum and } & $0.3 \%$ \\
\hline 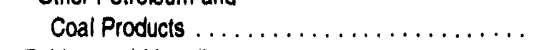 & 15.8 & 18.5 & 20.4 & 22.2 & $1.7 \%$ \\
\hline \multicolumn{6}{|l|}{ Rubber and Miscellaneous } \\
\hline Plastic Products ....... & 90.1 & 123.1 & 142.9 & 164.5 & $3.1 \%$ \\
\hline Leather and Leather Products & 10.3 & 10.7 & 11.1 & 12.5 & $1.0 \%$ \\
\hline Stone, Clay, and Glass Products & 61.7 & 75.6 & 83.7 & 90.8 & $2.0 \%$ \\
\hline Glass and Glass Products .... & 16.7 & 21.1 & 23.9 & 26.8 & $2.4 \%$ \\
\hline Cement, Hydraulic . .................. & 4.0 & 5.1 & 5.6 & 5.7 & $1.8 \%$ \\
\hline \multicolumn{6}{|l|}{ Other Stone, Clay, and } \\
\hline Glass Products ..... & 41.0 & 49.4 & 54.3 & 58.3 & $1.8 \%$ \\
\hline \multicolumn{5}{|l|}{ Blast Furnace and Basic } & $1.4 \%$ \\
\hline Stoel Products ...... & 51.5 & 55.9 & 58.0 & 57.6 & $0.6 \%$ \\
\hline Aluminum $\ldots \ldots \ldots \ldots \ldots \ldots \ldots \ldots$ & 9.1 & 11.1 & 11.7 & 12.1 & $1.4 \%$ \\
\hline Other Primary Metal Products & 57.4 & 69.9 & 78.6 & 87.0 & $2.1 \%$ \\
\hline Fabricated Metal Products .... & 142.7 & 177.8 & 200.8 & 222.8 & $2.3 \%$ \\
\hline \multicolumn{6}{|l|}{ Industrial Machinery and } \\
\hline Equipment ......... & 221.7 & 316.7 & 390.0 & 470.8 & $3.8 \%$ \\
\hline \multicolumn{6}{|l|}{ Electronic and Other Electric } \\
\hline Equipment & 248.0 & 385.7 & 471.0 & 567.1 & $4.2 \%$ \\
\hline Transportation Equipment $\ldots \ldots \ldots \ldots \ldots \ldots$ & 349.8 & 431.0 & 511.4 & 587.9 & $2.6 \%$ \\
\hline Instruments and Related Products & 62.8 & 83.8 & 97.5 & 112.9 & $3.0 \%$ \\
\hline \multicolumn{6}{|l|}{ Miscellaneous Manufacturing } \\
\hline Industries ............. & 32.2 & 39.5 & 43.3 & 49.4 & $2.2 \%$ \\
\hline Total Industrial Gross Output $\ldots \ldots \ldots \ldots \ldots$. & $3,410.1$ & $4,246.7$ & $4,774.0$ & $5,322.3$ & $2.4 \%$ \\
\hline
\end{tabular}

GDP $=$ Gross domestic pisduct.

Note: Totals may not equal sum of components due to independent rounding.

Sources: 1990: Data Resources Incorporated (DRI), DRI - IUOS/0293/ SERIES, DRI TREND0283. Projectlone: Energy Information Administration, AEO 1994 National Energy Modeling System run AEOQ4B.D1221034. 
Table 24. Transportation Sector Energy Use by Mode and Type (Trillion Btu per Year)

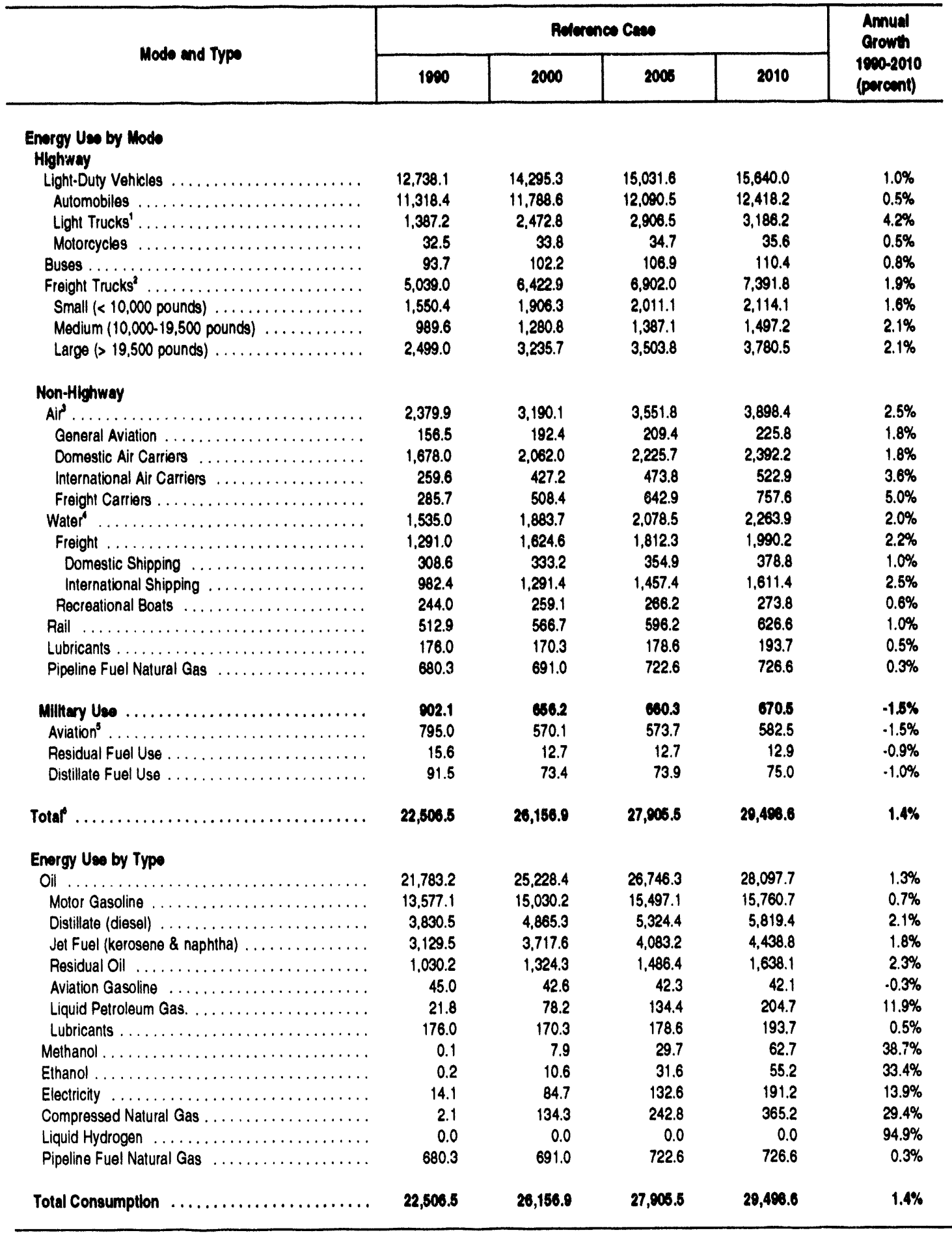

'Includes personal vehicles, fleet vehicles, and freight light trucks

${ }^{2}$ Does not include commercial bus and military use.

${ }^{3}$ Does not include military jet fuel use.

'Does not include military residual oil.

sincludes jet fuel and naphtha use.

- Total not sum of components due to double counting of freight light truck consumption.

Biu = British thermal unit.

Note: Tolals may not equal sum of components due to independent rounding.

Sources: 1990: Energy Information Administration (EIA), State Energy Data Report 1991, DOE-EIA-0214(91) (Washington,D.C.، May 1893): EIA, Fuel Oil and Kerosene Sales 1991, DOE/EIA-0536(91) (Washington, D.C., November 1992); Oak Ridge National Laboratory, Transportation Energy Book: 12 and 13, (March 1993); and Department of Defense, Delense Fuel Supply Center. Projectlone: ElA, AEO 1094 National Energy Modeling System run AEO94B.D1221934. 
Table 25. Transportation Sector Energy Use by Fuel Type Within a Mode (Trillion Btu per Year)

\begin{tabular}{|c|c|c|c|c|c|}
\hline \multirow{2}{*}{ Mode and Type } & \multicolumn{4}{|c|}{ Relerencos Cases } & \multirow{2}{*}{$\begin{array}{l}\text { Amual } \\
\text { Crowth } \\
1000-2010 \\
\text { (percanl) }\end{array}$} \\
\hline & 1000 & 2000 & 2000 & 2010 & \\
\hline \multicolumn{6}{|l|}{ Lloght-Duty Vehleles' } \\
\hline Motor Gasoline $\ldots \ldots \ldots \ldots \ldots \ldots \ldots \ldots$ & $12,516.62$ & $13,912.13$ & $14,388.58$ & $14,666.35$ & $0.8 \%$ \\
\hline Methanol .......................... & 0.09 & 7.87 & 29.67 & 62.72 & $38.7 \%$ \\
\hline$\ldots \ldots \ldots \ldots \ldots \ldots \ldots \ldots \ldots$ & 0.17 & 10.64 & 31.56 & 55.25 & $33.4 \%$ \\
\hline Compressed Natural Gas. & 2.10 & 136.98 & 244.63 & 367.01 & $29.6 \%$ \\
\hline Liquid Petroleum Gas ... & 8.75 & 61.48 & 116.32 & 185.25 & $16.5 \%$ \\
\hline Eloctricity $\ldots \ldots \ldots$ & 0.30 & 24.83 & 71.73 & 129.90 & $35.4 \%$ \\
\hline Liquid Hydrogen & 0.00 & 0.00 & 0.00 & 0.00 & $94.9 \%$ \\
\hline 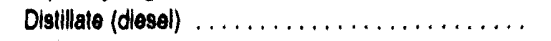 & 175.19 & 142.51 & 149.34 & 173.66 & $0.0 \%$ \\
\hline 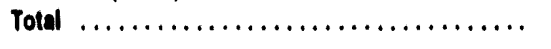 & $12,730.10$ & $14,298.40$ & $15,001.72$ & $16,640.14$ & $1.0 \%$ \\
\hline \multicolumn{6}{|l|}{ Frolight Truclat } \\
\hline Motor Gasoline & $2,303.09$ & $2,659.01$ & 2.716 .85 & $2,758.21$ & $0.9 \%$ \\
\hline Distillate (diesel) & $2,722.88$ & $3,747.08$ & $4,168.99$ & 4.614 .15 & $2.7 \%$ \\
\hline Methanol ....... & 0.00 & 0.00 & 0.00 & 0.00 & $N / A$ \\
\hline Compressed Nalural Gas. & 0.00 & 0.00 & 0.00 & 0.00 & N/A \\
\hline Liquid Petroleum Gas .. & 13.05 & 16.77 & 18.11 & 19.49 & $2.0 \%$ \\
\hline Total $\ldots \ldots \ldots \ldots \ldots \ldots \ldots \ldots \ldots \ldots \ldots \ldots$ & $8,009.02$ & $6,422.86$ & $0,001.06$ & $7,391.84$ & $1.9 \%$ \\
\hline \multicolumn{6}{|l|}{ Fralght Ralf" } \\
\hline Distillate (diesel) & 456.87 & 510.01 & 538.64 & 568.61 & $1.1 \%$ \\
\hline 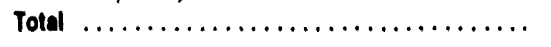 & 466.87 & 810.01 & 698.44 & 868.61 & $1.1 \%$ \\
\hline \multicolumn{6}{|l|}{ Domoutle Shipping } \\
\hline Distillate (diesel) & 214.19 & 231.25 & 246.36 & 262.96 & $1.0 \%$ \\
\hline Residual Oil .... & 94.37 & 101.92 & 108.55 & 115.82 & $1.0 \%$ \\
\hline Motor Gasoline & 0.00 & 0.00 & 0.00 & 0.00 & N/A \\
\hline Total $\ldots \ldots \ldots \ldots \ldots \ldots \ldots \ldots \ldots \ldots \ldots \ldots \ldots \ldots$ & 300.60 & 333.17 & 364.91 & 378.77 & $1.0 \%$ \\
\hline \multicolumn{6}{|l|}{ Iniernational Shlpping } \\
\hline Distillate (diesel) .... & 62.20 & 81.74 & 92.27 & 102.06 & $2.5 \%$ \\
\hline Residual Oil ... & 920.24 & $1,209.70$ & $1,365.11$ & $1,509.33$ & $2.5 \%$ \\
\hline$\ldots \ldots \ldots+\cdots, \ldots, \cdots$, & 92.4 & $1,291.44$ & $1,467.38$ & 1,011.38 & $2.8 \%$ \\
\hline \multicolumn{6}{|l|}{ Alr Transportation } \\
\hline Jet Fuel & $2,334.55$ & $3,147.50$ & $3,509.52$ & $3,856.30$ & $2.5 \%$ \\
\hline Aviation Gasoline $\ldots \ldots \ldots$ & 45.36 & 42.56 & 42.26 & 42.14 & $.0 .4 \%$ \\
\hline 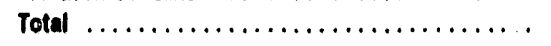 & $2,379.00$ & $3,100.06$ & $3,661.78$ & $3,890.44$ & $2.5 \%$ \\
\hline \multicolumn{6}{|l|}{ Mhecelleneous Trensportation } \\
\hline Jet Fuel (kerosene) ........ & 451.55 & 334.13 & 336.23 & 341.44 & $.1 .4 \%$ \\
\hline Jet Fuel (naphtha) . . . . . . & 343.40 & 235.95 & 237.43 & 241.11 & $.1 .8 \%$ \\
\hline Residual Fuel . . . . . . . . . . . & 15.58 & 12.66 & 12.74 & 12.94 & $.0 .9 \%$ \\
\hline Distillate $\ldots \ldots \ldots \ldots \ldots \ldots \ldots \ldots$ & 91.52 & 73.41 & 73.87 & 75.02 & $.1 .0 \%$ \\
\hline Total $\ldots \ldots \ldots \ldots \ldots \ldots \ldots \ldots \ldots \ldots$ & 002.00 & 60.16 & 860.28 & 870.51 & $.1 .6 \%$ \\
\hline \multicolumn{6}{|l|}{ Bus Traneportation } \\
\hline Total & $\$ 0.73$ & 102.21 & 108.86 & 110.40 & $0.8 \%$ \\
\hline
\end{tabular}


Table 25. Transportation Sector Energy Use by Fuel Type Within a Mode (Continued)

(Trillion Btu per Year)

\begin{tabular}{|c|c|c|c|c|c|}
\hline \multirow{2}{*}{ Mods and Typs } & \multicolumn{4}{|c|}{ Reterences Caes } & \multirow{2}{*}{$\begin{array}{l}\text { Amud } \\
\text { Crowth } \\
\text { teap-2010 } \\
\text { (percent) }\end{array}$} \\
\hline & 1000 & 2000 & 2006 & 2010 & \\
\hline \multicolumn{6}{|l|}{ Rall Tremeportation } \\
\hline Total ............. & 56.07 & 86.60 & 67.56 & 57.80 & $0.2 \%$ \\
\hline Rucreation Bosts. ... & 243.00 & 250.07 & 266.20 & 273.77 & $0.6 \%$ \\
\hline Lubricents $. . . \ldots \ldots \ldots \ldots \ldots \ldots \ldots . . . . . . . .$. & 176.00 & 170.32 & 178.61 & 193.71 & $0.5 \%$ \\
\hline Plpeline Fuld Natural Gas ................ & 690.27 & 690.97 & 722.67 & 726.64 & $0.3 \%$ \\
\hline Toted Mbealleneous ..................... & $2,160.42$ & $1,036.40$ & $1,002.06$ & $2,003.05$ & $-0.4 \%$ \\
\hline 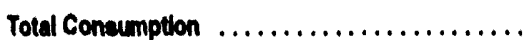 & $22,500,50$ & $26,156.91$ & $27,005.48$ & $20,403.64$ & $1.4 \%$ \\
\hline
\end{tabular}

IIncludes personal vehicles, fleet vehicles, and freight light trucks.

${ }^{2}$ Freight light trucks are included in both light duty vehicles and treight trucks. Does not include military

distillate. Does not include commercial buses.

Does not include passenger rall.

N/A $=$ Not applicable.

Note: Totals may not equal sum of components due to independent rounding.

Sources: 1090: Energy Intormation Administration (EIA), State Energy Data Report 1091, DOE-EIA-0214(81) (Washington, D.C., May 1993);

EIA, Fuel Oil and Kerosene Sales 1001, DOEJEIA-0535(01) (Weshington, D.C., November 1992); Oak Ridge National Laboratory, Transportation Energy Book: 12 and 13, (March 1993); and Department of Delense, Delense Fuel Supply Center. Propections: EIA, AEO 1994 National Energy Modeling System run AEOO4B.D1221934. 
Table 26. Light-Duty Vehicle Energy Consumption by Technology Type and Fuel Type (Trillion Btu per Year)

\begin{tabular}{|c|c|c|c|c|c|}
\hline \multirow{2}{*}{ Technology Type } & \multicolumn{4}{|c|}{ Reterencs Cases } & \multirow{2}{*}{$\begin{array}{l}\text { Amual } \\
\text { Growth } \\
1900-2010 \\
\text { (peraent) }\end{array}$} \\
\hline & 1900 & 2000 & 2000 & 2010 & \\
\hline \multicolumn{6}{|l|}{$\begin{array}{l}\text { Light-Duty Conoum. by Tech. Typo } \\
\text { Conventional Vehleies }\end{array}$} \\
\hline Gasoline ICE Vehicles ........... & $12,516.55$ & $13,903,49$ & $14,349.06$ & $14,587.02$ & $0.8 \%$ \\
\hline Dlstillate (diesel) ICE $\ldots \ldots \ldots \ldots \ldots \ldots \ldots$ & 175.19 & 142.51 & 149.34 & 173.66 & $0.0 \%$ \\
\hline \multicolumn{6}{|l|}{$\begin{array}{l}\text { Aliemntwe-Fud Vchlcles } \\
\text { Alcohol Fud Technology }\end{array}$} \\
\hline Methanol-Flex Fuel ICE. & 0.12 & 9.84 & 35.18 & 74.60 & $37.9 \%$ \\
\hline Methanol-Neal ICE & 0.00 & 0.10 & 0.91 & 3.57 & $51.0 \%$ \\
\hline Ethanol-Flex Fuel ICE ... & 0.20 & 13.04 & 39.59 & 67.62 & $33.7 \%$ \\
\hline Ethanol-Neat ICE $\ldots \ldots \ldots \ldots \ldots \ldots \ldots$ & 0.00 & 0.08 & 0.84 & 3.31 & $55.3 \%$ \\
\hline $\begin{array}{l}\text { Total Alcohol ............................ } \\
\text { Natural Cas Technology }\end{array}$ & 0.32 & 23.06 & 76.52 & 149.10 & $35 . \% \%$ \\
\hline Compressed Nalural Gas ICE $\ldots \ldots \ldots \ldots \ldots$ & 2.10 & 134.30 & 242.79 & 365.26 & $29.4 \%$ \\
\hline Liquid Petroloum Gas ICE ................. & 8.75 & 63.13 & 118.06 & 187.12 & $16.5 \%$ \\
\hline $\begin{array}{l}\text { Total Natural Ges ........................ } \\
\text { Electric Technology }\end{array}$ & 45.82 & 197.43 & 360.86 & s82.38 & $13.3 \%$ \\
\hline Electric Vehicle ... & 0.30 & 20.75 & 47.52 & 82.00 & $32.4 \%$ \\
\hline Electric Hybrid ..... & 0.00 & 8.06 & 45.95 & 77.94 & $93.7 \%$ \\
\hline Electric Hybrid 2 Stroke & 0.00 & 0.09 & 2.43 & 16.82 & $99.2 \%$ \\
\hline Electric Hybrid Turbine ... & 0.00 & 0.00 & 0.05 & 1.12 & $N / A$ \\
\hline Total Elsctrictly $\ldots \ldots \ldots \ldots \ldots \ldots \ldots \ldots$ & 0.30 & 28.00 & 85.04 & 177.87 & $37.6 \%$ \\
\hline \multicolumn{6}{|l|}{ Turblno Technology } \\
\hline Gas Turbine Gasoline & 0.00 & 0.00 & 0.00 & 0.06 & N/A \\
\hline Gas Turbine Compressed Natural Gas . & 0.00 & 0.00 & 0.00 & 0.01 & N/A \\
\hline Total Turbine $\ldots \ldots \ldots \ldots \ldots \ldots \ldots \ldots$ & 0.00 & 0.00 & 0.00 & 0.07 & N/A \\
\hline Fuel Coll Technology & & & & & \\
\hline Fuel Cell Methanol & 0.00 & 0.00 & 0.00 & 0.00 & $95.0 \%$ \\
\hline Fuel Cell Hydrogen. & 0.00 & 0.00 & 0.00 & 0.00 & $94.9 \%$ \\
\hline Total Fuel Cell ....... & 0.00 & 0.00 & 0.00 & 0.00 & $94.9 \%$ \\
\hline \multicolumn{6}{|l|}{ Light-Duty Consumption by Fuel Typo' } \\
\hline Motor Gasoline & $12,516.62$ & $13,912.13$ & $14,388.58$ & $14,666.35$ & $0.8 \%$ \\
\hline Distillate (diesel) .... & 175.19 & 142.51 & 149.34 & 173.66 & $0.0 \%$ \\
\hline 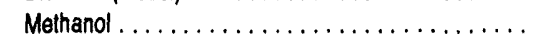 & 0.09 & 7.87 & 29.67 & 62.72 & $38.7 \%$ \\
\hline Ethanol ............ & 0.17 & 10.64 & 31.56 & 55.25 & $33.4 \%$ \\
\hline Compressed Natural Gas. & 2.10 & 135.95 & 244.53 & 367.01 & $29.5 \%$ \\
\hline Liquid Petroleum Gas & 8.75 & 61.48 & 116.32 & 185.25 & $16.5 \%$ \\
\hline (.................. & 0.30 & 24.83 & 71.73 & 129.90 & $35.4 \%$ \\
\hline Liquid Hydrogen $\ldots \ldots \ldots \ldots \ldots \ldots \ldots \ldots$ & 0.00 & 0.00 & 0.00 & 0.00 & $94.9 \%$ \\
\hline
\end{tabular}

'Includes personal vehicles, fleet vehicles, and freight line trucks. Includes both cars and trucks.

ICE = Internal combustion engine.

N/A $=$ Not applicable.

Source 1900 and Projectione: Energy Information Administration, AEO 1994 National Energy Modeling System run AEO94B.D1221834. 
Table 27. Light-Duty Vehicle Sales by Technology Type

(Millions)

\begin{tabular}{|c|c|c|c|c|c|}
\hline \multirow{2}{*}{ Technology Typo } & \multicolumn{4}{|c|}{ Reterenco Caso } & \multirow{2}{*}{$\begin{array}{c}\text { Amnual } \\
\text { Growth } \\
1900-2010 \\
\text { (percent) }\end{array}$} \\
\hline & 1000 & 2000 & 2005 & 2010 & \\
\hline \multicolumn{6}{|l|}{ LIght-Duty Now Car Sales' } \\
\hline \multicolumn{6}{|l|}{ Convention:! Vehicles } \\
\hline Gasoline ICE Vehicles & 9.56 & 9.44 & 9.04 & 9.19 & $.0 .2 \%$ \\
\hline Distillate (diesel) ICE ..... & 0.01 & 0.01 & 0.01 & 0.00 & $-2.9 \%$ \\
\hline Total Conventional $\ldots \ldots \ldots \ldots \ldots \ldots \ldots \ldots$ & 9.57 & 9.44 & 9.04 & 9.19 & $.0 .2 \%$ \\
\hline \multicolumn{6}{|l|}{ Alternative-Fuel Vehiclos } \\
\hline Methanol-Flex Fual ICE & 0.01 & 0.03 & 0.14 & 0.16 & $16.9 \%$ \\
\hline Methanol-Neat ICE .... & 0.00 & 0.00 & 0.00 & 0.01 & $38.1 \%$ \\
\hline Ethanol-Flex Fuel ICE & 0.00 & 0.05 & 0.09 & 0.10 & $25.2 \%$ \\
\hline Ethanol-Neat ICE. ... & $0.0^{n}$ & 0.00 & 0.00 & 0.01 & $42.0 \%$ \\
\hline \multicolumn{6}{|l|}{ Natural Gas Technology } \\
\hline Compressed Natural Gas ICE & 0.00 & 0.11 & 0.30 & 0.33 & $24.5 \%$ \\
\hline Liquid Petroleum Gas ICE ............... & 0.00 & 0.07 & 0.22 & 0.24 & $25.2 \%$ \\
\hline \multicolumn{6}{|l|}{ Electric Technology } \\
\hline Electric Vehicle & 0.00 & 0.04 & 0.14 & 0.13 & $29.9 \%$ \\
\hline Electric Hybrid . .................... & 0.00 & 0.04 & 0.15 & 0.11 & $69.0 \%$ \\
\hline Electric Hybrid 2 Stroke $\ldots \ldots \ldots \ldots \ldots \ldots$ & 0.00 & 0.00 & 0.02 & 0.08 & $84.3 \%$ \\
\hline Electric Hybrid Turbine $\ldots \ldots \ldots \ldots \ldots \ldots$ & 0.00 & 0.00 & 0.00 & 0.01 & N/A \\
\hline \multicolumn{6}{|l|}{ Turbine Technology } \\
\hline Gas Turbine Gasoline & 0.00 & 0.00 & 0.00 & 0.00 & N/A \\
\hline Gas Turbine Compressed Natural Gas ......... & 0.00 & 0.00 & 0.00 & 0.00 & N/A \\
\hline \multicolumn{6}{|l|}{ Fuel Cell Technology } \\
\hline Fuel Cell Methanol & 0.00 & 0.00 & 0.00 & 0.00 & N/A \\
\hline Fuel Cell Hydrogen ................... & 0.00 & 0.00 & 0.00 & 0.00 & N/A \\
\hline Total Alternatives ............... & 0.02 & 0.34 & 1.07 & 1.18 & $24.2 \%$ \\
\hline Percent Alternative Car Sales ................ & 0.16 & 3.43 & 10.61 & 11.37 & $23.7 \%$ \\
\hline Total Now Car Salos ..... & 0.58 & 9.78 & 10.12 & 10.37 & $0.4 \%$ \\
\hline \multicolumn{6}{|l|}{ Light-Duty Now Truck Salos? } \\
\hline \multicolumn{6}{|l|}{ Conventional Vehicles } \\
\hline Gasoline ICE Vehicles . & 4.34 & 5.40 & 5.73 & 5.89 & $1.5 \%$ \\
\hline Distillate (diesel) ICE .... & 0.05 & 0.10 & 0.15 & 0.20 & $7.5 \%$ \\
\hline Total Conventional ........ & 4.39 & 5.50 & 5.87 & 6.08 & $1.7 \%$ \\
\hline \multicolumn{6}{|l|}{ Alternattvo-Fuel Vehiclos } \\
\hline \multicolumn{6}{|l|}{ Alcohol Fuel Technology } \\
\hline Methanol.Flex Fuel ICE & 0.00 & 0.02 & 0.05 & 0.05 & $18.9 \%$ \\
\hline Methanol-Neat ICE & 0.00 & 0.00 & 0.00 & 0.00 & $40.2 \%$ \\
\hline Ethanol-Flex Fuel ICE & 0.00 & 0.02 & 0.04 & 0.04 & $27.0 \%$ \\
\hline Ethanol-Neat ICE $\ldots \ldots \ldots \ldots \ldots \ldots \ldots$ & 0.00 & 0.00 & 0.00 & 0.00 & $44.2 \%$ \\
\hline \multicolumn{6}{|l|}{ Natural Gas Technology } \\
\hline Compressed Natural Gas ICE & 0.00 & 0.06 & 0.09 & 0.10 & $21.7 \%$ \\
\hline Liquid Petroleum Gas ICE . & 0.00 & 0.03 & 0.06 & 0.07 & $17.0 \%$ \\
\hline \multicolumn{6}{|l|}{ Electric Technology } \\
\hline Electric Vehicle. & 0.00 & 0.02 & 0.07 & 0.06 & $32.3 \%$ \\
\hline Electric Hybrid. . & 0.00 & 0.02 & 0.08 & 0.06 & $74.7 \%$ \\
\hline Electric Hybrid 2 Stroke $\ldots \ldots \ldots \ldots \ldots \ldots \ldots$ & 0.00 & 0.00 & 0.01 & 0.04 & $90.4 \%$ \\
\hline Electric Hybrid Turbin $\theta \quad \ldots \ldots \ldots \ldots \ldots \ldots$ & 0.00 & 0.00 & 0.00 & 0.00 & N/A \\
\hline \multicolumn{6}{|l|}{ Turbine Technology } \\
\hline Gas Turbine Gasoline & 0.00 & 0.00 & 0.00 & 0.00 & N/A \\
\hline Gas Turbine Compressed Natural Gas ... & 0.00 & 0.00 & 0.00 & 0.00 & N/A \\
\hline Fuel Cell Technology & & & & & \\
\hline Fuel Cell Methanol & 0.00 & 0.00 & 0.00 & 0.00 & $N / A$ \\
\hline Fuel Cell Hydrogen & $0.0 \mathrm{~J}$ & 0.00 & 0.00 & 0.00 & N/A \\
\hline Total Alternatives ...... & 001 & 0.16 & 0.40 & 0.43 & $22.7 \%$ \\
\hline Percent Alternative Light Truck Sales & 0.17 & 2.84 & 6.31 & 6.67 & $20.3 \%$ \\
\hline Total Now Truck Salos. & 4.3e & 5.66 & 6.27 & 6.52 & $2.0 \%$ \\
\hline
\end{tabular}


Table 27. Light-Duty Vehlcle Sales by Technology Type (Continued) (Millions)

\begin{tabular}{|c|c|c|c|c|c|}
\hline \multirow{2}{*}{ Technology Typo } & \multicolumn{4}{|c|}{ Rexerence Case } & \multirow{2}{*}{$\begin{array}{l}\text { Annual } \\
\text { Growth } \\
1980-2010 \\
\text { (percent) }\end{array}$} \\
\hline & 1090 & 2000 & 2006 & 2010 & \\
\hline ZEVP Legislative Alternative Sales $\ldots \ldots \ldots \ldots \ldots$ & 0.00 & 0.06 & 0.31 & 0.32 & $N / A$ \\
\hline Total Vehicles Sales ..................... & 9.50 & 9.94 & 10.51 & 10.81 & $0.6 \%$ \\
\hline
\end{tabular}

'Includes personal, and fleet light-duty cars.

'Includes personal, fleet, and freight light-duty trucks.

ICE = Internal combustion engine.

EPACT = Energy Policy Act of 1992

ZEVP = Zero errission vehicles from the low emission vehicle program.

N/A = Not applicable.

Sources: 1990: California Air Resources Boaru, "Proposed Regulations for Low-Emission Vehicles and Clean Fuels, Staff Report"; United States Department of Energy, Office of Domestic and International Energy Policy, "Assessment of Costs and Benefits of Flexible and Alternative Fuel Use in the U.S. Transportation Seclor, Technical Report Ten: Analysis of Alternative-Fuel Fleet Requirements" (Washington, D.C., May 1992); Bunch, David S., Mark Bradley, Thomas F. Glob, Ryuichi Kitamura, Gareth P. Occhiuzzo, "Demand for Clean-Fuel Personal Vehicles in California: A Discrete-Choice Stated Preference Survey", (December 1901); and Energy Information Administration (EIA), AEO 1094 National Energy Modeling System run AEO94B.D1221934. Projections: EIA, AEO 1904 National Energy Modeling System run AEO94B.D1221934. 
Table 28. Light-Duty Vehicle Stock by Technology Type (Millions)

\begin{tabular}{|c|c|c|c|c|c|}
\hline \multirow{2}{*}{ Technology Type } & \multicolumn{4}{|c|}{ Peterenos Cas } & \multirow{2}{*}{$\begin{array}{l}\text { Annud } \\
\text { Growth } \\
1 \text { ceo-2010 } \\
\text { (percent) }\end{array}$} \\
\hline & 1900 & 2000 & 2005 & 2010 & \\
\hline \multicolumn{6}{|l|}{ Ught-Duty Cer Stock' } \\
\hline Gasoline ICE Vehicles $\ldots \ldots \ldots \ldots \ldots \ldots \ldots$ & 144.45 & 148.82 & 148.97 & 150.32 & $0.2 \%$ \\
\hline Distillate (diesel) ICE . . . . . . . . . . . . . . & 2.64 & 1.23 & 0.80 & 0.53 & $\cdot 7.7 \%$ \\
\hline Total Conventional . . . . . . . . . . . . . . . . & 147.08 & 150.06 & 140.78 & 150.85 & $0.1 \%$ \\
\hline \multicolumn{6}{|l|}{$\begin{array}{l}\text { Atiemuthe-Fuel Vehicise } \\
\text { Alcchol Fuel Technology }\end{array}$} \\
\hline Methanol-Flex Fuel ICE $\ldots \ldots \ldots \ldots \ldots \ldots$ & 0.00 & 0.14 & 0.59 & 1.19 & $40.3 \%$ \\
\hline Methanol-Neat ICE $\ldots \ldots \ldots \ldots \ldots \ldots$ & 0.00 & 0.00 & 0.01 & 0.05 & $49.8 \%$ \\
\hline Ethanol-Flex Fuel ICE $\ldots \ldots \ldots \ldots \ldots \ldots$ & 0.00 & 0.20 & 0.56 & 0.95 & $36.9 \%$ \\
\hline Ethanol-Neat ICE $\ldots \ldots \ldots \ldots \ldots \ldots \ldots$ & 0.00 & 0.00 & 0.01 & 0.05 & $54.0 \%$ \\
\hline \multicolumn{6}{|l|}{ Natural Gas Technology } \\
\hline Compressed Natural Gas ICE. & 0.01 & 0.74 & 1.65 & 2.86 & $35.2 \%$ \\
\hline Liquid Petroleum Gas ICE . ............... & 0.06 & 0.46 & 1.10 & 2.04 & $19.2 \%$ \\
\hline \multicolumn{6}{|l|}{ Electric Technology } \\
\hline Electric Vehicle .... & 0.00 & 0.20 & 0.66 & 1.26 & $40.9 \%$ \\
\hline Electric Hybrid $\ldots \ldots \ldots \ldots \ldots \ldots \ldots \ldots \ldots$ & 0.00 & 0.15 & 0.79 & 1.30 & $91.0 \%$ \\
\hline Electric Hybrid 2 Stroke . . . . . . . . . . . . . & 0.00 & 0.00 & 0.04 & 0.29 & $96.6 \%$ \\
\hline Electric Hybrid Turbine $\ldots \ldots \ldots \ldots \ldots \ldots$ & 0.00 & 0.00 & 0.00 & 0.02 & $N / A$ \\
\hline \multicolumn{6}{|l|}{ Turbine Technology } \\
\hline Gas Turbine Gasoline ................. & 0.00 & 0.00 & 0.00 & 0.00 & $N / A$ \\
\hline Gas Turbine Compressed Natural Gas ......... & 0.00 & 0.00 & 0.00 & 0.00 & N/A \\
\hline \multicolumn{6}{|l|}{ Fud Coll Technology } \\
\hline Fuel Cell Methanol $\ldots . . \ldots \ldots \ldots . . . \ldots$ & 0.00 & 0.00 & 0.00 & 0.00 & $N / A$ \\
\hline Fuel Cell Hydrogen . . . . . . . . . . . . . . & 0.00 & 0.00 & 0.00 & 0.00 & $N / A$ \\
\hline Total Alternathes $\ldots \ldots \ldots \ldots \ldots \ldots \ldots$ & 0.07 & 1.69 & 5.42 & 10.01 & $28.0 \%$ \\
\hline Total Cer Stock $\ldots \ldots \ldots \ldots \ldots \ldots \ldots \ldots$ & 147.16 & 151.85 & 155.20 & 160.86 & $0.4 \%$ \\
\hline \multicolumn{6}{|l|}{ Ught-Duty Truck Stock ${ }^{2}$} \\
\hline \multicolumn{6}{|l|}{ Conventional Vehicles } \\
\hline Gasoline ICE Vehicles & 38.14 & 56.38 & 63.36 & 67.60 & $2.9 \%$ \\
\hline Distillate (diesel) ICE . . . . . . . . . . . . . & 0.78 & 0.88 & 1.20 & 1.67 & $3.9 \%$ \\
\hline Total Conventional . . . . . . . . . . . . . . . & 38.92 & 57.26 & 64.56 & 69.27 & $2.8 \%$ \\
\hline \multicolumn{6}{|l|}{$\begin{array}{l}\text { Afternattve-Fued Vehiclos } \\
\text { Alcohol Fud Technology }\end{array}$} \\
\hline Methanol-Flex Fuel ICE $\ldots \ldots \ldots \ldots \ldots \ldots$ & 0.00 & 0.07 & 0.24 & 0.43 & $35.2 \%$ \\
\hline Methanol-Neat ICE $\ldots \ldots \ldots \ldots \ldots \ldots \ldots$ & 0.00 & 0.00 & 0.00 & 0.02 & $52.0 \%$ \\
\hline Ethanol-Flex Fuel ICE $\ldots \ldots \ldots \ldots \ldots \ldots$ & 0.00 & 0.08 & 0.22 & 0.35 & $26.7 \%$ \\
\hline $\begin{array}{l}\text { Ethanol-Neat ICE } \ldots \ldots \ldots \ldots \ldots \ldots \ldots \ldots \ldots \\
\text { Natural Gas Technology }\end{array}$ & 0.00 & 0.00 & 0.00 & 0.02 & $56.4 \%$ \\
\hline Compressed Nalural Gas ICE $\ldots \ldots \ldots \ldots \ldots$ & 0.03 & 0.39 & 0.69 & 0.96 & $19.0 \%$ \\
\hline Liquid Petroleum Gas ICE . . . . . . . . . . . & $0.3 !$ & 0.34 & 0.46 & 0.65 & $3.8 \%$ \\
\hline \multicolumn{6}{|l|}{ Electric Technology } \\
\hline Electric Vehicle & 0.00 & 0.10 & 0.33 & 0.60 & $30.4 \%$ \\
\hline$\ldots \ldots \ldots \ldots \ldots$ & 0.00 & 0.06 & 0.38 & 0.65 & $97.2 \%$ \\
\hline Electric Hybrid 2 Stroke $\ldots \ldots \ldots \ldots \ldots$ & 0.00 & 0.00 & 0.02 & 0.14 & N/A \\
\hline Electric Hybrid Turbine $\ldots \ldots \ldots \ldots \ldots$ & 0.00 & 0.00 & 0.00 & 0.01 & N/A \\
\hline
\end{tabular}


Table 28. Light-Duty Vehicle Stock by Technology Type (Continued) (Millions)

\begin{tabular}{|c|c|c|c|c|c|}
\hline \multirow{2}{*}{ Technology Typo } & \multicolumn{4}{|c|}{ Pelerences Cese } & \multirow{2}{*}{$\begin{array}{l}\text { Amnual } \\
\text { Growth } \\
1 \text { coo-2010 } \\
\text { (percant) }\end{array}$} \\
\hline & 1000 & 2000 & 2005 & 2010 & \\
\hline \multicolumn{6}{|l|}{ Turbline Technology } \\
\hline Gas Turbine Gasoline & 0.00 & 0.00 & 0.00 & 0.00 & $N / A$ \\
\hline Gas Turbine Compressed Natural Gas & 0.00 & 0.00 & 0.00 & 0.00 & N/A \\
\hline \multicolumn{6}{|l|}{ Fual Coll Tectnology } \\
\hline Fuel Cell Methanol & 0.00 & 0.00 & 0.00 & 0.00 & N/A \\
\hline Fuel Cell Hydrogen .................... & 0.00 & 0.00 & 0.00 & 0.00 & N/A \\
\hline Total Alternative ...................... & 0.34 & 1.04 & 2.35 & 3.83 & $12.8 \%$ \\
\hline Total Truck Stock $\ldots \ldots \ldots \ldots \ldots \ldots \ldots \ldots$ & 39.27 & 58.30 & 60.01 & 73.10 & $3.2 \%$ \\
\hline Total Vehleb Stock & 186.42 & 210.25 & 222.11 & 233.98 & $1.1 \%$ \\
\hline
\end{tabular}

'Includes personal and fleet vehicles.

'Includes personal vehicles, fleet vehicles, and freight light trucks.

ICE = Internal combustion engine.

N/A $=$ Not applicable.

Source: 1990: Energy Information Administration (EIA), Household Vehicles Energy Consumption 1991, DOE/EIA-0464(91) (Washington, D.C., December 1993). Projectione: EIA, AEO 1994 Natlonal Energy Modeling System run AEO94B.D1221934. 
Table 29. Light-Duty Vehicle MPG by Technology Type

(MPG Gasoline Equivalents)

\begin{tabular}{|c|c|c|c|c|c|}
\hline \multirow{2}{*}{ Technology Typese } & \multicolumn{4}{|c|}{ Relerencos Coses } & \multirow{2}{*}{$\begin{array}{l}\text { Annual } \\
\text { Crowth } \\
190-2010 \\
\text { (percent) }\end{array}$} \\
\hline & 1900 & 2000 & 2006 & 2010 & \\
\hline \multicolumn{6}{|l|}{ Automobllos" } \\
\hline \multicolumn{6}{|l|}{ Conventional Vehicies } \\
\hline Gasoline ICE Vehicles & 28.16 & 29.44 & 30.45 & 31.13 & $0.5 \%$ \\
\hline Distillate (diesel) ICE & 30.26 & 31.63 & 32.67 & 33.37 & $0.5 \%$ \\
\hline \multicolumn{6}{|l|}{$\begin{array}{l}\text { Aliernattve-Fuel Vehiclos } \\
\text { Alcohol Fud Technology }\end{array}$} \\
\hline Methanol-Flex Fuel ICE. & 28.75 & 31.80 & 34.38 & 35.31 & $1.0 \%$ \\
\hline Methanol-Neal ICE & 30,83 & 32.22 & 33.28 & 34.00 & $0.5 \%$ \\
\hline Ethanol-Flex Fuel ICE & 29.71 & 31.42 & 32.16 & 33.05 & $0.5 \%$ \\
\hline Ethanol-Neat ICE & 32.83 & 34.31 & 35.44 & 36.20 & $0.5 \%$ \\
\hline \multicolumn{6}{|l|}{ Matural Gas Technology } \\
\hline Compressed Natural Gas ICE & 27.02 & 28.44 & 28.99 & 29.62 & $0.5 \%$ \\
\hline Liquid Petroleum Gas ICE .......... & 36.73 & 38.67 & 39.40 & 40.26 & $0.5 \%$ \\
\hline \multicolumn{6}{|l|}{ Electric Tochnology } \\
\hline Electric Vehicle. & 43.40 & 45.30 & 46.28 & 47.44 & $0.4 \%$ \\
\hline Electric Hybrid . . & 39.96 & 40.62 & 42.02 & 42.91 & $0.4 \%$ \\
\hline Electric Hybrid 2 Stroke. & 39.96 & 41.77 & 42.15 & 43.07 & $0.4 \%$ \\
\hline Electric Hybrid Turbine & 39.96 & 41.77 & 43.14 & 42.69 & $0.3 \%$ \\
\hline \multicolumn{6}{|l|}{ Turbine Technotogy } \\
\hline Gas Turbine Gasoline & 37.11 & 38.79 & 40.06 & 40.93 & $0.5 \%$ \\
\hline Gas Turbine Compressed Natural Gas ... & 37.11 & 38.79 & 40.06 & 40.93 & $0.5 \%$ \\
\hline \multicolumn{6}{|l|}{ Fuel Coll Technology } \\
\hline Fuel Cell Methanol & 45.67 & 47.74 & 49.31 & 50.37 & $0.5 \%$ \\
\hline Fuel Cell Hydrogen $\ldots \ldots \ldots \ldots \ldots \ldots \ldots$ & 45.67 & 47.74 & 49.31 & 50.37 & $0.5 \%$ \\
\hline Average Now Car MPG $\ldots \ldots \ldots \ldots \ldots \ldots \ldots$ & 28.20 & 29.50 & 30.60 & 31.41 & $0.5 \%$ \\
\hline \multicolumn{6}{|l|}{ Llght-Duty Trucks ${ }^{2}$} \\
\hline \multicolumn{6}{|l|}{ Conventional Vehicles } \\
\hline Gasoline ICE Vehicles & 20.72 & 22.19 & 23.00 & 23.59 & $0.6 \%$ \\
\hline Distillate (diesel) ICE . . & 28.76 & 29.98 & 30.97 & 31.64 & $0.5 \%$ \\
\hline \multicolumn{6}{|l|}{ Alternative-Fuel Vehiclos } \\
\hline \multicolumn{6}{|l|}{ Alcohol Fuel Technology } \\
\hline Methanol-Flex Fuel ICE .. & 27.32 & 31.66 & 33.07 & 33.90 & $1.1 \%$ \\
\hline Methanol-Neat ICE ..... & 29.30 & 30.55 & 31.56 & 32.24 & $0.5 \%$ \\
\hline Ethanol-Flex Fuel ICE ....... & 29.26 & 29.96 & 30.72 & 31.45 & $0.4 \%$ \\
\hline Ethanol-Neat ICE $\ldots \ldots \ldots \ldots \ldots \ldots$ & 31.20 & 32.53 & 33.60 & 34.33 & $0.5 \%$ \\
\hline \multicolumn{6}{|l|}{ Natural Gas Technology } \\
\hline Compressed Natural Gas ICE & 25.92 & 26.97 & 27.89 & 28.49 & $0.5 \%$ \\
\hline Liquid Petroleum Gas ICE. ... & 35.48 & 36.92 & 38.18 & 39.01 & $0.5 \%$ \\
\hline \multicolumn{6}{|l|}{ Electric Tochnology } \\
\hline Electric Vehicle & 40.80 & 42.58 & 44.39 & 45.29 & $0.5 \%$ \\
\hline Electric Hybrid .......... & 37.98 & 40.39 & 42.02 & 42.95 & $0.6 \%$ \\
\hline Electric Hybrid 2 Stroke . ................ & 37.98 & 39.60 & 42.03 & 42.95 & $0.6 \%$ \\
\hline Electric Hybrid Turbine $\ldots \ldots \ldots \ldots \ldots \ldots$ & 37.98 & 39.60 & 40.91 & 42.95 & $0.6 \%$ \\
\hline \multicolumn{6}{|l|}{ Turbine Technology } \\
\hline Gas Turbine Gasoline & 35.27 & 36.77 & 37.99 & 38.80 & $0.5 \%$ \\
\hline Gas Turbine Compressed Natural Gas . . . . & 35.27 & 36.77 & 37.99 & 38.80 & $0.5 \%$ \\
\hline \multicolumn{6}{|l|}{ Fuel Coll Technology } \\
\hline Fuel Cell Methanol. & 43.41 & 45.26 & 46.75 & 47.76 & $0.5 \%$ \\
\hline Fuel Cell Hydrogen ... & 43.41 & 45.26 & 46.75 & 47.76 & $0.5 \%$ \\
\hline Average New Truck MPG. & 20.81 & 22.41 & 23.38 & 24.16 & $0.7 \%$ \\
\hline
\end{tabular}


Table 29. Light-Duty Vehicle MPG by Technology Type (Continued) (MPG Gasoline Equivalents)

\begin{tabular}{|c|c|c|c|c|c|}
\hline \multirow{2}{*}{ Technology Types } & \multicolumn{4}{|c|}{ Roterencs Case } & \multirow{2}{*}{$\begin{array}{l}\text { Annual } \\
\text { Growth } \\
1 \text { ce0-2010 } \\
\text { (perant) }\end{array}$} \\
\hline & 1000 & 2000 & 2005 & 2010 & \\
\hline Flent Average Stock Car MPG & 20.28 & 22.02 & 22.91 & 23.78 & $0.8 \%$ \\
\hline Flent Average Stock Truck MPG'. & 16.04 & 16.66 & 17.37 & 18.04 & $0.0 \%$ \\
\hline Fleet Average Stock Vehleb MPG' $\ldots \ldots \ldots \ldots$ & 18.90 & 20.21 & 20.80 & 21.63 & $0.7 \%$ \\
\hline
\end{tabular}

'Fuel elficiencies are EPA rated. Includes personal and fleel vehicles.

'Fuel olliciencies are EPA rated. Includes personal vehicles, lleel vehicles, and freight light trucks.

'Stock values are on road efliciencies. Includes personal vehicles, fleet vehicles, and treight light trucks.

MPG = Miles per Gallon.

$I C E=$ Internal combustion engine.

Sources: 1990: Decision Analysis Corporation ol Virginia and Science Applications International Corporation, "Alternative-Fuel Vehicie Module Database", Drat Report, Sublask 4, Prepared lor Energy Intormation Administration (ElA), September 15, 1992; Department of Energy, IDEAS Model. Prepared by Energy and Environmental Analysis Incorporated for the Office of Domestic and International Energy Policy; National Highway Traftic and Safety Administration, "Summary of Fuel Economy Performance", (February 1993). Projectlone: EIA, AEO 1994 National Energy Modeling System run AEO948.D1221934. 
Table 30. Light-Duty Vohicle VMT by Technology Type (Billion Miles Unless Otherwise Noted)

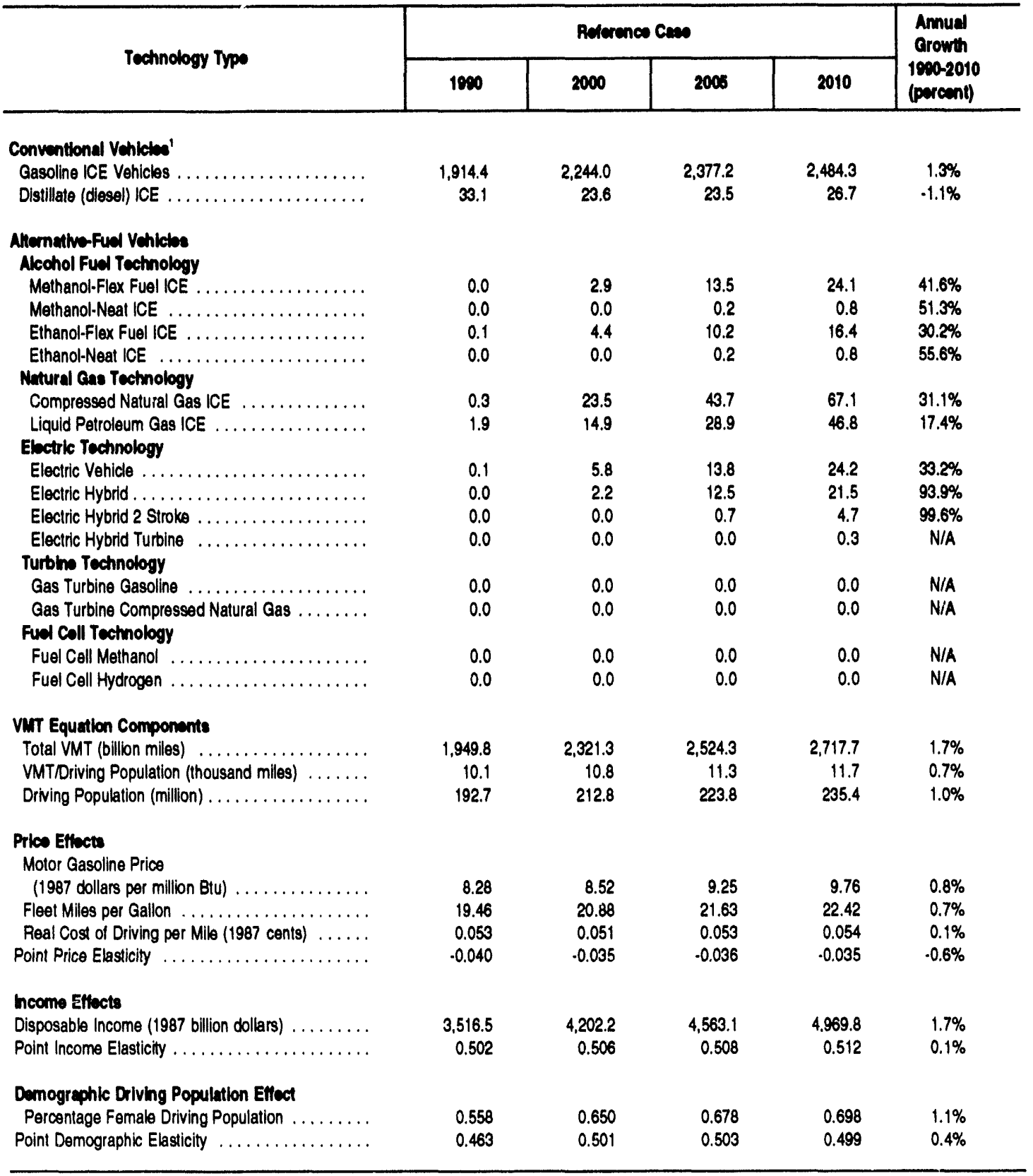

'Includes personal vehicles, fleet vehicles, and freight light trucks. Includes both cars and light frucks.

VMT $=$ Vehicle miles traveled.

ICE = Internal combustion engine.

N/A $=$ Not applicable.

Sources: 1990: Federal Highway Administration, Highway Statistics 1991, (1992); and Oak Ridge National Laboratory, Transportation Energy Data Book: 12 and 13, (March 1993). Projectlone: Energy Intormation Administration, AEO 1994 National Energy Modeling System run AEO94B.D1221934. 
Table 31. Transportation Fleot Car and Truck Fuel Consumption by Type and Technology

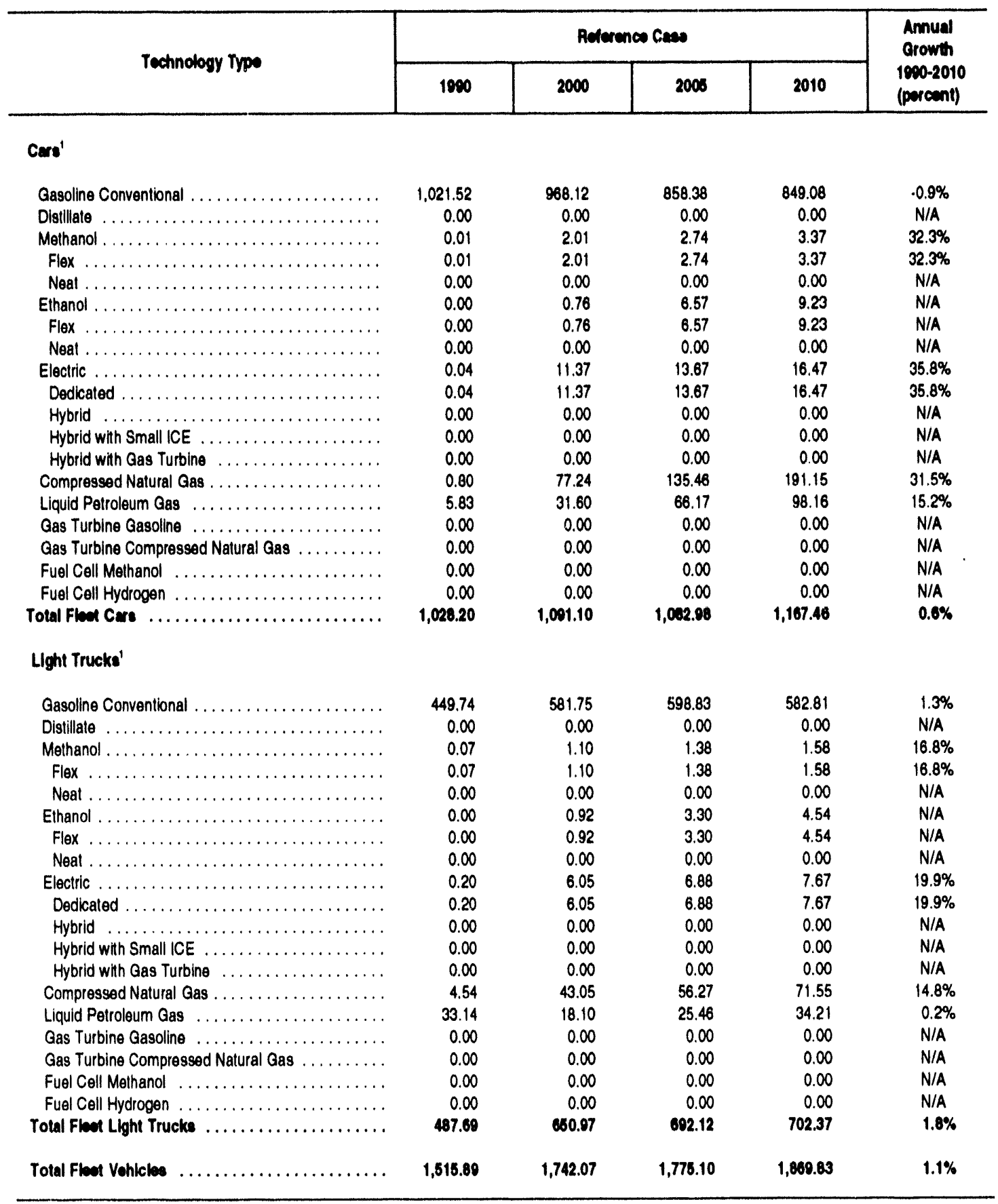

IInclude all commercial fleels of 10 or more.

ICE $=$ Internal combustion engine.

N/A $=$ Not applicable.

Sources: Oak Ridge National Laboratory, "Fleet Vehicles in the United States: Composition, Operating Characteristics, and Fueling Practices", Prepared for the Department of Energy, Office of Transportation Technologies, and Olfice of Policy Planning and Analysis, March 1992; Bobit Publishing Company, Fleet Fact Book, Redondo Beach Calitornia, various issues; United Stales Department of Energy, Office of Domestic and International Energy Policy, "Assessment of Costs and Benefits of Flexible and Alterne',re Fuel Use in the U.S. Transportation Sector, Technical Report Ten: Analysis of Alternative-Fuel Fleet Requirements", (May 1092). Projectione: Energy Information Administration, AEO 1994 National Energy Modeling System run AEO94B.D1221834. 
Table 32. Transportation Fleot Car and Truck Sales by Typo and Technology (Thousands)

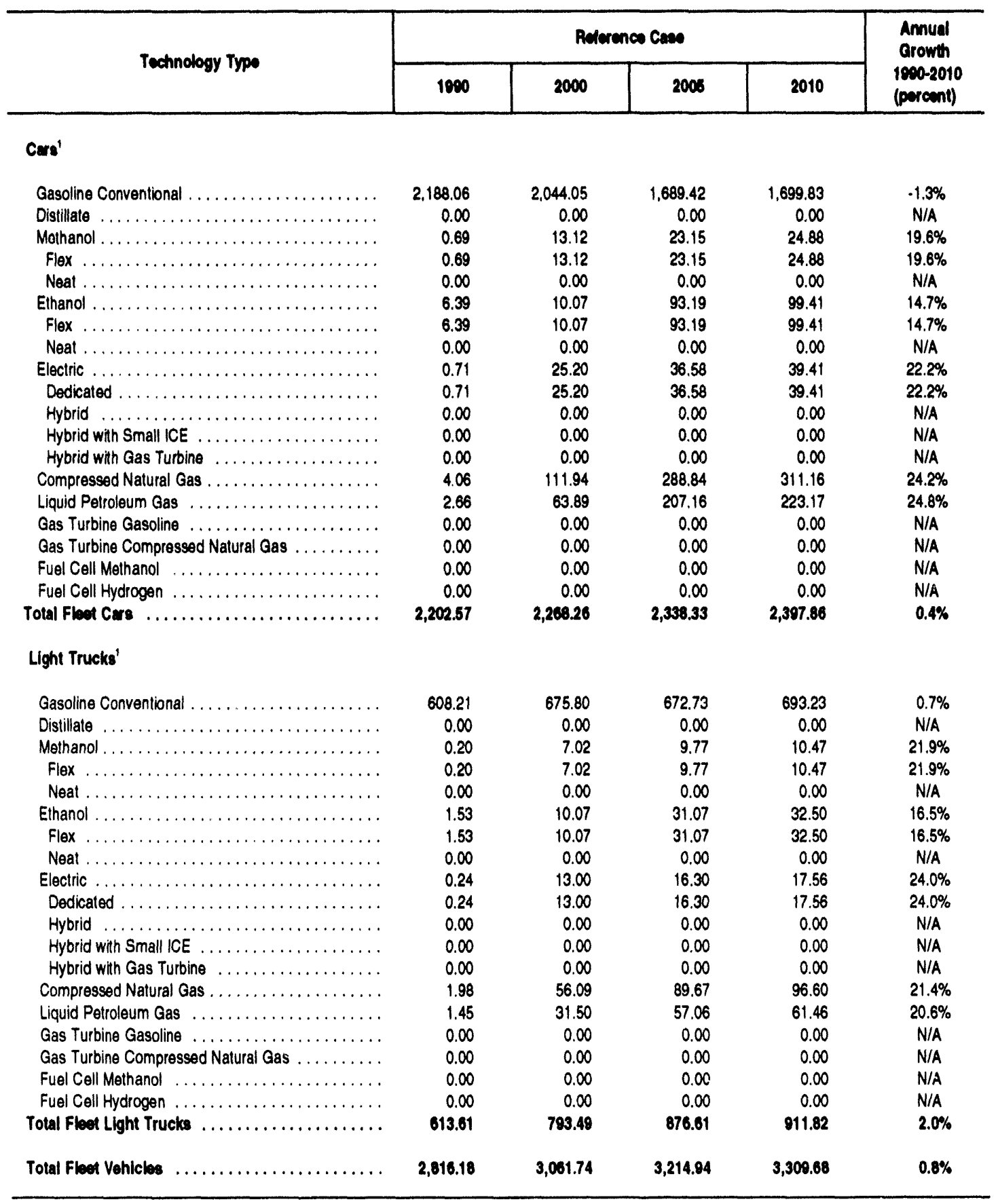

Includes all commercial fleets of 10 or more.

$I C E=$ internal combustion engine.

N/A = Not Applicable.

Sources: Oak Ridge National Laboratory, "Fleet Vehicles in the United States: Composition, Operating Characteristics, and Fueling Practices", Prepared for the Department of Energy, Otfice of Transportation Technologies, and Office of Policy Planning and Analysis, March 1992; Bobit Publishing Company, Floet Fact Book. Fedondo Beach Calitornia, various issues; United States Department of Energy, Otfice of Domestic and International Energy Policy, "Assessment of Costs and Benefits of Fiexible and Alternative Fuel Use in the U.S. Transportation Sector, Technical Report Ten: Analysis of Alternative-Fuel Fleet Requirements", (May 1992). Projectlons: Energy Information Administration, AEO 1994 National Energy Modeling System run AEO94B.D1221934. 
Table 33. Transportation Fleot Car and Truck Stock by Typo and Tochnology (Thousands)

\begin{tabular}{|c|c|c|c|c|c|}
\hline \multirow{2}{*}{ Technology Type } & \multicolumn{4}{|c|}{ Relerencos Cases } & \multirow{2}{*}{$\begin{array}{c}\text { Amnual } \\
\text { Crowth } \\
1 \text { ceo-2010 } \\
\text { (percent) }\end{array}$} \\
\hline & 1800 & 2000 & 2006 & 2010 & \\
\hline \multicolumn{6}{|l|}{ Curs' } \\
\hline Gasoline Conventional. & $8,245.13$ & $8,080.17$ & $7,285.55$ & $7,346.83$ & $.0 .6 \%$ \\
\hline Distillate $\ldots \ldots \ldots \ldots \ldots \ldots \ldots \ldots \ldots$ & $0 . \infty$ & 0.00 & 0.00 & 0.00 & N/A \\
\hline$\ldots \ldots \ldots \ldots \ldots \ldots \ldots \ldots \ldots$ & 0.43 & 72.74 & 102.83 & 131.03 & $33.1 \%$ \\
\hline Flex $\ldots \ldots \ldots \ldots \ldots \ldots \ldots \ldots \ldots$ & 0.43 & 72.74 & 102.83 & 131.03 & $33.1 \%$ \\
\hline Neat $\ldots \ldots \ldots \ldots \ldots \ldots \ldots \ldots \ldots$ & 0.00 & 0.00 & 0.00 & 0.00 & N/A \\
\hline Ethanol $\ldots \ldots \ldots \ldots \ldots \ldots \ldots \ldots \ldots$ & 0.00 & 28.87 & 259.66 & 376.81 & N/A \\
\hline$\ldots \ldots \ldots \ldots \ldots$ & 0.00 & 28.87 & 259.66 & 376.81 & N/A \\
\hline$\ldots \ldots \ldots \ldots$ & 0.00 & 0.00 & 0.00 & 0.00 & N/A \\
\hline Electric $\ldots \ldots \ldots \ldots \ldots \ldots \ldots \ldots$ & 0.43 & 142.55 & 178.65 & 222.84 & $36.7 \%$ \\
\hline Dedicated $\ldots \ldots \ldots \ldots \ldots \ldots \ldots \ldots \ldots$ & 0.43 & 142.55 & 178.65 & 222.84 & $36.7 \%$ \\
\hline$\ldots \ldots \ldots \ldots \ldots \ldots \ldots \ldots \ldots$ & 0.00 & 0.00 & 0.00 & 0.00 & N/A \\
\hline Hybrid with Small ICE . .................. & 0.00 & 0.00 & 0.00 & 0.00 & N/A \\
\hline Hybrid whth Gas Turbine $\ldots \ldots \ldots \ldots \ldots \ldots$ & 0.00 & 0.00 & 0.00 & 0.00 & N/A \\
\hline Compressed Natural Gas $\ldots \ldots \ldots \ldots \ldots \ldots$ & 6.00 & 608.14 & $1,102.15$ & $1,602.05$ & $32.2 \%$ \\
\hline 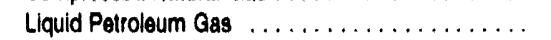 & 59.95 & 338.56 & 732.32 & $1,118.66$ & $15.8 \%$ \\
\hline (................. & 0.00 & 0.00 & 0.00 & 0.00 & N/A \\
\hline Gas Turbine Compressed Natural Gas .......... & 0.00 & 0.00 & 0.00 & 0.00 & N/A \\
\hline 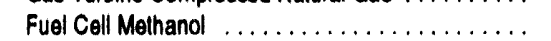 & 0.00 & 0.00 & 0.00 & 0.00 & N/A \\
\hline Fuel Cell Hydrogen $\ldots \ldots \ldots \ldots \ldots \ldots \ldots$ & 0.00 & 0.00 & 0.00 & 0.00 & N/A \\
\hline Totul Finet Cers $\ldots \ldots \ldots \ldots \ldots \ldots \ldots$ & $8,311.92$ & $9,251.02$ & $0,041.16$ & $10,793.22$ & $1.3 \%$ \\
\hline \multicolumn{6}{|l|}{ Light Trucke' } \\
\hline Gasoline Conventional & $2,450.50$ & $3,287.91$ & $3,463.09$ & $3,460.04$ & $1.7 \%$ \\
\hline Distillate $\ldots \ldots \ldots \ldots \ldots \ldots \ldots \ldots \ldots \ldots \ldots$ & 0.00 & 0.00 & 0.00 & 0.00 & N/A \\
\hline Methanol ........................... & 2.06 & 32.80 & 42.43 & 50.27 & $17.3 \%$ \\
\hline Flex $\ldots \ldots \ldots \ldots \ldots \ldots \ldots \ldots$ & 2.06 & 32.80 & 42.43 & 50.27 & $17.3 \%$ \\
\hline Neat $\ldots \ldots \ldots \ldots \ldots \ldots \ldots \ldots \ldots \ldots \ldots$ & 0.00 & 0.00 & 0.00 & 0.00 & N/A \\
\hline Ethanol $\ldots \ldots \ldots \ldots \ldots \ldots \ldots \ldots$ & 0.00 & 29.24 & 108.67 & 153.70 & N/A \\
\hline$\ldots \ldots \ldots \ldots \ldots$ & 0.00 & 29.24 & 108.67 & 153.70 & N/A \\
\hline Neat $\ldots \ldots \ldots \ldots \ldots \ldots \ldots \ldots \ldots \ldots$ & 0.00 & 0.00 & 0.00 & 0.00 & N/A \\
\hline Electric $\ldots \ldots \ldots \ldots \ldots \ldots \ldots \ldots \ldots$ & 2.06 & 62.57 & 73.55 & 84.54 & $20.4 \%$ \\
\hline$\ldots \ldots \ldots \ldots \ldots \ldots \ldots \ldots$ & 2.06 & 62.57 & 73.55 & 84.54 & $20.4 \%$ \\
\hline$\ldots \ldots \ldots \ldots \ldots \ldots$ & 0.00 & 0.00 & 0.00 & 0.00 & $N / A$ \\
\hline Hybrid with Small ICE & 0.00 & 0.00 & 0.00 & 0.00 & N/A \\
\hline Hybrid with Gas Turbine $\ldots \ldots \ldots \ldots \ldots \ldots$ & 0.00 & 0.00 & 0.00 & 0.00 & $\mathrm{~N} / \mathrm{A}$ \\
\hline Compressed Natural Gas . & 28.85 & 281.89 & 381.64 & 499.89 & $15.3 \%$ \\
\hline Liquid Petroleum Gas ... & 288.47 & 162.20 & 236.53 & 327.26 & $0.6 \%$ \\
\hline Gas Turbine Gasoline & 0.00 & 0.00 & 0.00 & 0.00 & N/A \\
\hline Gas Turbine Compressed Nalural Gas. & 0.00 & 0.00 & 0.00 & 0.00 & N/A \\
\hline 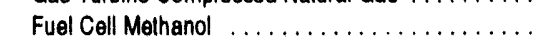 & 0.00 & 0.00 & 0.00 & 0.00 & N/A \\
\hline Fuel Cell Hydrogen & 0.00 & 0.00 & 0.00 & 0.00 & N/A \\
\hline Total Fleot Light Trucks .................. & $2,771.96$ & $3,866.61$ & $4,306.91$ & 4,576.70 & $2.5 \%$ \\
\hline Total Fled Vehicles $\ldots \ldots \ldots \ldots \ldots \ldots \ldots$ & $11,020.87$ & $13,107.63$ & $13,947.07$ & $15,373.02$ & $1.6 \%$ \\
\hline
\end{tabular}

'Includes all commercial tleets of 10 or more.

ICE = Internal combustion engine.

N/A $=$ Nol applicable.

Sources: Oak Fidge National Laboratory, "Fleel Vehicles in the United States: Composition, Operating Characteristics, and Fueling Practices", Prepared for the Department of Energy. Otfice of Transportation Technologies, and Office of Policy Planning and Analysis, March 1982; Bobit Publishing Company, Fleet Fact Book, Redondo Beach California, various issues; United States Department of Energy, Olfice of Domestic and International Energy Policy. "Assessment of Costs and Benelits of Floxible and Alternative Fuel Use in the U.S. Transportation Sector, Technical Report Ten: Analysis of Alternative-Fuel Fleol Requirements", (May 1892). Projectlone: Energy Information Administration, AEO 1094 National Energy Modeling System run AEO94B.D1221934. 
Table 34. Transportation Fieot Car and Truck VMT by Type and Technology (Trillion Btu per Year)

\begin{tabular}{|c|c|c|c|c|c|}
\hline \multirow{2}{*}{ Technology Typ } & \multicolumn{4}{|c|}{ Rulerences cen } & \multirow{2}{*}{ 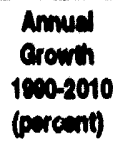 } \\
\hline & 1000 & 2000 & 200 & 2010 & \\
\hline \multicolumn{6}{|l|}{ Cent' } \\
\hline Gasoline Conventional $\ldots \ldots \ldots \ldots \ldots \ldots$ & 201.84 & 190.72 & 169.44 & 168.67 & $.0 .8 \%$ \\
\hline Distillate $\ldots \ldots \ldots \ldots \ldots \ldots \ldots \ldots \ldots \ldots$ & 0.00 & 0.00 & 0.00 & 0.00 & N/A \\
\hline Mothanol $\ldots \ldots \ldots \ldots \ldots \ldots \ldots \ldots$ & 0.01 & 1.72 & 2.40 & 3.01 & $32.7 \%$ \\
\hline Flex $\ldots \ldots \ldots \ldots \ldots \ldots \ldots \ldots \ldots$ & 0.01 & 1.72 & 2.40 & 3.01 & $32.7 \%$ \\
\hline Neat $\ldots \ldots \ldots \ldots \ldots \ldots \ldots \ldots \ldots \ldots$ & 0.00 & 0.00 & 0.00 & 0.00 & N/A \\
\hline Elhanol $\ldots \ldots \ldots \ldots \ldots \ldots \ldots \ldots \ldots$ & 0.00 & 0.68 & 6.08 & 8.65 & $N / A$ \\
\hline Flex $\ldots \ldots \ldots \ldots \ldots \ldots \ldots \ldots \ldots$ & 0.00 & 0.68 & 6.08 & 8.65 & N/A \\
\hline Neat $\ldots \ldots \ldots \ldots \ldots \ldots \ldots \ldots \ldots$ & 0.00 & 0.00 & 0.00 & 0.00 & N/A \\
\hline Electric $\ldots \ldots \ldots \ldots \ldots \ldots \ldots \ldots$ & 0.01 & 3.37 & 4.17 & 5.11 & $38.3 \%$ \\
\hline Dedicated $\ldots \ldots \ldots \ldots \ldots \ldots \ldots \ldots \ldots$ & 0.01 & 3.37 & 4.17 & 5.11 & $38.3 \%$ \\
\hline Hybrid $\ldots \ldots \ldots \ldots \ldots \ldots \ldots \ldots$ & 0.00 & 0.00 & 0.00 & 0.00 & N/A \\
\hline Hybrid with Small ICE . . . . . . . . . . . . . . . . & 0.00 & 0.00 & 0.00 & 0.00 & $N / A$ \\
\hline Hybrid with Gas Turbine $\ldots . \ldots \ldots \ldots \ldots \ldots$ & 0.00 & 0.00 & 0.00 & 0.00 & $\mathbf{N} / \mathbf{A}$ \\
\hline Compressed Natural Gas . . . . . . . . . . . . . . . . & 0.16 & 14.39 & 25.70 & 38.76 & $31.8 \%$ \\
\hline Liquid Pelroleum Gas . . . . . . . . . . . . . . . . & 1.47 & 8.01 & 17.08 & 25.67 & $15.4 \%$ \\
\hline Gas Turbine Gasoline $\ldots \ldots \ldots \ldots \ldots \ldots \ldots$ & 0.00 & 0.00 & 0.00 & 0.00 & N/A \\
\hline Gas Turbine Compressed Natural Gas ........ & 0.00 & 0.00 & 0.00 & 0.00 & N/A \\
\hline Fuel Cell Methanol $\ldots \ldots \ldots \ldots \ldots \ldots \ldots$ & 0.00 & 0.00 & 0.00 & 0.00 & $N / A$ \\
\hline Fuel Cell Hydrogen $\ldots \ldots \ldots \ldots \ldots \ldots \ldots \ldots$ & 0.00 & 0.00 & 0.00 & 0.00 & $\mathbf{N} / \mathbf{A}$ \\
\hline Total Fint Can ..................... & 203.47 & 218.90 & 224.4 & 247.70 & $1.0 \%$ \\
\hline \multicolumn{6}{|l|}{ Ught Trucks } \\
\hline Gasoline Coinventional . . . . . . . . . . . . . . . & 59.99 & 77.80 & 80.76 & 79.39 & $1.4 \%$ \\
\hline Distillate $\ldots \ldots \ldots \ldots \ldots \ldots \ldots \ldots \ldots$ & 0.00 & 0.00 & 0.00 & 0.00 & N/A \\
\hline Methanol $\ldots \ldots \ldots \ldots \ldots \ldots \ldots \ldots$ & 0.05 & 0.78 & 0.99 & 1.15 & $18.9 \%$ \\
\hline Flex $\ldots \ldots \ldots \ldots \ldots \ldots \ldots \ldots \ldots$ & 0.05 & 0.78 & 0.99 & 1.15 & $16.9 \%$ \\
\hline Neat $\ldots \ldots \ldots \ldots \ldots \ldots \ldots \ldots$ & 0.00 & 0.00 & 0.00 & 0.00 & N/A \\
\hline Ethanol $\ldots \ldots \ldots \ldots \ldots \ldots \ldots \ldots$ & 0.00 & 0.69 & 2.53 & 3.53 & N/A \\
\hline Flex $\ldots \ldots \ldots \ldots \ldots \ldots \ldots \ldots$ & 0.00 & 0.69 & 2.53 & 3.53 & N/A \\
\hline Neat $\ldots \ldots \ldots \ldots \ldots \ldots \ldots \ldots$ & 0.00 & 0.00 & 0.00 & 0.00 & N/A \\
\hline Eloctric $\ldots \ldots \ldots \ldots \ldots \ldots \ldots \ldots$ & 0.05 & 1.48 & 1.72 & 1.94 & $20.0 \%$ \\
\hline Dedicated $\ldots \ldots \ldots \ldots \ldots \ldots \ldots \ldots \ldots \ldots$ & 0.05 & 1.48 & 1.72 & 1.94 & $20.0 \%$ \\
\hline Hybrid $\ldots \ldots \ldots \ldots \ldots \ldots \ldots \ldots \ldots$ & 0.00 & 0.00 & 0.00 & 0.00 & $N / A$ \\
\hline Hybrid with Small ICE $\ldots \ldots \ldots \ldots \ldots \ldots \ldots$ & 0.00 & 0.00 & 0.00 & 0.00 & N/A \\
\hline Hybrid with Gas Turbine $\ldots \ldots \ldots \ldots \ldots$ & 0.00 & 0.00 & 0.00 & 0.00 & N/A \\
\hline Compressed Natural Gas . . . . . . . . . . . . . & 0.71 & 6.67 & 8.90 & 11.47 & $15.0 \%$ \\
\hline Liquid Petroleum Gas .................. & 7.08 & 3.84 & 5.52 & 7.51 & $0.3 \%$ \\
\hline Gas Turbine Gasoline $\ldots \ldots \ldots \ldots \ldots \ldots \ldots$ & 0.00 & 0.00 & 0.00 & 0.00 & N/A \\
\hline Gas Turbine Compressed Natural Gas $\ldots \ldots \ldots \ldots$ & 0.00 & 0.00 & 0.00 & 0.00 & N/A \\
\hline Fuel Cell Methanol $\ldots \ldots \ldots \ldots \ldots \ldots \ldots$ & 0.00 & 0.00 & 0.00 & 0.00 & N/A \\
\hline Fuel Cell Hydrogen $\ldots \ldots \ldots \ldots \ldots \ldots \ldots$ & 0.00 & 0.00 & 0.00 & 0.00 & $N / A$ \\
\hline Total Finot LIght Truck $\ldots \ldots \ldots \ldots \ldots \ldots$ & 67.86 & 91.20 & 100.42 & 104.90 & $2.2 \%$ \\
\hline Total Flast Vehleiss $\ldots \ldots \ldots \ldots \ldots \ldots \ldots$ & 271.39 & 310.16 & 326.23 & 382.76 & $1.3 \%$ \\
\hline
\end{tabular}

'Fleet vehicles include only centrally garaged vehicles.

ICE = Internal combustion engine.

N/A = Not applicable.

Sources: Oak Ridge National Laboratory. "Fleet Vehicies in the United States: Composition, Operating Characteristics, and Fueling Practices", Prepared lor the Department of Energy. OHice of Transportation Technologies, and Otlice of Policy Planning and Analysis, March 1982; Bobit Publishing Company, Fleet Fact Book, Redondo Beach Calitornia, various issues; United States Department of Energy, Otfice of Domestic and International Energy Policy, "Assessment of Costs and Benefits of Flexible and Alternative Fuel Use in the U.S. Transportation Sector, Technical Report Ten: Analysis of Alternative-Fuel Fleet Requirements", (May 1992). Projectlons: Energy Information Administration, AEO 1994 National Energy Modeling System run AEOQ4B.D1221934. 


\begin{tabular}{|c|c|c|c|c|c|}
\hline \multirow{2}{*}{ Indlentore } & \multicolumn{4}{|c|}{ Ruturences Conse } & \multirow{2}{*}{$\begin{array}{l}\text { Armud } \\
\text { Crowth } \\
\text { 19ep-2010 } \\
\text { (aronl) }\end{array}$} \\
\hline & 1900 & 2000 & 2000 & 2010 & \\
\hline \multicolumn{6}{|l|}{ Travel Demand (blillon of milen) } \\
\hline Revenue Passenger Miles Domestic . . . . . . . . . . & 302.7 & 478.0 & 532.8 & 590.6 & $2.5 \%$ \\
\hline RPM Business $\ldots \ldots \ldots \ldots \ldots \ldots \ldots$ & 166.9 & 218.2 & 248.2 & 275.4 & $2.5 \%$ \\
\hline Laad Factor Domestic ${ }^{\prime}$.. & 0.6 & 0.6 & 0.6 & 0.6 & N/A \\
\hline Revenue Passenger Miles Intemational $\ldots \ldots \ldots$ & 126.7 & 223.8 & 256.3 & 291.8 & $4.3 \%$ \\
\hline Load Faclor International' $\ldots \ldots \ldots \ldots \ldots$ & 0.7 & 0.7 & 0.7 & 0.7 & $N / A$ \\
\hline Revenue Ton MHles Freight (bllion ) . . . . . . . . & 10.1 & 19.3 & 25.2 & 30.6 & $5.7 \%$ \\
\hline GDP (billion 1987 dollars) $\ldots \ldots \ldots \ldots \ldots \ldots$ & 4.877 .4 & $6,040.7$ & $6,738.3$ & $7,396.7$ & $2.1 \%$ \\
\hline Fuel Cost (1991 dollars per thousand Btu) $\ldots \ldots$ & 5.0 & 4.5 & 5.1 & 5.7 & $0.6 \%$ \\
\hline Seat Miles Demanded (billion) $\ldots \ldots \ldots \ldots \ldots$ & 786.6 & $1,137.7$ & 1.310 .3 & $1,484.9$ & $3.2 \%$ \\
\hline \multicolumn{6}{|l|}{ Atroren salu } \\
\hline$\ldots \ldots \ldots \ldots \ldots \ldots$ & 279 & 244 & 206 & 225 & $.1 .1 \%$ \\
\hline Wide Body Alrcralt . . . . . . . . . . . . . . . . . & 55 & 76 & 80 & 90 & $2.5 \%$ \\
\hline \multicolumn{6}{|l|}{ Atrorent stock } \\
\hline Narrow Body Aircraft & 3,675 & 4,806 & 5,285 & 5,675 & $2.2 \%$ \\
\hline Wide Body Alrcralt . ..................... & 721 & 1.170 & 1,415 & 1,676 & $4.3 \%$ \\
\hline \multicolumn{6}{|l|}{ 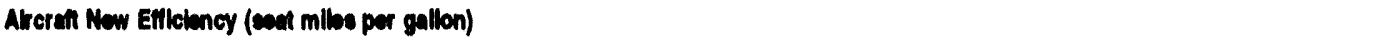 } \\
\hline Wide Body Arcraft . .................... & 55.1 & 60.3 & 61.7 & 63.8 & $0.7 \%$ \\
\hline Average Aircraft Elficiency $\ldots \ldots \ldots \ldots \ldots$ & 45.6 & 51.6 & 53.6 & 55.4 & $1.0 \%$ \\
\hline \multicolumn{6}{|l|}{ Akerath Stock Efilcioncy (ceat miles per gallon) } \\
\hline Narrow Bociy Alrcraht,$\ldots \ldots \ldots \ldots \ldots \ldots$ & 44.0 & 47.1 & 48.6 & 50.2 & $0.7 \%$ \\
\hline Wide Body Aircralt . . . . . . . . . . . . . . . & 55.0 & 57.6 & 58.9 & 60.2 & $0.5 \%$ \\
\hline Averago Aircraft Slock Effliciency $\ldots \ldots \ldots \ldots \ldots$ & 48.2 & 51.8 & 53.5 & 55.1 & $0.7 \%$ \\
\hline \multicolumn{6}{|l|}{ Seat Mlle Demanded (bllllon) } \\
\hline Narrow Body Aircraft $\ldots \ldots \ldots \ldots \ldots \ldots$ & 440.5 & 576.2 & 631.1 & 680.1 & $2.2 \%$ \\
\hline Wide Body Aircraft . . . . . . . . . . . . . . . . . & 346.1 & 561.5 & 679.2 & 804.8 & $4.3 \%$ \\
\hline \multicolumn{6}{|l|}{$\begin{array}{l}\text { Fud Consumption (trillion Btu) } \\
\text { Commerclal }\end{array}$} \\
\hline Jel Fuel $\ldots \ldots \ldots \ldots \ldots \ldots \ldots \ldots \ldots$ & $2,334.5$ & $3,147.5$ & $3,509.5$ & $3,856.3$ & $2.5 \%$ \\
\hline $\begin{array}{l}\text { Aviation Gasoline } \ldots \ldots \ldots \ldots \ldots \ldots \ldots \ldots \\
\text { Militery }\end{array}$ & 45.4 & 42.6 & 42.3 & 42.1 & $.0 .4 \%$ \\
\hline Jet Fuel & 795.0 & 570.1 & 573.7 & 582.5 & $\cdot 1.5 \%$ \\
\hline
\end{tabular}

'Fraction of seats filled.

APM = Revenue passenger miles.

GDP = Gross domestic product.

Blu $=$ British thermal unit

$N / A=$ Nol applicable

Sourcee: Federal Aviation Administration (FAA), FAA Aviation Forecasts, Fiscal Years 1001-2002, FAA-APO 91-1, and previous editions: United Slates Department of Transportation (DOT), Research and Special Programs Administration (RSPA). Fuel Cost and Consumption Tables. annual summaries, 1979-1090; DOT, ASPA, Air Carrier Financial Statistics Quarterly, December 1090/1989, and prior issues; DOT, RSPA, Air Carrier Traffic Statistics Monthly, December 1990/1080, and prior issues; Greene, D.L., "Energy Efticiency Improvement Polential of Commercial Aircraft to 2010", ORNL-6622, 6/1090; and Aalhi, A., B. Peterson, and D. Greene, Air Transport Energy Use Model, Oak Ridge National Laboratory, April 1091. Drafl. Propectlona: Energy Information Administration. AEO 1994 National Energy Modeling System run AEO94B.D1221934. 


\begin{tabular}{|c|c|c|c|c|c|}
\hline \multirow{2}{*}{ Technology and Fud } & \multicolumn{4}{|c|}{ Rumenes Cons } & \multirow{2}{*}{$\begin{array}{l}\text { Annucl } \\
\text { Crowth } \\
1 \text { cep-2010 } \\
\text { (pereent) }\end{array}$} \\
\hline & 1000 & 2000 & 2000 & 2010 & \\
\hline \multicolumn{6}{|l|}{$\begin{array}{l}\text { Trucks } \\
\text { Fud Effickency (mile per gallon of ful) } \\
\text { Small (< } 10,000 \text { pounds) }\end{array}$} \\
\hline$\ldots \ldots \ldots \ldots$ & 14.18 & 15.44 & 16.09 & 16.67 & $0.8 \%$ \\
\hline Diesel . . . . . . . . . . . . . . . . . . . & 17.14 & 18.68 & 19.44 & 20.15 & $0.8 \%$ \\
\hline$\ldots \ldots \ldots \ldots \ldots \ldots$ & 15.81 & 17.21 & 17.94 & 18.59 & $0.8 \%$ \\
\hline $\begin{array}{l}\text { Liquid Petroleum Gas } \ldots \ldots \ldots \ldots \ldots \ldots \ldots \ldots \\
\text { Madhum }(10,000-19,800 \text { pounda) }\end{array}$ & 15.81 & 17.21 & 17.94 & 18.59 & $0.8 \%$ \\
\hline Gasoline $\ldots \ldots \ldots \ldots \ldots \ldots \ldots \ldots$ & 6.83 & 7.08 & 7.20 & 7.27 & $0.3 \%$ \\
\hline Diesel . . . . . . . . . . . . . . . . . . & 7.49 & 7.76 & 7.88 & 7.97 & $0.3 \%$ \\
\hline Alcohol $\ldots \ldots \ldots \ldots \ldots \ldots \ldots \ldots$ & 5.04 & 5.22 & 5.30 & 5.38 & $0.3 \%$ \\
\hline \multicolumn{5}{|l|}{ Heary (> 19,500 pounds) } & $0.3 \%$ \\
\hline Gasoline ............ & 5.43 & 5.62 & 5.71 & 5.78 & $0.3 \%$ \\
\hline Diesel $\ldots \ldots \ldots \ldots \ldots \ldots \ldots \ldots \ldots$ & 5.33 & 5.52 & 5.61 & 5.67 & $0.3 \%$ \\
\hline Alcohol $\ldots \ldots \ldots \ldots \ldots \ldots \ldots \ldots$ & 5.02 & 5.20 & 5.29 & 5.35 & $0.3 \%$ \\
\hline Liquid Petroleum Gas $\ldots \ldots \ldots \ldots \ldots \ldots \ldots$ & 5.02 & 5.20 & 5.29 & 5.35 & $0.3 \%$ \\
\hline \multicolumn{6}{|l|}{ Vehich MIles Travelad (billion) } \\
\hline Small $(<10,000$ pounds) $\ldots \ldots \ldots \ldots \ldots$ & 170.34 & 227.81 & 250.66 & 273.40 & $2.4 \%$ \\
\hline Gasoline . . . . . . . . . . . . . . . . . & 166.02 & 217.89 & 238.40 & 253.14 & $2.1 \%$ \\
\hline Diesel . . . . . . . . . . . . . . . . . . & 4.17 & 9.72 & 14.04 & 20.02 & $8.2 \%$ \\
\hline Alcohol $\ldots \ldots \ldots \ldots \ldots \ldots \ldots \ldots$ & 0.00 & 0.00 & 0.00 & 0.00 & N/A \\
\hline Liquid Petroleum Gas $\ldots . \ldots \ldots \ldots \ldots$ & 0.15 & 0.21 & 0.23 & 0.25 & $2.4 \%$ \\
\hline Medium $(10,000-19,500$ pounds $) \ldots \ldots \ldots \ldots$ & 51.96 & 69.49 & 76.46 & 83.40 & $2.4 \%$ \\
\hline Gasoline $\ldots \ldots \ldots \ldots \ldots \ldots \ldots \ldots$ & 36.57 & 42.69 & 43.28 & 43.05 & $0.8 \%$ \\
\hline Diesel . . . . . . . . . . . . . . . . . & 15.03 & 26.30 & 32.64 & 39.76 & $5.0 \%$ \\
\hline Alcohol $\ldots \ldots \ldots \ldots \ldots \ldots \ldots \ldots$ & 0.00 & 0.00 & 0.00 & 0.00 & $N / A$ \\
\hline Liquid Petroleum Gas $\ldots \ldots \ldots \ldots \ldots \ldots$ & 0.37 & 0.49 & 0.54 & 0.59 & $2.4 \%$ \\
\hline Heavy $(>19.500$ pounds $) \ldots \ldots \ldots \ldots$ & 93.38 & 124.88 & 137.41 & 149.88 & $2.4 \%$ \\
\hline Gasoline . . . . . . . . . . . . . . . & 4.07 & 2.04 & 1.36 & 0.90 & $.7 .3 \%$ \\
\hline 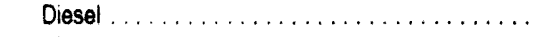 & 89.25 & 122.77 & 135.97 & 148.89 & $2.6 \%$ \\
\hline Alcohol $\ldots \ldots \ldots \ldots \ldots \ldots \ldots \ldots$ & 0.00 & 0.00 & 0.00 & 0.00 & N/A \\
\hline Liquid Petroleum Gas $\ldots \ldots \ldots \ldots \ldots$ & 0.06 & 0.07 & 0.08 & 0.09 & $2.4 \%$ \\
\hline Total Vehicte Mlles Travoled Trucks $\ldots . . \ldots \ldots$ & 315.68 & 422.18 & $\mathbf{4 4 5 3}$ & 500.69 & $2.4 \%$ \\
\hline \multicolumn{6}{|l|}{ Trucks } \\
\hline \multicolumn{6}{|l|}{ Fuel Consumption (trillion Btu) } \\
\hline$\ldots \ldots \ldots$ & $2,722.88$ & $3,747.08$ & $4,166.99$ & $4,614.15$ & $2.7 \%$ \\
\hline Motor Gasoline $\ldots \ldots \ldots \ldots \ldots \ldots \ldots$ & $2,303.09$ & $2,659.01$ & $2,716.85$ & $2,758.21$ & $0.9 \%$ \\
\hline Alcohol $\ldots \ldots \ldots \ldots \ldots \ldots \ldots \ldots \ldots$ & 0.00 & 0.00 & 0.00 & 0.00 & N/A \\
\hline Liquid Pelroleum Gas . . . . . . . . . . . . . . . . & 13.05 & 16.77 & 18.11 & 19.49 & $2.0 \%$ \\
\hline \multicolumn{6}{|l|}{ Rallroads } \\
\hline Ton Miles by Rail (billion ton miles) & 898.99 & $1,046.40$ & $1,119.74$ & $1,200.59$ & $1.5 \%$ \\
\hline Fuel Efticiency (ton miles per 1,000 Btu) $\ldots \ldots \ldots$ & 2.03 & 2.12 & 2.15 & 2.18 & $0.3 \%$ \\
\hline \multicolumn{6}{|l|}{ Fuel Consumption (trillion Btu) } \\
\hline Diesel (distillate) . . . . . . & 456.87 & 510.01 & 538.64 & 568.61 & $1.1 \%$ \\
\hline$\ldots \ldots \ldots \ldots \ldots \ldots \ldots \ldots$ & 0.00 & 0.00 & 0.00 & 0.00 & N/A \\
\hline Electricty $\ldots \ldots \ldots \ldots \ldots \ldots \ldots \ldots$ & 0.00 & 0.00 & 0.00 & 0.00 & N/A \\
\hline \multicolumn{6}{|l|}{ Domeatic Shipping } \\
\hline Ton Miles Shipping (billion ton miles) & 771.11 & 825.87 & 874.96 & 928.72 & $0.9 \%$ \\
\hline $\begin{array}{l}\text { Fuel Efliciency (ton miles per } 1,000 \text { Btu) } \ldots \ldots \ldots \\
\text { Fuel Consumption (trillion Btu) }\end{array}$ & 0.37 & 0.37 & 0.38 & 0.38 & $0.1 \%$ \\
\hline Diesel (distillate) $\ldots \ldots \ldots \ldots \ldots \ldots \ldots \ldots$ & 214.19 & 231.25 & 246.36 & 262.96 & $1.0 \%$ \\
\hline Residual Oil $\ldots \ldots \ldots \ldots \ldots \ldots \ldots \ldots$ & 94,37 & 101.92 & 108.55 & 115.82 & $1.0 \%$ \\
\hline Motor Gasoline . . & 0.00 & 0.00 & 0.00 & 0.00 & N/A \\
\hline
\end{tabular}


Tablo 36. Frelght Transportation Enorgy Uso (Continued)

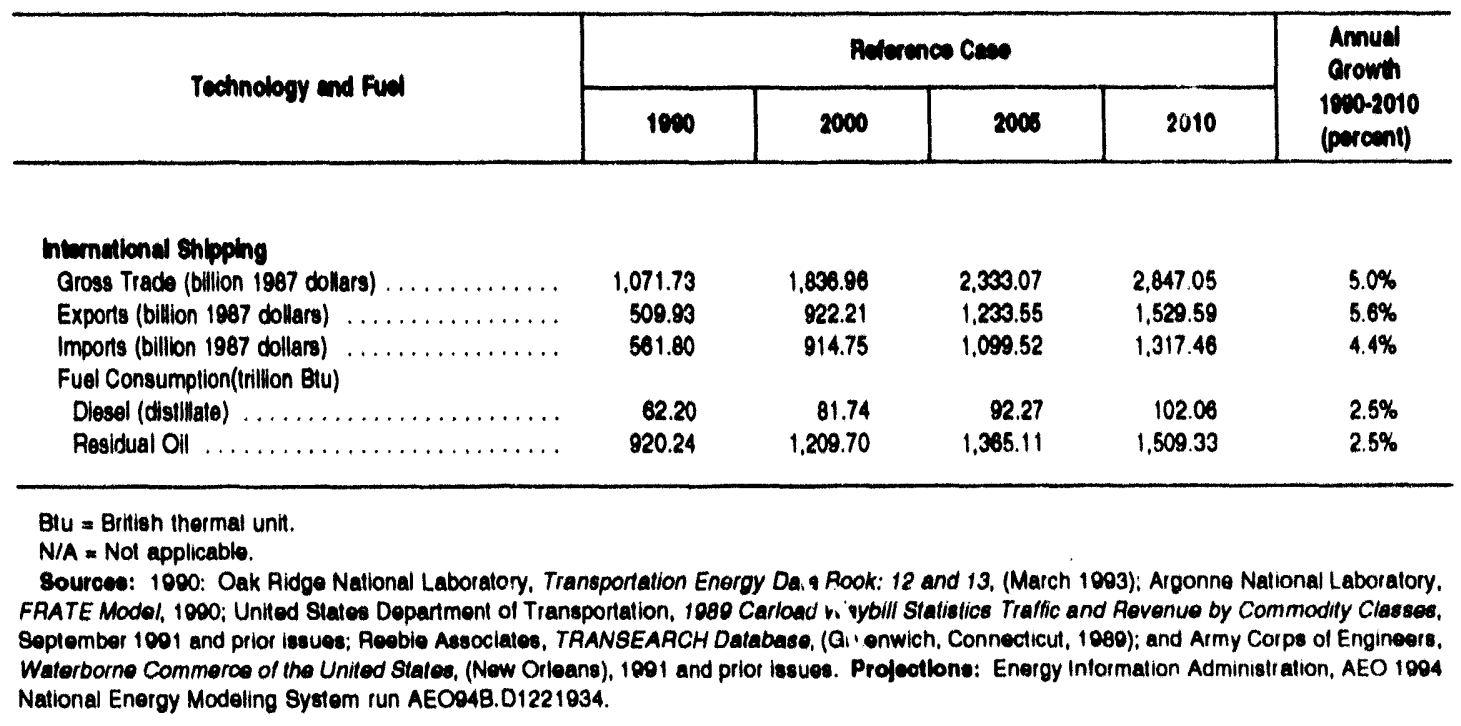


Table 37. Vehicle Sales by Census Division

(Millions)

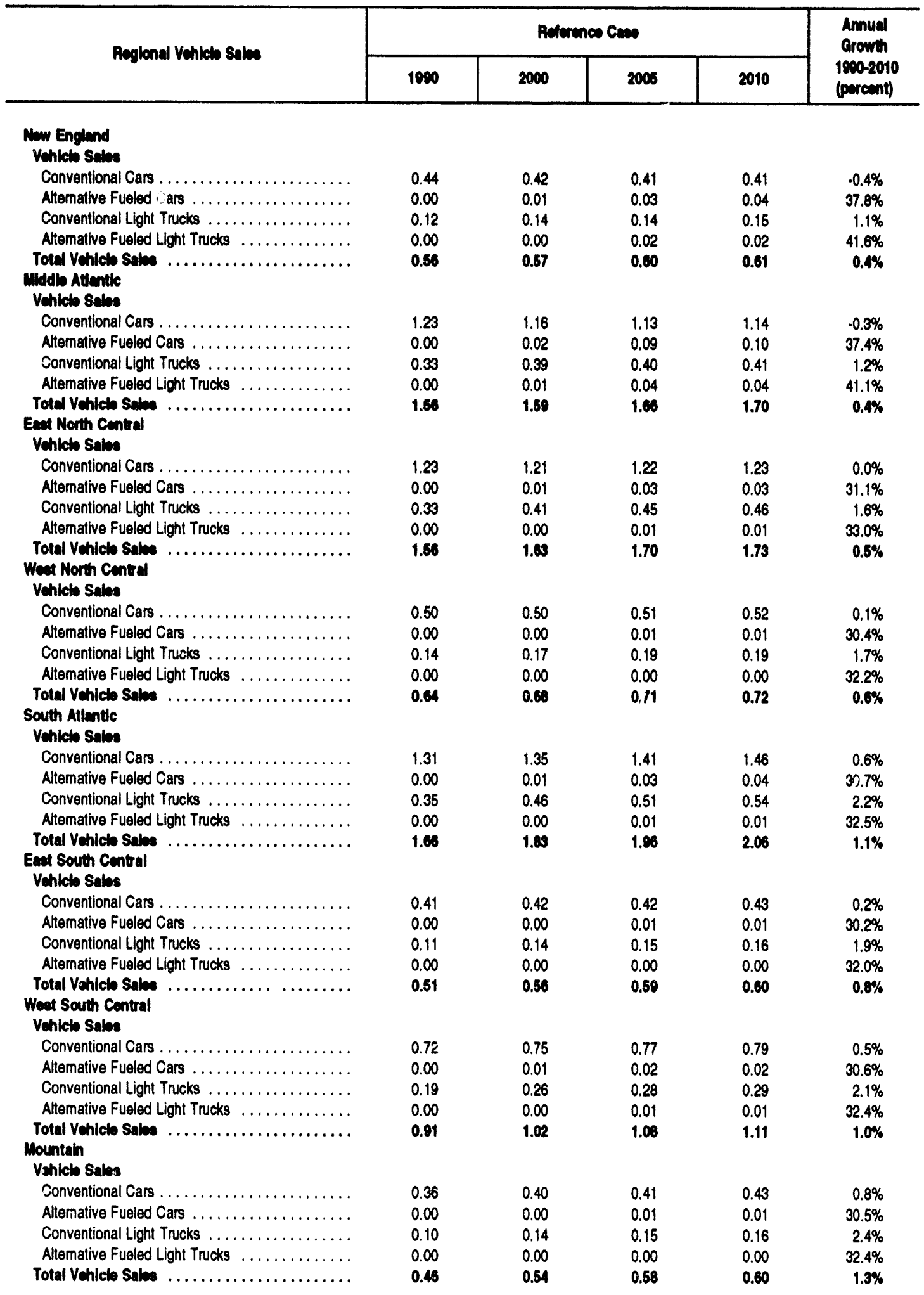


Table 37. Vehicle Sales by Census Division (Continued) (Millions)

\begin{tabular}{|c|c|c|c|c|c|}
\hline \multirow{2}{*}{ Reglond Vhich salo } & \multicolumn{4}{|c|}{ Peterences Cuse } & \multirow{2}{*}{$\begin{array}{l}\text { Amud } \\
\text { Orowth } \\
1900-2010 \\
\text { (peremil) }\end{array}$} \\
\hline & 1000 & 2000 & 2005 & 2010 & \\
\hline \multicolumn{6}{|l|}{$\begin{array}{l}\text { Pactile } \\
\text { Vehichs Salse }\end{array}$} \\
\hline Conventional Cars & 1.19 & 1.19 & 1.07 & 1.10 & $.0 .4 \%$ \\
\hline Alternative Fueled Cars $\ldots \ldots \ldots \ldots \ldots \ldots$ & 0.00 & 0.04 & 0.20 & 0.21 & $44.1 \%$ \\
\hline Conventional Light Trucks $\ldots \ldots \ldots \ldots \ldots \ldots$ & 0.32 & 0.40 & 0.36 & 0.38 & $0.8 \%$ \\
\hline Altemative Fueled Light Trucks & 0.00 & 0.02 & 0.10 & 0.11 & $48.8 \%$ \\
\hline Total Vehicts salm ................... & 1.51 & 1.6 & 1.74 & 1.80 & $0.8 \%$ \\
\hline
\end{tabular}

Sources: Oak Ridge National Laboratory, "Fieet Vehicles in the United States: Composition, Operaling Characteristics, and Fueling Practices", Prepared for the Department of Energy, Oftice of Transportation Technologies, and Otfice of Policy Planning and Analysis, March 1992; Bobit Publishing Company, Fleet Fact Book, Redondo Beach California, various issues; United States Department of Energy, Office of Domestic and International Energy Policy, "Acsessment of Costs and Benefits of Flexible and Alternative Fuel Use in the U.S. Transportation Sector, Technical Report Ten: Analysis of Alternative-Fuel Fleet Requirements", (May 1992). Projectlons: Energy Intormation Administration, AEO 1994 Nationa Energy Modeling System run AEO04B.D1221834. 
Table 38. Electric Power Data and Projections for the EMM Region

East Central Area Reliability Coordination Agreement (ECAR)

\begin{tabular}{l|l|l|l|l|l}
\hline \multirow{2}{*}{ Electriclty Supply and Demand } & \multicolumn{4}{|c|}{ Reterence Case } & $\begin{array}{l}\text { Anmual } \\
\text { Growth } \\
1890-2010 \\
\text { (percent) }\end{array}$ \\
\cline { 2 - 6 } & 1900 & 2000 & 2006 & 2010 & \\
\hline
\end{tabular}

\begin{tabular}{|c|c|c|c|c|c|}
\hline $\begin{array}{l}\text { Electriclty Generating Capacity' } \\
\text { (glgawatts) } \\
\text { Utiltiles } \\
\text { Capacity }\end{array}$ & & & & & \\
\hline Coal Steam & 84.29 & 81.14 & 80.78 & 80.48 & $-0.2 \%$ \\
\hline ............... & 4.60 & 3.50 & 2.71 & 2.68 & $.2 .7 \%$ \\
\hline Combined Cycle .................... & 0.39 & 0.39 & 0.39 & 1.26 & $6.0 \%$ \\
\hline Combustion Turbine/Diesel ................ & 3.26 & 6.08 & 8.76 & 9.37 & $5.4 \%$ \\
\hline Nuclear Power $\ldots \ldots \ldots \ldots \ldots \ldots \ldots \ldots$ & 7.63 & 7.56 & 7.56 & 6.81 & $.0 .6 \%$ \\
\hline Pumped Storage/Other ${ }^{3} \ldots \ldots \ldots \ldots \ldots \ldots$ & 3.26 & 3.26 & 3.26 & 3.26 & N/A \\
\hline Renewable $\ldots \ldots \ldots \ldots \ldots \ldots \ldots \ldots$ & 1.29 & 1.37 & 1.37 & 1.37 & $0.3 \%$ \\
\hline Total Utillites Capablilty $\ldots \ldots \ldots \ldots \ldots \ldots$ & 104.73 & 103.31 & 104.83 & 105.23 & $0.0 \%$ \\
\hline Cumulative Planned Additions $8^{8}$ & & & & & \\
\hline Coal Steam & 0.00 & 0.62 & 0.62 & 0.62 & N/A \\
\hline Other Fossil Steam ${ }^{2}$ & 0.00 & 0.00 & 0.00 & 0.00 & N/A \\
\hline$\ldots \ldots \ldots, \ldots, \ldots, \ldots$ & 0.00 & 0.00 & 0.00 & 0.00 & N/A \\
\hline Combustion Turbine/Diesel . . . . . . . . . . . . . & 0.00 & 2.83 & 3.41 & 3.41 & N/A \\
\hline$\ldots \ldots \ldots \ldots \ldots \ldots$ & 0.00 & 0.00 & 0.00 & 0.00 & N/A \\
\hline Pumped Storage/Other $\ldots \ldots \ldots \ldots \ldots$ & 0.00 & 0.00 & 0.00 & 0.00 & N/A \\
\hline Renewablet $\ldots \ldots \ldots \ldots \ldots \ldots \ldots$ & 0.00 & 0.08 & 0.08 & 0.08 & N/A \\
\hline Total (planned) $\ldots \ldots \ldots \ldots \ldots \ldots \ldots \ldots$ & 0.00 & 3.52 & 4.11 & 4.11 & NA \\
\hline Cumulattve Unplanned Additions ${ }^{5}$ & & & & & \\
\hline Coal Steam & 0.00 & 0.00 & 0.00 & 0.00 & N/A \\
\hline Other Fossil Steam ${ }^{2} \ldots \ldots \ldots \ldots \ldots \ldots \ldots$ & 0.00 & 0.00 & 0.00 & 0.00 & $N / A$ \\
\hline Combined Cycle $\ldots \ldots \ldots \ldots \ldots \ldots \ldots$ & 0.00 & 0.00 & 0.00 & 0.87 & $N / A$ \\
\hline Combustion Turbine/Diesel . ............... & 0.00 & 0.00 & 2.18 & 2.80 & N/A \\
\hline Nuclear Power $\ldots \ldots \ldots \ldots \ldots \ldots \ldots \ldots$ & 0.00 & 0.00 & 0.00 & 0.00 & N/A \\
\hline Pumped Storage/Other ${ }^{3} \ldots \ldots \ldots \ldots \ldots$ & 0.00 & 0.00 & 0.00 & 0.00 & N/A \\
\hline Renewable ${ }^{4} \ldots \ldots \ldots \ldots \ldots \ldots \ldots$ & 0.00 & 0.00 & 0.00 & 0.00 & N/A \\
\hline Total (unplanned) $\ldots \ldots \ldots \ldots \ldots \ldots \ldots$ & 0.00 & 0.00 & 2.18 & 3.67 & NA \\
\hline Cumulative Total Utillty Additions .......... & 0.00 & 3.52 & 6.30 & 7.78 & NA \\
\hline Cumulattve Utility Retirements $\ldots \ldots \ldots \ldots$ & 0.00 & 5.00 & 6.25 & 7.33 & NA \\
\hline $\begin{array}{l}\text { Nonutilitios (excludes cogenerators) } \\
\text { Capacity' }\end{array}$ & & & & & \\
\hline Coal Steam $\ldots \ldots \ldots \ldots \ldots \ldots$ & 0.00 & 0.20 & 0.20 & 0.92 & N/A \\
\hline$\ldots \ldots \ldots \ldots \ldots$ & 0.00 & 0.13 & 0.13 & 0.13 & N/A \\
\hline$\ldots \ldots \ldots \ldots \ldots$ & 0.00 & 0.00 & 1.90 & 6.14 & N/A \\
\hline Combustion Turbine/Diesel $\ldots \ldots \ldots \ldots \ldots \ldots$ & 0.00 & 0.28 & 1.88 & 1.88 & $N / A$ \\
\hline$\ldots \ldots \ldots \ldots \ldots \ldots$ & 0.00 & 0.00 & 0.00 & 0.00 & N/A \\
\hline Pumped Storage/Other' $\ldots \ldots \ldots \ldots \ldots \ldots$ & 0.00 & 0.00 & 0.00 & 0.00 & N/A \\
\hline Renewable ${ }^{4} \ldots \ldots \ldots \ldots \ldots \ldots \ldots$ & 0.14 & 2.17 & 2.73 & 3.28 & $16.9 \%$ \\
\hline Total Nonutillities Capability $\ldots \ldots \ldots \ldots \ldots$ & 0.14 & 2.78 & 6.84 & 12.36 & $24.9 \%$ \\
\hline Cogenerators $^{9} \ldots \ldots \ldots \ldots \ldots \ldots \ldots \ldots$ & 4.87 & 5.14 & 5.17 & 5.19 & $0.3 \%$ \\
\hline $\begin{array}{l}\text { Electricity Demand } \\
\text { (billon kilowatthours) }\end{array}$ & & & & & \\
\hline$\ldots \ldots \ldots \ldots \ldots \ldots$ & 130.34 & 37.53 & 139.72 & 143.25 & $0.5 \%$ \\
\hline Commercial/Other ..... & 115.46 & 133.16 & 137.90 & 138.73 & $0.9 \%$ \\
\hline Industrial $\ldots \ldots \ldots \ldots \ldots \ldots \ldots \ldots \ldots$ & 172.19 & 209.27 & 229.15 & 246.98 & $1.8 \%$ \\
\hline Transportation $\ldots \ldots \ldots \ldots \ldots \ldots \ldots \ldots$ & 2.67 & 3.71 & 5.72 & 8.17 & $5.7 \%$ \\
\hline Total Sales $\ldots \ldots \ldots \ldots \ldots \ldots \ldots \ldots \ldots \ldots$ & 420.67 & 483.67 & 512.50 & 537.13 & $1.2 \%$ \\
\hline
\end{tabular}


Table 38. Electric Power Data and Projections for the EMM Region East Central Area Reliability Coordination Agreement (ECAR) (Continued)

\begin{tabular}{|c|c|c|c|c|c|}
\hline \multirow{2}{*}{ Electriclty Supply riad Demend } & \multicolumn{4}{|c|}{ Reference Caes } & \multirow{2}{*}{$\begin{array}{c}\text { Annual } \\
\text { Crowth } \\
1000-2010 \\
\text { (percent) }\end{array}$} \\
\hline & 1980 & 2000 & 2005 & 2010 & \\
\hline \multicolumn{6}{|l|}{ Nht Energy for Load (billlon kilowatthoure) } \\
\hline Nel International Electricity Imports .......... & .10 .90 & 0.06 & 0.06 & 0.07 & N/A \\
\hline $\begin{array}{l}\text { Net Interregional Electricity Imports } \ldots \ldots \ldots \ldots \ldots \\
\text { Purchases from Nonutilities }\end{array}$ & .47 .76 & .25 .17 & $\cdot 19.02$ & .23 .83 & $-3.4 \%$ \\
\hline (including cogenerators) ${ }^{11} \ldots$ & 7.88 & 16.83 & 35.14 & 60.41 & $10.7 \%$ \\
\hline Generation by Utilities $\ldots \ldots \ldots \ldots \ldots \ldots \ldots$ & 491.40 & 523.67 & 529.91 & 535.49 & $0.4 \%$ \\
\hline Total Net Energy for Load . . . . . . . . . . . & 440.62 & 516.39 & 546.00 & 572.14 & $1.3 \%$ \\
\hline \multicolumn{6}{|l|}{$\begin{array}{l}\text { Generation by Ful Type } \\
\text { (blllion kllowatthours) } \\
\text { Utility Generation }\end{array}$} \\
\hline Coal $\ldots \ldots \ldots \ldots \ldots \ldots \ldots \ldots \ldots$ & 442.06 & 469.50 & 475.08 & 481.50 & $0.4 \%$ \\
\hline Petroleum $\ldots \ldots \ldots \ldots \ldots \ldots \ldots \ldots$ & 2.11 & 0.17 & 0.02 & 0.02 & $-20.8 \%$ \\
\hline Natural Gas $\ldots \ldots \ldots \ldots \ldots \ldots \ldots \ldots$ & 1.43 & 1.68 & 2.98 & 7.06 & $8.3 \%$ \\
\hline Nuclear $\ldots \ldots \ldots \ldots \ldots \ldots \ldots \ldots \ldots \ldots \ldots$ & 42.77 & 49.94 & 49.46 & 44.54 & $0.2 \%$ \\
\hline Pumped Storage/Oher ${ }^{12} \ldots \ldots \ldots \ldots \ldots$ & .0 .66 & -1.47 & $\cdot 1.47$ & -1.47 & $4.1 \%$ \\
\hline Renewablets $\ldots \ldots \ldots \ldots \ldots \ldots \ldots \ldots$ & 3.68 & 3.85 & 3.85 & 3.85 & $0.2 \%$ \\
\hline Total Utillity Generation" ${ }^{14} \ldots \ldots \ldots \ldots \ldots$ & 481.40 & 523.67 & 529.91 & 535.40 & $0.4 \%$ \\
\hline Cogenerators (billlon kllowatthours) ......... & 19.13 & 22.26 & 23.57 & 24.89 & $1.3 \%$ \\
\hline \multicolumn{6}{|l|}{$\begin{array}{l}\text { Nonutility Generation Including Cogeneration } \\
\text { (billion kllowatthours) }\end{array}$} \\
\hline 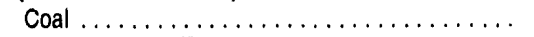 & 0.00 & 1.23 & 1.23 & 5.66 & N/A \\
\hline Petroleum/Other ${ }^{15} \ldots \ldots \ldots \ldots$ & 0.00 & 0.00 & 0.00 & 0.00 & $N / A$ \\
\hline Natural Gas $\ldots \ldots \ldots \ldots \ldots \ldots \ldots \ldots$ & 0.00 & 0.32 & 14.72 & 31.78 & $56.7 \%$ \\
\hline Renewable $\ldots \ldots \ldots \ldots \ldots \ldots \ldots \ldots \ldots$ & 0.96 & 7.06 & 10.70 & 14.23 & $14.5 \%$ \\
\hline Total Nonutility Generation . . . . . . . . . . . & 0.86 & 8.61 & 26.64 & 51.68 & $22.0 \%$ \\
\hline \multicolumn{6}{|l|}{ End-Use Prices ${ }^{16}$} \\
\hline \multicolumn{6}{|l|}{ (1992 cents per kilowatthour) } \\
\hline Residential $\ldots \ldots \ldots \ldots \ldots \ldots \ldots \ldots \ldots$ & 7.7 & 7.8 & 8.1 & 8.0 & $0.2 \%$ \\
\hline Commercial $\ldots \ldots \ldots \ldots \ldots \ldots \ldots \ldots \ldots$ & 7.2 & 7.3 & 7.6 & 7.3 & $0.0 \%$ \\
\hline Industrial $\ldots \ldots \ldots \ldots \ldots \ldots \ldots \ldots \ldots$ & 4.4 & 4.5 & 4.7 & 5.0 & $0.7 \%$ \\
\hline Transportation $\ldots \ldots \ldots \ldots \ldots \ldots \ldots \ldots$ & 4.6 & 4.5 & 4.5 & 4.4 & $.0 .2 \%$ \\
\hline All Sectors Average . . . . . . . . . . . . . & 6.2 & 6.2 & 6.4 & 6.4 & $0.2 \%$ \\
\hline \multicolumn{6}{|l|}{$\begin{array}{l}\text { Price Components }{ }^{10} \\
\text { (1992 cents per kllowatthour) }\end{array}$} \\
\hline Capital Component $\ldots \ldots \ldots \ldots \ldots \ldots \ldots$ & 2.6 & 2.4 & 2.2 & 2.1 & $.1 .1 \%$ \\
\hline Fuel Component $\ldots \ldots \ldots \ldots \ldots \ldots \ldots \ldots$ & 1.6 & 1.6 & 1.6 & 1.6 & $0.2 \%$ \\
\hline OsM Component . ...................... & 2.3 & 2.4 & 2.4 & 2.4 & $0.3 \%$ \\
\hline Wholesale Power Cost . . . . . . . . . . . . . . & -0.3 & $\cdot 0.1$ & 0.1 & 0.3 & $N / A$ \\
\hline Total $\ldots \ldots \ldots \ldots \ldots \ldots \ldots \ldots \ldots$ & 6.2 & 6.2 & 6.4 & 6.4 & $0.2 \%$ \\
\hline $\begin{array}{l}\text { Fuel Consumption (trillion Btu) } \ldots \ldots \ldots \ldots \ldots \\
\text { Utlittios }^{11}\end{array}$ & 0.02 & 0.02 & 0.14 & 0.31 & $13.5 \%$ \\
\hline Coal $\ldots \ldots \ldots \ldots \ldots \ldots \ldots$ & 4.48 & 4.77 & 4.81 & 4.88 & $0.4 \%$ \\
\hline Natural Gas $\ldots \ldots \ldots \ldots \ldots \ldots \ldots \ldots$ & 0.03 & 0.02 & 0.03 & 0.06 & $3.4 \%$ \\
\hline Oil $\ldots \ldots \ldots \ldots \ldots \ldots \ldots \ldots \ldots \ldots \ldots$ & 0.02 & 0.00 & 0.00 & 0.00 & $-21.0 \%$ \\
\hline \multicolumn{6}{|l|}{ Nonutilitios $^{18}$} \\
\hline Coal $\ldots \ldots \ldots \ldots \ldots \ldots \ldots \ldots \ldots$ & 0.00 & 0.01 & 0.01 & 0.06 & N/A \\
\hline Natural Gas $\ldots \ldots \ldots \ldots \ldots \ldots \ldots \ldots$ & 0.00 & 0.00 & 0.13 & 0.25 & N/A \\
\hline Oil $\ldots \ldots \ldots \ldots \ldots \ldots \ldots \ldots \ldots \ldots$ & 0.00 & 0.00 & 0.00 & 0.00 & N/A \\
\hline
\end{tabular}


Table 38. Electric Power Data and Projections for the EMM Region East Central Area Rellability Coordination Agreement (ECAR) (Continued)

\begin{tabular}{|c|c|c|c|c|c|}
\hline \multirow{2}{*}{ Electrictly Supply and Demend } & \multicolumn{4}{|c|}{ Reterencos Cases } & \multirow{2}{*}{$\begin{array}{l}\text { Annual } \\
\text { Crowth } \\
1090-2010 \\
\text { (percent) }\end{array}$} \\
\hline & 1000 & 2000 & 2006 & 2010 & \\
\hline \multicolumn{6}{|l|}{ Emiaclons (million short tons) } \\
\hline Total Carbon & 113.44 & 120.91 & 123.90 & 128.87 & $0.6 \%$ \\
\hline Carbon Dloxide & 415.94 & 443.35 & 454.32 & 472.53 & $0.6 \%$ \\
\hline Sullur Dioxide. & 5.36 & 3.29 & 2.66 & 2.57 & $-3.6 \%$ \\
\hline
\end{tabular}

'Net summer capability is the steady hourly output that generating equipment is expected to supply lo system load (exclusive of auxiliary power), as demonstrated by tests during summer peak demand.

Includes oil-, gas-, and dual-fired capability.

'Other includes methane and propane and blast turnace gas.

"Includes conventional hydroelectric, geothermal, wood, wood waste, municipal solid waste, other biomass, solar, and wind power.

'Cumulative additions after December 31, 1000.

Includes small power producers, independent power producers, and exempt wholesale generators, which produce electricity tor sales to utlities.

TNameplate capacity is reported for nonutlities. Nameplate capacity is designated by the manufacturer.

'Other includes hydrogen, sulfur, batteries, chemicals, fish oil, and spent sulfite llquor.

'Includes cogenerators at Industrial, commercial, and other facilities whose primary function is not electricily production. Nameplate capacity is reported for nonutilities. Nameplate capacity is designated by the manulacturer.

${ }^{10} \mathrm{Generation}$ to meet system load by source.

"Includes small power producers, independent power producers, and exempt wholesale generators, which produce electricity tor delivery to electric utilities.

${ }^{12}$ Other includes methane, propane, and blast furnace gas.

19ncludes conventional hydroelectric, geothermal, wood, wood waste, municipal solid waste, other biomass, solar and wind power.

14 Includes cogeneration at industrial, commercial, and other facilities whose primary function is not electricity production.

"Other includes hydrogen, sulfur, batteries, chemicals, fish oll, and spend sulfite liquor.

"Prices represent average revenue per kilowatthour.

1 In the end-use energy consumptions tables, projected fuel consumption in the utility sector includes fuel used by independent power producers.

In this table, fuel used by independent power producers is included in the nonutility category.

"includes fuel consumption by independent power producers and exempt wholesale generators, which produce electricity for sales to utiltiles.

${ }^{11}$ Estimated emissions from utilities and independent power producers.

$E M M=$ Electricty market module.

$O \& M=$ Operation and maintenance.

N/A $=$ Not applicable.

Note: Totals may not equal sum of components due to independent rounding.

Sources: 1990 (except for nonutility generation and prices): Energy Iniormation Administration (ElA), Electric Power Annual 1891, DOE/EIA-0348(91) (Washington, D.C., February 1993). 1990 Nonutility generation: Form ElA-861, "Annual Electric Utility Report" and the Form EIA-867, "Annual Nonutility Power Producer Report." The Form ElA-867 is filed by nonutilities reporting the energy delivered, while the ElA-861 is filed by electric utilities reporting the energy received. Because the Form ElA-861 collects data trom the universe of utilities, these ciata are used for electricity sold to utilities. Own use data is from Form EIA-867. Prlcee and all projectlone: EIA, AEO 1994 National Energy Modeling System run AEO94B.D1221834. 
Table 39. Electric Power Data and Projections for the EMM Reglon Electric Reliability Council of Texas (ERCOT)

\begin{tabular}{|c|c|c|c|c|c|}
\hline \multirow{2}{*}{ Elactriclty Supply and Demend } & \multicolumn{4}{|c|}{ Relerencos Caes } & \multirow{2}{*}{$\begin{array}{l}\text { Armual } \\
\text { Orowth } \\
1990-2010 \\
\text { (percent) }\end{array}$} \\
\hline & 1000 & 2000 & 2005 & 2010 & \\
\hline
\end{tabular}

\section{Electricty Conerating Cepacity' \\ (glgawatts) \\ Utillition \\ Cepactity}

Coal Sloam

Other Fossil Steam

Combined Cycle

烈

Nuclear Power .......................

Pumped Slorage/Other' ...................

Renewablet $\ldots \ldots \ldots \ldots \ldots \ldots \ldots \ldots$

Tolal Utilities Capability $\ldots \ldots \ldots \ldots \ldots \ldots$

Cumulative Plemned Additions ${ }^{8}$

Coal Stoam .........................

Other Fossil Steam ${ }^{2} \ldots \ldots \ldots \ldots \ldots \ldots . . . .$.

Combined Cycle .......................

Combustion Turblne/Diesel . . . . . . . . . . . . . .

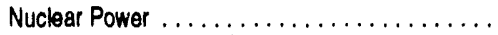

Pumped Storage/Othin' ..................

Renewable"

Total (planned)

$\ldots \ldots \ldots \ldots \ldots \ldots \ldots \ldots \ldots$

Cumulatwo Unplanned Additions

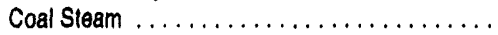

Other Fossil Steam ${ }^{2} \ldots \ldots \ldots \ldots \ldots \ldots$

Combined Cycle .......................

Combustion Turbine/Diesel . ..............

Nuclear Power ........................

Pumped Storage/Other' .................

Renewable 4 ....

Cumulathe Total Uillty Additions .......

Cumulattvo Utility Retrements

Nonutllitios (excludes cogenerators)"

\section{Capacity'}

Coal Steam . ...

Other Fossil Steam ${ }^{2} \ldots \ldots \ldots \ldots \ldots \ldots \ldots \ldots$

Combined Cycle ......................

Combustion Turbine/Diesel ...............

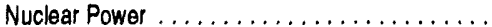

Pumped Storage/Other" ..................

Renewabl: "

Total Nonutilities Capabillty .............

Cogenerators?

\section{Elsectricity Demand}

(blllon Kllowatthoure)

Residential ..........

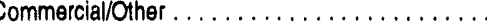

Industrial ..........................

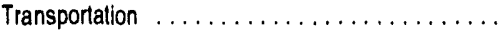

Total Sales

$\begin{array}{rr}14.06 & 16.20 \\ 30.26 & 29.73 \\ 0.74 & 1.94 \\ 2.28 & 3.06 \\ 3.63 & 4.78 \\ 0.00 & 0.00 \\ 0.56 & 0.56 \\ \mathbf{5 1 . 5 3} & 56.27\end{array}$

0.00

0.00

0.00

0.00

0.00

0.00

0.00

0.00

0.00

0.00

0.00

0.00

0.00

0.00

0.00

0.00

0.00

0.00

0.00

0.00

0.30

0.00

0.00

0.00

0.00

0.30

5.06

71.55

58.66

71.70

1.01

202.92
74.99
66.16
85.72
1.45
228.32

2.15
0.56
1.23
0.77
1.15
0.00
0.00
5.87

0.00

0.00

0.00

0.00

0.00

0.00

0.00

0.00

5.87

1.22

4.43

17.08
29.30
4.26
3.35
4.78
0.00
0.56
59.32

$\begin{array}{rl}18.53 & 1.4 \% \\ 28.67 & -0.3 \% \\ 4.76 & 9.7 \% \\ 3.47 & 2.1 \% \\ 4.78 & 1.4 \% \\ 0.00 & \mathrm{~N} / \mathrm{A} \\ 0.56 & 0.0 \% \\ 60.77 & 0.8 \%\end{array}$

3.02

0.56

3.55

1.06

1.15

0.00

0.00

9.35

$\begin{array}{rr}4.47 & \mathrm{~N} / \mathrm{A} \\ 0.56 & \mathrm{~N} / \mathrm{A} \\ 4.06 & \mathrm{~N} / \mathrm{A} \\ 1.18 & \mathrm{~N} / \mathrm{A} \\ 1.15 & \mathrm{~N} / \mathrm{A} \\ 0.00 & \mathrm{~N} / \mathrm{A} \\ 0.00 & \mathrm{~N} / \mathrm{A} \\ 11.43 & \mathrm{~N} / \mathrm{A}\end{array}$

0.00

0.00

0.00

0.00

0.00

0.00

0.00

0.00

9.35

1.65

2.28

NA

0.00
0.00
0.73
0.00
0.00
0.00
0.00
0.73

0.00

0.00

0.73

0.00

0.00

0.00

0.00

0.73

4.45

0.00

0.00

0.73

0.00

0.00

0.00

0.22

0.85

4.50

N/A
N/A
$4.5 \%$
N/A
N/A
N/A
N/A
$5.9 \%$
$.0 .6 \%$

76.97

68.63

93.31

80.10

69.80

100.54

$0.6 \%$

$0.9 \%$

$1.7 \%$

2.23
241.14

$\begin{array}{rr}3.19 & 5.9 \% \\ 253.63 & 1.1 \%\end{array}$ 
Table 39. Electric Power Data and Projections for the EMM Region

Electric Rellability Council of Texas (ERCOT) (Continued)

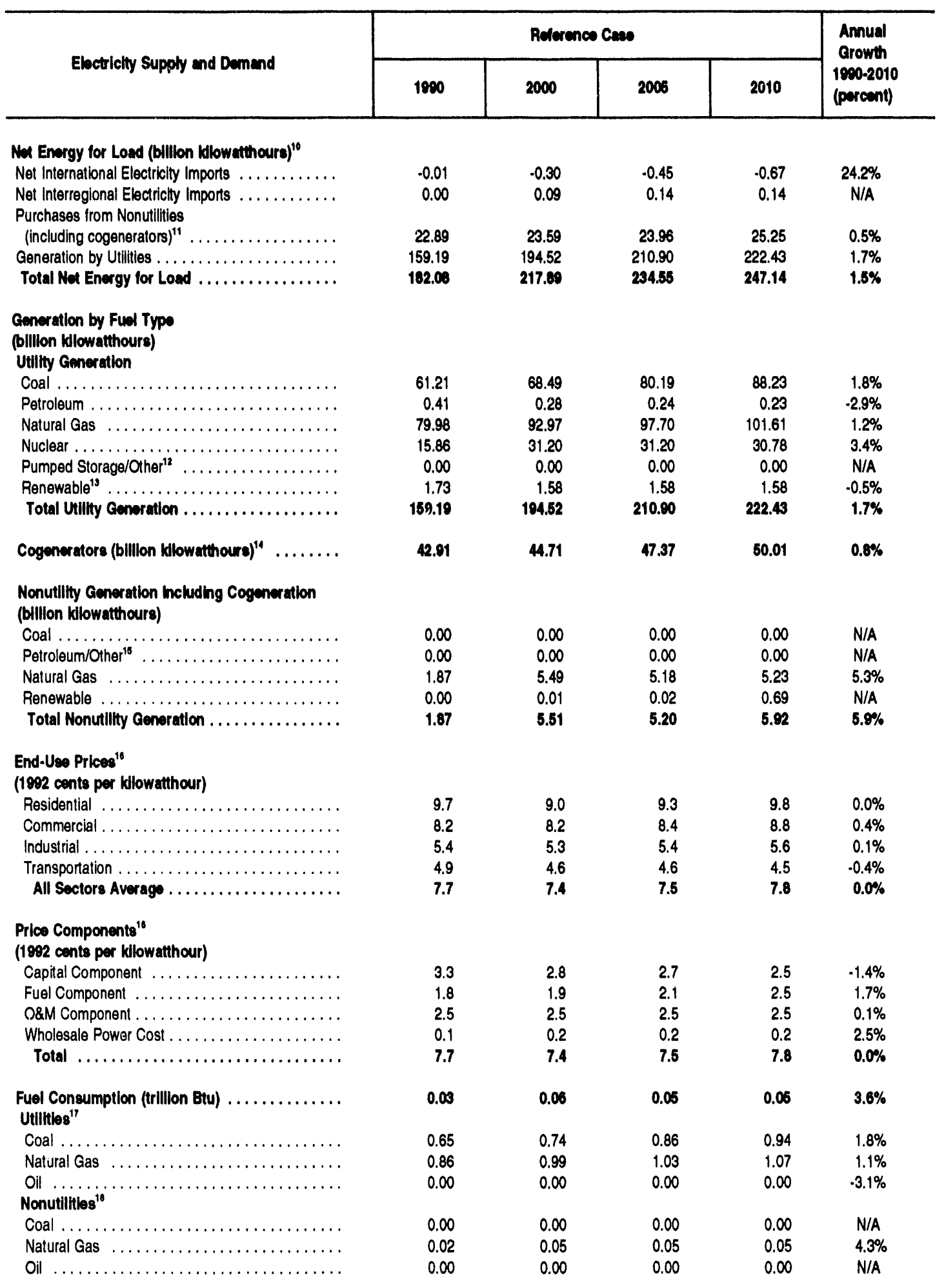


Table 39. Electric Power Data and Projections for the EMM Region Electric Rellability Council of Texas (ERCOT) (Continued)

\begin{tabular}{|c|c|c|c|c|c|}
\hline \multirow{2}{*}{ Electrlelity Supply end Demend } & \multicolumn{4}{|c|}{ Aderences Cases } & \multirow{2}{*}{$\begin{array}{l}\text { Amnual } \\
\text { Growth } \\
1900-2010 \\
\text { (porcant) }\end{array}$} \\
\hline & 1000 & 2000 & 2008 & 2010 & \\
\hline \multicolumn{6}{|l|}{ Emisalons (million short tons)" } \\
\hline Total Carbon & 30.80 & 34.31 & 38.09 & 40.78 & $1.4 \%$ \\
\hline Carbon Dioxide & 112.93 & 125.81 & 139.65 & 149.53 & $1.4 \%$ \\
\hline Sullur Dioxide. & 0.15 & 0.24 & 0.32 & 0.39 & $4.8 \%$ \\
\hline
\end{tabular}

'Net summer capability is the sleady hourly output that generating equipment is expected to supply to system load (exclusive of auxiliary power), as demonstrated by tests during summer peak demand.

'Includes oil-, gas-, and dual-fired capability.

'Other includes methane and propane and blast furnace gas.

"Includes conventional hydroeleclric, geothermal, wood, wood waste, municipal solid waste, other biomass, solar, and wind power.

'Cumulative additions after December 31, 1900.

'Includes small power producers, independent power producers, and exempt wholesale generators, which produce electricity tor sales to utilities.

'Nameplate capacity is reported for nonutilities. Nameplate capacity is designated by the manulacturer.

'Other includes hydrogen, sulfur, batteries, chemicais, fish oil, and spent sulfite liquor.

'Includes cogeneration at industrial, commercial, and other facilities whose primary function is not electricity production. is reported for nonutilities. Nameplate capacity is designated by the manufacturer.

${ }^{10}$ Generation to meet syslem load by source.

"Includes small power producers, independent power producers, and exempt wholesale generators, which produce electricity tor delivery to electric utilities.

${ }^{12}$ Other includes methane, propane, and blast furnace gas.

'Includes conventional hydroelectric, geothermal, wood, wood waste, municipal solid waste, other biomass, solat and wind power.

${ }^{14}$ Includes cogeneralors at industrial, commercial, and other lacilities whose primary function is not electricity production. Nameplate capacity

16 Other includes hydrogen, sulfur, batteries, chemicals, fish oil, and spend sulfite liquor.

"Prices represent average revenue per kilowatthour.

${ }^{17}$ In the end-use energy consumptions tables, projected fuel consumption in the utility seclor includes fuel used by independent power producers. In this table, fuel used by independent power producers is included in the nonutility calegory

"Includes fuel consumption by independent power producers and exempt wholesale generators, which produce electricity for sales to utilities.

${ }^{19}$ Estimated emissions trom utilities and independent power producers.

$E M M=$ Electricty market module.

$O \& M=$ Operatıon and maintenance.

N/A = Not applicable.

Nole: Totals may not equal sum of components due to independent rounding.

Sources: 1990 (except for nonutility generation and prices): Energy Intormation Administration (ElA), Electric Power Annual 1891, DOE/EIA-0348(81) (Washington, D.C., February 1993). 1990 Nonutility generation: Form ElA-861, "Annual Electric Utility Report" and the Form ElA-867, "Annual Nonutility Power Producer Report." The FormI ElA-867 is filed by nonutilities reporting the energy delivered, while the ElA-861 is filed by electric utilities reporting the energy received. Because the Form ElA-861 collects data trom the universe of utilities, these data are used for electricity sold to utilities. Own use data is from Form EIA-867. Prices and all projectlone: EIA, AEO 1994 Natıonal Energy Modeling System run AEO94B.D1221934. 
Table 40. Electric Power Data and Projections for the EMM Region Mid-Atlantic Area CouncII (MAAC)

\begin{tabular}{|c|c|c|c|c|c|}
\hline \multirow{2}{*}{ Electriclly Supply and Demend } & \multicolumn{4}{|c|}{ Reterencos Ceses } & \multirow{2}{*}{$\begin{array}{l}\text { Annual } \\
\text { Crowth } \\
1900-2010 \\
\text { (peremt) }\end{array}$} \\
\hline & 1900 & 2000 & 2000 & 2010 & \\
\hline
\end{tabular}

\begin{tabular}{|c|c|c|c|c|c|}
\hline $\begin{array}{l}\text { Ebetricity Conerating Cepacity' } \\
\text { (glgawetis) } \\
\text { Utillibe } \\
\text { Cepacity }\end{array}$ & & & & & \\
\hline Coal Sieam & 17.35 & 17.26 & 17.01 & 19.77 & $0.7 \%$ \\
\hline Other Fossil Steam ${ }^{2}$ & 10.34 & 8.67 & 8.06 & 6.02 & $.1 .3 \%$ \\
\hline Combined Cycle $\ldots \ldots \ldots \ldots \ldots \ldots \ldots$ & 0.32 & 3.00 & 4.30 & 4.72 & $14.4 \%$ \\
\hline Combustion Turbine/Diesel . ............... & 7.84 & 9.21 & 9.65 & 9.65 & $1.0 \%$ \\
\hline Nuclear Power $\ldots \ldots \ldots \ldots \ldots \ldots \ldots \ldots$ & 12.59 & 12.59 & 12.59 & 9.90 & $-1.2 \%$ \\
\hline Pumped Storage/Other" $\ldots \ldots \ldots \ldots \ldots \ldots$ & 1.32 & 1.32 & 1.32 & 1.32 & N/A \\
\hline Renowable $\ldots \ldots \ldots \ldots \ldots \ldots \ldots \ldots$ & 1.05 & 1.05 & 1.05 & 2.41 & $4.2 \%$ \\
\hline Total Utilitien Cepabillty $\ldots \ldots \ldots \ldots \ldots \ldots$ & 50.81 & 63.10 & 63.6 & 86.70 & $0.5 \%$ \\
\hline Cumulattve Plemned Additions" & & & & & \\
\hline Coal Sleam & 0.00 & 0.94 & 0.94 & 0.94 & N/A \\
\hline Other Fossil Steam² & 0.00 & 0.00 & 0.00 & 0.00 & $N / A$ \\
\hline Combined Cycle $\ldots \ldots \ldots \ldots \ldots \ldots \ldots$ & 0.00 & 2.68 & 3.99 & 3.99 & $N / A$ \\
\hline Combustion Turbine/Diesel $\ldots \ldots \ldots \ldots \ldots \ldots$ & 0.00 & 1.42 & 1.85 & 1.85 & N/A \\
\hline$\ldots \ldots \ldots \ldots \ldots, \ldots$ & 0.00 & 0.00 & 0.00 & 0.00 & N/A \\
\hline Pumped Storage/Other' $\ldots \ldots \ldots \ldots \ldots \ldots$ & 0.00 & 0.00 & 0.00 & 0.00 & N/A \\
\hline$\ldots \ldots+\ldots, \ldots, \ldots, \ldots, \ldots$ & 0.00 & 0.00 & 0.00 & 0.00 & N/A \\
\hline Total (planned) $\ldots \ldots \ldots \ldots \ldots \ldots \ldots \ldots$ & 0.00 & 5.04 & 6.78 & 6.76 & N/A \\
\hline Cumulativo Unplanned Additions" & & & & & \\
\hline Coal Steam & 0.00 & 0.00 & 0.00 & 2.76 & N/A \\
\hline Other Fossil Steam² & 0.00 & 0.00 & 0.00 & 0.00 & N/A \\
\hline$\ldots \ldots \ldots \ldots \ldots \ldots$ & 0.00 & 0.00 & 0.00 & 0.42 & N/A \\
\hline Combustion Turbine/Diesel . . . . . . . . . . . . . & 0.00 & 0.00 & 0.00 & 0.00 & N/A \\
\hline Nuclear Power $\ldots \ldots \ldots \ldots \ldots \ldots \ldots \ldots$ & 0.00 & 0.00 & 0.00 & 0.00 & N/A \\
\hline Pumped Storage/Other $\ldots \ldots \ldots \ldots \ldots \ldots$ & 0.00 & 0.00 & 0.00 & 0.00 & N/A \\
\hline$\ldots \ldots \ldots \ldots \ldots$ & 0.00 & 0.00 & 0.00 & 1.36 & N/A \\
\hline Total (unplenned) $\ldots \ldots \ldots \ldots \ldots \ldots \ldots$ & 0.00 & 0.00 & 0.00 & 4.54 & N/A \\
\hline Cumulative Total Utillity Additions ........... & 0.00 & 5.04 & 6.78 & 11.32 & NA \\
\hline Cumulattvo Utility Retroments $\ldots \ldots \ldots \ldots \ldots$ & 0.00 & 2.76 & 3.61 & 6.35 & NA \\
\hline $\begin{array}{l}\text { Nonutilitios (oxcludes cogenerators)' } \\
\text { Capacliy' }\end{array}$ & & & & & \\
\hline Coal Steam & 0.03 & 0.53 & 0.53 & 0.53 & $15.6 \%$ \\
\hline Other Fossil Steam² & 0.05 & 0.30 & 0.30 & 0.30 & $8.8 \%$ \\
\hline$\ldots \ldots \ldots \ldots \ldots \ldots$ & 0.00 & 0.50 & 0.50 & 0.50 & N/A \\
\hline Combustion Turbine/Diesel . ..... & 0.02 & 0.02 & 0.02 & 0.02 & N/A \\
\hline Nuclear Power & 0.00 & 0.00 & 0.00 & 0.00 & N/A \\
\hline Pumped Storage/Other" & 0.00 & 0.00 & 0.00 & 0.00 & N/A \\
\hline Renewable" ......... & 0.30 & 0.81 & 1.23 & 3.28 & $12.7 \%$ \\
\hline Total Nonutiltilos Cespablitty $\ldots \ldots \ldots \ldots \ldots$ & 0.41 & 2.17 & 2.59 & 4.64 & $12.9 \%$ \\
\hline Cogenerators ${ }^{\circ} \ldots \ldots \ldots \ldots \ldots \ldots \ldots \ldots$ & 2.38 & 4.70 & 4.72 & 4.72 & $3.6 \%$ \\
\hline $\begin{array}{l}\text { Electrictty Demand } \\
\text { (blllion klowatthours) }\end{array}$ & & & & & \\
\hline Residential ....... & 70.60 & 74.90 & 76.77 & 79.69 & $0.6 \%$ \\
\hline Commercial/Other $\ldots \ldots \ldots \ldots \ldots \ldots \ldots$ & 73.79 & 79.45 & 79.86 & 78.47 & $0.3 \%$ \\
\hline Industrial $\ldots \ldots \ldots \ldots \ldots \ldots \ldots \ldots \ldots$ & 61.76 & 70.47 & 76.26 & 81.05 & $1.4 \%$ \\
\hline Transportation ... & 1.61 & 2.25 & 3.58 & 5.21 & $6.1 \%$ \\
\hline Total Sales . & 207.75 & 227.08 & 236.46 & 244.42 & $0.8 \%$ \\
\hline
\end{tabular}


Table 40. Electric Power Data and Projections for the EMM Reglon Mid-Atlantic Area Councll (MAAC) (Continued)

\begin{tabular}{|c|c|c|c|c|c|}
\hline \multirow{2}{*}{ Elscirleity supply end Demend } & \multicolumn{4}{|c|}{ Peverincs Cese } & \multirow{2}{*}{$\begin{array}{l}\text { Annud } \\
\text { Crowth } \\
\text { 10ip-20 } \\
\text { (porem }\end{array}$} \\
\hline & 1000 & 2000 & 2004 & 2010 & \\
\hline \multicolumn{6}{|l|}{ Net Energy for Land (billion Idlownthoury)" } \\
\hline Net International Electricity Imports . . . . . . . . . & 0.00 & 0.00 & 0.00 & 0.00 & N/A \\
\hline $\begin{array}{l}\text { Net Interregional Eloctricliy Imports } \ldots \ldots \ldots \ldots \ldots \\
\text { Purchases from Nonutilities }\end{array}$ & 20.30 & 14.08 & 9.12 & 13.42 & $-2.0 \%$ \\
\hline (including cogeneralors)" $\ldots \ldots \ldots \ldots \ldots$ & 8.50 & 21.74 & 25.38 & 31.62 & $0.8 \%$ \\
\hline 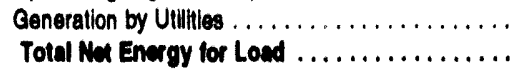 & $\begin{array}{l}196.91 \\
228.71\end{array}$ & $\begin{array}{l}211.93 \\
247.76\end{array}$ & $\begin{array}{l}223.17 \\
207.09\end{array}$ & $\begin{array}{l}223.55 \\
209.80\end{array}$ & $\begin{array}{l}0.6 \% \\
0.6 \%\end{array}$ \\
\hline \multicolumn{6}{|l|}{ 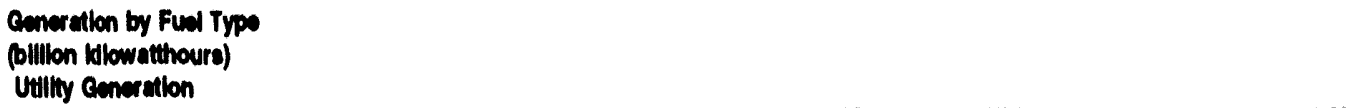 } \\
\hline Coal $\ldots \ldots \ldots \ldots \ldots \ldots \ldots \ldots$ & 103.84 & 108.25 & 107.33 & 127.33 & $1.0 \%$ \\
\hline Petroleum $\ldots \ldots \ldots \ldots \ldots \ldots \ldots \ldots \ldots$ & 10.89 & 5.28 & 4.31 & 3.00 & $-6.1 \%$ \\
\hline Natural Gas $\ldots \ldots \ldots \ldots \ldots \ldots \ldots \ldots$ & 6.22 & 14.44 & 28.02 & 21.52 & $6.4 \%$ \\
\hline Nuclear $\ldots \ldots \ldots \ldots \ldots \ldots \ldots \ldots \ldots \ldots$ & 72.31 & 83.38 & 82.93 & 65.18 & $.0 .5 \%$ \\
\hline Pumped Storage/Oher" $\ldots \ldots \ldots \ldots \ldots \ldots$ & .1 .03 & .0 .64 & .0 .64 & -0.64 & $.2 .4 \%$ \\
\hline Renewable ${ }^{12} \ldots \ldots \ldots \ldots \ldots \ldots \ldots$ & 4.88 & 3.22 & 3.22 & 7.07 & $1.8 \%$ \\
\hline Tolal Eillity comwation $\ldots \ldots \ldots \ldots \ldots \ldots$ & 198.91 & 211.93 & 223.17 & 2285 & $0.0 \%$ \\
\hline Cogmerators (blllion Wlowathours)" $\ldots \ldots$. & 9.69 & 13.40 & 14.12 & 14.73 & $2.2 \%$ \\
\hline \multicolumn{6}{|l|}{$\begin{array}{l}\text { Nonutilliy ementation holuding Cogeneration } \\
\text { (billion klowathours) }\end{array}$} \\
\hline Coal $\ldots \ldots \ldots \ldots \ldots \ldots \ldots \ldots \ldots$ & 0.26 & 3.27 & 3.27 & 3.27 & $13.5 \%$ \\
\hline Petroleum/Other ${ }^{18}$. & 0.16 & 0.46 & 0.64 & 0.22 & $1.5 \%$ \\
\hline Natural Gas $\ldots \ldots \ldots \ldots \ldots \ldots \ldots$ & 0.21 & 4.15 & 4.59 & 4.00 & $16.0 \%$ \\
\hline 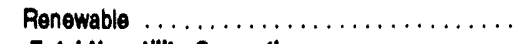 & 1.26 & 4.54 & 7.22 & 14.17 & $12.9 \%$ \\
\hline Total Nonutllity emeration . . . . . . . . . . & 1.68 & 12.42 & 16.71 & 21.68 & $13.0 \%$ \\
\hline \multirow{2}{*}{\multicolumn{6}{|c|}{$\begin{array}{l}\text { End-Uwe Prlases" } \\
\text { (1902 cents per Idlowathour) }\end{array}$}} \\
\hline (1992 cents per klowatthour) & & & & & \\
\hline Residential $\ldots \ldots \ldots \ldots \ldots \ldots \ldots \ldots$ & 9.9 & 10.0 & 10.4 & 11.2 & $0.6 \%$ \\
\hline Commercial $\ldots \ldots \ldots \ldots \ldots \ldots \ldots \ldots \ldots$ & 8.8 & 8.5 & 8.6 & 8.6 & $.0 .1 \%$ \\
\hline Industrial $\ldots \ldots \ldots \ldots \ldots \ldots \ldots \ldots \ldots$ & 6.8 & 6.4 & 6.4 & 8.5 & $0.0 \%$ \\
\hline Transportation $\ldots \ldots \ldots \ldots \ldots \ldots \ldots \ldots$ & 6.2 & 6.3 & 6.2 & 6.3 & $0.2 \%$ \\
\hline All Sectors Averag $\ldots \ldots \ldots \ldots \ldots \ldots \ldots$ & 8.5 & 8.3 & 8.4 & 8.7 & $0.1 \%$ \\
\hline \multicolumn{6}{|l|}{$\begin{array}{l}\text { Price Components" } \\
\text { (tees cents per illowatthour) }\end{array}$} \\
\hline Capital Component $\ldots \ldots \ldots \ldots \ldots \ldots \ldots$ & 4.0 & 3.8 & 3.6 & 3.7 & $.0 .4 \%$ \\
\hline Fuel Component $\ldots \ldots \ldots \ldots \ldots \ldots \ldots$ & 1.3 & 1.4 & 1.7 & 1.6 & $1.1 \%$ \\
\hline OsM Component $\ldots \ldots \ldots \ldots \ldots \ldots \ldots \ldots$ & 2.8 & 2.9 & 2.9 & 2.9 & $0.1 \%$ \\
\hline Wholesale Power Cost . . . . . . . . . . . . . . . & 0.4 & 0.3 & 0.3 & 0.5 & $1.4 \%$ \\
\hline Total $\ldots \ldots \ldots \ldots \ldots \ldots \ldots \ldots \ldots \ldots$ & 8.5 & 8.3 & 8.4 & 8.7 & $0.1 \%$ \\
\hline $\begin{array}{l}\text { Fud Consumption (trillion Btu) } \ldots \ldots \ldots \ldots \ldots \\
\text { Utilitios" }\end{array}$ & 0.14 & 0.14 & 0.14 & 0.11 & $.1 .1 \%$ \\
\hline$\ldots \ldots \ldots \ldots \ldots \ldots \ldots$ & 1.02 & 1.06 & 1.07 & 1.26 & $1.1 \%$ \\
\hline Natural Gas $\ldots \ldots \ldots \ldots \ldots \ldots \ldots$ & 0.08 & 0.18 & 0.30 & 0.23 & $5.4 \%$ \\
\hline Oil $\ldots \ldots \ldots \ldots \ldots \ldots \ldots \ldots \ldots \ldots \ldots \ldots \ldots \ldots$ & 0.14 & 0.06 & 0.05 & 0.04 & $.6 .5 \%$ \\
\hline Coal $\ldots \ldots \ldots$ & 0.00 & 0.03 & 0.03 & 0.03 & $15.8 \%$ \\
\hline Natural Gas . . & 0.00 & 0.04 & 0.05 & 0.04 & $18.8 \%$ \\
\hline$\ldots \ldots \ldots \ldots$ & 0.00 & 0.00 & 0.01 & 0.00 & $4.1 \%$ \\
\hline
\end{tabular}


Table 40. Electric Power Data and Projections for the EMM Reglon Mid-Atlantic Area Council (MAAC) (Continued)

\begin{tabular}{|c|c|c|c|c|c|}
\hline \multirow{2}{*}{ Electrlelty Supply and Damend } & \multicolumn{4}{|c|}{ Reterences Case } & \multirow{2}{*}{$\begin{array}{l}\text { Amual } \\
\text { Growth } \\
1900-201 \\
\text { (percent) }\end{array}$} \\
\hline & 1980 & 2000 & 2000 & 2010 & \\
\hline \multicolumn{6}{|l|}{ Embalions (million short tons)" } \\
\hline Total Carbon & 28.52 & 31.90 & 33.84 & 37.36 & $1.4 \%$ \\
\hline Carbon Dioxide & 104.57 & 116.97 & 124.06 & 136.99 & $1.4 \%$ \\
\hline Sufur Dioxide. & 1.21 & 0.90 & 0.77 & 0.76 & $.2 .3 \%$ \\
\hline
\end{tabular}

'Nel summer capability is the steady hourly output that generating equipment is expected to supply to system load (exclusive if auxiliary power), as demonstrated by tests during summer peak demand.

'Includes oll-, gas-, and dual-fired capability.

"Other includes methane and propane and blast furnace ges.

"Includes conventional hydroelectric, geothermal, wood, wood waste, municipal solid waste, other biomass, solar, and wind power.

'Cumulative additions after December 31, 1090.

"Includes small power producers, independent power producers, and exempt wholesale generators, which produce electricity for sales to utilities.

'Nameplate capacity is reported for nonutilitios. Nameplate capacity is designated by the manutacturer.

'Other includes hydrogen, sulfur, batteries, chemicals, fish oil, and spent sultite liquor

Includes cogenerators at industrial, commercial, and other facilities whose primary function is not electricity production. Nameplate capacity

is reported for nonutilities. Nameplate capacity is designated by the manutacturer.

"Generation to meet system load by source.

"Includes small power producers, independent power producers, and exempt wholesale generators, which produce electricity tor delivery to electric utilities.

${ }^{12}$ Other includes methane, propane, and blast furnace gas.

"Includes conventional hydroelectric, geothermal, wood, wood waste, municipal solid waste, other biomass, solar and wind power.

"Includes cogeneration at industrial, commercial, and other facilities whose primary function is not electricity production.

"Other includes hydrogen, sulfur, batteries, chemicals, fish oil, and spend sulfite liquor.

"Prices represent average revenue per kilowatthour.

"In the end-use energy consumptions lables, projected luel consumption in the utitity sector includes fuel used by independent power producers. In this table, fuel used by independent power producers is included in the nonutility category.

"11includes fuel consumption by independent power producers and exempt wholesale generators, which produce electricity for sales to utilities.

"Estimated emissions from utilities and independent power producers.

$E M M=$ Electricty market module.

$O \& M=$ Operation and maintenance.

N/A $=$ Not applicable.

Note: Totals may not equal sum of components due to independent rounding.

Sources: 1990 (except for nonutility generation and prices): Energy Information Administration (ElA), Electric Power Annual 1991, DOE/E $1 A-0348(91$ ) (Washington, D.C., February 1993). 1990 Nonutility generation: Form ElA-861, "Annual Electric Utility Report" and the Form ElA-867, "Annual Nonutility Power Producer Report." The Form ElA-867 is flled by nonutilities reporting the energy delivered, while the ElA-861 is filed by electric utilities reporting the energy received. Because the Form ElA-861 collects data from the universe of utilities, these data are used for electricity sold to utilities. Own use data is from Form EIA-867. Prices and all projectlons: EIA, AEO 1994 National Energy Modeling System run AEO94B.D1221934. 
Table 41. Electric Power Data and Projections for the EMM Reglon Mid-America Interconnected Network (MAIN)

\begin{tabular}{|c|c|c|c|c|c|}
\hline \multirow{2}{*}{ Electriclly Supply and Dannend } & \multicolumn{4}{|c|}{ Reterences Caes } & \multirow{2}{*}{$\begin{array}{c}\text { Annual } \\
\text { Growth } \\
1 \text { cea-2010 } \\
\text { (percent) }\end{array}$} \\
\hline & 1000 & 2000 & 2005 & 2010 & \\
\hline
\end{tabular}

Eluctrichy Cenerating Cepacity'

(glgawatts)

Utillibe

Cepacily

Coal Sleam .

Other Fossil Steam

27.46

Combined Cycle.

Combustion Turbine/Diesel

3.56

0.00

等,

Nuclear Power ...

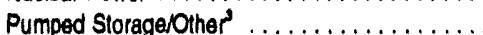

Renewable .

Total Utiltibe Cepsbility

$\ldots \ldots \ldots \ldots \ldots$

Total Uithitss Cepability

Cumulative Planned Additions"

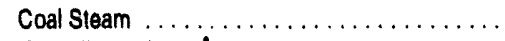

Other Fossil Steam ${ }^{2} \ldots \ldots \ldots \ldots \ldots \ldots \ldots \ldots$

Combined Cycle ...................

Combustion Turbine/Diesel . . . . . . . . . . . . . .

Nuclear Power $\ldots \ldots \ldots \ldots \ldots \ldots \ldots \ldots$.

Pumped Storage/Other $\ldots \ldots \ldots \ldots \ldots \ldots$.

Renewablet.

Total (planned)

$\ldots \ldots \ldots \ldots \ldots \ldots \ldots \ldots \ldots$

2.82

$\$ 4.86$

0.35

0.63

49.68

26.44
1.31
0.06
6.70
14.86
0.35
0.63
60.35

26.47
1.31
0.13
8.36
14.86
0.35
0.64
52.13

$\begin{array}{rc}26.14 & .0 .2 \% \\ 1.28 & .5 .0 \% \\ 0.13 & \mathrm{~N} / \mathrm{A} \\ 11.05 & 7.1 \% \\ 13.59 & -0.4 \% \\ 0.35 & \mathrm{~N} / \mathrm{A} \\ 0.64 & 0.1 \% \\ \mathbf{5 3 . 1 0} & 0.3 \%\end{array}$

Cumulative Unplanned Addhlons"

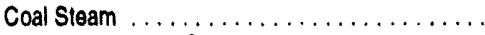

Other Fossil Steam ${ }^{2} \ldots \ldots \ldots \ldots \ldots \ldots \ldots$

Combined Cycle ....................

Combustion Turbine/Diesel . .............

Nuclear Power $\ldots \ldots \ldots \ldots \ldots \ldots \ldots \ldots$.

Pumped Storage/Other $\ldots \ldots \ldots \ldots \ldots \ldots$.

Renewable'

Total (unplanned) $\ldots \ldots \ldots \ldots \ldots \ldots \ldots \ldots \ldots$

Cumulative Total Utility Addhions

0.00

0.00

0.00

0.00

0.00

0.00

0.00

0.00

60.55

52.13

63.18

$0.3 \%$

Cumulathe Utility Retirements

0.00

0.00

0.00

0.00

0.00

0.00

0.00

0.00

0.28

0.00

0.06

3.88

0.00

0.00

0.01

4.22

$\begin{array}{lll}0.70 & 0.85 & \text { N/A } \\ 0.00 & 0.00 & \text { N/A } \\ 0.13 & 0.13 & \text { N/A } \\ 5.54 & 5.60 & \text { N/A } \\ 0.00 & 0.00 & \text { N/A } \\ 0.00 & 0.00 & \text { N/A } \\ 0.02 & 0.02 & \text { N/A } \\ 0.38 & 6.60 & \text { N/A }\end{array}$

Nonutilities (excludes cogenerators)'

Capacity'

0.00

0.00

0.00

0.00

0.00

0.00

0.00

0.00

0.00

0.00

4.22

3.61

0.00
0.00

0.00

0.00

0.00

0.00

0.00

0.00

6.38

3.99

0.00

0.00

0.00

2.63

0.00

0.00

0.00

2.69

9.23

5.78

Coal Stoam

Other Fossil Steam ${ }^{2}$

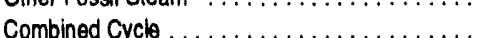

Combustion Turbine/Diesel . . . . . . . . . . .

Nuclear Power . ....................

Pumped Storage/Other" . . . . . . . . . . .

Renewable ${ }^{4}$

Total Nonutllitios Capability

$\ldots \ldots \ldots \ldots$

Cogenerators ${ }^{\circ}$

0.00

0.00

0.00

0.00

0.00

0.00

0.04

0.04

1.30

Electricity Demand

(blllion kllowatthours)

Residential ........

Industrial.

Transportation

Total Sales.

$\ldots \ldots \ldots \ldots \ldots \ldots \ldots \ldots \ldots \ldots \ldots$

52.43

81.09

1.24

193.81
0.00

0.00

0.00

3.99

0.00

0.00

0.23

4.22

1.23

61.47
60.11
99.20
1.72
222.50

62.00
62.00
108.71
2.63
235.34

63.05

61.76

117.19

3.73

245.73
N/A
N/A
N/A
N/A
N/A
N/A
N/A
N/A
N/A
N/A

N/A

N/A

N/A

N/A

N/A

N/A

$10.8 \%$

$27.7 \%$

$.0 .3 \%$

$$
\begin{aligned}
& 0.3 \% \\
& 0.8 \% \\
& 1.9 \% \\
& 5.6 \% \\
& 1.2 \%
\end{aligned}
$$


Table 41. Electrlc Power Data and Projections for the EMM Roglon Mid-America Interconnected Notwork (MAIN) (Continued)

\begin{tabular}{|c|c|c|c|c|c|}
\hline \multirow{2}{*}{ Elevericlity Supply and Domend } & \multicolumn{4}{|c|}{ Putermas Coss } & \multirow{2}{*}{ 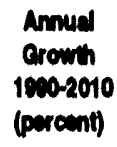 } \\
\hline & 1000 & 2000 & 2005 & 2010 & \\
\hline \multicolumn{6}{|l|}{ Mu Energy for Loed (billion ldowethourg)" } \\
\hline (including cogenerators) ${ }^{11} \ldots \ldots \ldots \ldots \ldots$ & 0.29 & 1.73 & 3.70 & 12.33 & $20.7 \%$ \\
\hline Generation by Utilities $\ldots \ldots \ldots \ldots \ldots \ldots$ & 204.02 & 237.08 & 245.32 & 247.15 & $1.0 \%$ \\
\hline Totel Ken Enmgy for Losd ............... & 188.10 & 227.18 & 240.39 & 201.20 & $1.6 \%$ \\
\hline \multicolumn{6}{|l|}{ 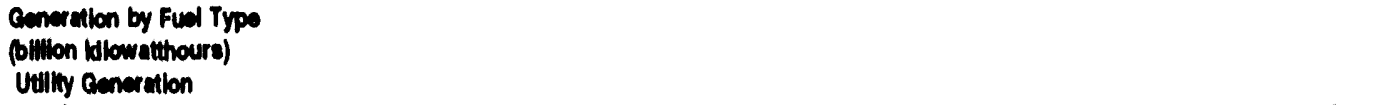 } \\
\hline Potroleum $\ldots \ldots \ldots \ldots \ldots \ldots \ldots \ldots$ & 0.52 & 0.03 & 0.03 & 0.02 & $.14 .9 \%$ \\
\hline Natural Gas $\ldots \ldots \ldots \ldots \ldots \ldots \ldots$ & 0.89 & 0.38 & 0.60 & 4.16 & $8.0 \%$ \\
\hline Nuclear $\ldots \ldots \ldots \ldots \ldots \ldots \ldots \ldots$ & 91.11 & 98.91 & 97.30 & 91.60 & $0.0 \%$ \\
\hline Pumped Slorage/Oher ${ }^{12} \ldots \ldots \ldots \ldots \ldots$ & .0 .04 & .0 .15 & -0.15 & .0 .15 & $7.4 \%$ \\
\hline Renewable ${ }^{13} \ldots \ldots \ldots \ldots \ldots \ldots \ldots \ldots$ & 2.20 & 2.93 & 2.94 & 2.94 & $1.5 \%$ \\
\hline Total Villity Coneration . ............... & 204.02 & 207.05 & 245.32 & 247.15 & $1.0 \%$ \\
\hline Cogeneratore (billion klowathours) ${ }^{14} \ldots \ldots \ldots$ & 6.49 & 6.88 & 7.04 & 7.65 & $1.6 \%$ \\
\hline \multicolumn{6}{|l|}{$\begin{array}{l}\text { Nonutllity Cemeration heluding Cogeneration } \\
\text { (billion klowetthours) }\end{array}$} \\
\hline \multicolumn{6}{|l|}{$\begin{array}{l}\text { End-Une Prices } 10 \\
\text { (1992 cents per klowatthour) }\end{array}$} \\
\hline Residential $\ldots \ldots \ldots \ldots \ldots \ldots \ldots \ldots \ldots$ & 8.8 & 9.2 & 9.6 & 10.7 & $1.0 \%$ \\
\hline Commercial $\ldots \ldots \ldots \ldots \ldots \ldots \ldots \ldots$ & 7.2 & 7.7 & 8.0 & 8.8 & $1.0 \%$ \\
\hline Industrial $\ldots \ldots \ldots \ldots \ldots \ldots \ldots \ldots \ldots$ & 4.7 & 5.0 & 5.2 & 5.7 & $0.9 \%$ \\
\hline Transportation . . . . . . . . . . . . . . . . & 5.1 & 5.5 & 5.6 & 5.7 & $0.6 \%$ \\
\hline All Sectors Avrag . . . . . . . . . . . . . . & 6.6 & 6.8 & 7.1 & 7.7 & $0.6 \%$ \\
\hline \multicolumn{6}{|l|}{$\begin{array}{l}\text { Price Components" } \\
\text { (1992 conts per Idlowetthour) }\end{array}$} \\
\hline Capital Component $\ldots \ldots \ldots \ldots \ldots \ldots$ & 3.1 & 3.3 & 3.3 & 3.4 & $0.4 \%$ \\
\hline Fuel Component $\ldots \ldots \ldots \ldots \ldots \ldots \ldots \ldots$ & 1.3 & 1.2 & 1.3 & 1.6 & $1.2 \%$ \\
\hline O\&M Component . . . . . . . . . . . . . . . & 2.4 & 2.4 & 2.5 & 2.5 & $0.2 \%$ \\
\hline Wholesale Power Cost . . . . . . . . . . . . . . & -0.1 & 0.0 & 0.1 & 0.3 & $N / A$ \\
\hline Total $\ldots \ldots \ldots \ldots \ldots \ldots \ldots \ldots \ldots \ldots$ & 6.6 & 6.9 & 7.1 & 7.7 & $0.6 \%$ \\
\hline $\begin{array}{l}\text { Fud Coneumption (trillion Btu) } \ldots \ldots \ldots \ldots \ldots \\
\text { Utillibs" }\end{array}$ & 0.01 & 0.01 & 0.03 & 0.10 & $10.3 \%$ \\
\hline Coal $\ldots \ldots \ldots \ldots \ldots \ldots \ldots \ldots \ldots$ & 1.17 & 1.50 & 1.59 & 1.62 & $1.6 \%$ \\
\hline Natural Gas $\ldots \ldots \ldots \ldots \ldots \ldots \ldots \ldots$ & 0.01 & 0.01 & 0.01 & 0.05 & $7.7 \%$ \\
\hline Oil $\ldots \ldots \ldots \ldots \ldots \ldots \ldots \ldots, \ldots \ldots \ldots$ & 0.01 & 0.00 & 0.00 & 0.00 & $.16 .5 \%$ \\
\hline
\end{tabular}




\section{Table 41. Electric Power Data and Projections for the EMM Reglon}

Mid-America Interconnected Network (MAIN) (Continued)

\begin{tabular}{|c|c|c|c|c|c|}
\hline \multirow{2}{*}{ Electiclity Supply and Demend } & \multicolumn{4}{|c|}{ Reterences Cess } & \multirow{2}{*}{$\begin{array}{l}\text { Annud } \\
\text { Crowth } \\
\text { 1epo-2010 } \\
\text { (prencent) }\end{array}$} \\
\hline & 1000 & 2000 & 2006 & 2010 & \\
\hline \multicolumn{6}{|l|}{ Emiselons (million short toms)" } \\
\hline Total Carbon & 34.34 & 38.50 & 40.93 & 44.52 & $1.3 \%$ \\
\hline Carbon Dioxide & 125.90 & 141.16 & 150.06 & 163.25 & $1.3 \%$ \\
\hline Sulfur Dioxide. & 1.54 & 1.22 & 1.08 & 1.02 & $-2.0 \%$ \\
\hline
\end{tabular}

'Net summer capability is the steady hourly output thal generating equipment is expected to supply to system load (exclusive of auxiliary power). as demonstrated by tests during summer peak demand.

Includes oll- gas-, and dual-fired capability.

'Other includes methane and propane and blast furnace gas.

"Includes conventional hydroelectric, geothermal, wood, wood waste, municipal solid waste, other biomass, solar, and wind power.

'Cumulative additions after December $31,1900$.

includes small power producers, independent power producers, and exempt wholesale generalors, which produce electricity tor sales to utilities.

'Nameplate capacity is reported tor nonutilities. Nameplate capacity is designated by the manulacturer.

'Other includes hydrogen, sullur, batteries, chemicals, fish oil and spent sulfite liquor.

'Includes cogenerators at industrial, commercial, and other facilities whose primary function is not electricity production. Nameplate capacity is reported for nonutilities. Nameplate capacity is designated by the manufacturer.

${ }^{10} \mathrm{Generation} 10$ meet system load by source.

"Includes small power producers, independent power producers, and exempt wholesale generators, which produce electricity tor delivery to electric utilities.

${ }^{12}$ Other includes methane, propane, and blast furnace gas.

13 Includes conventional hydroelectric, geothermal, wood, wood waste, municipal solid waste, other biomass, solar and wind power.

"Includes cogeneration at industrial, commercial, and other facilities whose primary function is not electricity production.

"Other includes hydrogen, sulfur, batteries, chemicals, fish oil, and spend sullite liquor.

1"Prices represent average revenue per kilowatthour.

1 In the end-use energy consumptions tables, projected fuel consumption in the utility sector includes fuel used by independent power producers. In this table, fuel used by independent power producers is included in the nonutility category.

1"Includes fuel consumption by independent power producers and exempt wholesale generators, which produce electricity tor sales to utilities.

"Estimated emissions from utilties and independent power producers.

EMM = Electricity market module.

$O \& M=$ Operatior and maintenance.

N/A $=$ Not applicable

Note: Totals may not equal sum of components due to independent rounding.

Sources: 1990 (except for nonutility generation and prices): Energy Intormation Administration (ElA). Electric Power Annual 1991, DOE/EIA-0348/91) (Washington, D.C., February 1993). 1990 Nonutility generation: Form E|A-861, "Annual Electric Utility Report" and the Form ElA-867, "Annual Nonutllity Power Producer Repon." The Form EIA-867 is tlled by nonutlities reporting the energy delivered, while the EIA-861 is filed by electric utilities reporting the energy received. Because th: Form ElA-861 collects data trom the universe of utilities, these data are used for electricity sold to utilities. Own use data is from Form ElA-867. Prices and all projectlons: EIA, AEO 1994 National Energy Modeling System run AEO94B.D1221934. 
Table 42. Electric Power Data and Projections for the EMM Region Mid-Continent Area Power Pool (MAPP)

\begin{tabular}{|c|c|c|c|c|c|}
\hline \multirow{2}{*}{ Elactriclty Supply and Demend } & \multicolumn{4}{|c|}{ Relerence Caeo } & \multirow{2}{*}{$\begin{array}{c}\text { Amual } \\
\text { Growth } \\
1900-2010 \\
\text { (percent) }\end{array}$} \\
\hline & 1980 & 2000 & 2005 & 2010 & \\
\hline
\end{tabular}

\begin{tabular}{|c|c|c|c|c|c|}
\hline \multicolumn{6}{|l|}{$\begin{array}{l}\text { Electriclty Generating Ceapacity' } \\
\text { (gigawatts) } \\
\text { Utilitios }\end{array}$} \\
\hline Coal Steam & 21.49 & 21.20 & 20.45 & 19.97 & $.0 .4 \%$ \\
\hline Other Fossil Steam ${ }^{2}$. & 0.61 & 0.36 & 0.19 & 0.17 & $.6 .2 \%$ \\
\hline Combined Cycle. & 0.09 & 0.09 & 0.09 & 0.09 & $0.0 \%$ \\
\hline Combustion Turbine/Diesel $\ldots \ldots \ldots \ldots \ldots \ldots$ & 4.26 & 5.03 & 5.22 & 5.22 & $1.0 \%$ \\
\hline Nuclear Power $\ldots \ldots \ldots \ldots \ldots \ldots \ldots$ & 3.70 & 3.70 & 3.70 & 2.69 & $-1.6 \%$ \\
\hline Pumped Storage/Other' $\ldots \ldots \ldots \ldots \ldots \ldots$ & 0.00 & 0.00 & 0.00 & 0.00 & N/A \\
\hline Renewablet $\ldots \ldots \ldots \ldots \ldots \ldots \ldots$ & 3.49 & 3.49 & 3.49 & 3.49 & N/A \\
\hline Total Utilities Capabillty ................ & 33.66 & 33.88 & 33.15 & 31.64 & $-0.3 \%$ \\
\hline \multicolumn{6}{|l|}{ Cumulative Planned Additions $s^{8}$} \\
\hline Coal Steam. & 0.00 & 0.84 & 0.84 & 0.84 & N/A \\
\hline Other Fossil Steam² & 0.00 & 0.00 & 0.00 & 0.00 & N/A \\
\hline Combined Cycle ..................... & 0.00 & 0.00 & 0.00 & 0.00 & N/A \\
\hline Combustion Turbine/Diesel $\ldots \ldots \ldots \ldots \ldots \ldots$ & 0.00 & 0.82 & 1.01 & 1.01 & $N / A$ \\
\hline$\ldots \ldots \ldots \ldots, \ldots$ & 0.00 & 0.00 & 0.00 & 0.00 & N/A \\
\hline Pumiped Storage/Other' $\ldots \ldots \ldots \ldots \ldots \ldots$ & 0.00 & 0.00 & 0.00 & 0.00 & N/A \\
\hline Renewable ${ }^{4} \ldots \ldots \ldots \ldots \ldots \ldots \ldots \ldots$ & 0.00 & 0.00 & 0.00 & 0.00 & $N / A$ \\
\hline Total (planned) $\ldots \ldots \ldots \ldots \ldots \ldots \ldots \ldots$ & 0.00 & 1.67 & 1.86 & 1.86 & NA \\
\hline \multicolumn{6}{|l|}{ Cumulatwe Unplanned Addhiong ${ }^{6}$} \\
\hline Coal Steam. & 0.00 & 0.00 & 0.00 & 0.00 & N/A \\
\hline Other Fossil Steam ${ }^{2}$. & 0.00 & 0.00 & 0.00 & 0.00 & N/A \\
\hline Combined Cycle $\ldots \ldots \ldots \ldots \ldots \ldots \ldots$ & 0.00 & 0.00 & 0.00 & 0.00 & N/A \\
\hline Combustion Turbine/Diesel . .............. & 0.00 & 0.00 & 0.00 & 0.00 & N/A \\
\hline Nuclear Power $\ldots \ldots \ldots \ldots \ldots \ldots \ldots \ldots$ & 0.00 & 0.00 & 0.00 & 0.00 & N/A \\
\hline Pumped Storage/Other' $\ldots \ldots \ldots \ldots \ldots \ldots$ & 0.00 & 0.00 & 0.00 & 0.00 & $N / A$ \\
\hline Renewable ${ }^{4} \ldots \ldots \ldots \ldots \ldots \ldots \ldots \ldots$ & 0.00 & 0.00 & 0.00 & 0.00 & $N / A$ \\
\hline Total (unplanned) $\ldots \ldots \ldots \ldots \ldots \ldots \ldots$ & 0.00 & 0.00 & 0.00 & 0.00 & NA \\
\hline Cumulative Total Utility Additions .......... & 0.00 & 1.67 & 1.86 & 1.86 & N/A \\
\hline Cumulative Utility Retirements ... & 0.00 & 1.46 & 2.38 & 3.80 & NA \\
\hline \multicolumn{6}{|l|}{$\begin{array}{l}\text { Nonutllitios (excludes cogenerators) } \\
\text { Capacity }^{\circ}\end{array}$} \\
\hline Coal Steam ...... & 0.00 & 0.01 & 0.01 & 0.01 & N/A \\
\hline$\ldots \ldots \ldots \ldots \ldots \ldots$ & 0.00 & 0.00 & 0.00 & 0.00 & $N / A$ \\
\hline Combined Cycle ..................... & 0.00 & 0.00 & 0.00 & 0.00 & $N / A$ \\
\hline Combustion Turbine/Diesel . ............. & 0.12 & 0.12 & 0.29 & 2.56 & $16.7 \%$ \\
\hline Nuclear Power $\ldots \ldots \ldots \ldots \ldots \ldots \ldots$ & 0.00 & 0.00 & 0.00 & 0.00 & N/A \\
\hline Pumped Storage/Other ${ }^{8} \ldots \ldots \ldots$ & 0.00 & 0.00 & 0.00 & 0.00 & $N / A$ \\
\hline Renewable ${ }^{4} \ldots \ldots \ldots \ldots \ldots$ & 0.05 & 0.07 & 0.09 & 0.13 & $5.3 \%$ \\
\hline Total Nonutilities Capability .............. & 0.16 & 0.20 & 0.40 & 2.71 & $15.0 \%$ \\
\hline Cogenerators $^{9} \ldots$. & 1.45 & 1.25 & 1.26 & 1.27 & $-0.7 \%$ \\
\hline \multicolumn{6}{|l|}{$\begin{array}{l}\text { Electricity Demand } \\
\text { (billion kllowatthours) }\end{array}$} \\
\hline Residential ......... & 41.91 & 44.00 & 44.58 & 45.51 & $0.4 \%$ \\
\hline Commercial/Other $\ldots \ldots \ldots \ldots \ldots \ldots \ldots$ & 34.31 & 37.32 & 37.78 & 36.67 & $0.3 \%$ \\
\hline Industrial $\ldots \ldots \ldots \ldots \ldots \ldots \ldots \ldots \ldots \ldots$ & 40.49 & 49.99 & 54.77 & 59.02 & $1.9 \%$ \\
\hline Transportation $\ldots \ldots \ldots \ldots \ldots \ldots \ldots$ & 0.78 & 1.08 & 1.65 & 2.34 & $5.7 \%$ \\
\hline Total Sales $\ldots \ldots \ldots \ldots \ldots \ldots \ldots \ldots \ldots$ & 117.49 & 132.38 & 138.78 & 143.53 & $1.0 \%$ \\
\hline
\end{tabular}


Table 42. Electric Power Data and Projections for the EMM Region Mid-Continent Area Power Pool (MAPP) (Continued)

\begin{tabular}{|c|c|c|c|c|c|}
\hline \multirow{2}{*}{ Electriclty Supply and Demend } & \multicolumn{4}{|c|}{ Relerence Case } & \multirow{2}{*}{$\begin{array}{c}\text { Annual } \\
\text { Growth } \\
1990-2010 \\
\text { (percent) }\end{array}$} \\
\hline & 1890 & 2000 & 2005 & 2010 & \\
\hline \multicolumn{6}{|l|}{ Not Energy for Load (billion kilowatthours) } \\
\hline Net International Electricity Imports . . . . . . . . . & 0.74 & 7.71 & 8.00 & 8.32 & $12.8 \%$ \\
\hline Net Interregional Electricity Imports $\ldots \ldots \ldots \ldots$ & -5.91 & -1.42 & -0.47 & -0.47 & $-11.9 \%$ \\
\hline $\begin{array}{l}\text { Purchases from Nonutilities } \\
\text { (including cogenerators) }\end{array}$ & 0.35 & 1.88 & 2.63 & 9.15 & $17.8 \%$ \\
\hline Generation by Utilities $\ldots \ldots \ldots \ldots \ldots \ldots \ldots \ldots$ & 131.21 & 134.91 & 140.25 & 138.94 & $0.3 \%$ \\
\hline Total Net Energy for Load .............. & 126.39 & 143.08 & 150.42 & 155.83 & $1.1 \%$ \\
\hline \multicolumn{6}{|l|}{$\begin{array}{l}\text { Generation by Fuel Type } \\
\text { (billion kilowatthours) } \\
\text { Utility Generation }\end{array}$} \\
\hline Coal $\ldots \ldots \ldots \ldots \ldots \ldots \ldots \ldots \ldots \ldots$ & 96.48 & 97.17 & 103.03 & 107.41 & $0.5 \%$ \\
\hline Petroleum $\ldots \ldots \ldots \ldots \ldots \ldots \ldots$ & 0.54 & 0.03 & 0.05 & 0.03 & $.14 .2 \%$ \\
\hline Natural Gas $\ldots \ldots \ldots \ldots \ldots \ldots \ldots \ldots$ & 0.91 & 2.69 & 2.21 & 0.44 & $-3.6 \%$ \\
\hline Nuclear $\ldots \ldots \ldots \ldots \ldots \ldots \ldots \ldots \ldots \ldots$ & 22.66 & 24.42 & 24.36 & 20.46 & $.0 .5 \%$ \\
\hline Pumped Storage/Oher ${ }^{12} \ldots \ldots \ldots \ldots \ldots \ldots$ & 0.00 & 0.00 & 0.00 & 0.00 & N/A \\
\hline Renewable ${ }^{13} \ldots \ldots \ldots \ldots \ldots \ldots \ldots$ & 10.60 & 10.60 & 10.60 & 10.60 & $0.0 \%$ \\
\hline Total Utillty Generation . . . . . . . . . . . . . & 131.21 & 134.91 & 140.25 & 138.94 & $0.3 \%$ \\
\hline Cogenerators (billion kllowatthours) ${ }^{14} \ldots \ldots$. & 2.11 & 2.99 & 3.17 & 3.34 & $2.3 \%$ \\
\hline \multicolumn{6}{|l|}{$\begin{array}{l}\text { Nonutlity Generation including Cogeneration } \\
\text { (billion kllowatthours) }\end{array}$} \\
\hline Coal $\ldots \ldots \ldots \ldots \ldots \ldots \ldots \ldots \ldots \ldots$ & 0.00 & 0.05 & 0.05 & 0.07 & N/A \\
\hline Petroleum/Other ${ }^{18} \ldots \ldots \ldots \ldots \ldots \ldots \ldots$ & 0.00 & 0.00 & 0.00 & 0.00 & $N / A$ \\
\hline Natural Gas $\ldots \ldots \ldots \ldots \ldots \ldots \ldots \ldots$ & $0.0 \mathrm{C}$ & 0.23 & 0.74 & 6.90 & $43.6 \%$ \\
\hline Renewable $\ldots \ldots \ldots \ldots \ldots \ldots \ldots \ldots \ldots$ & 0.25 & 0.30 & 0.50 & 0.77 & $5.8 \%$ \\
\hline Total Nonutility Generation .............. & 0.25 & 0.58 & 1.28 & 7.75 & $18.6 \%$ \\
\hline \multicolumn{6}{|l|}{$\begin{array}{l}\text { End-Use Prices } \\
\text { (1892 cents per kllowatthour) }\end{array}$} \\
\hline Residential $\ldots \ldots \ldots \ldots \ldots \ldots \ldots \ldots \ldots$ & 8.6 & 8.1 & 8.4 & 10.3 & $0.9 \%$ \\
\hline Commercial . . . . . . . . . . . . . . . & 7.3 & 7.1 & 6.9 & 7.9 & $0.4 \%$ \\
\hline Industrial $\ldots \ldots \ldots \ldots \ldots \ldots \ldots \ldots$ & 4.8 & 4.8 & 4.6 & 5.2 & $0.3 \%$ \\
\hline Transportation $\ldots \ldots \ldots \ldots \ldots \ldots \ldots \ldots$ & 4.9 & 4.8 & 4.7 & 5.1 & $0.1 \%$ \\
\hline All Sectors Average $\ldots \ldots \ldots \ldots \ldots \ldots \ldots$ & 6.8 & 6.6 & 6.5 & 7.5 & $0.4 \%$ \\
\hline \multicolumn{6}{|l|}{$\begin{array}{l}\text { Prico Components } \\
\text { (1892 cents per kilowatthour) }\end{array}$} \\
\hline Capital Component ........ & 2.9 & 2.4 & 2.1 & 2.3 & $.1 .2 \%$ \\
\hline Fuel Component $\ldots \ldots \ldots \ldots \ldots \ldots \ldots$ & 1.2 & 1.2 & 1.2 & 1.7 & $1.6 \%$ \\
\hline O\&M Component . . . . . . . . . . . . . . . & 2.7 & 2.7 & 2.7 & 2.7 & $0.1 \%$ \\
\hline Wholesale Power Cost $\ldots \ldots \ldots \ldots \ldots \ldots$ & 0.1 & 0.3 & 0.4 & 0.8 & $12.1 \%$ \\
\hline Total $\ldots \ldots \ldots \ldots \ldots \ldots \ldots \ldots$ & 6.9 & 6.6 & 6.5 & 7.5 & $0.4 \%$ \\
\hline $\begin{array}{l}\text { Fuel Consumption (trillion Btu) } \ldots \ldots \ldots \ldots \ldots \\
\text { Uttllties }^{19}\end{array}$ & 0.01 & 0.00 & 0.01 & 0.08 & $11.8 \%$ \\
\hline Coal $\ldots \ldots \ldots \ldots \ldots \ldots \ldots \ldots \ldots$ & 1.07 & 1.06 & 1.13 & 1.18 & $0.5 \%$ \\
\hline Natural Gas ....... & 0.01 & 0.04 & 0.03 & 0.01 & $.4 .1 \%$ \\
\hline Oil $\ldots \ldots \ldots$ & 0.01 & 0.00 & 0.00 & 0.00 & $\cdot 12.3 \%$ \\
\hline \multicolumn{6}{|l|}{ Nonutilities } \\
\hline Coal $\ldots \ldots \ldots \ldots \ldots \ldots \ldots \ldots \ldots$ & 0.00 & 0.00 & 0.00 & 0.00 & N/A \\
\hline Natural Gas $\ldots \ldots \ldots \ldots \ldots \ldots \ldots \ldots$ & 0.00 & 0.00 & 0.01 & 0.08 & $19.0 \%$ \\
\hline Oil $\ldots \ldots \ldots \ldots \ldots \ldots \ldots \ldots \ldots \ldots$ & 0.00 & 0.00 & 0.00 & 0.00 & $5.1 \%$ \\
\hline
\end{tabular}


Table 42. Electric Power Data and Projections for the EMM Region
Mld-Continent Area Power Pool (MAPP) (Continued)

\begin{tabular}{|c|c|c|c|c|c|}
\hline \multirow{2}{*}{ Eloctriclty Supply and Damend } & \multicolumn{4}{|c|}{ Reterences Caseo } & \multirow{2}{*}{$\begin{array}{l}\text { Annual } \\
\text { Growth } \\
1900-2010 \\
\text { (porcent) }\end{array}$} \\
\hline & 1000 & 2000 & sivts & 2010 & \\
\hline \multicolumn{6}{|l|}{ Emteslons (million short tons) } \\
\hline Total Carbon .............. & 25.77 & 28.25 & 30.02 & 31.93 & $1.1 \%$ \\
\hline Carbon Dloxide $\ldots$ & 94.51 & 103.58 & 110.06 & 117.09 & $1.1 \%$ \\
\hline Sulfur Dioxide . ...................... & 0.32 & 0.34 & 0.36 & 0.40 & $1.1 \%$ \\
\hline
\end{tabular}

'Net summer capability is the sleady hourly output that generating equipment is expected to supply to system load (exclusive of auxillary power), as demonstrated by tests during summer peak demand.

'Includes oil-, gas-, and dual-fired capability.

'Other includes methane and propane and blast furnace gas.

"Inciudes conventional hydroelectric, geothermal, wood, wood waste, municipal solid waste, other biomass, solar, and wind power.

"Cumulative additions after December 31, 1900.

Includes small power producers, independent power producers, and exempt wholesale generators, which produce electricity for sales to utilities.

'Nameplate capacity is reported for nonutilities. Nameplate capacily is designated by the manufacturer.

'Other includes hydrogen, sulfur, batteries, chemicals, fish oil, and spent sulfite liquor.

Includes cogenerators at industrial, commercial, and other facilities whose primary function is not electricity production. Nameplate capacity

is reported for nonutilities. Nameplate capacity is designated by the manufacturer.

${ }^{10}$ Generation to meet system load by source.

"Includes small power producers, independent power producers, and exempt wholesale generators, which produce electricity tor delivery to electric utilities.

${ }^{12}$ Other includes methane, propane, and blast furnace gas.

"Includes conventional hydroelectric, geothermal, wood, wood wasie, municipal solid waste, other biomass, solar and wind power.

"Includes cogeneration at industrial, commercial, and other facilities whose primary function is not electricity production.

${ }^{16}$ Other includes hydrogen, sulfur, batteries, chemicals, fish oil, and spend sulfite liquor.

"Prices represent average revenue per kilowatthour.

"In the end-use energy consumptions tables, projected fuel consumption in the utility sector includes fuel used by independent power producers. In this table, fuel used by independent power producers is included in the nonutility calegory.

"Includes fuel consumption by independent power producers and exempt wholesale generators, which produce electricity for sales to utilities.

"Estimated emissions from utilities and independent power producers.

$E M M=$ Electricity market module.

$O \& M=$ Operation and maintenance.

N/A = Not applicable

Note: Totals may not equal sum of components due to independent rounding.

Sources: 1990 (except for nonutility generation and prices): Energy Information Administration (ElA), Electric Power Annual 1991, DOE/EIA-0348(91) (Washington, D.C., February 1993). 1890 Nonutility generation: Form ElA-861, "Annual Electric Utility Report" and the Form EIA-867, "Annual Nonutility Power Producer Report." The Form ElA-867 is flled by nonutilities reporting the energy delivered, while the ElA-861 is filed by electric utilities reporting the energy received. Because the Form ElA-861 collects data from the universe of utilities, these data are used for electricity sold to utilities. Own use data is from Form EIA-867. Prices and all projectlone: EIA, AEO 1994 National Energy Modeling System run AEO94B.D1221834. 
Table 43. Electric Power Data and Projections for the EMM Region Northeast Power Coordinating Council/New York (NPCC/NY)

\begin{tabular}{|c|c|c|c|c|c|}
\hline \multirow{2}{*}{ Eloctrletty Supply and Demend } & \multicolumn{4}{|c|}{ Reterencos Cases } & \multirow{2}{*}{$\begin{array}{l}\text { Annual } \\
\text { Growth } \\
1 \text { cea-2010 } \\
\text { (percent) }\end{array}$} \\
\hline & 1900 & 2000 & 2005 & 2010 & \\
\hline
\end{tabular}

\begin{tabular}{|c|c|c|c|c|c|}
\hline \multicolumn{6}{|l|}{$\begin{array}{l}\text { Electrictly Generating Cepectity' } \\
\text { (glgawetto) } \\
\text { Utillitios } \\
\text { Cepactiy }\end{array}$} \\
\hline Coal Sleam & 4.84 & 4.03 & 3.87 & 4.56 & $.0 .3 \%$ \\
\hline Other Fossil Steam² & 12.86 & 11.86 & 11.79 & 11.74 & $.0 .5 \%$ \\
\hline$\ldots \ldots \ldots \ldots \ldots \ldots$ & 0.00 & 0.14 & 0.14 & 0.14 & $N / A$ \\
\hline Combustion Turbine/Dlesel . . . . . . . . . . . & 3.87 & 3.85 & 3.85 & 3.85 & $0.0 \%$ \\
\hline Nuclear Power,$\ldots \ldots \ldots \ldots \ldots \ldots \ldots \ldots$ & 4.83 & 4.83 & 4.83 & 3.76 & $-1.3 \%$ \\
\hline Pumped Storage/Other" .................. & 1.30 & 1.36 & 1.36 & 1.36 & $0.2 \%$ \\
\hline Renewable ${ }^{4} \ldots \ldots \ldots \ldots \ldots \ldots \ldots$ & 3.78 & 3.89 & 3.94 & 4.80 & $1.2 \%$ \\
\hline Total Utillitios Cespability .................. & 31.48 & 29.86 & 29.78 & 30.20 & $-0.2 \%$ \\
\hline \multicolumn{6}{|l|}{ Cumulattve Plamned Additiones" } \\
\hline Coal Steam $\ldots \ldots \ldots \ldots \ldots$ & 0.00 & 0.00 & 0.00 & 0.00 & $N / A$ \\
\hline Other Fossil Steam ${ }^{2} \ldots \ldots \ldots \ldots \ldots \ldots$ & 0.00 & 0.07 & 0.07 & 0.07 & $N / A$ \\
\hline Combined Cycle ...................... & 0.00 & 0.14 & 0.14 & 0.14 & $N / A$ \\
\hline Combustion Turbine/Diesel $\ldots \ldots \ldots \ldots \ldots \ldots$ & 0.00 & 0.01 & 0.01 & 0.01 & N/A \\
\hline Nuclear Power,$\ldots \ldots \ldots \ldots \ldots \ldots \ldots \ldots$ & 0.00 & 0.00 & 0.00 & 0.00 & N/A \\
\hline Pumped Storage/Other $\ldots \ldots \ldots \ldots \ldots \ldots$ & 0.00 & 0.06 & 0.06 & 0.06 & $N / A$ \\
\hline Renewable $\ldots \ldots \ldots \ldots \ldots \ldots \ldots$ & 0.00 & 0.07 & 0.07 & 0.07 & N/A \\
\hline Total (planned) $\ldots \ldots \ldots \ldots \ldots \ldots \ldots \ldots$ & 0.00 & 0.34 & 0.34 & 0.34 & NA \\
\hline \multicolumn{6}{|l|}{ Cumulative Unplanned Additions" } \\
\hline$\ldots \ldots \ldots \ldots \ldots \ldots \ldots \ldots$ & 0.00 & 0.00 & 0.00 & 0.69 & $N / A$ \\
\hline Other Fossil Steam ${ }^{2} \ldots \ldots \ldots \ldots \ldots \ldots \ldots$ & 0.00 & 0.00 & 0.00 & 0.00 & $N / A$ \\
\hline Combined Cycle $\ldots \ldots \ldots \ldots \ldots \ldots \ldots$ & 0.00 & 0.00 & 0.00 & 0.00 & $N / A$ \\
\hline Combustion Turbine/Diesel $\ldots \ldots \ldots \ldots \ldots \ldots$ & 0.00 & 0.00 & 0.00 & 0.00 & $N / A$ \\
\hline Nuclear Power $\ldots \ldots \ldots \ldots \ldots \ldots \ldots$ & 0.00 & 0.00 & 0.00 & 0.00 & $N / A$ \\
\hline Pumped Storage/Other' & 0.00 & 0.00 & 0.00 & 0.00 & $N / A$ \\
\hline Renewable ${ }^{4} \ldots \ldots \ldots \ldots \ldots \ldots \ldots \ldots$ & 0.00 & 0.00 & 0.00 & 0.82 & N/A \\
\hline Total (unplenned) $\ldots \ldots \ldots \ldots \ldots \ldots \ldots$ & 0.00 & 0.00 & 0.00 & 1.51 & NA \\
\hline Cumulative Total Utility Additions ........... & 0.00 & 0.34 & 0.34 & 1.86 & NA \\
\hline Cumulative Utilly Retremenis $\ldots \ldots \ldots \ldots$. & 0.00 & 1.02 & 2.15 & 3.28 & NA \\
\hline \multicolumn{6}{|l|}{$\begin{array}{l}\text { Nonutllities (excludes cogenerators)" } \\
\text { Capaclly' }\end{array}$} \\
\hline$\ldots \ldots \ldots \ldots \ldots \ldots$ & 0.00 & 0.09 & 0.09 & 0.09 & $N / A$ \\
\hline Other Fossil Steam ${ }^{2}$ & 0.00 & 0.02 & 0.02 & 0.02 & N/A \\
\hline Combined Cycle ............. & 0.00 & 0.72 & 0.72 & 0.72 & N/A \\
\hline Combustion Turbine/Diesel ............... & 0.00 & 0.05 & 0.05 & 0.05 & N/A \\
\hline Nuclear Power $\ldots \ldots \ldots \ldots \ldots \ldots \ldots \ldots$ & 0.00 & 0.00 & 0.00 & 0.00 & N/A \\
\hline Pumped Storage/Other" $\ldots \ldots \ldots \ldots \ldots \ldots$ & 0.00 & 0.00 & 0.00 & 0.00 & N/A \\
\hline Renewable ${ }^{4} \ldots \ldots \ldots \ldots \ldots \ldots \ldots \ldots$ & 0.34 & 0.55 & 0.72 & 1.37 & $7.2 \%$ \\
\hline Total Nonutillties Capsbility ............. & 0.34 & 1.42 & 1.60 & 2.24 & $9.9 \%$ \\
\hline Cogenerators ${ }^{\circ} \ldots \ldots \ldots \ldots \ldots \ldots \ldots \ldots$ & 1.64 & 3.36 & 3.37 & 3.37 & $3 . \%$ \\
\hline \multicolumn{6}{|l|}{$\begin{array}{l}\text { Eloctriclty Demand } \\
\text { (blilion Klowatthours) }\end{array}$} \\
\hline Residential .......... & 40.91 & 41.52 & 41.82 & 42.72 & $0.2 \%$ \\
\hline Commercial/Other ...................... & 47.91 & 49.14 & 47.78 & 45.01 & $.0 .3 \%$ \\
\hline Industrial $\ldots \ldots \ldots \ldots \ldots \ldots \ldots \ldots \ldots \ldots$ & 39.11 & 43.47 & 46.77 & 49.27 & $1.2 \%$ \\
\hline Transportation $\ldots \ldots \ldots \ldots \ldots \ldots \ldots \ldots$ & 1.11 & 1.53 & 2.43 & 3.53 & $6.0 \%$ \\
\hline 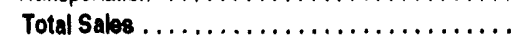 & 129.04 & 135.66 & 138.70 & 140.53 & $0.4 \%$ \\
\hline
\end{tabular}


Table 43. Electric Power Data and Projections for the EMM Region Northeast Power Coordinating Councll/New York (NPCC/NY) (Continued)

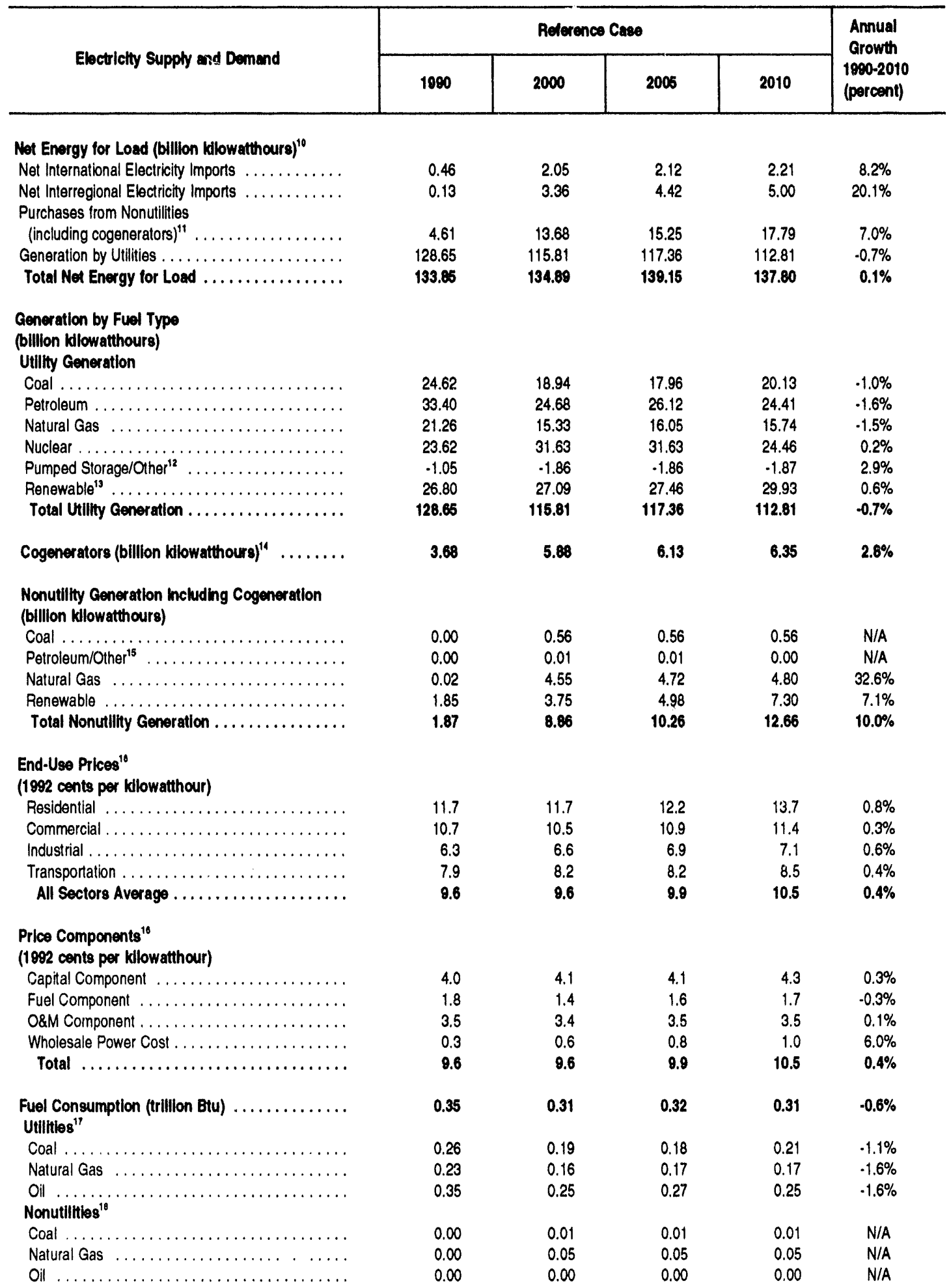


Table 43. Electric Power Data and Projections for the EMM Region Northeast Power Coordinating Council/New York (NPCC/NY) (Continued)

\begin{tabular}{|c|c|c|c|c|c|}
\hline \multirow{2}{*}{ Electriclty Supply and Demand } & \multicolumn{4}{|c|}{ Roterence Case } & \multirow{2}{*}{$\begin{array}{l}\text { Annual } \\
\text { Growth } \\
1990-2010 \\
\text { (percent) }\end{array}$} \\
\hline & 1990 & 2000 & 2005 & 2010 & \\
\hline \multicolumn{6}{|l|}{ Emissions (million short tons) } \\
\hline Sulfur Dioxide . . . . & 0.42 & 0.25 & 0.21 & 0.19 & $-3.8 \%$ \\
\hline
\end{tabular}

'Net summer capability is the steady hourly output that generating equipment is expected to supply to system load (exclusive of auxiliary power), as demonstrated by tests during summer peak demand.

'Includes oil-, gas-, and dual-fired capability.

'Other includes methane and propane and blast furnace gas.

"Includes conventional hydroelectric, geothermal, wood, wood waste, municipal solid wasle, other biomass, solar, and wind power.

'Cumulative additions after December $31,1990$.

"Includes small power producers, independent power producers, and exempt wholesale generators, which produce electricity for sales to utilities.

${ }^{7}$ Nameplate capacity is reported for nonutilities. Nameplate capacity is designated by the manutacturer.

'Other includes hydrogen, sulfur, batteries, chemicals, fish oil, and spent sulfite liquor.

'Includes cogenerators at industrial, commercial, and other facilities whose primary function is not electricity production. Nameplate capacity is reported for nonutilities. Nameplate capacity is designated by the manufacturer.

${ }^{10}$ Generation to meet system load by source.

${ }^{11}$ Includes small power producers, independent power producers, and exempt wholesale generators, which produce electricity tor delivery to electric utilities.

${ }^{12}$ Other includes methane, propane, and blast furnace gas.

${ }^{13}$ includes conventional hydroelectric, geothermal, wood, wood waste, municipal solid waste, other biomass, solar and wind power.

14 Includes cogeneration at industrial, commercial, and other facilities whose primary function is not electricity production.

${ }^{16}$ Other includes hydrogen, sulfur, batteries, chemicals, fish oil, and spend sulfite liquor.

${ }^{16}$ Prices represent average revenue per kilowatthour.

${ }^{17}$ In the end-use energy consumptions tables, projected fuel consumption in the utility sector includes fuel used by independent power producers. In this table, fuel used by independent power producers is included in the nonutility category.

${ }^{19}$ Includes fuel consumption by independent power producers and exempt wholesale generators, which produce electricity tor sales to utilities.

${ }^{19}$ Estimated emissions from utilities and independent power producers.

$E M M=$ Electricity market module.

$O \& M=$ Operation and maintenance.

N/A = Not applicable.

Note: Totals may not equal sum of components due to independent rounding.

Sources: 1990 (except for nonutility generation and prices): Energy Information Administration (ElA), Electric Power Annual 1991. DOE/EIA-0348(91) (Washington, D.C., February 1993). : ", Fo Noriutility generation: Form ElA-861, "Annual Electric Utility Report" and the Form EIA-867, "Annual Nonutility Power Producer Report." The Form ElA-867 is filed by nonutilities reporting the energy delivered, while the ElA-861 is filed by electric utilities reporting the energy received. Because the Form ElA-861 collects data from the universe of utilities, these data are used for electricity sold to utilities. Own use data is from Form EIA-867. Prices and all projectlons: EIA, AEO 1994 National Energy Modeling System run AEO94B.D1221934. 
Table 44. Electric Power Data and Projectlons for the EMM Reglon Northeast Power Coordinating Council/Now England (NPCC/NE)

\begin{tabular}{|c|c|c|c|c|c|}
\hline \multirow{2}{*}{ Eluctrictly Supply and Demend } & \multicolumn{4}{|c|}{ Retorenco Cases } & \multirow{2}{*}{$\begin{array}{c}\text { Amual } \\
\text { Crowti } \\
1000-2010 \\
\text { (percent) }\end{array}$} \\
\hline & 1800 & 2000 & 2005 & 2010 & \\
\hline
\end{tabular}

\section{Eloctrlety Cenerating Ceppecti'}

\section{(obometio)}

Uillibes

Ceppecliy

Cool Stoam ....

Combined Cycle ..........................

Combustion Turbine/Diesel ...............

Nuclear Power ........................

Pumped Storage/Other $\ldots \ldots \ldots \ldots \ldots \ldots .$.

Renewable'

Cumulativo Plemed Additions:

Coal Steam .........................

Other Fossil Steam ${ }^{2} \ldots \ldots \ldots \ldots \ldots \ldots \ldots$

Combined Cycle .......................

Combustion Turbine/Diesel . ...............

Nuclear Power ......................

Pumped Storage/Other' ..................

Renowabie'

Total (planned) $\ldots \ldots \ldots \ldots \ldots \ldots \ldots \ldots$

$\begin{array}{rrrrr}2.65 & 2.37 & 2.27 & 2.33 & -0.6 \% \\ 9.73 & 8.46 & 8.18 & 8.15 & -0.9 \% \\ 0.48 & 0.48 & 0.48 & 0.51 & 0.3 \% \\ 1.39 & 1.65 & 1.65 & 1.65 & 0.8 \% \\ 6.56 & 6.39 & 6.39 & 4.31 & -2.1 \% \\ 1.68 & 1.68 & 1.68 & 1.68 & \text { N/A } \\ 1.55 & 1.60 & 1.67 & 3.14 & 3.6 \% \\ 24.05 & 22.64 & 22.31 & 21.77 & -0.5 \%\end{array}$

Cumulative Unplanned Additions

Coal Steam ..........................

Other Fossil Steam ${ }^{2} \ldots \ldots \ldots \ldots \ldots \ldots \ldots$

Combined Cycle ........................

Combustion Turbine/Diesel ................

Nuclear Power ..........................

Pumped Storage/Other' ...................

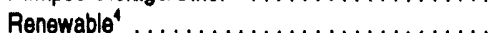

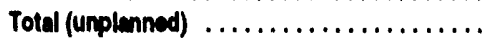

Cumulattve Total Utillty Additions

0.00

0.00

0.00

0.00

0.00

0.00

0.00

0.00

0.00
0.00
0.00
0.33
0.00
0.00
0.05
0.36

0.00

0.00

0.00

0.33

0.00

0.00

0.05

0.38

$\begin{array}{ll}0.00 & \text { N/A } \\ 0.00 & \text { N/A } \\ 0.00 & \text { N/A } \\ 0.33 & \text { N/A } \\ 0.00 & \text { N/A } \\ 0.00 & \text { N/A } \\ 0.05 & \text { N/A } \\ 0.38 & \text { N/A }\end{array}$

$\begin{array}{lll}0.00 & 0.06 & \text { N/A } \\ 0.00 & 0.00 & \text { N/A } \\ 0.00 & 0.03 & \text { N/A } \\ 0.00 & 0.00 & \text { N/A } \\ 0.00 & 0.00 & \text { N/A } \\ 0.00 & 0.00 & \text { N/A } \\ 0.06 & 1.54 & \text { N/A } \\ 0.06 & 1.63 & \text { NA } \\ 0.44 & 2.01 & \text { NAA } \\ 2.19 & 4.30 & \text { N/A }\end{array}$

Cumulattvo Utillity Retirements

Coal Sleam ........................

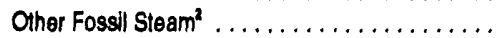

Combined Cycle .......................

Combustion Turbine/Diesel .................

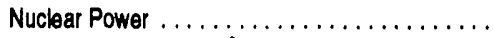

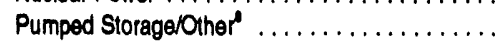

Renewablet .........................

Total Nonutlinies Capability

Cogenerators ${ }^{\circ}$

\section{Electrictly Demand}

(Billion klowatthours)

Residential .........................

Commercial/Other ......................

Industrial ...........................

Transportation $\ldots \ldots \ldots \ldots \ldots \ldots \ldots \ldots$

Total Salos

37.48
39.39
27.15
0.93
104.94


Table 44. Electric Power Data and Projections for the EMM Reglon Northeast Power Coordinating Council/New England (NPCC/NE) (Continued)

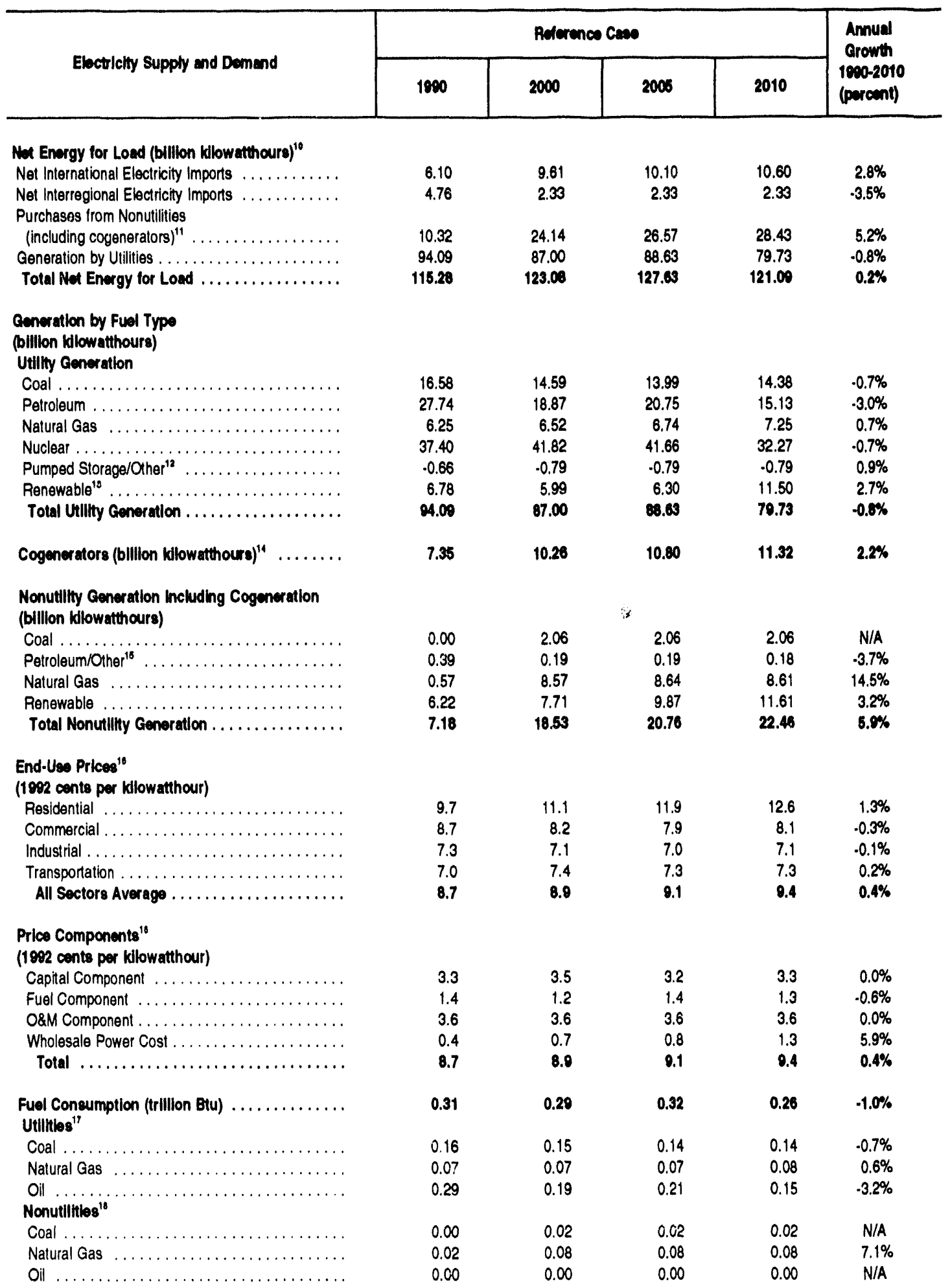


Table 44. Electric Power Data and Projections for the EMM Region Northeast Power Coordinating Council/Now England (NPCC/NE) (Continued)

\begin{tabular}{|c|c|c|c|c|c|}
\hline \multirow{2}{*}{ Eloctriclty Supply and Demand } & \multicolumn{4}{|c|}{ Relerences Case } & \multirow{2}{*}{$\begin{array}{l}\text { Annual } \\
\text { Growth } \\
\text { 1sea-2010 } \\
\text { (percent) }\end{array}$} \\
\hline & 1980 & 2000 & 2006 & 2010 & \\
\hline \multicolumn{6}{|l|}{ Emisslons (million short tons) } \\
\hline Total Carbon & 10.06 & 10.28 & 10.57 & 9.58 & $.0 .2 \%$ \\
\hline Carbon Dioxide & 36.87 & 37.71 & 38.74 & 35.12 & $.0 .2 \%$ \\
\hline Sultur Dioxida . . & 0.25 & 0.19 & 0.20 & 0.17 & $-2.0 \%$ \\
\hline
\end{tabular}

'Net summer capability is the steady hourly output that generating equipment is expected to supply to system load (exclusive of auxiliary power), as demonstrated by tests during summer peak demand.

'Includes oll-, gas-, and dual-fired capability.

'Other includes methane and propane and blast furnace gas.

"Includes conventional hydroelectric, geothermal, wood, wood waste, municipal solid waste, other biomass, solar, and wind power.

'Cumulative additions after December 31,1990

Includes small power producers, independent power producers, and exempt wholesale generators, which produce electricity for sales to utilities.

'Nameplate capacity is reported tor nonutilities. Nameplate capacity is designated by the manufacturer.

'Other includes hydrogen, sullur, batteries, chemicals, fish oil, and spent sulfite liquor.

"Includes cogenerators a. "Idustrial, commercial, and other facilities whose primary function is not electricity production. Nameplate capacity is reported for nonutilities. Nameplate capacity is designated by the manufacturer.

${ }^{10}$ Generation to meet system load by source.

${ }^{11}$ Inclucies small power producers, independent power producers, and exempt wholesale generators, which produce electricity tor delivery to electric utilities.

${ }^{12}$ Other includes methane. propane, and blast furnace gas

${ }^{13}$ Includes conventional hydroelectric, geothermal, wood, wood waste, municipal solid waste, other biomass, solar and wind power.

"Includes cogeneration at industrial, commercial, and other facilities whose primary function is not electricity production.

"Other includes hydrogen, sulfur, batteries, chemicals, tish oil, and spend sulfite liquor.

${ }^{16}$ Prices represent average revenue per kilowatthour.

"In the end-use energy consumptions lables, projected fuel consumption in the utility sector includes fuel used by independent power producers. In this table, fuel used by independent power producers is included in the nonutility category.

"Includes tuel consumption by independent power producers and exempt wholesale generators, which produce electricity for sales to utilities.

${ }^{19}$ Estimated emissions from utilities and independent power producers.

$E M M=$ Electricty market module.

$O \& M=$ Operation and maintenance.

N/A $=$ Not applicable

Note: Totals may not equal sum of components due to independent rounding.

Sources: 1990 (except for nonutility generation and prices): Energy Inlormation Administration (ElA), Electric Power Annual 1991, DOE/EIA-0348(91) (Washington, D.C., February 1993). 1990 Nonutlity generation: Form ElA-861, "Annual Electric Utility Report" and the Form EIA-867, "Annual Nonutility Power Producer Report." The Form ElA-867 is filed by nonutilities reporting the energy delivered, while the ElA-861 is filed by electric utilities reporting the energy received. Because the Form EIA-861 collects data from the universe of utilities, these data are used for electricity sold to utilities. Own use data is trom Form EIA-867. Prices and all projectione: EIA, AEO 1894 National Energy Modeling System run AEO94B.D1221934 
Table 45. Electric Power Data and Projections for the EMM Region

Southeastern Electric Rellability Councll/Fiorida (SERC/STV)

\begin{tabular}{|c|c|c|c|c|c|}
\hline \multirow{2}{*}{ Electriclyy Supply and Dumend } & \multicolumn{4}{|c|}{ Reterence Case } & \multirow{2}{*}{$\begin{array}{l}\text { Armual } \\
\text { Growth } \\
\text { 1epo-201 } \\
\text { (percent) }\end{array}$} \\
\hline & 1900 & 2000 & 2005 & 2010 & \\
\hline
\end{tabular}

Electricity Cenerating Cepacity

(gignwatto)

Utilitibs

Cepectity

Coal Sieam

Combined Cycle .........................

Combustion Turbina/Diesel ...............

Nuclear Power

Renewable ${ }^{4}$.

Total Utiltites Cesablility ................

8.86

13.50

0.84

4.47

3.83

0.00

0.05

31.34

Cumulative Plemed Addilions

Coal Steam.

Other Fossil Steam ${ }^{2} \ldots \ldots \ldots \ldots \ldots \ldots \ldots$.

Combined Cycle ........................

Combustion Turbine/Diesel ................

Nucloar Power

Pumped Stomager........

Renewable ${ }^{4}$....

Total (planned)

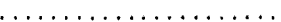

Cumulative Unplanned Additions"

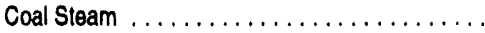

Other Fossil Steam ${ }^{2} \ldots \ldots \ldots \ldots \ldots \ldots$

Combined Cycle .......................

Combustion Turbine/Diesel ...............

Nuclear Power ........................

Pumped Storage/Other' ..................

Renewable'...

Total (unplenned) $\ldots \ldots \ldots \ldots \ldots \ldots . .$.

Cumulative Total Utilliy Additions ....

Cumulativo Utility Retrements

............

Nonutlitibs (excludes cogeneretiors)"

\section{Cespacity'}

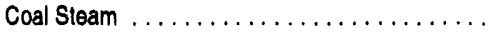

Other Fossil Steam ${ }^{2} \ldots \ldots \ldots \ldots \ldots \ldots \ldots$

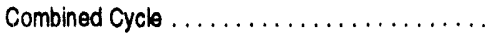

Combustion Turbine/Dlesel . ...............

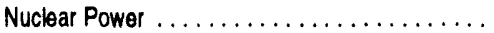

Pumped Storage/Other ${ }^{\circ} \ldots \ldots \ldots \ldots \ldots \ldots . . . . .$.

Renewable"...

Total Nonutilities Cespablity

Cogeneratore

Eloctricity Domand

(Billion kllowatthours)

Residential ...........................

Commercial/Other ......................

Industrial ............................

Transportation $\ldots \ldots \ldots \ldots \ldots \ldots \ldots \ldots \ldots . . . .$.

Total Saloe
0.00

0.00

0.00

0.00

0.00

0.00

0.00

0.00

0.00

0.00

0.00

0.00

0.00

0.00

0.00

0.00

0.00

0.00

0.00

0.00

0.00

0.00

0.00

0.00

0.33

0.33

2.04

53.74

43.10

38.57

0.78

136,20
9.30

12.52

3.79

5.72

3.83

0.00

0.05

35.21

0.44

0.00

3.16

1.29$$
0.00
$$

$$
0.00
$$$$
0.00
$$

4.88

$$
0.00
$$

$$
0.00
$$$$
0.00
$$$$
0.00
$$$$
0.00
$$$$
0.00
$$$$
0.00
$$$$
0.00
$$

4.88

1.03

0.00
0.00

0.29

0.12

0.00

0.00

0.57

0.97

2.47

61.79
52.60
46.95
1.15
$\mathbf{1 6 2 . 5 0}$

65.19
56.97
51.50
1.83
175.50

9.30
12.04
3.96
5.73
3.83
0.00
0.05
34.91

0.44

0.00

3.33

1.34

0.00

0.00

0.00

$$
5.11
$$

$$
0.00
$$

$$
0.00
$$$$
0.00
$$$$
0.00
$$$$
0.00
$$$$
0.00
$$$$
0.00
$$$$
0.00
$$$$
5.11
$$$$
1.55
$$

0.00

$$
0.00
$$$$
0.72
$$$$
0.12
$$$$
0.00
$$$$
0.00
$$$$
0.60
$$$$
1.44
$$

$\begin{array}{rc}12.39 & 1.7 \% \\ 11.54 & .0 .8 \% \\ 3.96 & 9.6 \% \\ 5.73 & 1.3 \% \\ 2.50 & -2.1 \% \\ 0.00 & \text { N/A } \\ 0.05 & \text { N/A } \\ 36.16 & 0.7 \%\end{array}$

0.44

0.00

3.33

1.34

0.00

0.00

0.00

5.11

N/A
N/A
N/A
$N / A$
$N / A$
$N / A$
$N / A$
N/A

3.09

$$
0.00
$$$$
0.00
$$$$
0.00
$$$$
0.00
$$$$
0.00
$$$$
0.00
$$$$
3.09
$$

N/A

N/A

N/A

N/A

N/A

N/A

N/A

NA

8.20

NA

3.39

NA

N/A

N/A

N/A

N/A

N/A

N/A

$4.1 \%$

$12.2 \%$

$1.0 \%$

$\begin{array}{rr}69.42 & 1.3 \% \\ 60.91 & 1.7 \% \\ 55.84 & 1.9 \% \\ 2.68 & 6.4 \% \\ 188.86 & 1.6 \%\end{array}$


Tablo 45. Electric Power Data and Projections for the EMM Region Southeastorn Electric Rellability CouncIVFIorida (SERC/STV) (Continued)

\begin{tabular}{|c|c|c|c|c|c|}
\hline \multirow{2}{*}{ Electleny supply end Demand } & \multicolumn{4}{|c|}{ Reterence Cens } & \multirow{2}{*}{$\begin{array}{l}\text { Amust } \\
\text { Crowth } \\
\text { 1eve-2010 } \\
\text { (perent) }\end{array}$} \\
\hline & 1000 & 2000 & 2005 & 2010 & \\
\hline \multicolumn{6}{|l|}{ 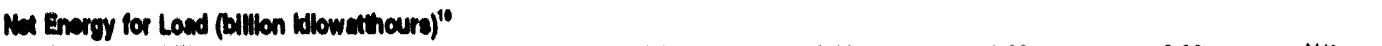 } \\
\hline Net International Electricity Imports $\ldots \ldots \ldots \ldots$ & 0.00 & 0.00 & 0.00 & 0.00 & $N / A$ \\
\hline Net interregional Eloctrichy Imports .......... & 26.66 & 18.60 & 21.01 & 23.80 & $.0 .6 \%$ \\
\hline Purchases from Nonutitiles & & & & & \\
\hline (including cogenerators)" ${ }^{11} \ldots \ldots \ldots \ldots \ldots \ldots$ & 2.43 & $\begin{array}{r}5.82 \\
15031\end{array}$ & $\begin{array}{r}9.61 \\
156.43\end{array}$ & $\begin{array}{r}20.54 \\
14301\end{array}$ & $11.3 \%$ \\
\hline $\begin{array}{l}\text { Generation by Utilities } \ldots \ldots \ldots \ldots \ldots \ldots \ldots \ldots \\
\text { Toted Ku Energy for Loed } \ldots \ldots \ldots \ldots \ldots \ldots \ldots\end{array}$ & $\begin{array}{l}117.60 \\
146.60\end{array}$ & $\begin{array}{l}150.31 \\
174.72\end{array}$ & 187.06 & 187.36 & $\begin{array}{l}1.0 \% \\
1.2 \%\end{array}$ \\
\hline \multicolumn{6}{|l|}{ 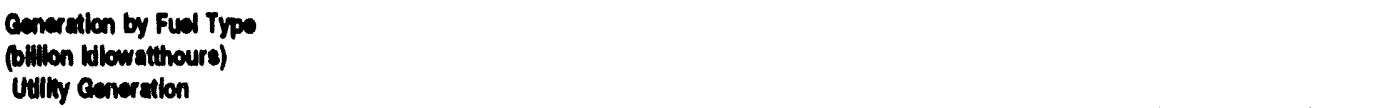 } \\
\hline Coal $\ldots \ldots \ldots \ldots \ldots \ldots \ldots \ldots \ldots$ & 53.17 & 54.92 & 55.08 & 59.99 & $0.6 \%$ \\
\hline 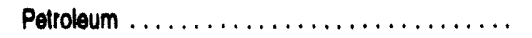 & 25.08 & 29.68 & 32.64 & 27.23 & $0.4 \%$ \\
\hline Natural Gas $\ldots \ldots \ldots \ldots \ldots \ldots \ldots \ldots$ & 17.40 & 40.52 & 43.65 & 39.34 & $4.2 \%$ \\
\hline Nuclear $\ldots \ldots \ldots \ldots \ldots \ldots \ldots \ldots \ldots \ldots$ & 21.78 & 25.07 & 24.94 & 16.33 & $.1 .4 \%$ \\
\hline Pumped Storage/Other ${ }^{12} \ldots \ldots \ldots \ldots \ldots$ & 0.00 & 0.00 & 0.00 & 0.00 & N/A \\
\hline Renewable $e^{13} \ldots \ldots \ldots \ldots \ldots \ldots \ldots \ldots$ & 0.18 & 0.12 & 0.12 & 0.12 & $\cdot 2.0 \%$ \\
\hline Total Villity emeration ................. & 117.60 & 160.31 & 156.43 & 149.01 & $1.0 \%$ \\
\hline Cogenerators (bllition Wlowethoury) ${ }^{14} \ldots \ldots$. & 5.33 & 6.38 & 6.83 & 7.30 & $1.6 \%$ \\
\hline \multicolumn{6}{|l|}{$\begin{array}{l}\text { Nonutllity Ceneration hotuding Cogneration } \\
\text { (billion ldlowathours) }\end{array}$} \\
\hline 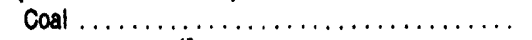 & 0.00 & 0.00 & 0.00 & 10.06 & N/A \\
\hline Petroleum/Other 15 & 0.00 & 0.00 & 0.00 & 0.00 & $N / A$ \\
\hline Natural Gas $\ldots \ldots \ldots \ldots \ldots \ldots \ldots$ & 0.00 & 2.65 & 6.04 & 5.99 & $54.5 \%$ \\
\hline Renewable $\ldots \ldots \ldots \ldots \ldots \ldots \ldots \ldots$ & 1.77 & 2.76 & 3.05 & 3.96 & $4.1 \%$ \\
\hline Total Monutllity Ceneration . . . . . . . . . . . . & 1.77 & 5.42 & 9.10 & 20.01 & $12.9 \%$ \\
\hline \multicolumn{6}{|l|}{$\begin{array}{l}\text { End-Une Pricee" } \\
\text { (19e2 cents per ldlowatthour) }\end{array}$} \\
\hline Residential $\ldots \ldots \ldots \ldots \ldots \ldots \ldots \ldots$ & 9.1 & 9.0 & 9.6 & 10.1 & $0.5 \%$ \\
\hline Commercial . . . . . . . . . . . . . . . & 7.5 & 7.5 & 7.9 & 8.1 & $0.3 \%$ \\
\hline Industrial $\ldots \ldots \ldots \ldots \ldots \ldots \ldots \ldots \ldots$ & 7.2 & 7.0 & 7.3 & 7.4 & $0.1 \%$ \\
\hline Transportation $\ldots \ldots \ldots \ldots \ldots \ldots \ldots \ldots$ & 4.5 & 4.5 & 4.5 & 4.4 & $.0 .2 \%$ \\
\hline All Sectors Averags . . . . . . . . . . . . . & 8.1 & 7.9 & 8.3 & 8.6 & $0.3 \%$ \\
\hline \multicolumn{6}{|l|}{$\begin{array}{l}\text { Prlos Components" } \\
\text { (1092 cents per lilowatthour) }\end{array}$} \\
\hline Capital Component $\ldots \ldots \ldots \ldots \ldots \ldots$ & 2.7 & 2.3 & 2.1 & 1.9 & $-1.7 \%$ \\
\hline Fuel Component $\ldots \ldots \ldots \ldots \ldots \ldots \ldots$ & 1.9 & 2.4 & 2.8 & 2.8 & $1.9 \%$ \\
\hline OsM Component . . . . . . . . . . . . . . . . & 2.6 & 2.6 & 2.7 & 2.6 & $0.1 \%$ \\
\hline Wholesale Power Cost ................ & 0.8 & 0.6 & 0.8 & 1.2 & $2.0 \%$ \\
\hline Total $\ldots \ldots \ldots \ldots \ldots \ldots \ldots \ldots \ldots$ & 8.1 & 7.9 & 8.3 & 8.6 & $0.3 \%$ \\
\hline $\begin{array}{l}\text { Fud Consumption (trillion Btu) } \ldots \ldots \ldots \ldots \ldots \\
\text { Utillibs" }\end{array}$ & 0.26 & 0.35 & 0.41 & 0.45 & $2.8 \%$ \\
\hline Coal $\ldots \ldots \ldots \ldots \ldots \ldots \ldots \ldots \ldots$ & 0.53 & 0.55 & 0.55 & 0.60 & $0.6 \%$ \\
\hline Natural Gas $\ldots \ldots \ldots \ldots \ldots \ldots \ldots$ & 0.19 & 0.44 & 0.47 & 0.43 & $4.1 \%$ \\
\hline Oil $\ldots \ldots \ldots \ldots \ldots \ldots \ldots \ldots \ldots \ldots \ldots \ldots \ldots$ & 0.26 & 0.32 & 0.36 & 0.30 & $0.8 \%$ \\
\hline Coal $\ldots \ldots \ldots \ldots \ldots \ldots \ldots \ldots \ldots \ldots$ & 0.00 & 0.00 & 0.00 & 0.10 & N/A \\
\hline Natural Gas $\ldots \ldots \ldots \ldots \ldots \ldots \ldots \ldots$ & 0.00 & 0.03 & 0.05 & 0.05 & $N / A$ \\
\hline Oil $\ldots \ldots \ldots \ldots \ldots \ldots \ldots \ldots \ldots \ldots$ & 0.00 & 0.00 & 0.00 & 0.00 & $N / A$ \\
\hline
\end{tabular}


Table 46. Electric Power Data and Projections for the EMM Roglon

Southeastern Electric Rellability CounclifFlorida (8ERC/STV) (Continued)

\begin{tabular}{|c|c|c|c|c|c|}
\hline \multirow{2}{*}{ Electrielty supply and Damend } & \multicolumn{4}{|c|}{ Reterencen cerso } & \multirow{2}{*}{$\begin{array}{l}\text { Annud } \\
\text { Crown } \\
\text { 1ema-2010 } \\
\text { (perant) }\end{array}$} \\
\hline & 1900 & 2000 & 2000 & 2010 & \\
\hline \multicolumn{6}{|l|}{ Emisclons (million chort tons)" } \\
\hline Total Carbon & 21.60 & 27.17 & 28.69 & 30.60 & $1.8 \%$ \\
\hline Carbon Dioxide & 79.21 & 99.61 & 105.21 & 112.20 & $1.8 \%$ \\
\hline Sulfur Dioxide. & 0.68 & 0.49 & 0.29 & 0.25 & $.4 .8 \%$ \\
\hline
\end{tabular}

'Nel summer capability is the steady hourly output that generating equipment is expected to supply to system load (excluaive of auxiliary power). as demonstrated by tests during summer peak demand.

'Includes oil-, gas-, and dual-fired capability.

'Other includes methane and propane and blast furnace gas.

"Includes conventional hydroelectric, geothermal, wood, wood waste, municipal solid waste, other biomass, solar, and wind power.

'Cumulative additions atter December $31,1890$.

"Includes small power producers, independent power producers, and exempt wholesale generators, which produce electricity for salee to utilitios.

'Nameplate capacify is reported for nonutilities. Nameplale cepacity is designated by the manufacturer.

'Other inciudes hydrogen, sulfur, batteries, chemicals, fish oll, and spent sulfite liquor.

"Includes cogenerators at industrial, commercial, and other tacilities whose primary function is nol alectricity production. Nameplate capacity

is reported for nonutilities. Nameplate capacity is designated by the manulacturer.

${ }^{10} \mathrm{Generation}$ to meel system load by source.

"Includes small power producers, independent power producers, and exempt wholesale generators, which produce electricity for delivery to electric utilities.

"Other includes methane, propane, and blast furnace gas.

"Includes conventional hydroelectric, geothermal, wood, wood waste, municipal solid waste, other biomass, solar and wind power.

"Includes cogeneration at industrial, commercial, and other facilities whose primary function is not electricity production.

"Other includes hydrogen, sulfur, batteries, chemicals, fish oil, and spend sulfite liquor.

1"Prices represent average revenue per kilowatthour.

17 In the end-use energy consumptions tables, projected fuel consumption in the utility sector includes fuel used by independent power producers. In this table, fuel used by independent power producers is included in the nonutility category.

11 Includes fuel consumption by independent power producers and exempt wholesale generators, which produce electricity for sales to utilities.

"Estimated emissions from utilities and independent power producers.

$E M M=$ Electricty market module.

O\&M = Operation and maintenance.

N/A $=$ Not applicable.

Note: Totals may not equal sum of components due to independent rounding.

Sources: 1990 (except for nonutility generation and prices): Energy Information Administration (ElA). Electric Power Annual 1001, DOEJEIA-0348(91) (Washington, D.C.. February 1993). 1990 Nonutility generation: Form EIA-861, "Annual Electric Utility Report" and the Form ElA-867, "Annual Nonutility Power Producer Report." The Form ElA-867 is filed by nonutilities reporting the energy delivered, while the ElA-881 is filed by electric utilities reporting the energy received. Because the Form ElA-861 collects data from the universe of utilities, these data are used for electricity sold to utilities. Own use data is trom Form EIA-867. Prices and all propeotlone: EIA, AEO 1094 National Energy Modeling System run AEO94B.D1221934. 
Table 46. Electric Power Data and Projections for the EMM Reglon Southeastern Electric Reliability Councll/oxcluding Florida (SERC/STV)

\begin{tabular}{|c|c|c|c|c|c|}
\hline \multirow{2}{*}{ Electrlefly Supply and Demend } & \multicolumn{4}{|c|}{ Relerences Cases } & \multirow{2}{*}{$\begin{array}{c}\text { Annual } \\
\text { Growth } \\
1000-2010 \\
\text { (perant) }\end{array}$} \\
\hline & 1000 & 2000 & 2000 & 2010 & \\
\hline
\end{tabular}

\begin{tabular}{|c|c|c|c|c|c|}
\hline $\begin{array}{l}\text { Electriclity Cenerating Ceapacity' } \\
\text { (glgawatts) } \\
\text { Utilltibs } \\
\text { Capacity }\end{array}$ & & & & & \\
\hline Coal Sleam & 61.91 & 62.00 & 61.23 & 66.20 & $0.3 \%$ \\
\hline Other Fossil Steam ${ }^{2}$ & 3.26 & 2.61 & 2.30 & 2.20 & $.1 .9 \%$ \\
\hline$\ldots \ldots \ldots \ldots \ldots$ & 0.61 & 1.06 & 3.64 & 5.22 & $11.3 \%$ \\
\hline Combustion Turbine/Diesel . .............. & 6.35 & 11.83 & 11.73 & 11.67 & $3.1 \%$ \\
\hline Nuclear Power $\ldots \ldots \ldots \ldots \ldots \ldots \ldots$ & 25.31 & 28.92 & 30.13 & 29.45 & $0.8 \%$ \\
\hline Pumped Storage/Other' $\ldots \ldots \ldots \ldots \ldots \ldots$ & 4.50 & 6.78 & 6.78 & 6.78 & $2.1 \%$ \\
\hline Renewable $\ldots \ldots \ldots \ldots \ldots \ldots \ldots \ldots$ & 11.18 & 11.18 & 11.18 & 11.18 & N/A \\
\hline Total Utillitios Capablilty $\ldots \ldots \ldots \ldots \ldots \ldots$ & 113.12 & 124.30 & 127.00 & 132.72 & $0.8 \%$ \\
\hline Cumulative Plemned Additions ${ }^{5}$ & & & & & \\
\hline Coal Steam ....... & 0.00 & 1.71 & 1.71 & 1.71 & N/A \\
\hline$\ldots \ldots \ldots \ldots \ldots \ldots$ & 0.00 & 0.00 & 0.00 & 0.00 & N/A \\
\hline Combined Cycle ... & 0.00 & 0.52 & 1.29 & 1.29 & N/A \\
\hline Combustion Turbine/Diesel ............... & 0.00 & 5.54 & 6.59 & 6.59 & N/A \\
\hline Nuclear Power $\ldots \ldots \ldots \ldots \ldots \ldots \ldots \ldots$ & 0.00 & 3.55 & 4.76 & 4.76 & N/A \\
\hline Pumped Storage/Other' ................... & 0.00 & 2.28 & 2.28 & 2.28 & N/A \\
\hline Renewable ${ }^{4} \ldots \ldots \ldots$ & 0.00 & 0.00 & 0.00 & 0.00 & N/A \\
\hline Total (planned) $\ldots \ldots \ldots \ldots \ldots \ldots \ldots \ldots$ & 0.00 & 13.60 & 16.63 & 16.60 & NA \\
\hline Cumulative Unplanned Additions ${ }^{\circ}$ & & & & & \\
\hline Coal Stoam ................. & 0.00 & 0.00 & 0.00 & 6.11 & N/A \\
\hline$\ldots \ldots \ldots \ldots \ldots \ldots$ & 0.00 & 0.00 & 0.00 & 0.00 & N/A \\
\hline$\ldots \ldots \ldots \ldots \ldots \ldots$ & 0.00 & 0.00 & 1.82 & 3.39 & N/A \\
\hline Combustion Turbine/Diesel & 0.00 & 0.00 & 0.00 & 0.00 & N/A \\
\hline Nuclear Power ......... & 0.00 & 0.00 & 0.00 & 0.00 & N/A \\
\hline Pumped Storage/Other" & 0.00 & 0.00 & 0.00 & 0.00 & N/A \\
\hline Renewable ${ }^{4} \ldots \ldots$ & 0.00 & 0.00 & 0.00 & 0.00 & N/A \\
\hline Total (unplenned) $\ldots \ldots \ldots \ldots \ldots \ldots \ldots$ & 0.00 & 0.00 & 1.82 & 9.50 & NA \\
\hline Cumulative Total Utility Additions .......... & 0.00 & 13.60 & 18.45 & 26.13 & NA \\
\hline Cumulattve Utility Retirements $\ldots \ldots \ldots \ldots$ & 0.00 & 2.41 & 4.65 & 6.62 & NA \\
\hline $\begin{array}{l}\text { Nonutillities (excludes cogenerators)" } \\
\text { Cepacily' }\end{array}$ & & & & & \\
\hline Coal Sleam .... & 0.00 & 0.16 & 0.16 & 0.16 & N/A \\
\hline Other Fossil Steam² & 0.00 & $0 . w$ & 0.00 & 0.00 & N/A \\
\hline (................. & 0.25 & 1.00 & 2.33 & 4.97 & $16.1 \%$ \\
\hline Combustion Turbine/Tiesel ............... & 0.00 & 0.31 & 0.31 & 0.31 & N/A \\
\hline Nuclear Power ........................ & 0.00 & 0.00 & 0.00 & 0.00 & N/A \\
\hline Pumped Storage/Jther ${ }^{\circ} \ldots \ldots \ldots \ldots \ldots \ldots$ & 0.00 & 0.00 & 0.00 & 0.00 & N/A \\
\hline Renewable ${ }^{4} \ldots \ldots \ldots \ldots$ & 0.24 & 0.42 & 1.26 & 2.10 & $11.6 \%$ \\
\hline Total Nonutilltiles Capabillty ............. & 0.40 & 1.80 & 4.07 & 7.55 & $14.7 \%$ \\
\hline Cogenerators ${ }^{\circ}$. & 8.63 & 9.03 & 9.06 & 9.00 & $0.3 \%$ \\
\hline $\begin{array}{l}\text { Electriclty Demand } \\
\text { (billion kllowatthouro) }\end{array}$ & & & & & \\
\hline Residential ......... & 170.34 & 191.42 & 200.00 & 210.91 & $1.1 \%$ \\
\hline Commercial/Other ...................... & 123.10 & 147.78 & 157.91 & 166.38 & $1.5 \%$ \\
\hline 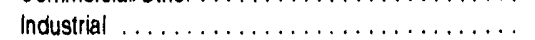 & 158.59 & 193.54 & 212.30 & 230.19 & $1.9 \%$ \\
\hline Transportation & 2.44 & 3.51 & 5.49 & 7.97 & $6.1 \%$ \\
\hline Total Sales $\ldots \ldots \ldots \ldots \ldots \ldots \ldots \ldots \ldots \ldots$ & 454.46 & 536.24 & 575.71 & 615.46 & $1.5 \%$ \\
\hline
\end{tabular}


Table 46. Electric Power Data and Projections for the EMM Reglon Southeastern Electric Rellability CounclVexcluding Florida (SERC/BTY) (Continued)

\begin{tabular}{|c|c|c|c|c|c|}
\hline \multirow{2}{*}{ Electricly Supply and Damend } & \multicolumn{4}{|c|}{ Relerences Ceses } & \multirow{2}{*}{$\begin{array}{l}\text { Annud } \\
\text { Crowth } \\
\text { 1cep-2010 } \\
\text { (perent) }\end{array}$} \\
\hline & 1000 & 2000 & 2000 & 2010 & \\
\hline \multicolumn{6}{|l|}{ Net Energy for Load (billion Wlowathours) } \\
\hline Net International Electricity Imports & 0.00 & 0.00 & 0.00 & 0.00 & N/A \\
\hline Net Interregional Electricity Imports & .4 .41 & $\cdot 13.20$ & $\cdot 18.52$ & .27 .00 & $9.5 \%$ \\
\hline Purchases from Nonutillites & & & & & \\
\hline (including cogenerators)" & 8.50 & 15.95 & 31.51 & 45.01 & $8.7 \%$ \\
\hline Generation by Utilities $\ldots \ldots \ldots \ldots \ldots \ldots \ldots$ & 479.24 & 578.72 & 611.26 & 663.49 & $1.6 \%$ \\
\hline Total Net Energy for Loed $\ldots \ldots \ldots \ldots \ldots \ldots$ & 483.33 & 801.40 & 624.26 & 601.40 & $1.7 \%$ \\
\hline \multicolumn{6}{|l|}{$\begin{array}{l}\text { Comeration by Fual Typs } \\
\text { (billion kllowatthours) }\end{array}$} \\
\hline \multicolumn{6}{|l|}{ Uttilly Comaration } \\
\hline Coal $\ldots \ldots \ldots$ & 289.25 & 331.04 & 336.80 & 392.07 & $1.5 \%$ \\
\hline$\ldots \ldots \ldots \ldots$ & 1.89 & 1.83 & 2.92 & 2.17 & $0.7 \%$ \\
\hline Natural Gas & 4.42 & 12.79 & 29.39 & 30.01 & $10.0 \%$ \\
\hline Nuclear $\ldots \ldots \ldots \ldots$. & 147.00 & 197.68 & 206.78 & 203.87 & $1.6 \%$ \\
\hline Pumped Storage/Other'ta & .0 .99 & -3.35 & .3 .36 & .3 .37 & $6.3 \%$ \\
\hline Renewable" ......... & 37.67 & 38.73 & 38.73 & 38.73 & $0.1 \%$ \\
\hline Total Uilliny Comeration . .................... & 470.24 & 578.72 & 611.26 & 603.40 & $1.0 \%$ \\
\hline Cogmmators (billion kllowatthoure)" $\ldots$...... & 23.16 & 28.40 & 30.22 & 32.06 & $1.0 \%$ \\
\hline \multicolumn{6}{|l|}{$\begin{array}{l}\text { Monutlliny Cencration moluding Cogeneration } \\
\text { (blikkil kliowatthours) }\end{array}$} \\
\hline Coal ......... & 0.00 & 0.98 & 1.01 & 1.01 & N/A \\
\hline Petroleum/Other ${ }^{15}$ & 0.01 & 0.00 & 0.00 & 0.00 & $N / A$ \\
\hline Natural Gas $\ldots$. & 0.04 & 4.48 & 14.48 & 22.50 & $37.1 \%$ \\
\hline$\ldots \ldots \ldots \ldots \ldots \ldots \ldots \ldots \ldots$ & 0.85 & 2.45 & 7.68 & 12.91 & $14.6 \%$ \\
\hline Total Monutillity Ceneration ................. & 0.80 & 7.91 & 23.18 & 36.42 & $20.3 \%$ \\
\hline \multicolumn{6}{|l|}{$\begin{array}{l}\text { End-Uen Prices" } \\
\text { (1902 cents per Klowatthour) }\end{array}$} \\
\hline Residential ............ & 7.9 & 7.7 & 8.0 & 8.5 & $0.4 \%$ \\
\hline Commercial ......................... & 7.3 & 6.9 & 6.7 & 6.7 & $.0 .4 \%$ \\
\hline Industrial $\ldots \ldots \ldots \ldots \ldots \ldots \ldots \ldots \ldots$ & 5.0 & 4.6 & 4.5 & 4.6 & $.0 .5 \%$ \\
\hline Transportation $\ldots \ldots \ldots \ldots \ldots \ldots \ldots \ldots \ldots$ & 4.5 & 4.4 & 4.3 & 4.4 & $-0.1 \%$ \\
\hline All Sectors Average $\ldots \ldots \ldots \ldots \ldots \ldots \ldots$ & 6.7 & 6.4 & 6.3 & 6.5 & $0.2 \%$ \\
\hline \multicolumn{6}{|l|}{$\begin{array}{l}\text { Price Components" } \\
\text { (1002 conts per Illowatthour) }\end{array}$} \\
\hline Capital Component $\ldots \ldots \ldots \ldots \ldots \ldots \ldots$ & 3.1 & 2.7 & 2.4 & 2.5 & $-1.2 \%$ \\
\hline Fuel Component $\ldots . . \ldots \ldots$ & 1.3 & 1.4 & 1.5 & 1.6 & $1.0 \%$ \\
\hline 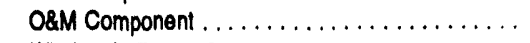 & 2.3 & 2.3 & 2.3 & 2.3 & $0.1 \%$ \\
\hline Wholesale Power Cost ................. & 0.0 & 0.0 & 0.1 & 0.1 & N/A \\
\hline Total $\ldots \ldots \ldots \ldots \ldots, \ldots, \ldots, \ldots, \ldots, \ldots$ & 6.7 & 6.4 & 6.3 & 6.5 & $.0 .2 \%$ \\
\hline $\begin{array}{l}\text { Full Consumption (tuillion Btu) } \ldots \ldots \ldots \ldots \ldots \\
\text { Utillitios" }\end{array}$ & 0.03 & ن.08 & 0.19 & 0.23 & $11.6 \%$ \\
\hline$\ldots \ldots \ldots \ldots$ & 2.87 & 3.21 & 3.26 & 3.81 & $1.4 \%$ \\
\hline Natural Gas $\ldots \ldots \ldots \ldots \ldots \ldots \ldots \ldots \ldots$ & 0.06 & 0.20 & 0.33 & 0.31 & $9.0 \%$ \\
\hline$\ldots \ldots \ldots \ldots \ldots \ldots \ldots, \ldots$ & 0.02 & 0.03 & 0.05 & 0.03 & $2.8 \%$ \\
\hline \multicolumn{6}{|l|}{ Nonutlitibs" } \\
\hline Coal $\ldots \ldots$ & 0.00 & 0.01 & 0.01 & 0.01 & $N / A$ \\
\hline Natural Gas $\ldots \ldots \ldots \ldots \ldots \ldots \ldots \ldots \ldots$ & 0.01 & 0.05 & 0.13 & 0.18 & $18.5 \%$ \\
\hline$\ldots \ldots \ldots \ldots \ldots \ldots \ldots$ & 0.00 & 0.00 & 0.00 & 0.00 & N/A \\
\hline
\end{tabular}


Table 46. Electric Power Data and Projections for the EMM Region Southeastern Electric Reliability CounciVexcluding Florida (SERC/STV) (Continued)

\begin{tabular}{|c|c|c|c|c|c|}
\hline \multirow{2}{*}{ Eloctriclty Supply and Demend } & \multicolumn{4}{|c|}{ Reterenco Case } & \multirow{2}{*}{$\begin{array}{c}\text { Annual } \\
\text { Growth } \\
1000-2010 \\
\text { (percent) }\end{array}$} \\
\hline & $199 n$ & 2000 & 2005 & 2010 & \\
\hline \multicolumn{6}{|l|}{ Emlselons (million short tons) } \\
\hline Total Carbon $\ldots \ldots \ldots \ldots$ & 72.01 & 84.92 & 89.91 & 104.31 & $1.9 \%$ \\
\hline Carbon Dioxide. & 264.05 & 311.37 & 329.67 & 382.47 & $1.9 \%$ \\
\hline Sulfur Dioxide .... & 3.16 & 1.31 & 1.19 & 1.16 & $.4 .9 \%$ \\
\hline
\end{tabular}

'Net summer capability is the steady hourly output that generating equipment is expected to supply to system load (exclusive of auxiliary power), as demonstrated by tests during summer peak demand.

'includes oil-, gas-, and dual-tired capability.

'Other includes methane and propane and blast furnace gas.

"Includes conventional hydroelectric, geothermal, wood, wood waste, municipal solid waste, other blomass, solar, and wind power.

'Cumulative additions after December 31, 1900.

includes small power producers, independent power producers, and exempt wholesale generators, which produce electricity for sales to utilities.

${ }^{7}$ Nameplate capacity is reported for nonutilities. Nameplate capacity is designated by the manufacturer.

'Other includes hydrogen, sulfur, batteries, chemicals, fish oil, and spent sulfite liquor.

'includes cogenerators at industrial, commercial, and other facilities whose primary function is not electricity production. Nameplate capacity

is reported for nonutilities. Nameplate capacity is designated by the manufacturer.

${ }^{10} \mathrm{Generation}$ to meet system load by source.

"includes small power producers, independent power producers, and exempt wholesale generators, which produce electricity for delivery to electric utilities.

${ }^{12}$ Other includes methane, propane, and blast furnace gas.

19 Includes conventional hydroelectric, geothermal, wood, wood waste, municipal solid waste, other biomass, solar and wind power.

"Includes cogeneration at industrial, commercial, and other facilities whose primary function is not electricity production.

${ }^{16}$ Other includes hydrogen, sulfur, batteries, chemicals, fish oil, and spend sulfite liquor.

${ }^{10}$ Prices represent average revenue per kilowatthour.

${ }^{17}$ In the end-use energy consumptions tables, projected fuel consumption in the utility sector includes fuel used by independent power prodli. $7 \mathrm{rs}$ In this table, fuel used by independent power producers is included in the nonutility category.

"Includes fuel consumption by independent power producers and exempt wholesale generators, which produce electricity for sales to utilities.

${ }^{19}$ Estimated emissions from utilities and independent power prod.

$E M M=$ Electricity market module.

$O \& M=$ Operation and maintenance.

N/A = Not applicable

Note: Totals may not equal sum of components due to indepe

ing.

Sources: 1980 (except for nonutility generation and prices): Liluiyy Information Administration (ElA), Electric Power Annual 1891, DOEJEIA-0348(91) (Washington, D.C., February 1993). 1990 Nonutility generation: Form EIA-861, "Annual Electric Utility Report" and the Form EIA-867, "Annual Nonutility Power Producer Report." The Form EIA-867 is filed by nonutilities reporting the energy delivered, while the ElA-861 is filed by electric utilities reporting the energy recelved. Because the Form EIA-861 collects data from the universe of utilities, these data are used for electricity sold to utilities. Own use data is from Form EIA-867. Prices and all projectlone: EIA, AEO 1994 National Energy Modeling System run AEO94B.D1221934. 
Tabie 47. Electric Power Data and Projections for the EMM Region Southwest Power Pool (SPP)

\begin{tabular}{|c|c|c|c|c|c|}
\hline \multirow{2}{*}{ Eloctricity Supply and Demend } & \multicolumn{4}{|c|}{ Referenco Cereo } & \multirow{2}{*}{$\begin{array}{c}\text { Amnual } \\
\text { Growth } \\
1980-2010 \\
\text { (percent) }\end{array}$} \\
\hline & 1000 & 2000 & 2005 & 2010 & \\
\hline
\end{tabular}

Electricity Generating Capacity
(glgawatts)

Utillitios

Cepacity

Coal Steam ...................... 27.26

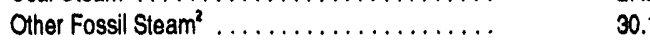

Combined Cycle .......................

Combustion Turbine/Diesel ...............

Nuclear Power ........................

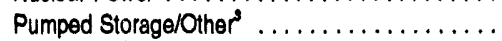

Renewable $\ldots \ldots \ldots \ldots \ldots \ldots \ldots \ldots . .$.

Total Utilities Capability

30.11
1.11

1.11
4.16

5.89

0.51

2.43

71.46

Cumulattvo Plemned Addhions

Coal Steam ....................... 0.00

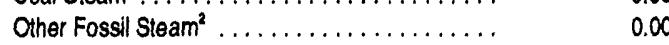

Combined Cycle ..................... $\quad 0.00$

Combustion Turbine/Dieser ................ $\quad 0.00$

Nuclear Power ........................

Pumped Storage/Other' $\ldots \ldots \ldots \ldots \ldots \ldots$.

Renewable ....

Total (planned) $\ldots \ldots \ldots \ldots \ldots \ldots \ldots \ldots \ldots$

Cumulative Unplanned Additions

Coal Steam ........................

Other Fossil Steam ${ }^{2} \ldots \ldots \ldots \ldots \ldots \ldots \ldots$

Combinad Cycle .......................

Combustion Turbine/Diesel ...............

Nuclear Power ........................

Pumped Storage/Other"

Renewable

Total (unplanned)

.

Cumulative Total Utility Additions

Cumulative Utillty Retirements

atore $)^{6}$

Nonutillibs

\section{Coal Stoam .....}

Coal sloam ..........................

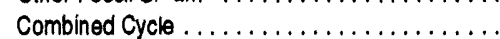

Combustion Turbine/Diesel ................

Nuclear Power .......................

Pumped Storage/Other $\ldots . \ldots \ldots \ldots \ldots \ldots$.

Renewable" ...

Total Nonetilitiles Cepablilty

n.............

Cogenerators?

Eloctriclty Demand

(billion kdlowatthours)

Residential .........................

Commercial/Other .......................

Industrial ..........................

Transportation

Fotal Sales .

$\ldots \ldots \ldots \ldots \ldots \ldots \ldots \ldots$

$\begin{array}{rr}83.96 & 88.25 \\ 67.92 & 75.93 \\ 84.16 & 101.45 \\ 1.27 & 1.80 \\ 237.31 & 267.45\end{array}$

$\begin{array}{lll}1.96 & 1.96 & \text { N/A } \\ 0.97 & 0.97 & \text { N/A } \\ 0.51 & 0.51 & \text { N/A } \\ 1.25 & 1.44 & \text { N/A } \\ 0.00 & 0.00 & \text { N/A } \\ 0.00 & 0.00 & \text { N/A } \\ 0.08 & 0.08 & \text { N/A } \\ 4.78 & 4.97 & \text { N/A }\end{array}$

$\begin{array}{lll}0.00 & 3.39 & \text { N/A } \\ 0.00 & 0.00 & \text { N/A } \\ 0.00 & 0.00 & \text { N/A } \\ 0.00 & 0.00 & \text { N/A } \\ 0.00 & 0.00 & \text { N/A } \\ 0.00 & 0.00 & \text { N/A } \\ 0.00 & 0.00 & \text { N/A } \\ 0.00 & 3.39 & \text { N/A } \\ 4.78 & 8.36 & \text { N/A } \\ & & \\ 0.49 & 7.72 & \end{array}$

\subsection{8}

NA

$\begin{array}{llc}0.00 & 0.00 & \mathrm{~N} / \mathrm{A} \\ 0.06 & 0.06 & 1.2 \% \\ 0.00 & 0.09 & \mathrm{~N} / \mathrm{A} \\ 0.76 & 1.99 & 15.9 \% \\ 0.00 & 0.00 & \mathrm{~N} / \mathrm{A} \\ 0.00 & 0.00 & \mathrm{~N} / \mathrm{A} \\ 0.47 & 0.90 & 24.5 \% \\ 1.28 & 3.03 & 15.9 \% \\ & & \\ 3.52 & 3.55 & -0.6 \%\end{array}$

3.50

$$
9.62
$$

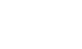

$\begin{array}{rrr}90.34 & 93.60 & 0.5 \% \\ 78.26 & 78.68 & 0.7 \% \\ 110.63 & 119.25 & 1.8 \% \\ 2.77 & 3.95 & 5.8 \% \\ 232.00 & 295.48 & 1.1 \%\end{array}$


Table 47. Electric Power Data and Projections for the EMM Region Southwest Power Pool (SPP) (Continued)

\begin{tabular}{|c|c|c|c|c|c|}
\hline \multirow{2}{*}{ Eloctriclty Supply and Demend } & \multicolumn{4}{|c|}{ Reference Case } & \multirow{2}{*}{$\begin{array}{l}\text { Annual } \\
\text { Growth } \\
\text { 19e0-201 } \\
\text { (percent }\end{array}$} \\
\hline & 1990 & 2000 & 2005 & 2010 & \\
\hline \multicolumn{6}{|l|}{ Nex Energy for Loed (billion klowathours)" } \\
\hline Net International Electricity Imports $\ldots \ldots \ldots \ldots$ & 0.00 & 0.00 & 0.00 & 0.00 & N/A \\
\hline Net Interregional Electricty Imports $\ldots \ldots \ldots \ldots$ & 18.51 & 9.04 & 5.83 & 12.34 & $-2.0 \%$ \\
\hline $\begin{array}{l}\text { Purchases from Nonutillties } \\
\text { (including cogenerators)" }\end{array}$ & 3.51 & 6.34 & 10.28 & 15.67 & $7.8 \%$ \\
\hline Generation by Utilities ..... & 282.63 & 287.84 & 300.02 & 303.09 & $0.4 \%$ \\
\hline Total Not Energy for Load ............... & 304.66 & 303.22 & 316.13 & 331.10 & $0.4 \%$ \\
\hline \multicolumn{6}{|l|}{$\begin{array}{l}\text { Comeration by Fuel Type } \\
\text { (olitlon kllowatthours) }\end{array}$} \\
\hline Coal ............... & 167.00 & 189.36 & 195.70 & 209.99 & $1.2 \%$ \\
\hline Petroleum $\ldots \ldots \ldots \ldots \ldots \ldots \ldots \ldots \ldots$ & 1.12 & 0.63 & 0.92 & 0.80 & $-1.7 \%$ \\
\hline Natural Gas $\ldots \ldots \ldots \ldots \ldots \ldots \ldots \ldots \ldots$ & 69.04 & 63.86 & 69.19 & 58.28 & $.0 .8 \%$ \\
\hline Nuclear ............ & 37.23 & 27.20 & 27.42 & 27.23 & $-1.6 \%$ \\
\hline Pumped Storage/Other ${ }^{12}$ & 0.35 & .0 .44 & -0.44 & -0.44 & N/A \\
\hline Renewables" ........ & 7.90 & 7.24 & 7.24 & 7.24 & $-0.4 \%$ \\
\hline 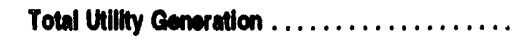 & 282.63 & 287.84 & 300.02 & 303.00 & $0.4 \%$ \\
\hline Cogenerators (billion klowatthours)" $\ldots \ldots \ldots$ & 27.17 & 33.44 & 35.75 & 38.12 & $1.7 \%$ \\
\hline \multicolumn{6}{|l|}{$\begin{array}{l}\text { Nonutllity Generation Ineluding Cogeneration } \\
\text { (Blllion Wllowatthours) }\end{array}$} \\
\hline 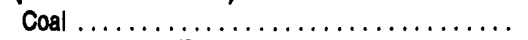 & 0.00 & 0.00 & 0.00 & 0.00 & N/A \\
\hline Petroleum/Other ${ }^{15}$ & 0.00 & 0.00 & 0.00 & 0.00 & N/A \\
\hline Natural Gas $\ldots \ldots \ldots \ldots \ldots \ldots \ldots \ldots$ & 0.09 & 0.51 & 2.13 & 4.97 & $22.1 \%$ \\
\hline Renewable $\ldots \ldots \ldots \ldots \ldots \ldots \ldots \ldots \ldots$ & 0.10 & 0.87 & 3.01 & 5.40 & $22.1 \%$ \\
\hline Total Nonutility Generation .............. & 0.19 & 1.38 & 5.13 & 10.37 & $22.1 \%$ \\
\hline \multicolumn{6}{|l|}{$\begin{array}{l}\text { End-Ues Pricese" } \\
\text { (19e2 cents per lilowatthour) }\end{array}$} \\
\hline Residential ............... & 7.7 & 7.7 & 8.3 & 9.6 & $1.1 \%$ \\
\hline Commercial $\ldots \ldots \ldots \ldots \ldots \ldots \ldots \ldots \ldots$ & 6.8 & 7.1 & 7.5 & 8.7 & $1.2 \%$ \\
\hline Industrial $\ldots \ldots \ldots \ldots \ldots \ldots \ldots \ldots \ldots$ & 4.5 & 4.6 & 4.9 & 5.5 & $1.1 \%$ \\
\hline Transportation ....................... & 4.0 & 4.0 & 4.1 & 4.4 & $0.5 \%$ \\
\hline All Sectors Average .................. & 6.3 & 6.3 & 6.7 & 7.6 & $1.0 \%$ \\
\hline \multicolumn{6}{|l|}{$\begin{array}{l}\text { Prico Components } \\
\text { (1002 conts per Klowathour) }\end{array}$} \\
\hline Capital Component ....... & 2.0 & 1.8 & 1.9 & 2.3 & $0.5 \%$ \\
\hline Fuel Component & 1.6 & 1.8 & 2.0 & 2.4 & $2.0 \%$ \\
\hline 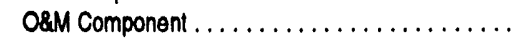 & 2.4 & 2.5 & 2.5 & 2.6 & $0.3 \%$ \\
\hline Wholesale Power Cost $\ldots \ldots \ldots \ldots \ldots \ldots$ & 0.2 & 0.2 & 0.2 & 0.4 & $3.4 \%$ \\
\hline 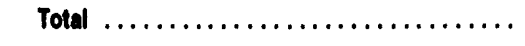 & 6.3 & 6.3 & 6.7 & 7.6 & $1.0 \%$ \\
\hline $\begin{array}{l}\text { Full Consumption (trillion Btu) } \ldots \ldots \ldots \ldots \ldots \text {. } \\
\text { Utullibes" }\end{array}$ & 0.01 & 0.01 & 0.04 & 0.06 & $7.8 \%$ \\
\hline Coal $\ldots \ldots \ldots \ldots \ldots \ldots \ldots \ldots \ldots \ldots, \ldots$, & 1.81 & 2.05 & 2.11 & 2.25 & $1.1 \%$ \\
\hline Natural Gas .... & 0.74 & 0.68 & 0.74 & 0.62 & $.0 .9 \%$ \\
\hline Oll $\ldots \ldots \ldots$........ & 0.01 & 0.01 & 0.01 & 0.01 & $-0.8 \%$ \\
\hline \multicolumn{6}{|l|}{ Nonutillition" } \\
\hline Coal $\ldots \ldots \ldots$ & 0.00 & 0.00 & 0.00 & 0.00 & $N / A$ \\
\hline Natural Gas $\ldots \ldots \ldots \ldots \ldots \ldots \ldots$ & 0.00 & 0.01 & 0.02 & 0.05 & $22.2 \%$ \\
\hline 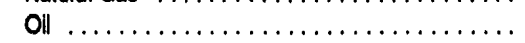 & 0.00 & 0.00 & 0.00 & 0.00 & N/A \\
\hline
\end{tabular}



Table 47. Electric Power Data and Projections for the EMM Region
Southwest Power Pool (SPP) (Continued)

\begin{tabular}{|c|c|c|c|c|c|}
\hline \multirow{2}{*}{ Electriclty Supply and Demand } & \multicolumn{4}{|c|}{ Reterence Case } & \multirow{2}{*}{$\begin{array}{l}\text { Annud } \\
\text { Crowth } \\
1 \text { ero-2010 } \\
\text { (percent) }\end{array}$} \\
\hline & 1900 & 2000 & 2005 & 2010 & \\
\hline \multicolumn{6}{|l|}{ Emissions (million short tons) ${ }^{10}$} \\
\hline Sulfur Dioxide . . . . . . . & 0.98 & 0.89 & 0.75 & 0.73 & $.1 .4 \%$ \\
\hline
\end{tabular}

'Net summer capability is the steady hourly output that generating equipment is expected to supply to system load (exclusive of auxillary power), as demonstrated by tests during summer peak demand.

'Includes oil-, gas-, and dual-fired capability.

'Other includes methane and propane and blast furnace gas.

"Includes conventional hydroelectric, geothermal, wood, wood waste, municipal solid waste, other biomass, solar, and wind power.

${ }^{8}$ Cumulative additions after December $31,1990$.

"Includes small power producers, independent power producers, and exempt wholesale generators, which produce electricity for sales to utilities.

${ }^{7}$ Nameplate capac is reported for nonutilities. Nameplate capacity is designated by the manufacturer.

'Other includes hydrogen, sulfur, batteries, chemicals, fish oil, and spent sulfite liquor.

Includes cogenerators at industrial, commerclal, and other facilities whose primary function is not electricity production. Nameplate capacity is reported for nonutilities. Nameplate capacity is designated by the manufacturer.

${ }^{10}$ Generation to meet system load by source.

"Includes small power producers, independent power producers, and exempt wholesale generators, which produce electricity for delivery to electric utilities.

${ }^{12}$ Other includes methane, propane, and blast furnace gas.

${ }^{19}$ Includes conventional hydroelectric, geothermal, wood, wood waste, municipal solid waste, other biomass, solar and wind power.

"Includes cogeneration at industrial, commercial, and other facilities whose primary function is not electricity production.

${ }^{13}$ Other includes hydrogen, sulfur, batteries, chemicals, fish oil, and spend sultite liquor.

${ }^{10} \mathrm{P}$ rices represent average revenue per kilowatthour.

${ }^{17}$ In the end-use energy consumptions tables, projected fuel consumption in the utility sector includes fuel used by independent power producers. In this table, fuel used by independent power producers is included in the nonutility category.

"Includes fuel consumption by independent power producers and exempt wholesale generators, which produce electricity for sales to utilities.

${ }^{10}$ Estimated emissions from utilities and independent power producers.

EMM = Electricity market module.

O\&M = Operation and maintenance

N/A $=$ Not applicable.

Note: Totals may not equal sum of components due to independent rounding.

Sources: 1990 (except for nonutility generation and prices): Energy Intormation Administration (ElA), Electric Power Annual 1001, DOE/EIA-0348(91) (Washington, D.C., February 1993). 1990 Nonutility generation: Form ElA-861, "Annual Electric Utility Report" and the Form EIA-867, "Annual Nonutility Power Producer Report." The Form EIA-867 is filed by nonutilities reporting the energy delivered, while the ElA-861 is filed by electric utilities reporting the energy received. Because the Form EIA-861 coliects data from the universe of utilities, these data are used for electricity sold to utilities. Own use data is from Form EIA-867. Prices and all projectlons: EIA, AEO 1994 National Energy Modeling System run AEO94B.D1221934. 
Table 48. Electric Power Data and Projections for the EMM Region Western Systems Coordinating Council/Northwest Power Pool Area (WSCC/NWP)

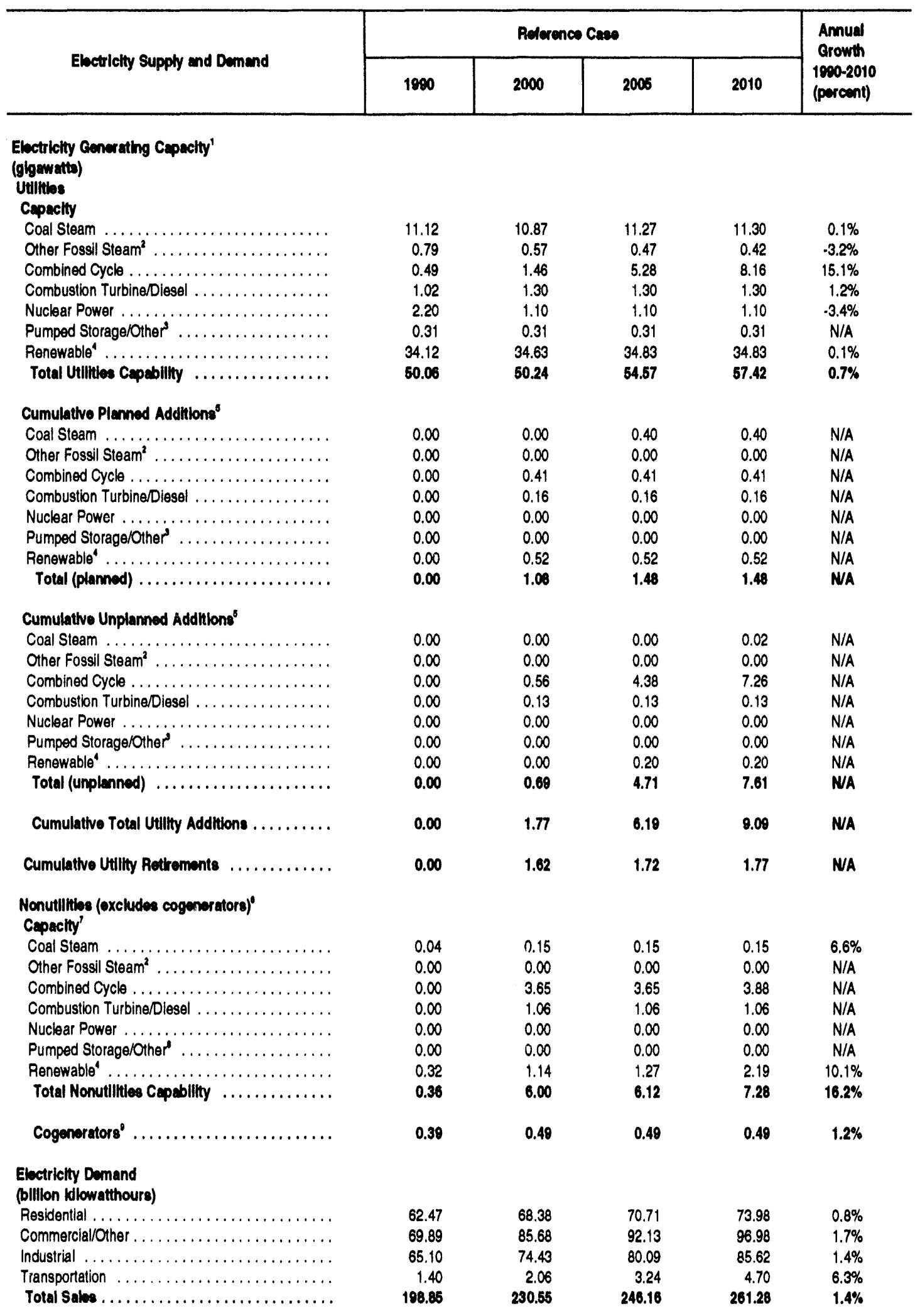


Table 48. Electric Power Data and Projections for the EMM Region Western Systems Coordinating Council/Northwest Power Pool Area (WSCC/NWP) (Continued)

\begin{tabular}{|c|c|c|c|c|c|c|}
\hline \multirow{2}{*}{ Eloctricity Supply and Demand } & \multicolumn{5}{|c|}{ Reterence Caceo } & \multirow{2}{*}{$\begin{array}{l}\text { Amual } \\
\text { Growth } \\
1000-201 \\
\text { (percent }\end{array}$} \\
\hline & 1900 & & 2000 & 2000 & 2010 & \\
\hline \multicolumn{7}{|l|}{ Net Energy for Load (billion kdlowatthours) } \\
\hline Net International Electricity Imports ........ & 2.19 & & -0.61 & -0.23 & 0.18 & $.11 .7 \%$ \\
\hline $\begin{array}{l}\text { Net Interregional Electricity Imponts } \ldots \ldots \ldots \ldots \ldots \\
\text { Purchases from Nonutilities }\end{array}$ & $\cdot 28.41$ & & -35.25 & .40 .22 & .40 .15 & $1.7 \%$ \\
\hline (including cogenerators)" $\ldots \ldots \ldots \ldots \ldots$ & 3.32 & $j$ & 38.70 & 37.03 & 37.42 & $12.9 \%$ \\
\hline Generation by Utilities ....... & 239.31 & & 253.36 & 285.54 & 302.68 & $1.2 \%$ \\
\hline Total Net Energy for Load ............... & 216.41 & & 256.10 & 282.11 & 300.13 & $1.6 \%$ \\
\hline \multicolumn{7}{|l|}{$\begin{array}{l}\text { Generation by Fuel Type } \\
\text { (billion kllowatthours) } \\
\text { Utility Generation }\end{array}$} \\
\hline Coal $\ldots \ldots \ldots \ldots$ & 76.88 & & 78.24 & 80.43 & 80.67 & $0.2 \%$ \\
\hline Petroleum $\ldots \ldots \ldots \ldots \ldots \ldots \ldots \ldots \ldots \ldots$ & 0.30 & & 0.15 & 0.16 & 0.06 & $.7 .7 \%$ \\
\hline Natural Gas $\ldots \ldots \ldots \ldots \ldots \ldots \ldots \ldots$ & 2.48 & & 14.13 & 42.74 & 59.66 & $17.2 \%$ \\
\hline Nuclear $\ldots \ldots \ldots \ldots$. & 11.82 & & 7.19 & 7.17 & 7.17 & $-2.5 \%$ \\
\hline Pumped Storage/Other ${ }^{12}$ & 0.00 & & .0 .59 & .0 .59 & -0.59 & N/A \\
\hline Renewables $\ldots \ldots \ldots \ldots \ldots \ldots \ldots \ldots$ & 147.83 & & 154.24 & 155.63 & 155.71 & $0.3 \%$ \\
\hline Total Utillity Generation .................. & 239.31 & & 253.36 & 285.54 & 302.68 & $1.2 \%$ \\
\hline Cogenerators (bllllon klowatthoure)" $\ldots . \ldots$. & 3.17 & & 4.22 & 4.48 & 4.75 & $2.0 \%$ \\
\hline \multicolumn{7}{|l|}{$\begin{array}{l}\text { Nonutllity Generation including Cogeneration } \\
\text { (billion kilowatthours) }\end{array}$} \\
\hline Coal $\ldots \ldots, \ldots, \ldots, \ldots, \ldots, \ldots, \ldots, \ldots$ & 0.25 & & 1.04 & 1.02 & 1.02 & $7.3 \%$ \\
\hline Petroleum/Other ${ }^{15} \ldots \ldots \ldots \ldots \ldots \ldots$ & 0.00 & & 0.00 & 0.00 & 0.00 & N/A \\
\hline Natural Gas $\ldots \ldots \ldots \ldots \ldots \ldots \ldots$ & 0.00 & & 29.66 & 27.15 & 21.61 & $64.7 \%$ \\
\hline Renewable $\ldots \ldots \ldots \ldots \ldots \ldots \ldots \ldots$ & 1.60 & & 6.83 & 7.66 & 13.56 & $11.3 \%$ \\
\hline Total Nonutllity Generation ............... & 1.85 & & 37.53 & 35.83 & 36.19 & $16.0 \%$ \\
\hline \multicolumn{7}{|l|}{$\begin{array}{l}\text { End-Uso Prices } \\
\text { (1992 cents per kilowatthour) }\end{array}$} \\
\hline Residential ............ & 5.7 & & 6.4 & 7.0 & 7.5 & $1.4 \%$ \\
\hline Commerclal $\ldots \ldots \ldots \ldots \ldots \ldots \ldots \ldots \ldots$ & 5.2 & & 5.5 & 5.7 & 6.3 & $1.0 \%$ \\
\hline Industrial $\ldots \ldots \ldots \ldots \ldots \ldots \ldots \ldots \ldots$ & 2.8 & & 2.9 & 3.0 & 3.3 & $0.8 \%$ \\
\hline Transportation $\ldots \ldots \ldots \ldots \ldots \ldots \ldots \ldots$ & 3.8 & & 4.0 & 4.3 & 4.3 & $0.6 \%$ \\
\hline All Sectors Average ..................... & 4.6 & & 4.9 & 5.2 & 5.6 & $1.1 \%$ \\
\hline \multicolumn{7}{|l|}{$\begin{array}{l}\text { Price Components" } \\
\text { (1992 cents per Kllowatthour) }\end{array}$} \\
\hline Capital Component $\ldots \ldots \ldots \ldots \ldots \ldots$ & 1.9 & & 1.8 & 1.9 & 1.9 & $-0.1 \%$ \\
\hline Fuel Component $\ldots \ldots \ldots \ldots \ldots \ldots \ldots$ & 0.6 & & 0.6 & 0.9 & 1.3 & $3.9 \%$ \\
\hline O\&M Component ...................... & 2.3 & & 2.2 & 2.3 & 2.3 & $0.0 \%$ \\
\hline Wholesale Power Cost .................... & -0.3 & & 0.3 & 0.0 & 0.1 & $N / A$ \\
\hline Total $\ldots \ldots \ldots \ldots \ldots \ldots \ldots \ldots \ldots \ldots \ldots$ & 4.6 & & 4.9 & 5.2 & 5.6 & $1.1 \%$ \\
\hline $\begin{array}{l}\text { Fuel Consumption (trillion Btu) } \ldots \ldots \ldots \ldots \ldots \\
\text { Utillitios" }\end{array}$ & 0.01 & & 0.26 & 0.24 & 0.19 & $18.6 \%$ \\
\hline$\ldots \ldots \ldots \ldots \ldots$ & 0.79 & & 0.81 & 0.83 & 0.84 & $0.3 \%$ \\
\hline Natural Gas $\ldots \ldots \ldots \ldots \ldots \ldots \ldots$ & 0.03 & & 0.14 & 0.37 & 0.49 & $15.8 \%$ \\
\hline$\ldots \ldots \ldots \ldots$ & 0.00 & & 0.00 & 0.00 & 0.00 & $\cdot 7.9 \%$ \\
\hline \multicolumn{7}{|l|}{ Nonutlitios" } \\
\hline$\ldots \ldots \ldots \ldots \ldots \ldots \ldots \ldots, \ldots$ & 0.00 & & 0.01 & 0.01 & 0.01 & $6.7 \%$ \\
\hline Natural Gas $\ldots \ldots \ldots \ldots \ldots \ldots \ldots \ldots \ldots$ & 0.00 & & 0.25 & 0.23 & 0.18 & N/A \\
\hline$\ldots \ldots \ldots \ldots$ & 0.00 & & 0.00 & 0.00 & 0.00 & N/A \\
\hline
\end{tabular}


Table 48. Electric Power Data and Projections for the EMM Region

Western Systems Coordinating Council/Northwest Power Pool Area

(WSCC/NWP) (Continued)

\begin{tabular}{|c|c|c|c|c|c|}
\hline \multirow{2}{*}{ Electriclly Supply and Demand } & \multicolumn{4}{|c|}{ Reterence Case } & \multirow{2}{*}{$\begin{array}{l}\text { Annual } \\
\text { Grown } \\
1900-2010 \\
\text { (percent) }\end{array}$} \\
\hline & 1080 & 2000 & 2005 & 2010 & \\
\hline \multicolumn{6}{|l|}{ Embelons (million short tons) } \\
\hline Total Carbon & 22.56 & 26.79 & 30.31 & 31.46 & $1.7 \%$ \\
\hline Carbon Dioxide & 82.85 & 99.10 & 112.13 & 117.10 & $1.7 \%$ \\
\hline Sullur Dioxide . ..... & 0.14 & 0.12 & 0.13 & 0.14 & $0.1 \%$ \\
\hline
\end{tabular}

'Net summer capability is the steady hourly output that generating equipment is expected to supply to system load (exclusive of auxiliary power), as demonstrated by tests during summer peak demand.

'Includes oll-, gas-, and dual-fired capability.

'Other includes methane and propane and blast furnace gas.

"Includes conventional hydroelectric, geothermal, wood, wood waste, municipal solid waste, other biomass, solar, and wind power.

"Cumulative additions after December 31, 1900.

Includes small power producers, independent power producers, and exempt wholesale generators, which produce electricity for sales to utilities.

TNameplate capacity is reported for nonutilities. Nameplate capacity is designated by the manufacturer.

'Other includes hydrogen, sulfur, batteries, chemicals, fish oil, and spent sulfite liquor.

'Includes cogenerators at industrial, commercial, and other facilities whose primary function is not electricity production. Nameplate capacity

is reported for nonutilities. Nameplate capacity is designated by the manufacturer.

${ }^{10}$ Generation to meet system load by source.

"Includes small power producers, independent power producers, and exempt wholesale generators, which produce electricity tor delivery to electric utilities.

${ }^{12}$ Other includes methane, propane, and blast furnace gas.

${ }^{19}$ Includes conventional hydroelectric, genthermal, wood, wood waste, municipal solid waste, other biomass, solar and wind power.

${ }^{14}$ Includes cogeneration at industrial, com. 1ercial, and other facilities whose primary function is not electricity production.

"Other includes hydrogen, sulfur, batteries, chemicals, fish oil, and spend sulfite liquor.

"Prices represent average revenue per kilowatthour.

$"$ "In the end-use energy consumptions tables, projected fuel consumption in the utility sector includes fuel used by independent power producers. In this table, fuel used by independent power producers is included in the nonutility category.

"Includes fuel consumption by independent power producers and exempt wholesale generators, which produce electricity for sales to utilities.

${ }^{19}$ Estimated emissions from utilities and independent power producers.

$E M M=$ Electricity market module.

$O \& M=$ Operation and maintenance

N/A $=$ Not applicable.

Note: Totals may not equal sum of components due to independent rounding.

Sources: 1990 (except for nonutility generation and prices): Energy Information Administration (ElA), Electric Power Annual 1991, DOE/EIA-0348(91) (Washington, D.C., Februaly 1993). 1990 Nonutility generation: Form ElA-861, "Annual Electric Utility Report" and the Form EIA-867, "Annual Nonutility Power Producer Peport." The Form ElA-867 is filed by nonutilities reporting the energy delivered, while the ElA-861 is filed by electric utilities reporting the energy receiver. Because the Form ElA-861 collects data from the universe of utilities, these data are used for electricity sold to utilities. Own use data is from Form EIA-867. Prices and all projectlone: EIA, AEO 1994 National Energy Modeling System run AEC04B.D1221934. 
Table 49. Electrlc Power and Projections for the EMM Reglon

Western Systems Coordinating Council/Rocky Mountain Power Area and Arizona (WSCC/RA)

\begin{tabular}{|c|c|c|c|c|c|}
\hline \multirow{2}{*}{ Eloctricity Supply and Demend } & \multicolumn{4}{|c|}{ Relerenco Caseo } & \multirow{2}{*}{$\begin{array}{l}\text { Annual } \\
\text { Growth } \\
1890-2010 \\
\text { (percent) }\end{array}$} \\
\hline & 1980 & 2000 & 2005 & 2010 & \\
\hline \multicolumn{6}{|l|}{$\begin{array}{l}\text { Electricity Cenerating Cepacity' } \\
\text { (glgewatti) } \\
\text { Utilitios } \\
\text { Cepacily }\end{array}$} \\
\hline Coal Steam & 13.05 & 13.87 & 13.78 & 15.02 & $0.7 \%$ \\
\hline Other Fossil Steam² & 2.66 & 2.12 & 1.84 & 1.57 & $-2.6 \%$ \\
\hline Combined Cycle .......... & 0.84 & 1.48 & 1.67 & 1.94 & $4.3 \%$ \\
\hline Combustion Turbine/Diesel . .............. & 1.93 & 2.53 & 2.67 & 2.67 & $1.6 \%$ \\
\hline Nuclear Power $\ldots \ldots \ldots \ldots \ldots \ldots \ldots$ & 2.77 & 2.77 & 2.77 & 2.77 & N/A \\
\hline Pumped Storage/Other" $\ldots \ldots \ldots \ldots \ldots \ldots$ & 0.68 & 0.79 & 0.79 & 0.79 & $0.8 \%$ \\
\hline Renewable $\ldots \ldots \ldots \ldots \ldots \ldots \ldots \ldots$ & 3.86 & 4.03 & 4.03 & 5.37 & $1.7 \%$ \\
\hline Total Utillitice Cespabllity ................. & 25.70 & 27.60 & 27.56 & 30.12 & $0.8 \%$ \\
\hline \multicolumn{6}{|l|}{ Cumulattvo Plenned Addhtions ${ }^{5}$} \\
\hline Coal Sleam $\ldots \ldots \ldots \ldots \ldots$ & 0.00 & 0.95 & 0.95 & 1.50 & N/A \\
\hline Other Fossil Steam ${ }^{2} \ldots \ldots \ldots \ldots \ldots \ldots$ & 0.00 & 0.00 & 0.00 & 0.00 & N/A \\
\hline Combined Cycle $\ldots \ldots \ldots \ldots \ldots \ldots \ldots$ & 0.00 & 0.36 & 0.55 & 0.73 & N/A \\
\hline Combustion Turbine/Diesel . .............. & 0.00 & 0.25 & 0.38 & 0.38 & N/A \\
\hline Nuclear Power $\ldots \ldots \ldots \ldots \ldots \ldots \ldots \ldots$ & 0.00 & 0.00 & 0.00 & 0.00 & N/A \\
\hline Pumped Storage/Other' $\ldots \ldots \ldots \ldots \ldots \ldots$ & 0.00 & 0.11 & 0.11 & 0.11 & $N / A$ \\
\hline 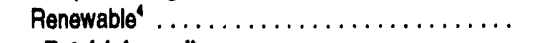 & 0.00 & 0.05 & 0.05 & 0.05 & N/A \\
\hline Total (planned) $\ldots \ldots \ldots \ldots \ldots \ldots \ldots \ldots$ & 0.00 & 1.73 & 2.04 & 2.78 & NA \\
\hline \multicolumn{6}{|l|}{ Cumulativo Unplanned Additions" } \\
\hline Coal Steam & 0.00 & 0.00 & 0.00 & 0.82 & N/A \\
\hline Other Fossil Steam ${ }^{2}$ & 0.00 & 0.00 & 0.00 & 0.00 & $N / A$ \\
\hline Combined Cycle ........ & 0.00 & 0.25 & 0.25 & 0.33 & N/A \\
\hline Combustion Turbine/Diesel . ............. & 0.00 & 0.37 & 0.37 & 0.37 & N/A \\
\hline Nuclear Power $\ldots \ldots \ldots \ldots \ldots \ldots \ldots \ldots$ & 0.00 & 0.00 & 0.00 & 0.00 & N/A \\
\hline Pumped Storage/Other' $\ldots \ldots \ldots \ldots \ldots \ldots$ & 0.00 & 0.00 & 0.00 & 0.00 & N/A \\
\hline Renewablet $\ldots \ldots \ldots \ldots \ldots \ldots \ldots \ldots$ & 0.00 & 0.00 & 0.00 & 1.33 & N/A \\
\hline Total (unplenned) $\ldots \ldots \ldots \ldots \ldots \ldots \ldots$ & 0.00 & 0.62 & 0.62 & 2.86 & NA \\
\hline Cumulative Total Utility Additions .......... & 0.00 & 2.35 & 2.66 & 5.63 & NA \\
\hline Cumulattvo Utility Rotirements $\ldots \ldots \ldots \ldots$ & 0.00 & 0.79 & 1.19 & 1.60 & NA \\
\hline \multicolumn{6}{|l|}{$\begin{array}{l}\text { Nonutillibs (oxcludes cogenerators)" } \\
\text { Cepacily' }\end{array}$} \\
\hline Coal Steam ..... & 0.00 & 0.00 & 0.02 & 0.02 & N/A \\
\hline Other Fossil Steam ${ }^{2} \ldots \ldots \ldots \ldots \ldots \ldots \ldots$ & 0.00 & 0.00 & 0.00 & 0.00 & N/A \\
\hline Combined Cycle .................... & 0.00 & 0.37 & 1.64 & 1.64 & N/A \\
\hline Combustion Turbine/Diesel ............... & 0.00 & 0.00 & 0.00 & 0.00 & N/A \\
\hline Nuclear Power $\ldots \ldots \ldots \ldots \ldots \ldots \ldots$ & 0.00 & 0.00 & 0.00 & 0.00 & N/A \\
\hline Pumped Storage/Other" $\ldots \ldots \ldots \ldots \ldots \ldots$ & 0.00 & 0.00 & 0.00 & 0.00 & N/A \\
\hline 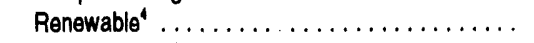 & 0.09 & 0.09 & 0.23 & 1.28 & $14.4 \%$ \\
\hline Total Nonutillites Ceapabillty $\ldots . \ldots \ldots \ldots .$. & 0.00 & 0.46 & 1.88 & 2.83 & $10.2 \%$ \\
\hline Cogenerators ${ }^{\circ} \ldots \ldots \ldots \ldots \ldots \ldots \ldots \ldots$ & 0.60 & 0.90 & 0.80 & 0.80 & $2.1 \%$ \\
\hline \multicolumn{6}{|l|}{$\begin{array}{l}\text { Electricity Demand } \\
\text { (billion Kllowatthours) }\end{array}$} \\
\hline Residential $\ldots \ldots \ldots \ldots \ldots \ldots \ldots \ldots$ & 27.13 & 31.36 & 32.94 & 35.07 & $1.3 \%$ \\
\hline Commercial/Other ..................... & 30.80 & 35.63 & 36.73 & 36.68 & $0.9 \%$ \\
\hline Industrial $\ldots \ldots \ldots \ldots \ldots \ldots \ldots \ldots \ldots$ & 29.76 & 34.32 & 37.04 & 39.69 & $1.5 \%$ \\
\hline Transportation $\ldots \ldots \ldots \ldots \ldots \ldots \ldots \ldots \ldots$ & 0.53 & 0.79 & 1.21 & 1.74 & $6.1 \%$ \\
\hline Total Sales $\ldots \ldots \ldots \ldots \ldots \ldots \ldots \ldots \ldots$ & 88.22 & 102.09 & 107.91 & 113.18 & $1.3 \%$ \\
\hline
\end{tabular}


Table 49. Electric Power and Projectlons for the EMM Region Western Systems Coordinating CounciVRocky Mountaln Power Area and Arizona (WSCC/RA) (Continued)

\begin{tabular}{|c|c|c|c|c|c|}
\hline \multirow{2}{*}{ Elocticlity Supply and Demend } & \multicolumn{4}{|c|}{ Refintines Cuss } & \multirow{2}{*}{$\begin{array}{l}\text { Amun } \\
\text { Crowth } \\
1902-20 \\
\text { (perent }\end{array}$} \\
\hline & 1000 & 2000 & 2006 & 2010 & \\
\hline \multicolumn{6}{|l|}{ Mn Energy for Load (billion idlowethoure) } \\
\hline Net International Electricity Imports $\ldots \ldots \ldots \ldots$ & 0.00 & 0.00 & 0.00 & 0.00 & $N / A$ \\
\hline Net Interreglonal Electricity Imponts ........... & .35 .02 & .35 .30 & .34 .10 & .38 .87 & $0.5 \%$ \\
\hline Purchases from Nonutilities & & & & & \\
\hline (including cogenerators) ${ }^{11} \ldots \ldots \ldots \ldots \ldots$ & 2.86 & 3.69 & 14.13 & 17.30 & $9.4 \%$ \\
\hline Generation by Utllities . . . . . . . . . . . . . & 142.89 & 169.21 & 163.71 & 172.05 & $0.9 \%$ \\
\hline Total Net Energy for Load . . . . . . . . . . . . . & 110.73 & 137.60 & 149.74 & 160.48 & $1.5 \%$ \\
\hline \multicolumn{6}{|l|}{$\begin{array}{l}\text { Cenwation by Ful Typo } \\
\text { (billion Idlowatthours) } \\
\text { Utility Ceneration }\end{array}$} \\
\hline Coal $\ldots \ldots \ldots \ldots \ldots \ldots \ldots \ldots \ldots$ & 106.79 & 108.21 & 108.47 & 119.55 & $0.6 \%$ \\
\hline 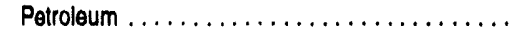 & 0.26 & 0.22 & 0.14 & 0.01 & $.15 .8 \%$ \\
\hline Natural Gas $\ldots \ldots \ldots \ldots \ldots \ldots \ldots$ & 5.15 & 27.23 & 21.78 & 14.63 & $5.4 \%$ \\
\hline Nuclear $\ldots \ldots \ldots \ldots \ldots \ldots \ldots \ldots \ldots$ & 20.60 & 20.58 & 20.33 & 20.53 & $0.0 \%$ \\
\hline Pumped Storage/Oher ${ }^{12} \ldots \ldots \ldots \ldots \ldots \ldots$ & 0.37 & -0.37 & $\cdot 0.37$ & .0 .37 & $N / A$ \\
\hline Renewablets $\ldots \ldots \ldots \ldots \ldots \ldots \ldots$ & 9.72 & 13.35 & 13.36 & 17.71 & $3.0 \%$ \\
\hline Total Utllity Ceneration . . . . . . . . . . . . . & 142.90 & 160.21 & 163.71 & 172.05 & $0.9 \%$ \\
\hline Cogenerators (billion Illowathours) ${ }^{14} \ldots \ldots$. & 1.46 & 1.84 & 1.98 & 2.12 & $1.0 \%$ \\
\hline \multicolumn{6}{|l|}{$\begin{array}{l}\text { Nonutility Generation lnchuding Cogeneration } \\
\text { (billion kllowatthours) }\end{array}$} \\
\hline Coal $\ldots \ldots \ldots \ldots \ldots \ldots \ldots \ldots \ldots$ & 0.00 & 0.00 & 0.11 & 0.11 & N/A \\
\hline Petroleum/Other $^{15} \ldots \ldots \ldots \ldots \ldots \ldots \ldots$ & 0.00 & 0.00 & 0.00 & 0.00 & N/A \\
\hline Natural Gas $\ldots \ldots \ldots \ldots \ldots \ldots \ldots \ldots$ & 0.00 & 2.94 & 12.74 & 12.54 & $N / A$ \\
\hline Renewable $\ldots \ldots \ldots \ldots \ldots \ldots \ldots$ & 2.86 & 0.75 & 1.28 & 4.64 & $2.4 \%$ \\
\hline Total Nonutllity Generation . . . . . . . . . . . . & 2.88 & 3.60 & 14.13 & 17.30 & $9.4 \%$ \\
\hline \multicolumn{6}{|l|}{$\begin{array}{l}\text { End-Une Prices" } \\
\text { (19e2 cents per Ilowatthour) }\end{array}$} \\
\hline Residential $\ldots \ldots \ldots \ldots \ldots \ldots \ldots \ldots$ & 9.8 & 9.6 & 10.0 & 10.3 & $0.2 \%$ \\
\hline Commercial . . . . . . . . . . . . . . . . . . & 8.2 & 7.6 & 7.6 & 7.7 & $.0 .3 \%$ \\
\hline Industrial $\ldots \ldots \ldots \ldots \ldots \ldots \ldots \ldots$ & 6.6 & 6.0 & 6.0 & 6.0 & $.0 .5 \%$ \\
\hline Transportation $\ldots \ldots \ldots \ldots \ldots \ldots \ldots \ldots$ & 6.9 & 7.0 & 7.0 & 7.1 & $0.2 \%$ \\
\hline All Sectors Average $\ldots \ldots \ldots \ldots \ldots \ldots \ldots$ & 8.2 & 7.7 & 7.8 & 7.9 & $-0.2 \%$ \\
\hline \multicolumn{6}{|l|}{$\begin{array}{l}\text { Prlos Components } \\
\text { (1992 cents per klowatthour) }\end{array}$} \\
\hline Capital Component $\ldots \ldots \ldots \ldots \ldots \ldots \ldots$ & 4.5 & 4.2 & 4.0 & 4.1 & $-0.5 \%$ \\
\hline Fuel Component $\ldots \ldots \ldots \ldots \ldots \ldots \ldots$ & 2.1 & 2.0 & 1.8 & 2.0 & $.0 .1 \%$ \\
\hline O\&M Component $\ldots \ldots \ldots \ldots \ldots \ldots \ldots \ldots$ & 3.2 & 3.1 & 3.1 & 3.1 & $-0.1 \%$ \\
\hline Wholesale Power Cost ................... & -1.6 & $\cdot 1.6$ & -1.2 & -1.3 & $-1.0 \%$ \\
\hline Total $\ldots \ldots \ldots \ldots \ldots \ldots \ldots \ldots \ldots \ldots \ldots$ & 8.2 & 7.7 & 7.8 & 7.8 & $-0.2 \%$ \\
\hline $\begin{array}{l}\text { Fuel Consumption (trillion Btu) } \ldots \ldots \ldots \ldots \ldots \text {. } \\
\text { Utllitibs" }\end{array}$ & 0.00 & 0.03 & 0.11 & 0.10 & $19.2 \%$ \\
\hline Coal $\ldots \ldots \ldots \ldots \ldots \ldots \ldots \ldots \ldots \ldots$ & 1.14 & 1.16 & 1.16 & 1.27 & $0.5 \%$ \\
\hline Natural Gas $\ldots \ldots \ldots \ldots \ldots \ldots \ldots \ldots$ & 0.06 & 0.33 & 0.24 & 0.15 & $4.7 \%$ \\
\hline 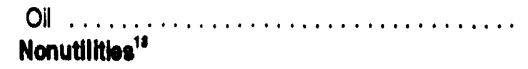 & 0.00 & 0.00 & $v .00$ & 0.00 & $-15.5 \%$ \\
\hline Coal $\ldots \ldots \ldots \ldots \ldots \ldots \ldots \ldots \ldots$ & 0.00 & 0.00 & 0.00 & 0.00 & N/A \\
\hline Natural Gas $\ldots \ldots \ldots \ldots \ldots \ldots \ldots \ldots$ & 0.00 & 0.03 & 0.10 & 0.10 & N/A \\
\hline Oil $\ldots \ldots \ldots \ldots \ldots \ldots \ldots \ldots \ldots \ldots \ldots \ldots$ & 0.00 & 0.00 & 0.00 & 0.00 & N/A \\
\hline
\end{tabular}


Table 49. Electric Power and Projections for the EMM Reglon

Western Systems Coordinating Council/Rocky Mountain Power Area and Arizona (WSCC/RA) (Continued)

\begin{tabular}{|c|c|c|c|c|c|}
\hline \multirow{2}{*}{ Electricity Supply and Damend } & \multicolumn{4}{|c|}{ Roterence Case } & \multirow{2}{*}{$\begin{array}{c}\text { Amual } \\
\text { Crowth } \\
1900-2010 \\
\text { (percent) }\end{array}$} \\
\hline & 1990 & 2000 & 2006 & 2010 & \\
\hline \multicolumn{6}{|l|}{ Emisalons (million short tons)" } \\
\hline Total Carbon & 33.26 & 34.97 & 34.90 & 36.22 & $0.4 \%$ \\
\hline Carbon Dloxido & 122.07 & 128.34 & 128.14 & 133.01 & $0.4 \%$ \\
\hline Suttur Dioxide. . & 0.27 & 0.38 & 0.34 & 0.35 & $1.4 \%$ \\
\hline
\end{tabular}

'Net summer capability is the steady hourly output that generating equipment is expected to supply to system load (exclusive of auxiliary power), as demonstrated by tests during summer peak demand.

${ }^{2}$ Includes oil-, gas, and dual-fired capability.

'Other includes meihane and propane and blast furnace gas.

"Includes conventional hydroelectric, geothermal, wood, wood waste, municipal solid waste, other biomass, solar, and wind power.

${ }^{3}$ Cumulative additions atter December $31,1990$.

"Includes small power producers, independent power producers, and exempt wholesale generators, which produce electricity for sales to utilities.

${ }^{7}$ Nameplate capacity is reported for nonutilities. INameplate capacity is designated by the manufacturer.

'Other includes hydrogen, sulfur, batteries, chemicals, fish oil, and spent sulfite liquor.

Includes cogenerators at industrial, commercial, and other facilities whose primary function is not electricity production. Nameplate capacity

is reported for nonutilities. Nameplate capacity is designated by the manufacturer.

${ }^{10}$ Generation to meet system load by source.

"Includes small power producers, independent power producers, and exempt wholesale generators, which produce electricity for delivery to electric utilities.

${ }^{12}$ Other includes methane, propane, and blast furnace gas.

19Includes conventional hydroelectric, geothermal, wood, wood waste, municipal solid waste, other biomass, solar and wind power.

14 Includes cogeneration at industrial, commercial, and other facilities whose primary function is not electricity production.

${ }^{16}$ Other includes hydrogen, sulfur, batteries, chemicals, fish oll, and spend sulfite liquor.

${ }^{16}$ Prices represent average revenue per kilowatthour.

${ }^{17}$ In the end-use energy consumptions tables, projected fuel consumption in the utility sector includes fuel used by independent power producers. In this table, fuel used by independent power producers is included in the nonutility calegory.

"Inciudes fuel consumption by independent power producers and exempt wholesale generators, which produce electricity for sales to utilities.

${ }^{10}$ Estimated emissions from utilities and independent power producers.

EMM = Electricity market module.

$O \& M=$ Operation and maintenance

N/A = Not applicable.

Note: Totals may not equal sum of components due to independent rounding.

Sources: 1990 (except for nonutility generation and prices): Energy Information Administration (ElA), Electric Power Annual 1891, DOEJEIA-0348(81) (Washington, D.C., February 1993). 1990 Nonutility generation: Form ElA-861, "Annual Electric Utility Report" and the Form ElA-867, "Annual Nonutility Power Producer Report." The Form ElA-867 is filed by nonutilities reporting the energy delivered, while the ElA-861 is filed by electric utilities reporting the energy received. Because the Form ElA-861 collects data from the universe of utilities, these data are used for electricity sold to utilities. Own use data is from Form ElA-867. Prices and all projectlone: ElA, AEO 1994 National Energy Modeling System run AEOQ4B.D1221934. 
Table 60. Electrle Power and Projections for the EMM Region Western Systems Coordinating CounclVCallfornla-Southern Nevada Power (WSCC/CNV)

\begin{tabular}{|c|c|c|c|c|c|}
\hline \multirow{2}{*}{ Eloctriclty supply and Demend } & \multicolumn{4}{|c|}{ Relerences Cases } & \multirow{2}{*}{$\begin{array}{l}\text { Amual } \\
\text { Crowth } \\
1 \text { (sco-2010 } \\
\text { (percent) }\end{array}$} \\
\hline & 1900 & 2000 & 2006 & 2010 & \\
\hline \multicolumn{6}{|l|}{$\begin{array}{l}\text { Electricity Generating Cepacti's' } \\
\text { (glgawatto) } \\
\text { Utilition } \\
\text { Cepacity }\end{array}$} \\
\hline Coal Steam ....... & 5.19 & 5.19 & 8.94 & 8.53 & $2.5 \%$ \\
\hline Other Fossil Steam ${ }^{2}$ & 21.57 & 20.16 & 19.61 & 19.21 & $.0 .6 \%$ \\
\hline Combined Cycle $\ldots \ldots \ldots \ldots \ldots \ldots \ldots$ & 1.46 & 2.53 & 2.53 & 2.53 & $2.8 \%$ \\
\hline Combustion Turbine/Dlesel .............. & 1.96 & 2.72 & 3.14 & 3.14 & $2.4 \%$ \\
\hline Nuclear Power $\ldots \ldots \ldots \ldots \ldots \ldots \ldots \ldots$ & 5.79 & 5.35 & 5.35 & 3.19 & $-2.9 \%$ \\
\hline Pumped Storage/Other $\ldots \ldots \ldots \ldots \ldots \ldots$ & 3.73 & 3.83 & 3.83 & 3.83 & $0.1 \%$ \\
\hline Renewable $\ldots \ldots \ldots \ldots$ & 12.00 & 12.49 & 12.73 & 13.08 & $0.4 \%$ \\
\hline Total Utilities Cespablity $\ldots . . \ldots \ldots \ldots \ldots$ & 81.70 & 52.26 & 34.14 & 33.53 & $0.2 \%$ \\
\hline \multicolumn{6}{|l|}{ Cumulative Planned Adritions ${ }^{5}$} \\
\hline Coal Steam & 0.00 & 0.00 & 1.75 & 2.50 & $N / A$ \\
\hline Other Fossil Steam² & 0.00 & 0.03 & 0.03 & 0.03 & N/A \\
\hline Combined Cycle ...................... & 0.00 & 0.42 & 0.42 & 0.42 & $N / A$ \\
\hline Combustion Turbine/Diesel ................ & 0.00 & 0.82 & 1.24 & 1.24 & N/A \\
\hline Nuclear Power $\ldots \ldots \ldots \ldots \ldots \ldots \ldots \ldots$ & 0.00 & 0.00 & 0.00 & 0.00 & N/A \\
\hline Pumped Storage/Other' $\ldots \ldots \ldots \ldots \ldots \ldots$ & 0.00 & 0.10 & 0.10 & 0.10 & N/A \\
\hline Renewable" $\ldots \ldots \ldots \ldots \ldots \ldots \ldots \ldots$ & 0.00 & 0.28 & 0.28 & 0.28 & N/A \\
\hline Total (planned) $\ldots \ldots \ldots \ldots \ldots \ldots \ldots \ldots$ & 0.00 & 1.66 & 3.83 & 4.58 & NA \\
\hline \multicolumn{6}{|l|}{ Cumulative Unplanned Additions } \\
\hline Coal Steam ....... & 0.00 & 0.00 & 0.00 & 0.84 & N/A \\
\hline Other Fossil Steam ${ }^{2}$. & 0.00 & 0.00 & 0.00 & 0.00 & N/A \\
\hline$\ldots \ldots \ldots \ldots \ldots \ldots$ & 0.00 & 0.64 & 0.64 & 0.64 & N/A \\
\hline Combustion Turbine/Diesel . ............. & 0.00 & 0.00 & 0.00 & 0.00 & N/A \\
\hline Nuclear Power $\ldots \ldots \ldots \ldots \ldots \ldots \ldots \ldots$ & 0.00 & 0.00 & 0.00 & 0.00 & N/A \\
\hline Pumped Storage/Other' $\ldots . . . \ldots \ldots \ldots \ldots$ & 0.00 & 0.00 & 0.00 & 0.00 & N/A \\
\hline Renewable ${ }^{4} \ldots \ldots \ldots \ldots \ldots \ldots \ldots \ldots$ & 0.00 & 0.37 & 0.61 & 0.96 & N/A \\
\hline Tolal (unplanned) $\ldots \ldots \ldots \ldots \ldots \ldots \ldots$ & 0.00 & 1.01 & 1.26 & 2.45 & NA \\
\hline Cumulative Total Utillity Additions ........... & 0.00 & 2.60 & 6.08 & 7.03 & NA \\
\hline Cumulative Utility Retirements $\ldots \ldots \ldots \ldots$ & 0.00 & 3.02 & 3.56 & 6.12 & NA \\
\hline \multicolumn{6}{|l|}{$\begin{array}{l}\text { Nonutllitios (oxcludes cogenerators)' } \\
\text { Capacity' }\end{array}$} \\
\hline Coal Sleam & 0.02 & 0.02 & 0.02 & 3.22 & $29.0 \%$ \\
\hline Other Fossil Steam ${ }^{2} \ldots \ldots \ldots \ldots \ldots \ldots$ & 0.13 & 0.23 & 0.23 & 0.23 & $2.8 \%$ \\
\hline Combined Cycle ..................... & 0.14 & 1.27 & 2.80 & 2.80 & $16.2 \%$ \\
\hline Combustion Turbine/Diesel ............... & 0.64 & 0.76 & 0.76 & 0.76 & $0.9 \%$ \\
\hline Nuclear Power $\ldots \ldots \ldots \ldots \ldots \ldots \ldots$ & 0.00 & 0.00 & 0.00 & 0.00 & N/A \\
\hline Pumped Storage/Other $\ldots \ldots \ldots \ldots \ldots \ldots$ & 0.00 & 0.00 & 0.00 & 0.00 & N/A \\
\hline Renewablet $\ldots \ldots \ldots \ldots \ldots \ldots \ldots \ldots$ & 3.84 & 6.12 & 7.02 & 8.40 & $4.0 \%$ \\
\hline Total Nonutillites Cespabllity $\ldots \ldots \ldots \ldots \ldots$ & 4.77 & 8.39 & 10.83 & 15.40 & $6.0 \%$ \\
\hline Cogenerators $^{9} \ldots \ldots \ldots \ldots \ldots \ldots \ldots \ldots$ & 5.18 & 4.88 & 5.23 & 5.55 & $0.3 \%$ \\
\hline \multicolumn{6}{|l|}{$\begin{array}{l}\text { Eloctriclty Demand } \\
\text { (billion kilowatthours) }\end{array}$} \\
\hline$\ldots \ldots \ldots \ldots \ldots \ldots$ & 69.72 & 74.46 & 76.42 & 79.27 & $0.6 \%$ \\
\hline Commercial/Other ........................ & 76.95 & 96.45 & 105.33 & 112.93 & $1.9 \%$ \\
\hline Indusirial $\ldots \ldots \ldots \ldots \ldots \ldots \ldots \ldots \ldots$ & 70.96 & 80.93 & 86.99 & 92.92 & $1.4 \%$ \\
\hline Transportation $\ldots \ldots \ldots \ldots \ldots \ldots \ldots \ldots$ & 1.62 & 2.39 & 3.79 & 5.51 & $6.3 \%$ \\
\hline Total Sales . . . . . . . . . . . . . . . . . . . . & 219.26 & 254.23 & 272.53 & 290.63 & $1.4 \%$ \\
\hline
\end{tabular}


Table 50. Electric Power and Projectlons for the EMM Reglon Western Systems Coordinating CouncilVallfornla-Southern Novada Power (WSCC/CNV) (Continued)

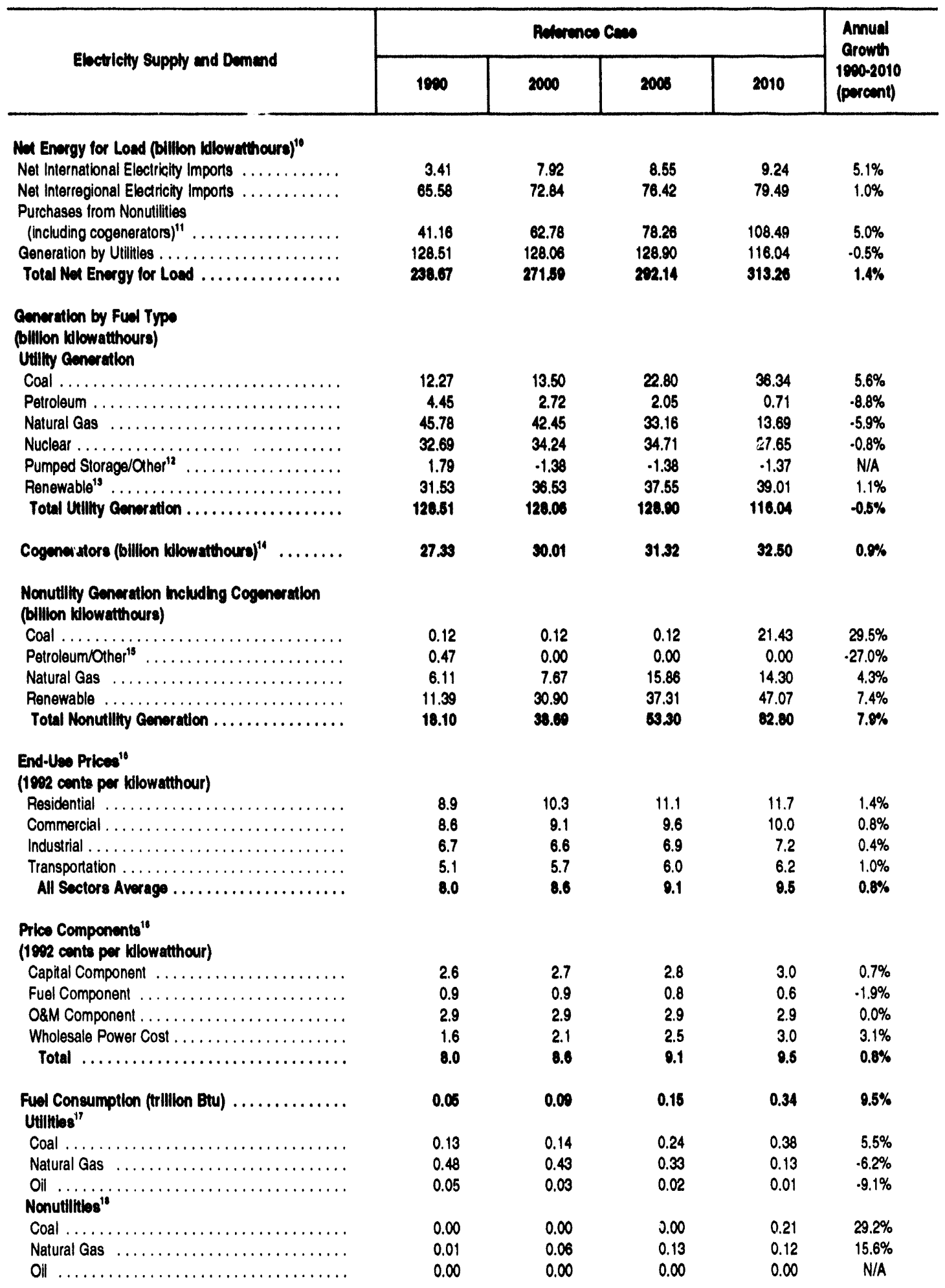


Table 50. Electric Power and Projections for the EMM Reglon

Western Systems Coordinating CouncilCallfornla-Southern Nevada Power (WSCC/CNV) (Continued)

\begin{tabular}{|c|c|c|c|c|c|}
\hline \multirow{2}{*}{ Eloctrictiy supply and Demend } & \multicolumn{4}{|c|}{ Rderence Case } & \multirow{2}{*}{$\begin{array}{l}\text { Amnual } \\
\text { Growth } \\
1900-2010 \\
\text { (percent) }\end{array}$} \\
\hline & 1090 & 2000 & 2000 & 2010 & \\
\hline \multicolumn{6}{|l|}{ Embecions (million short tons)" } \\
\hline Total Carbon & 8.73 & 11.26 & 13.19 & 18.66 & $3.9 \%$ \\
\hline Carbon Dloxide & 35.14 & 46.90 & 55.21 & 77.06 & $4.0 \%$ \\
\hline Sulur Dioxide ........... & 0.05 & 0.06 & 0.08 & 0.13 & $4.6 \%$ \\
\hline
\end{tabular}

'Net summer capability is the steady hourly output that generating equipment is expected to supply to system load (exclusive of auxiliary power), as demonstrated by tests during summer peak demand.

'Includes oil-, gas-, and dual-lired capability.

'Other includes methane and propane and blast furnace gas.

"includes conventional hydroelectric, geothermal, wood, wood waste, municipal solid waste, other biomass, solar, and wind power.

'Cumulative additions after December 31, 1900.

"includes small power producers, independent power producers, and exempt wholesale generators, which produce electricity tor sales to utillities.

'Nameplate capacity is reported for nonutilities. Nameplate capacity is designated by the manufacturer.

Other includes hydrogen, sulfur, batteries, chemicals, fish oil, and spent sulfite liquor.

includes cogenerators at industrial, commercial, and other lacilities whose primary function is not electricity production. Nameplate capacity

is reported for nonutilities. Nameplate capacity is designated by the manufacturer.

${ }^{10}$ Generation to meet system load by source.

"Includes small power producers, independent power producers, and exempl wholesale generators, which produce electricity ter delivery to electric utilities.

${ }^{12}$ Other includes methane, propane, and blast furnace gas.

"Includes conventional hydroelectric, geothermal, wood, wood waste, municipal solid waste, other biomass, solar and wind power.

"Includes cogeneration at industrial, commercial, and other facilities whose primary function is not electricity production.

"Other includes hyorogen, sulfur, batteries, chemicals, $f i$ ih oil, and spend sulfite liquor.

"Prices represent average revenue per kilowatthour.

${ }^{17}$ in the end-use energy consumptions tables, projected fuel consumption in the utility sector includes fuel used by independent power pruaces In this table, fuel used by independent power producers is included in the nonutlity calegory.

1"Includes fuel consumption by independent power producers and exempt wholesale generators, which produce electricity for sales to utilitios.

"Estimated emissions from utilities and independent power producers.

$E M M=$ Electricity market module.

$O \& M=$ Operation and maintenance.

N/A $=$ Not applicable

Note: Totals may not equal sum of components due to independent rounding.

Sources: 1990 (except for nonutility generation and prices): Energy Information Administration (ElA), Electric Power Annual 1891, DOE/EIA-034B(81) (Washinglon, D.C., February 1993). 1990 Nonutility generation: Form ElA-861, "Annual Electric Utility Report" and the Form ElA-867, "Annual Nonutility Power Producer Report." The Form ElA-867 is filed by nonutilities reponting the energy delivered, while the ElA-861 is filed by electric utilities reporting the energy received. Because the Form ElA-861 collects data from the universe of utilities, these data are used for electricity sold to utilities. Own use data is from Form ElA-867. Prlces and all projections: ElA, AEO 1994 National Energy Modeling System run AEO94B.D1221934. 
Table 51. Electric Power and Projections for the United States

\begin{tabular}{|c|c|c|c|c|c|}
\hline Eketrleity Supply and Domend & 1400 & 2000 & 2005 & 2010 & $\begin{array}{l}\text { Annual } \\
\text { Crowth } \\
\text { 1eco-2ovo } \\
\text { (pereent) }\end{array}$ \\
\hline
\end{tabular}

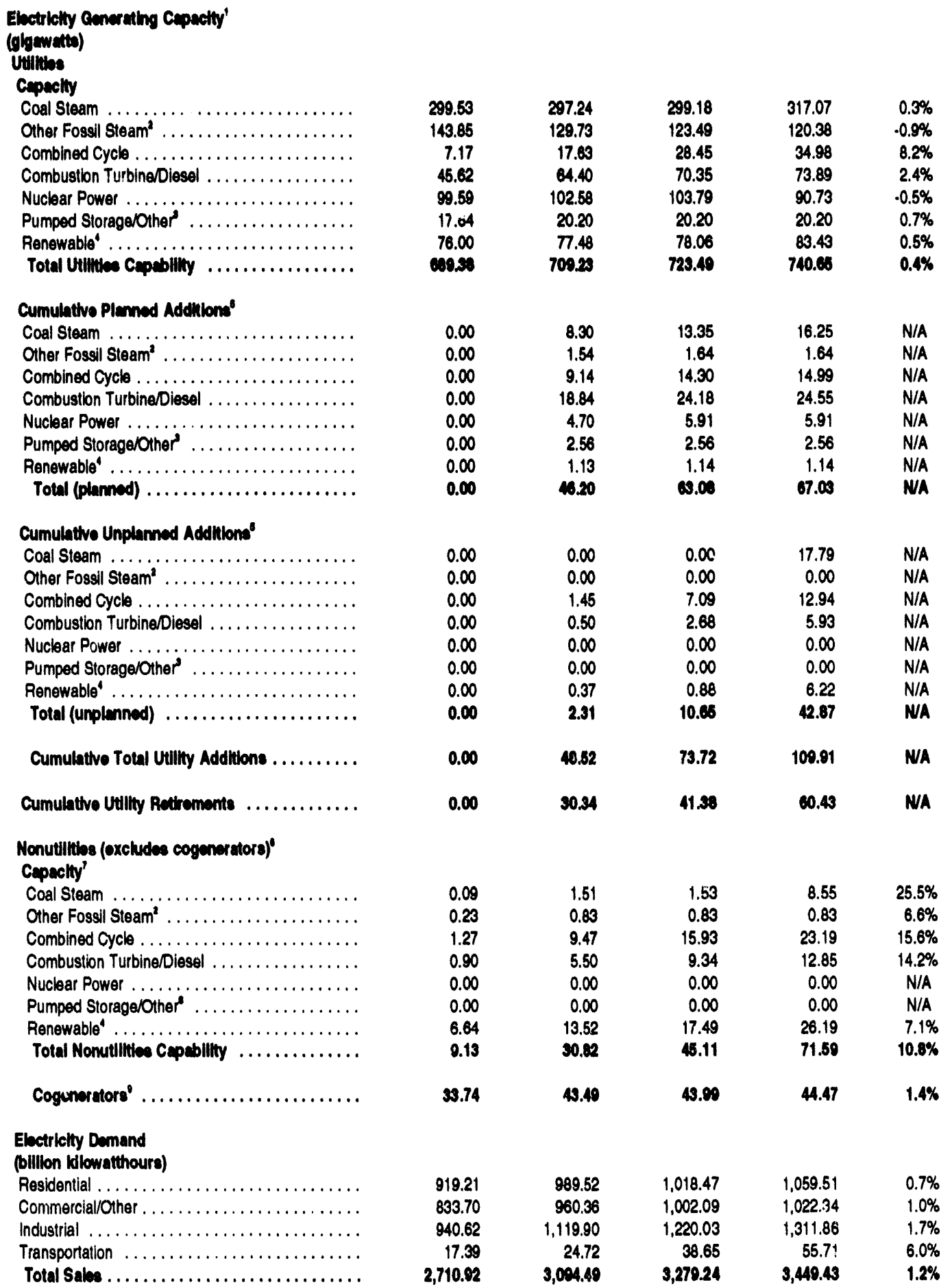




$$
\begin{aligned}
& \text { 震 }
\end{aligned}
$$

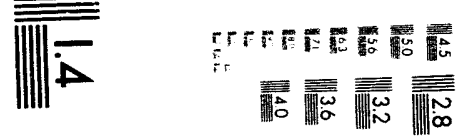

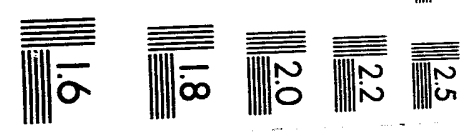



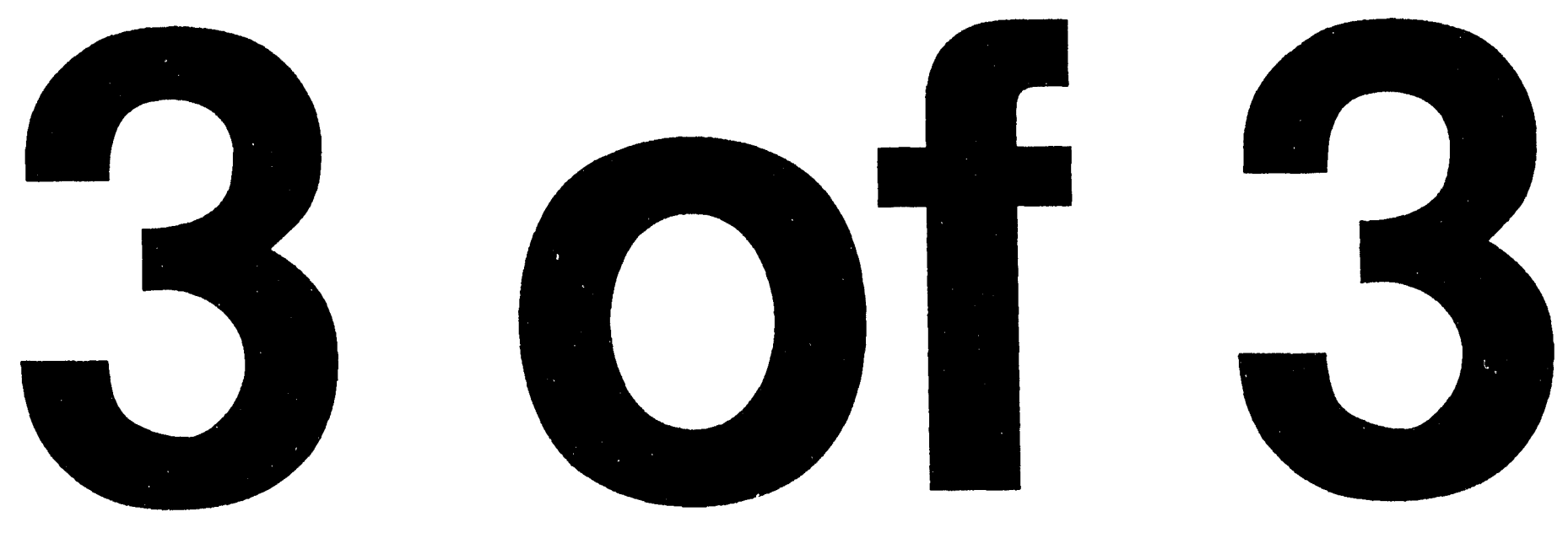
Table 51. Electric Power and Projections for the United States (Continued)

\begin{tabular}{|c|c|c|c|c|c|}
\hline \multirow{2}{*}{ Electricliy Supply and Demand } & \multicolumn{4}{|c|}{ Retcrence Case } & \multirow{2}{*}{$\begin{array}{l}\text { Annual } \\
\text { Crowth } \\
1900-2010 \\
\text { (percent) }\end{array}$} \\
\hline & 1990 & 2000 & 2005 & 2010 & \\
\hline \multicolumn{6}{|l|}{ Not Energy for Load (billion Nllowatthours) ${ }^{10}$} \\
\hline Net International Electricity imports $\ldots \ldots \ldots \ldots$ & 2.00 & 26.43 & 28.16 & 29.94 & $14.5 \%$ \\
\hline Net interregional Electricity Imports .......... & $\cdot 1.78$ & -1.72 & $\cdot 1.71$ & -2.01 & $0.6 \%$ \\
\hline Purchases from Nonutilities & & & & & \\
\hline (including cogenerators)" & 116.04 & 236.95 & 313.47 & 429.39 & $6.8 \%$ \\
\hline Generation by Utilities $\ldots \ldots \ldots \ldots \ldots \ldots \ldots$ & $2,808.14$ & $3,072.39$ & $3,201.41$ & $3,260.46$ & $0.7 \%$ \\
\hline Total Net Energy for Load ................ & $2,824.41$ & $3,334.06$ & $3,541,32$ & $3,717.78$ & $1.2 \%$ \\
\hline \multicolumn{6}{|l|}{$\begin{array}{l}\text { Generation by Fuel Type } \\
\text { (blilion kilowatthours) } \\
\text { Utility Generation }\end{array}$} \\
\hline 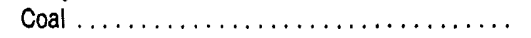 & $1,559.60$ & $1,687.17$ & $1,741.48$ & $1,886.17$ & $1.0 \%$ \\
\hline Petroleum $\ldots \ldots \ldots \ldots \ldots \ldots \ldots \ldots$ & 117.02 & 84.55 & 90.33 & 73.91 & $-2.3 \%$ \\
\hline Natural Gas $\ldots \ldots \ldots \ldots \ldots \ldots \ldots \ldots$ & 264.09 & 335.00 & 392.20 & 373.39 & $1.7 \%$ \\
\hline Nuclear $\ldots \ldots \ldots \ldots \ldots \ldots \ldots \ldots \ldots$ & 576.86 & 671.26 & 679.88 & 612.06 & $0.3 \%$ \\
\hline Pumped Storage/Other ${ }^{12} \ldots \ldots \ldots \ldots \ldots$ & .1 .92 & .11 .05 & .11 .06 & .11 .05 & $9.1 \%$ \\
\hline Renewable ${ }^{19} \ldots \ldots \ldots$ & 292.50 & 305.46 & 308.57 & 325.98 & $0.5 \%$ \\
\hline Total Utility Generation . . . . . . . . . . . . & $2,808.14$ & $3,072.39$ & $3,201.41$ & $3,260.46$ & $0.7 \%$ \\
\hline Cogenerators (billion klowatthoure) ${ }^{14} \ldots \ldots$. & 177.87 & 210.39 & 222.78 & 235.04 & $1.4 \%$ \\
\hline \multicolumn{6}{|l|}{$\begin{array}{l}\text { Nonutlity Generation meluding Cogeneration } \\
\text { (billion klowatthours) }\end{array}$} \\
\hline Coal $\ldots \ldots \ldots \ldots \ldots \ldots \ldots \ldots \ldots$ & 0.63 & 9.31 & 9.43 & 54.21 & $25.0 \%$ \\
\hline Petroleum/Other ${ }^{15}$ & 1.04 & 0.66 & 0.84 & 0.41 & $-4.6 \%$ \\
\hline Natural Gas $\ldots \ldots \ldots \ldots \ldots \ldots \ldots$ & 8.91 & 72.07 & 119.19 & 144.41 & $14.9 \%$ \\
\hline Renewable $\ldots \ldots \ldots \ldots \ldots \ldots \ldots \ldots$ & 28.82 & 68.81 & 94.77 & 138.53 & $8.2 \%$ \\
\hline Total Nonutillty Generation ............. & 39.40 & 150.85 & 224.23 & 337.55 & $11.3 \%$ \\
\hline \multicolumn{6}{|l|}{$\begin{array}{l}\text { End-Use Prices } \\
\text { (1092 cents per kllowatthour) }\end{array}$} \\
\hline Residential $\ldots \ldots \ldots \ldots \ldots \ldots \ldots$ & 8.5 & 8.7 & 9.1 & 9.8 & $0.7 \%$ \\
\hline Commercial . . . . . . . . . . . . . . . . . . . & 7.7 & 7.6 & 7.8 & 8.1 & $0.3 \%$ \\
\hline Industrial $\ldots \ldots \ldots \ldots \ldots \ldots \ldots \ldots$ & 5.2 & 5.1 & 5.2 & 5.5 & $0.3 \%$ \\
\hline 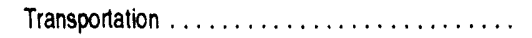 & 5.1 & 5.2 & 5.3 & 5.4 & $0.2 \%$ \\
\hline All Sectors Average $\ldots \ldots \ldots \ldots \ldots \ldots \ldots$ & 7.1 & 7.0 & 7.2 & 7.6 & $0.3 \%$ \\
\hline \multicolumn{6}{|l|}{ Prico Components ${ }^{10}$} \\
\hline 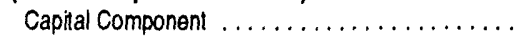 & 3.0 & 2.7 & 2.6 & 2.7 & $-0.5 \%$ \\
\hline Fuel Component $\ldots \ldots \ldots \ldots \ldots \ldots \ldots$ & 1.4 & 1.4 & 1.6 & 1.7 & $1.0 \%$ \\
\hline 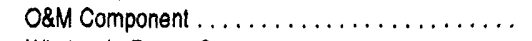 & 2.6 & 2.6 & 2.6 & 2.6 & $0.1 \%$ \\
\hline Wholesale Power Cost . . . . . . . . . . . . . . & 0.1 & 0.3 & 0.4 & 0.6 & $7.2 \%$ \\
\hline Total $\ldots \ldots \ldots \ldots \ldots \ldots \ldots \ldots \ldots$ & 7.1 & 7.0 & 7.2 & 7.6 & $0.3 \%$ \\
\hline $\begin{array}{l}\text { Fuel Consumption ftrillion Btu) } \ldots \ldots \ldots \ldots \ldots \\
\text { Utilitios }^{17}\end{array}$ & 1.32 & 1.68 & 2.15 & 2.60 & $3.4 \%$ \\
\hline Coal $\ldots \ldots \ldots \ldots \ldots \ldots \ldots \ldots \ldots$ & 16.10 & 17.39 & 17.94 & 19.39 & $0.9 \%$ \\
\hline Natural Gas $\ldots \ldots \ldots \ldots \ldots \ldots \ldots$ & 2.88 & 3.66 & 4.13 & 3.79 & $1.4 \%$ \\
\hline$\underset{\text { Nonutilitios }^{10}}{\text { Oil }} \ldots \ldots \ldots \ldots \ldots \ldots \ldots \ldots \ldots \ldots \ldots$ & 1.26 & 0.90 & 0.98 & 0.80 & $-2.2 \%$ \\
\hline Coal $\ldots \ldots \ldots \ldots \ldots \ldots \ldots \ldots \ldots$ & 0.01 & 0.10 & 0.10 & 0.54 & $25.3 \%$ \\
\hline Natural Gas $\ldots \ldots \ldots \ldots \ldots \ldots \ldots \ldots$ & 0.06 & 0.66 & 1.06 & 1.26 & $16.4 \%$ \\
\hline Oil $\ldots \ldots \ldots \ldots \ldots \ldots \ldots \ldots \ldots$ & 0.00 & 0.01 & 0.01 & 0.00 & $7.3 \%$ \\
\hline
\end{tabular}


Table 51. Electric Power and Projections for the United States (Continued)

\begin{tabular}{|c|c|c|c|c|c|}
\hline \multirow{2}{*}{ Electricity Supply and Demand } & \multicolumn{4}{|c|}{ Reference Caso } & \multirow{2}{*}{$\begin{array}{l}\text { Annual } \\
\text { Growth } \\
1990-2010 \\
\text { (percent) }\end{array}$} \\
\hline & 1990 & 2000 & 2005 & 2010 & \\
\hline \multicolumn{6}{|l|}{ Emissions (million short tons) ${ }^{10}$} \\
\hline Total Carbon & 472.35 & 525.39 & 553.63 & 595.85 & $1.2 \%$ \\
\hline Carbon Dioxide .... & $1,735.35$ & $1,933.06$ & $2,037.94$ & $2,195.36$ & $1.2 \%$ \\
\hline Suttur Dioxide $\ldots \ldots \ldots \ldots$ & 14.53 & 9.66 & 8.35 & 8.28 & $-2.8 \%$ \\
\hline
\end{tabular}

'Net summer capability is the steady hourly output that generating equipment is expected to supply to system load (exclusive of auxiliary power), as demonstrated by tests during summer peak demand.

${ }^{2}$ Includes oil-, gas-, and dual-fired capability

${ }^{3}$ Other includes methane and propane and blast furnace gas.

"Includes conventional hydroelectric, geothermal, wood, wood waste, municipal solid waste, other biomass, solar, and wind power.

${ }^{5}$ Cumulative additions after December $31,1990$.

includes small power producers, independent power producers, and exempt wholesale generators, which produce electricity tor sales to utilities.

${ }^{7}$ Nameplate capacity is reported for nonutilities. Nameplate capacity is designated by the manufacturer.

Other includes hydrogen, sulfur, batteries, chemicals, fish oil, and spent sulfite liquor.

Includes cogenerators at industrial, commercial, and other facilities whose primary function is not electricity production. Nameplate capacity

is reported for nonutilities. Nameplate capacity is designated by the manufacturer.

${ }^{10}$ Generation to meet system load by source.

"Includes small power producers, independent power producers, and exempt wholesale generators, which produce electricity for delivery to electric utilities.

${ }^{12}$ Other includes methane, propane, and blast furnace gas.

'Includes conventional hydroelectric, geothermal, wood, wood waste, municipal solid waste, other biomass, solar and wind power.

1"Includes cogeneration at industrial, commercial, and other facilities whose primary function is not electricity production.

${ }^{16}$ Other includes hydrogen, sulfur, batieries, chemicals, fish oil, and spend sulfite liquor.

${ }^{10}$ Prices represent average revenue per kilowatthour.

${ }^{17}$ In the end-use energy consumptions tables, projected fuel consumption in the utility sector includes fuel used by independent power producers. In this table, fuel used by independent power producers is included in the nonutility category.

${ }^{19}$ includes fuel consumption by independent power producers and exempt wholesale generators, which produce electricity for sales to utilities.

${ }^{10}$ Estimated emissions from utilities and independent power producers.

$O \& M=$ Operation and maintenance.

N/A $=$ Nol applicable.

Note: Totals may not equal sum of components due to independent rounding.

Sources: 1990 (except for nonutility generation and prices): Energy Information Administration (ElA), Electric Power Annual 1091, DOE/EIA-0348(91) (Washington, D.C.. February 1993). 1990 Nonutility generation: Form ElA-861, "Annual Electric Utility Report" and the Form EIA-867, "Annual Nonutility Power Producer Report." The Form EIA-867 is filed by nonutilities reporting the energy delivered, while the ElA-861 is filed by electric utilities reporting the energy received. Because the Form ElA-861 collects data from the universe of utilities, these data are used for electricity sold to utilities. Own use data is from Form EIA-867. Prices and all projectlons: EIA, AEO 1994 National Energy Modeling System run AEO94B.D1221934. 
Table 52. Electric Generation by Electricity Market Module Reglon and Source (Billion Kilowatthours)

\begin{tabular}{|c|c|c|c|c|c|}
\hline \multirow{2}{*}{ Region and Source } & \multicolumn{4}{|c|}{ Reterence Cases } & \multirow{2}{*}{$\begin{array}{l}\text { Annual } \\
\text { Growth } \\
1890-2010 \\
\text { (percent) }\end{array}$} \\
\hline & 1090 & 2000 & 2005 & 2010 & \\
\hline \multicolumn{6}{|l|}{$\begin{array}{l}\text { Eaet Central Area Rellebility } \\
\text { Coordhatton Agraement (ECAR) }\end{array}$} \\
\hline Coal $\ldots \ldots \ldots \ldots \ldots \ldots \ldots$ & 442.06 & 470.72 & 476.31 & 487.16 & $0.5 \%$ \\
\hline Petroleum $\ldots \ldots \ldots \ldots \ldots \ldots \ldots \ldots \ldots$ & 2.11 & 0.17 & 0.02 & 0.02 & $-20.8 \%$ \\
\hline Natural Gas $\ldots \ldots \ldots \ldots \ldots \ldots \ldots \ldots$ & 1.44 & 2.00 & 17.70 & 38.84 & $17.9 \%$ \\
\hline Nuclear $\ldots \ldots \ldots \ldots \ldots \ldots \ldots \ldots \ldots \ldots$ & 42.77 & 49.94 & 49.46 & 44.54 & $0.2 \%$ \\
\hline Pumped Storage/OAher' $\ldots \ldots \ldots \ldots \ldots \ldots \ldots$ & -0.66 & -1.47 & -1.47 & -1.47 & $4.1 \%$ \\
\hline Renewabies" $\ldots \ldots \ldots \ldots \ldots \ldots \ldots \ldots \ldots$ & 4.63 & 10.91 & 14.55 & 18.08 & $7.0 \%$ \\
\hline Total $\ldots \ldots \ldots \ldots \ldots \ldots \ldots \ldots \ldots \ldots \ldots$ & 492.36 & 532.28 & 556.55 & 587.18 & $0.9 \%$ \\
\hline \multicolumn{6}{|l|}{ Elactric Reliebility Council of Toxes (ERCOT) } \\
\hline 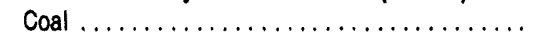 & 61.21 & 68.49 & 80.19 & 88.23 & $1.8 \%$ \\
\hline Petroleum $\ldots \ldots \ldots \ldots \ldots \ldots \ldots \ldots$ & 0.41 & 0.28 & 0.24 & 0.23 & $-2.9 \%$ \\
\hline$\ldots \ldots \ldots \ldots \ldots \ldots \ldots$ & 81.85 & 98.46 & 102.88 & 106.84 & $1.3 \%$ \\
\hline Nuclear $\ldots \ldots \ldots, \ldots \ldots \ldots \ldots \ldots \ldots \ldots$ & 15.86 & 31.20 & 31.20 & 30.78 & $3.4 \%$ \\
\hline Pumped Storage/Oher' $\ldots \ldots \ldots \ldots \ldots \ldots \ldots$ & 0.00 & 0.00 & 0.00 & 0.00 & N/A \\
\hline Renewables ${ }^{2} \ldots \ldots \ldots \ldots \ldots \ldots \ldots \ldots$ & 1.73 & 1.59 & 1.59 & 2.27 & $1.4 \%$ \\
\hline Total $\ldots \ldots \ldots \ldots \ldots \ldots \ldots \ldots \ldots \ldots \ldots \ldots$ & 161.00 & 200.03 & 216.10 & 228.35 & $1.0 \%$ \\
\hline \multicolumn{6}{|l|}{ Mid-Atientic Area Council (MAAC) } \\
\hline Coal $\ldots \ldots \ldots \ldots \ldots \ldots$ & 103.90 & 109.52 & 110.60 & 130.60 & $1.2 \%$ \\
\hline Petroleum $\ldots \ldots \ldots \ldots \ldots \ldots \ldots \ldots \ldots$ & 11.05 & 5.73 & 4.95 & 3.31 & $.5 .8 \%$ \\
\hline Natural Gas $\ldots \ldots \ldots \ldots \ldots \ldots \ldots \ldots \ldots \ldots$ & 6.43 & 18.59 & 30.60 & 25.52 & $7.1 \%$ \\
\hline Nuclear $\ldots \ldots \ldots \ldots \ldots \ldots \ldots \ldots \ldots \ldots \ldots$ & 72.31 & 83.38 & 82.93 & 65.18 & $.0 .5 \%$ \\
\hline Pumped Storage/Oher' $\ldots \ldots \ldots \ldots \ldots \ldots$ & -1.03 & -0.64 & .0 .64 & .0 .64 & $-2.4 \%$ \\
\hline Renewables ${ }^{2} \ldots \ldots \ldots$ & 6.14 & 7.77 & 10.44 & 21.24 & $6.4 \%$ \\
\hline Total $\ldots \ldots \ldots \ldots \ldots \ldots \ldots \ldots \ldots \ldots \ldots \ldots \ldots$ & 189.79 & 224.36 & 238.88 & 245.21 & $1.1 \%$ \\
\hline \multicolumn{6}{|l|}{ Mid-Amerlca intorconnected Notwork (MAIN) } \\
\hline 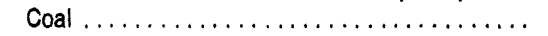 & 109.34 & 136.96 & 144.61 & 157.54 & $1.8 \%$ \\
\hline Petroleum. $\ldots \ldots \ldots \ldots \ldots \ldots \ldots \ldots \ldots \ldots$ & 0.52 & 0.03 & 0.03 & 0.02 & $-14.9 \%$ \\
\hline Natural Gas $\ldots \ldots \ldots \ldots \ldots \ldots \ldots \ldots$ & 0.89 & 1.23 & 2.80 & 5.33 & $9.3 \%$ \\
\hline$\ldots \ldots \ldots \ldots$ & 91.11 & 96.91 & 97.30 & 91.60 & $0.0 \%$ \\
\hline Pumped Storage/Ohher $r^{\prime} \ldots$ & -0.04 & .0 .15 & -0.15 & -0.15 & $7.4 \%$ \\
\hline Renewables ${ }^{2} \ldots \ldots \ldots \ldots$ & 2.48 & 3.80 & 4.44 & 5.15 & $3.7 \%$ \\
\hline Total $\ldots \ldots \ldots \ldots \ldots \ldots \ldots \ldots \ldots \ldots \ldots \ldots$ & 204.31 & 238.79 & 249.02 & 259.47 & $1.2 \%$ \\
\hline \multicolumn{6}{|l|}{ Mid-Conthent Area Power Pool (MAPP) } \\
\hline Coal $\ldots \ldots \ldots \ldots \ldots \ldots \ldots \ldots \ldots \ldots \ldots$ & 96.48 & 97.22 & 103.08 & 107.48 & $0.5 \%$ \\
\hline Pelroleum $\ldots \ldots \ldots \ldots \ldots \ldots \ldots \ldots$ & 0.54 & 0.03 & 0.05 & 0.03 & $-13.9 \%$ \\
\hline Natural Gas $\ldots \ldots \ldots \ldots \ldots \ldots \ldots \ldots \ldots$ & 0.92 & 2.91 & 2.95 & 7.35 & $11.0 \%$ \\
\hline Nuclear $\ldots \ldots \ldots \ldots \ldots \ldots \ldots \ldots \ldots$ & 22.66 & 24.42 & 24.36 & 20.46 & $.0 .5 \%$ \\
\hline Pumped Storage/OTher' $\ldots \ldots \ldots \ldots \ldots \ldots$ & 0.00 & 0.00 & 0.00 & 0.00 & N/A \\
\hline Renewables ${ }^{2} \ldots \ldots \ldots \ldots \ldots \ldots \ldots \ldots$ & 10.85 & 10.90 & 11.10 & 11.38 & $0.2 \%$ \\
\hline Total $\ldots \ldots \ldots \ldots \ldots \ldots \ldots \ldots \ldots \ldots$ & 131.46 & 135.49 & 141.53 & 146.69 & $0.5 \%$ \\
\hline \multicolumn{6}{|l|}{$\begin{array}{l}\text { Northeast Power Coordhating } \\
\text { Councinlow York (NPCCNY) }\end{array}$} \\
\hline Coal $\ldots \ldots \ldots \ldots \ldots \ldots$ & 24.62 & 19.49 & 18.51 & 20.69 & $-0.9 \%$ \\
\hline Petroleum ........... & 33.40 & 24.69 & 26.13 & 24.41 & $-1.6 \%$ \\
\hline Natural Gas $\ldots \ldots \ldots \ldots \ldots \ldots \ldots \ldots$ & 21.28 & 19.88 & 20.77 & 20.54 & $-0.2 \%$ \\
\hline Nuclear $\ldots \ldots \ldots \ldots \ldots \ldots \ldots \ldots \ldots \ldots$ & 23.62 & 31.63 & 31.63 & 24.46 & $0.2 \%$ \\
\hline Pumped Storage/Other' & -1.05 & -1.86 & -1.86 & -1.87 & $2.9 \%$ \\
\hline Renewables ${ }^{2} \ldots \ldots$. & 28.65 & 30.84 & 32.44 & 37.24 & $1.3 \%$ \\
\hline$\ldots \ldots \ldots \ldots \ldots \ldots \ldots \ldots \ldots$ & 130.52 & 124.66 & 127.62 & 125.47 & $.0 .2 \%$ \\
\hline
\end{tabular}


Table 52. Electric Generation by Electriclty Market Module Region and Source (Continued)

(Billion Kilowatthours)

\begin{tabular}{|c|c|c|c|c|c|}
\hline \multirow{2}{*}{ Reglon and Source } & \multicolumn{4}{|c|}{ Reterencos Caso } & \multirow{2}{*}{$\begin{array}{c}\text { Amnual } \\
\text { Growth } \\
1900-2010 \\
\text { (percent) }\end{array}$} \\
\hline & 1990 & 2000 & 2005 & 2010 & \\
\hline \multicolumn{6}{|l|}{$\begin{array}{l}\text { Northeaset Power Coordhating } \\
\text { Councilnow Englend (NPCCNE) }\end{array}$} \\
\hline 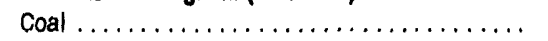 & 16.58 & 16.65 & 16.05 & 16.44 & $0.0 \%$ \\
\hline Petroleum $\ldots \ldots \ldots \ldots \ldots \ldots \ldots \ldots \ldots$ & 28.13 & 19.05 & 20.94 & 15.31 & $.3 .0 \%$ \\
\hline Natural Gas & 6.82 & 15.09 & 15.37 & 15.85 & $4.3 \%$ \\
\hline Nuclear .... & 37.40 & 41.82 & 41.66 & 32.27 & $.0 .7 \%$ \\
\hline Pumped Storage/Other' & .0 .66 & -0.79 & .0 .79 & .0 .79 & $0.9 \%$ \\
\hline Renewables ${ }^{2} \ldots \ldots \ldots$ & 13.00 & 13.70 & 16.16 & 23.11 & $2.9 \%$ \\
\hline Total $\ldots \ldots \ldots \ldots \ldots \ldots \ldots \ldots \ldots \ldots \ldots$ & 101.27 & 105.53 & 109.39 & 102.20 & $0.0 \%$ \\
\hline \multicolumn{6}{|l|}{$\begin{array}{l}\text { Southoastern Eloctric Rellebllity } \\
\text { CounciVFlorida (SERC/STV) }\end{array}$} \\
\hline Coal $\ldots \ldots \ldots \ldots \ldots \ldots \ldots \ldots \ldots \ldots \ldots \ldots$ & 53.17 & 54.92 & 55.08 & 70.05 & $1.4 \%$ \\
\hline Petroleum $\ldots \ldots \ldots \ldots \ldots \ldots \ldots \ldots \ldots$ & 25.08 & 29.68 & 32.64 & 27.23 & $0.4 \%$ \\
\hline Natural Gas $\ldots \ldots \ldots \ldots \ldots \ldots \ldots \ldots$ & 17.40 & 43.18 & 49.70 & 45.34 & $4.9 \%$ \\
\hline Nuclear $\ldots \ldots \ldots \ldots \ldots \ldots \ldots \ldots \ldots \ldots$ & 21.78 & 25.07 & 24.94 & 16.33 & $.1 .4 \%$ \\
\hline Pumped Storage/Oher' $\ldots \ldots \ldots \ldots \ldots \ldots$ & 0.00 & 0.00 & 0.00 & 0.00 & $N / A$ \\
\hline Renewables ${ }^{2} \ldots \ldots \ldots \ldots \ldots \ldots \ldots \ldots$ & 1.94 & 2.88 & 3.17 & 4.08 & $3.8 \%$ \\
\hline Tetal $\ldots \ldots \ldots \ldots \ldots \ldots \ldots \ldots \ldots \ldots \ldots$ & 119.37 & 155.72 & 165.53 & 163.02 & $1.6 \%$ \\
\hline \multicolumn{6}{|l|}{$\begin{array}{l}\text { Southoastern Eloctrlc Reliebillty } \\
\text { CounciVexchudhy Florida (SERC/STV) }\end{array}$} \\
\hline Coal $\ldots \ldots \ldots \ldots \ldots \ldots \ldots$ & 289.25 & 332.02 & 337.81 & 393.08 & $1.5 \%$ \\
\hline Petroleum $\ldots \ldots \ldots \ldots \ldots \ldots \ldots \ldots \ldots$ & 1.90 & 1.83 & 2.92 & 2.17 & $0.7 \%$ \\
\hline Natural Gas & 4.46 & 17.27 & 43.88 & 52.51 & $13.1 \%$ \\
\hline Nuclear $\ldots \ldots \ldots \ldots \ldots \ldots \ldots \ldots \ldots$ & 147.00 & 197.68 & 206.78 & 203.87 & $1.6 \%$ \\
\hline Pumped Storage/Cherer' .................. & -0.99 & .3 .35 & -3.36 & .3 .37 & $6.3 \%$ \\
\hline Renewables ${ }^{2} \ldots \ldots \ldots$ & 38.52 & 41.18 & 46.41 & 51.65 & $1.5 \%$ \\
\hline Total $\ldots \ldots \ldots \ldots \ldots \ldots \ldots \ldots \ldots \ldots \ldots \ldots$ & 480.14 & 586.63 & 694.44 & 698.91 & $1.0 \%$ \\
\hline \multicolumn{6}{|l|}{ Southwost Power Pool (SPP) } \\
\hline 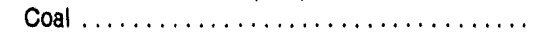 & 167.00 & 189.36 & 195.70 & 209.99 & $1.2 \%$ \\
\hline Petroleum. $\ldots \ldots \ldots \ldots \ldots \ldots \ldots \ldots$ & 1.12 & 0.63 & 0.92 & 0.80 & $-1.7 \%$ \\
\hline Natural Gas $\ldots \ldots \ldots \ldots \ldots \ldots \ldots \ldots$ & 69.13 & 64.37 & 71.32 & 63.25 & $.0 .4 \%$ \\
\hline Nuclear ......... & 37.23 & 27.20 & 27.42 & 27.23 & $-1.6 \%$ \\
\hline Pumped Storage/Oher' & 0.35 & .0 .44 & -0.44 & .0 .44 & N/A \\
\hline Renewables ${ }^{2} \ldots \ldots$ & 8.00 & 8.11 & 10.24 & 12.64 & $2.3 \%$ \\
\hline Total $\ldots \ldots \ldots \ldots \ldots \ldots \ldots \ldots \ldots \ldots \ldots$ & 282.62 & 289.22 & 305.16 & 313.46 & $0.5 \%$ \\
\hline \multicolumn{6}{|l|}{$\begin{array}{l}\text { Western Systems Coordinating CounclV } \\
\text { Northweet Power Pool Area (WSCCNWP) }\end{array}$} \\
\hline 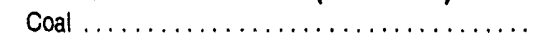 & 77.13 & 79.28 & 81.45 & 81.69 & $0.3 \%$ \\
\hline Petroleum ........ & 0.30 & 0.15 & 0.16 & 0.06 & $.7 .7 \%$ \\
\hline Natural Gas $\ldots \ldots \ldots \ldots \ldots \ldots \ldots \ldots$ & 2.46 & 43.79 & 69.89 & 81.27 & $19.1 \%$ \\
\hline Nuclear $\ldots \ldots \ldots \ldots \ldots \ldots \ldots \ldots \ldots$ & 11.82 & 7.19 & 7.17 & 7.17 & $-2.5 \%$ \\
\hline Pumped Storage/Other' $\ldots \ldots \ldots \ldots \ldots \ldots \ldots$ & 0.00 & .0 .59 & .0 .59 & .0 .59 & N/A \\
\hline Renewables ${ }^{2} \ldots \ldots \ldots$ & 149.43 & 161.07 & 163.29 & 169.28 & $0.6 \%$ \\
\hline Total $\ldots \ldots \ldots \ldots \ldots \ldots \ldots \ldots \ldots \ldots \ldots \ldots \ldots$ & 241.16 & 280.80 & 321.37 & 338.87 & $1.7 \%$ \\
\hline \multicolumn{6}{|l|}{$\begin{array}{l}\text { Weatern Systems Coordinating CounclV Rocky } \\
\text { Mountaln Power Area and Arizona (WSCCRA) }\end{array}$} \\
\hline Coal $\ldots \ldots \ldots \ldots \ldots \ldots \ldots \ldots \ldots \ldots$ & 106.79 & 108.21 & 108.59 & 119.66 & $0.6 \%$ \\
\hline Petroloum $\ldots \ldots \ldots \ldots \ldots \ldots \ldots \ldots \ldots$ & 0.26 & 0.22 & 0.14 & 0.01 & $-15.8 \%$ \\
\hline Natural Gas $\ldots \ldots \ldots \ldots \ldots \ldots \ldots \ldots$ & 5.15 & 30.17 & 34.52 & 27.17 & $8.7 \%$ \\
\hline Nuciear ............ & 20.60 & 20.58 & 20.33 & 20.53 & $0.0 \%$ \\
\hline Pumped Storage/Othar ${ }^{1}$. & 0.37 & .0 .37 & -0.37 & -0.37 & $N / A$ \\
\hline Renewables ${ }^{2} \ldots \ldots \ldots$ & 12.58 & 14.10 & 14.64 & 22.35 & $2.9 \%$ \\
\hline$\ldots \ldots \ldots \ldots \ldots \ldots$ & 145.75 & 172.90 & 177.84 & 189.35 & $1.3 \%$ \\
\hline
\end{tabular}


Table 52. Electric Generation by Electricity Market Module Region and Source (Continued)

(Billion Kilowatthours)

\begin{tabular}{|c|c|c|c|c|c|}
\hline \multirow{2}{*}{ Region and Source } & \multicolumn{4}{|c|}{ Relerencos Case } & \multirow{2}{*}{$\begin{array}{l}\text { Annual } \\
\text { Growth } \\
\text { temo-2010 } \\
\text { (percent) }\end{array}$} \\
\hline & 1000 & 2000 & 2005 & 2010 & \\
\hline \multicolumn{6}{|l|}{$\begin{array}{l}\text { Wedem Syetem Coordlnating CounclV } \\
\text { Celliomin-Southern Novada Power (WSCCCNV) }\end{array}$} \\
\hline Coal $\ldots \ldots \ldots \ldots \ldots \ldots \ldots \ldots \ldots \ldots \ldots$ & 12.39 & 13.62 & 22.93 & 57.77 & $8.0 \%$ \\
\hline$\ldots \ldots \ldots \ldots \ldots \ldots \ldots \ldots$ & 4.93 & 2.72 & 2.06 & 0.71 & $-9.2 \%$ \\
\hline Natural Gas & 51.88 & 50.12 & 49.02 & 28.00 & $-3.0 \%$ \\
\hline Nuclear .... & 32.69 & 34.24 & 34.71 & 27.65 & $.0 .8 \%$ \\
\hline Pumped Storage/Other" & 1.79 & -1.38 & .1 .38 & -1.37 & N/A \\
\hline Renewables ${ }^{2} \ldots \ldots \ldots$ & 42.92 & 67.42 & 74.86 & 86.07 & $3.5 \%$ \\
\hline Tota $\ldots \ldots \ldots \ldots \ldots \ldots \ldots \ldots \ldots \ldots \ldots$ & 146.61 & 166.74 & 182.20 & 198.84 & $1.5 \%$ \\
\hline
\end{tabular}

'Other include methane, propane and blast furnace gas for utilities and hydrogen, sulfur, batteries, chemicals, fish oil, and spend sulfite liquor for nonutillities.

'Penewables includes conventional hydroelectric, geothermal, wood, wood waste, municipal solid waste, other biomass, solar, and wind power.

N/A = Not applicable.

Notes: Totals may not equal sum of components due to independent rounding. Generation from electric utilities and nonutilities (excluding cogenerators); i.e. from independent and small power producers and exempt wholesale generators which produce electricity for delivery to electric utilities.

Sources: 1990 utility generation: Energy Intormation Administration (ElA), Electric Power Annual 1991, DOE/ElA-0348(91) (Washington, D.C., February 1993). 1990 nonutility generation: EIA, Form ElA-867, "Annual Nonutlity Power Producer Report." Projectlone: EIA, AEO 1994 National Energy Modeling System run AEO94B.D1221934. 
Table 53. Electricity Generating Capacity by Electricty Market Module Region and Source

(Thousand Megawatts)

\begin{tabular}{|c|c|c|c|c|c|}
\hline \multirow{2}{*}{ Region and Sources } & \multicolumn{4}{|c|}{ Relerence Case } & \multirow{2}{*}{$\begin{array}{l}\text { Amud } \\
\text { Crowth } \\
1 \text { cop-2010 } \\
\text { (percent) }\end{array}$} \\
\hline & 1800 & 2000 & 2000 & 2010 & \\
\hline \multicolumn{6}{|l|}{$\begin{array}{l}\text { Eaet Central Area Rellebility } \\
\text { Coordination Agreement (ECAR) }\end{array}$} \\
\hline Coal Steam ................. & 84.29 & 81.34 & 80.98 & 81.40 & $.0 .2 \%$ \\
\hline Other Fossil Steam ${ }^{\prime} \ldots \ldots \ldots \ldots \ldots \ldots \ldots$ & 4.60 & 3.63 & 2.84 & 2.81 & $-2.4 \%$ \\
\hline Combined Cycle ...................... & 0.39 & 0.39 & 2.29 & 7.41 & $15.8 \%$ \\
\hline Combustion Turbine/Diesel $\ldots \ldots \ldots \ldots \ldots$ & 3.26 & 6.36 & 10.64 & 11.25 & $6.4 \%$ \\
\hline Nuclear Power $\ldots \ldots \ldots \ldots \ldots \ldots \ldots \ldots$ & 7.63 & 7.56 & 7.56 & 6.81 & $-0.6 \%$ \\
\hline Pumped Storage/OTher ${ }^{2}$ & 3.26 & 3.26 & 3.26 & 3.26 & N/A \\
\hline Renewable Sources ${ }^{3} \ldots$ & 1.44 & 3.54 & 4.10 & 4.65 & $6.0 \%$ \\
\hline Total $\ldots \ldots \ldots \ldots \ldots \ldots \ldots \ldots \ldots \ldots \ldots$ & 104.88 & 106.09 & 111.67 & 117.59 & $0.6 \%$ \\
\hline \multicolumn{6}{|l|}{ Electric Relisbility Council of Toxes (ERCOT) } \\
\hline Coal Steam ........................ & 14.06 & 16.20 & 17.08 & 18.53 & $1.4 \%$ \\
\hline$\ldots \ldots \ldots \ldots \ldots \ldots \ldots$ & 30.26 & 29.73 & 29.30 & 28.67 & $.0 .3 \%$ \\
\hline Combined Cycle ... & 1.05 & 2.66 & 4.99 & 5.49 & $8.6 \%$ \\
\hline Combustion Turbine/Diesel $\ldots \ldots \ldots \ldots \ldots \ldots$ & 2.28 & 3.06 & 3.35 & 3.47 & $2.1 \%$ \\
\hline Nuclear Power $\ldots \ldots \ldots \ldots \ldots \ldots \ldots \ldots$ & 3.63 & 4.78 & 4.78 & 4.78 & $1.4 \%$ \\
\hline Pumped Storage/Oher ${ }^{2} \ldots \ldots \ldots \ldots \ldots \ldots$ & 0.00 & 0.00 & 0.00 & 0.00 & N/A \\
\hline Renewable Sources' $\ldots$ & 0.56 & 0.56 & 0.57 & 0.79 & $1.7 \%$ \\
\hline Total $\ldots \ldots \ldots \ldots \ldots \ldots \ldots \ldots \ldots \ldots \ldots \ldots$ & 51.84 & 57.00 & 60.06 & 61.72 & $0.0 \%$ \\
\hline \multicolumn{6}{|l|}{ Wid-Atlentlc Ares Councll (MAAC) } \\
\hline Coal Steam ................ & 17.38 & 17.80 & 17.55 & 20.30 & $0.8 \%$ \\
\hline Other Fossil Steam ${ }^{1}$. & 10.40 & 8.96 & 8.36 & 8.32 & $-1.1 \%$ \\
\hline$\ldots \ldots \ldots \ldots \ldots \ldots$ & 0.32 & 3.51 & 4.81 & 5.23 & $15.0 \%$ \\
\hline Combustion Turbine/Diesel $\ldots \ldots \ldots \ldots \ldots \ldots$ & 7.87 & 9.24 & 9.67 & 9.67 & $1.0 \%$ \\
\hline Nuclear Power $\ldots \ldots \ldots \ldots \ldots \ldots \ldots \ldots \ldots$ & 12.59 & 12.59 & 12.59 & 9.90 & $.1 .2 \%$ \\
\hline Pumped Storage/Other ${ }^{2}$ & 1.32 & 1.32 & 1.32 & 1.32 & N/A \\
\hline Renewable Sources ${ }^{3} \ldots$ & 1.35 & 1.86 & 2.28 & 5.69 & $7.5 \%$ \\
\hline 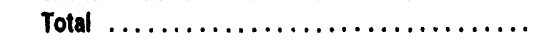 & 51.22 & 55.27 & 56.58 & 60.42 & $0.8 \%$ \\
\hline \multicolumn{6}{|l|}{ Mid-America Intorconnected Network (MAIN) } \\
\hline Coal Steam $\ldots \ldots \ldots \ldots \ldots \ldots \ldots \ldots \ldots \ldots$ & 27.46 & 26.44 & 26.47 & 27.60 & $0.0 \%$ \\
\hline Other Fossil Steam ${ }^{\prime} \ldots \ldots \ldots \ldots \ldots \ldots \ldots$ & 3.56 & 1.31 & 1.31 & 1.28 & $.5 .0 \%$ \\
\hline$\ldots \ldots \ldots \ldots \ldots \ldots \ldots \ldots$ & 0.00 & 0.06 & 0.13 & 0.13 & N/A \\
\hline Combustion Turbine/Diesel $\ldots \ldots \ldots \ldots \ldots \ldots$ & 2.82 & 9.26 & 12.35 & 15.04 & $8.7 \%$ \\
\hline Nuclear Power $\ldots \ldots \ldots \ldots \ldots \ldots \ldots \ldots$ & 14.86 & 14.86 & 14.86 & 13.59 & $.0 .4 \%$ \\
\hline Pumped Storage/Other ${ }^{2} \ldots \ldots \ldots \ldots \ldots \ldots$ & 0.35 & 0.35 & 0.35 & 0.35 & $N / A$ \\
\hline Renewable Sources". & 0.67 & 0.77 & 0.88 & 0.98 & $1.9 \%$ \\
\hline Total $\ldots \ldots \ldots \ldots \ldots \ldots \ldots \ldots \ldots \ldots \ldots \ldots \ldots$ & 49.73 & 53.05 & 56.34 & 58.97 & $0.9 \%$ \\
\hline \multicolumn{6}{|l|}{ Mid-Conthent Area Power Pool (MAPP) } \\
\hline Coal Steam $\ldots \ldots \ldots \ldots \ldots \ldots \ldots \ldots \ldots$ & 21.49 & 21.21 & 20.47 & 19.99 & $.0 .4 \%$ \\
\hline Other Fossil Steam ${ }^{1} \ldots \ldots \ldots \ldots \ldots \ldots \ldots$ & 0.61 & 0.36 & 0.19 & 0.17 & $-6.2 \%$ \\
\hline Combined Cycle $\ldots \ldots \ldots \ldots \ldots \ldots \ldots$ & 0.09 & 0.09 & 0.09 & 0.09 & $0.0 \%$ \\
\hline Combustion Turbine/Diesel $\ldots \ldots \ldots \ldots \ldots \ldots$ & 4.38 & 5.15 & 5.51 & 7.78 & $2.9 \%$ \\
\hline Nuclear Power $\ldots \ldots \ldots \ldots \ldots \ldots \ldots \ldots$ & 3.70 & 3.70 & 3.70 & 2.69 & $-1.6 \%$ \\
\hline Pumped Storage/Other ${ }^{2}$ & 0.00 & 0.00 & 0.20 & 0.00 & N/A \\
\hline Renewable Sources' .. & 3.54 & 3.56 & 3.59 & 3.62 & $0.1 \%$ \\
\hline 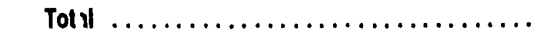 & 33.82 & 34.08 & 33.55 & 34.34 & $0.1 \%$ \\
\hline \multicolumn{6}{|l|}{$\begin{array}{l}\text { Northeast Power Coordinating } \\
\text { CouncilWow York (NPCCNY) }\end{array}$} \\
\hline Coal Steam ............... & 4.84 & 4.12 & 3.96 & 4.65 & $.0 .2 \%$ \\
\hline Other Fossil Steam ${ }^{1} . . . . .$. & 12.86 & 11.88 & 11.81 & 11.76 & $.0 .4 \%$ \\
\hline Combined Cycle $\ldots \ldots \ldots \ldots \ldots \ldots \ldots \ldots$ & 0.00 & 0.85 & 0.85 & 0.85 & N/A \\
\hline Combustion Turbine/Diesel $\ldots \ldots \ldots \ldots \ldots \ldots$ & 3.87 & 3.90 & 3.90 & 3.90 & $0.0 \%$ \\
\hline Nuclear Power $\ldots \ldots \ldots \ldots \ldots \ldots \ldots \ldots$ & 4.83 & 4.83 & 4.83 & 3.76 & $-1.3 \%$ \\
\hline Pumped Storage/Other ${ }^{2}$ & 1.30 & 1.36 & 1.36 & 1.36 & $0.2 \%$ \\
\hline Renewable Sources ${ }^{3}$.. & 4.12 & 4.43 & 4.66 & 6.16 & $2.0 \%$ \\
\hline Total $\ldots \ldots \ldots \ldots$ & 31.82 & 31.38 & 31.38 & 32.45 & $0.1 \%$ \\
\hline
\end{tabular}


Table 53. Electriclty Generating Capacity by Electricty Market Module Reglon and Source (Contlinued)

(Thousand Megawatts)

\begin{tabular}{|c|c|c|c|c|c|}
\hline \multirow{2}{*}{ Region and Sourco } & \multicolumn{4}{|c|}{ Reterencos Case } & \multirow{2}{*}{$\begin{array}{l}\text { Amual } \\
\text { Growth } \\
1990-2010 \\
\text { (percant) }\end{array}$} \\
\hline & 1900 & 2000 & 2005 & 2010 & \\
\hline \multicolumn{6}{|l|}{$\begin{array}{l}\text { Northeast Power Coordhathy } \\
\text { CounciWiow England (NPCCNE) }\end{array}$} \\
\hline Coal Steam .................. & 2.65 & 2.71 & 2.61 & 2.67 & $0.0 \%$ \\
\hline Other Fossil Steam ${ }^{1} \ldots \ldots \ldots \ldots \ldots \ldots \ldots$ & 9.73 & 8.56 & 8.27 & 8.24 & $.0 .8 \%$ \\
\hline Combined Cycle $\ldots \ldots \ldots \ldots \ldots \ldots \ldots$ & 1.06 & 1.44 & 1.44 & 1.47 & $1.6 \%$ \\
\hline Combustion Turbine/Diesel $\ldots \ldots \ldots \ldots \ldots \ldots$ & 1.41 & 1.75 & 1.75 & 1.75 & $1.1 \%$ \\
\hline Nuclear Power $\ldots \ldots \ldots \ldots \ldots \ldots \ldots \ldots \ldots$ & 6.56 & 6.39 & 6.39 & 4.31 & $-2.1 \%$ \\
\hline Pumped Storage/Other ${ }^{2}$ & 1.68 & 1.68 & 1.68 & 1.68 & N/A \\
\hline Renewable Sources ${ }^{3} \ldots$ & 2.49 & 2.92 & 3.29 & 5.11 & $3.7 \%$ \\
\hline Total $\ldots \ldots \ldots \ldots \ldots \ldots \ldots \ldots \ldots \ldots \ldots \ldots$ & 25.58 & 25.44 & 25.43 & 25.23 & $-0.1 \%$ \\
\hline \multicolumn{6}{|l|}{$\begin{array}{l}\text { Southeatem Eloctric Rellability } \\
\text { Councliflorlda (SERC/STY) }\end{array}$} \\
\hline Coal Steam $\ldots \ldots \ldots \ldots \ldots \ldots \ldots \ldots \ldots$ & 8.86 & 9.30 & 9.30 & 14.03 & $2.3 \%$ \\
\hline Other Fossil Steam' . . & 13.50 & 12.52 & 12.04 & 11.54 & $.0 .8 \%$ \\
\hline Combined Cycle ... & 0.64 & 4.08 & 4.68 & 4.74 & $10.5 \%$ \\
\hline Combustion Turbine/Diesel $\ldots \ldots \ldots \ldots \ldots \ldots$ & 4.47 & 5.84 & 5.85 & 5.85 & $1.4 \%$ \\
\hline Nuclear Power $\ldots \ldots \ldots \ldots \ldots \ldots \ldots \ldots$ & 3.83 & 3.83 & 3.83 & 2.50 & $.2 .1 \%$ \\
\hline Pumped Storage/Oher ${ }^{2}$. & 0.00 & 0.00 & 0.00 & 0.00 & N/A \\
\hline Renewable Sources ${ }^{3}$. & 0.37 & 0.61 & 0.65 & 0.77 & $3.7 \%$ \\
\hline Total $\ldots \ldots \ldots \ldots \ldots \ldots \ldots \ldots \ldots \ldots \ldots \ldots \ldots \ldots$ & 31.67 & 36.18 & 36.35 & 39.42 & $1.1 \%$ \\
\hline \multicolumn{6}{|l|}{$\begin{array}{l}\text { Southwaetern Elsctric Rolleblilty } \\
\text { Counclibxcluding Florlda (SERC/STV) }\end{array}$} \\
\hline Coal Steam $\ldots \ldots \ldots \ldots \ldots \ldots \ldots \ldots \ldots$ & 61.91 & 62.17 & 61.40 & 66.37 & $0.3 \%$ \\
\hline Other Fossil Steam' .................... & 3.26 & 2.61 & 2.30 & 2.20 & $-1.9 \%$ \\
\hline Combined Cycle ... & 0.86 & 2.05 & 5.97 & 10.19 & $13.1 \%$ \\
\hline Combustion Turbine/Diesel & 6.35 & 12.15 & 12.04 & 11.99 & $3.2 \%$ \\
\hline Nuclear Power & 25.31 & 28.92 & 30.13 & 29.45 & $0.8 \%$ \\
\hline Pumped Storaga/Oher ${ }^{2}$. & 4.50 & 6.78 & 6.78 & 6.78 & $2.1 \%$ \\
\hline Renewable Sources' ... & 11.42 & 11.60 & 12.45 & 13.29 & $0.8 \%$ \\
\hline 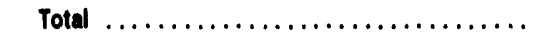 & 113.61 & 126.29 & 131.07 & 140.27 & $1.1 \%$ \\
\hline \multicolumn{6}{|l|}{ Southweat Power Pool (SPP) } \\
\hline Coal Steam. & 27.26 & 27.36 & 28.73 & 31.85 & $0.8 \%$ \\
\hline Other Fossil Steam'. & 30.15 & 27.92 & 25.74 & 24.79 & $-1.0 \%$ \\
\hline Combined Cycle .... & 1.11 & 1.21 & 1.56 & 1.65 & $2.0 \%$ \\
\hline Combustion Turbine/Diesel $\ldots \ldots \ldots \ldots \ldots \ldots$ & 4.26 & 4.82 & 5.72 & 7.12 & $2.6 \%$ \\
\hline Nuclear Power $\ldots \ldots \ldots \ldots \ldots \ldots \ldots \ldots$ & 5.89 & 5.89 & 5.89 & 5.89 & $\mathrm{~N} / \mathrm{A}$ \\
\hline Pumped Storage/Oher ${ }^{2}$ & 0.51 & 0.51 & 0.51 & 0.51 & N/A \\
\hline Renewable Sources's & 2.44 & 2.63 & 2.97 & 3.41 & $1.7 \%$ \\
\hline 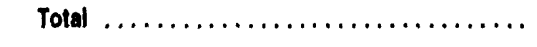 & 71.62 & 70.34 & 71.11 & 75.20 & $0.2 \%$ \\
\hline \multicolumn{6}{|l|}{$\begin{array}{l}\text { Weatern Syetems Coordhating Council } \\
\text { Northweat Powet Pool Area (WSCCNWP) }\end{array}$} \\
\hline Coal Steam ....... & 11.16 & 11.02 & 11.42 & 11.45 & $0.1 \%$ \\
\hline Other Fossil Steam'. . & 0.79 & 0.57 & 0.47 & 0.42 & $.3 .2 \%$ \\
\hline Combined Cycle .... & 0.49 & 5.11 & 8.93 & 12.03 & $17.3 \%$ \\
\hline Combustion Turbine/Diesel ......... & 1.02 & 2.36 & 2.36 & 2.36 & $4.3 \%$ \\
\hline Nuclear Power $\ldots . . .$. & 2.20 & 1.10 & 1.10 & 1.10 & $.3 .4 \%$ \\
\hline Pumped Storage/Oher" & 0.31 & 0.31 & 0.31 & 0.31 & N/A \\
\hline Renewable Sources" .. & 34.44 & 35.77 & 36.10 & 37.02 & $0.4 \%$ \\
\hline Total & 50.42 & 56.24 & 60.70 & 64.69 & $1.3 \%$ \\
\hline
\end{tabular}


Table 53. Electricity Generating Capacity by Electricty Market Module Region and Source (Continued) (Thousand Megawatts)

\begin{tabular}{|c|c|c|c|c|c|}
\hline \multirow{2}{*}{ Reglon and Source } & \multicolumn{4}{|c|}{ Reterence Case } & \multirow{2}{*}{$\begin{array}{l}\text { Annual } \\
\text { Crowth } \\
1900-2010 \\
\text { (percent) }\end{array}$} \\
\hline & 1000 & 2000 & 2005 & 2010 & \\
\hline \multicolumn{6}{|l|}{$\begin{array}{l}\text { Weatem Systoms Coordinating CouncIV Rocky } \\
\text { Mountah Power Area and Arizona (WSCCRA) }\end{array}$} \\
\hline Coal Steam $\ldots \ldots \ldots \ldots \ldots \ldots \ldots \ldots \ldots$ & 13.05 & 13.87 & 13.80 & 15.04 & $0.7 \%$ \\
\hline Other Fossil Steam' . . . . . . . . . . . . . . . & 2.66 & 2.12 & 1.84 & 1.57 & $.2 .6 \%$ \\
\hline Combined Cycle $\ldots \ldots \ldots \ldots \ldots \ldots \ldots$ & 0.84 & 1.85 & 3.31 & 3.58 & $7.5 \%$ \\
\hline Combustion Turbine/Diesel $\ldots \ldots \ldots \ldots \ldots \ldots$ & 1.93 & 2.53 & 2.67 & 2.67 & $1.6 \%$ \\
\hline Nuclear Power $\ldots \ldots \ldots \ldots \ldots \ldots \ldots \ldots$ & 2.77 & 2.77 & 2.77 & 2.77 & $N / A$ \\
\hline Pumped Storage/Oher' . . . . . . . . . . . . . . . . & 0.68 & 0.79 & 0.79 & 0.79 & $0.8 \%$ \\
\hline Renewable Sources ${ }^{3} \ldots$ & 3.95 & 4.13 & 4.26 & 6.64 & $2.6 \%$ \\
\hline Total $\ldots \ldots \ldots \ldots \ldots \ldots \ldots \ldots$ & 25.87 & 28.06 & 29.44 & 33.06 & $1.2 \%$ \\
\hline \multicolumn{6}{|l|}{$\begin{array}{l}\text { Weatern Systems Coordinating CounciV } \\
\text { Calliornla-Southern Nevada Power (WSCCCNV) }\end{array}$} \\
\hline Coal Støam . . . . . . . . . . . . . . . . . & 5.21 & 5.21 & 6.96 & 11.75 & $4.2 \%$ \\
\hline Other Fossil Steam'. & 21.70 & 20.38 & 19.84 & 19.44 & $.0 .5 \%$ \\
\hline Combined Cycle $\ldots \ldots \ldots \ldots \ldots \ldots \ldots \ldots$ & 1.59 & 3.80 & 5.33 & 5.33 & $6.2 \%$ \\
\hline Combustion Turbine/Diesel $\ldots \ldots \ldots \ldots \ldots$ & 2.60 & 3.48 & 3.91 & 3.91 & $2.1 \%$ \\
\hline Nuclear Power $\ldots \ldots \ldots \ldots \ldots \ldots \ldots$ & 5.79 & 5.35 & 5.35 & 3.19 & $-2.9 \%$ \\
\hline Pumped Storage/Oher ${ }^{2} \ldots \ldots \ldots \ldots \ldots \ldots \ldots$ & 3.73 & 3.83 & 3.83 & 3.83 & $0.1 \%$ \\
\hline Renewable Sources ${ }^{3} \ldots \ldots \ldots \ldots \ldots \ldots$ & 15.84 & 18.61 & 19.75 & 21.48 & $1.5 \%$ \\
\hline Total $\ldots \ldots \ldots \ldots \ldots \ldots \ldots \ldots \ldots \ldots$ & 56.47 & 60.68 & 64.97 & 68.83 & $1.0 \%$ \\
\hline
\end{tabular}

'includes oil-, gas-, and fuel fired capacity.

'Other includes methane, propane, blast furnace gas, hydrogen, sulfur, batteries, chemicals, fish oil, and spend sulfite liquor.

${ }^{3}$ Renewable sources include conventional hydroelectric, geothermal, wood, wood waste, municipal solid waste, other biomass, solar, and wind power.

N/A = Not applicable.

Notes: Totals may nol equal sum of components due to independent rounding. Capacity for utilities and nonutilities (excluding cogenerators). Utility capacity is net summer capacity, i.e., the steady hourly output that generating equipment is expected to supply to system load (exclusive of auxiliary power), as demonstrated by tests during summer peak demand. Nonutility capacity is nameplate capacity, i.e., the capacity as designated by the manutacturer.

Source: 1990: Energy Information Administration (EIA), Electric Power Annual 1991, DOAEIA-0384(91) (Washington, D.C., February 1993). Profections: EIA, AEO 1994 National Energy Modeling System run AEO94B.D1221934. 
Table 54. Domestic Refinery Distillation Base Capacity, Expansion, and Utilization (Millions of Barrels per Day)

\begin{tabular}{|c|c|c|c|c|c|}
\hline \multirow{2}{*}{ Region } & \multicolumn{4}{|c|}{ Reterence Case } & \multirow{2}{*}{$\begin{array}{l}\text { Amual } \\
\text { Crowth } \\
1900-2010 \\
\text { (percent) }\end{array}$} \\
\hline & 1000 & 2000 & 2005 & 2010 & \\
\hline \multicolumn{6}{|l|}{ PAD Dletrict I } \\
\hline Base Capacity $\ldots \ldots \ldots \ldots \ldots \ldots \ldots \ldots$ & 1.5 & 1.6 & 1.6 & 1.6 & $0.3 \%$ \\
\hline Total Capacity . . . . . . . . . . . . . . . . . . & 1.5 & 1.6 & 1.6 & 1.6 & $0.3 \%$ \\
\hline Utilization $\ldots \ldots \ldots \ldots \ldots \ldots \ldots \ldots \ldots$ & 83.6 & 89.3 & 90.0 & 90.0 & $0.4 \%$ \\
\hline \multicolumn{6}{|l|}{ PAD Dlatrict II } \\
\hline Base Capacity $\ldots \ldots \ldots \ldots \ldots \ldots \ldots \ldots$ & 3.3 & 3.4 & 3.4 & 3.4 & $0.1 \%$ \\
\hline Capacity Additions $\ldots \ldots \ldots \ldots \ldots \ldots \ldots$ & 0.0 & 0.0 & 0.0 & 0.0 & N/A \\
\hline Utilization $\ldots \ldots \ldots \ldots \ldots \ldots \ldots \ldots \ldots$ & 92.0 & 90.0 & 90.0 & 90.0 & $-0.1 \%$ \\
\hline \multicolumn{6}{|l|}{ PAD Dtatrict III } \\
\hline Base Capacity . . . . . . . . . . . . . . . . & 7.2 & 6.9 & 6.9 & 6.9 & $-0.2 \%$ \\
\hline Capacity Additions $\ldots \ldots \ldots \ldots \ldots \ldots \ldots \ldots$ & 0.0 & 0.0 & 0.1 & 0.3 & N/A \\
\hline Total Capacity . . . . . . . . . . . . . . . . . . & 7.2 & 6.9 & 7.0 & 7.2 & $0.0 \%$ \\
\hline Utilization $\ldots \ldots \ldots \ldots \ldots \ldots \ldots \ldots \ldots$ & 85.6 & 90.0 & 90.0 & 90.0 & $0.3 \%$ \\
\hline \multicolumn{6}{|l|}{ PAD Dletrict IV } \\
\hline Base Capacity $\ldots \ldots \ldots \ldots \ldots \ldots \ldots \ldots$ & 0.6 & 0.5 & 0.5 & 0.5 & $.0 .5 \%$ \\
\hline Capacity Additions $\ldots \ldots \ldots \ldots \ldots \ldots \ldots$ & 0.0 & 0.0 & 0.0 & 0.0 & N/A \\
\hline Total Capacity . . . . . . . . . . . . . . . . . . & 0.6 & 0.5 & 0.5 & 0.5 & $.0 .5 \%$ \\
\hline Utilization $\ldots \ldots \ldots \ldots \ldots \ldots \ldots \ldots$ & 83.5 & 90.0 & 90.0 & 90.0 & $0.4 \%$ \\
\hline \multicolumn{6}{|l|}{ PAD Dletrict V } \\
\hline Base Capacity $\ldots \ldots \ldots \ldots \ldots \ldots \ldots$ & 3.1 & 3.0 & 3.0 & 3.0 & $.0 .2 \%$ \\
\hline Capacity Additions $\ldots \ldots \ldots \ldots \ldots \ldots \ldots$ & 0.0 & 0.0 & 0.0 & 0.0 & N/A \\
\hline Total Capacity $\ldots \ldots \ldots \ldots \ldots \ldots \ldots \ldots$ & 3.1 & 3.0 & 3.0 & 3.0 & $-0.2 \%$ \\
\hline Utilization $\ldots \ldots \ldots \ldots \ldots \ldots \ldots \ldots \ldots$ & 87.9 & 86.6 & 88.8 & 89.3 & $0.1 \%$ \\
\hline \multicolumn{6}{|l|}{ Unhed Stalos } \\
\hline Base Capacity . . . . . . . . . . . . . . & 15.6 & 15.3 & 15.3 & 15.3 & $-0.1 \%$ \\
\hline Capacity Additions $\ldots \ldots \ldots \ldots \ldots \ldots \ldots$ & 0.0 & 0.0 & 0.1 & 0.3 & N/A \\
\hline Total Capacity $\ldots \ldots \ldots \ldots \ldots \ldots \ldots \ldots$ & 15.6 & 15.3 & 154 & 15.6 & $0.0 \%$ \\
\hline Utilization $\ldots \ldots \ldots \ldots \ldots \ldots \ldots \ldots \ldots$ & 87.1 & 89.3 & 39.8 & 89.9 & $0.2 \%$ \\
\hline
\end{tabular}

$P A D=$ Petroleum Administration for Delense.

N/A = Not applicable.

Source: 1990: Energy Information Administration (EIA), Petroleum Supply Annual 1990, DOE/EIA-0340(80) (Washington, D.C., May 1991). Projectlons: EIA, AEO 1994 National Energy Modeling System run AEO94B.D1221934. 
Table 55. Lower 48 Crude OII Production and Wellhead Prices by Supply Region

\begin{tabular}{|c|c|c|c|c|c|}
\hline \multirow{2}{*}{ Reglon } & \multicolumn{4}{|c|}{ Referenco Caso } & \multirow{2}{*}{$\begin{array}{l}\text { Annual } \\
\text { Crowth } \\
1 \text { cep-2010 } \\
\text { (percent) }\end{array}$} \\
\hline & 1090 & 2000 & 2005 & 2010 & \\
\hline \multicolumn{6}{|l|}{$\begin{array}{l}\text { Production' } \\
\text { (million barrels per day) }\end{array}$} \\
\hline Lower 48 Total $\ldots \ldots \ldots \ldots \ldots \ldots \ldots \ldots$ & 5.58 & 4.31 & 4.25 & 4.35 & $-1.2 \%$ \\
\hline \multicolumn{6}{|l|}{ Lower 48 Onahore } \\
\hline Northeast $\ldots \ldots \ldots \ldots \ldots \ldots \ldots \ldots \ldots$ & 0.18 & 0.11 & 0.11 & 0.12 & $-2.0 \%$ \\
\hline Gulf Coast $\ldots \ldots \ldots \ldots \ldots \ldots \ldots \ldots$ & 1.03 & 0.60 & 0.64 & 0.71 & $-1.8 \%$ \\
\hline Midcontinent $\ldots \ldots \ldots \ldots \ldots \ldots \ldots \ldots \ldots$ & 0.54 & 0.37 & 0.35 & 0.34 & $-2.4 \%$ \\
\hline Southwest $\ldots \ldots \ldots \ldots \ldots \ldots \ldots \ldots \ldots$ & 1.44 & 1.22 & 1.11 & 1.02 & $-1.7 \%$ \\
\hline Rocky Mountain $\ldots \ldots \ldots \ldots \ldots \ldots$ & 0.63 & 0.59 & 0.60 & 0.62 & $0.0 \%$ \\
\hline West Coast $\ldots \ldots \ldots \ldots \ldots \ldots \ldots \ldots \ldots$ & 0.81 & 0.74 & 0.78 & 0.82 & $0.1 \%$ \\
\hline \multicolumn{6}{|l|}{ Lower 48 Olfshore } \\
\hline 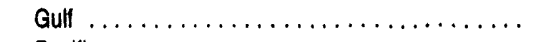 & 0.81 & 0.50 & 0.46 & 0.51 & $-2.3 \%$ \\
\hline Pacific $\ldots \ldots \ldots \ldots \ldots \ldots \ldots \ldots \ldots \ldots \ldots \ldots \ldots \ldots \ldots \ldots \ldots$ & 0.15 & 0.18 & 0.19 & 0.21 & $1.8 \%$ \\
\hline Atlantic $\ldots \ldots \ldots \ldots \ldots \ldots \ldots \ldots \ldots$ & 0.00 & 0.00 & 0.00 & 0.00 & N/A \\
\hline \multicolumn{6}{|l|}{ Wellhead Prices (1892 dollars per barrel) } \\
\hline Lower 48 Average $\ldots \ldots \ldots \ldots \ldots \ldots \ldots$ & 23.02 & 20.19 & 23.99 & 26.98 & $0.8 \%$ \\
\hline \multicolumn{6}{|l|}{ Lower 48 Onshore } \\
\hline$\ldots \ldots \ldots \ldots \ldots \ldots$ & 24.67 & 21.03 & 24.97 & 27.99 & $0.6 \%$ \\
\hline Gult Coast $\ldots \ldots \ldots \ldots \ldots \ldots \ldots \ldots$ & 24.00 & 21.21 & 25.18 & 28.23 & $0.8 \%$ \\
\hline Midcontinent $\ldots \ldots \ldots \ldots \ldots \ldots \ldots \ldots$ & 24.42 & 20.85 & 24.83 & 27.88 & $0.7 \%$ \\
\hline Southwest $\ldots \ldots \ldots \ldots \ldots \ldots \ldots \ldots$ & 23.89 & 20.78 & 24.71 & 27.73 & $0.7 \%$ \\
\hline Rocky Mountain $\ldots \ldots \ldots \ldots \ldots \ldots$ & 23.21 & 19.74 & 23.58 & 26.54 & $0.7 \%$ \\
\hline West Coast $\ldots \ldots \ldots \ldots \ldots \ldots \ldots \ldots \ldots$ & 19.01 & 16.42 & 19.51 & 21.88 & $0.7 \%$ \\
\hline \multicolumn{6}{|l|}{ Lower 48 Otfshore } \\
\hline Gulf $\ldots \ldots \ldots \ldots$ & 23.96 & 22.02 & 25.98 & 29.00 & $1.0 \%$ \\
\hline 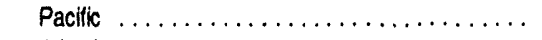 & 18.05 & 15.06 & 18.11 & 20.47 & $0.6 \%$ \\
\hline 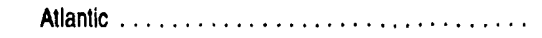 & 0.00 & 0.00 & 0.00 & 0.00 & N/A \\
\hline
\end{tabular}

'includes lease condensate.

N/A $=$ Not applicable.

Notes: Supply regions are defined in the Appendix. Totals may not equal sum of components due to independent rounding.

Sources: 1990 lower 48 total, Gulf, Pacific, Atlantic production: Energy Information Administration (ElA), Petroleum Supply Annual 1980, DOE/EIA-0340(90)/1 (Washington, D.C., May 1991). 1990 lower 48 average wellhead price: ElA, Annual Energy Review 1982, DOEJEIA-0384(82) (Washington, D.C., June 1993); Other 1990: ElA, Office of Integrated Analysis and Forecasting. Figures for 1990 data may differ from published dala due to internal conversion factors within the AEO 1994 Forecasting System. Projectlons: EIA, AEO 1994 National Energy Modeling System run AEO94B.D1221834. 
Table 56. Lower 48 Natural Gas Production and Wellhead Prices by Supply Reglon

\begin{tabular}{|c|c|c|c|c|c|}
\hline \multirow{2}{*}{ Reglon } & \multicolumn{4}{|c|}{ Reterence Case } & \multirow{2}{*}{$\begin{array}{l}\text { Amud } \\
\text { Crowtin } \\
\text { 19e0-2010 } \\
\text { (percent) }\end{array}$} \\
\hline & 1000 & 2000 & 2005 & 2010 & \\
\hline \multicolumn{6}{|l|}{ Production (trililion cuble fent) } \\
\hline Lower 49 Total . . . . . . . . . . . . . . . . & 17.43 & 18.43 & 19.64 & 19.72 & $0.6 \%$ \\
\hline \multicolumn{6}{|l|}{ Lower 48 Onhhore } \\
\hline Northeast $\ldots \ldots \ldots \ldots \ldots \ldots \ldots \ldots$ & 0.78 & 1.19 & 1.21 & 1.18 & $2.1 \%$ \\
\hline Gutt Coast $\ldots \ldots \ldots \ldots \ldots \ldots \ldots \ldots$ & 4.38 & 5.40 & 5.49 & 5.64 & $1.3 \%$ \\
\hline Mldcontinent $\ldots \ldots \ldots \ldots \ldots \ldots \ldots$ & 3.38 & 3.20 & 3.04 & 2.83 & $.0 .9 \%$ \\
\hline Southwest $\ldots \ldots \ldots \ldots \ldots \ldots \ldots \ldots$ & 1.64 & 1.72 & 1.63 & 1.53 & $-0.4 \%$ \\
\hline Rocky Mountain $\ldots \ldots \ldots \ldots \ldots \ldots \ldots$ & 1.66 & 3.11 & 3.18 & 3.11 & $3.2 \%$ \\
\hline West Coast $\ldots \ldots \ldots \ldots \ldots \ldots \ldots \ldots$ & 0.30 & 0.24 & 0.27 & 0.27 & $-0.5 \%$ \\
\hline \multicolumn{6}{|l|}{ Lowk 48 Olishore } \\
\hline$\ldots \ldots \ldots \ldots \ldots \ldots$ & 5.23 & 3.51 & 4.76 & 5.09 & $-0.1 \%$ \\
\hline 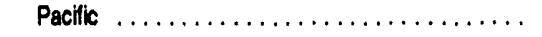 & 0.05 & 0.06 & 0.06 & 0.07 & $1.6 \%$ \\
\hline Allantic $\ldots \ldots \ldots \ldots \ldots \ldots \ldots \ldots$ & 0.00 & 0.00 & 0.00 & 0.00 & N/A \\
\hline \multicolumn{6}{|l|}{$\begin{array}{l}\text { Welliead Prices } \\
\text { (1002 dollars per thousand cuble ted) }\end{array}$} \\
\hline Lower 48 Averags $\ldots \ldots \ldots \ldots \ldots \ldots \ldots$ & 1.86 & 2.42 & 2.80 & 3.47 & $3.2 \%$ \\
\hline \multicolumn{6}{|l|}{ Lower 48 Onshore } \\
\hline East Coast $\ldots \ldots \ldots \ldots \ldots \ldots \ldots \ldots$ & 2.86 & 2.86 & 3.48 & 4.21 & $1.9 \%$ \\
\hline Guff Coast $\ldots \ldots \ldots \ldots \ldots \ldots \ldots \ldots$ & 1.78 & 2.43 & 2.85 & 3.42 & $3.3 \%$ \\
\hline Midcontinent $\ldots \ldots \ldots \ldots \ldots \ldots \ldots \ldots$ & 1.70 & 2.47 & 2.89 & 3.47 & $3.6 \%$ \\
\hline Southwost $\ldots \ldots \ldots \ldots \ldots \ldots \ldots \ldots$ & 1.70 & 2.38 & 2.84 & 3.41 & $3.5 \%$ \\
\hline Rocky Mountain $\ldots \ldots \ldots \ldots \ldots \ldots$ & 1.53 & 2.22 & 2.86 & 3.43 & $4.1 \%$ \\
\hline West Coast $\ldots \ldots \ldots \ldots \ldots \ldots \ldots \ldots$ & 2.43 & 2.49 & 3.20 & 3.86 & $2.3 \%$ \\
\hline \multicolumn{6}{|l|}{ Lower 48 Otichore } \\
\hline GuH $\ldots \ldots \ldots \ldots \ldots \ldots \ldots \ldots$ & 1.97 & 2.40 & 2.81 & 3.38 & $2.7 \%$ \\
\hline Pacific $\ldots \ldots \ldots \ldots \ldots \ldots \ldots \ldots$ & 2.97 & 2.49 & 3.20 & 3.86 & $1.3 \%$ \\
\hline Atlantic $\ldots \ldots \ldots \ldots \ldots \ldots \ldots \ldots \ldots$ & 0.00 & 0.00 & 0.00 & 0.00 & N/A \\
\hline
\end{tabular}

'Dry marketed production minus nonhydrocarbon gas removed.

N/A = Not applicable.

Notes: Supply regions afe defined in the Appendix. Totals may not equal the sum of the components due to independent rounding.

Sources: 1800 lower 48 total production: Energy Intormation Administration (ElA), Natural Gas Annual 1891, DOE/EIA-0131 (81) (Washington, D.C., October 1992). 1990 Gult, Pacific, Atlantic lower 48 oftshore production: ElA, U.S. Crude Oil, Natural Gas, and Natural Gas Liquids Reserves, DOE/EIA-0216(90) (Washington, D.C., September 1991). 1900 lower 48 average wellhead price: ElA, Annual Energy Review 1982, DOEJEIA-0384(02) (Washington, D.C., June 1993). Other 1090: ElA, Office of Integrated Analysis and Forecasting. Figures for 1990 may differ from published data due to internal conversion factors within the AEO 1994 Forecasting System. Projections: ElA, AEO 1994 National Energy Modeling System run AEO94B.D1221934. 


\begin{tabular}{|c|c|c|c|c|c|}
\hline \multirow{2}{*}{ Calcogribe } & \multicolumn{4}{|c|}{ Adienencos Caso } & \multirow{2}{*}{ 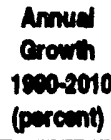 } \\
\hline & 1000 & 2000 & 2000 & 2010 & \\
\hline \multicolumn{6}{|l|}{$\begin{array}{l}\text { Crude Ol' } \\
\text { Recerven (billion barreb) }\end{array}$} \\
\hline U.S. Total & 27.56 & 18.84 & 17.46 & 18.31 & $-2.0 \%$ \\
\hline Lower 48 Onshore. & 17.33 & 11.75 & 11.46 & 11.50 & $-2.0 \%$ \\
\hline Conventional .... & 14.24 & 9.22 & 8.32 & 7.80 & $-3.0 \%$ \\
\hline Enhanced Oil Recovery. & 3.08 & 2.53 & 3.14 & 3.70 & $0.9 \%$ \\
\hline Lower 48 Nitshore ...... & 3.70 & 2.28 & 2.09 & 2.11 & $-2.8 \%$ \\
\hline Alaska $\ldots \ldots \ldots \ldots \ldots$ & 6.52 & 4.80 & 3.91 & 4.71 & $-1.6 \%$ \\
\hline \multicolumn{6}{|l|}{$\begin{array}{l}\text { Dry Matural Gese } \\
\text { Romenves (trillion able tea) }\end{array}$} \\
\hline U.S. Total ...... & 169.3 & 164.8 & 156.7 & 152.4 & $.0 .5 \%$ \\
\hline Lower 48 Onshore. & 127.0 & 122.8 & 115.9 & 113.8 & $.0 .5 \%$ \\
\hline Associated-Dissolved ${ }^{2}$ & 17.3 & 13.3 & 13.2 & 13.5 & $-1.3 \%$ \\
\hline Non-Associated ...... & 109.7 & 109.5 & 102.7 & 100.3 & $.0 .4 \%$ \\
\hline Conventional & 89.0 & 76.4 & 70.6 & 68.8 & $-1.3 \%$ \\
\hline Unconventional .......................... & 20.6 & 33.2 & 32.1 & 31.5 & $2.1 \%$ \\
\hline Tight Sands $\ldots \ldots \ldots \ldots \ldots \ldots \ldots \ldots$ & 13.5 & 19.1 & 19.0 & 19.2 & $1.8 \%$ \\
\hline Coal Bed Methane $\ldots \ldots \ldots \ldots \ldots \ldots \ldots$ & 5.1 & 10.8 & 10.1 & 9.4 & $3.1 \%$ \\
\hline Devonian Shale & 2.0 & 3.2 & 3.0 & 2.8 & $1.6 \%$ \\
\hline Lower 48 Ottshore. . & 33.1 & 31.8 & 30.2 & 27.3 & $.0 .9 \%$ \\
\hline Associated-Dissolvede & 7.1 & 5.6 & 5.5 & 5.7 & $.1 .1 \%$ \\
\hline Non-Assrxiated $\ldots \ldots \ldots \ldots \ldots \ldots \ldots \ldots \ldots$ & 26.0 & 26.2 & 24.7 & 21.6 & $.0 .9 \%$ \\
\hline Alaska & 9.3 & 10.3 & 10.6 & 11.3 & $1.0 \%$ \\
\hline
\end{tabular}

'Includes lease condensate.

${ }^{2}$ Gas which occurs in crude oll reservoirs either as free gas (associated) or as a se in solution with crude oil (dissolved).

Note: Totals may not equal sums due to independent rounding.

Sources: 1990 conventional, enhanced oil recovery crude oil, unconventional, tight sands, coal bed methane,devonian shale natural gas reserves: Energy Information Administration (EIA), Ottice of Integrated Analysis and Forecasting. Oner 1900: ElA, U.S. Crude Oll, Natural Gas and Natural Gas Liquids Reserves, DOEJElA-0216(00) (Washington, D.C., September 1991). Figures for 1990 may differ from published data due to internal conversion factors within the AEO 1094 Forecasting System. Projections: ElA, AEO 1994 National Energy Modeling System pun AEOQ4B.D1221934. 
Table 58. Natural Gas Imports and Exports

\begin{tabular}{|c|c|c|c|c|c|}
\hline \multirow{2}{*}{ Volumes and Prices } & \multicolumn{4}{|c|}{ Reterences Cases } & \multirow{2}{*}{$\begin{array}{l}\text { Annud } \\
\text { Cromth } \\
\text { 1exo-2010 } \\
\text { (percent) }\end{array}$} \\
\hline & 1000 & 2000 & 2005 & 2010 & \\
\hline \multicolumn{6}{|l|}{ Volumes (trillion cuble inet) } \\
\hline $\begin{array}{l}\text { Total Net Imports } \ldots \ldots \ldots \ldots \ldots \ldots \ldots \ldots \ldots \ldots \\
\text { Pipeline }\end{array}$ & 1.45 & 2.93 & 3.31 & 3.85 & $5.0 \%$ \\
\hline Imports trom Canada $\ldots \ldots \ldots \ldots \ldots \ldots$ & 1.45 & 2.81 & 2.96 & 3.16 & $4.0 \%$ \\
\hline Exports to Canada $\ldots \ldots \ldots \ldots \ldots \ldots \ldots$ & 0.02 & 0.14 & 0.20 & 0.24 & $14.0 \%$ \\
\hline Imports from Mexico ................. & 0.00 & 0.00 & 0.01 & 0.18 & N/A \\
\hline $\begin{array}{l}\text { Exports to Mexico ..................... } \\
\text { Liquefied Natural Gas }\end{array}$ & 0.02 & 0.05 & 0.01 & 0.01 & $-2.3 \%$ \\
\hline imports $\ldots \ldots \ldots \ldots \ldots \ldots \ldots \ldots$ & 0.08 & 0.36 & 0.60 & 0.80 & $11.9 \%$ \\
\hline Exports $\ldots \ldots \ldots \ldots \ldots \ldots \ldots \ldots$ & 0.05 & 0.05 & 0.05 & 0.05 & $-0.2 \%$ \\
\hline \multicolumn{6}{|l|}{$\begin{array}{l}\text { Border Prices } \\
\text { (1982 dollars per thouseand cuble bel) }\end{array}$} \\
\hline $\begin{array}{l}\text { Average Import Price } \ldots \ldots \ldots \ldots \ldots \ldots \ldots \ldots \ldots \\
\text { Pipeline Import Prices }\end{array}$ & 2.06 & 2.42 & 3.03 & 3.69 & $2.9 \%$ \\
\hline From Canada $\ldots \ldots \ldots \ldots \ldots \ldots \ldots \ldots$ & 2.03 & 2.38 & 2.96 & 3.57 & $2.9 \%$ \\
\hline From Mexico $\ldots \ldots \ldots \ldots \ldots \ldots \ldots$ & 0.00 & 0.00 & 0.00 & 0.00 & N/A \\
\hline LNG Price (including regasification) . . . . . . . . . & 2.63 & 2.74 & 3.40 & 4.16 & $2.3 \%$ \\
\hline
\end{tabular}

N/A = Not applicable.

Note: Totals may not equal sum of components due to independent rounding.

Sources: 1990 import and export volumes: Energy Information Administration (ElA), "U.S. Natural Gas Imports and Exports--1981", Natural Gas Monthly - August 1992, DOE/EIA-0130(92/OB) (Washington, D.C., September 1992). 1990 pipeline import price from Canada and 1990 LNG price: EIA, Natural Gas Annual 1891, DOE/ElA-0131(91) Washington, D.C.. October 1992). Other 1990: ElA, Office of Integraled Analysis and Forecasting. Figures for 1900 may differ trom the published data due to internal conversion factors within the AEO 1994 Forecasting System. Projectione: ElA, AEO 1994 National Engigy Modeling System run AEO94B.01221934. 
Table 59. Domestic Coal Supply, Disposition, and Prices New England Census Division

\begin{tabular}{|c|c|c|c|c|c|}
\hline \multirow{2}{*}{$\begin{array}{l}\text { Supply, Consumption, } \\
\text { and Prices }\end{array}$} & \multicolumn{4}{|c|}{ Rderence Case } & \multirow{2}{*}{$\begin{array}{l}\text { Annual } \\
\text { Growth } \\
1890-2010 \\
\text { (percent) }\end{array}$} \\
\hline & 1980 & 2000 & 2005 & 2010 & \\
\hline \multicolumn{6}{|l|}{ Sources of Supply (million short tons) } \\
\hline \multicolumn{6}{|l|}{ Distribution From } \\
\hline Northern Appalachia . & 3.2 & 3.7 & 5.8 & 6.0 & $3.2 \%$ \\
\hline Southern Appalachia $\ldots \ldots \ldots \ldots \ldots \ldots$ & 2.3 & 2.8 & 0.5 & 0.6 & $-6.6 \%$ \\
\hline 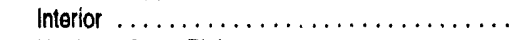 & 0.0 & 0.0 & 0.0 & 0.0 & N/A \\
\hline Northem Great Plains $\ldots \ldots \ldots \ldots \ldots \ldots$ & 0.0 & 0.0 & 0.0 & 0.0 & N/A \\
\hline Other West $\ldots \ldots \ldots \ldots \ldots \ldots \ldots \ldots$ & 0.0 & 0.0 & 0.0 & 0.0 & N/A \\
\hline Non-Contiguous $\ldots \ldots \ldots \ldots \ldots \ldots \ldots$ & 0.0 & 0.0 & 0.0 & 0.0 & N/A \\
\hline $\begin{array}{l}\text { Total Distrbution } \\
\text { (excludes exports)' } \ldots \ldots \ldots \ldots \ldots \ldots \ldots\end{array}$ & 5.6 & 6.5 & 6.3 & 6.6 & $0.8 \%$ \\
\hline Imports $\ldots \ldots \ldots \ldots \ldots \ldots \ldots \ldots \ldots \ldots \ldots$ & 0.3 & 0.5 & 0.5 & 0.5 & $2.1 \%$ \\
\hline Total Supply $\ldots \ldots \ldots \ldots \ldots \ldots \ldots \ldots$ & 5.8 & 7.0 & 6.8 & 7.0 & $1.0 \%$ \\
\hline \multicolumn{6}{|l|}{ Consumption (million short tons) } \\
\hline ResidentiaVCommercial . . . . . . . . . . . . . & 0.1 & 0.1 & 0.1 & 0.1 & $0.5 \%$ \\
\hline Industrial $\ldots \ldots \ldots \ldots \ldots \ldots \ldots \ldots$ & 0.3 & 0.4 & 0.5 & 0.6 & $3.7 \%$ \\
\hline Coke Plants $\ldots \ldots \ldots \ldots \ldots \ldots \ldots \ldots$ & 0.0 & 0.0 & 0.0 & 0.0 & N/A \\
\hline Electricity $\ldots \ldots \ldots \ldots \ldots \ldots \ldots \ldots$ & 6.3 & 6.4 & 6.1 & 6.3 & $0.0 \%$ \\
\hline Total Consumption $\ldots \ldots \ldots \ldots \ldots \ldots \ldots$ & 6.8 & 7.0 & 6.8 & 7.0 & $0.2 \%$ \\
\hline Discrepancy ${ }^{2} \ldots \ldots \ldots \ldots \ldots \ldots \ldots$ & -0.9 & 0.0 & 0.0 & 0.0 & NA \\
\hline \multicolumn{6}{|l|}{$\begin{array}{l}\text { Dellwered Prices } \\
\text { (1992 dollars per short ton) }\end{array}$} \\
\hline Industrial $\ldots \ldots \ldots \ldots \ldots \ldots \ldots \ldots \ldots$ & 69.94 & 73.90 & 74.15 & 73.54 & $0.3 \%$ \\
\hline Coke Plants $\ldots \ldots \ldots \ldots \ldots \ldots \ldots$ & 0.00 & 0.00 & 0.00 & 0.00 & $N / A$ \\
\hline Electricity $\ldots \ldots \ldots \ldots \ldots \ldots \ldots \ldots \ldots$ & 50.56 & 51.81 & 55.90 & 53.23 & $0.3 \%$ \\
\hline Average Pricos $\ldots \ldots \ldots \ldots \ldots \ldots \ldots$ & 51.51 & 53.18 & 57.26 & 55.04 & $0.3 \%$ \\
\hline
\end{tabular}

'Excludes distribution to unknown destinations from unknown origins.

'Includes stock changes.

Weighted average. Excludes residential/commercial prices.

N/A = Not applicable.

Note: Total may not equal sum of components due to independent rounding.

Source: 1990 distribution: Energy Inlormation Administration (EIA), Coal Distribution January-December 1990, DOE/ElA-0125(80/4Q) (Washington, D.C., April 1991). 1990 imports: U.S. Bureau of the Census, Form IM-145. 1990 consumer stock withdrawals: ElA, Quarterly Coal Report, October-December 1991, DOE/EIA-0121(91/4Q) (Washington, D.C., May 1992) and EIA, Quarterly Coal Report, October-December 1990, DOE/EIA-0121(90/4Q) (Washington, D.C., May 1991), 1990 consumption: residential/commercial, electricity, total industrial, and total consumption: ElA, State Energy Data Report, Consumption Estimates 1960-1990, DOE/EIA-0214(90) (Washington, D.C., May 1992). Other 1990 industrial and coke plant consumption estimated from sectoral coal distribution: Quarterly Coal Report, October-December 1980, DOE/ElA-0121(90/4Q) (Washington, D.C. May 1991). 1990 delivered prices: Quarterly Coal Report, October-December 1990, DOEJEIA-0121(90/4Q) (Washington, D.C., May 1991). Projectlons: EIA, AEO 1994 National Energy Modeling System run AEO94B.D1221934. 
Table 60. Domestic Coal Supply, Disposition, and Prices Middie Atlantic Census Division

\begin{tabular}{|c|c|c|c|c|c|}
\hline \multirow{2}{*}{$\begin{array}{l}\text { Supply, Consumption, } \\
\text { and Pricese }\end{array}$} & \multicolumn{4}{|c|}{ Relerence Case } & \multirow{2}{*}{$\begin{array}{l}\text { Annual } \\
\text { Growth } \\
1900-2010 \\
\text { (parcent) }\end{array}$} \\
\hline & 1000 & 2000 & 2005 & 2010 & \\
\hline \multicolumn{6}{|l|}{ Sourcese of Supply (million short tons) } \\
\hline \multicolumn{6}{|l|}{ Distbution From } \\
\hline Northern Appalachia & 66.5 & 61.8 & 55.9 & 72.2 & $0.4 \%$ \\
\hline Southem Appalachia ................. & 11.0 & 5.2 & 9.7 & 1.8 & $.8 .8 \%$ \\
\hline Interior ............ & 0.0 & 0.0 & 0.0 & 0.0 & N/A \\
\hline Northern Great Plains . & 0.0 & 0.3 & 0.4 & 1.5 & N/A \\
\hline Oher West $\ldots \ldots \ldots \ldots \ldots \ldots \ldots \ldots \ldots$ & 0.0 & 0.0 & 0.0 & 0.0 & N/A \\
\hline Non-Contiguous $\ldots \ldots \ldots \ldots \ldots \ldots$ & 0.0 & 0.0 & 0.0 & 0.0 & N/A \\
\hline $\begin{array}{l}\text { Total Distrbution } \\
\text { (oxctudse exports) } \\
1 \ldots \ldots \ldots \ldots \ldots \ldots\end{array}$ & 77.4 & 67.3 & 66.0 & 75.4 & $-0.1 \%$ \\
\hline imports $\ldots \ldots \ldots \ldots \ldots \ldots \ldots \ldots \ldots \ldots \ldots$ & 0.1 & 0.1 & 0.1 & 0.1 & $-0.1 \%$ \\
\hline Total Supply ...... & 77.5 & 67.4 & 66.1 & 75.5 & $-0.1 \%$ \\
\hline \multicolumn{6}{|l|}{ Consumption (mililon short tons) } \\
\hline Residentialcommercial & 1.6 & 1.4 & 1.3 & 1.3 & $.1 .1 \%$ \\
\hline Industrial ............ & 18.0 & 6.3 & 7.3 & 7.9 & $.4 .0 \%$ \\
\hline Coke Plants & 0.0 & 8.7 & 7.6 & 6.6 & N/A \\
\hline Electricity $\ldots \ldots \ldots \ldots \ldots \ldots \ldots \ldots \ldots$ & 54.2 & 51.1 & 49.9 & 59.8 & $0.5 \%$ \\
\hline Total Conaumption ........... & 73.8 & 67.4 & 66.1 & 75.5 & $0.1 \%$ \\
\hline Discrepener ${ }^{2} \ldots \ldots \ldots \ldots \ldots \ldots \ldots \ldots$ & 3.7 & 0.0 & -0.1 & 0.0 & NA \\
\hline \multicolumn{6}{|l|}{$\begin{array}{l}\text { Dellwered Pricese } \\
\text { (1902 dollars per short ton) }\end{array}$} \\
\hline Industrial ... & 46.40 & 41.15 & 42.51 & 43.59 & $.0 .3 \%$ \\
\hline Coke Plants & 0.00 & 54.84 & 58.25 & 56.80 & N/A \\
\hline Electricity .. & 41.15 & 42.28 & 44.99 & 43.68 & $0.3 \%$ \\
\hline Averags Pricos'............ & 42.46 & 43.82 & 46.25 & 44.83 & $0.3 \%$ \\
\hline
\end{tabular}

'Excludes distribution to unknown destinations from unknown origins.

includes stock changes.

Weighted average. Excludes residential/commercial prices.

N/A $=$ Not applicable.

Note: Total may not equal sum of components due to independent rounding.

Source: 1990 distribution: Energy Intormation Administration (EIA), Coal Distribution January-December 1990, DOE/EIA-0125(90/4Q)

(Washington, D.C., April 1991). 1990 imports: U.S. Bureau of the Census, Form IM-145. 1990 consumer stock withdrawals: EIA, Quarterly Coal Report, October-December 1991, DOE/EIA-0121(91/4Q) (Washington, D.C., May 1982) and ElA, Quarterly Coal Report, October-December 1990, DOE/EIA-0121(90/4Q) (Washington, D.C., May 1891). 1990 consumption: residential/commercial, electricity, total industrial, and total consumption: EIA, State Energy Data Report, Consumption Estimates 1960-1990, DOE/EIA-0214(90) (Washington, D.C., May 1992). Other 1900 industrial and coke plant consumption estimated from sectoral coal distribution: Quarterly Coal Report, October-December 1990, DOEJEIA-0121(90/4Q) (Washington, D.C., May 1991). 1990 delivered prices: Quarterly Coal Report, October-December 1980, DOE/EIA-0121(80/4Q) (Washington, D.C. May 1991). Projectlons: EIA, AEO 1994 National Energy Modeling System run AEO94B.D1221934. 
Table 61. Domestic Coal Supply, Disposition, and Prices East North Contral Census Division

\begin{tabular}{|c|c|c|c|c|c|}
\hline \multirow{2}{*}{$\begin{array}{l}\text { Supply, Consumption, } \\
\text { and Prlace }\end{array}$} & \multicolumn{4}{|c|}{ Referencos Casos } & \multirow{2}{*}{$\begin{array}{c}\text { Annual } \\
\text { Growth } \\
1 \text { ceo-2010 } \\
\text { (percent) }\end{array}$} \\
\hline & 1900 & 2000 & 2005 & 2010 & \\
\hline \multicolumn{6}{|l|}{ Sources of Supply (million short tone) } \\
\hline \multicolumn{6}{|l|}{ Diatribution From } \\
\hline Northerm Appalachia & 44.2 & 66.6 & 71.3 & 74.9 & $2.7 \%$ \\
\hline Southem Appalachia & 57.2 & 70.0 & 68.2 & 77.6 & $1.5 \%$ \\
\hline Interior $\ldots \ldots \ldots \ldots$ & 66.2 & 38.1 & 33.0 & 25.4 & $.4 .7 \%$ \\
\hline Northern Great Plains . & 45.7 & 51.6 & 52.8 & 56.2 & $1.0 \%$ \\
\hline Other West $\ldots \ldots \ldots \ldots \ldots \ldots \ldots \ldots \ldots$ & 0.9 & 0.0 & 1.3 & 0.0 & N/A \\
\hline Non-Contiguous $\ldots \ldots \ldots \ldots \ldots \ldots \ldots$ & 0.0 & 0.0 & 0.0 & 0.0 & N/A \\
\hline $\begin{array}{l}\text { Total Digtrbution } \\
\text { (exchiss exports) }{ }^{\prime} \ldots \ldots \ldots \ldots \ldots \ldots \ldots\end{array}$ & 214.2 & 226.3 & 226.7 & 234.1 & $0.4 \%$ \\
\hline imports $\ldots \ldots \ldots \ldots \ldots \ldots \ldots \ldots \ldots \ldots$ & 0.3 & 0.0 & 0.8 & 0.8 & $5.0 \%$ \\
\hline Total Supply $\ldots \ldots \ldots \ldots \ldots \ldots \ldots \ldots$ & 214.5 & 227.2 & 227.6 & 235.0 & $0.5 \%$ \\
\hline \multicolumn{6}{|l|}{ Consumption (million short tons) } \\
\hline ResidentiavCommercial. & 1.7 & 1.5 & 1.4 & 1.4 & $-0.9 \%$ \\
\hline Industrial ......................... & 36.1 & 20.9 & 22.8 & 23.7 & $-2.1 \%$ \\
\hline Coke Plants $\ldots \ldots \ldots \ldots \ldots \ldots \ldots \ldots \ldots \ldots$ & 0.0 & 11.8 & 10.4 & 9.2 & N/A \\
\hline 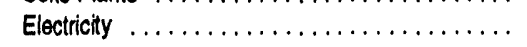 & 171.8 & 193.1 & 192.8 & 199.1 & $0.7 \%$ \\
\hline Total Consumption ................. & 209.6 & 227.3 & 227.5 & 233.4 & $0.5 \%$ \\
\hline Dlecrepenery ${ }^{2} \ldots \ldots \ldots \ldots \ldots \ldots \ldots \ldots$ & 4.8 & -0.1 & 0.1 & 1.6 & $5.3 \%$ \\
\hline \multicolumn{6}{|l|}{$\begin{array}{l}\text { Dellwered Prices } \\
\text { (1902 dollars per short ton) }\end{array}$} \\
\hline Industrial. & 45.13 & 38.50 & 40.81 & 41.09 & $-0.5 \%$ \\
\hline Coke Plants & 0.00 & 58.44 & 63.77 & 61.99 & N/A \\
\hline 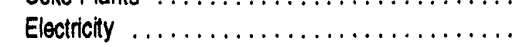 & 35.40 & 34.95 & 37.22 & 41.15 & $0.8 \%$ \\
\hline Average Pricos ... & 37.09 & 36.51 & 38.80 & 41.97 & $0.6 \%$ \\
\hline
\end{tabular}

'Excludes distribution to unknown destinations from unknown origins.

${ }^{2}$ Includes stock changes.

Weighted average. Excludes residential/commercial prices.

$N / A=$ Not applicable.

Note: Total may not equal sum of components due to independent rounding.

Source: 1890 distribution: Energy Information Administration (EIA), Coal Distribution January-December 1990, DOE/EIA-0125(80/4Q) Washington, D.C., April 1991). 1990 imports: U.S. Bureau of the Census, Form IM-145. 1900 consumer stock withdrawals: ElA, Quarterly Coal Report, October-December 1991, DOE/EIA-0121(91/4Q) (Washington, D.C., May 1992) and EIA, Quarterly Coal Report, October-December 1990, DOE/EIA-0121(90/4Q) (Washington, D.C., May 1991). 1990 consumption: residential/commercial, electricity, total industrial, and total consumption: ElA, State Energy Data Report, Consumption Estimates 1960-1990, DOE/EIA-0214(90) (Washington, D.C., May 1992). Other 1990 industrial and coke plant consumption estimated from sectoral coal distribution: Quarterly Coal Report, October-December 1090, DOEJEIA-0121(90/4Q) (Washington, D.C., May 1991). 1990 delivered prices: Quarterly Coal Report, October-December 1800, DOEIEIA-0121(90/4Q) (Washington, D.C., May 1901). Projectlons: EIA, AEO 1994 National Energy Modeling System run AEO94B.D1221934. 
Table 62. Domestic Coal Supply, Disposition, and Prices West North Central Census Division

\begin{tabular}{|c|c|c|c|c|c|}
\hline \multirow{2}{*}{$\begin{array}{l}\text { Supply, Consumption, } \\
\text { and Prices }\end{array}$} & \multicolumn{4}{|c|}{ Relerence Case } & \multirow{2}{*}{$\begin{array}{l}\text { Annual } \\
\text { Growth } \\
1000-2010 \\
\text { (percent) }\end{array}$} \\
\hline & 1900 & 2000 & 2005 & 2010 & \\
\hline \multicolumn{6}{|l|}{ Sources of Supply (million short tons) } \\
\hline \multicolumn{6}{|l|}{ Distrbution From } \\
\hline Northern Appalachia & 0.1 & 0.0 & 0.0 & 0.0 & N/A \\
\hline Southern Appalachia $\ldots \ldots \ldots \ldots \ldots \ldots \ldots$ & 0.9 & 2.6 & 4.2 & 4.2 & $8.0 \%$ \\
\hline Interior $\ldots \ldots \ldots \ldots \ldots \ldots \ldots \ldots \ldots \ldots$ & 24.2 & 26.8 & 21.2 & 21.6 & $.0 .6 \%$ \\
\hline Northern Great Plains ... & 91.3 & 100.7 & 111.0 & 125.4 & $1.6 \%$ \\
\hline Other West $\ldots \ldots \ldots \ldots \ldots \ldots \ldots \ldots$ & 0.7 & 0.3 & 2.6 & 0.8 & $0.8 \%$ \\
\hline Non-Contiguous $\ldots \ldots \ldots \ldots \ldots \ldots \ldots$ & 0.0 & 0.0 & 0.0 & 0.0 & $N / A$ \\
\hline $\begin{array}{l}\text { Total Distribution } \\
\text { (excludes oxports) })^{1} . .\end{array}$ & 117.3 & 130.4 & 139.1 & 152.0 & $1.3 \%$ \\
\hline imports $\ldots \ldots \ldots \ldots \ldots \ldots \ldots \ldots \ldots \ldots \ldots$ & 0.6 & 0.0 & 0.0 & 0.0 & NA \\
\hline Total Supply $\ldots \ldots \ldots \ldots \ldots \ldots \ldots \ldots$ & 117.8 & 130.4 & 139.1 & 152.0 & $1.3 \%$ \\
\hline \multicolumn{6}{|l|}{ Consumption (million short tons) } \\
\hline ResidentiaVCommercial .. & 0.9 & 0.9 & 0.8 & 0.6 & $.1 .8 \%$ \\
\hline Industrial ............ & 12.0 & 14.7 & 15.9 & 16.7 & $1.7 \%$ \\
\hline Coke Plants $\ldots \ldots \ldots \ldots \ldots \ldots \ldots \ldots$ & 0.0 & 0.0 & 0.0 & 0.0 & N/A \\
\hline Electricity $\ldots \ldots \ldots \ldots \ldots \ldots \ldots \ldots \ldots \ldots$ & 103.4 & 114.9 & 122.3 & 134.7 & $1.3 \%$ \\
\hline Total Consumption .................... & 116.3 & 130.6 & 139.1 & 152.0 & $1.3 \%$ \\
\hline Discrepancy ${ }^{2}$ & 1.5 & -0.2 & 0.0 & .0 .1 & NA \\
\hline \multicolumn{6}{|l|}{$\begin{array}{l}\text { Delivered Prices } \\
\text { (1902 dollars per short ton) }\end{array}$} \\
\hline Industrial ....... & 37.54 & 20.79 & 22.38 & 30.81 & $-1.0 \%$ \\
\hline Coke Plants & 0.00 & 0.00 & 0.00 & 0.00 & N/A \\
\hline Electricity $\ldots \ldots \ldots \ldots \ldots \ldots \ldots \ldots \ldots$ & 20.98 & 23.25 & 25.03 & 34.70 & $2.5 \%$ \\
\hline Average Prices. & 22.70 & 22.86 & 24.73 & 34.27 & $2.1 \%$ \\
\hline
\end{tabular}

'Excludes distribution to unknown destinations from unknown origins.

${ }^{2}$ Includes stock changes.

'Weighted average. Excludes residential/commercial prices.

N/A $=$ Not applicable.

Note: Total may not equal sum of components due to independent rounding.

Source: 1990 distribution: Energy Information Administration (EIA), Coal Distribution January-December 1990, DOE/EIA-0125(90/4Q) (Washington, D.C., April 1991). 1990 imports: U.S. Bureau of the Census, Form IM-145. 1990 consumer stock withdrawals: ElA, Quarterly Coal Report, October-December 1991, DOE/EIA-0121(91/4Q) (Washington, D.C., May 1982) and EIA, Quarterly Coal Report, October-December 1990, DOE/EIA-0121(90/4Q) (Washington, D.C., May 1991). 1990 consumption: residential/commercial, electricity, total industrial, and total consumption: EIA, State Energy Data Report, Consumption Estimates 1960-1990, DOE/EIA-0214(90) (Washington, D.C., May 1982). Other 1990 industrial and coke plant consumption estimated from sectoral coal distribution: Quarterly Coal Report, October-Decembar 1990, DOE/EIA-0121(90/4Q) (Washington, D.C., May 1991). 1990 delivered prices: Quarterly Coal Report, October-December 1990, DOEJEIA-0121(80/4Q) (Washington, D.C., May 1991). Projections: EIA, AEO 1994 National Energy Modeling System run AEO94B.D1221934. 
Table 63. Domestic Coal Supply, Disposition, and Prices South Atlantic Census Division

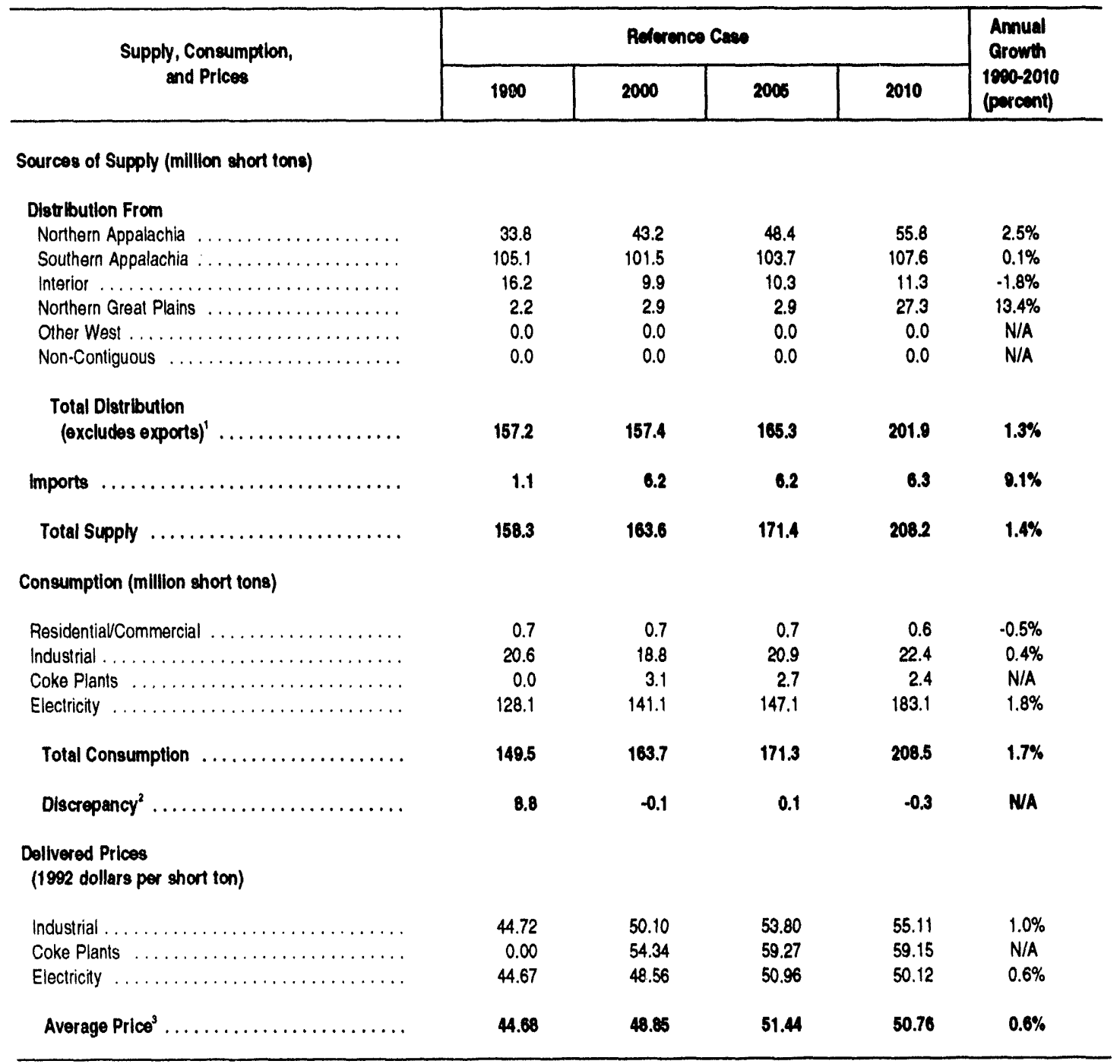

'Excludes distribution to unknown destinations from unknown origins.

${ }^{2}$ Includes stock changes.

${ }^{3}$ Weighted average. Excludes residential/commercial prices.

N/A $=$ Not applicable.

Note: Total may not equal sum of components due to independent rounding.

Source: 1990 distribution: Energy Intormation Administration (EIA), Coal Distribution January-December 1990, DOE/EIA-0125/90/4Q) (Washington, D.C., April 1991). 1990 imports: U.S. Bureau of the Census, Form IM-145. 1990 consumer stock withdrawals: ElA, Quarterly Coal Report, October-December 1991, DOE/EIA-0121(91/4Q) (Washington, D.C., May 1992) and EIA, Quarterly Coal Report, October-December 1990, DOE/EIA-0121(90/4Q) (Washington, D.C., May 1991). 1990 consumption: residential/commercial, electricity, total industrial, and total consumption: ElA, State Energy Data Report, Consumption Estimates 1960-1990, DOEJElA-0214(90) (Washington, D.C., May 1992). Other 1990 industrial and coke plant consumption estimated trom sectoral coal distribution: Quarterly Coal Report, October-December 1990, DOE/EIA-0121(90/4Q) (Washington, D.C., May 1991). 1990 delivered prices: Quarterly Coal Report, October-December 1990, DOE/E.A-0121(90/4Q) (Washington, D.C., May 1991). Projectlons: ElA, AEO 1994 National Energy Modeling System run AEO94B.D1221934. 
Table 64. Domestic Coøl Supply, Disposition, and Prices East South Contral Census Division

\begin{tabular}{|c|c|c|c|c|c|}
\hline \multirow{2}{*}{$\begin{array}{l}\text { Supply, Consumption, } \\
\text { and Prices }\end{array}$} & \multicolumn{4}{|c|}{ Relerenco Ceses } & \multirow{2}{*}{$\begin{array}{l}\text { Annuel } \\
\text { Crowth } \\
1690-2010 \\
\text { (percent) }\end{array}$} \\
\hline & 1900 & 2000 & 2005 & 2010 & \\
\hline \multicolumn{6}{|l|}{ Sources of Supply (million shart tons) } \\
\hline \multicolumn{6}{|l|}{ Distribution From } \\
\hline Northern Appalachia & 0.8 & 0.0 & 6.3 & 7.6 & $11.9 \%$ \\
\hline Southern Appalachia ... & 55.9 & 62.1 & 68.5 & 73.9 & $1.4 \%$ \\
\hline Interior ........... & 37.2 & 34.6 & 21.9 & 15.2 & $.4 .4 \%$ \\
\hline Northern Great Plains & 0.4 & 0.0 & 0.0 & 0.0 & N/A \\
\hline Other West $\ldots \ldots \ldots \ldots \ldots \ldots \ldots \ldots$ & 0.0 & 0.0 & 0.0 & 0.0 & N/A \\
\hline Non-Contiguous $\ldots \ldots \ldots \ldots \ldots \ldots \ldots$ & 0.0 & 0.0 & 0.0 & 0.0 & N/A \\
\hline $\begin{array}{l}\text { Total Distribution } \\
\text { (oxchudos exports)' . }\end{array}$ & 043 & 06.8 & $\$ 9.7$ & $\$ 6.7$ & $0.1 \%$ \\
\hline Imports $\ldots \ldots \ldots \ldots \ldots \ldots \ldots \ldots \ldots \ldots$ & 0.0 & 0.1 & 0.2 & 0.6 & NA \\
\hline Total Supply $\ldots \ldots \ldots \ldots \ldots \ldots \ldots \ldots$ & 94.3 & $\mathbf{8 6 . 8}$ & $\boldsymbol{8 9 . 0}$ & 97.3 & $0.2 \%$ \\
\hline \multicolumn{6}{|l|}{ Consumption (million chort tone) } \\
\hline ResidentiaVCommerclal. & 0.5 & 0.4 & 0.4 & 0.4 & $.1 .2 \%$ \\
\hline Industrial ........... & 13.1 & 10.2 & 11.2 & 12.2 & $.0 .4 \%$ \\
\hline Coke Plants $\ldots \ldots \ldots \ldots \ldots \ldots \ldots$ & 0.0 & 3.3 & 2.9 & 2.5 & N/A \\
\hline Electricity $\ldots \ldots \ldots \ldots \ldots \ldots \ldots \ldots \ldots$ & 77.6 & 82.9 & 82.5 & 82.1 & $0.3 \%$ \\
\hline Total Consumption $\ldots \ldots \ldots \ldots \ldots \ldots \ldots$ & 91.1 & 80.9 & 97.0 & 97.2 & $0.3 \%$ \\
\hline Dlscrepency $^{2} \ldots \ldots \ldots \ldots \ldots \ldots \ldots \ldots$ & 3.1 & 0.0 & -0.1 & 0.0 & $-10.4 \%$ \\
\hline \multicolumn{6}{|l|}{$\begin{array}{l}\text { Dellwered Prices } \\
\text { (1982 dollars per short ton) }\end{array}$} \\
\hline Industrial ...... & 45.60 & 46.24 & 50.93 & 52.01 & $0.7 \%$ \\
\hline Coke Plants & 0.00 & 54.27 & 60.20 & 57.67 & N/A \\
\hline Electricity $\ldots \ldots \ldots \ldots \ldots \ldots \ldots \ldots$ & 36.26 & 39.71 & 43.07 & 43.65 & $0.9 \%$ \\
\hline Average Prico $\ldots$ & 37.61 & 40.00 & 44.49 & 45.07 & $0.8 \%$ \\
\hline
\end{tabular}

'Excludes distribution to unknown destinations from unknown origins.

'Includes slock changes.

'Weighted average. E cludes residential/commercial prices.

$N / A=$ Not applicable.

Note: Total may not equal sum of components due to independent rounding.

Source: 1990 distribution: Energy information Administration (EIA), Coal Distribution January-December 1990, DOE/EIA-0125(90/4Q) (Washington, D.C., April 1991). 1990 imports: U.S. Bureau of the Census, Form IM-145. 1900 consumer stock withdrawals: EIA, Quarterly Coal Report, October-December 1991, DOE/ElA-0121(81/4Q) (Washington, D.C., May 1992) and ElA, Quarterly Coal Report, October-December 1990, DOEJEIA-0121(90/4Q) (Washington, D.C., May 1991). 1900 consumption: residential/commercial, electricity, total industrial, and total consumption: EIA, Slate Energy Data Report, Consumption Estimates 1960-1090, DOE/EIA-0214(80) (Washington, D.C., May 1992). Other 1990 industrial and coke plant consumption estimated from sectoral coal distribution: Quarterly Coal Report, October-December 1990, DOE/EIA-0121(90/4Q) Washington, D.C., May 1991). 1980 delivered prices: Quarterly Coal Report, October-December 1980, DOE/EIA-0121(90/4Q) (Washington, D.C., May 1991). Projectlone: EIA, AEO 1994 National Energy Modeling System run AEO94B.D1221934. 
Table 65. Domestic Coal Supply, Disposition, and Prices

West South Central Census. Division

\begin{tabular}{|c|c|c|c|c|c|}
\hline \multirow{2}{*}{$\begin{array}{l}\text { Supply, Concumption, } \\
\text { and Prices }\end{array}$} & \multicolumn{4}{|c|}{ Relorence Ceses } & \multirow{2}{*}{$\begin{array}{l}\text { Annual } \\
\text { Crowth } \\
\text { 19c0-2010 } \\
\text { (percent) }\end{array}$} \\
\hline & 1000 & 2000 & 2006 & 2010 & \\
\hline \multicolumn{6}{|l|}{ Sources of Supply (million short tons) } \\
\hline \multicolumn{6}{|l|}{ Diatribution From } \\
\hline Northem Appalachia & 0.0 & 0.0 & 0.0 & 0.0 & N/A \\
\hline Southem Appalachia .................. & 0.5 & 1.0 & 0.2 & 1.2 & $4.6 \%$ \\
\hline Interior $\ldots \ldots \ldots \ldots \ldots \ldots \ldots \ldots \ldots$ & 60.2 & 64.4 & 69.5 & 80.9 & $1.5 \%$ \\
\hline Northern Great Plains $\ldots \ldots \ldots \ldots \ldots \ldots$ & 67.4 & 76.9 & 78.7 & 73.3 & $0.4 \%$ \\
\hline Other West $\ldots \ldots \ldots \ldots \ldots \ldots \ldots \ldots$ & 2.6 & 0.6 & 3.0 & 0.7 & $.6 .5 \%$ \\
\hline Non-Contiguous $\ldots \ldots \ldots \ldots \ldots \ldots \ldots$ & 0.0 & 0.0 & 0.0 & 0.0 & N/A \\
\hline $\begin{array}{l}\text { Total Distribution } \\
\text { (oxeludbs expats)' .. }\end{array}$ & 130.7 & 143.0 & 161.6 & 166.1 & $0.0 \%$ \\
\hline imports $\ldots \ldots \ldots \ldots \ldots \ldots \ldots \ldots \ldots \ldots$ & 0.0 & 0.1 & 0.1 & 0.2 & NA \\
\hline Total Supply $\ldots \ldots \ldots \ldots \ldots \ldots \ldots \ldots$ & 130.7 & 143.1 & 161.7 & 186.3 & $0.0 \%$ \\
\hline \multicolumn{6}{|l|}{ Consumption (million chort tons) } \\
\hline ResidentiavCommercial & 0.0 & 0.0 & 0.0 & 0.0 & N/A \\
\hline Industrial ............ & 5.8 & 7.2 & 6.8 & 9.1 & $2.3 \%$ \\
\hline Coke Plants $\ldots \ldots \ldots \ldots \ldots \ldots \ldots \ldots$ & 0.0 & 0.0 & 0.0 & 0.0 & N/A \\
\hline Electricity $\ldots \ldots \ldots \ldots \ldots \ldots \ldots \ldots$ & 125.7 & 135.9 & 145.0 & 146.1 & $0.8 \%$ \\
\hline Total Conaumption...$\ldots \ldots \ldots \ldots \ldots$ & 131.5 & 143.2 & 151.8 & 155.3 & $0.8 \%$ \\
\hline Descrepeney". & -0.8 & -0.1 & -0.1 & 1.0 & NA \\
\hline \multicolumn{6}{|l|}{$\begin{array}{l}\text { Dellwered Prices } \\
\text { (1992 dollars per short ton) }\end{array}$} \\
\hline Industrial. & 22.77 & 20.59 & 24.48 & 20.57 & $.0 .5 \%$ \\
\hline Coke Plants & 0.00 & 0.00 & 0.00 & 0.00 & N/A \\
\hline Electricity $\ldots \ldots \ldots \ldots \ldots \ldots \ldots \ldots \ldots$ & 24.45 & 25.71 & 25.46 & 34.58 & $1.7 \%$ \\
\hline Averago Pricos ... & 24.37 & 25.45 & 25.41 & 33.76 & $1.6 \%$ \\
\hline
\end{tabular}

'Excludes distribution to unknown destinations from unknown origins.

"Includes stock changes.

Weighted average. Excludes residential/commercial prices.

N/A $=$ Not applicable.

Note: Total may not equal sum ol components due to independent rounding.

Source: 1990 distribution: Energy Information Administration (EIA), Coal Distribution January-December 1900, DOEJEIA-0125(90/4Q) (Washington, D.C., April 1991). 1980 imports: U.S. Bureau of the Census, Form IM-145. 1990 consumer stock withdrawals: ElA, Quarterly Coal Report, October-December 1991, DOE/EIA-0121(91/4Q) (Washington, D.C., May 1992) and EIA, Quarterty Coal Report, October-December 1990, DOE/EIA-0121(80/4Q) (Washington, D.C., May 1991). 1990 consumption: residential/commercial, electricity, total industrial, and total consumption: ElA, State Energy Data Report, Consumption Estimates 1960-1980, DOEJEIA-0214(90) (Washington, D.C., May 1982). Other 1990 industrial and coke plant consumption estimated from sectoral coal distribution: Quarterly Coal Report, October-December 1900, DOEJEIA-0121(90/4Q) (Washington, D.C.. May 1991). 1990 delivered prices: Quarterly Coal Repon, October-December 1990, DOEJEIA-0121(90/4Q) (Washington, D.C., May 1991). Propectlone: EIA, AEO 1994 National Energy Modeling System run AEO94B.D1221934. 
Table 66. Domestic Coal Supply, Disposition, and Prices Mountain Census Division

\begin{tabular}{|c|c|c|c|c|c|}
\hline \multirow{2}{*}{$\begin{array}{l}\text { Supply, Coneumption, } \\
\text { and Prices }\end{array}$} & \multicolumn{4}{|c|}{ Relerenco Case } & \multirow{2}{*}{$\begin{array}{l}\text { Annual } \\
\text { Growth } \\
1800-2010 \\
\text { (percent) }\end{array}$} \\
\hline & 1990 & 2000 & 2005 & 2010 & \\
\hline \multicolumn{6}{|l|}{ Sources of Supply (million short tons) } \\
\hline \multicolumn{6}{|l|}{ Distribution From } \\
\hline Northern Appalachia $\ldots \ldots \ldots \ldots \ldots \ldots$ & 0.0 & 0.0 & 0.0 & 0.0 & N/A \\
\hline Southern Appalachia $\ldots \ldots \ldots \ldots \ldots \ldots$ & 0.0 & 0.0 & 0.0 & 0.0 & N/A \\
\hline Interior $\ldots \ldots \ldots \ldots$ & 0.0 & 0.0 & 0.0 & 0.0 & N/A \\
\hline Northern Great Plains $\ldots \ldots \ldots \ldots \ldots \ldots$ & 41.7 & 46.7 & 46.0 & 50.8 & $1.0 \%$ \\
\hline Other West $\ldots \ldots \ldots \ldots \ldots \ldots \ldots \ldots \ldots \ldots$ & 65.4 & 61.5 & 67.8 & 85.3 & $1.3 \%$ \\
\hline Non-Contiguous $\ldots \ldots \ldots \ldots \ldots \ldots \ldots$ & 0.0 & 0.0 & 0.0 & 0.0 & N/A \\
\hline $\begin{array}{l}\text { Total Distribution } \\
\text { (oxcludes exporte)' ... }\end{array}$ & 107.1 & 108.2 & 113.8 & 136.0 & $1.2 \%$ \\
\hline imports $\ldots \ldots \ldots$ & 0.0 & 0.0 & 0.0 & 0.0 & NA \\
\hline Total Supply $\ldots \ldots \ldots \ldots \ldots \ldots \ldots \ldots$ & 107.2 & 108.2 & 113.8 & 136.0 & $1.2 \%$ \\
\hline \multicolumn{6}{|l|}{ Consumption (million short tons) } \\
\hline ResidentiaVCommercial & 0.0 & 0.6 & 0.6 & 0.5 & $N / A$ \\
\hline Indusstrial $\ldots \ldots \ldots \ldots \ldots \ldots \ldots \ldots \ldots \ldots$ & 6.7 & 4.9 & 5.2 & 5.2 & $-1.2 \%$ \\
\hline Coke Plants $\ldots \ldots \ldots \ldots \ldots \ldots \ldots \ldots \ldots$ & 0.0 & 0.9 & 0.8 & 0.7 & N/A \\
\hline Electricity $\ldots \ldots \ldots \ldots \ldots \ldots \ldots \ldots$ & 100.5 & 101.7 & 107.2 & 129.6 & $1.3 \%$ \\
\hline Total Consumption .................... & 107.2 & 108.2 & 113.8 & 136.0 & $1.2 \%$ \\
\hline Discrepancy ${ }^{2} \ldots \ldots \ldots \ldots \ldots \ldots \ldots \ldots$ & 0.0 & 0.0 & 0.0 & 0.0 & NA \\
\hline \multicolumn{6}{|l|}{$\begin{array}{l}\text { Dellvered Prices } \\
\text { (1992 dollars per short ton) }\end{array}$} \\
\hline Industrial $\ldots \ldots \ldots \ldots \ldots \ldots \ldots \ldots \ldots$ & 35.42 & 36.69 & 37.09 & 45.83 & $1.3 \%$ \\
\hline Cokn Plants $\ldots \ldots \ldots \ldots \ldots \ldots \ldots \ldots \ldots \ldots$ & 0.00 & 41.71 & 41.43 & 42.50 & N/A \\
\hline Electricity $\ldots \ldots \ldots \ldots \ldots \ldots \ldots \ldots$ & 23.68 & 27.54 & 26.93 & 33.94 & $1.8 \%$ \\
\hline Average Prices. & 24.35 & 28.00 & 27.50 & 34.44 & $1.7 \%$ \\
\hline
\end{tabular}

${ }^{1}$ Excludes distribution to unknown destinations from unknown origins.

Includes stock changes.

'Weighted average. Excludes residential/commercial prices.

$N / A=$ Not applicable.

Nole: Total may not equal sum of cornponents due to independent rounding.

Source: 1990 distribution: Energy Information Administration (EIA), Coal Distribution January-December 1990, DOE/EIA-0125(90/4Q) (Washington, D.C. April 1991). 1990 imports: U.S. Bureau of the Census, Form IM-145. 1980 consumer stock withdrawals: ElA, Quarterly Coal Report, October-December 1991, DOE/EIA-0121(01/4Q) (Washington, D.C., May 1992) and EIA, Quarterly Coal Report, October-December 1990, DOE/EIA-0121(90/4Q) (Washington, D.C., May 1991). 1990 consumption: residential/commercial, electricity, total industrial, and total consumption: EIA, State Energy Data Report, Consumption Estimates 1960-1980, DOEJEIA-0214(90) (Washington, D.C. May 1992). Other 1990 industrial and coke plant consumption estimated from sectoral coal distribution: Quarterly Coal Report, October-December 1990. DOE/EIA-0121(90/4Q) (Washington, D.C., May 1991). 1990 delivered prices: Quarterly Coal Report, October-December 1990, DOEJEIA-0121(90/4Q) (Washington, D.C., May 1991). Propectlone: EIA, AEO 1994 National Energy Modeling System run AEO94B.D1221934 
Table 67. Domestic Coal Supply, Disposition, and Prices Pacific Census Division

\begin{tabular}{|c|c|c|c|c|c|}
\hline \multirow{2}{*}{$\begin{array}{l}\text { Supply, Concumption, } \\
\text { and Pricese }\end{array}$} & \multicolumn{4}{|c|}{ Reterence Case } & \multirow{2}{*}{$\begin{array}{c}\text { Armual } \\
\text { Growth } \\
1000-2010 \\
\text { (percent) }\end{array}$} \\
\hline & 1000 & 2000 & 2006 & 2010 & \\
\hline \multicolumn{6}{|l|}{ Sourcess of Supply (milition short tons) } \\
\hline \multicolumn{6}{|l|}{ Dhatrbution From } \\
\hline Northern Appalachia & 0.0 & 0.0 & 0.0 & 0.0 & N/A \\
\hline Southern Appalachia & 0.0 & 0.0 & 0.0 & 0.0 & N/A \\
\hline Interior . . ............. & 0.0 & 0.0 & 0.0 & 0.0 & N/A \\
\hline Northem Great Plains & 1.4 & 5.2 & 5.0 & 5.4 & $7.0 \%$ \\
\hline Other West ............ & 8.0 & 6.3 & 6.4 & 6.0 & $.1 .4 \%$ \\
\hline Non-Contiguous $\ldots \ldots \ldots \ldots \ldots \ldots$ & 0.8 & 0.4 & 0.4 & 0.4 & $.3 .2 \%$ \\
\hline $\begin{array}{l}\text { Total Dibtribution } \\
\text { (oxcludes exports) })^{1} \ldots\end{array}$ & 10.2 & 11.9 & 11.9 & 11.8 & $0.8 \%$ \\
\hline imports $\ldots \ldots \ldots \ldots \ldots \ldots \ldots \ldots \ldots \ldots \ldots \ldots$ & 0.4 & 1.0 & 2.0 & 2.1 & $8.7 \%$ \\
\hline Total Supply ...................... & 10.5 & 13.8 & 13.0 & 14.0 & $1.4 \%$ \\
\hline \multicolumn{6}{|l|}{ Consumption (million short ions) } \\
\hline ResidentiaVCommercial & 0.6 & 0.5 & 0.5 & 0.5 & $-1.1 \%$ \\
\hline Industrial $\ldots \ldots \ldots \ldots$ & 3.2 & 3.2 & 3.3 & 3.4 & $0.3 \%$ \\
\hline Coke Plants ............... & 0.0 & 0.0 & 0.0 & 0.0 & N/A \\
\hline Electricty $\ldots \ldots \ldots \ldots \ldots \ldots \ldots \ldots$ & 6.0 & 8.7 & 8.5 & 8.5 & $1.8 \%$ \\
\hline Total Coneumption...$\ldots \ldots \ldots \ldots \ldots \ldots$ & 9.8 & 12.4 & 12.4 & 12.4 & $1.2 \%$ \\
\hline Dbecrepener ${ }^{2} . \ldots \ldots \ldots$ & 0.8 & 1.4 & 1.5 & 1.6 & $3.5 \%$ \\
\hline \multicolumn{6}{|l|}{$\begin{array}{l}\text { Dellwered Prices } \\
\text { (1902 dollars per short ton) }\end{array}$} \\
\hline Industrial. & 48.87 & 33.26 & 32.82 & 33.79 & $-1.8 \%$ \\
\hline Coke Plants & 0.00 & 0.00 & 0.00 & 0.00 & N/A \\
\hline$\ldots \ldots \ldots \ldots \ldots \ldots$ & 26.06 & 22.42 & 21.41 & 34.57 & $1.4 \%$ \\
\hline Average Pricos ... & 34.02 & 25.31 & 24.62 & 34.35 & $0.0 \%$ \\
\hline
\end{tabular}

'Excludes distribution to unknown destinations from unknown origins.

Includes stock changes.

Weighted average. Excludes residential/commercial prices.

N/A = Not applicable.

Note: Total may not equal sum of components due to independent rounding.

Source: 1900 distribution: Energy Information Administration (EIA), COal Distribution January-December 1990, DOE/EIA-0125(80/4Q) (Washington, D.C. April 1991). 1990 imports: U.S. Bureau of the Census, Form IM-145. 1900 consumer stock withdrawals: EIA, Quarterly Coal Report, October-December 1991, DOE/EIA-0121(91/4Q) (Washington, D.C., May 1992) and ElA, Quarterly Coal Report, October-December 1980, DOE/EIA-0121(80/4Q) (Washington, D.C., May 1991). 1990 consumption: residential/commercial, electricity, total industrial, and total consumption: ElA, State Energy Data Report, Consumption Estimates 1960-1990, DOE/E/A-0214(90) (Washington. D.C., May 1992). Other 1990 industrial and coke plant consumption estimated from sectoral coal distribution: Quarterly Coal Report, October-December 1990, DOE/EIA-0121(80/4Q) (Washington, D.C. May 1991). 1990 delivered prices: Quarterly Coal Report, October-December 1890, DOE/EIA-0121(80/4Q) (Washington, D.C., May 1991). Projectlone: ElA, AEO 1994 National Energy Modeling System run AEO O4B.D1221934 
Table 68. Domestic Coal Supply, Disposition, and Prices United States

\begin{tabular}{|c|c|c|c|c|c|}
\hline \multirow{2}{*}{$\begin{array}{l}\text { Supply, Consumption, } \\
\text { and Pricese }\end{array}$} & \multicolumn{4}{|c|}{ Reterences Caso } & \multirow{2}{*}{$\begin{array}{c}\text { Amnual } \\
\text { Growh } \\
1900-2010 \\
\text { (percent) }\end{array}$} \\
\hline & 1900 & 2000 & 2000 & 2010 & \\
\hline \multicolumn{6}{|l|}{ Sourcess of Supply (million short tona) } \\
\hline \multicolumn{6}{|l|}{ Diatrbution From } \\
\hline Northern Appalachia & 148.6 & 175.4 & 187.8 & 216.4 & $1.9 \%$ \\
\hline Southem Appalachia . & 232.9 & 245.2 & 255.0 & 266.9 & $0.7 \%$ \\
\hline Interior ............. & 204.0 & 173.8 & 156.0 & 154.3 & $.1 .4 \%$ \\
\hline Northem Great Plains $\ldots \ldots \ldots \ldots \ldots \ldots$ & 250.2 & 284.4 & 296.8 & 339.9 & $1.5 \%$ \\
\hline Other West $\ldots \ldots \ldots \ldots \ldots \ldots \ldots \ldots \ldots \ldots$ & 77.5 & 68.7 & 81.2 & 92.8 & $0.9 \%$ \\
\hline Non-Contiguous $\ldots \ldots \ldots \ldots \ldots \ldots \ldots$ & 0.8 & 0.4 & 0.4 & 0.4 & $.3 .2 \%$ \\
\hline $\begin{array}{l}\text { Total Dlestrbution } \\
\text { (oxcludes exports) }{ }^{\prime} \ldots \ldots \ldots \ldots \ldots \ldots\end{array}$ & 914.0 & M7.0 & 077.1 & $1,070.8$ & $0.8 \%$ \\
\hline imports $\ldots \ldots \ldots \ldots \ldots \ldots \ldots \ldots \ldots \ldots$ & 2.7 & 0.7 & 10.0 & 10.6 & $7.1 \%$ \\
\hline Total Supply $\ldots \ldots \ldots \ldots \ldots \ldots \ldots \ldots$ & 916.6 & $\$ 67.6$ & 987.1 & $1,081.4$ & $0.8 \%$ \\
\hline \multicolumn{6}{|l|}{ Consumption (millition short tona) } \\
\hline ResidentialCommarcial & 6.7 & 6.1 & 5.9 & 5.5 & $.1 .0 \%$ \\
\hline Industrial ...... & 76.3 & 86.9 & 94.1 & 101.4 & $1.4 \%$ \\
\hline Coke Plaits $\ldots \ldots \ldots \ldots \ldots \ldots \ldots$ & 38.9 & 27.8 & 24.3 & 21.4 & $.3 .0 \%$ \\
\hline Electricity $\ldots \ldots \ldots \ldots \ldots \ldots \ldots \ldots \ldots$ & 773.5 & 836.9 & 862.4 & 950.4 & $1.0 \%$ \\
\hline Total Coneumption ................. & 8005.5 & $\mathbf{8 7 . 7}$ & $\$ 98.8$ & $1,076.8$ & $0.8 \%$ \\
\hline Dlscrepeney ${ }^{2}, \ldots \ldots \ldots \ldots \ldots \ldots \ldots$ & 21.2 & -0.2 & 0.3 & 2.8 & $-9.7 \%$ \\
\hline \multicolumn{6}{|l|}{$\begin{array}{l}\text { Deltwered Pricese } \\
\text { (1902 dollars per short ton) }\end{array}$} \\
\hline Industrial $\ldots \ldots \ldots \ldots \ldots \ldots \ldots \ldots$ & 35.85 & 37.43 & 40.37 & 42.30 & $0.8 \%$ \\
\hline Coke Plants $\ldots \ldots \ldots \ldots \ldots \ldots \ldots \ldots$ & 50.93 & 55.81 & 60.38 & 58.91 & $0.7 \%$ \\
\hline 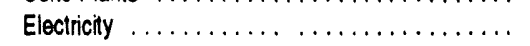 & 32.49 & 34.11 & 35.52 & 40.32 & $1.1 \%$ \\
\hline Average Pricos' $\ldots \ldots \ldots \ldots \ldots \ldots \ldots \ldots$ & 33.16 & 35.06 & 36.60 & 40.88 & $1.1 \%$ \\
\hline
\end{tabular}

'Excludes distribution to unknown destinations from unknown origins.

'Includes stock changes.

Weighted average. Excludes residential/commercial prices.

$V / A=$ Nol applicable.

A ote: Total may not equal sum of components due to independent rounding.

Ssurce: 1090 distribution: Energy Information Administration (EIA), Coal Distribution January-December 1980, DOE/EIA-0125(90/4Q) (Washington, D.C. April 1991). 1900 imports: U.S. Bureau of the Census, Form IM-145. 1990 consumer stock withdrawals: ElA, Quarterly Coal Report, October-December 1891, DOE/EIA-0121(81/4Q) (Washington, D.C. May 1992) and ElA, Quarterly COal Repont, October-December 1980, DOE/EIA-0121(80/4Q) Washington, D.C., May 1991). 1900 consumption: residential/commercial, electricity, total industrial, and total consumption: ElA, State Energy Data Report, Consumption Estimates 1060-1090, DOE/EIA-0214(90) (Washington, D.C., May 1992). Other 1990 industrial and coke plant consumption estimated from sectoral coal distribution: Quarterly Coal Report, October-December 1990 DOE/EIA-0121(80/4Q) (Washington, D.C.. May 1991). 1990 delivered prices: Quarterly Coal Report, October-December 1980, DOE/EIA-0121(90/4Q) (Washington, D.C., May 1991). Propections: EIA, AEO 1994 National Energy Modeling System rur, AEO94B.D1221934. 
Table 69. Coal Production and Minemouth Prices by Region

\begin{tabular}{|c|c|c|c|c|c|}
\hline \multirow{2}{*}{ Supply Regions } & \multicolumn{4}{|c|}{ Relerence Cases } & \multirow{2}{*}{$\begin{array}{l}\text { Annual } \\
\text { Growth } \\
\text { 19e0-2010 } \\
\text { (percent) }\end{array}$} \\
\hline & 1000 & 2000 & 2005 & 2010 & \\
\hline \multicolumn{6}{|l|}{ Production (million short tons per year) } \\
\hline$\ldots \ldots \ldots \ldots \ldots \ldots \ldots$ & 165.90 & 181.86 & 198.20 & 229.80 & $1.6 \%$ \\
\hline Southern Appalachia & 323.10 & 341.77 & 348.59 & 352.68 & $0.4 \%$ \\
\hline 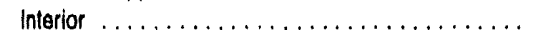 & 205.70 & 179.34 & 162.93 & 168.99 & $.1 .0 \%$ \\
\hline North Great Plains $\ldots \ldots \ldots \ldots \ldots \ldots$ & 251.10 & 294.19 & 308.06 & 349.47 & $1.7 \%$ \\
\hline Other West $\ldots \ldots \ldots \ldots \ldots \ldots \ldots \ldots$ & 81.60 & 81.87 & 101.65 & 119.77 & $1.9 \%$ \\
\hline Non-Contiguous $\ldots \ldots \ldots \ldots \ldots \ldots \ldots \ldots$ & 1.70 & 1.72 & 1.71 & 2.19 & $1.3 \%$ \\
\hline Appalachian. . . . . . . . . . . . . . . . & 489.00 & 523.63 & 546.79 & 582.48 & $0.9 \%$ \\
\hline 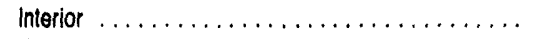 & 205.70 & 179.34 & 162.93 & 168.99 & $.1 .0 \%$ \\
\hline 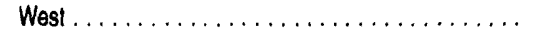 & 334.40 & 377.78 & 411.41 & 471.43 & $1.7 \%$ \\
\hline East of Mississippi River $\ldots \ldots \ldots \ldots \ldots \ldots$ & 630.20 & 629.89 & 629.68 & 649.85 & $0.2 \%$ \\
\hline West of Mississippi River . . . . . . . . . . . . & 398.90 & 450.87 & 491.44 & 573.05 & $1.8 \%$ \\
\hline U.S. Total $\ldots \ldots \ldots \ldots \ldots \ldots \ldots \ldots \ldots$ & $1,020.10$ & $1,060.75$ & $1,121.13$ & $1,222.90$ & $0 . \% \%$ \\
\hline \multicolumn{6}{|l|}{ Minemouth Prices (1802 dollers per short ton) } \\
\hline Northern Appalachia $\ldots \ldots \ldots \ldots \ldots \ldots$ & $w$ & 32.39 & 34.76 & 35.05 & N/A \\
\hline Southern Appalachia $\ldots \ldots \ldots \ldots \ldots \ldots \ldots$ & $w$ & 36.20 & 40.13 & 39.76 & N/A \\
\hline 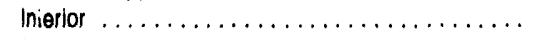 & 22.89 & 21.81 & 22.12 & 23.33 & $0.1 \%$ \\
\hline North Great Plains $\ldots \ldots \ldots \ldots \ldots \ldots \ldots$ & 9.06 & 10.14 & 10.75 & 24.06 & $5.0 \%$ \\
\hline Other West $\ldots \ldots \ldots \ldots \ldots \ldots \ldots \ldots \ldots$ & W & 26.13 & 24.06 & 27.35 & $N / A$ \\
\hline Non-Contiguous $\ldots \ldots \ldots \ldots \ldots \ldots \ldots \ldots$ & W & 21.87 & 20.90 & 22.04 & N/A \\
\hline Appalachia ... & 30.83 & 34.88 & 38.18 & 37.90 & $1.0 \%$ \\
\hline Interior $\ldots \ldots \ldots \ldots \ldots \ldots \ldots \ldots \ldots \ldots \ldots \ldots \ldots \ldots \ldots \ldots$ & 22.89 & 21.81 & 22.12 & 23.33 & $0.1 \%$ \\
\hline 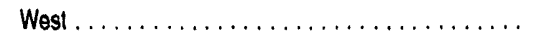 & 12.38 & 13.66 & 14.08 & 24.89 & $3.6 \%$ \\
\hline East ol Mississippi River & 29.98 & 33.43 & 37.02 & 37.34 & $1.1 \%$ \\
\hline West of Mississippi River $\ldots \ldots \ldots \ldots \ldots \ldots$ & 12.60 & 13.92 & 14.17 & 23.53 & $3.2 \%$ \\
\hline 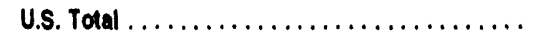 & 23.22 & 25.29 & 27.00 & 30.87 & $1.4 \%$ \\
\hline
\end{tabular}

Appalachia: PA,OH,MD,WV,VA,TN, AL,GA,EAST KY

Interior: MI,IL,IN,IA, MO,KS,AR,OK,LA,TX,WEST KY

West: ND,SD,MT,WY,CO,UT,AZ,NM,WA,OR,AK,CA

$W=$ Withheld to prevent disclosure of proprietary data

$\mathrm{N} / \mathrm{A}=$ Not applicable.

Note: Totals may not equal sum of components due to independent rounding.

Source: 1990: Energy Intormation Administration (EIA), Coal Production 1990, DOE/EIA-01 18(90) (Washington, D.C. September 1991), Tables 1, 17, and 19. Prolections: EIA, AEO 1994 National Energy Information System run AEOQ4B.D1221934. 
Table 70. Coal Production by Region and Type

(Million Short Tons per Year)

\begin{tabular}{|c|c|c|c|c|c|}
\hline \multirow{2}{*}{ Supply Reglons and Coal Types } & \multicolumn{4}{|c|}{ Rolerence Caes } & \multirow{2}{*}{$\begin{array}{l}\text { Annual } \\
\text { Growt } \\
\text { 10so-2010 } \\
\text { (percent) }\end{array}$} \\
\hline & 1980 & 2000 & 2005 & 2010 & \\
\hline Appalachia $\ldots \ldots \ldots \ldots \ldots \ldots \ldots \ldots \ldots$ & 488.89 & 523.63 & 546.78 & 582.46 & $0.9 \%$ \\
\hline Bltuminous $\ldots \ldots \ldots \ldots \ldots \ldots \ldots \ldots$ & 488.99 & 523.63 & 546.78 & 582.48 & $0.9 \%$ \\
\hline Low Suffur $\ldots \ldots \ldots \ldots \ldots \ldots \ldots \ldots \ldots$ & 60.85 & 131.39 & 156.60 & 188.70 & $5.8 \%$ \\
\hline Modium Sulfur . . . . . . . . . . . . . . . . . & 339.04 & 309.15 & 297.22 & 296.51 & $.0 .7 \%$ \\
\hline High Sulfur $\ldots \ldots \ldots \ldots \ldots \ldots \ldots \ldots \ldots$ & 89.11 & 83.09 & 92.97 & 97.26 & $0.4 \%$ \\
\hline Lignite (medlum sulfur) $\ldots \ldots \ldots \ldots \ldots \ldots$ & 0.00 & 0.00 & 0.00 & 0.00 & WA \\
\hline Interlor $\ldots \ldots \ldots \ldots \ldots \ldots \ldots \ldots \ldots \ldots \ldots$ & 205.65 & 179.34 & 162.83 & 168.99 & $-1.0 \%$ \\
\hline Bituminous $\ldots \ldots \ldots \ldots \ldots \ldots \ldots \ldots$ & 147.07 & 117.58 & 97.15 & 93.16 & $.2 .3 \%$ \\
\hline$\ldots \ldots \ldots \ldots \ldots \ldots \ldots \ldots$ & 0.77 & 0.88 & 2.12 & 2.27 & $5.6 \%$ \\
\hline Mediu'm Sulfur . . . . . . . . . . . . . . . . . & 18.94 & 35.56 & 44.17 & 50.99 & $5.1 \%$ \\
\hline High Sulfur $\ldots \ldots \ldots \ldots \ldots \ldots \ldots \ldots$ & 127.36 & 81.14 & 50.86 & 39.90 & $.5 .6 \%$ \\
\hline Lignite $\ldots \ldots \ldots \ldots \ldots \ldots \ldots \ldots$ & 58.59 & 61.76 & 65.79 & 75.82 & $1.3 \%$ \\
\hline Medium Sulfur . . . . . . . . . . . . . . & 43.18 & 48.74 & 50.07 & 63.48 & $1.9 \%$ \\
\hline High Sulfur $\ldots \ldots \ldots \ldots \ldots \ldots \ldots \ldots$ & 15.40 & 13.02 & 15.72 & 12.35 & $-1.1 \%$ \\
\hline West $\ldots \ldots \ldots \ldots \ldots \ldots \ldots \ldots \ldots \ldots \ldots \ldots$ & 334.43 & 377.78 & 411.41 & 471.43 & $1.7 \%$ \\
\hline Bituminous & 60.65 & 62.25 & 83.01 & 108.70 & $3.0 \%$ \\
\hline Low Sultur $\ldots \ldots \ldots \ldots \ldots \ldots \ldots \ldots$ & 54.82 & 56.82 & 75.18 & 95.34 & $2.8 \%$ \\
\hline Medium Sullur . . . . . . . . . . . . . . & 5.83 & 5.43 & 7.81 & 13.35 & $4.2 \%$ \\
\hline High Suffur $\ldots \ldots \ldots \ldots \ldots \ldots \ldots \ldots \ldots$ & 0.00 & 0.00 & 0.02 & 0.01 & N/A \\
\hline Sub-Bituminous . & 244.27 & 287.11 & 298.86 & 329.54 & $1.5 \%$ \\
\hline Low Sulfur $\ldots \ldots \ldots \ldots \ldots \ldots \ldots \ldots$ & 189.61 & 233.17 & 241.81 & 248.48 & $1.4 \%$ \\
\hline Medium Sulfur . . . . . . . . . . . . . . . . & 53.60 & 52.72 & 55.63 & 79.46 & $2.0 \%$ \\
\hline High Sulfur $\ldots \ldots \ldots \ldots \ldots \ldots \ldots \ldots \ldots$ & 1.07 & 1.22 & 1.42 & 1.59 & $2.0 \%$ \\
\hline$\ldots \ldots \ldots \ldots$ & 29.50 & 28.43 & 29.55 & 33.20 & $0.6 \%$ \\
\hline Low Sultur $\ldots \ldots \ldots \ldots \ldots \ldots \ldots \ldots$ & 0.10 & 0.08 & 0.09 & 0.10 & $.0 .1 \%$ \\
\hline Medium Sulfur . . . . . . . . . . . . . . . . & 26.55 & 25.64 & 26.67 & 29.84 & $0.6 \%$ \\
\hline High Sulfur $\ldots \ldots \ldots \ldots \ldots \ldots \ldots \ldots$ & 2.86 & 2.71 & 2.78 & 3.27 & $0.7 \%$ \\
\hline \multicolumn{6}{|l|}{ Subtotals: All Regions } \\
\hline Bituminous $\ldots \ldots \ldots \ldots \ldots \ldots \ldots \ldots$ & 696.71 & 703.46 & 726.94 & 784.34 & $0.6 \%$ \\
\hline Sub-Bituminous $\ldots \ldots \ldots \ldots \ldots \ldots \ldots \ldots$ & 244.27 & 287.11 & 298.86 & 329.54 & $1.5 \%$ \\
\hline Lignite $\ldots \ldots \ldots \ldots \ldots \ldots \ldots \ldots \ldots \ldots$ & 88.09 & 90.18 & 95.33 & 109.02 & $1.1 \%$ \\
\hline Low Sulfur & 306.15 & 422.34 & 475.80 & 534.89 & $2.8 \%$ \\
\hline Medium Sulfur $\ldots \ldots \ldots \ldots \ldots \ldots \ldots \ldots$ & 487.14 & 477.24 & 481.57 & 533.63 & $0.5 \%$ \\
\hline High Sulfur $\ldots \ldots \ldots \ldots \ldots \ldots \ldots \ldots \ldots$ & 235.79 & 181.17 & 163.76 & 154.37 & $\cdot 2.1 \%$ \\
\hline U.S. Total $\ldots \ldots \ldots \ldots \ldots \ldots \ldots \ldots \ldots$ & $1,029.08$ & $1,080.75$ & $1,121.13$ & $1,222.89$ & $0.9 \%$ \\
\hline
\end{tabular}

Appalachia: PA,OH,MO,WV,VA,TN,AL,GA,EAST KY Interior: MI,IL,IN,IA,MO,KS,AR,OK,LA,TX,WEST KY

West: ND,SD,MT,WY,CO,UT,AZ,NM,WA,OR,AK,CA

Sulfur Delinitions:

Low Sulfur: $\quad 0-0.60$ pounds of sulfur per million Btu.

Medium Sulfur: $0.61-1.67$ pounds of sulfur per million Btu.

High Sulfur: Over 1.67 pounds of sulfur per million Btu.

Btu $=$ British thermal unit.

N/A $=$ Not applicable.

Note: Totals may not equal sum of components due to independent rounding.

Source: 1990: Energy Information Administration (EIA), Coal Production 1990, DOE/EIA-0118(90) (Washington, O.C., September 1981), Tables

1 and 5. Projectlons: EIA, AEO 1994 National Energy Information System run AEO94B.D1221934. 
Table 71. World Steam Coal Flows By Importing Regions and Exporting Countries (Million Short Tons)

\begin{tabular}{|c|c|c|c|c|c|}
\hline \multirow{2}{*}{ Import and Export Regions } & \multicolumn{4}{|c|}{ Relerences Case } & \multirow{2}{*}{$\begin{array}{l}\text { Anmud } \\
\text { Crown } \\
\text { 1eep-2010 } \\
\text { (peremt) }\end{array}$} \\
\hline & 1900 & 2000 & 2005 & 2010 & \\
\hline \multicolumn{6}{|l|}{ Sinem Coal Exports to Europe } \\
\hline Australia $\ldots \ldots \ldots \ldots \ldots \ldots \ldots \ldots \ldots$ & 11.0 & 0.0 & 15.9 & 20.5 & $3.2 \%$ \\
\hline United States $\ldots \ldots \ldots \ldots \ldots \ldots \ldots \ldots$ & 24.0 & 50.7 & 58.8 & 62.0 & $4.9 \%$ \\
\hline Soush Arica $\ldots \ldots \ldots \ldots \ldots \ldots \ldots \ldots$ & 31.0 & 65.7 & 63.8 & 64.6 & $3.7 \%$ \\
\hline Former U.S.S.R $\ldots \ldots \ldots \ldots \ldots \ldots \ldots$ & 14.0 & 8.2 & 8.7 & 8.6 & $-2.4 \%$ \\
\hline$\ldots \ldots \ldots \ldots \ldots \ldots \ldots \ldots \ldots \ldots$ & 23.0 & 7.9 & 6.3 & 6.5 & $-6.1 \%$ \\
\hline Canada $\ldots \ldots \ldots \ldots \ldots \ldots \ldots \ldots \ldots$ & 1.0 & 4.6 & 1.8 & 0.0 & N/A \\
\hline$\ldots \ldots \ldots \ldots \ldots \ldots \ldots \ldots \ldots$ & 3.0 & 3.3 & 3.3 & 5.0 & $2.5 \%$ \\
\hline South America $\ldots \ldots \ldots \ldots \ldots \ldots \ldots \ldots$ & 11.0 & 4.2 & 9.9 & 18.7 & $2.7 \%$ \\
\hline 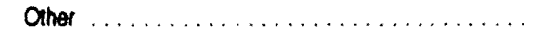 & 11.0 & 11.9 & 18.7 & 22.0 & $3.5 \%$ \\
\hline Totd $\ldots \ldots \ldots \ldots \ldots \ldots \ldots \ldots \ldots \ldots$ & 130.0 & 156.5 & 187.1 & 207.9 & $2.4 \%$ \\
\hline \multicolumn{6}{|l|}{ Stan Coal Exports to Ash } \\
\hline Austratis $\ldots \ldots \ldots \ldots \ldots \ldots \ldots \ldots$ & 41.0 & 93.6 & 113.0 & 123.7 & $5.7 \%$ \\
\hline United States $\ldots \ldots \ldots \ldots \ldots \ldots \ldots \ldots \ldots$ & 6.0 & 11.4 & 18.9 & 26.6 & $7.7 \%$ \\
\hline South Arica $\ldots \ldots \ldots \ldots \ldots \ldots \ldots \ldots$ & 18.0 & 0.0 & 14.9 & 22.1 & $1.0 \%$ \\
\hline Former U.S.S.R $\ldots \ldots \ldots \ldots \ldots \ldots \ldots \ldots$ & 3.0 & 4.4 & 4.1 & 3.8 & $1.2 \%$ \\
\hline Poland $\ldots \ldots \ldots \ldots \ldots \ldots \ldots \ldots \ldots \ldots$ & 0.0 & 0.0 & 0.0 & 0.0 & N/A \\
\hline Canada $\ldots \ldots \ldots \ldots \ldots \ldots \ldots \ldots \ldots$ & 3.0 & 40 & 7.0 & 8.9 & $5.6 \%$ \\
\hline 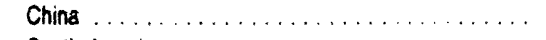 & 8.0 & 18.2 & 20.9 & 21.8 & $5.1 \%$ \\
\hline South America $\ldots \ldots \ldots \ldots \ldots \ldots \ldots$ & 1.0 & 39.7 & 55.9 & 60.3 & $22.7 \%$ \\
\hline Other $\ldots \ldots \ldots \ldots \ldots \ldots \ldots \ldots \ldots \ldots$ & 5.0 & 24.4 & 26.3 & 27.2 & $8.8 \%$ \\
\hline Total $\ldots \ldots \ldots \ldots \ldots \ldots \ldots \ldots \ldots \ldots \ldots$ & 84.0 & 185.7 & 261.0 & 294.5 & $6.5 \%$ \\
\hline \multicolumn{6}{|l|}{ Sinem Coal Exports to Others } \\
\hline$\ldots \ldots \ldots \ldots \ldots \ldots \ldots \ldots$ & 0.0 & 0.2 & 0.2 & 0.2 & N/A \\
\hline United Stales $\ldots \ldots \ldots \ldots \ldots \ldots \ldots \ldots$ & 11.0 & 9.2 & 7.7 & 8.8 & $-1.1 \%$ \\
\hline South Arrica $\quad \ldots \ldots \ldots \ldots \ldots \ldots \ldots$ & 1.0 & 2.3 & 1.6 & 2.0 & $3.4 \%$ \\
\hline Former U.S.S.R $\ldots \ldots \ldots \ldots \ldots \ldots \ldots$ & 0.0 & 2.4 & 2.9 & 4.0 & N/A \\
\hline Poland $\ldots \ldots \ldots \ldots \ldots \ldots \ldots \ldots$ & 0.0 & 0.6 & 2.6 & 2.4 & $N / A$ \\
\hline Canada $\ldots \ldots \ldots \ldots \ldots \ldots \ldots \ldots \ldots$ & 1.0 & 1.1 & 1.1 & 1.1 & $0.5 \%$ \\
\hline China $\ldots \ldots \ldots \ldots \ldots \ldots \ldots \ldots$ & 0.0 & 1.4 & 1.7 & 2.0 & N/A \\
\hline South America $\ldots \ldots \ldots \ldots \ldots \ldots \ldots \ldots$ & 2.0 & 8.3 & 9.2 & 10.3 & $8.6 \%$ \\
\hline 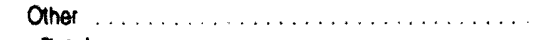 & 0.0 & 3.7 & 4.5 & 5.0 & N/A \\
\hline Totd $\ldots \ldots \ldots \ldots \ldots \ldots \ldots \ldots \ldots$ & 15.0 & 20.1 & 31.4 & 35.8 & $4.4 \%$ \\
\hline \multicolumn{6}{|l|}{ Total Stare Coel Exports } \\
\hline Austraka $\ldots \ldots \ldots \ldots \ldots \ldots \ldots$ & 54.0 & 93.8 & 129.1 & 144.4 & $5.0 \%$ \\
\hline United States $\ldots \ldots \ldots \ldots \ldots \ldots \ldots \ldots$ & 42.0 & 71.2 & 85.4 & 97.4 & $4.3 \%$ \\
\hline South Arrica $\ldots \ldots \ldots \ldots \ldots \ldots \ldots \ldots \ldots$ & 50.0 & 680 & 80.3 & 88.8 & $2.9 \%$ \\
\hline Former U.S.S.R $\ldots \ldots \ldots \ldots \ldots \ldots$ & 18.0 & 14.9 & 15.7 & 16.4 & $.0 .4 \%$ \\
\hline Poland $\ldots \ldots \ldots \ldots \ldots \ldots \ldots \ldots$ & 19.0 & 8.4 & 8.9 & 8.9 & $.3 .7 \%$ \\
\hline$\ldots \ldots \ldots \ldots \ldots \ldots \ldots \ldots$ & 5.0 & 9.7 & 9.9 & 10.0 & $3.5 \%$ \\
\hline$\ldots \ldots \ldots \ldots \ldots \ldots \ldots \ldots$ & 17.0 & 23.0 & 25.9 & 28.7 & $2.7 \%$ \\
\hline South Amenca $\ldots \ldots \ldots \ldots \ldots \ldots \ldots$ & 16.0 & 52.2 & 74.9 & 89.4 & $9.0 \%$ \\
\hline$\ldots \ldots \ldots \ldots \ldots$ & 14.0 & 40.0 & 49.5 & 54.2 & $7.0 \%$ \\
\hline Total $\ldots \ldots \ldots \ldots \ldots \ldots \ldots \ldots \ldots$ & $\mathbf{2 3 6 . 0}$ & 381.3 & 479.5 & 538.2 & $4.2 \%$ \\
\hline
\end{tabular}

N/A = Not applicabie

Note: Totals may nol equal sum of components due to independent rounding

Source: 1990: Energy information Administration (ElA). Supplement to the Annuai Energy Outlook 1993, DOEJ ElA-0554(83) (Washington, D.C., February 1893). Propoctions: EIA. AEO 1094 National Energy Modeling System run AEO94B.D1221934 
Table 72. World Metallurgical Coal Flows By Importing Regions and Exporting Countries Rogions

(Million Short Tons)

\begin{tabular}{|c|c|c|c|c|c|}
\hline \multirow{2}{*}{ Import and Export Rigitons } & \multicolumn{4}{|c|}{ Relerences Cases } & \multirow{2}{*}{$\begin{array}{l}\text { Annual } \\
\text { Growth } \\
1900-2010 \\
\text { (percent) }\end{array}$} \\
\hline & 1000 & 2000 & 2005 & 2010 & \\
\hline \multicolumn{6}{|l|}{ Untelurglical Cod Export to Europo } \\
\hline Australia .... & 14.0 & 11.4 & 10.7 & 10.1 & $-1.6 \%$ \\
\hline United Stales & 35.0 & 25.6 & 25.9 & 25.3 & $-1.6 \%$ \\
\hline South Africa . & 0.0 & 0.0 & 0.0 & 0.0 & $N / A$ \\
\hline 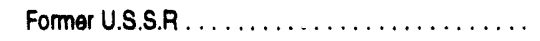 & 13.0 & 3.4 & 3.1 & 3.2 & $.6 .8 \%$ \\
\hline Poland $\ldots \ldots \ldots \ldots \ldots \ldots \ldots \ldots \ldots \ldots$ & 4.0 & 8.4 & 11.4 & 11.5 & $5.4 \%$ \\
\hline Canada,$\ldots \ldots \ldots \ldots \ldots \ldots \ldots \ldots \ldots \ldots$ & 3.0 & 5.5 & 3.8 & 3.5 & $0.8 \%$ \\
\hline China............................ & 0.0 & 0.0 & 0.0 & 0.0 & N/A \\
\hline South America $\ldots \ldots \ldots \ldots \ldots \ldots \ldots$ & 0.0 & 0.0 & 0.0 & 0.0 & N/A \\
\hline Oher $\ldots \ldots$. & 5.0 & 0.0 & 0.0 & 0.0 & N/A \\
\hline$\ldots \ldots \ldots \ldots$ & 74.0 & 54.1 & 55.0 & 53.6 & $-1.6 \%$ \\
\hline \multicolumn{6}{|l|}{ Antallurgical Coal Exports to Adela } \\
\hline 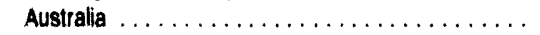 & 48.0 & 51.3 & 52.7 & 50.5 & $0.3 \%$ \\
\hline United States $\ldots \ldots \ldots \ldots \ldots \ldots \ldots \ldots$ & 14.0 & 23.2 & 19.8 & 17.7 & $1.2 \%$ \\
\hline$\ldots \ldots \ldots \ldots \ldots \ldots \ldots \ldots$ & 4.0 & 5.0 & 5.0 & 5.0 & $1.2 \%$ \\
\hline Former U.S.S.R $\ldots \ldots \ldots \ldots \ldots \ldots \ldots \ldots$ & 6.0 & 1.1 & 1.3 & 1.1 & $.8 .0 \%$ \\
\hline Poland $\ldots \ldots \ldots \ldots \ldots \ldots \ldots \ldots \ldots \ldots$ & 0.0 & 0.0 & 0.0 & 0.0 & N/A \\
\hline Canada $\ldots \ldots \ldots \ldots \ldots \ldots \ldots \ldots \ldots \ldots$ & 26.0 & 15.9 & 15.0 & 14.1 & $.3 .0 \%$ \\
\hline China $\ldots \ldots \ldots \ldots \ldots \ldots \ldots \ldots \ldots$ & 1.0 & 1.9 & 1.9 & 1.9 & $3.2 \%$ \\
\hline South America $\ldots \ldots \ldots \ldots \ldots \ldots \ldots$ & 0.0 & 0.0 & 0.0 & 0.0 & N/A \\
\hline Other $\ldots \ldots \ldots \ldots \ldots \ldots \ldots \ldots \ldots \ldots \ldots$ & 0.0 & 0.0 & 0.0 & 0.0 & N/A \\
\hline Total $\ldots \ldots \ldots \ldots \ldots \ldots \ldots \ldots \ldots \ldots \ldots \ldots \ldots \ldots$ & 100.0 & $\bullet 6.4$ & $\mathbf{\infty 6 . 7}$ & $\infty .4$ & $-0.5 \%$ \\
\hline \multicolumn{6}{|l|}{ Motellurgical Cosl Exports to Others } \\
\hline Australia $\ldots \ldots \ldots \ldots \ldots \ldots \ldots \ldots$ & 2.0 & 0.0 & 0.0 & 0.0 & N/A \\
\hline United States $\ldots \ldots \ldots \ldots \ldots \ldots \ldots \ldots$ & 12.0 & 13.2 & 13.2 & 12.0 & $0.0 \%$ \\
\hline$\ldots \ldots \ldots \ldots \ldots \ldots \ldots$ & 0.0 & 0.0 & 0.0 & 0.0 & N/A \\
\hline Former U.S.S.R $\ldots \ldots \ldots \ldots \ldots \ldots \ldots$ & 0.0 & 2.5 & 2.7 & 2.6 & N/A \\
\hline$\ldots \ldots \ldots \ldots \ldots \ldots \ldots \ldots$ & 3.0 & 0.4 & 0.3 & 0.2 & $.13 .4 \%$ \\
\hline Canada $\ldots \ldots \ldots \ldots \ldots \ldots \ldots \ldots \ldots$ & 2.0 & 0.7 & 0.6 & 0.6 & $.5 .8 \%$ \\
\hline$\ldots \ldots \ldots \ldots, \ldots, \ldots$, & 0.0 & 2.2 & 2.2 & 2.2 & N/A \\
\hline South America,$\ldots \ldots \ldots \ldots \ldots \ldots \ldots \ldots$ & 0.0 & 0.0 & 0.0 & 0.0 & $N / A$ \\
\hline$\ldots \ldots \ldots \ldots \ldots \ldots \ldots \ldots$ & 0.0 & 0.0 & 0.0 & 0.0 & N/A \\
\hline 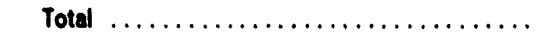 & 18.0 & 19.0 & 19.0 & 17.6 & $-0.1 \%$ \\
\hline \multicolumn{6}{|l|}{ Total Metallurglcal Coal Exports } \\
\hline Australia .... & 63.0 & 62.6 & 63.4 & 60.6 & $.0 .2 \%$ \\
\hline$\ldots \ldots \ldots, \ldots, \ldots, \ldots$ & 63.0 & 62.0 & 59.0 & 55.0 & $.0 .7 \%$ \\
\hline$\ldots \ldots \ldots \ldots \ldots \ldots \ldots$, & 4.0 & 5.0 & 5.0 & 5.0 & $1.2 \%$ \\
\hline Former U.S.S.R . & 25.0 & 6.9 & 7.1 & 6.9 & $.6 .2 \%$ \\
\hline Poland $\ldots \ldots \ldots \ldots \ldots \ldots \ldots \ldots \ldots \ldots \ldots$ & 12.0 & 8.8 & 11.7 & 11.7 & $-0.1 \%$ \\
\hline Canada $\ldots \ldots \ldots \ldots \ldots \ldots \ldots \ldots \ldots$ & 30.0 & 22.0 & 19.4 & 18.3 & $-2.5 \%$ \\
\hline$\ldots \ldots \ldots \ldots \ldots \ldots \ldots \ldots$ & 2.0 & 4.1 & 4.1 & 4.1 & $3.7 \%$ \\
\hline South America $\ldots \ldots \ldots \ldots \ldots \ldots \ldots$ & 1.0 & 0.0 & 0.0 & 0.0 & $N / A$ \\
\hline Other $\ldots \ldots \ldots \ldots \ldots \ldots \ldots \ldots \ldots \ldots \ldots \ldots \ldots \ldots \ldots \ldots$ & 6.0 & 0.0 & 0.0 & 0.0 & $N / A$ \\
\hline 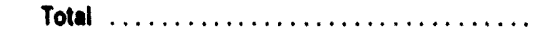 & 205.0 & 171.4 & 169.7 & 161.6 & $-1.2 \%$ \\
\hline
\end{tabular}

N/A $=$ Not applicable.

Note: Totals may not equal surn of components due to independent rounding.

Source: 1990: Energy Information Administration (EIA). Supplement to the Annual Energy Outlook 1993, DOE/EIA-0554(93) (Washington, D.C.,

February 1993). Propetions: ElA, AEO 1904 National Energy Modeling System run AEO94B.D1221934. 
Table 73. World Total Coal Flows By Importing Regions and Exporting Countries (Million Short Tons)

\begin{tabular}{|c|c|c|c|c|c|}
\hline \multirow{2}{*}{ Import and Export Regions } & \multicolumn{4}{|c|}{ Reterencos Ceses } & \multirow{2}{*}{$\begin{array}{l}\text { Annual } \\
\text { Crowth } \\
1900-2010 \\
\text { (percent) }\end{array}$} \\
\hline & 1900 & 2000 & 2005 & 2010 & \\
\hline \multicolumn{6}{|l|}{ Total Coal Exports to Europe } \\
\hline Australia $\ldots \ldots \ldots \ldots \ldots \ldots \ldots \ldots \ldots$ & 24.0 & 11.4 & 26.5 & 30.6 & $1.2 \%$ \\
\hline United States $\ldots \ldots \ldots \ldots \ldots \ldots \ldots \ldots$ & 59.0 & 76.2 & 84.8 & 87.3 & $2.0 \%$ \\
\hline South Africa $\ldots \ldots \ldots \ldots \ldots \ldots \ldots \ldots \ldots$ & 32.0 & 65.7 & 63.8 & 64.6 & $3.6 \%$ \\
\hline Former U.S.S.R $\ldots \ldots \ldots \ldots \ldots \ldots \ldots \ldots$ & 27.0 & 11.6 & 11.8 & 11.8 & $-4.0 \%$ \\
\hline Poland $\ldots \ldots \ldots \ldots \ldots \ldots \ldots \ldots \ldots$ & 27.0 & 16.2 & 17.7 & 18.0 & $-2.0 \%$ \\
\hline 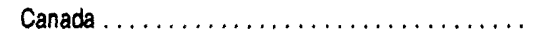 & 4.0 & 10.1 & 5.5 & 3.5 & $-0.6 \%$ \\
\hline China $\ldots \ldots \ldots \ldots \ldots \ldots \ldots \ldots$ & 3.0 & 3.3 & 3.3 & 5.0 & $2.5 \%$ \\
\hline South America $\ldots \ldots \ldots \ldots \ldots \ldots \ldots$ & 11.0 & 4.2 & 9.9 & 18.7 & $2.7 \%$ \\
\hline Other $\ldots \ldots \ldots \ldots \ldots \ldots \ldots \ldots \ldots \ldots$ & 16.0 & 11.9 & 18.7 & 22.0 & $1.6 \%$ \\
\hline Total $\ldots \ldots \ldots \ldots \ldots \ldots \ldots \ldots \ldots$ & 204.0 & 210.6 & 242.0 & 261.6 & $1.3 \%$ \\
\hline \multicolumn{6}{|l|}{ Total Coal Exports to Acla } \\
\hline Australia $\ldots \ldots \ldots \ldots \ldots \ldots \ldots \ldots \ldots$ & 89.0 & 144.9 & 165.7 & 174.3 & $3.4 \%$ \\
\hline United States $\ldots \ldots \ldots \ldots \ldots \ldots \ldots \ldots$ & 21.0 & 34.6 & 38.6 & 44.3 & $3.8 \%$ \\
\hline South Atrica $\ldots \ldots \ldots \ldots \ldots \ldots \ldots \ldots \ldots$ & 22.0 & 5.0 & 19.9 & 27.2 & $1.1 \%$ \\
\hline 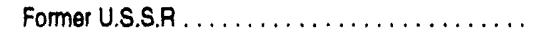 & 9.0 & 5.5 & 5.5 & 5.0 & $-2.9 \%$ \\
\hline Poland $\ldots \ldots \ldots \ldots \ldots \ldots \ldots \ldots \ldots$ & 0.0 & 0.0 & 0.0 & 0.0 & N/A \\
\hline Canada $\ldots \ldots \ldots \ldots \ldots \ldots \ldots \ldots$ & 28.0 & 19.9 & 22.0 & 23.0 & $-1.0 \%$ \\
\hline China $\ldots \ldots \ldots \ldots \ldots \ldots \ldots \ldots \ldots$ & 9.0 & 20.1 & 22.8 & 23.7 & $5.0 \%$ \\
\hline South America $\ldots \ldots \ldots \ldots \ldots \ldots \ldots \ldots$ & 1.0 & 39.7 & 55.9 & 60.3 & $22.7 \%$ \\
\hline Other $\ldots \ldots \ldots \ldots \ldots \ldots \ldots \ldots \ldots \ldots \ldots$ & 5.0 & 24.4 & 26.3 & 27.2 & $8.8 \%$ \\
\hline Total $\ldots \ldots \ldots \ldots \ldots \ldots \ldots \ldots \ldots$ & 184.0 & 294.0 & 356.7 & 384.9 & $3.8 \%$ \\
\hline \multicolumn{6}{|l|}{ Total Coal Exports to Othres } \\
\hline Australia $\ldots \ldots \ldots \ldots \ldots \ldots \ldots \ldots$ & 2.0 & 0.2 & 0.2 & 0.2 & $-11.3 \%$ \\
\hline United States $\ldots \ldots \ldots \ldots \ldots \ldots \ldots \ldots \ldots$ & 23.0 & 22.4 & 21.0 & 20.8 & $-0.5 \%$ \\
\hline South Africa $\ldots \ldots \ldots \ldots \ldots \ldots \ldots \ldots$ & 1.0 & 2.3 & 1.6 & 2.0 & $3.4 \%$ \\
\hline Former U.S.S.R $\ldots \ldots \ldots \ldots \ldots \ldots \ldots$ & 0.0 & 4.8 & 5.5 & 6.6 & N/A \\
\hline Poland $\ldots \ldots \ldots \ldots \ldots \ldots \ldots \ldots \ldots$ & 3.0 & 1.0 & 2.9 & 2.6 & $.0 .7 \%$ \\
\hline Canada $\ldots \ldots \ldots \ldots \ldots \ldots \ldots \ldots \ldots$ & 3.0 & 1.8 & 1.8 & 1.7 & $\cdot 2.7 \%$ \\
\hline China $\ldots \ldots \ldots \ldots \ldots \ldots \ldots \ldots \ldots$ & 0.0 & 3.7 & 3.9 & 4.2 & $N / A$ \\
\hline South America $\ldots \ldots \ldots \ldots \ldots \ldots \ldots$ & 2.0 & 8.3 & 9.2 & 10.3 & $8.6 \%$ \\
\hline$\ldots \ldots \ldots \ldots \ldots \ldots \ldots \ldots$ & 0.0 & 3.7 & 4.5 & 5.0 & N/A \\
\hline Total $\ldots \ldots \ldots \ldots \ldots \ldots \ldots \ldots \ldots$ & 33.0 & 48.1 & 50.5 & 53.4 & $2.4 \%$ \\
\hline \multicolumn{6}{|l|}{ Total Coal Exports } \\
\hline Australia $\ldots \ldots \ldots \ldots \ldots$ & 117.0 & 156.4 & 192.4 & 205.0 & $2.8 \%$ \\
\hline United States $\ldots \ldots \ldots \ldots \ldots \ldots \ldots \ldots \ldots$ & 106.0 & 133.2 & 144.4 & 152.4 & $1.8 \%$ \\
\hline South Africa $\ldots \ldots \ldots \ldots \ldots \ldots \ldots$ & 54.0 & 73.1 & 85.3 & 93.8 & $2.8 \%$ \\
\hline Former U.S.S.R $\ldots \ldots \ldots \ldots \ldots \ldots \ldots \ldots$ & 43.0 & 21.9 & 22.8 & 23.4 & $-3.0 \%$ \\
\hline 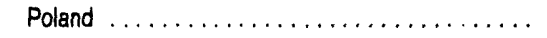 & 31.0 & 17.2 & 20.6 & 20.6 & $\cdot 2.0 \%$ \\
\hline Canada $\ldots \ldots \ldots \ldots \ldots \ldots \ldots \ldots \ldots$ & 34.0 & 31.7 & 29.3 & 28.3 & $.0 .9 \%$ \\
\hline China $\ldots \ldots \ldots \ldots \ldots \ldots \ldots \ldots \ldots$ & 19.0 & 27.1 & 30.0 & 32.8 & $2.8 \%$ \\
\hline South America $\ldots \ldots \ldots \ldots \ldots \ldots \ldots$ & 17.0 & 52.2 & 74.9 & 89.4 & $8.7 \%$ \\
\hline Other $\ldots \ldots \ldots \ldots \ldots \ldots \ldots \ldots \ldots$ & 20.0 & 40.0 & 49.5 & 54.2 & $5.1 \%$ \\
\hline Total $\ldots \ldots \ldots \ldots \ldots \ldots \ldots \ldots \ldots \ldots$ & 41.0 & 552.7 & 649.2 & 699.9 & $2.3 \%$ \\
\hline
\end{tabular}

N/A $=$ Not applicable

Note: Totals may not equal sum of components due to independent rounding.

Source: 1990: Energy Intormation Administration (EIA), Supplement to the Annual Energy Outlook 1983, DOE/EIA-0554(93) (Washington, D.C., February 1993). Propectlone: EIA, AEO 1094 National Energy Modeling System run AEO94B.D1221934. 
Table 74. Indicators of Macroeconomic Activity

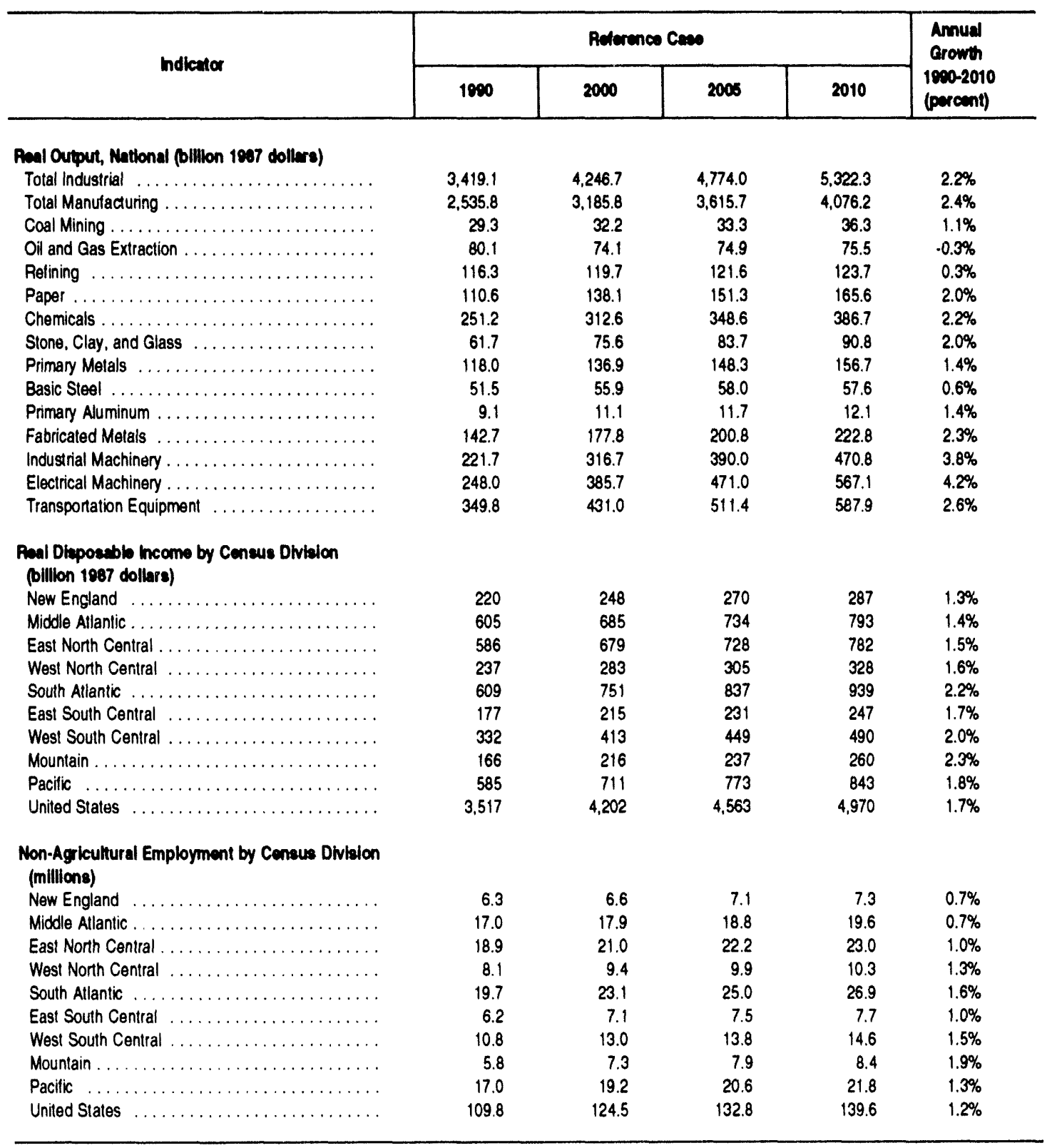

Note: Totals may nol equal sum of components due to independent rounding.

Sources: 1990: Data Resources Incorporated (DRI), DRI IOUS/O2931/SERIES. Projectlone: Energy Information Administration, AEO 1984 National Energy Modeling System run AEO94B.D1221934. 
Table 75. Imported Petroleum by Source (Million Barrels per Day)

\begin{tabular}{|c|c|c|c|c|c|}
\hline \multirow{2}{*}{ Souran } & \multicolumn{4}{|c|}{ Reterence Case } & \multirow{2}{*}{$\begin{array}{l}\text { Annual } \\
\text { Growth } \\
\text { 19e0-2010 } \\
\text { (percent) }\end{array}$} \\
\hline & 1900 & 2000 & 2005 & 2010 & \\
\hline \multicolumn{6}{|l|}{ Crude Oll } \\
\hline$\ldots \ldots \ldots \ldots \ldots \ldots \ldots \ldots \ldots \ldots$ & 0.30 & 0.00 & 0.00 & 1.29 & $7.5 \%$ \\
\hline Mexico $\ldots \ldots \ldots \ldots \ldots \ldots \ldots \ldots$ & 0.05 & 0.00 & 0.00 & 0.34 & $10.0 \%$ \\
\hline North Sea $\ldots \ldots \ldots \ldots \ldots \ldots \ldots \ldots \ldots$ & 0.01 & 0.00 & 0.00 & 0.13 & $11.7 \%$ \\
\hline$\ldots \ldots \ldots \ldots \ldots \ldots \ldots \ldots \ldots$ & 0.36 & 0.00 & 0.00 & 2.76 & $10.7 \%$ \\
\hline Latin America $\ldots \ldots \ldots \ldots \ldots \ldots \ldots$ & 0.11 & 0.00 & 0.00 & 0.95 & $11.4 \%$ \\
\hline North Africa $\ldots \ldots \ldots \ldots \ldots \ldots \ldots \ldots$ & 0.00 & 0.00 & 0.00 & 0.02 & $9.8 \%$ \\
\hline West Africa $\ldots \ldots \ldots \ldots \ldots \ldots \ldots \ldots$ & 0.06 & 0.00 & 0.00 & 0.43 & $10.7 \%$ \\
\hline Indonesia $\ldots \ldots \ldots \ldots \ldots \ldots \ldots \ldots$ & 0.03 & 0.00 & 0.00 & 0.09 & $5.3 \%$ \\
\hline Persian Gult $\ldots \ldots \ldots \ldots \ldots \ldots \ldots \ldots$ & 0.16 & 0.00 & 0.00 & 1.27 & $11.0 \%$ \\
\hline Other Middle East $\ldots \ldots \ldots \ldots \ldots \ldots \ldots$ & 0.00 & 0.00 & 0.00 & 0.02 & $7.3 \%$ \\
\hline Other Latin America . . . . . . . . . . . . . . . & 0.01 & 0.00 & 0.00 & 0.06 & $8.6 \%$ \\
\hline Other Alrica $\ldots \ldots \ldots \ldots \ldots \ldots \ldots$ & 0.03 & 0.00 & 0.00 & 0.20 & $11.0 \%$ \\
\hline Other Asia. . . . . . . . . . . . . . . . . . . . & 0.06 & 0.00 & 0.00 & 0.21 & $6.7 \%$ \\
\hline \multicolumn{6}{|l|}{ Light Pofined Products' } \\
\hline 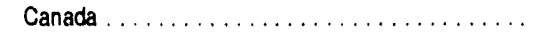 & 0.19 & 0.56 & 0.69 & 0.91 & $8.2 \%$ \\
\hline Northern Europe $\ldots \ldots \ldots \ldots \ldots \ldots \ldots \ldots$ & 0.03 & 0.06 & 0.08 & 0.09 & $5.0 \%$ \\
\hline Southern Europe $\ldots \ldots \ldots \ldots \ldots \ldots$ & 0.04 & 0.05 & 0.06 & 0.07 & $2.4 \%$ \\
\hline OPEC $\ldots \ldots \ldots \ldots \ldots \ldots \ldots \ldots \ldots \ldots$ & 0.06 & 0.00 & 000 & 0.43 & $10.7 \%$ \\
\hline Latin America $\ldots \ldots \ldots \ldots \ldots \ldots \ldots$ & 0.09 & 0.16 & 0.23 & 0.29 & $5.9 \%$ \\
\hline North Africa $\ldots \ldots \ldots \ldots \ldots \ldots \ldots \ldots$ & 0.01 & 0.02 & 0.04 & 0.05 & $6.9 \%$ \\
\hline West Alrica . . . . . . . . . . . . . . . & 0.00 & 0.00 & 0.00 & 0.00 & $\cdot 1.5 \%$ \\
\hline Indonesia $\ldots \ldots \ldots \ldots \ldots \ldots \ldots \ldots \ldots$ & 0.00 & 0.00 & 0.00 & 0.00 & $N / A$ \\
\hline Persian Gull $\ldots \ldots \ldots \ldots \ldots \ldots \ldots \ldots$ & 0.09 & 0.05 & 0.07 & 0.09 & $0.1 \%$ \\
\hline Caribbean Basin $\ldots \ldots \ldots \ldots \ldots \ldots \ldots \ldots$ & 0.08 & 0.21 & 0.36 & 0.45 & $9.2 \%$ \\
\hline Asian Exporters $\ldots \ldots \ldots \ldots \ldots \ldots \ldots \ldots$ & 0.02 & 0.01 & 0.02 & 0.02 & $2.1 \%$ \\
\hline Other $\ldots \ldots \ldots \ldots \ldots \ldots \ldots \ldots \ldots \ldots$ & 0.04 & 0.03 & 0.04 & 0.04 & $.0 .1 \%$ \\
\hline \multicolumn{6}{|l|}{ Heavy Retined Products ${ }^{2}$} \\
\hline Canada $\ldots \ldots \ldots \ldots \ldots \ldots \ldots \ldots$ & 0.10 & 0.09 & 0.11 & 0.16 & $2.3 \%$ \\
\hline Northern Europe $\ldots \ldots \ldots \ldots \ldots \ldots \ldots$ & 0.02 & 0.02 & 0.03 & 0.03 & $3.7 \%$ \\
\hline Southern Europe $\ldots \ldots \ldots \ldots \ldots \ldots \ldots \ldots$ & 0.02 & 0.01 & 0.01 & 0.01 & $.1 .8 \%$ \\
\hline OPEC $\ldots \ldots \ldots \ldots \ldots \ldots \ldots \ldots \ldots$ & 0.10 & 0.13 & 0.19 & 0.22 & $3.9 \%$ \\
\hline Latin America $\ldots \ldots \ldots \ldots \ldots \ldots \ldots \ldots$ & 0.04 & 0.04 & 0.05 & 0.06 & $1.9 \%$ \\
\hline North Africa $\ldots \ldots \ldots \ldots \ldots \ldots \ldots$ & 0.03 & 0.05 & 0.09 & 0.09 & $6.6 \%$ \\
\hline West Alrica $\ldots \ldots \ldots \ldots \ldots \ldots \ldots \ldots \ldots$ & 0.01 & 0.00 & 0.00 & 0.01 & $.0 .9 \%$ \\
\hline Indonesia $\ldots \ldots \ldots \ldots \ldots \ldots \ldots \ldots$ & 0.01 & 0.03 & 0.04 & 0.05 & $8.4 \%$ \\
\hline Persian Gulf $\ldots \ldots \ldots \ldots \ldots \ldots \ldots$ & 0.02 & 0.01 & 0.01 & 0.01 & $\cdot 2.5 \%$ \\
\hline Caribbean Basin $\ldots \ldots \ldots \ldots \ldots \ldots \ldots \ldots$ & 0.07 & 0.06 & 0.06 & 0.07 & $.0 .4 \%$ \\
\hline Asian Exporters .... & 0.03 & 0.04 & 0.05 & 0.07 & $5.1 \%$ \\
\hline Other $\ldots \ldots \ldots \ldots \ldots \ldots \ldots \ldots \ldots \ldots \ldots$ & 0.05 & 0.04 & 0.05 & 0.06 & $1.4 \%$ \\
\hline
\end{tabular}

'Inciudes gasoline, distillate, jel fuel, and liquitied petroleum gases

Includes residual fuel oil and other retined products.

OPEC = Organization ol Petroleum Exponting Countries - Algeria, Gabon, Indonesia, Iran, Iraq, Kuwait, Libya, Nigeria, Qatar, Saudi Arabia, the United Arab Emirates, and Venezuela.

Caribbean Basil = Columbia, Ecuador, Guatemala, Jamacia, Mexico, Netherlands Antilles, Panama, Puerto Rico, Trinidad and Tobago, Venezuela, and the Virgin islands.

$\mathrm{N} / \mathrm{A}=$ Not applicable.

Source: Energy information Administration, AEO 1994 National Energy Modeling System Iun AEO94B.D1221934. 


\section{Appendix A}

\section{Maps}

Figure A1. U.S. Consus Divisions

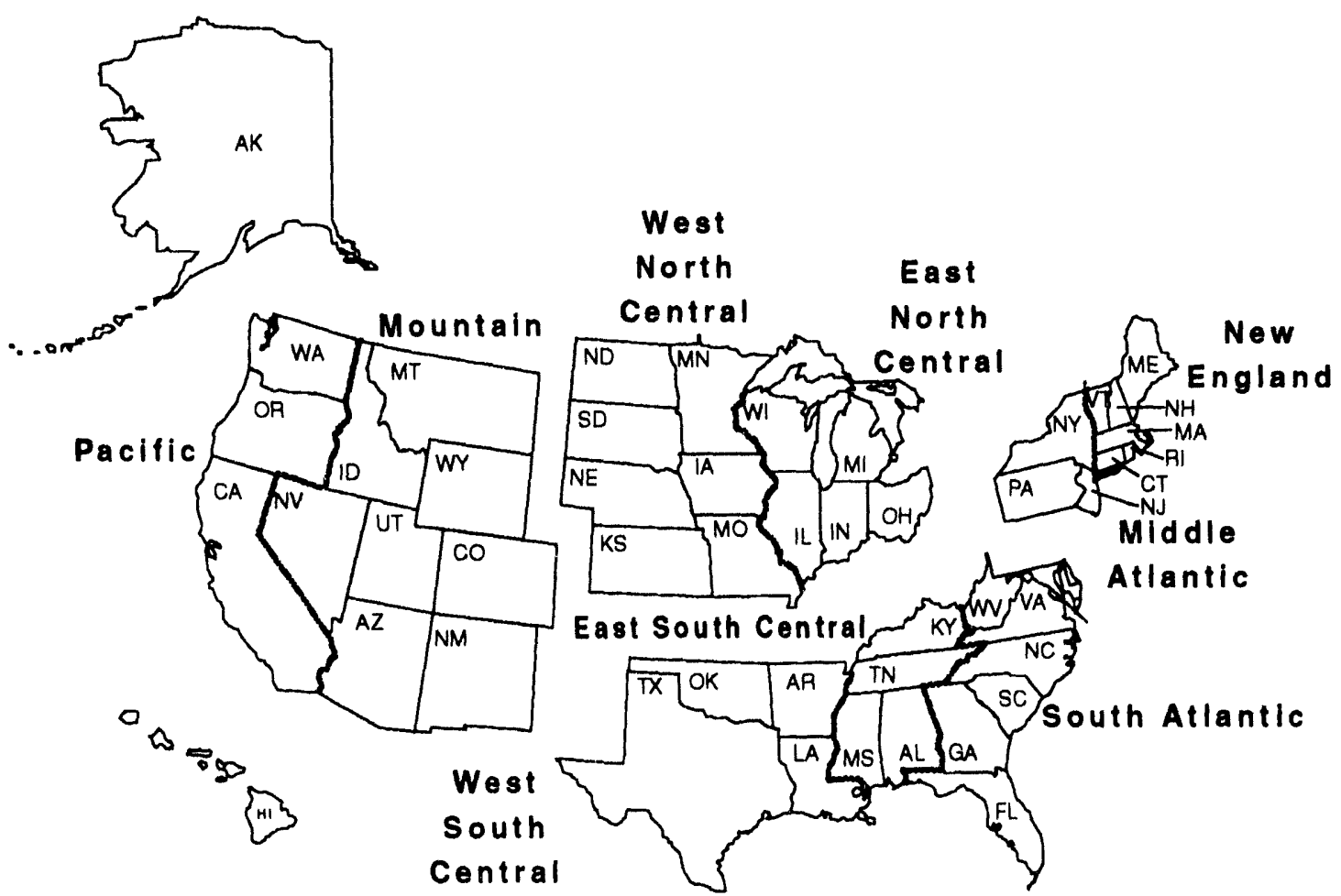

\begin{tabular}{|c|c|c|c|c|}
\hline$\frac{\text { Divlalon } 1}{\text { New England }}$ & $\frac{\text { Dlvislon } 3}{\text { East North Central }}$ & $\frac{\text { Division } 5}{\text { South Atlantic }}$ & $\frac{\text { Dlviaion } 7}{\text { West South Central }}$ & $\frac{\text { Division } 9}{\text { Paclific }}$ \\
\hline $\begin{array}{l}\text { Connecticut } \\
\text { Maine } \\
\text { Massachusetts } \\
\text { New Hampshire } \\
\text { Rhode Island } \\
\text { Vermont } \\
\text { Divlolon } 2 \\
\text { Mlddle Atlantlc } \\
\text { New Jersey } \\
\text { New York } \\
\text { Pennsylvania }\end{array}$ & $\begin{array}{l}\text { Illinois } \\
\text { Indiana } \\
\text { Michigan } \\
\text { Ohio } \\
\text { Wisconsin } \\
\text { Division } 4 \\
\text { West North Central } \\
\text { lowa } \\
\text { Kansas } \\
\text { Minnesota } \\
\text { Missouri } \\
\text { Nebraska } \\
\text { North Dakota } \\
\text { South Dakota }\end{array}$ & $\begin{array}{l}\text { Delaware } \\
\text { District of Columbia } \\
\text { Florida } \\
\text { Georgia } \\
\text { Maryland } \\
\text { North Carolina } \\
\text { South Carolina } \\
\text { Virginia } \\
\text { West Virginia } \\
\text { Divislon } 6 \\
\text { East South Central } \\
\text { Alabama } \\
\text { Kentucky } \\
\text { Mississippi } \\
\text { Tennessee }\end{array}$ & $\begin{array}{l}\text { Arkansas } \\
\text { Louisiana } \\
\text { Oklahoma } \\
\text { Texas } \\
\text { Dlvision } 8 \\
\text { Mountain } \\
\text { Arizona } \\
\text { Colorado } \\
\text { Idaho } \\
\text { Montana } \\
\text { Nevada } \\
\text { New Mexico } \\
\text { Utah } \\
\text { Wyoming }\end{array}$ & $\begin{array}{l}\text { Alaska } \\
\text { Callfornla } \\
\text { Hawail } \\
\text { Orogon } \\
\text { Washington }\end{array}$ \\
\hline
\end{tabular}

Source: Energy Information Administration, Office of Integrated Arialysis and Forecasting. 
Figure A2. Electricity Market Module (EMM) Regions
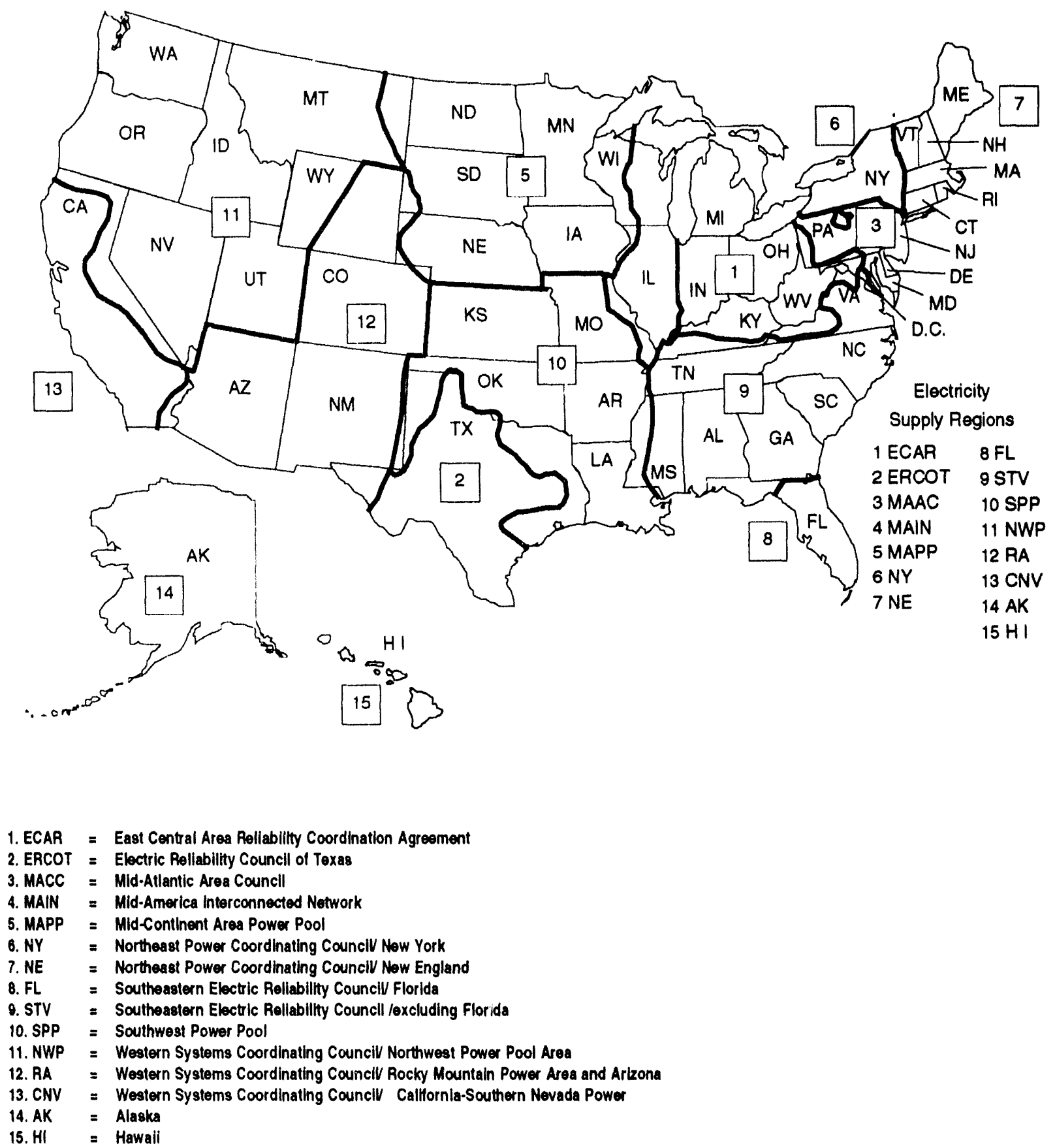

Source: Energy Information Administration, Office of Integrated Analysis and Forecasting. 
Figure A3. Petroleum Administration for Defense Districts

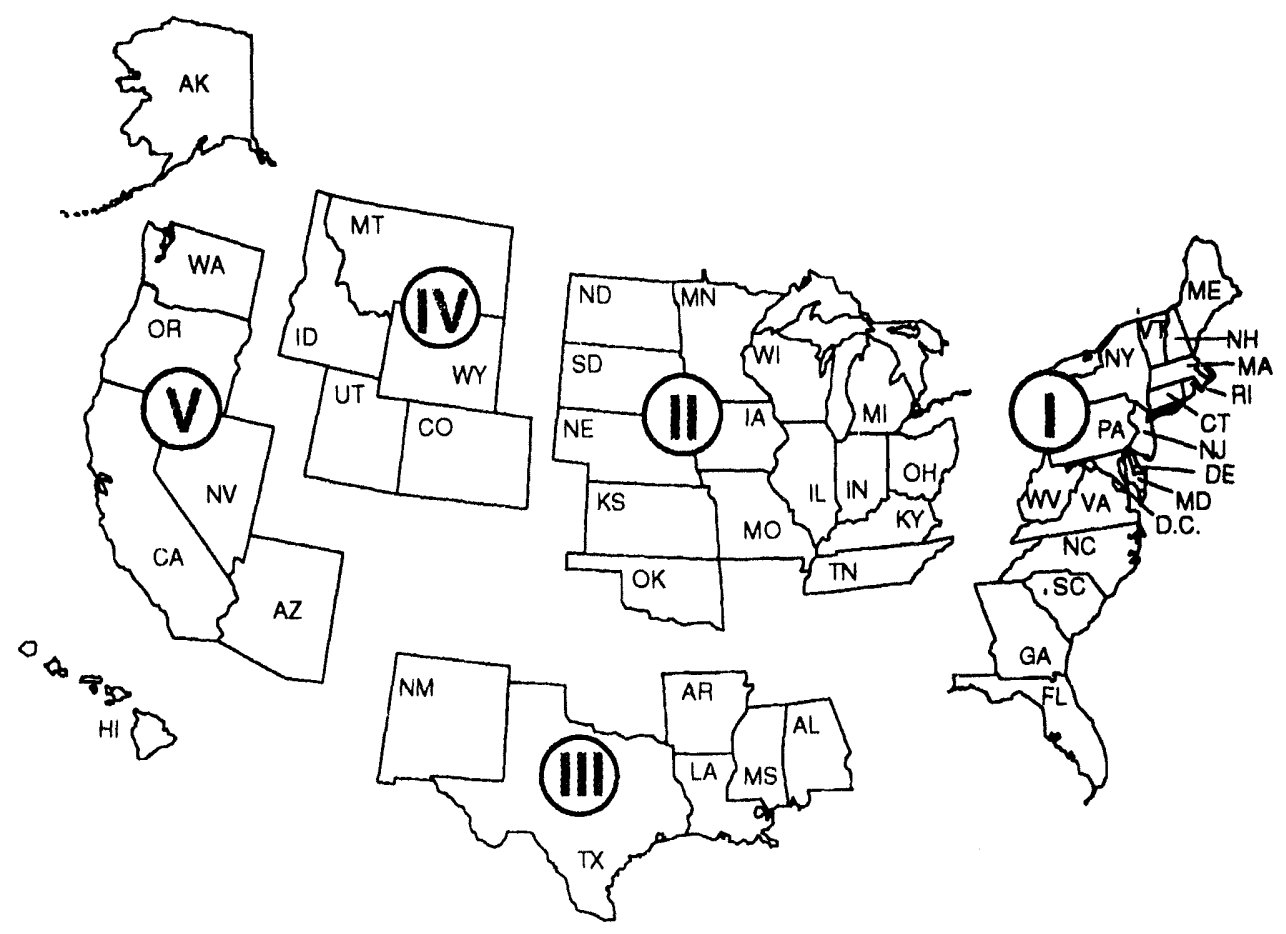

Source: Energy Information Administration, Office of integrated Analysis and Forecasting. 
Figure A4. OII and Gas Supply Module Regions
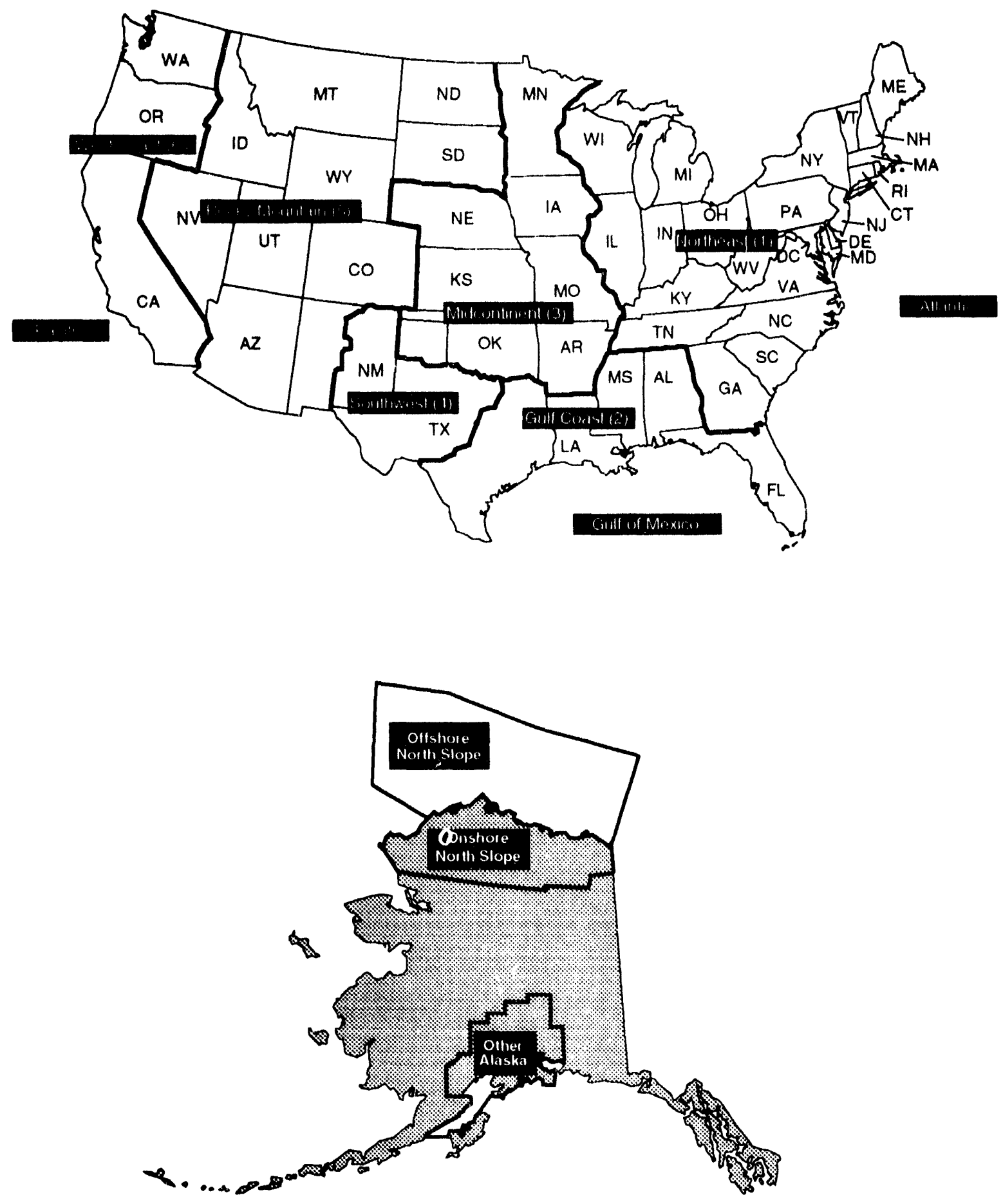

Source: Energy Information Administration, Office of Integrated Analysis and Forecasting. 
Figure A5. Natural Gas Transmission and Distribution Module Reglons

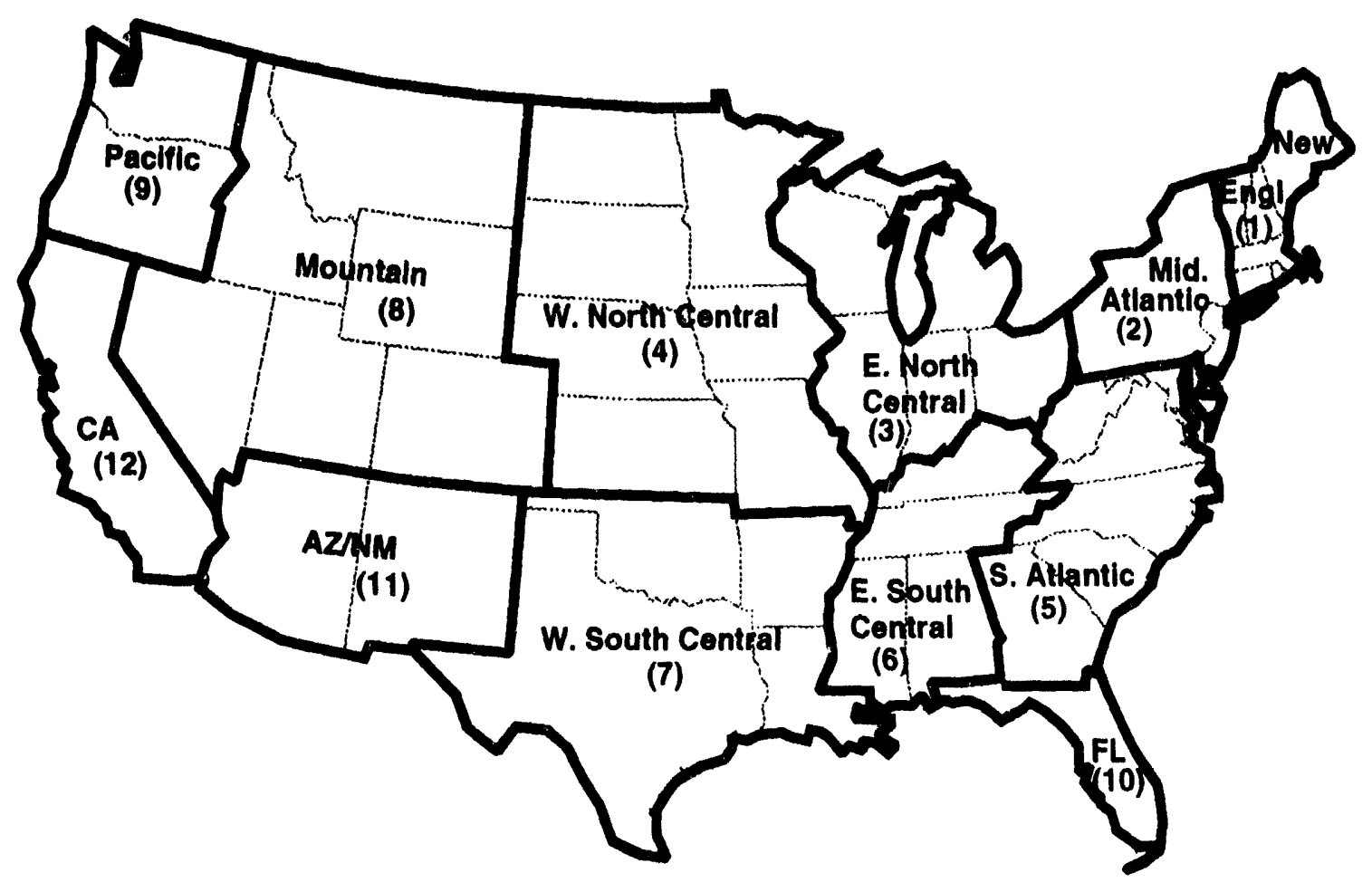

Source: Energy Information Administration, Office of Integrated Analysis and Forecasting. 
Figure A6. Coal Market Module Supply Reglons

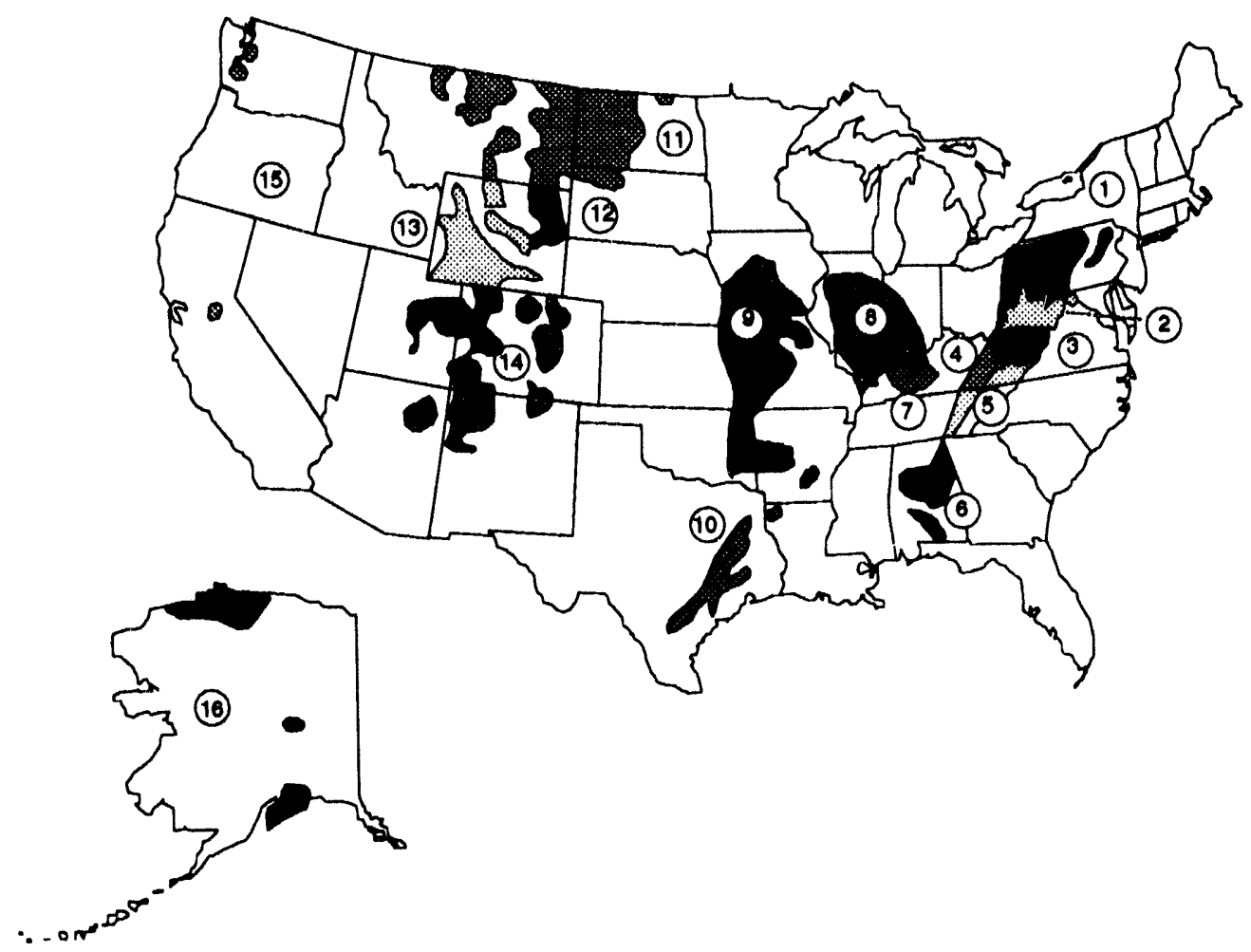

Region

Definition

\begin{tabular}{|c|c|c|}
\hline Northern Appalachia & $\begin{array}{l}1 \\
2\end{array}$ & $\begin{array}{l}\text { Pennsylvania, Maryland, and Ohio } \\
\text { West Virginia (north) }\end{array}$ \\
\hline \multirow[t]{3}{*}{ Southern Appalachla } & 3 & West Virginia (south) \\
\hline & 4 & Kentucky (east) \\
\hline & 5 & Virginia and Tennessee \\
\hline \multirow[t]{4}{*}{ Interior } & $\begin{array}{l}6 \\
7\end{array}$ & $\begin{array}{l}\text { Alabama } \\
\text { Kentucky (west) }\end{array}$ \\
\hline & 8 & Illinois and Indiana \\
\hline & 9 & Arkansas, lowa, Kansas, Missouri, and Oklahoma \\
\hline & 10 & Texas and Louisiana \\
\hline \multirow{2}{*}{ North Great Plains } & 11 & North Dakota, South Dakota, and Montana \\
\hline & 12 & Wyoming (east) \\
\hline Other West & $\begin{array}{l}13 \\
14\end{array}$ & $\begin{array}{l}\text { Wyoming (west) } \\
\text { Arizona, New Mexico, Colorado, and Utah }\end{array}$ \\
\hline & 15 & Washington, Oregon, and California \\
\hline Alaska & 16 & Alaska \\
\hline
\end{tabular}

Source: Energy Information Administration, Office of Integrated Analysis and Forecasting. 


\section{Appendix B \\ Model Documentation Reports}

The National Energy Modeling System is documented in a series of 15 model documentation reports, available early in 1994 by contacting the National Energy Information Center (202/586-8800).

Energy Information Administration, National Energy Modeling System Integrating Module Documentation Report, DOE/EIA-M057 (Washington, DC, December 1993).

Energy Information Administration, Model Documentation Report: Macroeconomic Activity Module of the National Eneryy Modeling System, forthcoming.

Energy Information Administration, Documentation of the D.R.I. Model of the U.S. Economy, forthcoming.

Energy Information Administration, National Energy Modeling System International Energy Model Documentation Report, forthcoming.

Energy Information Administration, World Oil Refining, Logistics, and Demand Model Documentation Report, forthcoming.

Energy Information Administration, Model Documentation Report: Residential Sector Demand Module of the National Energy Modeling System, forthcoming.

Energy Information Administration, Model Documentation Report: Commercial Sector Demand Module of the National Energy Modeling System, forthcoming.

Energy Information Administration, Model Documentation Report: Industrial Sector Demand Module of the National Energy Modeling System, forthcoming.

Energy Information Administration, Model Documentation Report: Transportation Sector Demand Module of the National Energy Modeling System, forthcoming.

Energy Information Administration, Documentation of the Electricity Market Module, forthcoming.

Energy Information Administration, Documentation of the Oil and Gas Supply Module, forthcoming.

Energy Information Administration, Model Documentation: Natural Gas Transmission and Distribution Model of the National Energy Modeling System, forthcoming.

Energy Information Administration, EIA Model Documentation: Petroleum Market Module of the National Energy Modeling System, forthcoming.

Energy Information Administration, Model Documentation: Coal Market Module, forthcoming.

Energy Information Administration, Model Documentation Report: Renewable Fuels Module, forthcoming. 

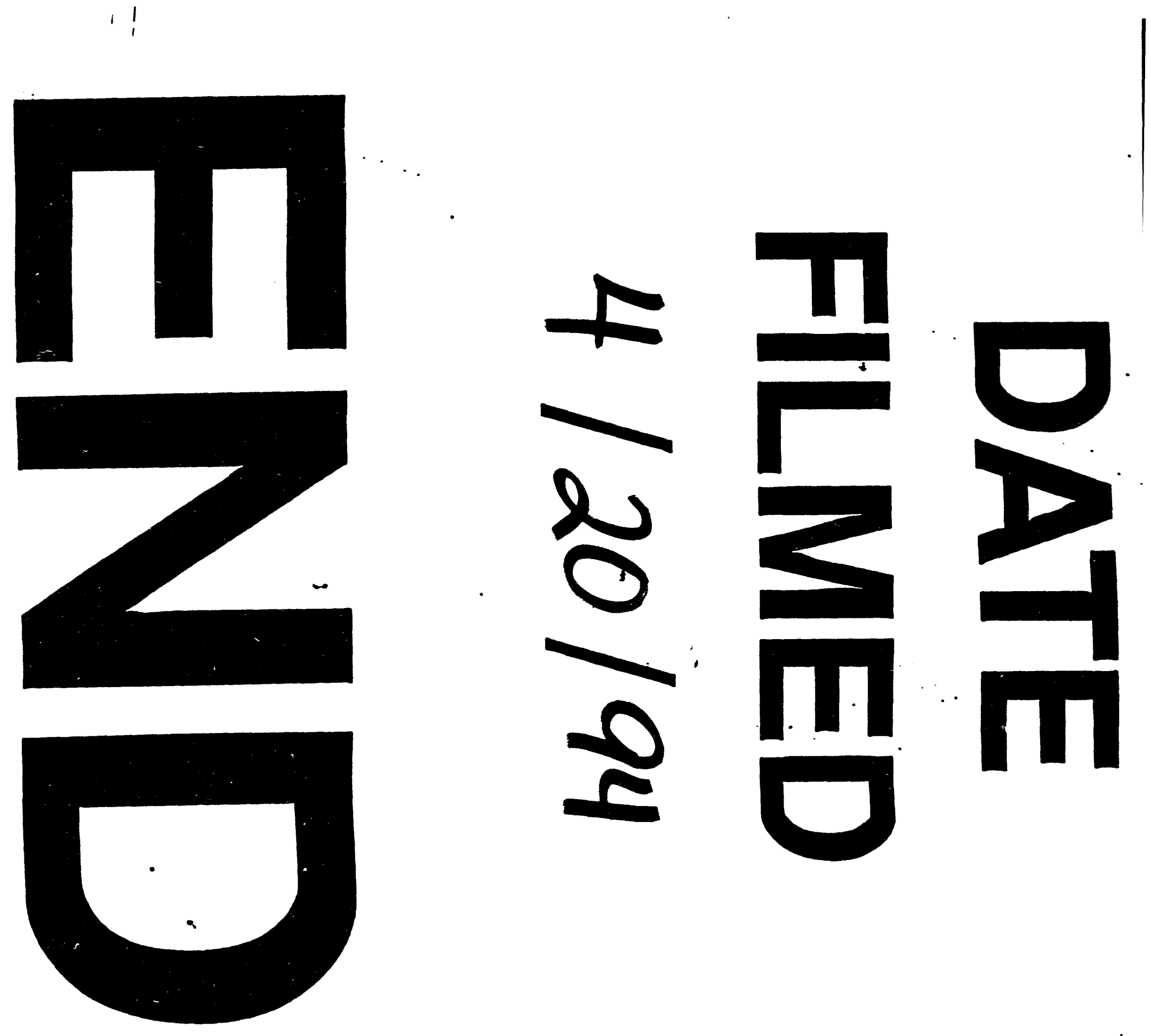
